João Olympio de Araújo Neto

\title{
Análise da precisão e acurácia de pontos georreferenciados com a técnica do código suavizado pela fase da portadora utilizando GPS de simples freqüência
}

Dissertação apresentada à Escola de Engenharia de São Carlos, da Universidade de São Paulo, como parte dos requisitos para obtenção do título de Mestre em Engenharia Civil: Transportes.

Orientador: Prof. Dr. Irineu da Silva

São Carlos

2006 
Tos meus amados pais, Ludvan Oysmpio e Ivonildes Fiernandes; à mintia graciosa avó, Maria Fiernandes, e aos meus queridos ímãos, Dú, Dó e Tânia. Pelo anor e carintio que nunca deixaram faltar, principalmente nos momentos dificeis. 


\section{AGRADECIMENTOS}

Ao onisciente, onipresente e onipotente Sr. Deus, que sempre está ao lado dos filhos, aparando-os.

Ao orientador e amigo, Prof. Dr. Irineu da Silva, pelas orientações e rotas apresentadas, neste trabalho e na vida;

Ao Prof. Dr. Paulo C. L. Segantine, pelos conselhos (sempre bem ouvidos) e pela amizade e, ao Prof. Dr. Ricardo Ernesto Schaal;

Aos professores do curso de Engenharia de Agrimensura Universidade Federal de Viçosa, em especial ao Profo Dr. Carlos Alexandre, responsáveis por minha formação acadêmica;

Ao "irmão", Prof. Dr. Artur Pantoja Marques, pela convivência em sala, companheirismo e "co-orientação" neste trabalho;

Aos amigos, Marcelo S. Teles, Rodrigo Leandro, Willian Dal Poz e Adson Alecrin pela essencial ajuda e sugestões;

Aos amigos, Eduardo, Paulinho e Gustavo, pela coleta de dados;

Á querida Vanessa e aos amigos: Antônio, Vivian, Cynthya, Aline, Rogério, Fernando, Francis, Idalíria, Lia, Shirley, Cida, Vitor, Dani, Queli, Geraldo, Deborah, Anderson, Mauro, Ana, Gilmerson, Cláudia, Rodrigo, Karina, Karênina, Celane, Marcos, Deise, Camila, Gauchinha, Luciano, João e Igor.

A todos os professores do Departamento de Transportes da EESCUSP e, aos funcionários: Heloísa, Beth, Lílian, Magali, Tôco.

Á CAPES, pela bolsa de estudos concedida. 
TUbDO ten o seu tempo determinado, e há tempo para todo o propósito debaixo do céu.

Ifá tempo de nascer, e tempo de morrer; tempo de plantar, e tempo de arrancar o que se plantou;

Tempo de matar, e tempo de curar; tempo de derrubar, e tempo de edificar:

Tempo de chiorar, e tempo de rir; tempo de prantear, $e$ tempo de dançar:

Tempo de espaltiar pedras, e tempo de ajuntar pedras; tempo de abraçar, e tempo de a fastar-se de abraçar; Tempo de buscar, e tempo de perder; tempo de guardar, $e$ tempo de lançar fora:

Tempo de rasgar, e tempo de coser; tempo de estar calado, e tempo de falar:

Tempo de amar, e tempo de odiar; tempo de guerra, $e$ tempo de paz. 
ARAÚJO NETO, J. O. (2006). Análise da precisão e acurácia de pontos georreferenciados com a técnica do código suavizado pela fase da portadora utilizando GPS de simples freqüência. (DISSERTAÇÃO) - Escola de Engenharia de São Carlos, Universidade de São Paulo, São Carlos, 2006.

A presente dissertação teve como finalidade avaliar a precisão e a discrepância das coordenadas (acurácia) obtidas por meio das observações GPS, no modo estático rápido, medidas com receptores de uma freqüência, empregando-se a técnica de suavização do código C/A pela fase da portadora para diferentes comprimentos de linha base (20, 50, 75, 100, 150, 200 e $300 \mathrm{~km})$, a partir da estação de monitoramento continuo da EESC/USP. Essa técnica obteve boa repercussão no Brasil, a partir do momento em que foi permitida sua utilização para fins de georreferenciamento de imóveis rurais, conforme a Norma Técnica do INCRA, que permite a utilização da suavização do código pela fase da portadora, desde que esta apresente acurácia com valores iguais ou inferiores a $50 \mathrm{~cm}$.

Atualmente, trabalhos com tal técnica estão sendo desenvolvidos e aceitos para compor o banco de dados do cadastro rural nacional. Pelos resultados obtidos nesta dissertação, foi possível avaliar que a aplicação dessa técnica não atende à exigência requerida em $100 \%$ das medições e, ao mesmo tempo, verificar a diferença entre a precisão do pós-processamento, indicada pelos softwares comerciais e a acurácia dos pontos medidos comparados com os pontos de controle estabelecidos para esse fim.

Palavras-chave: suavização do código pela fase da portadora, receptor de uma freqüência, precisão, acurácia. 
ARAÚJO NETO, J. O. (2006). Precision and accuracy analysis of georeferencing points using the carrier-smoothed-code technique with GPS single frequency receiver (L1). (DISSERTATION) - Escola de Engenharia de São Carlos, Universidade de São Paulo, São Carlos, 2006.

The present dissertation has as objective to evaluate precision and discrepancies of coordinates (accuracy) obtained through GPS observations, in a rapid static method, measured by single frequency, which applies carriersmoothed-code for different baseline length $(20,50,75,100,150,200$ and $300 \mathrm{~km})$ since continuous monitoring station from EESC/USP. This technique obtained a good repercussion in Brazil, since when its use was legitimate in rural property georeferencing, according to INCRA's Norma Técnica (Technical Rule), which allows the use of carrier-smoothed-code in view of the fact that presents accuracy with equal or inferior values to $50 \mathrm{~cm}$.

Currently, works using such technique are developed and accepted in order to compound database of national rural survey in Brazil. Based on the obtained results it was possible to evaluate that the technique does not guaranteed to requested requirement in $100 \%$ of measurements, and at the same time to verify the difference between post-processing precision, indicated by commercial software, as well as measured point accuracy compared with points established for this purposed.

Keywords: Carrier-smoothed-code, receiver L1, precision, accuracy 
Figura 1 - Princípio básico do posicionamento por GPS ............................................................................11

Figura 2 - Princípio do processamento dos sinais das portadoras ............................................................12

Figura 3 - Regiões do mundo com alta atividade ionosférica .....................................................................16

Figura 4 - Modelo troposférico (densidade das camadas politrópicas) ......................................................17

Figura 5 - Rede de observatórios geomagnéticos para a determinação do índice Dst..............................19

Figura 6 - Ilustração feita com os conceitos de precisão e acurácia............................................................22

Figura 7 - Correlação entre o código enviado pelo satélite com sua réplica ............................................25

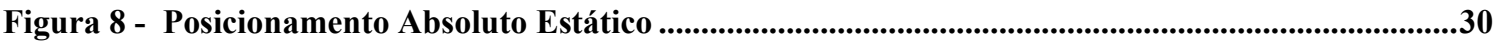

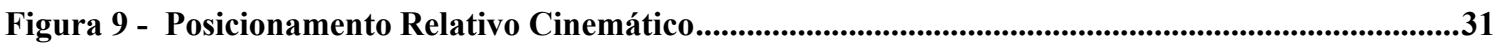

Figura 10 - Posicionamento relativo estático ..............................................................................................32

Figura 11 - Receptor GPS Smart Rover - Leica Geosystems................................................................36

Figura 12 - Receptor para navegação ........................................................................................................................37

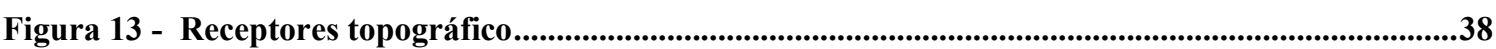

Figura 14 - Receptor Geodésico .................................................................................................................40

Figura 15 - Desvio padrão da pseudodistância filtrada pela fase da portadora .....................................51

Figura 16 - Localização dos marcos ao longo da rodovia Washington Luís .............................................54

Figura 17 - Clinômetro de bolso e GPS de navegação........................................................................56

Figura 18 - Marco cilíndrico de concreto após a materialização …............................................................57

Figura 19 - Número de satélites disponíveis (27-11-2004) ........................................................................58

Figura 20 - Trajetória e elevação dos satélites disponíveis (27-11-2004) .................................................59

Figura 21 - Diluição da precisão (PDOP e GDOP) …..................................................................................59

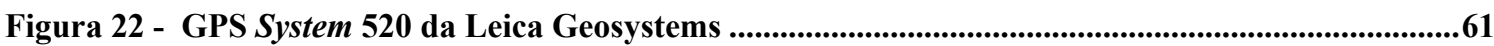

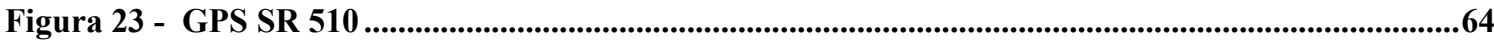

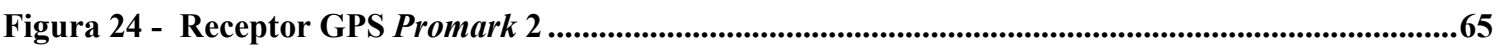

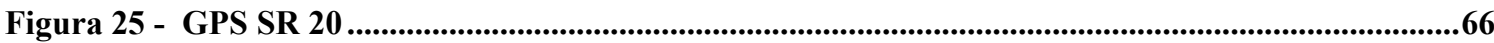

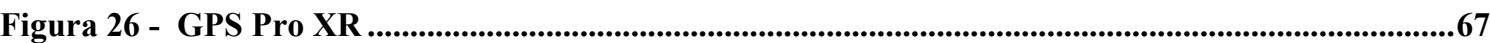

Figura 27 - Transferência de dados por meio de leitor de cartão ...........................................................68

Figura 28 - Processamento Relativo com observações L1/L2 .......................................................................70

Figura 29 - Processamento Relativo com observações L1 ....................................................................71

Figura 30 - Processo de fechamento poligonal por meio dos vetores .....................................................73

Figura 31 - Processamento no modo estático rápido pelo código suavizado .................................................74

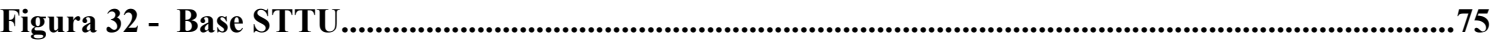

Figura 33 - Acurácia e precisão das coordenadas na seção 01 (localizada a $20 \mathrm{~km}$ da estação de referência 
Figura 34 - Acurácia e precisão das coordenadas na seção 02 (localizada a 50 km da estação de referência)

Figura 35 - Acurácia e precisão das coordenadas na seção 03 (localizada a 75 km da estação de referência)

Figura 36 - Acurácia e precisão das coordenadas na seção 04 (localizada a 100 km da estação de referência)

Figura 37 - Acurácia e precisão das coordenadas na seção 05 (localizada a 150 km da estação de referência)

Figura 38 - Acurácia e precisão das coordenadas na seção 06, localizada a 200 km da estação ..............83

Figura 39 - Acurácia e precisão das coordenadas na seção 07, localizada a 300 km da estação ..............83

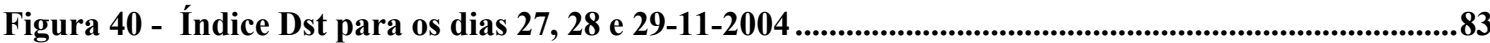

Figura 41 - Acurácia e precisão das coordenadas na seção 01, obtidas no $1^{\circ}$ dia de observação .............84

Figura 42 - Acurácia e precisão das coordenadas na seção 01 , obtidas no $2^{\circ}$ dia de observação ............84

Figura 43 - Acurácia e precisão das coordenadas na seção 02, obtidas no $1^{\circ}$ dia de observação .............85

Figura 44 - Acurácia e precisão das coordenadas na seção 02, obtidas no $2^{\circ}$ dia de observação .............85

Figura 45 - Acurácia e precisão das coordenadas na seção 03, obtidas no $1^{0}$ dia de observação .............85

Figura 46 - Acurácia e precisão das coordenadas na seção 03 , obtidas no $2^{\circ}$ dia de observação ............86

Figura 47 - Acurácia e precisão das coordenadas na seção 04, obtidas no $1^{\circ}$ dia de observação .............86

Figura 48 - Acurácia e precisão das coordenadas na seção 04, $2^{\circ}$ dia de observação .................................86

Figura 49 - Acurácia e precisão das coordenadas na seção 05, obtidas no $1^{0}$ dia de observação .............87

Figura 50 - Acurácia e precisão das coordenadas na seção 05, obtidas no $2^{\circ}$ dia de observação .............87

Figura 51 - Acurácia e precisão das coordenadas na seção 06, obtidas no $1^{0}$ dia de observação .............87

Figura 52 - Acurácia e precisão das coordenadas na seção 06, obtidas no $2^{\circ}$ dia de observação .............88

Figura 53 - Acurácia e precisão das coordenadas na seção 07, obtidas no $1^{0}$ dia de observação .............88

Figura 54 - Acurácia e precisão das coordenadas na seção 07, obtidas no $2^{\circ}$ dia de observação .............88

Figura 55 - Índice Dst para os dias 18 e 19-12-2004 (22-01-2006) ..........................................................89

Figura 56 - Acurácia e precisão das coordenadas na seção 01, obtidas no $1^{0}$ dia de observação .............90

Figura 57 - Acurácia e precisão das coordenadas na seção 01, obtidas no $2^{\circ}$ dia de observação .............90

Figura 58 - Acurácia e precisão das coordenadas na seção 01, obtidas no $3^{\circ}$ dia de observação .............90

Figura 59 - Acurácia e precisão das coordenadas na seção 01, obtidas no $4^{0}$ dia de observação .............91

Figura 60 - Acurácia e precisão das coordenadas na seção 02, obtidas no $1^{\circ}$ dia de observação .............91

Figura 61 - Acurácia e precisão das coordenadas na seção 02, obtidas no $2^{\circ}$ dia de observação .............91

Figura 62 - Acurácia e precisão das coordenadas na seção 02, obtidas no $3^{\circ}$ dia de observação .............92

Figura 63 - Acurácia e precisão das coordenadas na seção 02, obtidas no $4^{\circ}$ dia de observação .............92

Figura 64 - Acurácia e precisão das coordenadas na seção 03, obtidas no $1^{\circ}$ dia de observação .............92

Figura 65 - Acurácia e precisão das coordenadas na seção 03, obtidas no $2^{\circ}$ dia de observação .............93

Figura 66 - Acurácia e precisão das coordenadas na seção 03, obtidas no $3^{\circ}$ dia de observação .............93

Figura 67 - Acurácia e precisão das coordenadas na seção 03, obtidas no $4^{0}$ dia de observação .............93 
Figura 68 - Acurácia e precisão das coordenadas na seção 04, obtidas no $1^{\circ}$ dia de observação .............94

Figura 69 - Acurácia e precisão das coordenadas na seção 04, obtidas no $2^{\circ}$ dia de observação .............94

Figura 70 - Acurácia e precisão das coordenadas na seção 04, obtidas no $3^{\circ}$ dia de observação .............94

Figura 71 - Acurácia e precisão das coordenadas na seção 04, obtidas no $4^{0}$ dia de observação .............95

Figura 72 - Acurácia e precisão das coordenadas na seção 05, obtidas no $1^{\circ}$ dia de observação .............95

Figura 73 - Acurácia e precisão das coordenadas na seção 05, obtidas no $2^{\circ}$ dia de observação .............95

Figura 74 - Acurácia e precisão das coordenadas na seção 05, obtidas no $3^{\circ}$ dia de observação .............96

Figura 75 - Acurácia e precisão das coordenadas na seção 05, obtidas no $4^{0}$ dia de observação .............96

Figura 76 - Acurácia e precisão das coordenadas na seção 06, obtidas no $1^{\circ}$ dia de observação .............96

Figura 77 - Acurácia e precisão das coordenadas na seção 06, obtidas no $2^{\circ}$ dia de observação .............97

Figura 78 - Acurácia e precisão das coordenadas na seção 06, obtidas no $3^{\circ}$ dia de observação .............97

Figura 79 - Acurácia e precisão das coordenadas na seção 06, obtidas no $4^{0}$ dia de observação .............97

Figura 80 - Acurácia e precisão das coordenadas na seção 07, obtidas no $1^{\circ}$ dia de observação .............98

Figura 81 - Acurácia e precisão das coordenadas na seção 07, obtidas no $2^{\circ}$ dia de observação .............98

Figura 82 - Acurácia e precisão das coordenadas na seção 07, obtidas no $3^{\circ}$ dia de observação .............98

Figura 83 - Acurácia e precisão das coordenadas na seção 07, obtidas no $4^{\circ}$ dia de observação .............99

Figura 84 - Acurácia e precisão das coordenadas na seção 01, obtidas no $1^{\circ}$ dia de observação ...........100

Figura 85 - Acurácia e precisão das coordenadas na seção 01, obtidas no $2^{\circ}$ dia de observação ...........100

Figura 86 - Acurácia e precisão das coordenadas na seção 01, obtidas no $3^{\circ}$ dia de observação ...........100

Figura 87 - Acurácia e precisão das coordenadas na seção 01, obtidas no $4^{0}$ dia de observação ...........101

Figura 88 - Acurácia e precisão das coordenadas na seção 02, obtidas no $1^{\circ}$ dia de observação ...........101

Figura 89 - Acurácia e precisão das coordenadas na seção 02, obtidas no $2^{\circ}$ dia de observação ...........101

Figura 90 - Acurácia e precisão das coordenadas na seção 02, obtidas no $3^{\circ}$ dia de observação ...........102

Figura 91 - Acurácia e precisão das coordenadas na seção 02, obtidas no $4^{0}$ dia de observação ...........102

Figura 92 - Acurácia e precisão das coordenadas na seção 03, obtidas no $1^{\circ}$ dia de observação ...........102

Figura 93 - Acurácia e precisão das coordenadas na seção 03, obtidas no $2^{\circ}$ dia de observação ........... 103

Figura 94 - Acurácia e precisão das coordenadas na seção 03, obtidas no $3^{\circ}$ dia de observação ........... 103

Figura 95 - Acurácia e precisão das coordenadas na seção 03, obtidas no $4^{0}$ dia de observação ...........103

Figura 96 - Acurácia e precisão das coordenadas na seção 04, obtidas no $1^{\circ}$ dia de observação ...........104

Figura 97 - Acurácia e precisão das coordenadas na seção 04, obtidas no $2^{\circ}$ dia de observação ...........104

Figura 98 - Acurácia e precisão das coordenadas na seção 04, obtidas no $3^{\circ}$ dia de observação ...........104

Figura 99 - Acurácia e precisão das coordenadas na seção 04, obtidas no $4^{0}$ dia de observação ...........105

Figura 100 - Acurácia e precisão das coordenadas na seção 05, obtidas no $1^{\circ}$ dia de observação .........105

Figura 101 - Acurácia e precisão das coordenadas na seção 05, obtidas no $2^{\circ}$ dia de observação .........105

Figura 102 - Acurácia e precisão das coordenadas na seção 05, obtidas no $3^{\circ}$ dia de observação .........106

Figura 103 - Acurácia e precisão das coordenadas na seção 05, obtidas no $4^{0}$ dia de observação .........106

Figura 104 - Acurácia e precisão das coordenadas na seção 06, obtidas no $1^{\circ}$ dia de observação .........106

Figura 105 - Acurácia e precisão das coordenadas na seção 06, obtidas no $2^{\circ}$ dia de observação .........107 
Figura 106 - Acurácia e precisão das coordenadas na seção 06, obtidas no $3^{\circ}$ dia de observação .........107

Figura 107 - Acurácia e precisão das coordenadas na seção 06, obtidas no $4^{0}$ dia de observação .........107

Figura 108 - Acurácia e precisão das coordenadas na seção 07, obtidas no $1^{\circ}$ dia de observação .........108

Figura 109 - Acurácia e precisão das coordenadas na seção 07, obtidas no $2^{\circ}$ dia de observação .........108

Figura 110 - Acurácia e precisão das coordenadas na seção 07, obtidas no $3^{\circ}$ dia de observação .........108

Figura 111 - Acurácia e precisão das coordenadas na seção 07, obtidas no $4^{0}$ dia de observação .........109

Figura 112 - Índice Dst para os dias 26 e 27-03-2005 ......................................................................109

Figura 113 - Índice Dst para os dias 02 e 03-04-2005 ............................................................................109

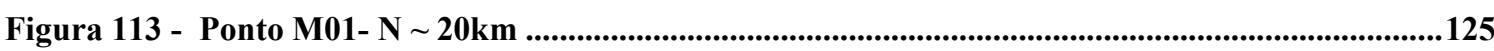

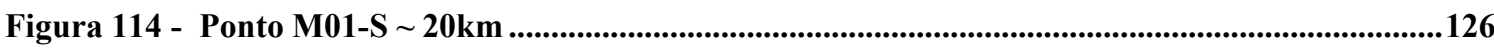

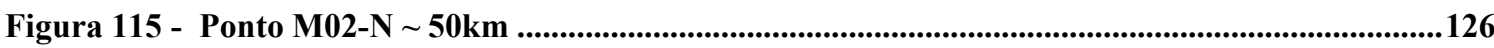

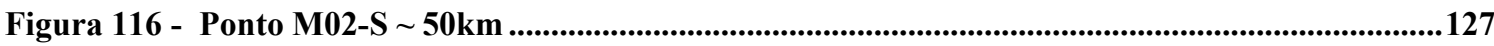

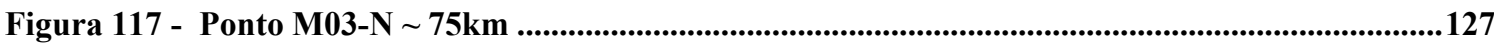

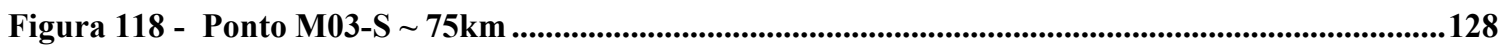

Figura 119 - Ponto M04-N 100km …................................................................................................128

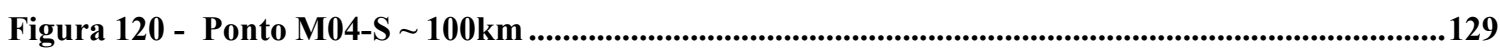

Figura 121 - Ponto M05-N 150km …...................................................................................................129

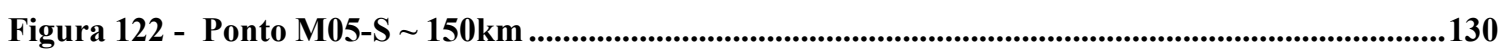

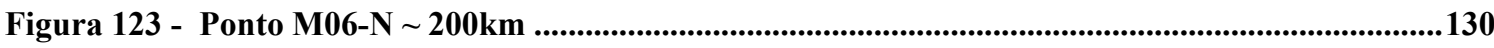

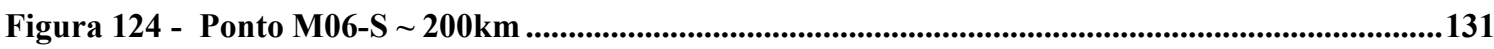

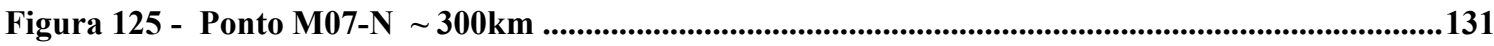

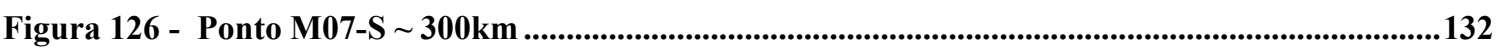

Figura 127 - Rastreio de dados em uma das estações de referência..........................................................133

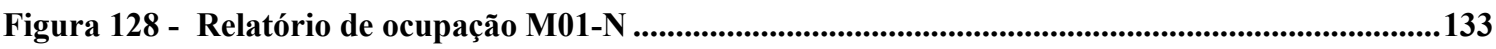

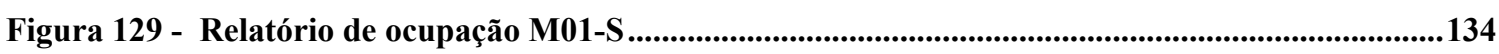

Figura 130 - Relatório de ocupação M02-N ..............................................................................................134

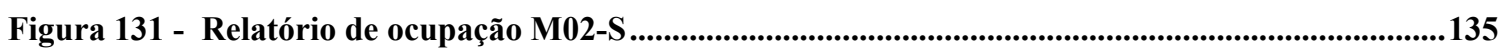

Figura 132 - Relatório de ocupação M03-N .........................................................................................................135

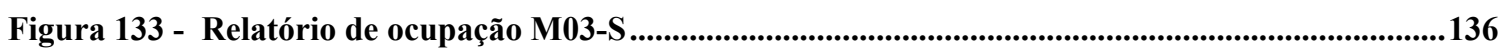

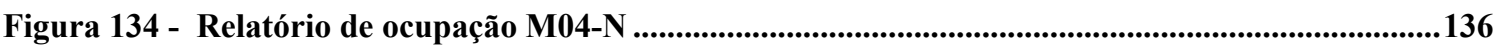

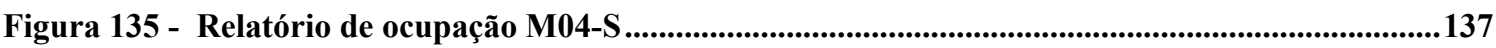

Figura 136 - Relatório de ocupação M05-N .....................................................................................137

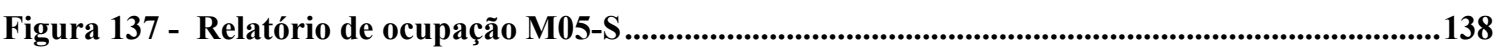

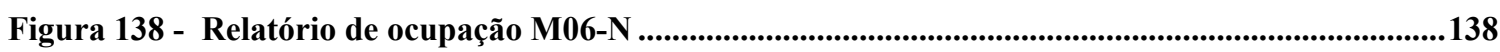

Figura 139 - Relatório de ocupação M06-S.................................................................................................139

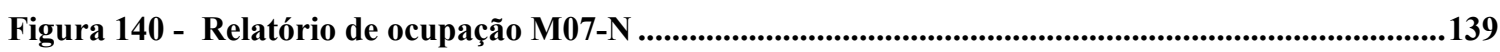

Figura 141 - Relatório de ocupação M07-S ...........................................................................................................140 


\section{LISTA DE TABELAS}

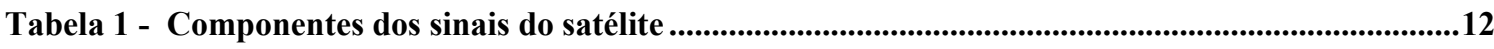

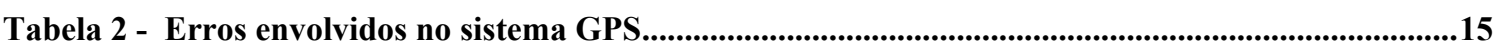

Tabela 3 - Nível de intensidade de tempestade magnética...........................................................20

Tabela 4 - Classificação da categoria dos receptores GPS quanto a sua precisão ......................................34

Tabela 5 - Relação entre tempo de ocupação e linha base em levantamentos de controle ........................62

Tabela 6 - Relação entre tempo de ocupação e comprimento da linha base .............................................62

Tabela 7 - Datas das campanhas de observações com receptores L1 .....................................................67

Tabela 8 - Coordenadas (em UTM - WGS 84) dos pontos de controle......................................................78

Tabela 9 - Erros de fechamento linear, nas direções Norte e Sul, do polígono formado pelos ..................79

Tabela 10 - Erros de fechamento do polígono formado pelos vetores (estação STTU / marcos)..............79

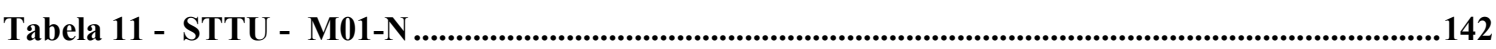

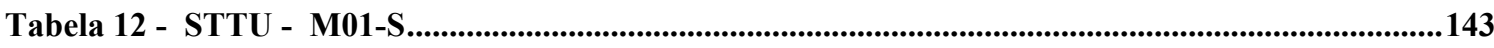

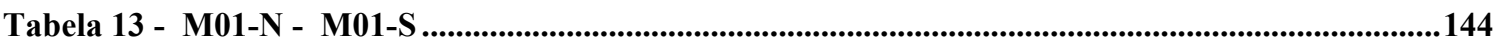

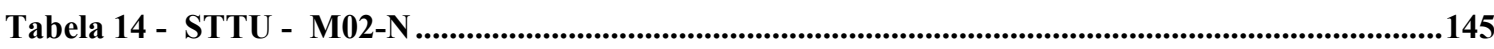

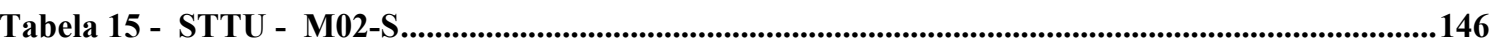

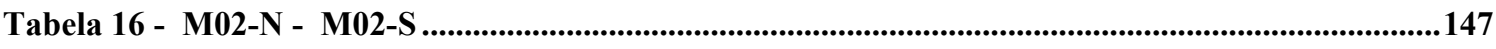

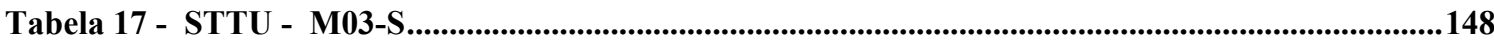

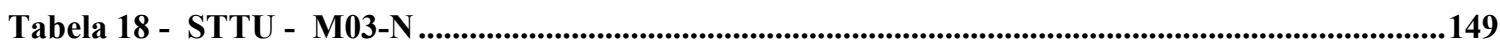

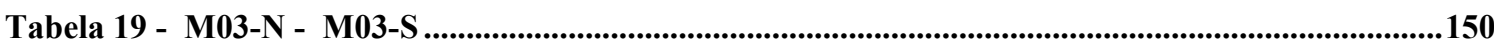

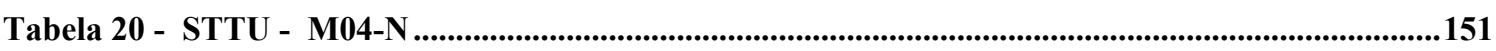

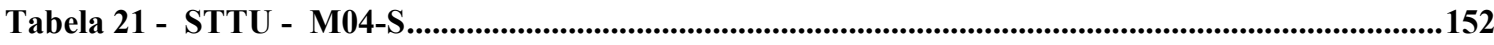

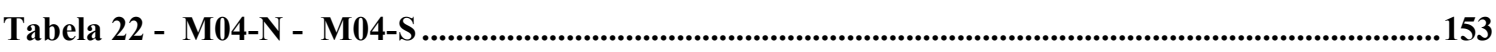

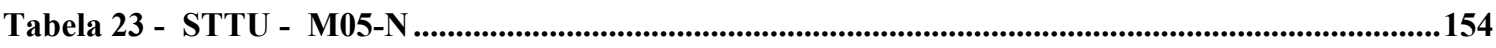

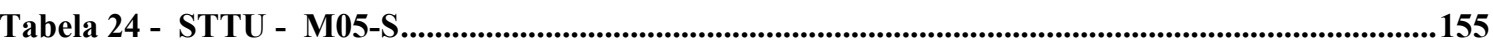

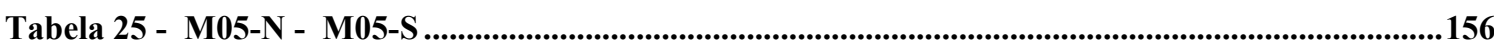

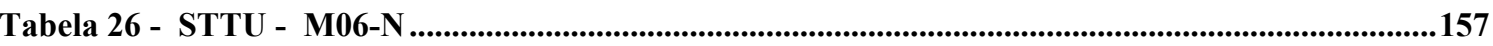

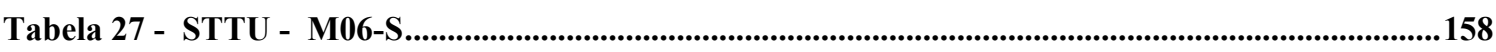

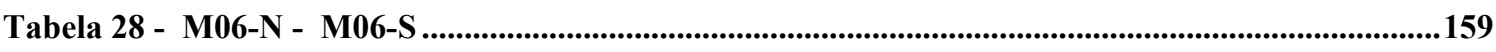

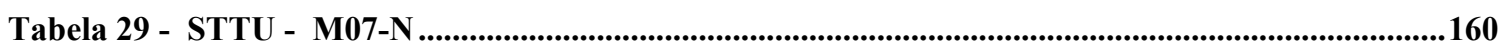

Tabela 30 - STTU - M07-S....................................................................................................................161

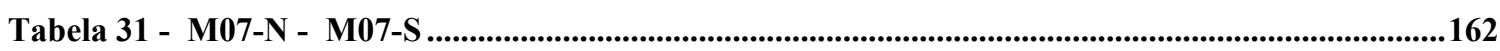

Tabela 32 - Resultados do Receptor A para 0 marco M01 20 km.......................................................164

Tabela 33 - Resultados do Receptor A para o marco M02 50 km.....................................................164

Tabela 34 - Resultados do Receptor A para 0 marco M03 75 km.......................................................164

Tabela 35 - Resultados do Receptor A para o marco M04 100 km.................................................165

Tabela 36 - Resultados do Receptor A para o marco M05 150 km..................................................165 
Tabela 37 - Resultados do Receptor A para o marco M06 200 km.....................................................165

Tabela 38 - Resultados do Receptor A para o marco M07 300 km..................................................165

Tabela 39 - Resultados do Receptor B, $1^{\circ}$ dia, para 0 marco M01 20 km ...........................................166

Tabela 40 - Resultados do Receptor B, $2^{\circ}$ dia, para 0 marco M01 20 km ..........................................166

Tabela 41 - Resultados do Receptor B, $1^{\circ}$ dia, para 0 marco $M 02 ~ 50$ km ..........................................167

Tabela 42 - Resultados do Receptor B, $2^{\circ}$ dia, para o marco M02 50 km ...........................................167

Tabela 43 - Resultados do Receptor B, $1^{\circ}$ dia, para 0 marco M03 75 km ...........................................167

Tabela 44 - Resultados do Receptor B, $2^{\circ}$ dia, para o marco M03 75 km ...........................................168

Tabela 45 - Resultados do Receptor B, $1^{\circ}$ dia, para 0 marco M04 100 km ........................................168

Tabela 46 - Resultados do Receptor B, $2^{\circ}$ dia, para o marco M04 100 km ........................................168

Tabela 47 - Resultados do Receptor B, $1^{\circ}$ dia, para o marco M05 150 km ........................................169

Tabela 48 - Resultados do Receptor B, $2^{\circ}$ dia, para 0 marco M05 150 km ........................................169

Tabela 49 - Resultados do Receptor B, $1^{\circ}$ dia, para 0 marco M06 200 km .......................................169

Tabela 50 - Resultados do Receptor B, $2^{\circ}$ dia, para 0 marco $M 06 \sim 200$ km ........................................170

Tabela 51 - Resultados do Receptor B, $1^{\circ}$ dia, para 0 marco M07 300 km ..........................................170

Tabela 52 - Resultados do Receptor B, $2^{\circ}$ dia, para o marco M07 300 km ...........................................170

Tabela 53 - Resultados do Receptor C, $1^{\circ}$ dia, para 0 marco M01 $\sim 20 \mathrm{~km} \quad\left(3^{\mathrm{a}}\right.$ Campanha)...............171

Tabela 54 - Resultados do Receptor C, $2^{\circ}$ dia, para o marco M01 20 km $\quad\left(3^{\text {a }}\right.$ Campanha)...............171

Tabela 55 - Resultados do Receptor C, $1^{\circ}$ dia, para o marco M01 $\sim 20$ km (4 Campanha)................171

Tabela 56 - Resultados do Receptor C, $2^{\circ}$ dia, para o marco M01 20 km (4 Campanha)...............172

Tabela 57 - Resultados do Receptor C, $1^{\circ}$ dia, para o marco M02 50 km (3 ${ }^{\text {a }}$ Campanha)................172

Tabela 58 - Resultados do Receptor C, $2^{\circ}$ dia, para 0 marco M02 50 km (3a Campanha)...............172

Tabela 59 - Resultados do Receptor C, $1^{\circ}$ dia, para o marco M02 50 km $\quad$ (4 $4^{\text {a }}$ Campanha)...............173

Tabela 60 - Resultados do Receptor C, $2^{\circ}$ dia, para 0 marco M02 50 km (4 ${ }^{\text {a }}$ Campanha)...............173

Tabela 61 - Resultados do Receptor C, $1^{\circ}$ dia, para 0 marco M03 75 km $\quad\left(3^{\text {a }}\right.$ Campanha)...............173

Tabela 62 - Resultados do Receptor C, $2^{\circ}$ dia, para 0 marco M03 75 km (3 Campanha)...............174

Tabela 63 - Resultados do Receptor C, $1^{\circ}$ dia, para o marco M03 75 km $\quad$ (4 Campanha)................174

Tabela 64 - Resultados do Receptor C, $2^{\circ}$ dia, para o marco M03 75 km (4 Campanha)................174

Tabela 65 - Resultados do Receptor C, $1^{\circ}$ dia, para o marco M04 100 km (3 ${ }^{\text {a }}$ Campanha)............... 175

Tabela 66 - Resultados do Receptor C, $2^{\circ}$ dia, para o marco M04 100 km (3a Campanha)...............175

Tabela 67 - Resultados do Receptor C, $1^{\circ}$ dia, para o marco M04 100 km (4 ${ }^{\text {a }}$ Campanha)...............175

Tabela 68 - Resultados do Receptor C, $2^{\circ}$ dia, para o marco M04 100 km (4 $4^{\text {a }}$ Campanha)................176

Tabela 69 - Resultados do Receptor C, $1^{\circ}$ dia, para o marco M05 $150 \mathrm{~km}\left(3^{\mathrm{a}}\right.$ Campanha)...............176

Tabela 70 - Resultados do Receptor C, $2^{\circ}$ dia, para o marco M05 150 km (3 ${ }^{\text {a }}$ Campanha)...............176

Tabela 71 - Resultados do Receptor C, $1^{\circ}$ dia, para o marco M05 150 km (4 Campanha)...............177

Tabela 72 - Resultados do Receptor C, $2^{\circ}$ dia, para o marco M05 150 km (4 Campanha)................177

Tabela 73 - Resultados do Receptor C, $1^{\circ}$ dia, para 0 marco M06 200 km (3 Campanha)...............177

Tabela 74 - Resultados do Receptor C, $2^{\circ}$ dia, para o marco M06 200 km (3 ${ }^{\text {a }}$ Campanha)...............178 
Tabela 75 - Resultados do Receptor C, $1^{\circ}$ dia, para o marco M06 200 km (4 Campanha)...............178

Tabela 76 - Resultados do Receptor C, $2^{\circ}$ dia, para o marco M06 200 km (4 Campanha)................178

Tabela 77 - Resultados do Receptor C, $1^{\circ}$ dia, para o marco M07 300 km (3 ${ }^{\text {a }}$ Campanha)..............179

Tabela 78 - Resultados do Receptor C, $2^{\circ}$ dia, para o marco M07 300 km (3a Campanha)...............179

Tabela 79 - Resultados do Receptor C, $1^{\circ}$ dia, para o marco M07 300 km (4 Campanha)...............179

Tabela 80 - Resultados do Receptor C, $2^{\circ}$ dia, para o marco M07 300 km (4 ${ }^{\text {a }}$ Campanha)................180

Tabela 81 - Resultados do Receptor D, $1^{\circ}$ dia, para o marco M01 $\sim 20 \mathrm{~km} \quad\left(3^{\mathrm{a}}\right.$ Campanha)................180

Tabela 82 - Resultados do Receptor D, $2^{\circ}$ dia, para 0 marco M01 20 km (3a Campanha)................180

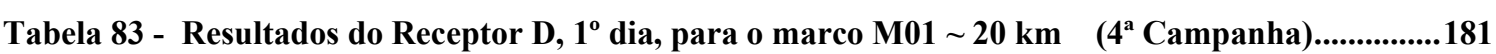

Tabela 84 - Resultados do Receptor D, $2^{\circ}$ dia, para 0 marco M01 $\sim 20 \mathrm{~km} \quad$ (4 $4^{\text {a }}$ Campanha)................181

Tabela 85 - Resultados do Receptor D, $1^{\circ}$ dia, para 0 marco M02 50 km $\quad\left(3^{\text {a }}\right.$ Campanha)...............181

Tabela 86 - Resultados do Receptor D, $2^{\circ}$ dia, para 0 marco M02 $\sim 50 \mathrm{~km} \quad\left(3^{\mathrm{a}}\right.$ Campanha)...............182

Tabela 87 - Resultados do Receptor D, $1^{\circ}$ dia, para 0 marco $M 02 \sim 50$ km (4 Campanha)................182

Tabela 88 - Resultados do Receptor D, $2^{\circ}$ dia, para o marco M02 $\sim 50 \mathrm{~km} \quad$ (4 Campanha)................182

Tabela 89 - Resultados do Receptor D, $1^{\circ}$ dia, para 0 marco M03 75 km $\quad\left(3^{\text {a }}\right.$ Campanha)...............183

Tabela 90 - Resultados do Receptor D, $2^{\circ}$ dia, para o marco M03 75 km $\quad\left(3^{\text {a }}\right.$ Campanha)...............183

Tabela 91 - Resultados do Receptor D, $1^{\circ}$ dia, para 0 marco M03 75 km (4a Campanha)...............183

Tabela 92 - Resultados do Receptor D, $2^{\circ}$ dia, para o marco M03 75 km $\quad\left(4^{\text {a }}\right.$ Campanha)...............184

Tabela 93 - Resultados do Receptor D, $1^{\circ}$ dia, para 0 marco M04 100 km (3a Campanha)................184

Tabela 94 - Resultados do Receptor D, $2^{\circ}$ dia, para 0 marco $M 04 \sim 100$ km (3 ${ }^{\text {a }}$ Campanha)...............184

Tabela 95 - Resultados do Receptor D, $1^{\circ}$ dia, para o marco M04 100 km (4 ${ }^{\text {a }}$ Campanha)................185

Tabela 96 - Resultados do Receptor D, $2^{\circ}$ dia, para 0 marco $M 04 \sim 100$ km (4 ${ }^{\text {a }}$ Campanha)...............185

Tabela 97 - Resultados do Receptor D, $1^{\circ}$ dia, para 0 marco M05 150 km ( $3^{\text {a }}$ Campanha)...............185

Tabela 98 - Resultados do Receptor D, $2^{\circ}$ dia, para 0 marco M05 150 km (3a Campanha)...............186

Tabela 99 - Resultados do Receptor D, $1^{\circ}$ dia, para 0 marco M05 150 km (4 Campanha)...............186

Tabela 100 - Resultados do Receptor D, $2^{\circ}$ dia, para 0 marco M05 150 km (4 Campanha)..............186

Tabela 101 - Resultados do Receptor D, $1^{\circ}$ dia, para o marco M06 200 km (3 ${ }^{\text {a }}$ Campanha)..............187

Tabela 102 - Resultados do Receptor D, $2^{\circ}$ dia, para 0 marco M06 200 km (3 ${ }^{\text {a }}$ Campanha)..............187

Tabela 103 - Resultados do Receptor D, $1^{\circ}$ dia, para 0 marco M06 200 km (4 Campanha)..............187

Tabela 104 - Resultados do Receptor D, $2^{\circ}$ dia, para 0 marco M06 200 km (4 Campanha).............188

Tabela 105 - Resultados do Receptor D, $1^{\circ}$ dia, para 0 marco M07 300 km ( $3^{\text {a }}$ Campanha).............188

Tabela 106 - Resultados do Receptor D, $2^{\circ}$ dia, para o marco M07 300 km (3 ${ }^{\text {a }}$ Campanha).............188

Tabela 107 - Resultados do Receptor D, $1^{\circ}$ dia, para o marco M07 300 km (4 $4^{\text {a }}$ Campanha)..............189

Tabela 108 - Resultados do Receptor D, $2^{\circ}$ dia, para o marco M07 300 km (4 Campanha)..............189 


\section{LISTA DE ABREVIATURAS E SIGLAS}

$\begin{array}{ll}\text { AAF } & \text { American Air Force - USA } \\ \text { ABNT } & \text { Associação Brasileira de Normas Técnicas } \\ \text { AS } & \text { Antispoofing } \\ \text { C/A-code } & \text { Coarse/Acquisition Code (1.023Mhz) } \\ \text { CONFEA } & \text { Conselho Federal de Engenharia Arquitetura e Agronomia } \\ \text { DGPS } & \text { Differential GPS } \\ \text { DoD } & \text { United States Department of Defense } \\ \text { DOP } & \text { Dilution of Precision } \\ \text { Dst } & \text { Disturbance Storm Time Index } \\ \text { EQA } & \text { European Quality Award } \\ \text { FGCC } & \text { Federal Geodetic Control Committee - USA } \\ \text { FGDC } & \text { Federal Geographic Data Committee - USA } \\ \text { GDOP } & \text { Geometric Dilution of Precision } \\ \text { GLONASS } & \text { Global'naya Navigatsionnaya Sputnikkovaya Sistema } \\ \text { GNSS } & \text { Global Navigation Sattelite System } \\ \text { GPS } & \text { Global Positioning System } \\ \text { GQ } & \text { Garantia de Qualidade } \\ \text { HDOP } & \text { Horizontal Dilution of Precision } \\ \text { HD } & \text { Hard Disk } \\ \text { I/O } & \text { Input / Output } \\ \text { IBGE } & \text { Instituto Brasileiro de Geografia e Estatística } \\ \text { INCRA } & \text { Instituto Nacional de Colonização e Reforma Agrária } \\ \text { L1 } & \text { Portadora L1 (freqüência de 1575,42 Mhz) } \\ \text { L2 } & \text { Portadora L2 (freqüência de 1227,6 Mhz) } \\ \text { L5 } & \text { Portadora L5 (freqüência de 1176,45 Mhz) } \\ \text { NAVSTAR } & \text { Navigation Satellite Timing and Ranging } \\ \text { P-code } & \text { Precision Code (10,23 Mhz) } \\ \text { PDGPS } & \text { Precise Differential Global Positioning System. } \\ \text { PDOP } & \text { Positional Dilution of Precision } \\ \text { ppm } & \text { Partes por Milhão } \\ \text { PPS } & \text { Precise Positioning Service } \\ \text { PRN } & \text { Pseudorandon Noise } \\ \text { RF } & \text { Radio Frequency } \\ \text { RHCP } & \text { Right-Hand Circularly Polarized } \\ \text { RIBAC } & \text { Rede Incra de Bases de Apoio Comunitário } \\ \text { RINEX } & \text { Receiver Independent Exchange Format } \\ & \end{array}$


RTK Real-time Kinemetic Positioning

SA Selective Availability

SIG Sistema de Informação Geográfica

SPS Standard Positioning Service

TDOP Time Dilution of Precision

TQC Total Quality Control

TQM Total Quality Management

TRANSIT Navy Navigation Satellite System

UTC Coordinate Universal Time

USAF - JPO United States Air Force Joint Program Office

VDOP Vertical Dilution of Precision

WADGPS Wide Area Differential GPS

WGS 84 World Geodetic System of 1984

Y-code Encrypted P-code 


\section{SUMÁRIO}

1. INTRODUÇÃO... $\ldots 1$

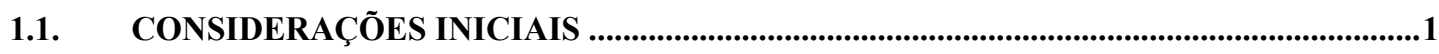

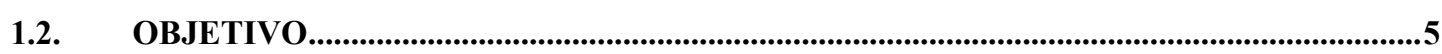

1.3. JUSTIFICATIVA E MOTIVAÇÃO DA PESQUISA ..........................................................

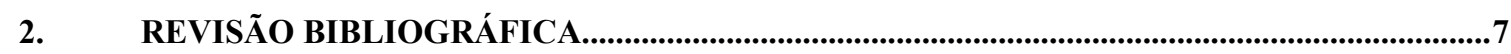

2.1. INTRODUÇÃO AO SISTEMA GNSS ............................................................................

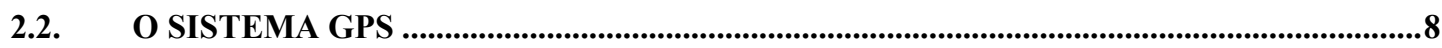

2.3. SINAIS TRANSMITIDOS PELOS SATÉLITES DO SISTEMA GPS ................................11

2.4. ERROS INERENTES AO SISTEMA GPS ..............................................................14

2.4.1. ERRO OCASIONADO PELA REFRAÇÃO IONOSFÉRICA .........................................15

2.4.2. ERRO OCASIONADO PELA REFRAÇÃO TROPOSFÉRICA.......................................16

2.4.3. PERDA DE CICLO ...............................................................................................

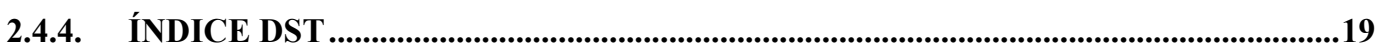

2.5. CONCEITOS DE PRECISÃO E ACURÁCIA .................................................................20

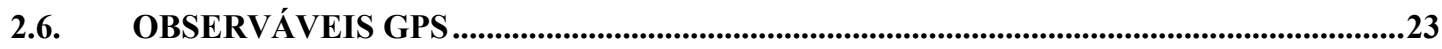

2.6.1. A PSEUDODISTÂNCIA...........................................................................................24

2.6.2. FASE DA PORTADORA......................................................................................................27

2.7. MÉTODO DE POSICIONAMENTO ........................................................................................29

2.7.1. PRINCÍPIO BÁSICO DO POSICIONAMENTO GPS ..................................................29

2.7.2. POSICIONAMENTO RELATIVO .................................................................................30

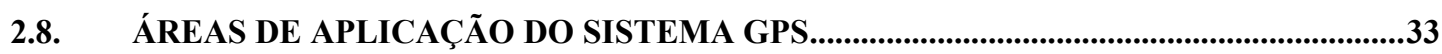

2.9. CLASSIFICAÇÃO QUANTO AO TIPO DOS RECEPTORES GPS ......................................35

2.9.1. RECEPTOR PARA NAVEGAÇÃO (CÓDIGO)...................................................................36

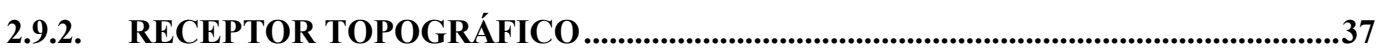


2.9.3. RECEPTOR GEODÉSICO...........................................................................................38

2.10. ESPECIFICAÇÕES E NORMAS PARA O USO DO SISTEMA GPS .................................40

2.10.1. NORMAS BRASILEIRA.......................................................................................................41

2.10.2. NORMAS INTERNACIONAIS ....................................................................................44

3. SUAVIZAÇÃO DO CÓDIGO PELA FASE DA PORTADORA ..................................................46

4. INSTRUMENTAÇÃO E PROCEDIMENTOS UTILIZADOS................................................53

4.1. DEFINIÇÃO DO LOCAL PARA IMPLANTAÇÃO DOS MARCOS DE CONTROLE...53

4.2. RECONHECIMENTO E MATERIALIZAÇÃO DOS MARCOS DE CONTROLE ...........55

4.2.1. RECONHECIMENTO DO LOCAL DE ESTUDO...........................................................55

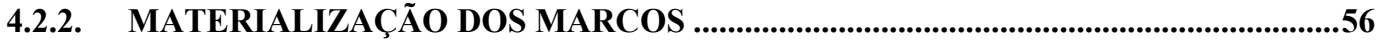

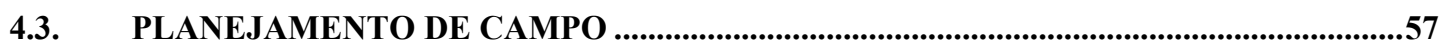

4.3.1. PLANEJAMENTO DA COLETA DE DADOS................................................................57

4.4. POSICIONAMENTO POR GPS.................................................................................................60

4.4.1. RASTREAMENTO COM GPS DE DUPLA FREQÜÊNCIA (L1/L2)...........................60

4.4.2. RASTREAMENTO COM GPS DE SIMPLES FREQÜÊNCIA (L1)..............................63

4.5. CAMPANHAS DE POSICIONAMENTO COM RECEPTORES GPS DE SIMPLES

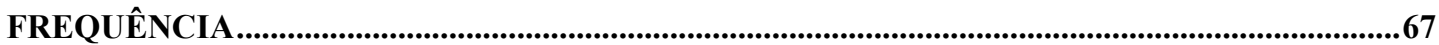

4.6. ARMAZENAMENTO DOS DADOS................................................................................68

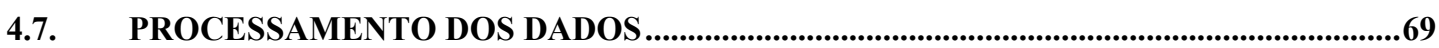

4.7.1. PROCESSAMENTO DAS OBSERVAÇÕES DOS PONTOS DE CONTROLE ..........69

4.7.2. PROCESSAMENTO DAS OBSERVAÇÕES DOS PONTOS DE CONTROLE COM RECEPTORES L1 1...................................................................................................................

4.7.3. AVALIAÇÃO DAS COORDENADAS DOS PONTOS DE CONTROLE......................72

4.7.4. ESTRATÉGIAS DE PROCESSAMENTO NO MÉTODO “ESTÁTICO RÁPIDO”..73

4.8. A ESTAÇÃO DE REFERÊNCIA UTILIZADA........................................................................75 


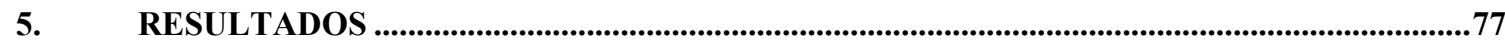

5.1. COORDENADAS DOS PONTOS DE CONTROLE (L1/L2) ..............................................77

5.2. ACURÁCIA E PRECISÃO OBTIDAS COM RECEPTORES DE UMA FREQÜÊNCIA 80 5.2.1. RECEPTOR A - RESULTADOS OBTIDOS .....................................................................81

5.2.2. RECEPTOR B - RESULTADOS OBTIDOS .....................................................................84

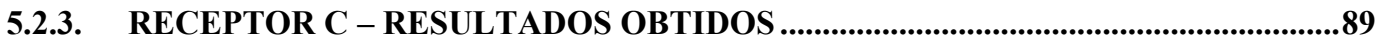

5.2.4. RECEPTOR D - RESULTADOS OBTIDOS ………..........................................................99

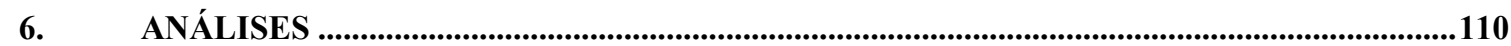

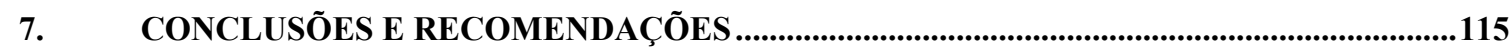

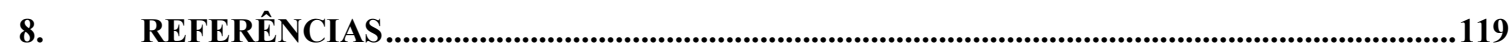

APÊNDICE A - REGISTROS DE CAMPO COM GPS (L1/L2)_.......................................................124

APÊNDICE B - RELATÓRIOS DE PROCESSAMENTO (L1/L2).......................................................141

APÊNDICE C - TABELAS DAS DISCREPÂNCIAS DAS COORDENADAS OBTIDAS COM OS

RECEPTORES L1 E SUAS RESPECTIVAS PRECISÕES.............................................................163 


\section{INTRODUÇÃO}

Este trabalho apresenta um estudo sobre a discrepância da acurácia e da precisão de coordenadas obtidas a partir das observações feitas com receptor GPS de uma freqüência, utilizando o código suavizado pela fase da portadora.

\subsection{CONSIDERAÇÕES INICIAIS}

O Sistema de Posicionamento Global (GPS) ${ }^{1}$ vem se consolidando ultimamente como uma ferramenta indispensável para o posicionamento de pontos na superfície terrestre, principalmente nas áreas da engenharia que trabalham com o georreferenciamento. Assuntos sobre referenciamento geográfico ou navegação dificilmente serão tratados sem trazer à memória esse sistema de posicionamento. O sistema GPS, com suas limitações de uso, permite a determinação da posição de pontos e a velocidade de objetos na superfície terrestre ou em suas proximidades, tomadas em um sistema de referência definido em relação ao centro de massa da Terra.

\footnotetext{
${ }^{1}$ Sigla que vem do inglês e que significa Global Positioning System
} 
O georreferenciamento com o uso dos satélites artificiais tem substituído, com eficiência, os métodos tradicionais como a astronomia de posição (pouco utilizada nos dias atuais), bem como as técnicas de triangulação e trilateração usadas nos procedimentos de implantação de redes geodésicas. O advento dessa geotecnologia veio racionar o tempo despendido nesses trabalhos e fornecer maior confiabilidade nas medidas resultantes de tal processo.

Nas redes geodésicas clássicas, todas as coordenadas de seus vértices são relacionadas a um único ponto do sistema. Esse ponto é chamado de datum horizontal. Nele, as coordenadas, latitude e longitude, assim como o azimute de uma linha de base, até há pouco tempo eram determinadas pela astronomia de posição. Recentemente, essa operação tem sido feita utilizando-se a Geodésia Espacial, com maior eficácia e menor tempo de trabalho.

O emprego do GPS nos trabalhos para georreferenciamento possibilita obter coordenadas acuradas e precisas ${ }^{2}$ nos processos de cadastramento ou recadastramento fundiário. No entanto, deve-se destacar que embora esse sistema esteja disponível para toda comunidade civil, há necessidade de um maior empenho e mobilização do governo junto aos órgãos responsáveis, no que diz respeito à forma de cadastramento dos imóveis rurais, como também à criação das diretrizes básicas a serem seguidas para que tal tecnologia seja aplicada de forma apropriada pelos profissionais da área. Um primeiro passo nesse sentido já foi dado com a sanção da Lei 10.267/01 (BRASIL, 2001), a qual rege as diretrizes

\footnotetext{
${ }^{2}$ Os conceitos de precisão e acurácia serão abordados no item 2.7.
} 
e procedimentos para a realização do cadastro nacional dos imóveis rurais de forma global (georreferenciamento), como também o controle territorial do Brasil. Essa nova lei obriga os proprietários de imóveis rurais de todo o país a cadastrarem suas propriedades conforme as especificações da norma emergente.

O receptor GPS é, sem dúvida, o equipamento mais adequado para o georreferenciamento. Deve-se ressaltar, entretanto, que embora esse equipamento possibilite maior eficiência nas medições, ele possui suas limitações em função da técnica aplicada e do tipo de equipamento utilizado (se uma ou duas freqüências); do comprimento da linha de base ou do tempo de observação, além das condições de contorno dos locais de medição, principalmente com relação à influência de multicaminhamentos.

Como é de conhecimento dos profissionais da área de Mensuração, o posicionamento com receptores de dupla freqüência, no que diz respeito à qualidade das observações e à qualidade das coordenadas determinadas, são mais confiáveis que os receptores de uma freqüência. Porém, deve-se ressaltar que devido ao custo dos equipamentos de uma freqüência, que na maioria dos casos é metade do valor de um equipamento de dupla freqüência, eles são muitas vezes escolhidos por usuários com poucos recursos financeiros ou com certo desconhecimento teórico do sistema GPS.

Basicamente, as observações armazenadas pelos receptores GPS (uma ou duas freqüências) consistem de informações sobre as fases das portadoras L1 e/ou L2 e de informações sobre os códigos C/A e/ou P. No caso de receptores de duas freqüências, as observações para o posicionamento preciso consistem das 
fases das portadoras L1, L2 e dos códigos C/A e P. Já, no caso dos receptores de uma freqüência, eles consistem da fase portadora L1 e do código C/A.

No caso dos receptores de uma freqüência, a determinação das coordenadas terrestres é feita considerando-se apenas a portadora $\mathrm{L} 1$, o código C/A ou uma combinação linear entre a portadora L1 e o código C/A, denominada de "Suavização do Código pela Portadora". Essa técnica foi primeiramente observada por Ronald Ron Hatch $(\mathrm{HATCH}, 1982)$ e, por isso, é conhecida mundialmente como "Filtro de Hatch". Outros autores, tais como LARSON (1986), LACHAPELLE (1995), MEYERHOFF e EVANS (1986) e TEUNISSEN (1991) (HOFMANN-WELLENHOF, 2001), propuseram modificações no algoritmo original, o que permitiu melhora significativa de sua eficiência.

A discussão sobre o Filtro de Hatch tornou-se importante no Brasil a partir da promulgação da Lei $10.267 / 01$, pois a Norma que regulamenta tal lei permite a utilização desse filtro na determinação das coordenadas para cadastramento rural. A Norma explicita que a acurácia de um ponto de cadastro, determinado com GPS, deve ser menor ou igual a $50 \mathrm{~cm}$. A questão que veio à tona desde então é saber se realmente o Filtro de Hatch permite alcançar tal acurácia e sob quais condições ela poderá ser alcançada. 


\subsection{OBJETIVO}

Esta dissertação possui dois objetivos principais. O primeiro é o estudo sobre a teoria de suavização do código pela portadora, conforme observado por HATCH (1982) e seus seguidores. O segundo objetivo é a realização de uma série de experimentos de campo, com diversas marcas de receptores de uma freqüência para determinar os limites práticos de aplicação da teoria de suavização do código pela portadora, considerando-se as restrições impostas pela Norma Técnica para Georreferenciamento Rurais.

\subsection{JUSTIFICATIVA E MOTIVAÇÃO DA PESQUISA}

Com o sancionamento da Lei 10.267/INCRA (BRASIL, 2001), que trata da obrigatoriedade do cadastro dos imóveis rurais no Brasil, foram apresentados técnicas e instrumentos a serem empregados para se fazer o georreferenciamento. Entre os equipamentos permitidos para uso nesses serviços, o receptor GPS de uma freqüência foi liberado para uso em "Apoio Geodésico" e para "Levantamento de Perímetro" (INCRA, 2003).

A Norma técnica do INCRA (INCRA, 2003) permite a utilização da "combinação linear" da fase da portadora L1 com o código C/A para os cálculos das coordenadas, no que tange ao georreferenciamento, e descreve as principais condições a serem observadas para que se possa alcançar uma acurácia melhor ou igual a $50 \mathrm{~cm}$ utilizando processo de levantamento por GPS. Porém, a técnica de medição por meio do sistema GPS a partir do código C/A, mesmo com a suavização da portadora em L1, não é um processo que garante a qualidade dos 
resultados obtidos; a própria Norma indica que, em caso de dúvida, deve-se adotar as recomendações do fabricante do instrumento GPS. Essa asserção da Norma, infelizmente, tem provocado indefinições sobre o tipo de equipamento a ser usado e, principalmente, sobre a distância e o tempo de observação que se deve ter para garantir a acurácia desejada.

Alguns profissionais, que trabalham com GPS de uma freqüência e fazem uso do Filtro de Hatch no pós-processamento, têm argumentado que algumas coordenadas estão variando mais de $50 \mathrm{~cm}$ em um mesmo ponto, considerandose os dados das observáveis coletadas em dias diferentes. Também têm questionado o valor máximo para o comprimento da linha de base, com o qual se possa trabalhar seguramente para alcançar-se a acurácia exigida pela Norma.

Devido aos questionamentos e divergências de opiniões sobre o assunto, viu-se a necessidade de um trabalho prático e teórico sobre as questões que envolve essa metodologia de trabalho. Portanto, este trabalho servirá para tirar eventuais dúvidas com relação aos níveis de exatidão e precisão que se possam alcançar com os receptores de uma freqüência, fazendo uso da combinação linear do código com a fase da portadora em diferentes comprimentos de linha base e nas condições disponibilizadas pela Norma. 


\section{REVISÃO BIBLIOGRÁFICA}

\subsection{INTRODUÇÃO AO SISTEMA GNSS}

O GNSS (Global Navegation Satellite System) é um sistema composto por outros "sistemas" cuja estrutura é formada por satélites e outros segmentos, os quais são utilizados para determinar a posição geográfica de qualquer ponto na superfície terrestre, desde que respeitada suas limitações. Atualmente há em operação dois sistemas de posicionamento global compondo o GNSS: o americano NAVSTAR-GPS e o russo GLONASS (Global'naya Navigatsionnaya Sputnikkovaya Sistema), ambos públicos e de domínio do estado. Um outro sistema denominado GALILEO da iniciativa privada está em desenvolvimento pela comunidade civil européia e por parcerias com outros países de outros continentes; o primeiro satélite (GSTB-V2A) deste sistema foi lançado em 28 de dezembro de 2005. Países, como a China e o Japão, também já demonstraram interesse em desenvolver seus próprios sistemas. Quando o sistema GALILEO fizer parte do GNSS, ele será denominado com GNSS GGG. Dos sistemas que compõe o GNSS, o GPS será o único utilizado nos trabalhos dessa pesquisa, pois os receptores e programas utilizados fazem uso somente dele. 


\subsection{O SISTEMA GPS}

No início dos anos 70, o Departamento de Defesa dos Estados Unidos, por meio de um programa oficial governamental denominado $\mathrm{JPO}^{3}$ (Joint Program Office), desenvolveu um novo sistema de navegação por satélites, ao qual deu o nome de Global Positioning System - GPS. Esse novo sistema tinha como objetivo a melhora da precisão no posicionamento militar e na medida do tempo (SEGANTINE, 2005). Porém, com a descoberta das vantagens do sistema também para o uso civil, ele foi aberto para esse setor com algumas limitações. Mesmo com as restrições iniciais, a expansão do uso desse novo sistema de posicionamento pela comunidade civil foi surpreendente, fato que obrigou os órgãos responsáveis a suspenderem parte das restrições como, por exemplo, a Disponibilidade Seletiva - SA ${ }^{4}$ (Selective Avaibility).

O sistema GPS possibilita ao usuário determinar as coordenadas tridimensionais em qualquer ponto da Terra ou em suas proximidades, com poucas limitações de uso. Esse sistema foi nominalmente patenteado como NAVSTAR-GPS (Navigation System with Time And Ranging - GPS) e trata-se de um sistema integrado por satélites artificiais orbitando ao redor da Terra, a cerca de $20.800 \mathrm{~km}$, e transmitindo sinais de ondas de rádio, as quais permitem obter posicionamento global em 3 dimensões (PARKINSON, 1996).

\footnotetext{
${ }^{3}$ Programa unido pela Força Aérea Espacial e Organização de Mísseis.

${ }^{4}$ Desativada às 4 horas (sistema universal de tempo) do dia 02 de maio de 2000.
} 
O GPS disponibiliza dois tipos de serviços para posicionamento e navegação, esses serviços são conhecidos como SPS ${ }^{5}$ (Serviço de Posicionamento Padrão) e PPS ${ }^{6}$ (Serviço de Posicionamento Preciso). O SPS é destinado aos usuários civis e o PPS é destinado, exclusivamente, aos militares americanos e usuários (civis) autorizados. Ambos utilizam as fases das portadoras e dos códigos emitidos pelos satélites. A diferença ente eles é que o serviço PPS alcança maior acurácia no posicionamento absoluto que o serviço SPS.

O posicionamento com GPS consiste na determinação das coordenadas do centro de fase da antena de um receptor, que capta os sinais enviados pelos satélites do sistema GPS. Ele baseia-se no princípio da medição das distâncias entre os satélites e a antena do receptor. Conhecendo-se as coordenadas dos satélites, em um sistema de referência apropriado, é possível calcular as coordenadas do ponto sobre o qual se encontra a antena do receptor GPS, no mesmo sistema de referência. Trata-se fundamentalmente de um problema de ressecção espacial, o qual será geometricamente definido desde que se conheçam as coordenadas de 3 satélites e as distâncias entre eles e o ponto a ser determinado. $\mathrm{Na}$ prática, entretanto, o modelo matemático adotado para a determinação das coordenadas do ponto na superfície da Terra exige a inserção de uma incógnita adicional (dt). Essa incógnita corresponde ao erro de não sincronismo do relógio do receptor com o sistema de tempo GPS. Dessa forma, torna-se necessária a inclusão dos sinais de um quarto satélite para a

\footnotetext{
${ }^{5}$ Standard Positioning Service.

${ }^{6}$ Precise Positioning Service.
} 
determinação de uma posição, na superfície terrestre.

A distância entre cada satélite e a antena do receptor GPS pode ser vista pela Figura 01, ou calculada de acordo com a Equação 1 apresentada a seguir:

$$
\begin{aligned}
& \mathrm{r}_{\mathrm{a}}^{\mathrm{s}}=\mathrm{c}\left|\left(\mathrm{t}_{\mathrm{r}}+\mathrm{dt}\right)-\left(\mathrm{t}^{\mathrm{e}}+\mathrm{dT}\right)=\right| \overrightarrow{\mathrm{r}}_{\mathrm{S}}-\overrightarrow{\mathrm{r}}_{\mathrm{A}} \mid+\mathrm{cdt}-\mathrm{cdT}= \\
& {\left[\left(\mathrm{x}_{\mathrm{s}}-\mathrm{x}_{\mathrm{a}}\right)^{2}+\left(\mathrm{y}_{\mathrm{s}}-\mathrm{y}_{\mathrm{a}}\right)^{2}+\left(\mathrm{z}_{\mathrm{s}}-\mathrm{z}_{\mathrm{a}}\right)^{2}\right]^{1 / 2}+\mathrm{c}(\mathrm{dt}-\mathrm{dT})} \\
& \text { onde: }
\end{aligned}
$$

$\mathrm{r}_{\mathrm{a}}^{\mathrm{s}}$ : distância entre a antena do receptor " $\mathrm{A}$ " e o satélite " $\mathrm{S}$ ";

c: velocidade da luz;

$t_{r}$ : instante de recepção do sinal;

$\mathrm{t}^{\mathrm{e}}$ : instante de emissão do sinal;

dt: erro do relógio do receptor;

dT: erro do relógio do satélite;

$\mathrm{X}_{\mathrm{s}}$ : coordenada cartesiana do satélite na abscissa;

$\mathrm{X}_{\mathrm{a}}$ : coordenada cartesiana da antena na abscissa;

$Y_{s}$ : coordenada cartesiana do satélite na ordenada;

$\mathrm{Y}_{\mathrm{a}}$ : coordenada cartesiana da antena na ordenada;

$Z_{s}$ : coordenada cartesiana do satélite na altura; e

$\mathrm{Z}_{\mathrm{a}}$ : coordenada cartesiana da antena na altura.

As distâncias entre os satélites e a antena do receptor GPS (podendo ser vista na Figura 1) podem ser determinadas a partir da medição do tempo de

${ }^{7} \mathrm{c}=299792458 \mathrm{~m} / \mathrm{s}^{-1}$ 
percurso do sinal codificado, multiplicado pela velocidade da luz ou pela contagem dos ciclos de fase da portadora do sinal. A determinação do vetor-posição dos satélites rastreados no instante $\mathrm{t}^{\mathrm{e}}$ requer o conhecimento da dinâmica dos satélites contida nas "efemérides transmitidas", incluídas nos sinais dos satélites (SEEBER, 1993 apud SANTOS, 2005).

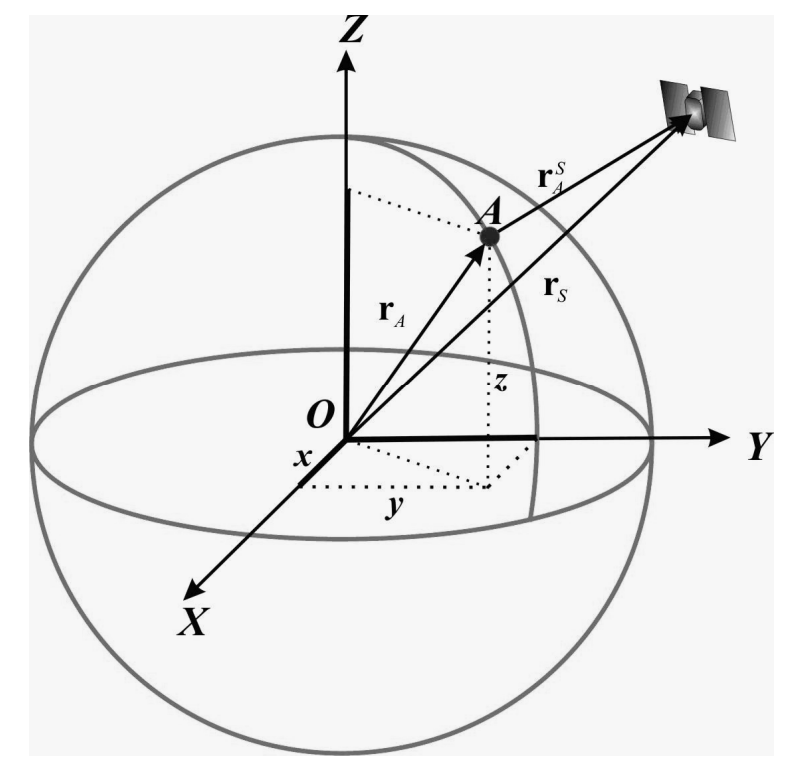

Figura 1 - Princípio básico do posicionamento por GPS

\subsection{SINAIS TRANSMITIDOS PELOS SATÉLITES DO SISTEMA GPS}

A geração dos sinais transmitidos pelos satélites do sistema GPS é feita a partir do uso de osciladores estáveis. Tais osciladores possibilitam a geração de uma freqüência fundamental $\left(f_{o}\right)$ de $10,23 \mathrm{MHz}$, da qual são geradas duas portadoras na banda $L$ (fixada na banda de ondas de rádio, na escala do espectro eletromagnético) (SEEBER, 2003). Essas duas portadoras são conhecidas como L1 e L2 e são obtidas por multiplicadores inteiros 154 e 120, respectivamente à freqüência fundamental, conforme mostra a Figura 2. 


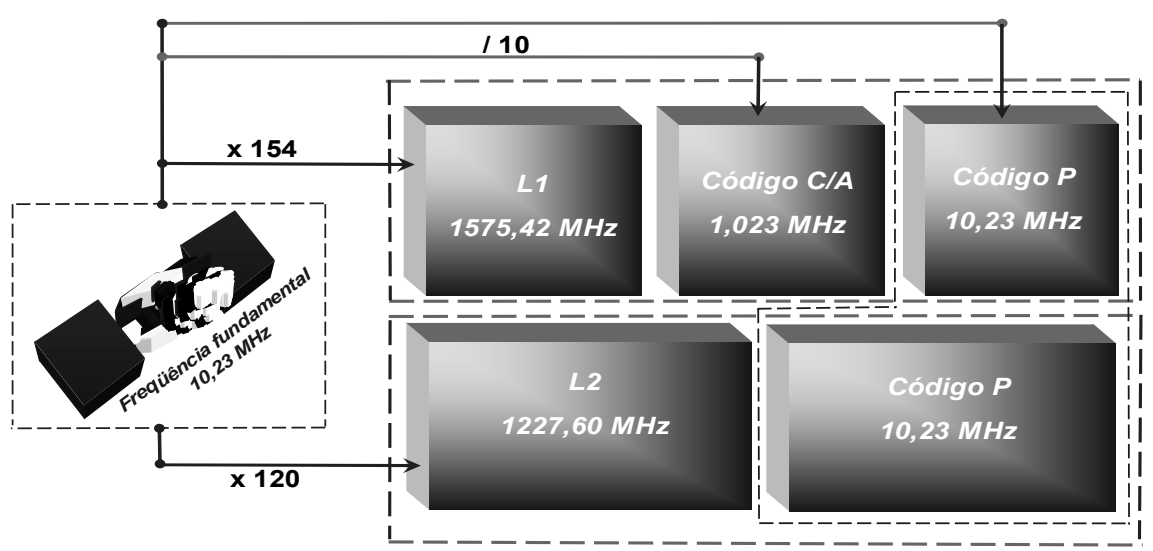

Figura 2 - Princípio do processamento dos sinais das portadoras - Fonte: Adaptado de MONICO (2000)

As duas freqüências são transmitidas simultaneamente, possibilitando aos usuários a correção de grande parte dos erros encontrados nesse sistema (ionosfera, troposfera, multicaminhamento, etc). Pode-se observar na Tabela 1 uma sinopse dos principais componentes dos sinais transmitidos pelos satélites do sistema GPS.

Tabela 1 - Componentes dos sinais do satélite - Adaptado de HOFMANN (2001)

\begin{tabular}{llll}
\hline Componente & Freqüência & MHz & Comprimento (cm) \\
\hline Freqüência Fundamental & $\mathrm{f}_{\mathrm{o}}$ & 10,23 & \\
\hline Portadora L1 & $154^{*} \mathrm{f}_{\mathrm{o}}$ & 1575,42 & 19,04 \\
\hline Portadora L2 & $120^{*} \mathrm{f}_{\mathrm{o}}$ & 1227,60 & 24,44 \\
\hline Código P & $\mathrm{f}_{\mathrm{o}}$ & 10,23 & \\
\hline Código C/A & $\mathrm{f}_{\mathrm{o}} / 10$ & 1,023 & \\
\hline Mensagem de Navegação & $\mathrm{f}_{\mathrm{o}} / 204600$ & $50 * 10^{-6}$ & \\
\hline
\end{tabular}


Os sinais emitidos pelos satélites são transmitidos pela modulação das freqüências L1 e L2. Por possuírem o papel de transportar esses sinais, as freqüências são comumente chamadas de freqüências da portadora ou, simplesmente, portadoras. As observáveis oriundas da contagem de ciclos das portadoras são denominadas fase da portadora.

Os sinais de navegação transmitidos pela portadora são conhecidos como código. O código preciso, denominado código $\mathrm{P}$ (quando criptografado é denominado código Y), está disponível apenas para usuários autorizados, modulado nas portadoras L1 e L2. O código de fácil aquisição, denominado código C/A, até o ano de 2005 era modulado apenas na portadora L1. A partir do início do ano 2006, os novos satélites lançados possuem o código C/A também na portadora L2. (por exemplo: o satélite 17, lançado em início de 2006, http://www.gpsreview.net/understanding-I2c-I2-gps/, acessado em 26-02-2006).

Uma nova portadora, denominada L5, deverá em breve estar também disponível aos usuários civis. Ela corresponderá a 115 vezes a freqüência fundamental, formando uma onda com uma freqüência de 1176,45 $\mathrm{MHz}$ e comprimento de $25,50 \mathrm{~cm}$. Esta freqüência foi projetada para estar disponível para testes até o ano 2012, com capacidade operacional completa antes do ano 2015 (http://gps.faa.gov/gpsbasics/GPSmodernization-text.htm, acessado em 26-022006). A literatura informa que a portadora L5 poderá ser rastreada em condições adversas, até mesmo quando os sinais L1 não puderem ser localizados, por exemplo, em baixas elevações ou, até mesmo, no interior de edificações (LEICK, 2004). 


\subsection{ERROS INERENTES AO SISTEMA GPS}

Como é de conhecimento, nos resultados de qualquer medição ${ }^{8}$ podem estar embutidos de erros grosseiros, sistemáticos e aleatórios; o sistema GPS não foge a essa regra. As observáveis desse sistema são influenciadas por perturbações, desde o momento em que são emitidas pelos satélites até o instante de captação pela antena receptora. Os sinais transmitidos pelos satélites propagam-se pela atmosfera, atravessando camadas de diferentes naturezas e estados variáveis, que compõem a troposfera e a ionosfera. Dessa forma, sofrem diferentes tipos de influências que podem provocar variações na direção e velocidade de propagação, na polarização e na qualidade do sinal. O desvio acaba ocasionando um atraso do código e um avanço da fase, devido à alteração que o campo magnético, presente na atmosfera, causa em suas velocidades. As amplitudes desses erros são afetadas pelo movimento aparente do sol, estação do ano, ciclo solar, posição geográfica do receptor, movimento das marés e campo magnético da Terra. O efeito sistemático provocado pela ionosfera é o principal fator limitante do posicionamento de precisão quando se utilizam receptores de uma freqüência, quer seja no posicionamento absoluto quer no posicionamento relativo de linhas de base médias e longas (CAMARGO, 1999).

Para ilustrar, a Tabela 2 apresenta as principais fontes de erros do sistema GPS e os elementos que os causam.

\footnotetext{
${ }^{8}$ Conjunto de operações que tem por objetivo determinar um valor de uma grandeza (SILVA,
} 2004). 
Tabela 2 - Erros envolvidos no sistema GPS - Adaptado de MONICO (2002)

\begin{tabular}{ll} 
Fonte de erro & Causa \\
\hline \multirow{3}{*}{ Satélite } & Erro da órbita; \\
& Erro do relógio; \\
& Relatividade; \\
& Atraso entre as duas portadoras; e hardware. \\
\hline & Refração da troposfera; \\
& Refração da ionosfera; \\
& Perdas de ciclo; \\
Propagação do sinal & Multicaminhamento ou sinais refletidos; e \\
& Rotação da terra. \\
\hline \multirow{3}{*}{ Receptor/Antena } & Erro do relógio; \\
& Erro entre os canais; e \\
& Centro de fase da antena. \\
\hline & Erro nas coordenadas; \\
& Multicaminhamento; \\
& Marés terrestres; \\
Estação & Movimento do pólo; \\
& Carga dos oceanos; e \\
& Pressão da atmosfera. \\
\hline
\end{tabular}

\subsubsection{Erro ocasionado pela refração ionosférica}

O principal efeito causado pela refração ionosférica é caracterizado pela alteração da velocidade de propagação dos sinais emitidos pelos satélites, somada a uma curvatura de irradiação do sinal. Nos dados dos códigos são acrescidos atrasos, ocasionando uma medida superestimada nos valores das pseudodistâncias, ao contrário do que ocorre nas observáveis da fase que têm suas ondas avançadas, disponibilizando os valores das pseudodistâncias com valores reduzidos.

A região de composição da ionosfera está, aproximadamente, situada entre 100 e 1.000 km acima da superfície da terra, composta por elétrons livres. Quando as ondas portadoras passam por esses elétrons livres, ocorre um atraso na modulação da portadora, conhecido como atraso da ionosfera, o qual, aumenta o 
caminho a ser percorrido pelo sinal emitido (SEGANTINE, 1995).

A Figura 3 representa as regiões (por limites pontilhados), nas diferentes partes do mundo, com maior atividade ionosférica. Observa-se que quase todo o território brasileiro (região equatorial) é afetado por essa atividade.

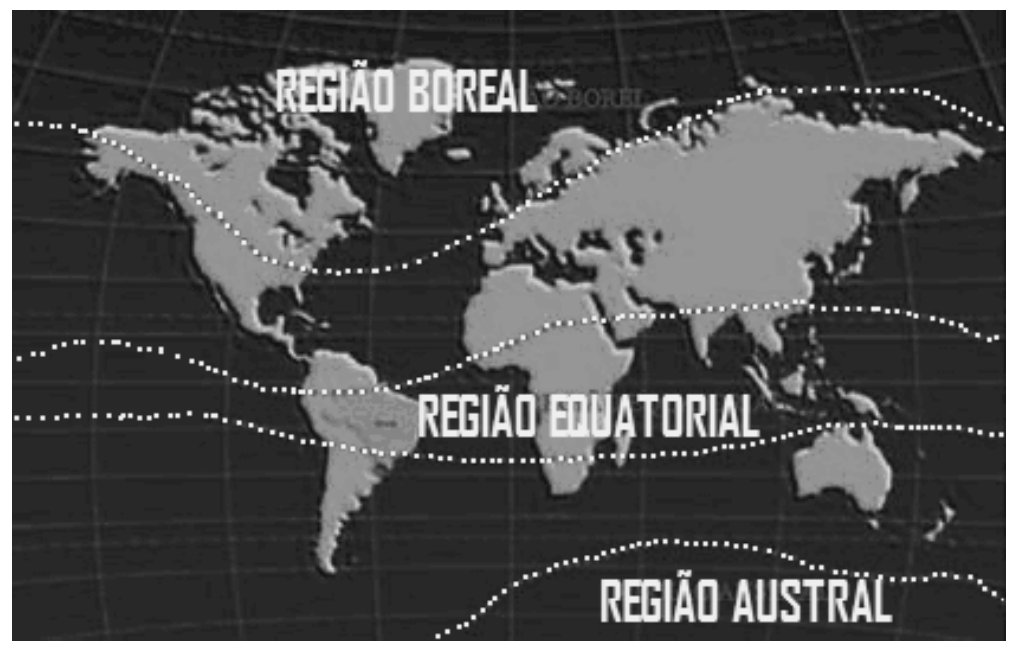

Figura 3 - Regiões do mundo com alta atividade ionosférica - Adaptado de SEEBER (2003)

\subsubsection{Erro ocasionado pela refração troposférica}

Com a mesma intensidade, a refração troposférica atinge os sinais do código e da fase da portadora, ocasionando um retardo na velocidade de propagação. Em função disso, o valor numérico da pseudodistância é fornecido com um relativo acréscimo que varia aproximadamente com a cossecante do ângulo de elevação de cada satélite, ocasionando um erro em torno de 28 m com um ângulo de elevação de $5^{\circ}$. Não se pode eliminar tais erros por medições de dupla freqüência, devido ao fato da refração troposférica não depender da freqüência. Contudo, esse erro pode ser reduzido com a introdução de modelos matemáticos no pós-processamento das observáveis GPS (LEICK, 1995 apud 
LAROCCA, 2004).

A Figura 4 mostra um esquema da camada troposférica, com suas subdivisões, utilizada por Hopfield (a qual mostra uma idéia das altitudes aproximadas utilizadas nos modelos). Esse modelo considera as relatividades seca e úmida como sendo funções da altura, dando uma noção da divisão das camadas quanto ao comportamento da atividade ionosférica.

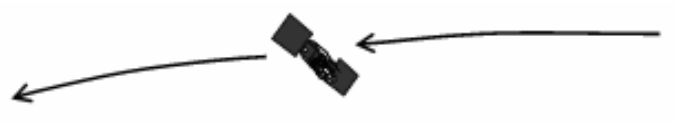

\section{IONOSFERA}

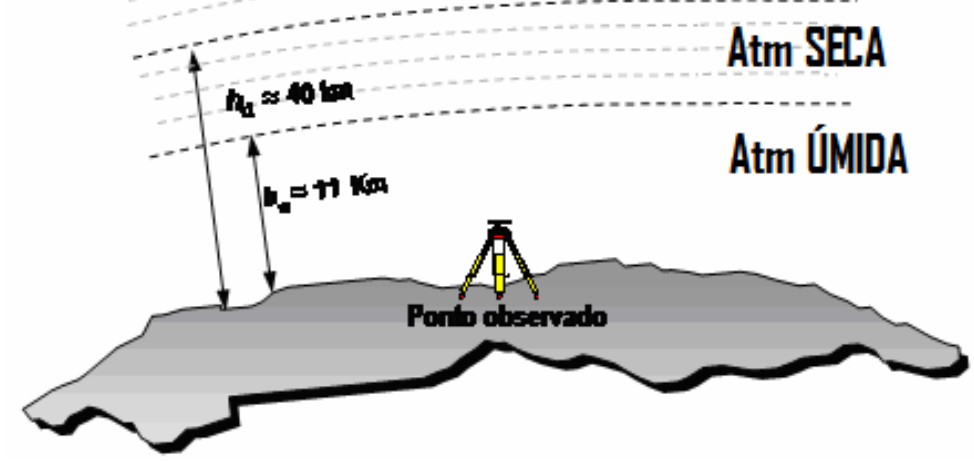

Figura 4 - Modelo troposférico (densidade das camadas politrópicas) - Adaptado de HOFMANN-WELLENHOF (2001)

\subsubsection{Perda de Ciclo}

Segundo LEICK (2004), a perda de ciclo é caracterizada por um salto das observáveis da fase da portadora por um número inteiro de ciclos, os quais podem ser corrigidos. Esse problema pode ocorrer entre duas ou mais épocas. Entretanto, sabe-se que um levantamento com elevado índice de perdas de ciclos dificulta a solução das ambigüidades e pode prejudicar toda a sessão do rastreio. Existem diversas técnicas desenvolvidas para solucionar esse problema, as quais podem 
ser encontradas em detalhes nos livros técnicos sobre o assunto. Segundo SEEBER (2003) e SEGANTINE (2005), há vários fenômenos que fazem com que ocorra a perda de ciclo. Entre eles são citados:

a) Dependentes da observação

$\checkmark$ obstrução do sinal devido à presença de edificações, arborização, montanhas, etc;

$\checkmark$ enfraquecimento do sinal, cintilações (variações na amplitude e na fase do sinal) ionosférica, multicaminhamento, deslocamento brusco com a antena do receptor GPS; e

$\checkmark$ satélite situado em baixa elevação ou com osciladores em mal estado.

b) Dependentes do receptor

$\checkmark$ sinal fraco, particularmente causado por interferência do sinal;

$\checkmark$ qualidade da antena do receptor; e

$\checkmark$ inclinação da antena do receptor em levantamentos (no modo cinemático), etc.

Segundo TEUNISSEN (1991) e JIN (1996), a diminuição da perda de ciclo é fundamental para as observações feitas com o propósito de aplicar correções diferenciais, a partir da técnica de suavização do código por meio da portadora. Quando ocorre esse fenômeno, o algoritmo é reiniciado, prejudicando a confiabilidade do algoritmo podendo inclusive comprometer o processo da suavização. 


\subsection{4. Índice Dst}

Segundo FONSECA Jr (2002), o índice Dst (Disturbance Storm Time Index) indica o grau da atividade magnética, o qual é analisado a partir de uma rede composta por quatro observatórios geomagnéticos, que são: Hermanaus - África do Sul, Kakiota - Japão, Honolulu - Hawaii e San Juan - Porto Rico. A localização desses observatórios foi escolhida estrategicamente, com o intuito de mantê-los suficientemente afastados do eletrojato equatorial e da região de ocorrência da aurora boreal. Vide Figura 5.

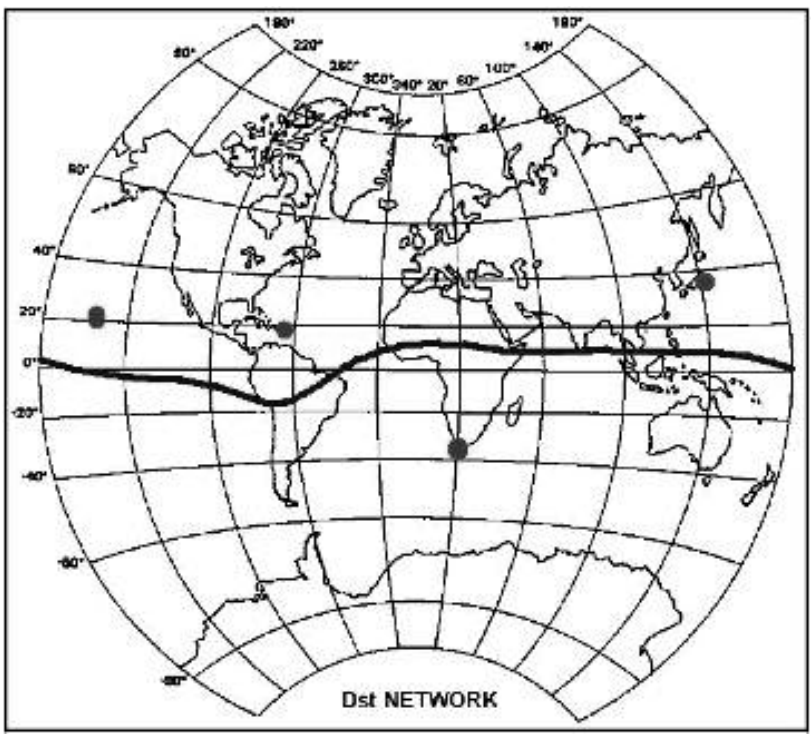

Figura 5 - Rede de observatórios geomagnéticos para a determinação do índice Dst - Fonte: Adaptado de http://swdcdb.kugi.kyotou.ac.jp/dst2/onDstindex.html (26-02-2006).

A Tabela 3 mostra a distribuição da intensidade da tempestade magnética representada pelo índice Dst, o qual é usado para identificar a agressividade dessas tempestades. O índice Dst é expresso em nano telas (nT), fundamentado na média da componente horizontal do campo magnético terrestre medido a cada hora (SUGIURA, 1964 apud FONSECA Jr 2002). 
O valor do índice Dst apresenta o grau de atividade magnética para cada época, tornando-se um indicador do comportamento da ionosfera e da troposfera. Os valores desses índices, geomagnéticos, serão utilizados nessa pesquisa para verificar se existe alguma relação entre a acurácia obtida com as coordenadas calculadas, fazendo uso do Filtro de Hatch, com o comportamento da atividade solar.

Tabela 3 - Nível de intensidade de tempestade magnética Tempestade magnética Índice Dst

\begin{tabular}{ll}
\hline baixa intensidade & Dst $>-20 \mathrm{nT}$ \\
\hline média intensidade & $-20 \mathrm{nT}>\mathrm{Dst}>-50 \mathrm{nT}$ \\
\hline alta intensidade & $-50 \mathrm{nT}>\mathrm{Dst}>-100 \mathrm{nT}$ \\
\hline extrema intensidade & Dst $<-100 \mathrm{nT}$ \\
\hline
\end{tabular}

\subsection{CONCEITOS DE PRECISÃO E ACURÁCIA}

Há certa confusão e, algumas vezes, até falta de clareza nas definições dos termos precisão e acurácia no campo da mensuração. Segundo o dicionário Aurélio, precisão possui várias acepções, entre elas:

$\checkmark$ exatidão de cálculos;

$\checkmark$ regularidade na execução, exatidão;

$\checkmark$ funcionamento sem falhas, perfeição, e

$\checkmark$ rigor em concisão. 
O mesmo dicionário sugere a seguinte definição para a palavra acurácia:

$\checkmark$ exatidão de uma operação ou de uma tabela;

$\checkmark$ propriedade da medida de uma grandeza física que foi obtida por instrumentos e processos isentos de erros sistemáticos, e $\checkmark$ precisão, rigor.

Observa-se, pelos conceitos apresentados, certa semelhança nas definições dos termos no que tange à área de avaliação da qualidade das medidas.

A falta de clareza conceitual entre esses termos, por profissionais da mensuração, em particular no que tange ao georreferenciamento, causa ilegitimidade na avaliação da qualidade dos trabalhos, pois os programas que processam as observáveis do sistema GPS, no que se refere ao posicionamento, somente fornecem as precisões dos pontos medidos.

Segundo AMORIN (2004), o termo precisão é o grau de refinamento com o qual uma grandeza é medida. Em outras palavras, significa o quanto os valores de uma série de medidas estão próximos uns dos outros. Se uma grandeza é medida várias vezes e os resultados dessa operação forem valores muito próximos um dos outros, diz-se que a precisão é alta. Normalmente, a precisão é expressa em termos do desvio padrão ou de variância das medições.

Já no caso da acurácia, segundo WEBER (1999), existem diferentes tipos e conceitos. Entre eles destacam-se:

acurácia posicional ou geométrica: produto da medição de quanto o dado difere espacialmente (em termos de posição absoluta, relativa e forma) daquele tomado, então, como referência; 
acurácia temporal: diz-se da medida de atualidade dos dados; em geral é descrita pela data ou época de produção dos dados; e

acurácia de atributos: mostra a fidelidade dos dados descritivos, avaliando de forma sucinta a identificação de entidades e atribuição de valores de atributo no conjunto de dados. Suas avaliações são feitas por meio de funções estatísticas que estimam o grau de concordância ou discordância dos atributos existentes em relação àqueles tidos como verdadeiros.

Observa-se que a primeira definição de acurácia (acurácia posicional) é a que mais se aproxima dos propósitos deste trabalho, já que ele trata de medidas no âmbito posicional. A melhor forma de exemplificar as diferenças entre os conceitos dados é o uso de um alvo de tiro, conforme ilustrado na Figura 6.

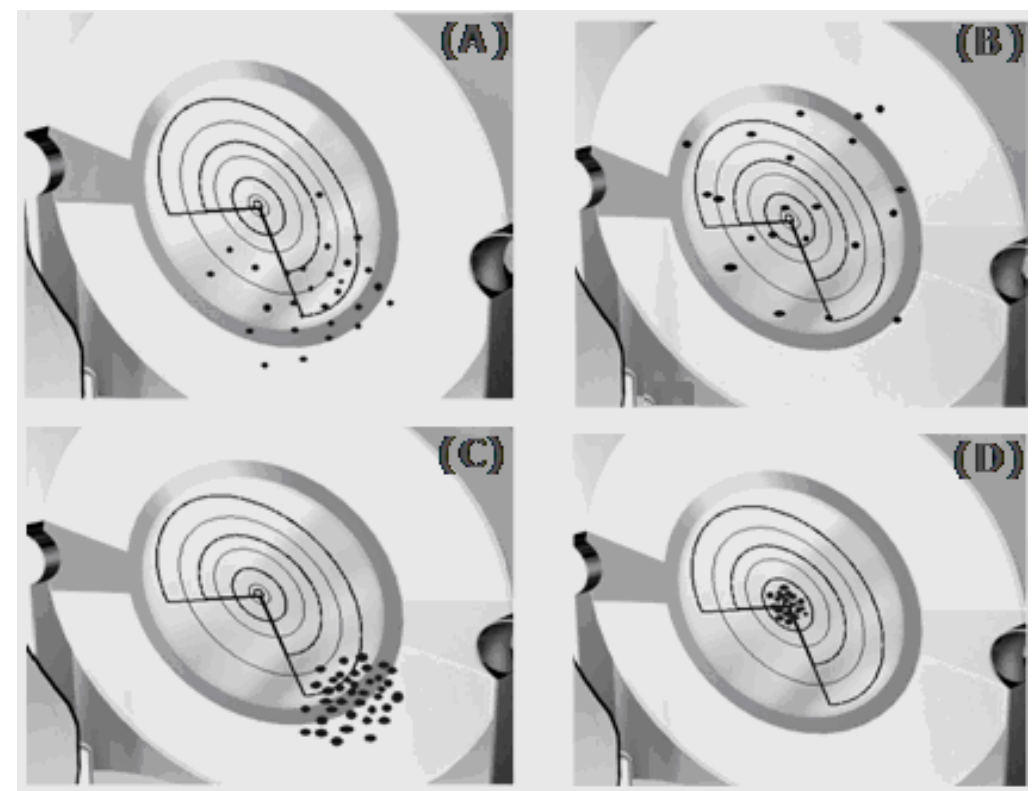

Figura 6 - Ilustração feita com os conceitos de precisão e acurácia 
a) observações com pouca acurácia e imprecisas;

b) observações com média exata (boa acurácia), porém imprecisas;

c) observações precisas, porém com pouca acurácia, e

d) observações precisas e com alta acurácia.

O valor exato de uma medida naturalmente nunca é conhecido. Porém, ele pode ser estimado a partir de observações e da aplicação de modelos matemáticos, como, por exemplo, o Método dos Mínimos Quadrados (MMQ). Aliados a esses modelos, se os equipamentos de medição estiverem adequadamente calibrados e forem confiáveis, pode-se obter resultados com alto nível de acurácia. Vale a pena ressaltar aqui que o nível de acurácia não é absoluto e varia, dependendo do tipo de medição, do objeto medido e do objetivo usado na medição.

No caso do sistema GPS, o nível de acurácia depende do tipo de sinal rastreado e do algoritmo de processamento dos dados. Mesmo assim, ele é altamente influenciado pelas condições atmosféricas, que podem embutir erros sistemáticos dificilmente detectáveis pelos algoritmos de processamento.

\subsection{OBSERVÁVEIS GPS}

De acordo com HOFMANN-WELLENHOF (2001), as observáveis GPS são distâncias estimadas por meio de medidas do tempo ou diferenças de fase, baseadas na comparação entre os sinais recebidos e os sinais gerados no receptor. 
Basicamente, as observáveis obtidas com o receptor GPS são a medida da pseudodistância (por meio de um dos códigos disponíveis ou da fase da portadora) e a medida da fase da portadora (SEGANTINE, 2005).

\subsubsection{A Pseudodistância}

A medida da pseudodistância é uma observável comum para qualquer tipo de aparelho GPS, sendo também a mais simples. O cálculo da medida da pseudodistância pode ser feito a partir do código C/A ou do código $\mathrm{P}$, ambos modulados pelo sinal da portadora. Fundamentalmente, trata-se da distância relativa entre o satélite e o receptor, em um determinado tempo. Essa medida tem como participação o código gerado no satélite, correlacionado com a réplica gerada no sensor. A diferença entre o instante da informação emitida e da recebida fornece o tempo $(\Delta \mathrm{t})$. Este é o tempo que o código leva para deslocar-se do satélite até o receptor (tempo de propagação). À distância calculada dessa forma dá-se o nome de pseudodistância.

A Figura 7 apresenta o processo da correlação entre o código transmitido pelo satélite com aquele gerado no receptor, individualmente, o qual fornece as principais componentes para o cálculo da distância entre cada satélite e o receptor. 


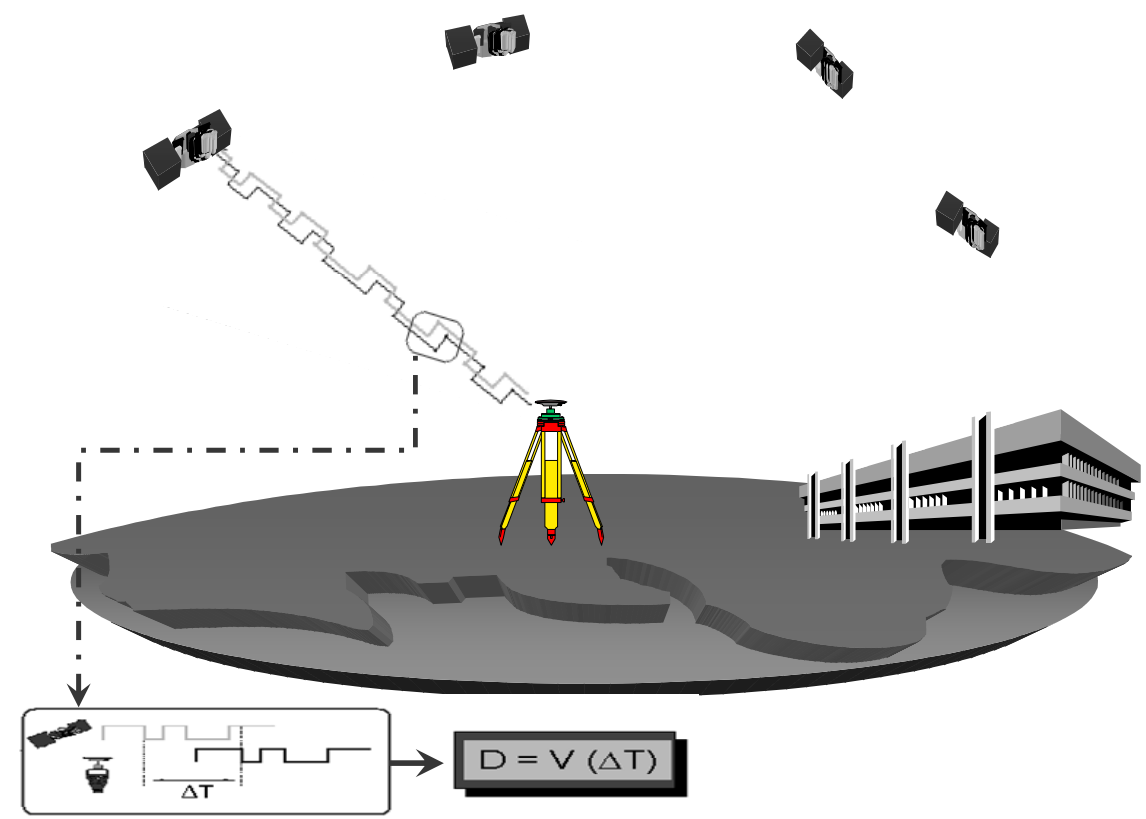

Figura 7 - Correlação entre o código enviado pelo satélite com sua réplica

Pode-se afirmar que a distância entre cada satélite e a antena receptora pode obtida por meio do produto do tempo de trajeto dos sinais pela velocidade de propagação da onda portadora (velocidade da luz), a qual trata-se da equação

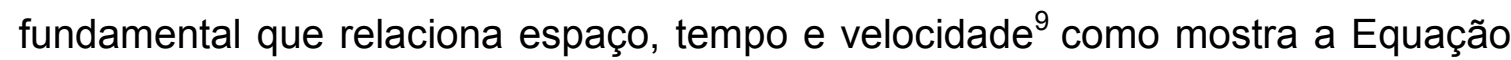
$2^{10}$

$$
\mathrm{PD}=\Delta \mathrm{T} \times \mathrm{c}
$$

sendo:

$$
\text { PD = Pseudodistância }
$$
receptor, pois não leva em consideração todos os erros existente no sistema.
} 


$$
\begin{aligned}
\Delta \mathrm{T} & =\mathrm{t}_{\mathrm{r}}-\mathrm{t}^{\mathrm{s}} \quad \text { (tempo receptor }- \text { tempo GPS, incluindo erros dos relógios) } \\
\mathrm{c} & =\text { velocidade da luz }
\end{aligned}
$$

Incluindo os efeitos da troposfera e da ionosfera, o atraso do relógio do satélite e do receptor, obtém-se a Equação 3, conforme indicado a seguir:

$$
\mathrm{PD}_{\mathrm{r}}^{\mathrm{S}}\left(\mathrm{t}_{\mathrm{r}, \mathrm{S}}\right)=\rho_{\mathrm{r}}^{\mathrm{S}}\left(\mathrm{t}_{\mathrm{r}}\right)-\mathrm{c}\left(\mathrm{dt}_{\mathrm{r}}-\mathrm{dt}^{\mathrm{S}}\right)+\mathrm{I}_{\mathrm{r}, \mathrm{P}}^{\mathrm{S}}\left(\mathrm{t}_{\mathrm{r}}\right)+\mathrm{T}_{\mathrm{r}}^{\mathrm{S}}\left(\mathrm{t}_{\mathrm{r}}\right)+\delta_{\mathrm{r}, \mathrm{P}}^{\mathrm{S}}\left(\mathrm{t}_{\mathrm{r}}\right)+\varepsilon_{\mathrm{P}}
$$

sendo:

$$
\begin{aligned}
& \rho_{\mathrm{r}}^{\mathrm{S}}\left(\mathrm{t}_{\mathrm{r}}\right)=\sqrt{\left(\mathrm{u}^{\mathrm{S}}-\mathrm{u}_{\mathrm{r}}\right)^{2}+\left(\mathrm{v}^{\mathrm{S}}-\mathrm{v}_{\mathrm{r}}\right)^{2}+\left(\mathrm{w}^{\mathrm{S}}-\mathrm{w}_{\mathrm{r}}\right)^{2}} \\
& \delta_{\mathrm{r}, \mathrm{P}}^{\mathrm{S}}\left(\mathrm{t}_{\mathrm{r}}\right)=\mathrm{d}_{\mathrm{r}, \mathrm{P}}\left(\mathrm{t}_{r}\right)+\mathrm{d}_{r}^{S}+\mathrm{d}_{r}^{S}\left(\mathrm{t}_{\mathrm{s}}\right)
\end{aligned}
$$

onde:

$\operatorname{PD}_{\mathrm{r}}^{\mathrm{s}}\left(\mathrm{t}_{\mathrm{r}}\right)=$ pseudodistância entre o satélite (s) e o receptor GPS (r) no tempo $t_{r}$, levando-se em conta os erros inerentes ao sistema;

$\rho_{\mathrm{r}}^{\mathrm{S}}\left(\mathrm{t}_{\mathrm{r}}\right)=$ distância geométrica ${ }^{11}$, calculada a partir do tempo de trajeto do sinal, entre o satélite (s) ao receptor ( $r$ ) no tempo $t_{r}$;

$\mathrm{I}_{\mathrm{r}, \mathrm{P}}^{\mathrm{S}}\left(\mathrm{t}_{\mathrm{r}}\right), \mathrm{T}_{\mathrm{r}}^{\mathrm{s}}\left(\mathrm{t}_{\mathrm{r}}\right)=$ componentes da ionosfera e troposfera

$\mathrm{d}_{\mathrm{r}, \mathrm{P}}\left(\mathrm{t}_{r}\right), \mathrm{d}_{\mathrm{P}}^{\mathrm{s}}\left(\mathrm{t}_{\mathrm{r}}\right)=$ ruídos causados pelo receptor e pelo satélite do sistema GPS;

$\mathrm{d}_{r}^{s}\left(\mathrm{t}_{\mathrm{r}}\right)=$ multicaminhamento ${ }^{12}$

$\mathrm{dt}_{\mathrm{r}}, \mathrm{dt}^{\mathrm{r}}=$ erros do relógio do receptor e do satélite, nos instantes $\mathrm{t}_{\mathrm{r}}$ e $\mathrm{t}^{\mathrm{s}}$, respectivamente;

\footnotetext{
${ }^{11}$ Distância topocêntrica.

$12 \mathrm{O}$ multicaminhamento depende da geometria (característica) da antena e da geometria dos satélites, em relação aos objetos localizados nas proximidades da antena.
} 
$\varepsilon_{\mathrm{P}}=$ contribuição dos ruídos nos cálculos das pseudodistâncias (dependendo da f fabricação do receptor).

Para garantir um posicionamento com alto nível de exatidão, é necessário considerar todos os efeitos inerentes ao sistema, por menores que sejam, pois o acúmulo deles poderão comprometer a qualidade do posicionamento.

\subsubsection{Fase da portadora}

Com a precisão de observação superior à fornecida pelo código, a fase da onda portadora - comumente conhecida como fase da portadora - é utilizada sempre em trabalhos que exijam maior qualidade nos posicionamentos. Para tanto, ela deve ser utilizada em conjunto com a técnica de resolução da ambigüidade (SEGANTINE, 2005).

O processo de medição da fase da portadora pode ser analisado da mesma forma que o da pseudodistância, visto que as informações enviadas pelo satélite percorrerão o mesmo trajeto das enviados pelo código, sofrendo os mesmos retardos e fontes de erros comuns ao sistema. Segundo SEGANTINE (1995), apud LEANDRO (2003), a grandeza da fase é definida como sendo a diferença, em ciclos, entre a fase transmitida pela antena do satélite ${ }^{13}$ e a fase gerada internamente pelo VCO (Voltage Controlled Oscillator), dispositivo eletrônico do receptor que faz as comparações entre o sinal recebido e o emitido.

A equação da fase da portadora, de acordo com o modelo baseado na geometria constituída entre o satélite e a antena receptora, é representada por

\footnotetext{
${ }^{13}$ É recebida na antena do receptor GPS.
} 
frações da fase da portadora, em uma freqüência denominada $f$, a qual é recebida na antena do receptor "r", transmitidas por um satélite "s", em tempo denominado "t", somadas a um valor inteiro e constante, que representa as ondas inteiras. A Equação 4 mostra como é calculada essa a fase, considerando-se os principais parâmetros envolvidos no processo:

$\varphi_{r}^{s}(t)=f\left(\frac{\rho_{r}^{s}-I_{r}^{s}+T_{r}^{s}+d m_{\varphi r}^{s}}{c}\right)+f\left(d t_{r}-d t^{s}\right)+\left[\varphi^{s}\left(t_{o}\right)-\varphi_{r}\left(t_{o}\right)\right]+N_{r}^{s}+\varepsilon_{\varphi r}^{s}$

sendo:

$f=$ freqüência nominal da fase;

$\varphi^{s}\left(t_{o}\right)=$ a fase gerada pelo satélite na época inicial (instante $\left.t_{0}\right) ;$

$\varphi_{r}\left(t_{o}\right)=$ a fase captada pelo receptor na época inicial (instante $\left.t_{0}\right)$;

$N_{r}^{s}=$ a ambigüidade da fase (número de ciclos desconhecidos);

$d m_{\varphi r}^{s}=$ o erro referente ao multicaminhamento ocasionado pela fase, e

$\varepsilon_{\varphi r}^{s}=$ o erro da fase da portadora.

Segundo TEUNISSEN (1998), somente a parte fracionária da onda portadora pode ser medida quando o sinal do satélite é recebido pelo receptor, o número inteiro de ciclos $(N)$ é desconhecido, ele é denominado como a ambigüidade da fase. Nas observações GPS empregando-se a fase da portadora, o tempo de resolução das ambigüidades é um fator que indica a qualidade da medida e está relacionado, principalmente, ao comprimento da linha de base 
(LEICK, 2004). As técnicas que usam a medição da fase da portadora geralmente diferem na forma pela qual abordam o problema da ambigüidade.

\subsection{MÉTODO DE POSICIONAMENTO}

As técnicas de GPS a serem empregadas nos trabalhos de posicionamento, dependerão, exclusivamente, do objetivo e da exatidão desejada. Segundo HOFFMANN (2001), as principais técnicas de observações por GPS são, basicamente: posicionamento por ponto (absoluto), diferencial e posicionamento relativo. Contudo, há certa ramificação entre essas técnicas. Pode-se tomar como base as principais técnicas apresentadas pela norma brasileira de levantamento GPS, conforme recomendações proposta pelo IBGE.

\subsubsection{Princípio básico do posicionamento GPS}

O cálculo das coordenadas de um ponto, por meio do sistema GPS, é baseado na medição das pseudodistâncias entre a antena do receptor e as antenas dos satélites que compõem a constelação do sistema ${ }^{14}$. A partir das medidas das pseudodistâncias (no mínimo quatro), pode-se determinar a posição do centro de fase da antena do receptor, e consequentemente, a posição onde está instalado o instrumento, conforme Figura 8.

\footnotetext{
${ }^{14}$ Está relacionada ao centro de massa da terra (coordenadas geocêntricas).
} 


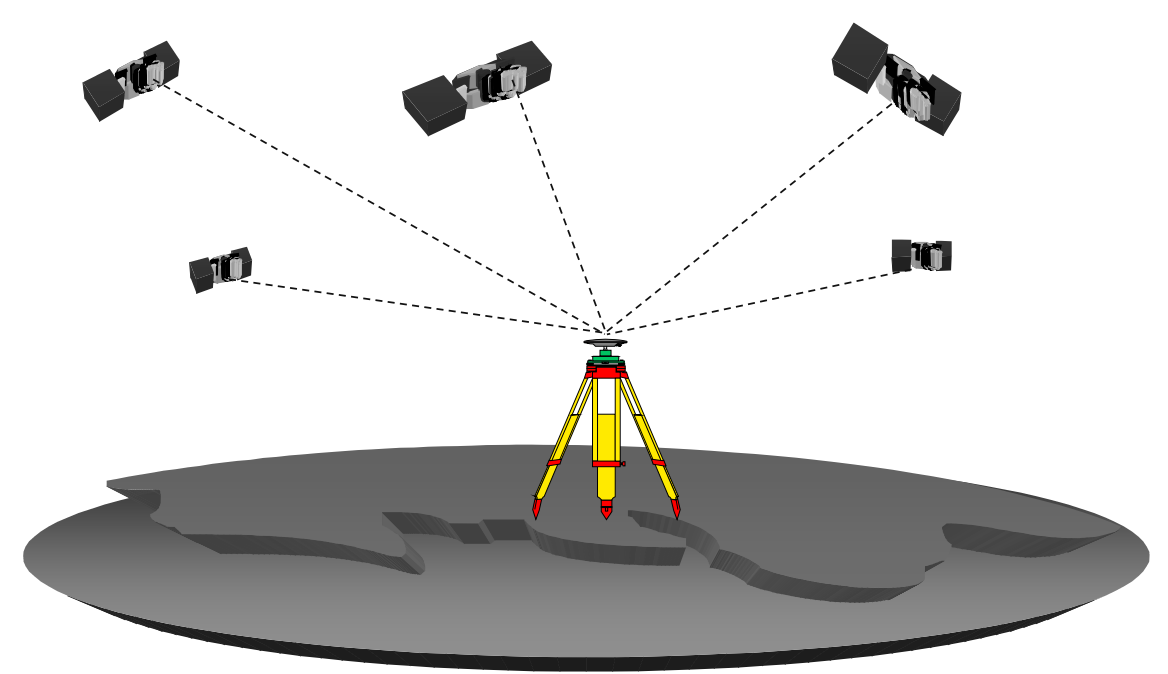

Figura 8 - Posicionamento Absoluto Estático

\subsubsection{Posicionamento Relativo}

Esse tipo de posicionamento baseia-se na coleta de dados, empregando dois ou mais receptores GPS, simultaneamente. No entanto, nem sempre há a necessidade do usuário dispor de mais de um receptor, pois é possível fazer uso dos dados disponibilizados por uma Estação de Referência de Monitoramento Contínuo (RBMC - IBGE, RIBAC ${ }^{15}$ - INCRA e outras). Os dados dessas Estações são, normalmente, obtidos a partir da Internet, adquiridos por meio de correio eletrônico, ou em um dispositivo de gravação. No caso de medições GPS para o uso em registro de imóveis, exige-se que as Estações de Referências faça parte do Sistema Geodésico Brasileiro, ou seja, homologadas pelo IBGE.

\footnotetext{
${ }^{15}$ Utilizar para fins de Georreferênciamento quando homologado pelo IBGE.
} 
O posicionamento relativo pode ser realizado pelo método cinemático, quando o receptor remoto movimenta-se durante a observação (Figura 9). Quando o receptor remoto permanece em repouso durante a observação, diz-se que o posicionamento é feito pelo método estático, como representa a Figura 8.

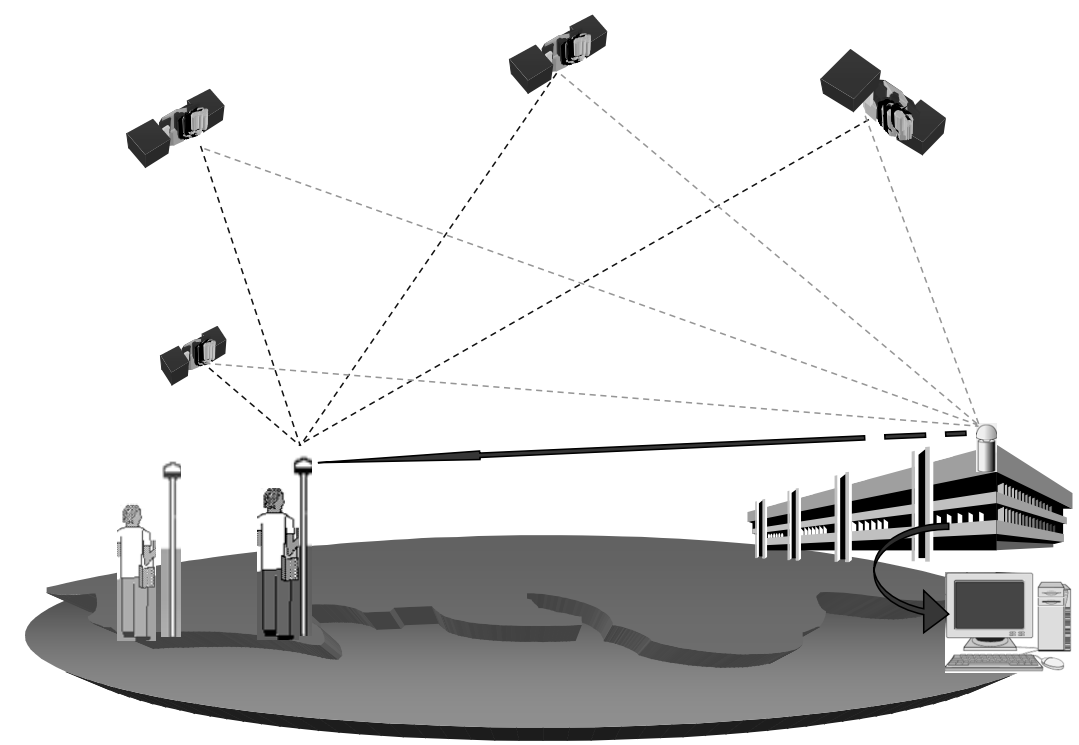

Figura 9 - Posicionamento Relativo Cinemático

O tempo de coleta de dados, nos dois casos, pode variar de minutos a algumas horas dependendo do comprimento do vetor da linha base, do número de satélites observados, de sua geometria (responsável pela diluição da precisão) e do tipo de receptor (L1 ou L1/L2).

Pode-se falar de uma variação do posicionamento relativo, o posicionamento relativo-estático. Ele é considerado como tal quando dois ou mais receptores são utilizados para coletar o código, ou a fase da portadora, simultaneamente. A coleta das observáveis pode variar de minutos a algumas horas, dependendo do comprimento da linha de base entre o receptor remoto e a 
estação de referência, do número de satélites observados, da geometria entre os satélites e os receptores, do tipo de receptor (se L1 ou L1/L2) e do tipo de trabalho executado. As coordenadas são obtidas após o pós-processamento dos dados, coletados pelos receptores remotos e pelo receptor da estação referência, cujas coordenadas são conhecidas, como mostra a Figura 10.

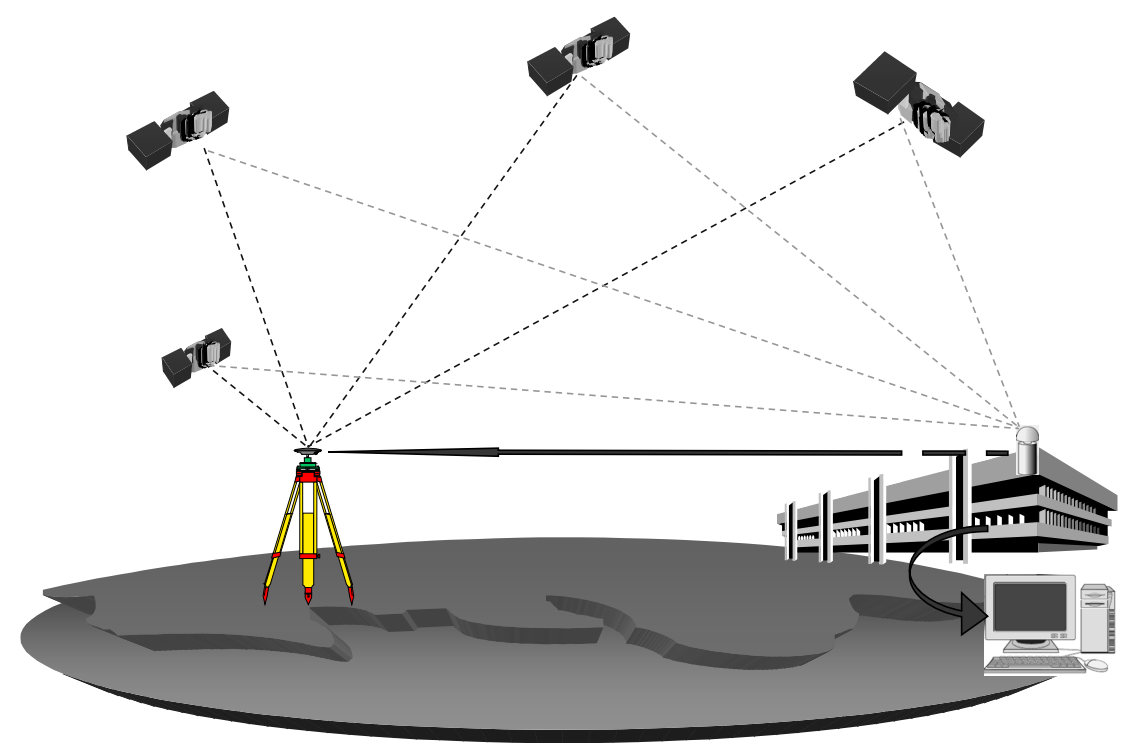

Figura 10 - Posicionamento relativo estático

O posicionamento relativo estático é a técnica de posicionamento mais utilizada nos serviços de campo. Ela pode alcançar precisões da ordem de 1 ppm ou melhores, com o uso de receptores de dupla freqüência. Aplica-se na implantação de pontos de apoio e controle, tais como: estabelecimento de redes geodésicas (regionais, nacionais e internacionais), deslocamentos e/ou deformações de barragens, deslocamentos de placas tectônicas, ou estruturas de obras em geral que necessitem de medidas acuradas. O tempo de observação varia de alguns minutos a algumas horas de rastreio. 
Segundo MONICO (2000) e SEGANTINE (2005), o método de posicionamento no modo estático-rápido ${ }^{16}$ é derivado do posicionamento estático, com diferença na redução do tempo de observação. No método estático, o tempo de rastreio poderá levar algumas horas, enquanto que no estático-rápido, leva poucos minutos.

\section{8. ÁREAS DE APLICAÇÃO DO SISTEMA GPS}

Segundo MARQUES (2006), o sistema GPS possui inúmeras aplicações, não se limitando apenas ao posicionamento global como sugere seu nome. Entre as várias aplicações, destacam-se:

posicionamento e mapeamento: levantamento cadastral urbano e rural, coleta de dados para gerar e alimentar Sistemas de Informações Geográficas (SIG), na agricultura de precisão, mapeamento do comportamento ionosférico, monitoramento de veículos, navegação, etc;

aplicações geodésicas: implantação de redes geodésicas, posicionamento e monitoramento para a engenharia de modo geral, e

aplicações geodinâmicas: monitoramento vertical e horizontal da crosta terrestre ${ }^{17}$.

Com base nas inúmeras aplicações do sistema GPS, é proposta uma classificação por categorias conforme seu grau de exigência. A Tabela 5 classifica

\footnotetext{
${ }^{16}$ Também chamado de rápido-estático.

${ }^{17}$ Torna-se, também, um sismógrafo.
} 
a categoria da aplicação GPS quanto a sua precisão nominal ${ }^{18}$

Tabela 4 - Classificação ${ }^{19}$ da categoria dos receptores GPS quanto a sua precisão - Fonte: MARQUES (2006)

\begin{tabular}{ll}
\hline Classificação & Exigência de precisão \\
\hline Categoria A (científica) & Menor que 1 ppm \\
\hline Categoria B (geodésica) & de 1 a 10 ppm \\
\hline Categoria C (topográficas) & de 10 ppm a 0,5m \\
\hline Categoria D (levantamentos para SIG) & de 0,5 a $3 \mathrm{~m}$ \\
\hline Categoria E (navegação) & Acima de $10 \mathrm{~m}$ \\
\hline
\end{tabular}

categoria A: envolve as pesquisas nas áreas de posicionamentos para engenharia de precisão, análise de deformação e aplicações geodinâmicas. Considerada como precursor no uso de "tecnologia de ponta" e estratégias de processamento que possam ser adotadas futuramente pelas categorias $B, C$ e D;

categoria B: diz respeito às análises referentes a trabalhos geodésicos para o estabelecimento, densificação e manutenção de redes de controle e apoio à cartografia de modo geral;

categoria C: abrange os posicionamentos de precisões menores, dentro da topografia, tais como implantações de coordenadas de apoio urbano, cadastrais, geofísicos e locações de obras;

categoria D: engloba os posicionamentos cadastrais para implantação e gestões de SIG e aplicações da cartografia com propósitos gerais e temáticos.

\footnotetext{
${ }^{18}$ Precisão disponibilizada pelos fabricantes dos receptores GPS.

${ }^{19}$ Essa classificação não é oficial, entretanto fornece uma divisão dos posicionamentos com GPS e apresenta as semelhanças e diferenças entre as categorias.
} 
Junto com as categorias B e C formam a maioria dos usuários da comunidade civil;

categoria E: inclui a áreas de recreação e lazer, navegação, esportes e localização de pontos isolados. É a única categoria na qual se disponibilizam apenas as coordenadas absolutas.

\subsection{CLASSIFICAÇÃO QUANTO AO TIPO DOS RECEPTORES GPS}

Atualmente, no comércio de equipamentos GPS voltados à Mensuração, há diversos modelos de receptores GPS disponíveis para a aquisição pelo usuário civil. Os fabricantes estão cada vez mais empenhados em fornecer equipamentos com qualidade e precisão, bem como prover uma interface amigável com o usuário $^{20}$, com gravação de dados em cartões do tipo "PC card", com sistema bluetooth ${ }^{21}$ para envio de dados da antena para o sensor, e interface no padrão Windows ${ }^{\circledR}$.

Os receptores modernos estão cada vez mais fáceis de serem operados, com teclados alfanuméricos, visor com comando táctil e iluminado e com disponibilidade de uso de atributos e códigos rápidos. Como exemplo, na Figura 11 o receptor GPS GX 1200 da Leica Geosystems é apresentado.

\footnotetext{
${ }^{20}$ Conjunto de elementos de hardware e software destinados a prover melhor interação com o usuário.

${ }^{21}$ Tecnologia que descarta o uso de fio para o envio de sinais.
} 


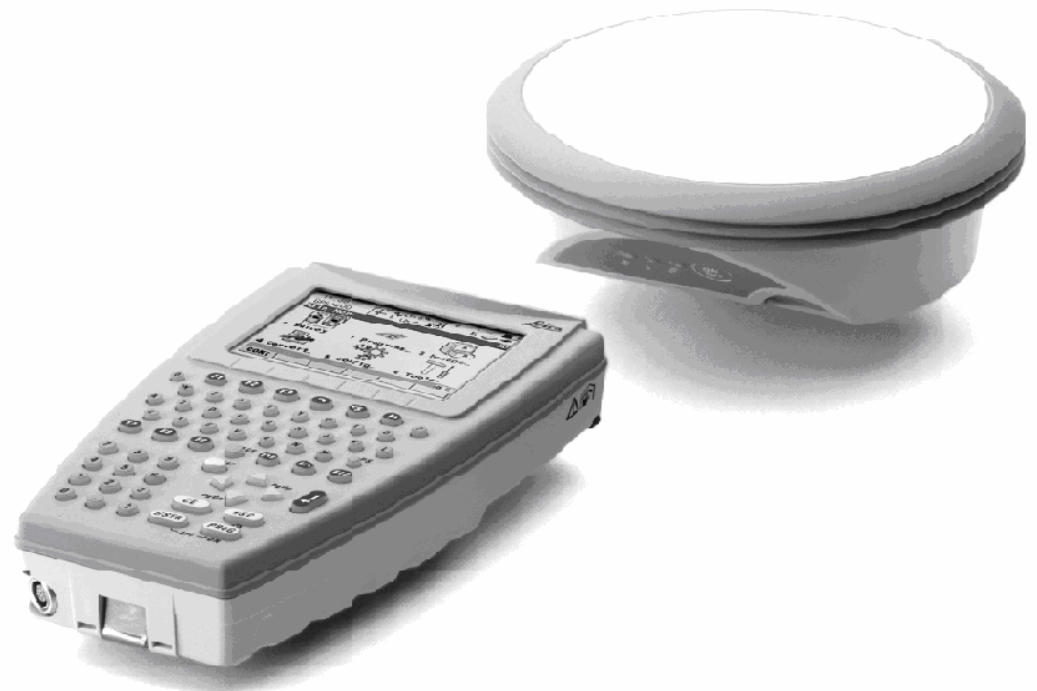

Figura 11 - Receptor GPS Smart Rover - Leica Geosystems

\subsubsection{Receptor para navegação (Código)}

O GPS de navegação é o mais simples tecnologicamente e o que possui menor custo. Destinado às várias tarefas que não exijam precisão nem exatidão em seus posicionamentos; o GPS de navegação, também chamado GPS de mão ou também recreação, é normalmente empregado para navegação nas áreas de esporte, laser e em atividades que exijam noção pontual de certa localidade, ou mesmo de deslocamento.

O que basicamente difere o GPS de navegação dos demais consiste no registro dos dados GPS para posteriores processamentos, refinamento e análise. Os dados coletados são, instantaneamente, usados para o cálculo das coordenadas do ponto em tempo real, sem nenhum ajuste ou controle dos erros sistemáticos inerentes ao sistema; além de possuir apenas as observáveis do código C/A. 
O consumo de energia é da ordem de 1 Watt ou menos. Seu peso varia em poucas gramas. Alguns modelos possuem ou um mapa na tela, ou a facilidade para introduzir um outro. A Figura 12, receptor de navegação com erro de até 15 metros, serve como exemplo para ilustrar tal fato.

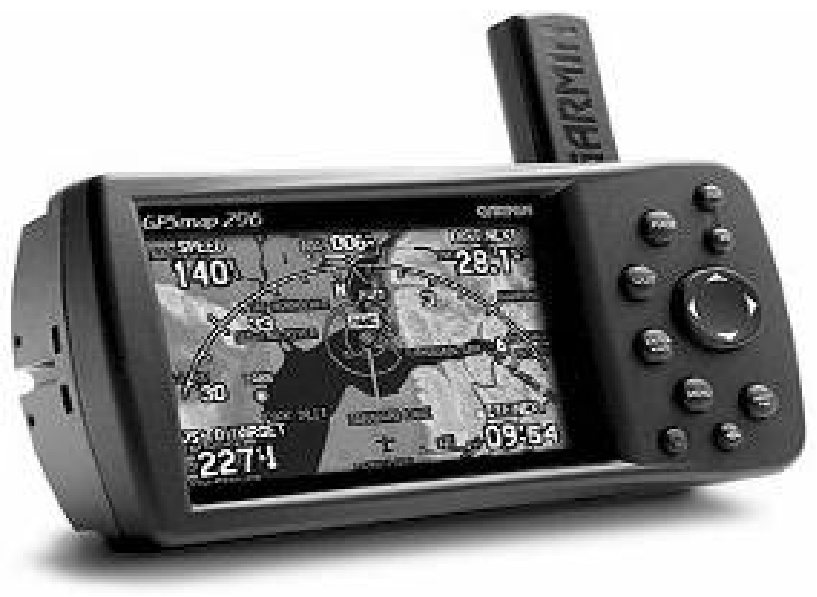

Figura 12 - Receptor para navegação

\subsubsection{Receptor topográfico}

Dá-se o nome de receptor topográfico ao receptor de uma freqüência. $A$ precisão nominal desse tipo de receptor varia de 20 a $10 \mathrm{~mm}+2 \mathrm{ppm}$, no caso de resolução da ambigüidade, e pode alcançar valores submétricos nos casos de soluções a partir do uso do código C/A. Ele pode ser usado em trabalhos que exijam acurácia da ordem do centímetro, desde que as linhas de base sejam menores que $15 \mathrm{~km}$, nas quais o efeito da ionosfera é moderado. Para bases superiores a $15 \mathrm{~km}$, para alcançar a mesma precisão, é indicado o uso de receptores de dupla freqüência (MENZORI, 2005).

Atualmente existem no mercado vários tipos de receptores de uma freqüência. Todos eles possuem características semelhantes e podem ser 
atualizados para receptores de dupla freqüência com uma simples modificação do firmware $^{22}$ interno do equipamento. A Figura 13 mostra exemplos de receptores topográficos.

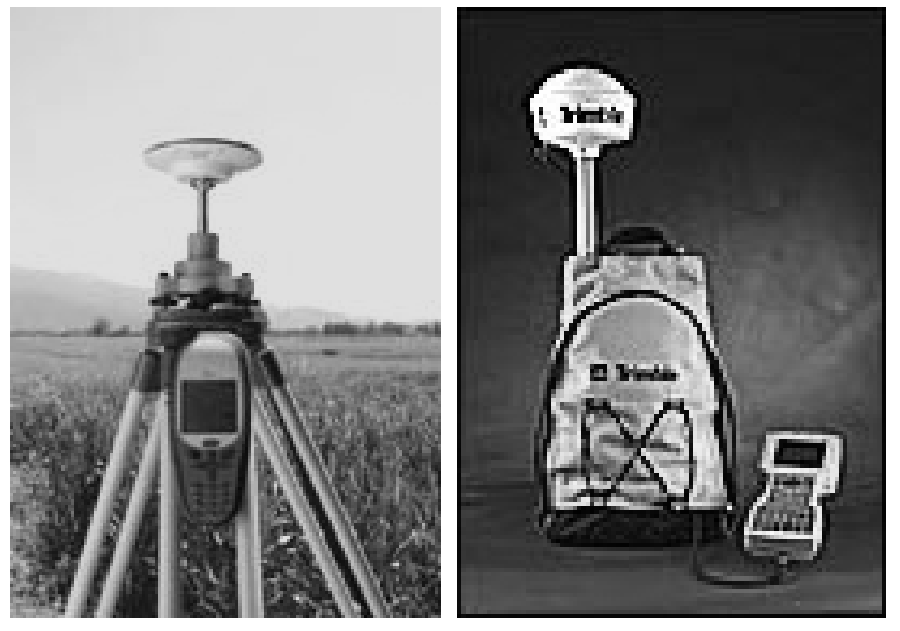

Figura 13 - Receptores topográfico

\subsubsection{Receptor geodésico}

Popularmente qualificado como GPS de dupla freqüência, ou GPS L1/L2, o GPS geodésico é o receptor que apresenta resultados com maior acurácia e confiabilidade.

Segundo SEEBER (2003), quase todos os modelos de receptores geodésicos foram desenvolvidos, inicialmente, rastreando-se dados de simples freqüência e código C/A, com capacidade de rastrear não mais que 4 satélites. Um segundo passo foi a implementação da portadora L2, usando a técnica de quadratura do sinal e incremento do número de satélites passíveis de observação. Um terceiro procedimento foi caracterizado pelo incremento do código $\mathrm{P}$ na coleta

\footnotetext{
${ }^{22}$ Programa responsável pelo sistema operacional do instrumento.
} 
de dados na portadora L2 e em alguns receptores, nas duas portadoras disponíveis; com o objetivo de elevar a qualidade dos dados da portadora L2. O passo seguinte foi a inclusão da técnica sem o uso do código (codeless) na reorganização da portadora L2. Isto visando aumentar a qualidade do sinal da portadora sobre a atividade $S A$ (criptografia do código $\mathrm{P}$ ).

A precisão nominal desse tipo de receptor é da ordem de 3 a $5 \mathrm{~mm}+0,5$ ppm, no caso de resolução da ambigüidade, e de ordem submétrica, no caso de observações com apenas o código C/A.

A principal vantagem do receptor geodésico é sua capacidade de alcançar excelente precisão nominal, independente do comprimento da linha base. A variável, neste caso, é o tempo de rastreio. Segundo LEICK (2004), a degradação da precisão e exatidão nos aparelhos topográficos e de navegação é em função da interferência da ionosfera sobre as observáveis, uma vez que o atraso do código e o avanço da fase, devido à ionosfera, dependem da freqüência, podendo ser eliminados no caso de observações feitas com receptores de dupla freqüência.

Assim como os instrumentos topográficos, os receptores geodésicos são encontrados em vários modelos e fabricantes diferentes, como mostra a Figura 14. 

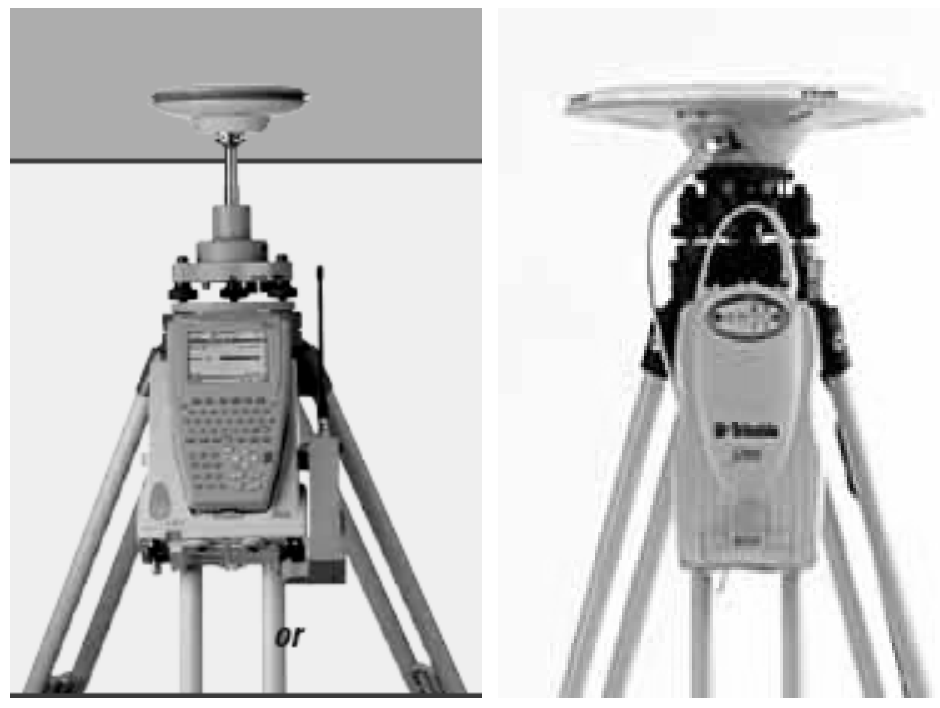

Figura 14 - Receptor Geodésico

\subsection{ESPECIFICAÇÕES E NORMAS PARA O USO DO SISTEMA GPS}

Toda norma, especificação ou instruções técnicas têm como objetivo apresentar regras básicas, com informações para padronizar e qualificar os serviços. Trabalhos de georreferenciamento com o sistema GPS não poderiam ser diferentes. Suas regras básicas são definidas a partir de critérios mínimos de execução e aceitação dos trabalhos, definido por cada país de acordo com suas necessidades e propósitos. As regras, neste caso, exigem procedimentos, tanto de campo como de escritório, diferenciados para que os serviços atendam as especificações, alcancem a acurácia exigida pelo órgão responsável e sejam aceitos.

Portanto, segundo MARQUES (2006), a função das regras é definir a melhor forma dos padrões serem atingidos. Elas envolvem o planejamento, 0 processo de execução do projeto, a instrumentação usada, os procedimentos de 
campo e escritório, a elaboração dos resultados e os critérios de aceitação.

O sistema GPS está em constante evolução, satélites estão sendo substituídos e os sinais incrementados. Com isso, a atualização periódica das regras, que regulamentam a utilização do sistema para determinados fins, torna-se imprescindível. A organização geodésica pioneira em padrões e especificações para levantamento com GPS foi o U.S. National Geodetic Survey, por meio do Federal Geodetic Control Committee - FGCC (1988). As regras criada pelo FGCC são precursoras e têm sido adotadas em vários países, com alterações secundárias feitas para atender os diferentes padrões de precisão de posicionamentos.

O material oficial atualmente disponível, no Brasil, sobre posicionamento com GPS, consta de duas publicações, uma do IBGE - Instituto Brasileiro de Geografia e Estatística (IBGE, 1992) e outra feita pelo INCRA - Instituto Nacional de Colonização e Reforma Agrária (INCRA, 2003). Além do material promulgado, uma razoável quantidade de informações pode ser obtida em artigos de congressos, teses e dissertações, embora o acesso a esses materiais seja difícil para quem não seja do meio acadêmico.

\subsubsection{Normas brasileira}

\section{INCRA}

A norma disponibilizada, em 2003, pelo INCRA, cujo título é Norma Técnica para Georreferenciamento de Imóveis Rurais, não se restringe, unicamente, ao posicionamento por GPS. Ela inclui também instrumentos topográficos 
convencionais. Ela contém segmentos de normas anteriores, às quais foram adicionados e/ou melhorados tópicos relacionados à "Sistema de Informações Geográficas" e instruções sobre técnicas de posicionamentos com GPS, voltadas às exigências do órgão para cadastramento de imóveis rurais.

O objetivo dessa Norma visa orientar profissionais que atuam nas áreas de delimitação, medição e georreferenciamento de imóveis rurais no que tange a lei 10.267/01, a qual contém os seguintes tópicos:

$\checkmark$ informações sobre $o$ modo de habilitação de profissionais autorizados e documentação do posicionamento;

$\checkmark$ classificação quanto aos padrões de precisão e exatidão;

$\checkmark$ características de monumentação;

$\checkmark$ informações sobre o sistema cartográfico nacional;

$\checkmark$ métodos de posicionamento para apoio básico (convencionais e por GPS);

$\checkmark$ métodos de posicionamento altimétrico e perimétrico (convencional e por GPS);

$\checkmark$ ajustamento e avaliação dos resultados;

$\checkmark$ apresentação dos trabalhos, e

$\checkmark$ modelos de formulários para documentação do serviço. 
Nessa Norma, as técnicas de posicionamentos com GPS são classificadas da seguinte forma:

GPS1 - Solução "de navegação" instantânea, sem correção diferencial e baseada no código $C / \mathrm{A}^{23}$. Essa técnica de posicionamento não é admitida para o levantamento do perímetro e nem para a execução dos serviços de georreferenciamento de imóveis rurais por não alcançar a precisão de 0,50 m na determinação das coordenadas;

GPS2 - Solução diferencial baseada no código C/A ou Y com correções em Tempo Real e DGPS corrigidos via satélite. Essa técnica de posicionamento não é admitida para a execução dos serviços de georreferenciamento de imóveis rurais pelos mesmos motivos do GPS1;

GPS3 - Solução baseada nos códigos C/A e/ou Y e/ou fase da portadora com correção diferencial obtida em pós-processamento com utilização de técnicas baseadas em suavização do código pela portadora;

GPS4 - Soluções baseadas na fase da portadora com resolução da ambigüidade e com correção diferencial pós-processada e alternativamente, link de comunicação para solução em tempo real.

Essa norma é a mais recente e, por essa razão, engloba as principais características e técnicas de posicionamento GPS atualmente existentes. Com isso, proporciona apoio básico aos prestadores de serviços de georreferenciamento dos imóveis rurais no Brasil.

\footnotetext{
${ }^{23}$ Posicionamento Isolado.
} 


\section{IBGE}

A norma do IBGE, intitulada Especificações e Normas Gerais para Levantamentos GPS (Preliminar), descreve todo o sistema GPS e apresenta conceitos sobre os elementos principais do sistema, tais como:

$\checkmark$ códigos e portadoras;

$\checkmark$ tipos de observação;

$\checkmark$ classificação e aplicações;

$\checkmark$ equipamentos e técnicas de posicionamento;

$\checkmark$ geometria de rede;

$\checkmark$ observações de campo;

$\checkmark$ processamento; e

$\checkmark$ modelos de formulários para a documentação do posicionamento.

Esse material, por ser o pioneiro, é bastante consultado e abrange quase todos os aspectos de um posicionamento, porém, com os avanços tecnológicos do sistema, tornou-se desatualizado, principalmente com relação aos novos métodos de posicionamento rápidos e cinemáticos e, também, à ausência de informações claras sobre ajustamentos e análises de erros (precisão e acurácia).

\subsubsection{Normas internacionais}

As normas, instruções e especificações para posicionamentos com GPS internacionais são geralmente específicas e destinam-se a levantamentos de redes de controle geodésico e apoio a projetos de engenharia e cadastro. Entre as normas internacionais consultadas, vale a pena ressaltar as seguintes: 
$\checkmark$ Geospatial Positioning Accuracy Standard do Federal Geographic Data Committee - FGDC - 1998, EUA;

$\checkmark$ Geometric Geodetic Accuracy Standards and Specifications for using GPS Relative Positioning Technique do Federal Geodetic Control Committee FGCC - 1988 , EUA;

$\checkmark$ Standards and Practices for Control Surveys (SP1) do Inter-Governmental Advisory Committee on Surveying and Mapping - ICSM - 2002, Australia. 


\section{SUAVIZAÇÃO DO CÓDIGO PELA FASE}

As observações da fase da portadora apresentam menor ruído comparadas às do código. Uma alternativa para minimizar o nível de ruído das observações de código é a filtragem dessas observações usando as medidas de fase da portadora, através de um algoritmo de suavização. Este algoritmo possui como princípio a combinação entre pseudodistância e fase da portadora, produzindo uma nova observação que possui um ruído consideravelmente menor que a pseudodistância original e, ao mesmo tempo, não é ambígua como a fase. Um dos métodos existentes para tal fim é conhecido como Filtro de Hatch, desenvolvido por Ronald Hatch (HATCH, 1982). Estudos a respeito desse filtro são encontrados na literatura, por exemplo, em TEUNISSEN (1991), e JIN (1996).

No decorrer desse capítulo será apresentado o principio do algoritmo de suavização do código pela portadora para receptores de simples e dupla freqüência.

A diferença da fase da portadora entre duas épocas $\left(t_{k-1}\right.$ e $\left.t_{k}\right)$ fornece uma variação da distância entre as antenas do satélite e do receptor, que corresponde 
à medida integrada Doppler ${ }^{24}$. Essa medida inclui também a variação de todos os efeitos sofridos pelas medidas da fase, como, por exemplo, a variação dos erros do relógio e da troposfera, tornando-se uma medida de variação da pseudodistância. Apesar de ser o termo mais adequado para se referir a essa quantidade, nesse capítulo ela será mencionada como "variação da distância" para evitar conflito com o termo pseudodistância quando usado como a medida de distância (entre as antenas do satélite e da antena receptor GPS) mais os erros obtidos através do código.

Denotando-se as diferenças no intervalo $\left(t_{k-1}\right.$ e $\left.t_{k}\right)$, respectivamente, para $L 1$ e L2, como $D_{k-1, k}^{1}$ e $D_{k-1, k}^{2}$, em unidade linear, tem-se que:

$$
\mathrm{D}_{\mathrm{k}-1, \mathrm{k}}^{1}=\lambda_{1} \varphi_{1 \mathrm{rk}}^{\mathrm{s}}-\lambda_{1} \varphi_{1 \mathrm{rk}-1}^{\mathrm{s}}=\rho_{\mathrm{k}-1, \mathrm{k}}+\mathrm{T}_{\mathrm{k}-1, \mathrm{k}}-\mathrm{I}_{\mathrm{k}-1, \mathrm{k}}^{1}+\left(\mathrm{dt}_{\mathrm{k}-1, \mathrm{k}}-\mathrm{dT}_{\mathrm{k}-1, \mathrm{k}}\right)
$$

e

$$
\mathrm{D}_{\mathrm{k}-1, \mathrm{k}}^{2}=\lambda_{2} \varphi_{2 \mathrm{rk}}^{\mathrm{s}}-\lambda_{2} \varphi_{2 \mathrm{rk}-1}^{\mathrm{s}}=\rho_{\mathrm{k}-1, \mathrm{k}}+\mathrm{T}_{\mathrm{k}-1, \mathrm{k}}-\mathrm{I}_{\mathrm{k}-1, \mathrm{k}}^{2}+\left(\mathrm{dt}_{\mathrm{k}-1, \mathrm{k}}-\mathrm{dT}_{\mathrm{k}-1, \mathrm{k}}\right)
$$

onde:

$D_{k-1, k}^{1}=$ delta range na portadora $\mathrm{L} 1$, considerando os erros do sistema;

$D_{k-1, k}^{2}=$ delta range na portadora $\mathrm{L} 2$, considerando os erros do sistema; $\lambda_{1}, \lambda_{2}=$ comprimento da onda dos sinais da portadoras L1 e L2, respectivamente;

\footnotetext{
${ }^{24}$ Em inglês, é conhecido como delta range.
} 
$\phi_{1}^{s}, \phi_{2}^{s}=$ medida da fase da portadora, em ciclos, para L1 e L2, respectivamente;

$\lambda_{1} \varphi_{1 \mathrm{rk}}^{\mathrm{s}}=$ pseudodistância, em unidade linear, obtida com a portadora L1 no tempo $t_{1}$;

$\lambda_{2} \varphi_{2 \mathrm{rk}}^{\mathrm{s}}=$ pseudodistância, em unidade linear, obtida com a portadora $\mathrm{L} 2$ no tempo $t_{1}$;

$\mathrm{T}_{\mathrm{k}-1, \mathrm{k}}=$ erro que envolve a troposfera na época $\mathrm{t}_{\mathrm{k}-1}$;

$\mathrm{I}_{\mathrm{k}-1, \mathrm{k}}^{2}=$ erro que envolve a ionosfera na época $\mathrm{t}_{\mathrm{k}-1}$;

$\mathrm{dt}_{\mathrm{k}-1, \mathrm{k}}=$ atraso do relógio do receptor na época $\mathrm{t}_{\mathrm{k}-1}$;

$\mathrm{dT}_{\mathrm{k}-1, \mathrm{k}}=$ atraso do relógio do satélite na época $\mathrm{t}_{\mathrm{k}-1}$;

$\rho_{\mathrm{k}-1, \mathrm{k}}=$ deslocamento de cada satélite em cada época, sem efeitos externos.

A partir das Equações (5) e (6) uma variação de distância livre do efeito da ionosfera pode ser obtida por meio da expressão (CAMARGO, 1999):

$\mathrm{D}_{\mathrm{k}-1, \mathrm{k}}=\frac{\mathrm{f}_{1}^{2}}{\mathrm{f}_{1}^{2}-\mathrm{f}_{2}^{2}} \mathrm{D}_{\mathrm{k}-1, \mathrm{k}}^{1}-\frac{\mathrm{f}_{2}^{2}}{\mathrm{f}_{1}^{2}-\mathrm{f}_{2}^{2}} \mathrm{D}_{\mathrm{k}-1, \mathrm{k}}^{2}$

Onde:

$\mathrm{f}_{1}, \mathrm{f}_{2}$ : freqüência nas portadoras $L 1$ e $L 2$, respectivamente; 
Enquanto os termos $D_{k-1, k}^{1}$ e $D_{k-1, k}^{2}$ possuem uma relação com a refração ionosférica, a combinação dada pela equação (7) elimina, matematicamente, esse efeito. Isso é possível devido ao fato da ionosfera ser um meio dispersivo, fazendo com que a refração causada em sinais na banda usada pelo GPS (banda L) dependa do valor da freqüência do sinal (LEANDRO, 2004). Uma outra característica devida à dispersão da ionosfera é o fato de que a pseudodistância sofre um atraso no sinal, enquanto que a fase da portadora sofre um avanço (avanço de fase). O atraso e o avanço têm a mesma magnitude para observáveis de mesma freqüência, porém com sinais opostos. Esse efeito deve ser levado em consideração no processo de filtragem do código (ou pseudodistâncias) a partir da fase.

Uma maneira de lidar com a diferença entre o código e a fase em relação à refração ionosférica seria a utilização da combinação das variações da distância (calculadas a partir da fase), com e sem o efeito da ionosfera. Dependendo da freqüência na qual se deseja fazer a filtragem pode-se usar as variações dadas pelas equações (5) e (7), no caso de L1, ou Equações (6) e (7), para L2. Dessa maneira, pode-se fazer uma combinação entre o código e a fase, multiplicando duas vezes a Equação (7) menos a Equação (5) ou (6), fazendo incidir a diferença em distância da fase da portadora em equivalente diferença em distância da pseudodistância, respectivamente para L1 e L2. Assim:

$$
\mathrm{M}_{\mathrm{k}-1, \mathrm{k}}^{\mathrm{i}}=2 \mathrm{D}_{\mathrm{k}-1, \mathrm{k}}-\mathrm{D}_{\mathrm{k}-1, \mathrm{k}}^{\mathrm{i}}
$$


para $\mathrm{i}=1$ e 2 .

Nesse processo, obtém-se equações similares as (5) e (6), porém, com o sinal trocado para a refração ionosférica. Nota-se que esse processo é válido apenas para os casos nos quais se tenha acesso a, pelo menos, duas freqüências de sinal (atualmente, é o caso das freqüências L1 e L2 no sistema GPS).

Segundo JIN (1996) e HOFMANN (2001), os valores de $M_{k-1, k}^{i}$ têm uma importante função, destinada a conter as mesmas informações que fazem parte da diferença entre pseudodistância em épocas subseqüentes $\left(\mathrm{P}_{i r k}^{S}-\mathrm{P}_{i r k-1}^{S}\right)$, porém, com ruído reduzido, que corresponde a, aproximadamente, 0,3 do ruído da pseudodistância original.

Em uma época inicial $\left(\mathrm{t}_{0}\right)$, a pseudodistância filtrada pela fase da portadora é dada pela própria pseudodistância observada $\left(\mathrm{P}_{\mathrm{ir} 0 / 0}^{\mathrm{S}}=\mathrm{P}_{\mathrm{ir} 0}^{\mathrm{S}}\right)$. A partir dela, podese calcular um valor para a pseudodistância, para a época seguinte $\left(t_{k}\right)$, a qual pode ser obtida pela expressão (JIN, 1996):

$$
\mathrm{P}_{\mathrm{irk} / \mathrm{k}-1}^{\mathrm{s}}=\mathrm{P}_{\mathrm{irk}-1 / \mathrm{k}-1}^{\mathrm{s}}+\mathrm{M}_{\mathrm{k}-1, \mathrm{k}}^{\mathrm{i}}
$$

onde $\mathrm{i}=1,2 \mathrm{e} \mathrm{k}=1,2, \ldots, \mathrm{t}_{\mathrm{k}}$. Na equação (9) $P_{i r k / k-1}^{s}$, representa a pseudodistância filtrada na época $t_{k-1}$.

A pseudodistância filtrada pela fase da portadora para a época $t_{k}$ é dada por (JIN, 1996): 


$$
\mathrm{P}_{\mathrm{irk} / \mathrm{k}}^{\mathrm{s}}=\mathrm{P}_{\mathrm{irk} / \mathrm{k}-1}^{\mathrm{S}}+\frac{1}{\mathrm{k}+1}\left(\mathrm{P}_{\mathrm{irk}}^{\mathrm{s}}-\mathrm{P}_{\mathrm{irk} / \mathrm{k}-1}^{\mathrm{s}}\right)
$$

onde $\mathrm{P}_{i r k}^{s}$ é a pseudodistância observada e $\mathrm{P}_{i r k / k-1}^{s}$, a calculada em uma época anterior.

A Figura 15 mostra a precisão para as pseudodistância (C/A, (P1) e P2) filtradas pela fase, obtida com a Equação (10), considerando $\sigma_{P 1}=1 \mathrm{~m}, \sigma_{P 2}=1,5$ $\mathrm{m}, \sigma_{\varphi 1}=0,0030 \mathrm{~m}$ e $\sigma_{\varphi 2}=0,0039 \mathrm{~m}$, para $\mathrm{k}_{\mathrm{i}}=1,2, \ldots, \mathrm{t}_{\mathrm{k}}$, com $\mathrm{i}=1,2$.

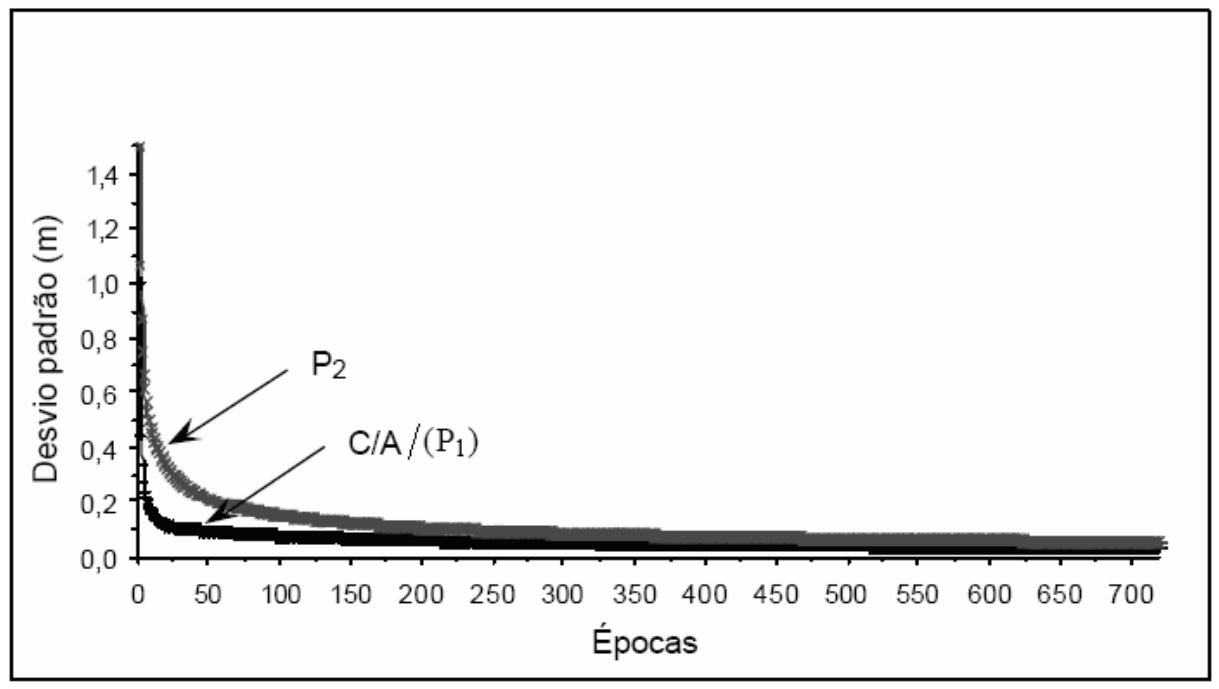

Figura 15 - Desvio padrão da pseudodistância filtrada pela fase da portadora Fonte: Camargo (1999)

A Figura 15 mostra que existe uma melhora na precisão das pseudodistâncias quando se aplica o algoritmo de filtragem do código pela fase; entretanto, observa-se que os valores dos desvios padrão se firmam depois de algumas épocas. Logicamente, a cada perda de sinal, o algoritmo deve ser reinicializado e o desvio padrão volta a ser o da pseudodistância referente à época inicial. O processo é reiniciado e o sistema levará alguns minutos para reduzir o 
ruído e convergir novamente.

A metodologia descrita, até então, trata do algoritmo para suavizar a pseudodistância pela fase da onda portadora ao empregar observações das duas portadoras. Contudo, ao considerar a vasta utilização de receptores de simples freqüência, autores têm estudado a filtragem de observações do código a partir das observações da portadora L1, apenas. Como exemplo, GOAD (1991), TEUNISSEN (1991) e JIN (1996) são alguns dos que vêm trabalhando nessa linha de pesquisa.

No caso de receptores GPS de simples freqüência, não se pode mais obter uma distância relativa livre do efeito da ionosfera (Equação 7). Em tal caso, substitui-se $M_{k-1, k}$ da Equação 9 por $D_{k-1, k}^{1}$ (Delta range em L1), expresso na Equação 6. Diante disso, pode-se obter um valor predito para a pseudodistância, numa época $\left(t_{k}\right)$, unicamente com informações da portadora L1, conforme indicado na expressão a seguir (JIN, 1996):

$$
\mathrm{P}_{\text {irk } / \mathrm{k}-1}^{\mathrm{S}}=\mathrm{P}_{\mathrm{irk}-1 / \mathrm{k}-1}^{\mathrm{S}}+\mathrm{D}_{\mathrm{k}-1, \mathrm{k}}^{1}
$$

Assim, a partir das Equações 5 e 11, pode-se obter observações de pseudodistâncias filtradas a partir de dados somente da portadora L1. Nesse tipo de aplicação, utilizando-se apenas uma freqüência, o tempo, durante o qual se pode manter o filtro funcionando sem reiniciar, torna-se uma restrição devido à divergência do efeito da ionosfera no código e na fase. Alguns autores indicam algo em torno de 30 minutos como um período máximo de observação. 


\section{INSTRUMENTAÇÃO E PROCEDIMENTOS UTILIZADOS}

Este trabalho foi desenvolvido nas seguintes etapas: (1) definição dos locais para implantação dos marcos de controle; (2) reconhecimento do local e materialização dos marcos; (3) planejamento para rastreamento com GPS de duas freqüências; (4) rastreamento com GPS de duas freqüências; (5) rastreamento com GPS de uma freqüência, e (6) descrição da estação de referência utilizada.

\subsection{DEFINIÇÃO DO LOCAL PARA IMPLANTAÇÃO DOS MARCOS DE CONTROLE}

Foram analisadas e comparadas diferentes localidades para implantação dos marcos geodésicos. Os principais aspectos levados em consideração foram: obstruções existentes nas proximidades dos marcos, segurança (humana e material), melhor acesso, vida útil do marco implantado, apoio em atividade de campo e implantação dos marcos na macrorregião da cidade de São Carlos.

Após a análise das possibilidades, constatou-se que a alternativa de implantação dos marcos ao longo de uma rodovia, a fim de se facilitar o acesso, a locomoção e a otimização de realização das sessões de observações, foi a que 
mais se adequou às necessidades do projeto.

O trecho da rodovia Washington Luis ${ }^{25}$, entre as cidades de São Carlos e General Salgado, no Estado de São Paulo, foi escolhida para a materialização das estações de controle, principalmente devido à proximidade da estação de referência da EESCIUSP. Nesta fase, foi definido que os marcos seriam materializados a distâncias aproximadas de 20,50, 75, 100, 150, 200 e 300 km da estação de referência, totalizando sete seções, como mostra a Figura 18. Os espaçamentos entre os marcos de controle foram escolhidos com o objetivo de avaliar a acurácia do posicionamento em função, também, dos erros ocorridos por causa da ionosfera, os quais são proporcionais ao comprimento da base para receptores de uma freqüência.

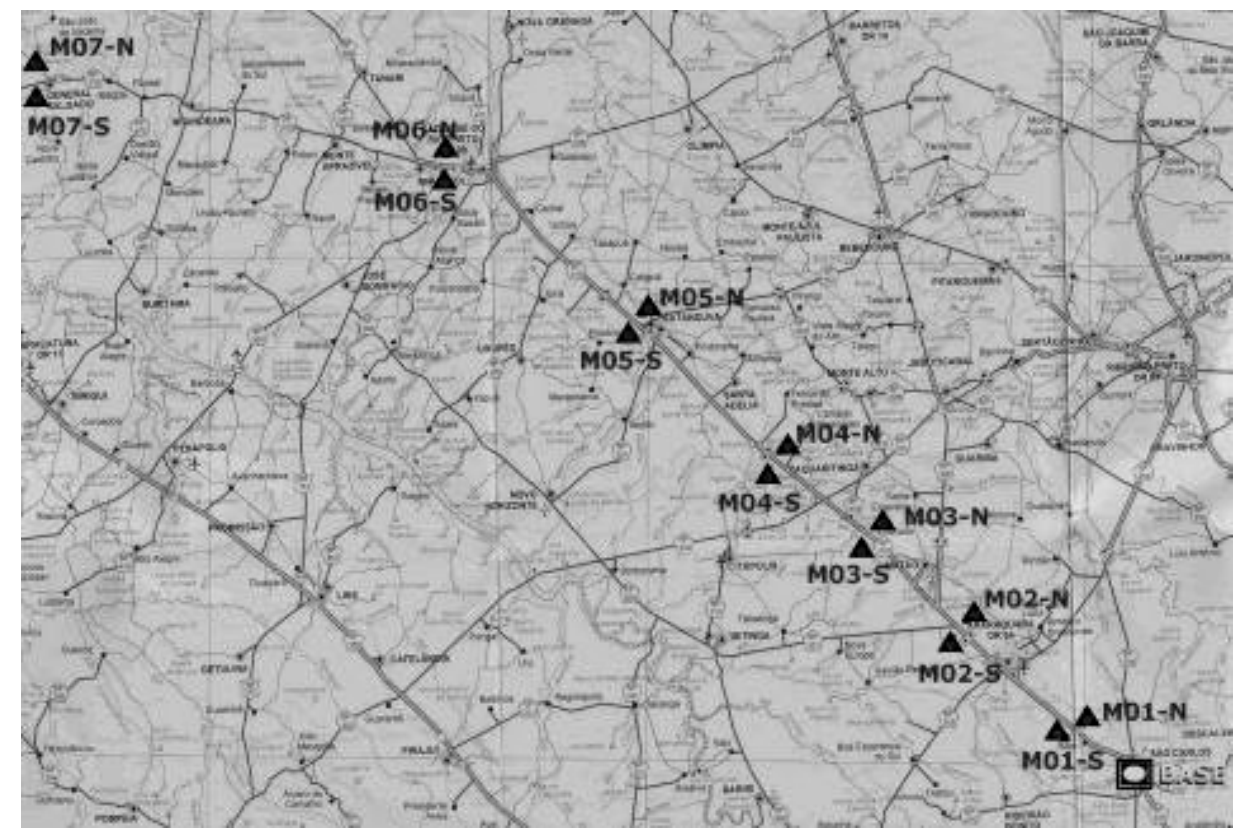

Figura 16 - Localização dos marcos ao longo da rodovia Washington Luís Fonte: adaptado de www.der.sp.gov.br 


\subsection{RECONHECIMENTO E MATERIALIZAÇÃO DOS MARCOS DE CONTROLE}

\subsubsection{Reconhecimento do local de estudo}

Para reconhecimento da área em estudo e implantação dos pontos de controle, foi necessária uma autorização da empresa "Triângulo do Sol Auto Estradas S/A" que possui concessão administrativa da rodovia Washington Luís (do Estado de São Paulo), sendo preciso avisar antecipadamente sempre que fosse necessário ir a campo.

Depois do estudo da área potencial para coleta de dados e tendo em mãos a devida autorização para trabalhar temporariamente nos setores predefinidos da rodovia, deu-se início a pesquisa de campo. Possuindo os comprimentos aproximados ${ }^{26}$ dos vetores das seções entre a estação de referência da EESCIUSP e os marcos de controle, seguiu-se com a fase de reconhecimento do local para materialização dos marcos.

Nos locais predefinidos, fez-se um reconhecimento cuidadoso, registrandose todas as possíveis obstruções superiores a $10^{\circ}$ de elevação, considerando como referência de visão o ponto no qual se desejava materializar o marco. Com o auxílio de um clinômetro de bolso (Figura 17a) e um GPS de navegação (GarminEtrex Vista - Figura 17b), registrou-se as obstruções existentes nas proximidades de todos os pontos.

\footnotetext{
${ }^{26}$ Os comprimentos aproximados foram extraídos de um mapa rodoviário do estado de São Paulo, na escala de 1:1.000.000.
} 
Para fazer a marcação das possíveis obstruções, utilizou-se uma adaptação do modelo de relatório para implantação dos marcos, com a descrição da estação proposta pelo IBGE. Os relatórios estão devidamente preenchidos e disponíveis no Apêndice A.
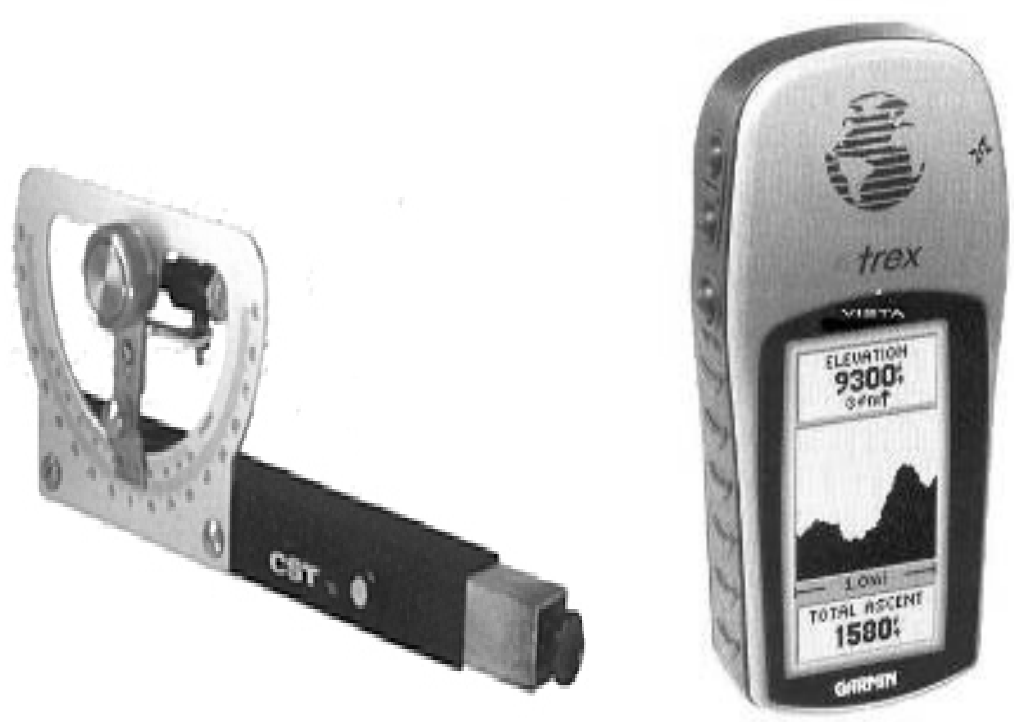

Figura 17 - Clinômetro de bolso e GPS de navegação

\subsubsection{Materialização dos marcos}

Um marco foi implantado, em todas as seções, em cada lado da faixa de domínio, de acordo com o sentido norte $(\mathrm{N})$ e sul $(\mathrm{S})^{27}$. Esse procedimento foi de grande importância devido a vários fatores, entre a organização e planejamento para as viagens de campo, facilidade no planejamento para rastrear dados no mesmo horário (observando-se a mesma constelação GPS), minimização do tempo despendido em campo, localização dos marcos em eventuais trabalhos futuros, etc.

\footnotetext{
${ }^{27}$ Nomenclatura empregada nas quilometragens de identificação da rodovia.
} 
Os marcos utilizados são de concreto, com formato cilíndrico, possuindo 15 $\mathrm{cm}$ de diâmetro e $35 \mathrm{~cm}$ de altura. Como ponto de centragem foi utilizado um parafuso inoxidável e devidamente perfurado. A fim de fornecer maior vida útil aos marcos, eles foram colocados a $33 \mathrm{~cm}$ do nível do terreno, deixando um ressalto de $2 \mathrm{~cm}$, conforme mostra a Figura 20 .

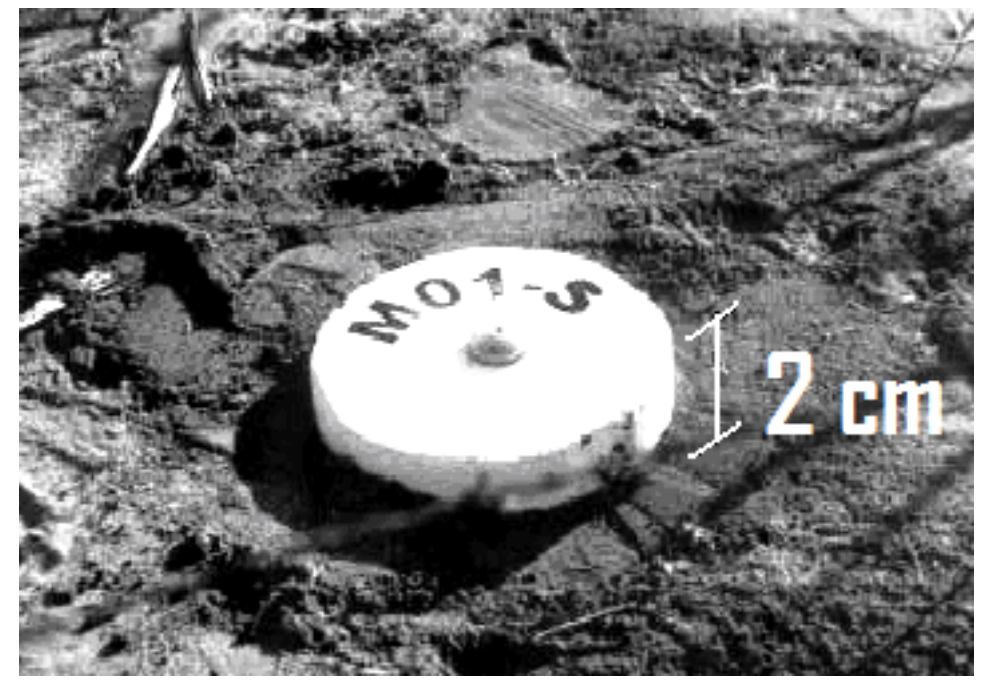

Figura 18 - Marco cilíndrico de concreto após a materialização

\subsection{PLANEJAMENTO DE CAMPO}

Depois de concluída a etapa da escolha dos locais e já materializados os marcos (pontos de controle), prosseguiu-se com o planejamento de campo. Esta fase teve como objetivo definir processos e técnicas a serem adotadas em campo.

\subsubsection{Planejamento da coleta de dados}

Com o objetivo de maximizar a precisão das coordenadas dos pontos de controle deste trabalho, foram feitas análises do comportamento e disponibilidade dos satélites, nível dos DOPs (Dilution of Precision), etc. 
É possível fazer uma pré-análise dos itens anteriormente citados em diferentes programas de processamento de dados GPS existentes no mercado. Para este trabalho, utilizou-se o software SKI-Pro, versão 3.0, da Leica Geosystems, que possui um módulo para planejamento das missões de campo. Como se sabe, o planejamento não elimina eventuais surpresas que possam inviabilizar o serviço de campo serve, no entanto, para reduzir essa possibilidade.

Tendo em mãos as coordenadas aproximadas dos pontos de controle, obtidas com GPS de navegação, ainda na etapa de implantação dos marcos, assim como um almanaque atualizado (dois dias antes da ida ao campo), foi possível fazer uma prévia do comportamento do sistema no dia e horário de rastreio das observações GPS naquela região. A Figura 19 apresenta o número de satélites disponíveis ao longo do dia 27-11-2004. Na Figura 20 é apresentada a trajetória (Sky Plot) e a elevação dos satélites disponíveis no mesmo dia. A Figura 21 mostra a degradação da precisão das observáveis ao longo do dia.

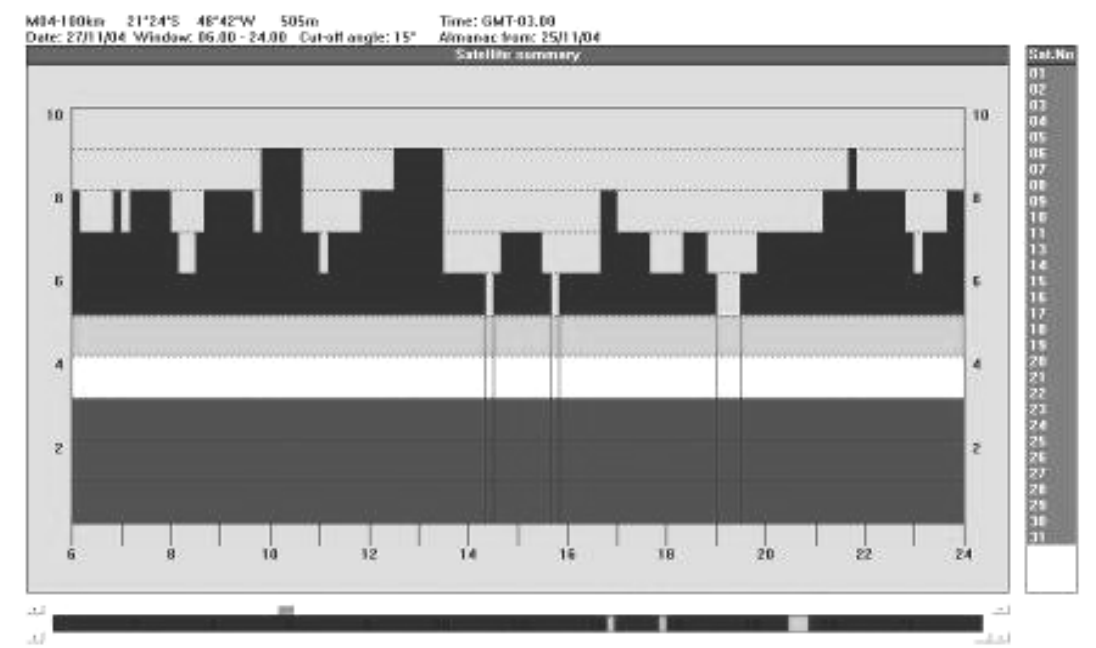

Figura 19 - Número de satélites disponíveis (27-11-2004) 


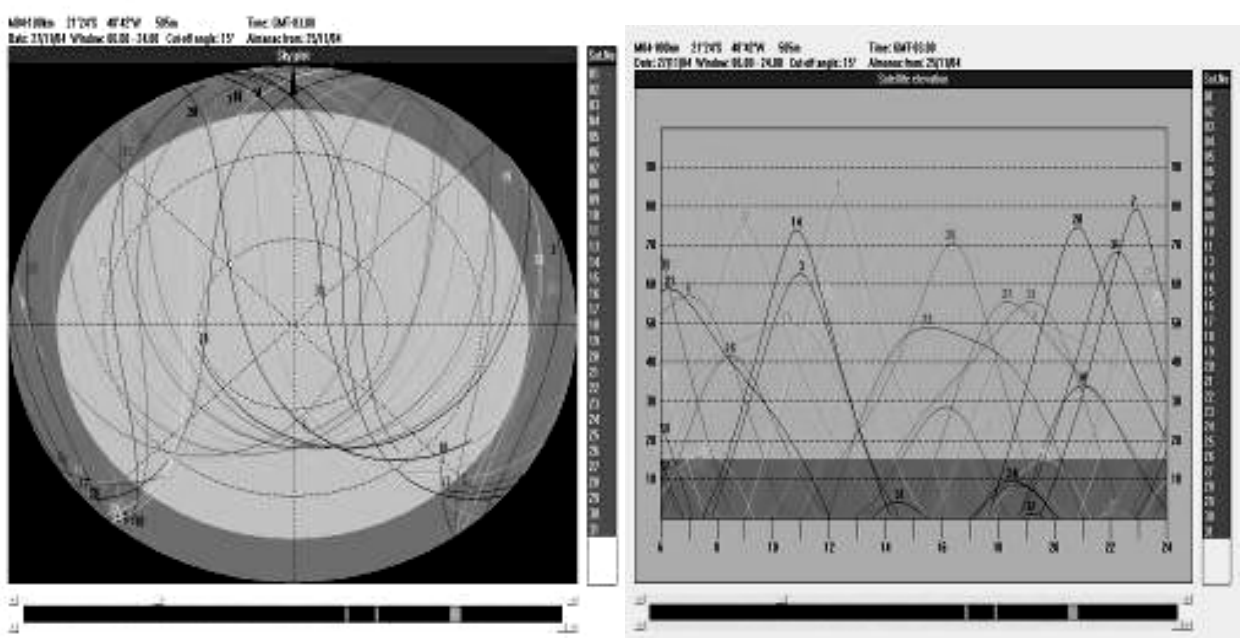

Figura 20 - Trajetória e elevação dos satélites disponíveis (27-11-2004)

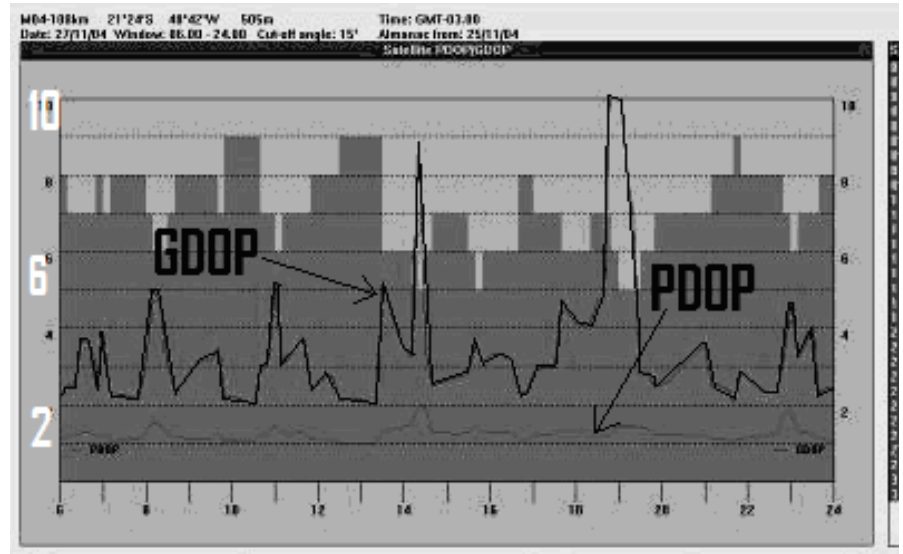

Figura 21 - Diluição da precisão (PDOP e GDOP)

Em função dessas informações, foi possível fazer um planejamento dos horários de rastreio para que se tenha uma melhor precisão no resultado final. Como se pode notar na Figura 21, a diluição da precisão de posicionamento $(P D O P)$ foi bastante satisfatória (com pequenas variações em torno de 2 unidades de diluição). Ressalta-se aqui a importância dessa variação neste trabalho, devido ao fato da análise dos dados restringir-se à verificação da acurácia das coordenadas calculadas pelas observações com receptores de uma freqüência. 


\subsection{POSICIONAMENTO POR GPS}

Para a determinação das coordenadas das estações de controle, dividiu-se o posicionamento por GPS em duas partes: a primeira trata do posicionamento com GPS de dupla freqüência, usado na determinação das coordenadas de referência das estações de controle; a segunda aborda o posicionamento com GPS de simples freqüência.

\subsubsection{Rastreamento com GPS de dupla freqüência (L1/L2)}

A equipe de trabalho envolvida na coleta de dados foi formada por quatro pessoas - estudantes e/ou funcionários do Departamento de Transportes da EESC-USP. Foi necessária a presença de um funcionário responsável pela vistoria do funcionamento da estação de referência. Além disso, houve uma inspeção, a cada 30 minutos, dos receptores em campo para que ocorresse total sincronismo no rastreio dos receptores envolvidos na coleta de dados.

O processo de armazenamento e transferência das observações GPS foram fatores que também mereceram cuidado. Levou-se um computador portátil (Notebook) para descarregar os dados logo após sua coleta (no deslocamento de um ponto a outro). Após serem descarregados, os dados foram gravados em um dispositivo de gravação (tipo disco compacto) para backup. Mesmo tendo-se armazenado os dados em locais diferentes, eles não foram apagados do cartão do receptor antes de se proceder a uma minuciosa verificação das observações. 
Utilizou-se 02 (dois) receptores GPS geodésicos em cada seção da rodovia, em um mesmo período de observação, a fim de garantir maior controle dos desvios das coordenadas de cada ponto, fazendo-se os ajustes necessários. Os aparelhos foram gentilmente emprestados pela empresa Comercial e Importadora Wild Ltda.

\subsubsection{Característica do equipamento}

Os receptores GPS utilizados, para definir as coordenadas georreferenciadas, foram do modelo GPS System 520, fabricado pela LeicaGeosystems. Segundo o fabricante, este instrumento apresenta uma precisão nominal igual a $3 \mathrm{~mm}+0,5 \mathrm{ppm}$ (rms). O receptor é composto de um sensor, uma antena e um terminal, conforme mostra a Figura 22.

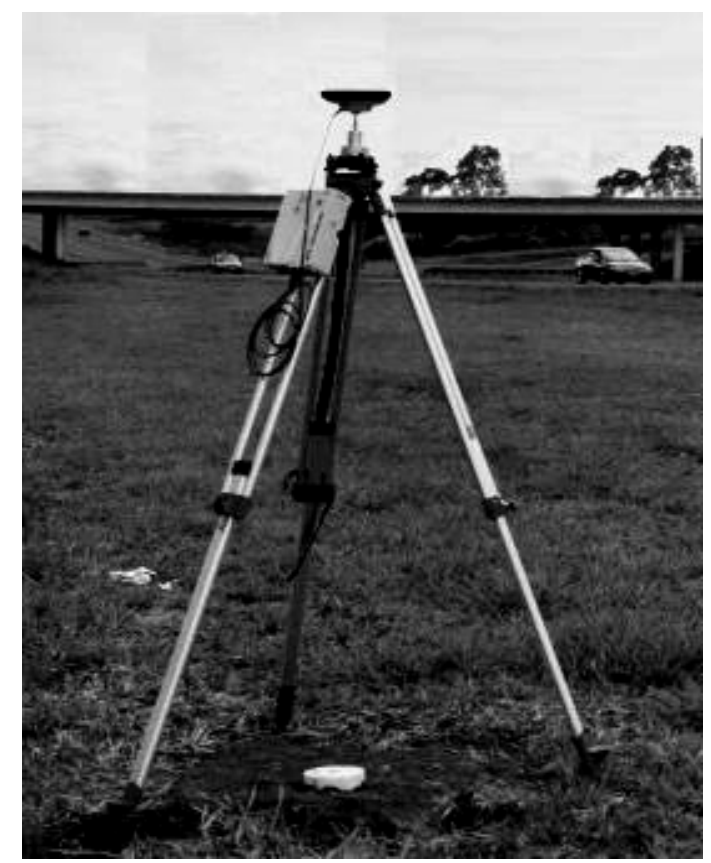

Figura 22 - GPS System 520 da Leica Geosystems 


\subsubsection{Tempo de rastreio de dados}

O tempo mínimo de ocupação em cada ponto da seção de trabalho foi baseado nas recomendações feitas pela Norma técnica para georreferenciamento de imóveis rurais (INCRA - 2003), com o objetivo de coletar uma quantidade suficiente de observáveis para se fazer a combinação entre os dados das duas portadoras (ionosfera livre), quando já não era possível resolver as ambigüidades.

O tempo de observação depende exclusivamente do comprimento da linha base (distância entre o ponto de interesse e a estação de referência). A Tabela 5 apresenta o tempo proposto pela Norma; a Tabela 6 mostra o tempo de ocupação adotado neste trabalho.

Tabela 5 - Relação entre tempo de ocupação e linha base em levantamentos de controle (INCRA - 2003)

\begin{tabular}{cccc}
\hline $\begin{array}{c}\text { Distância entre } \\
\text { estações } \mathbf{( k m )}\end{array}$ & $\begin{array}{c}\text { Ocupação } \\
\text { mínima em horas }\end{array}$ & Observáveis & $\begin{array}{c}\text { Tipo de solução } \\
\text { esperada }\end{array}$ \\
\hline Até 20 & 0,5 & $\varphi$ L1 ou $\varphi$ L1/L2 & DD Fixa \\
\hline $20-50$ & 2,0 & $\varphi$ L1/L2 & DD Fixa \\
\hline Acima de 100 & 4,0 & $\varphi$ L1/L2 & DD Float \\
\hline
\end{tabular}

Tabela 6 - Relação entre tempo de ocupação e comprimento da linha base

\begin{tabular}{ccc}
\hline $\begin{array}{l}\text { Distância entre } \\
\text { estações } \mathbf{( k m )}\end{array}$ & $\begin{array}{l}\text { Tempo mínimo de ocupação } \\
\text { em horas }\end{array}$ & $\begin{array}{l}\text { Tipo de solução } \\
\text { obtida }\end{array}$ \\
\hline 20 & 0,5 & Fixa L1L2/ Fixa L1L2 \\
\hline 50 & 1,0 & Fixa L1L2/ Fixa L1L2 \\
\hline 75 & 2,0 & Fixa L1L2/ Fixa L1L2 \\
\hline 100 & 3,0 & Fixa L1L2/ Fixa L1L2 \\
\hline 150 & 4,0 & Fixa L1L2/ Fixa L1L2 \\
\hline 200 & 4,0 & Float/Float \\
\hline 300 & 5,0 & Float/Float \\
\hline
\end{tabular}


Para os pontos de controle, o ideal seria fazer uma rede com duração mínima de 04 (quatro) horas em cada ponto e fazer uso das estações da RBMC, conforme especificações do IBGE. No entanto, optou-se pelo menor tempo de rastreio e pelo uso de apenas uma estação de referência com receptor de dupla freqüência (L1/L2).

Esse procedimento foi utilizado devido ao tempo reduzido para utilizar os receptores de dupla freqüência, visto tratarem-se de equipamentos emprestados. Outro fator significativo para a escolha do tempo de rastreio foi o fato de as viagens serem muito dispendiosas e caras, pelos gastos com a equipe.

\subsubsection{Rastreamento com GPS de simples freqüência (L1)}

Para o rastreio com aparelho GPS de simples freqüência (L1), foram empregados 4 (quatro) tipos de receptores GPS topográficos. Cada aparelho foi instalado no mínimo duas vezes no mesmo marco de cada seção da rodovia, em dias diferentes, por um período aproximado de uma hora, subdivido em sessões de cinco minutos, independente da distância da estação de referência.

\subsubsection{Receptor GPS SR510 - Leica Geosystems}

O receptor SR510 coleta observáveis do código e fase na portadora L1. Ele possui uma precisão nominal de 5 a $10 \mathrm{~mm}+2 \mathrm{ppm}$, de acordo com as especificações do fabricante. Utiliza memória interna e/ou cartão $P C C A R D$ de 32 Mb e 12 canais independentes. A antena externa utilizada foi a AT501. O equipamento possui um terminal com teclado alfanumérico separado do sensor. 
O software SKI Pro v 3.0 foi utilizado no processamento das observações. O SKI Pro faz uso do processo de filtragem do código com suavização auxiliada pela fase da portadora, quando esta não fixa sua ambigüidade. O SR510 é de fabricação da Leica Geosystems. A Figura 23 apresenta o receptor SR510 em operação de campo.

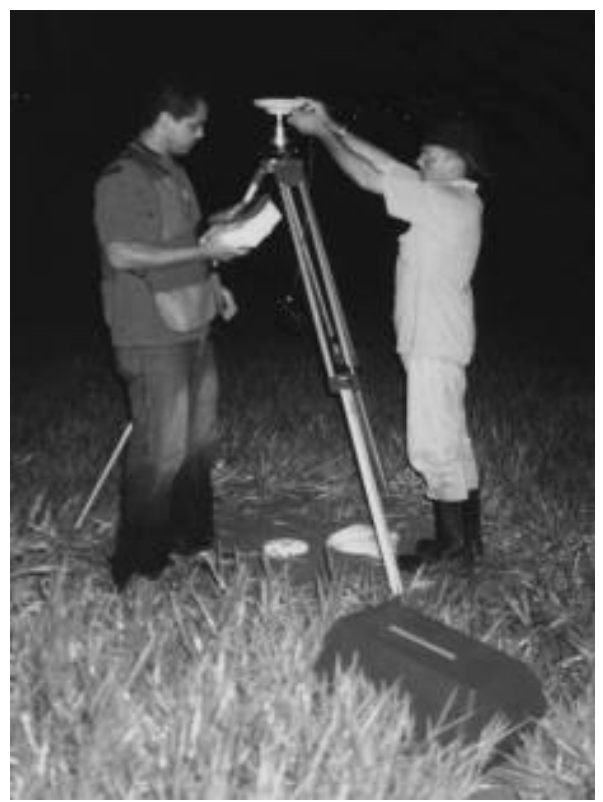

Figura 23 - GPS SR 510

\subsubsection{Receptor GPS Promark 2 - Ashtech}

O receptor Promark 2 é um equipamento de simples freqüência (L1 e C/A), possui uma precisão horizontal nominal (segundo informações do fabricante) igual a $5 \mathrm{~mm}+1 \mathrm{ppm}$ (rms), com uma memória interna de $8 \mathrm{Mb}$ e 10 canais independentes em L1.

Esse instrumento é o único nesta pesquisa que "não" utiliza a suavização do código pela fase da portadora. Ele faz uso apenas das observáveis transmitidas pela fase. O software que acompanha o aparelho é o Ashtech 
Solution v. 2.6, ambos fabricados pela THALES NAVIGATION. A Figura 24 apresenta o receptor Promark 2 em levantamento de campo.

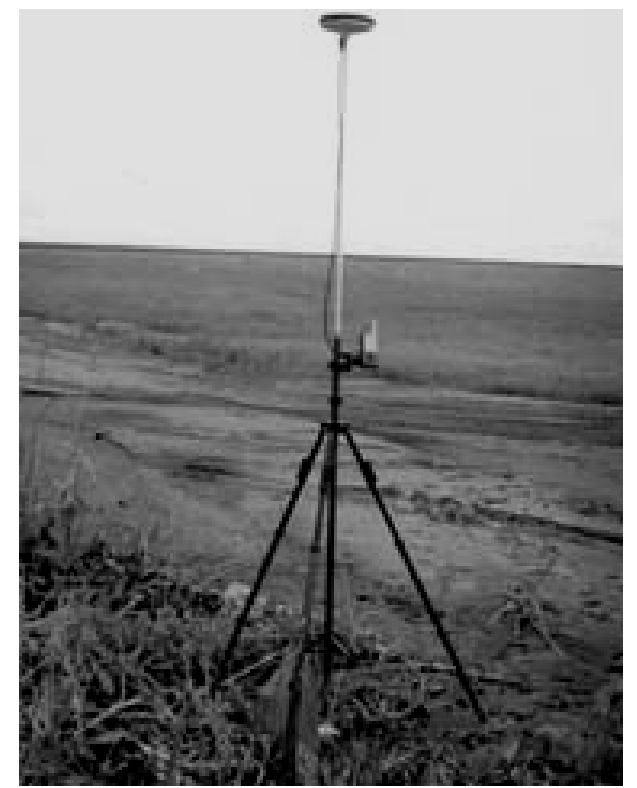

Figura 24 - Receptor GPS Promark 2

\subsubsection{Receptor GPS SR 20 - Leica Geosystems}

O receptor SR20 coleta observáveis do código e da fase da portadora em única freqüência (L1). Este equipamento possui uma precisão nominal de 5 a 10 mm + 2 ppm e 12 canais independentes, de acordo com o fabricante. O cartão de memória é do tipo Compact Flash com 32 Mb. A antena externa padrão é a AT501; a interna é a AT575.

Para o pós-processamento das observações, utilizou-se o software Leica Geo Office (LGO) v. 2.0. O LGO faz uso do processo de filtragem do código com suavização auxiliada pela fase da portadora, quando esta não fixa sua ambigüidade. Tanto o SR20 quanto o LGO são de fabricação da Leica Geosystems. A Figura 25 apresenta o receptor SR 20 no trabalho de campo. 


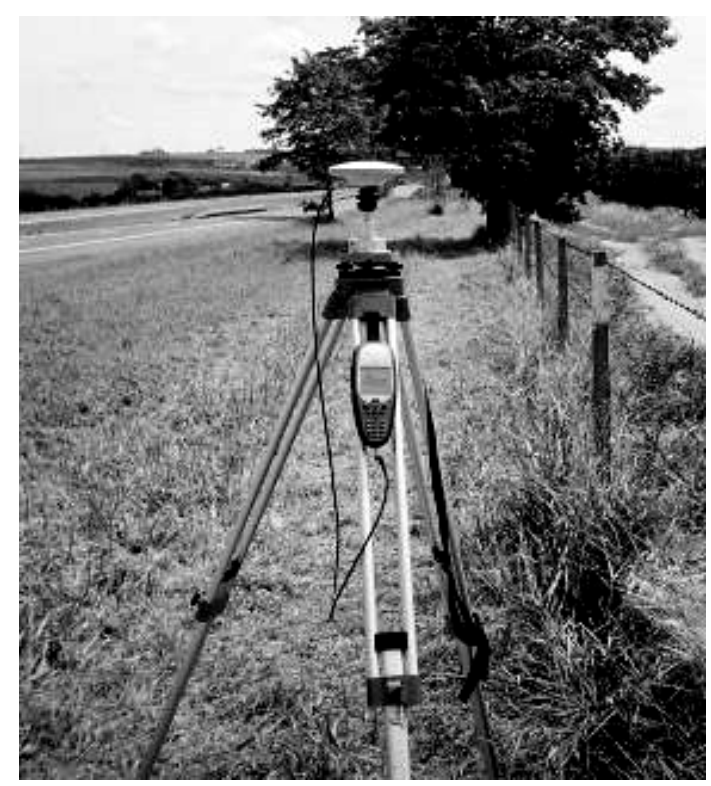

Figura 25 - GPS SR 20

\subsubsection{Receptor GPS Pro XR - Trimble}

O GPS ProXR é um receptor composto por três partes: sensor, coletora (TSC1) e antena (combinada L1 GPS/beacon). A precisão nominal horizontal deste equipamento é igual $5 \mathrm{~mm}+1 \mathrm{ppm}$. Possui 12 canais independentes com tecnologia para rejeição de sinais refletidos (multicaminhamento).

O software utilizado no pós-processamento das observações é o Pathfinder Office v. 2.9, de fabricação da Trimble. Este software faz, também, uso do algoritmo de suavização do código pela fase da portadora, quando esta não tiver sua ambigüidade fixada. A Figura 26 ilustra o GPS ProXR em operação. 


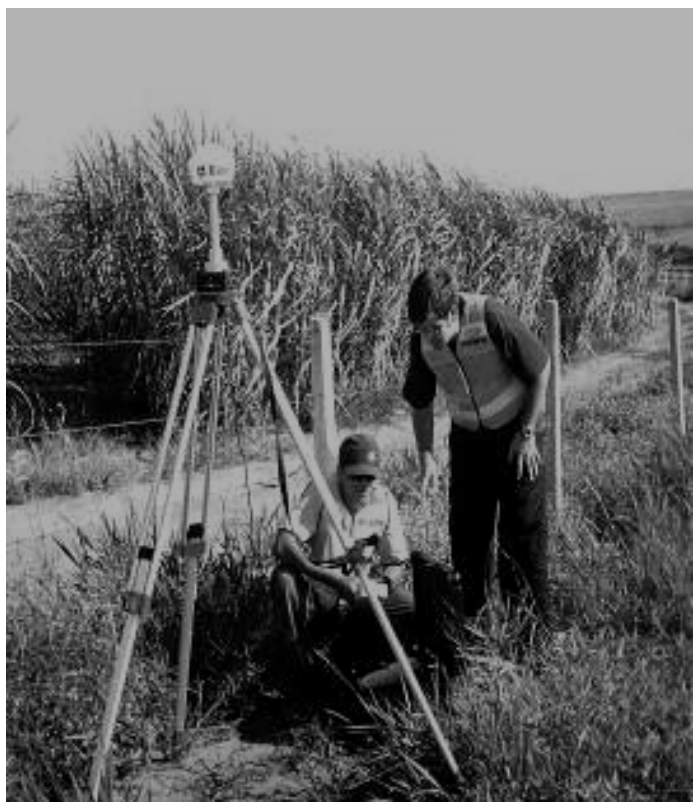

Figura 26 - GPS Pro XR

\subsection{CAMPANHAS DE POSICIONAMENTO COM RECEPTORES GPS DE SIMPLES FREQUÊNCIA}

A organização dos trabalhos de campo envolvidos nesta pesquisa foram organizadas em 4 (quatro) campanhas, em diferentes épocas e, na maioria das vezes, por distintos receptores, como indica a Tabela 7. Essa subdivisão permitiu obter dados com diferentes influências externas, possibilitando obter um trabalho simule o cotidiano de quem trabalha no ramo do GPS.

\begin{tabular}{|c|c|c|}
\hline Campanha & Receptor & Data \\
\hline 01 & SR 510 & 27 e $28 / 11 / 2004$ \\
\hline 02 & Promark 2 & 18 e $19 / 12 / 2004$ \\
\hline 03 & SR 20 e Pro XR & 26 e $27 / 03 / 2005$ \\
\hline 04 & SR 20 e Pro XR & 02 e 03/04/2005 \\
\hline
\end{tabular}




\subsection{ARMAZENAMENTO DOS DADOS}

A organização, o armazenamento e a fragmentação dos intervalos das observações fazem parte do pós-processamento dos dados, pois elas, uma vez perdidas ou corrompidas, poderão requerer uma nova visita em campo ou mesmo comprometer todo o levantamento.

O armazenamento das observações foram feitas imediatamente após o rastreio. Para o armazenamento dos dados foi utilizado um computador portátil, tipo Lap Top, a partir do qual foram feitas cópias e armazenadas em discos CDRW.

A exportação dos dados para o computador foi feita via cabo serial ou via cartão de memória, conforme o equipamento utilizado.

A Figura 27 apresenta uma ilustração da transferência e armazenamento dos dados de um dos receptores de simples freqüência, via cartão compact flash.

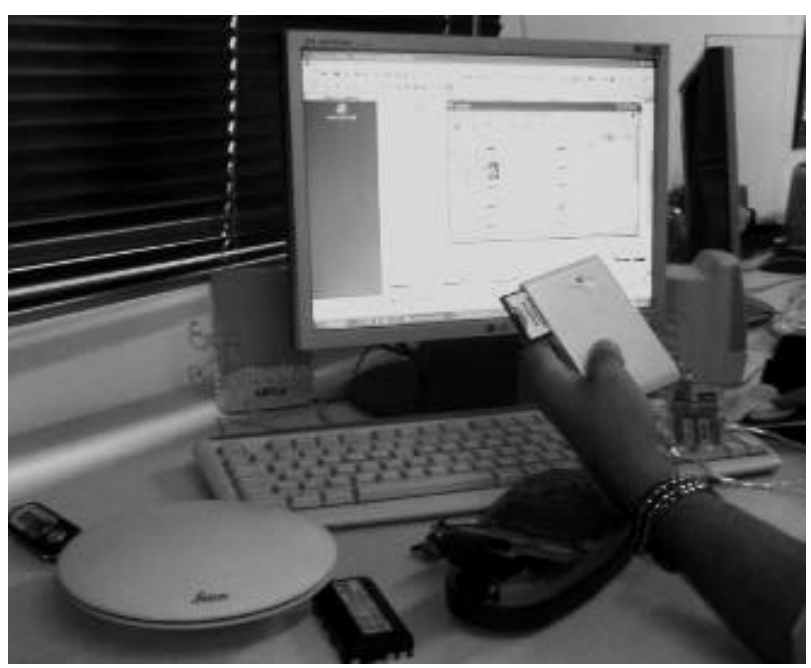

Figura 27 - Transferência de dados por meio de leitor de cartão 


\subsection{PROCESSAMENTO DOS DADOS}

As coordenadas (dos marcos) dos pontos de controle exerceram papel fundamental na fase de análises desta pesquisa, pois serviram como base e padrão de avaliação, de forma qualitativa, das coordenadas obtidas pelos receptores de simples freqüência, pós-processadas pelo código suavizado pela fase da portadora.

\subsubsection{Processamento das observações dos pontos de controle (L1/L2)}

As coordenadas de referência das estações de controle foram determinadas por meio do pós-processamento, tomando como referência os dados da estação de monitoramento contínuo da EESC/USP. Nos processamentos, utilizou-se os seguintes parâmetros:

$\checkmark$ freqüência: L1/L2;

$\checkmark$ estação de referência: EESC/USP

$\checkmark$ intervalo de amostragem: 1 segundo;

$\checkmark$ duração da sessão: em função do comprimento da linha base (Tabela 6);

$\checkmark$ ângulo de elevação mínimo: $15^{\circ}$;

$\checkmark$ tipo de efemérides: transmitidas, e

$\checkmark$ modelo de Troposfera: Hopfield.

A Figura 28 mostra um esquema dos vetores resultantes do pósprocessamento (nas duas freqüências) dos marcos M01S e M01N. 


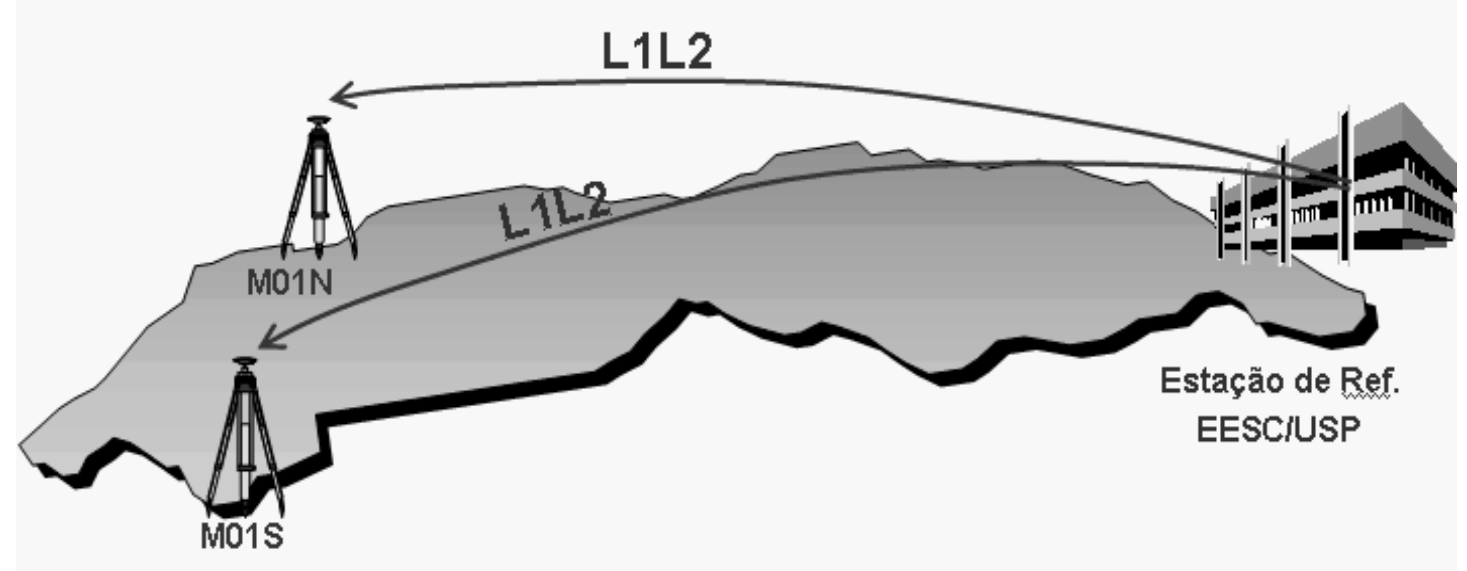

Figura 28 - Processamento Relativo com observações L1/L2

Os pós-processamentos das observações GPS foram realizados com o software SKI Pro, versão 3.0. Por se tratar de um programa comercial empregaram-se apenas os parâmetros de processamento dos dados disponíveis.

Os relatórios obtidos em todos os processamentos encontram-se no Apêndice B.

\subsubsection{Processamento das observações dos pontos de controle com receptores $\mathrm{L} 1$}

Conforme mostrado na Seção 4.4.2, cada estação implantada neste trabalho foi rastreada com receptores de uma freqüência (L1), sendo que os dois marcos de cada sessão foram observados simultaneamente.

No processamento, utilizou-se um dos marcos como estação de referência e o outro como remoto, por exemplo, na primeira seção, foi utilizada a estação M01N como referência e a M01S como remoto (ver Figura 29). As coordenadas das estações utilizadas como referência foram as obtidas com o receptor GPS de 
duas freqüências. Como resultado desses processamentos, foram obtidas as coordenadas dos marcos considerados como remotos.

A Figura 29 mostra um esquema com o vetor resultante do processamento dos dados (em simples freqüência) da estação M01S para o marco M01N.

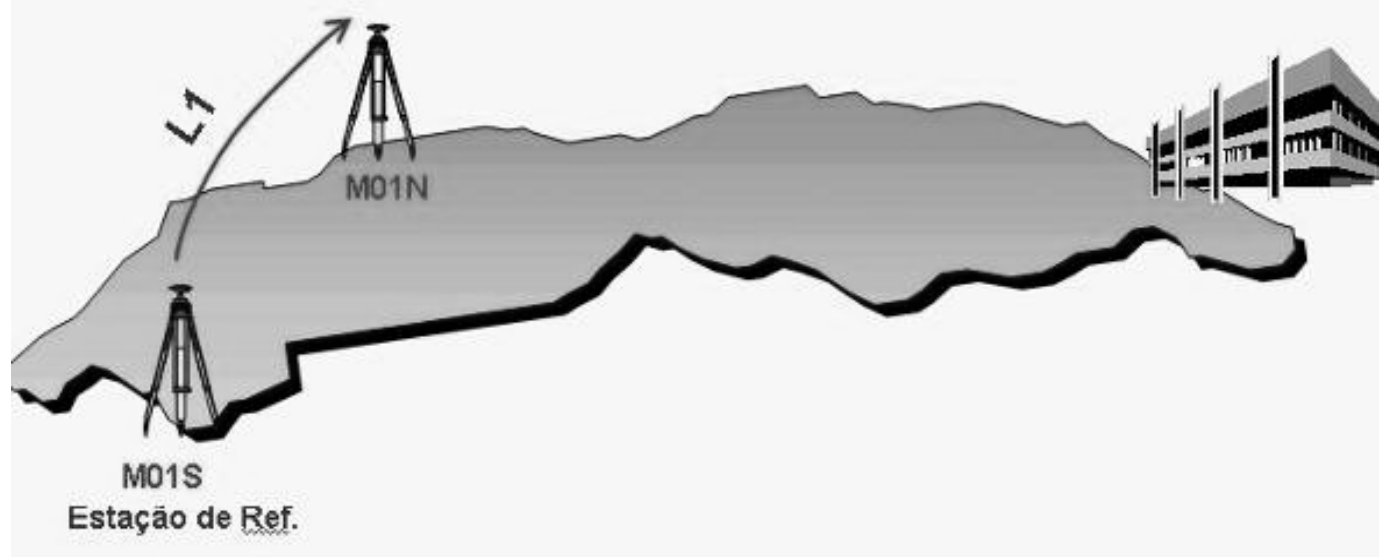

Figura 29 - Processamento Relativo com observações L1

Este procedimento foi realizado, individualmente, nas sete sessões, com o intuito de verificar o erro de fechamento da poligonal (triângulo) formada entre os dois marcos de cada sessão e a estação de referência da EESC/USP, conforme apresentado na sessão 4.6.3.

Os parâmetros de processamento utilizados para as observações dos receptores de uma freqüência foram os seguintes:

\footnotetext{
$\checkmark$ freqüência: L1;

$\checkmark$ estação de referência: M01S;

$\checkmark$ duração da sessão: 60 minutos;

$\checkmark$ intervalo de amostragem: 1 s;
} 


\footnotetext{
$\checkmark$ ângulo de elevação mínimo: $15^{\circ}$;

$\checkmark$ tipo de efemérides: transmitidas, e

$\checkmark$ modelo de troposfera: Hopfield.
}

\subsubsection{Avaliação das coordenadas dos pontos de controle}

As coordenadas dos pontos de controle (L1/L2) foram determinadas utilizando-se apenas uma estação de referência (EESC/USP). Neste tipo de processamento, apenas um vetor é gerado entre a estação de referência e o ponto de interesse. Nesse caso, o programa de processamento fornece, além das coordenadas geodésicas do ponto, seus desvios padrões.

No entanto, os desvios padrões representam a dispersão dos vetores determinados durante a sessão, não fornecendo, portanto, o indicativo da acurácia das coordenadas obtidas. Além disso, segundo RODRIGUES (2002), com uma avaliação unilateral de vetores, somente a partir dos desvios padrão resultantes do processamento, é possível chegar-se a informações conclusivas, mas de forma equivocadas, pois sabe-se que os desvios são bastante otimistas.

Uma forma de analisar a acurácia dos vetores seria a análise feita pelo cálculo dos erros de fechamento dos polígonos que envolvam tais vetores. Portanto, a acurácia das coordenadas dos pontos de controle foi avaliada pelo erro de fechamento do polígono (triângulo), formado entre a estação de referência (EESC/USP) e as estações de controle, como indica a Figura 30. 


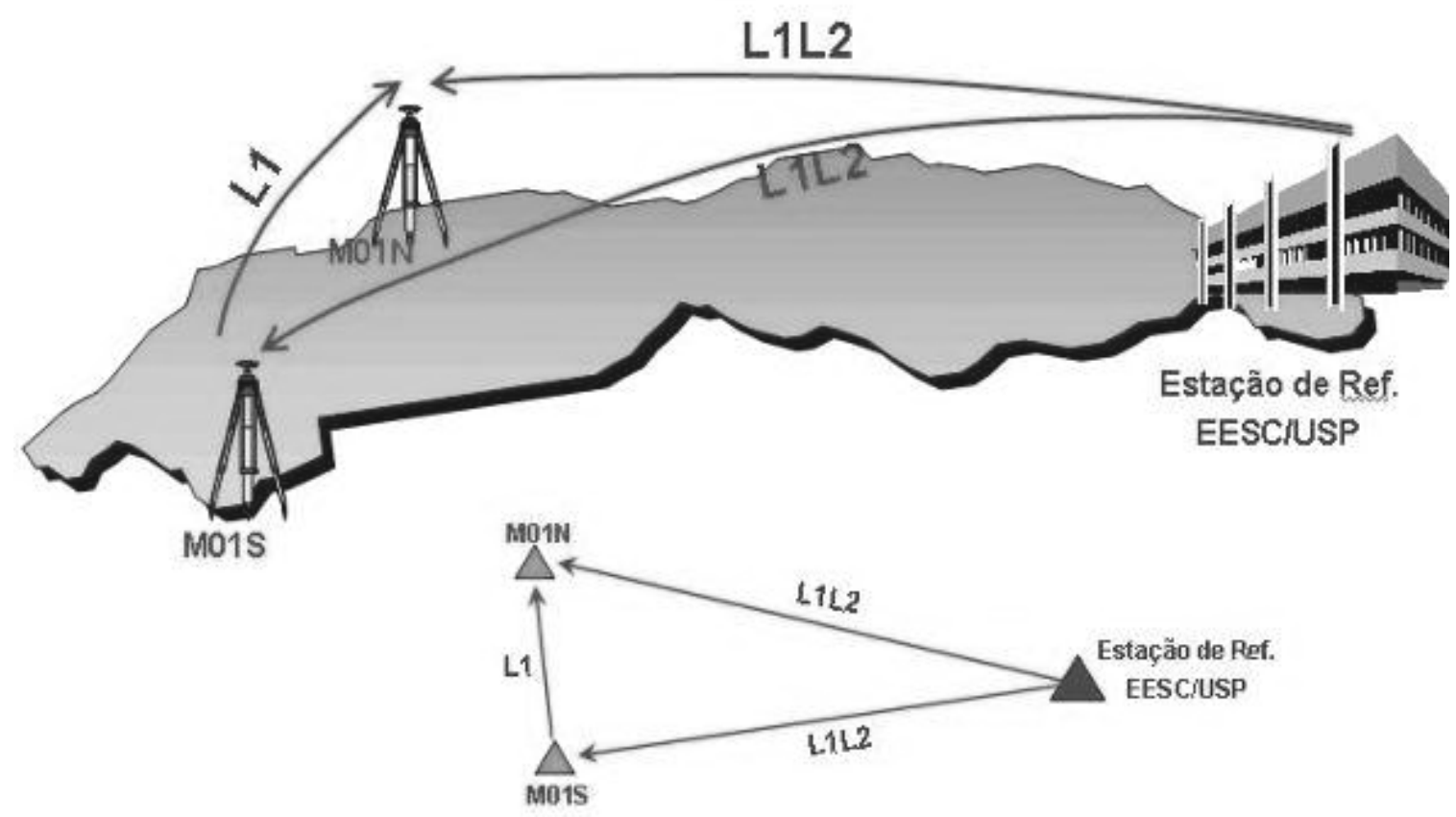

Figura 30 - Processo de fechamento poligonal por meio dos vetores

Os vetores formados entre a estação de referência e as estações de controle foram os determinados com receptores de dupla freqüência (Seção 4.6.1). Já o vetor formado entre as estações de controle foi determinado por receptor de simples freqüência (Seção 4.7.2). Tal procedimento foi utilizado para evitar erros sistemáticos devido à dependência estatística dos vetores.

\subsubsection{Estratégias de processamento no método "estático rápido"}

Com o objetivo de avaliar o levantamento relativo estático rápido, geralmente utilizado no georreferenciamento de imóveis rurais, seguindo-se a Norma do INCRA, cada sessão de observações de 60 minutos (receptor L1) foi re- 
amostrada e fragmentada ${ }^{28}$ em 12 sessões de 5 minutos. No processamento, foi utilizada apenas a estação da EESC/USP como referência.

No processamento dessas sessões, foram utilizados os seguintes parâmetros:

$\checkmark$ freqüência: L1 (receptores a, b, c e d) e código suavizado pela fase;

$\checkmark$ duração da sessão: 5 minutos;

$\checkmark$ intervalo de amostragem: 1 s;

$\checkmark$ ângulo de elevação mínimo: $15^{\circ}$;

$\checkmark$ tipo de efemérides: transmitidas, e

$\checkmark$ modelo de Troposfera: Hopfield;

A Figura 31 apresenta um esquema com os vetores resultantes do processamento dos dados da estação M01S e M01N.

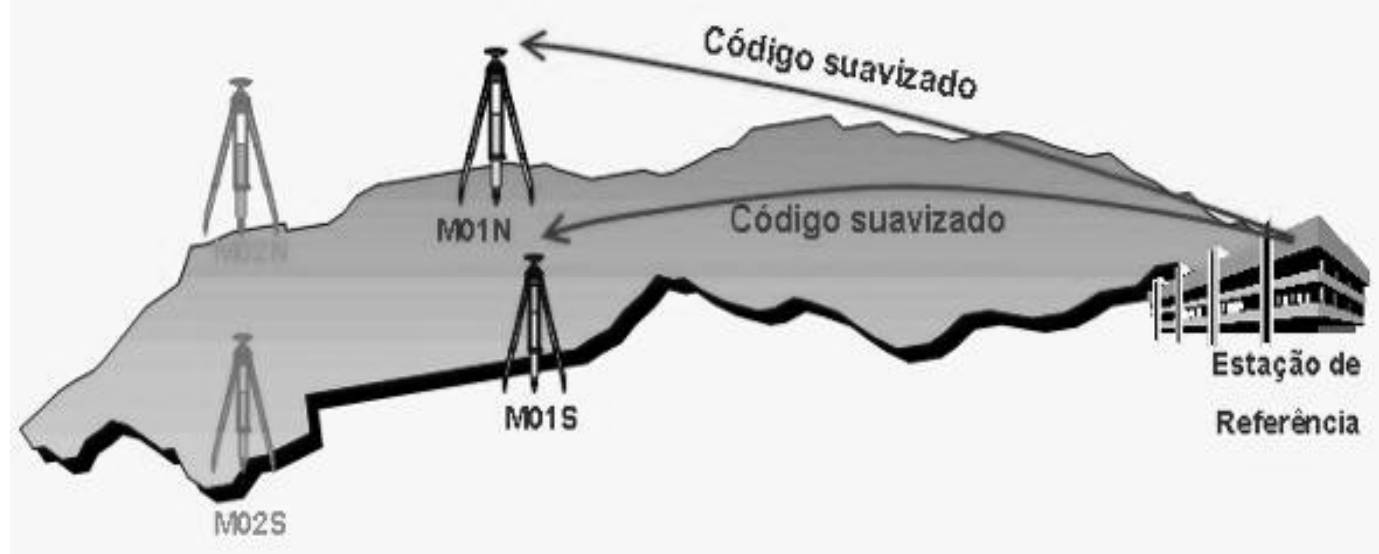

Figura 31 - Processamento no modo estático rápido pelo código suavizado

\footnotetext{
${ }^{28}$ A fragmentação das observações de uma hora foram feitas apenas pelos programas que permitiam tal divisão.
} 


\subsection{A ESTAÇÃO DE REFERÊNCIA UTILIZADA}

A estação GPS de monitoramento contínuo da Escola de Engenharia de São Carlos - Campus da USP, cujo responsável é o Departamento de Transportes (STTU) do Laboratório de Mensuração, localizada na laje superior da caixa d'água, disponibiliza, pública e gratuitamente, dados GPS para correções diferenciais, caracterizada pela elevada precisão nas medidas de GPS. O vértice dessa estação é denominado STTU.

Para obter-se as observações da estação de referência STTU, basta acessar os dados via download ${ }^{29}$. Os dados GPS são fornecidos no formato Leica (System 200 DS-Format) compactados na extensão “.zip”, desde 29 de outubro de 2002.

A Figura 32 apresenta a estruturação da antena do vértice STTU e suas coordenadas ajustadas.

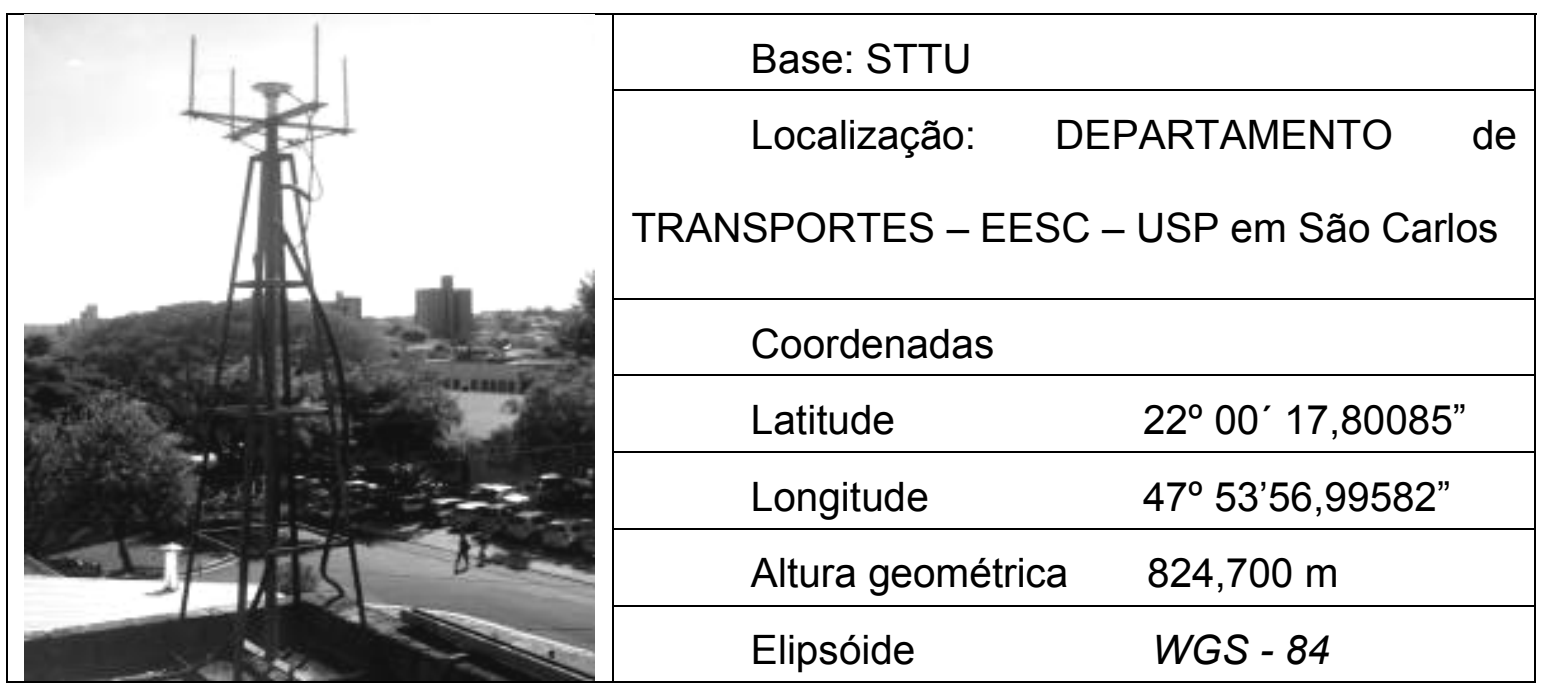

Figura 32 - Base STTU

${ }^{29}$ Na página da internet www.stt.usp.br 
O receptor GPS da estação, disponível no período da coleta de dados desta pesquisa, foi o receptor SR9500 de fabricação da Leica Geosystems, com duas freqüências, apresentando precisão horizontal nominal (segundo informações do fabricante) igual a $10 \mathrm{~mm}+1 \mathrm{ppm}(\mathrm{rms})$ com disponibilidade para as portadoras L1 e L2. 


\section{RESULTADOS}

Este capítulo apresenta os resultados obtidos na pesquisa. A Seção 5.1 apresenta as coordenadas dos pontos de controle (obtidas pelos receptores de dupla freqüência), utilizadas como referência na avaliação das coordenadas obtidas pelas estratégias propostas, e os erros obtidos no fechamento da poligonal pelos vetores envolventes. A Seção 5.2 apresenta, graficamente, às dispersões das coordenadas e as precisões, ambas obtidas com os receptores de uma freqüência.

\subsection{COORDENADAS DOS PONTOS DE CONTROLE (L1/L2)}

Como descrito no capítulo 4, as coordenadas dos pontos de controle obtidas por GPS de dupla freqüência foram utilizadas como referência para a avaliação das coordenadas obtidas por meio das estratégias de levantamento e processamento proposto.

A Tabela 8 apresenta as coordenadas dos marcos de referência, no sistema de projeção UTM e o elipsóide no WGS 84. A estação de referência está localizada no fuso 23 e os marcos no fuso 22 . 
Tabela 8 - Coordenadas (em UTM - WGS 84) dos pontos de controle

\begin{tabular}{llllll}
\hline ID & Este $(\mathbf{m})$ & Norte $(\mathbf{m})$ & Altura $(\mathbf{m})$ & $\sigma E(\mathbf{m})$ & $\sigma \mathbf{N}(\mathbf{m})$ \\
\hline M01-N & 804549,497 & 7574525,922 & 772,190 & 0,0023 & 0,0023 \\
\hline M01-S & 804542,258 & 7574442,159 & 772,503 & 0,0023 & 0,0023 \\
\hline M02-N & 779587,390 & 7595338,749 & 615,022 & 0,0017 & 0,0018 \\
\hline M02-S & 779487,982 & 7595259,938 & 624,924 & 0,0017 & 0,0018 \\
\hline M03-N & 763433,396 & 7611921,512 & 553,463 & 0,0004 & 0,0004 \\
\hline M03-S & 763429,669 & 7611824,210 & 551,969 & 0,0004 & 0,0004 \\
\hline M04-N & 738540,673 & 7631201,865 & 505,387 & 0,0011 & 0,0010 \\
\hline M04-S & 738566,036 & 7631092,949 & 504,522 & 0,0011 & 0,0010 \\
\hline M05-N & 704136,375 & 7663039,732 & 525,121 & 0,0007 & 0,0011 \\
\hline M05-S & 704010,596 & 7662968,425 & 528,763 & 0,0007 & 0,0011 \\
\hline M06-N & 659684,122 & 7697597,427 & 515,956 & 0,0188 & 0,0057 \\
\hline M06-S & 659674,305 & 7697521,032 & 520,368 & 0,0190 & 0,0060 \\
\hline M07-N & 562574,047 & 7716836,605 & 459,278 & 0,0030 & 0,0009 \\
\hline M07-S & 562549,239 & 7716786,709 & 459,748 & 0,0030 & 0,0009 \\
\hline
\end{tabular}

Os erros padrões das coordenadas de referência dos pontos de controle, estimados nos processamentos, tiveram precisão de poucos milímetros. Porém, não se pode inferir a respeito da acurácia. Segundo RODRIGUES (2002), uma avaliação das coordenadas, somente a partir dos desvios padrões resultantes do processamento, pode fornecer informações equivocadas, pois sabe-se que os desvios são otimistas. Um modo de analisar tais vetores seria por meio do erro de fechamento do polígono formado pelos vetores que ligam as estações.

Nesse caso, a acurácia das coordenadas de referência foi avaliada através erro de fechamento do polígono formado entre a estação GPS de referência da EESC/USP e as estações de controle em cada seção da rodovia (ver Seção 4.7.3). 
A Tabela 9 apresenta os erros estimados com os vetores formados entre as estações de controle em cada seção da rodovia (marcos de referência); a Tabela 10 apresenta os erros de fechamento do polígono formado entre a estação de referência GPS e as estações de controle em cada seção.

Tabela 9 - Erros de fechamento linear, nas direções Norte e Sul, do polígono formado pelos vetores (estação STTU / marcos)

\begin{tabular}{llll}
\hline Polígono & $\Delta \mathbf{E}(\mathbf{m})$ & $\Delta \mathbf{N}(\mathbf{m})$ & $\Delta \mathbf{H}(\mathbf{m})$ \\
\hline STTU/M01-S/M01-N & 0,0072 & 0,0018 & 0,0030 \\
\hline STTU/M02-S/M02-N & 0,0002 & 0,0001 & 0,0139 \\
\hline STTU/M03-S/M03-N & 0,0002 & 0,0015 & 0,0017 \\
\hline STTU/M04-S/M04-N & 0,0026 & 0,0009 & 0,0069 \\
\hline STTU/M05-S/M05-N & 0,0020 & 0,0005 & 0,0069 \\
\hline STTU/M06-S/M06-N & 0,1050 & 0,0395 & 0,0166 \\
\hline STTU/M07-S/M07-N & 0,0015 & 0,0084 & 0,0019 \\
\hline
\end{tabular}

Tabela 10 - Erros de fechamento do polígono formado pelos vetores (estação STTU / marcos)

\begin{tabular}{|c|c|c|c|c|c|c|c|}
\hline STTU & M01-N & M02-N & M03-N & M04-N & M05-N & M06-N & M07-N \\
\hline M01-S & 0,008 & & & & & & \\
\hline M02-S & & 0,013 & & & & & \\
\hline M03-S & & & 0,002 & & & & \\
\hline M04-S & & & & 0,008 & & & \\
\hline M05-S & & & & & 0,007 & & \\
\hline M06-S & & & & & & 0,044 & \\
\hline M07-S & & & & & & & 0,009 \\
\hline
\end{tabular}




\subsection{ACURÁCIA E PRECISÃO OBTIDAS COM RECEPTORES DE UMA FREQÜÊNCIA}

Como mostrado anteriormente, nesta pesquisa foram empregados quatro tipos de receptores de simples freqüência, os quais, para a apresentação dos resultados, foram rotulados como Receptor A, B, C e D. Deve-se notar que o intuito da pesquisa é a avaliação dos resultados do uso da filtragem do código a partir da portadora em diferentes receptores, e não a comparação qualitativa dos equipamentos envolvidos.

Foram feitos vários levantamentos em diferentes dias e horários, para se obter maior diversidade de intervenções externas, tais como diferentes constelações, índices de diluição da precisão, níveis de influência do meio de propagação dos sinais, multicaminhamento, etc.

Nas apresentações de todas as campanhas de rastreio serão apresentadas às distribuições da acurácia e da precisão, como também o índice Dst (Disturbance Storm Time Index) nos diferentes dias e horários de rastreio, conforme teoria disponibilizada na sessão 2.3.4.

Os tópicos a seguir apresentam, graficamente, as discrepâncias das coordenadas obtidas por meio dos receptores analisados. E, no apêndice C, são apresentadas as tabelas com os valores das discrepâncias, bem como as médias, desvios padrões e os valores máximos e mínimos das coordenadas. 


\subsubsection{Receptor A - Resultados obtidos}

As Figuras 33 a 39 ilustram, graficamente, a distribuição da acurácia e da precisão das coordenadas obtidas com o Receptor A, nas estações de controle previamente estabelecidas. Nessas figuras é apresentado o comportamento dos pontos sob a tolerância de $50 \mathrm{~cm}$, estipulada pela norma técnica para Georreferenciamento de imóveis rurais (INCRA, 2004). A Figura 40 ilustra o índice Dst para os dias 27, 28 e 29-11-2004.
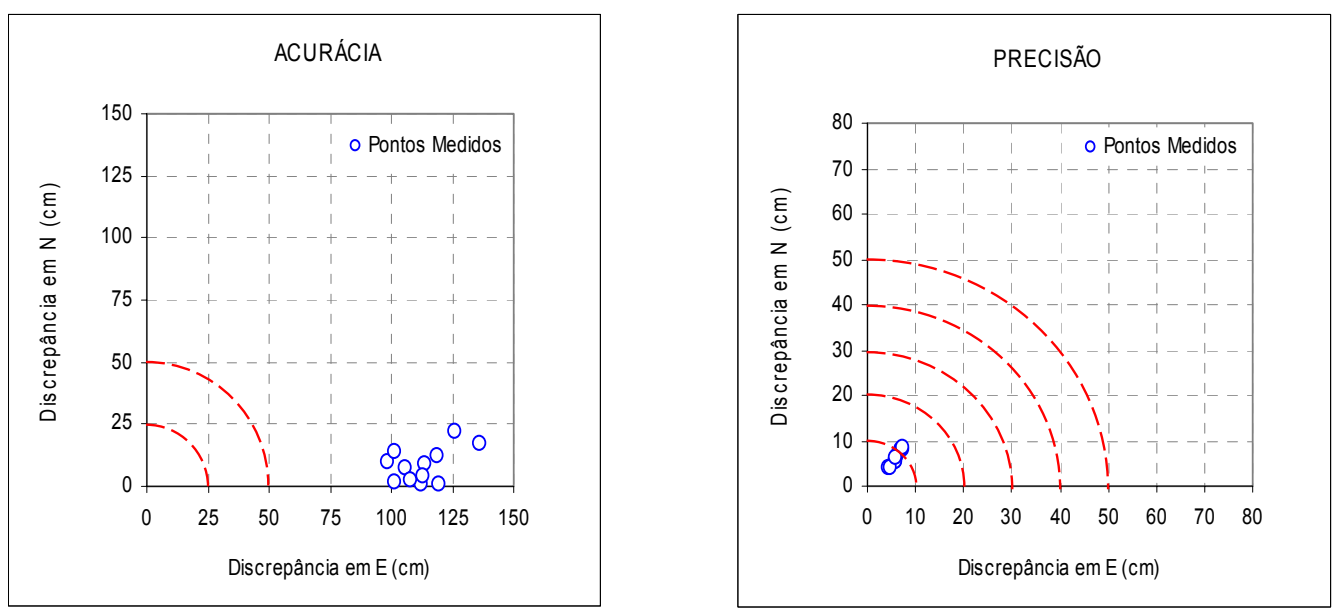

Figura 33 - Acurácia e precisão das coordenadas na seção 01(localizada a 20 km da estação de referência
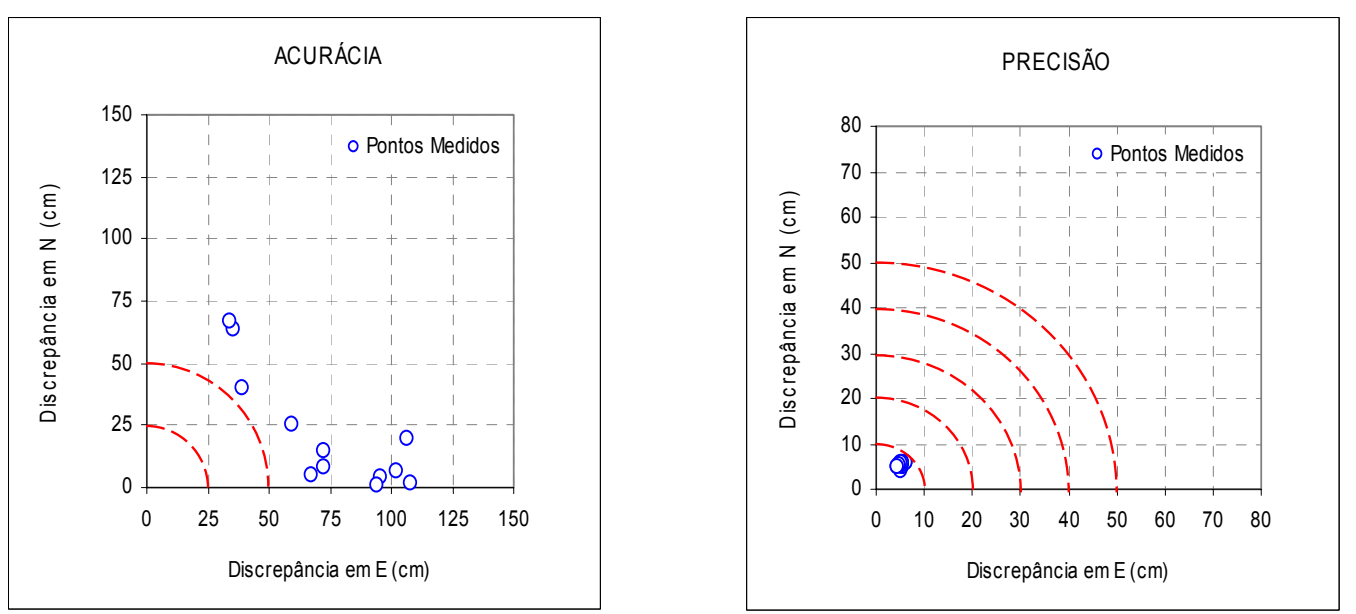

Figura 34 - Acurácia e precisão das coordenadas na seção 02 (localizada a 50 km da estação de referência) 

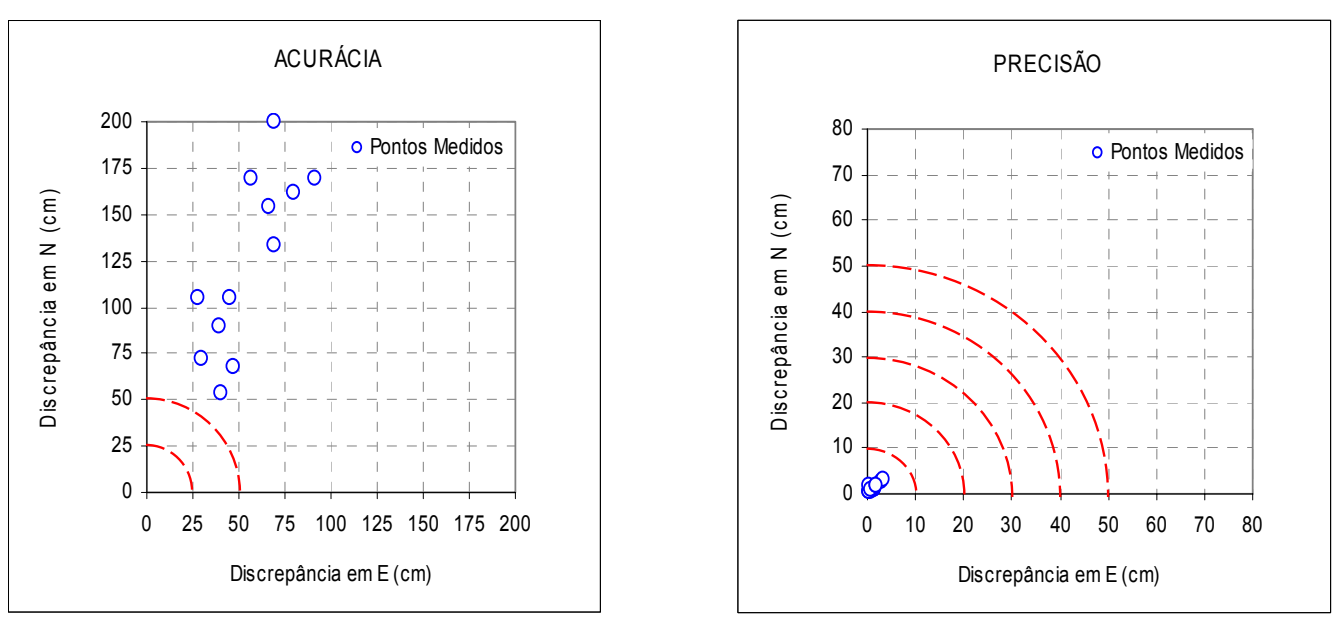

Figura 35 - Acurácia e precisão das coordenadas na seção 03 (localizada a 75 km da estação de referência)
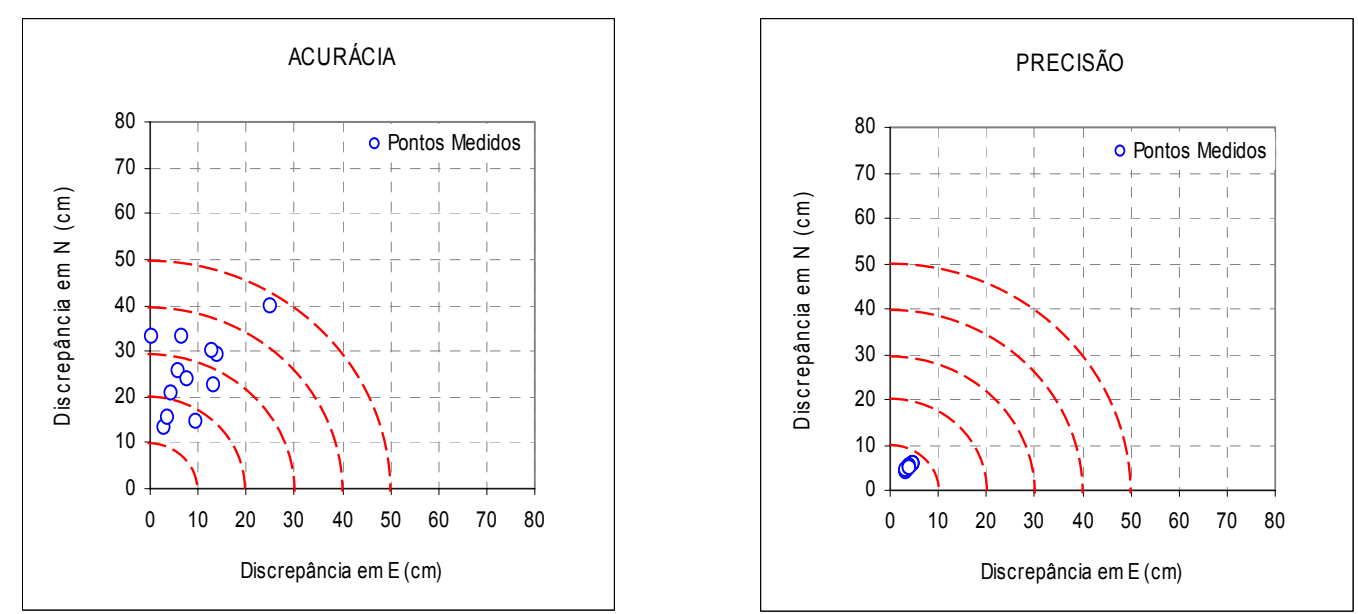

Figura 36 - Acurácia e precisão das coordenadas na seção 04 (localizada a 100 km da estação de referência)
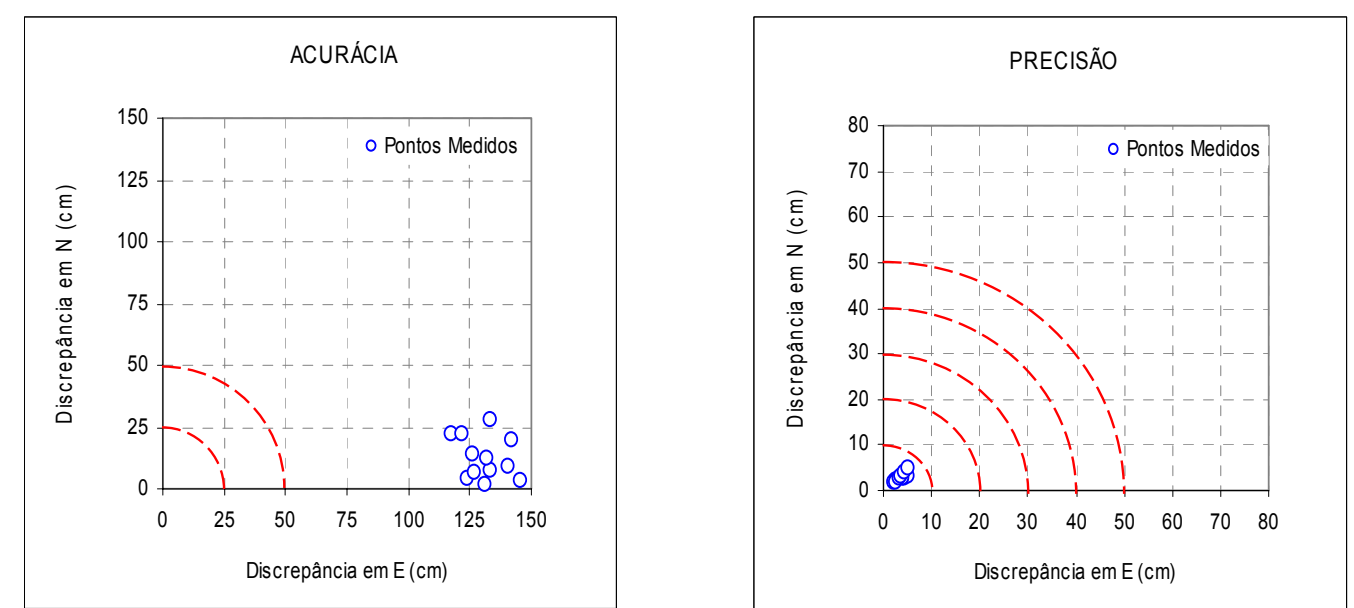

Figura 37 - Acurácia e precisão das coordenadas na seção 05 (localizada a 150 km da estação de referência) 

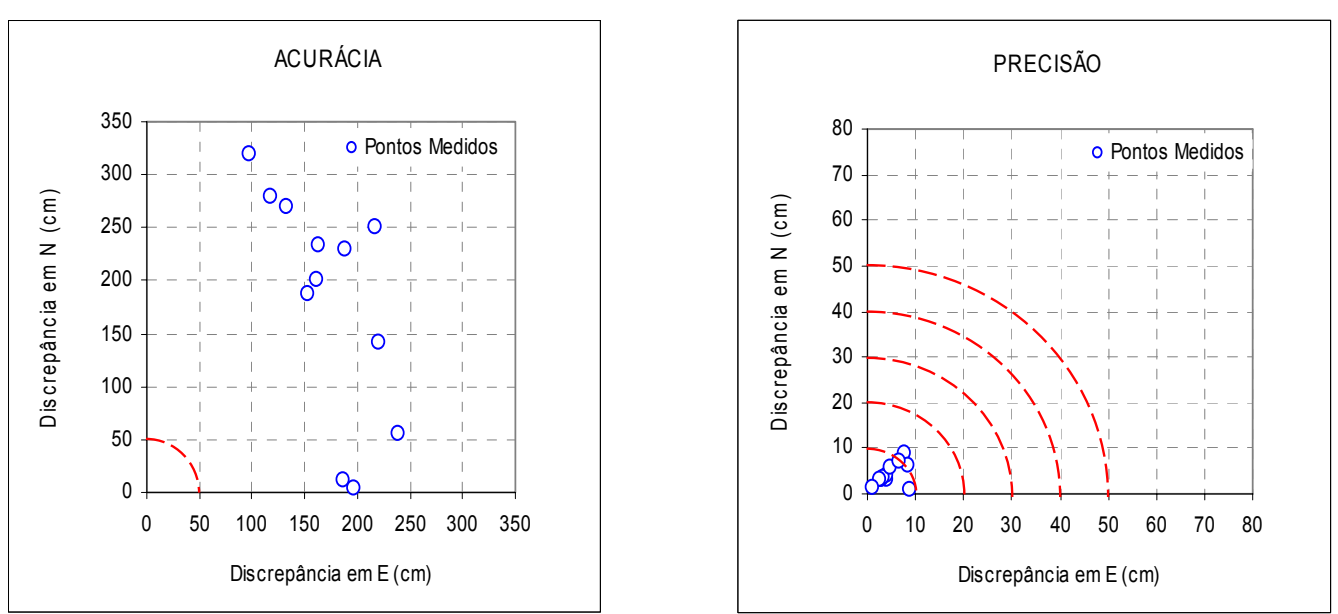

Figura 38 - Acurácia e precisão das coordenadas na seção 06 (localizada a 200 km da estação de referência)
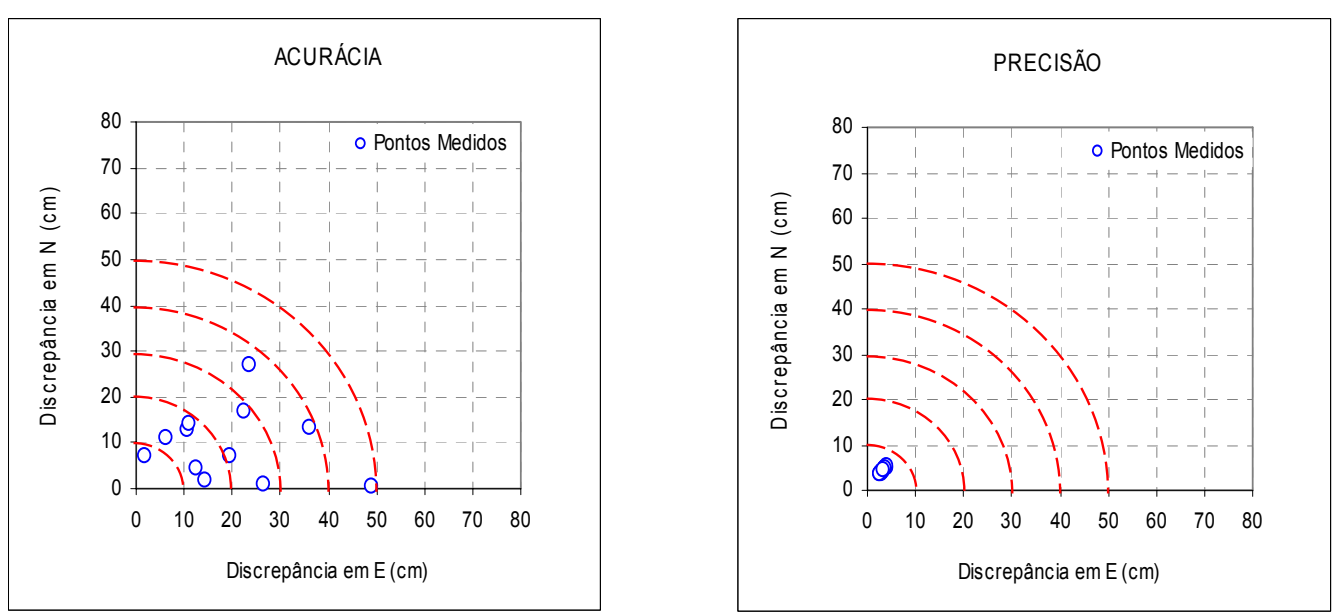

Figura 39 - Acurácia e precisão das coordenadas na seção 07 (localizada a 300 km da estação de referência)

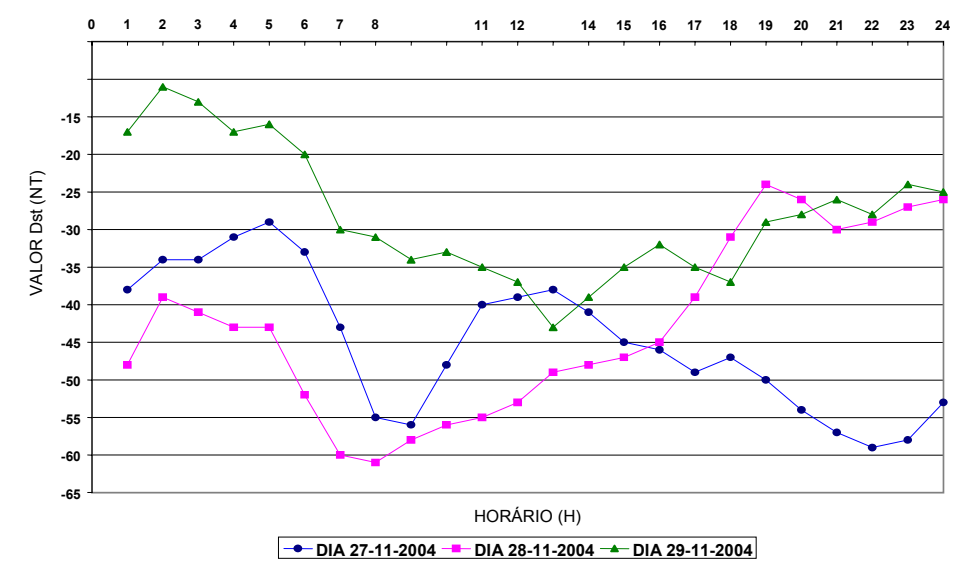

Figura 40 - Índice Dst para os dias 27, 28 e 29-11-2004 - Fonte: Adaptado de http://swdcwww.kugi.kyoto-u.ac.jp/dstdir/dst1/prov.html, (22-01-2006) 


\subsubsection{Receptor $B$ - resultados obtidos}

As Figuras 41 a 54 ilustram graficamente a distribuição da acurácia e da precisão das coordenadas obtidas por meio do Receptor $B$, nas estações de controle previamente estabelecidas. Nessas figuras é apresentado o comportamento dos pontos sob a tolerância de $50 \mathrm{~cm}$, estipulada pela norma técnica para Georreferenciamento de imóveis rurais (INCRA, 2004). A Figura 55 ilustra o índice Dst para os dias 18 e 19-12-2004.
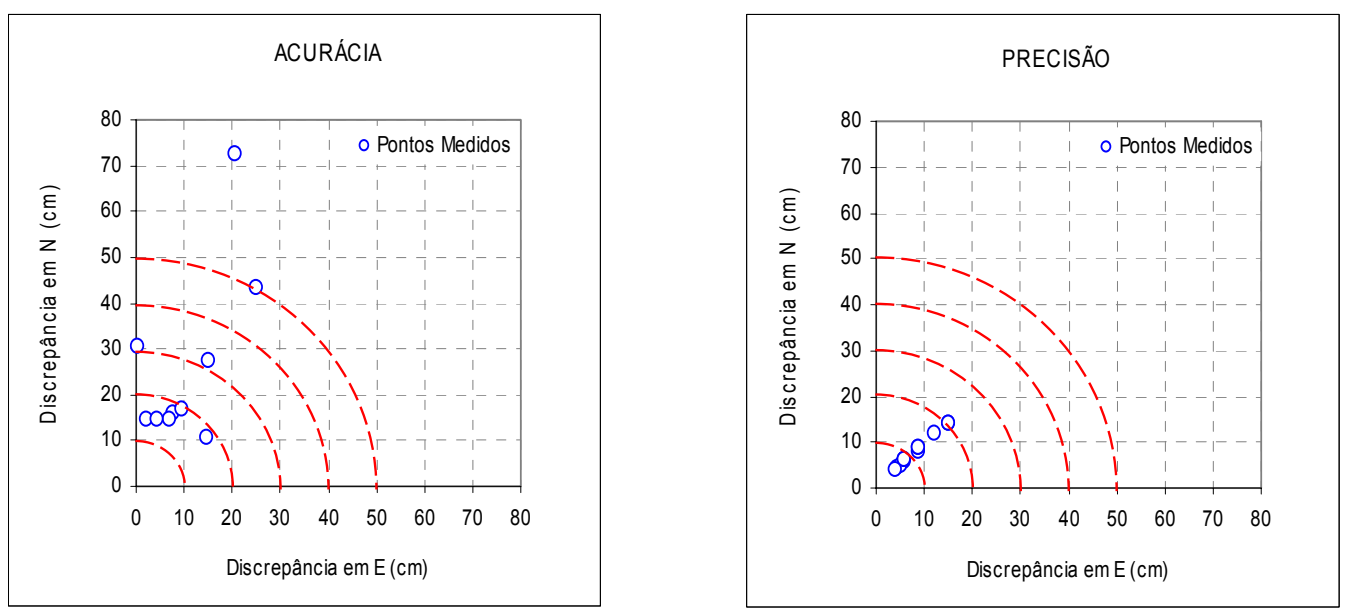

Figura 41 - Acurácia e precisão das coordenadas na seção 01 (localizada a 20 km da estação de referência), obtidas no $1^{\circ}$ dia de observação
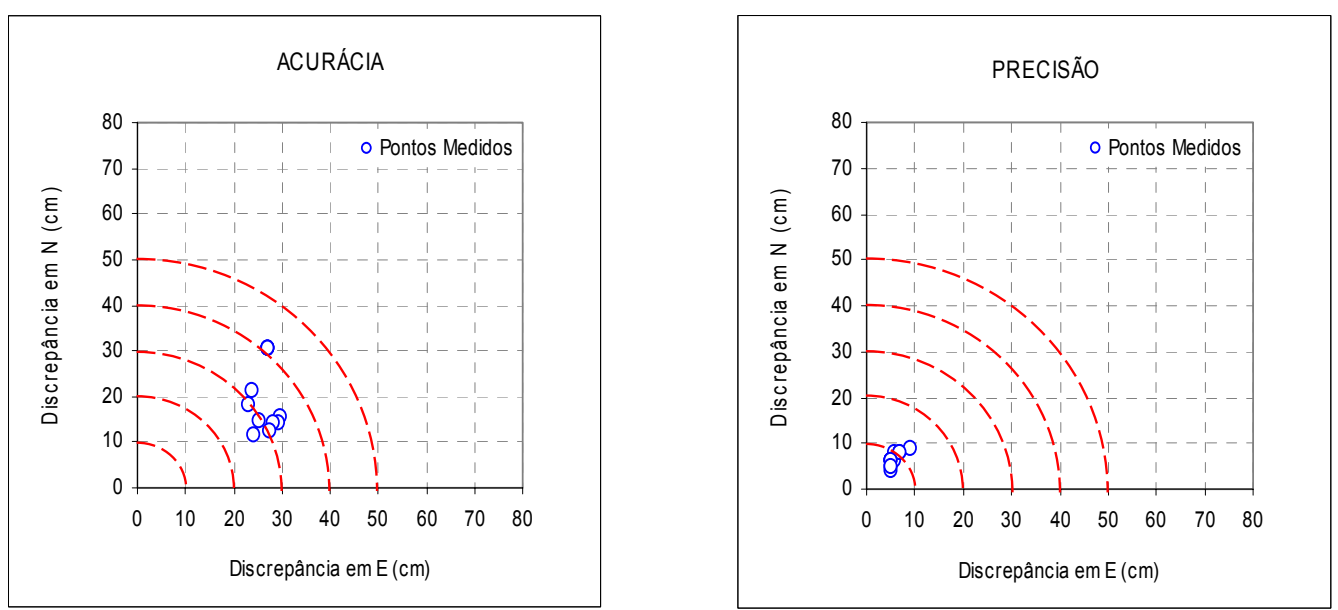

Figura 42 - Acurácia e precisão das coordenadas na seção 01 (localizada a 20 km da estação de referência), obtidas no $2^{\circ}$ dia de observação 

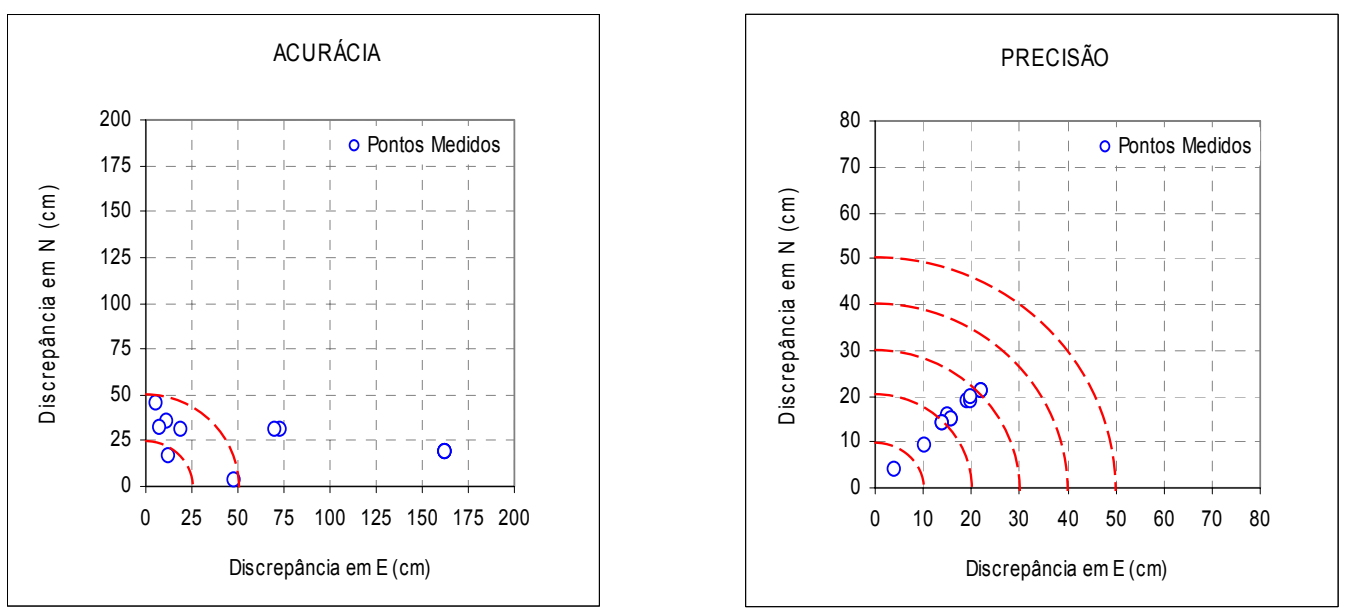

Figura 43 - Acurácia e precisão das coordenadas na seção 02 (localizada a 50 km da estação de referência), obtidas no $1^{\circ}$ dia de observação
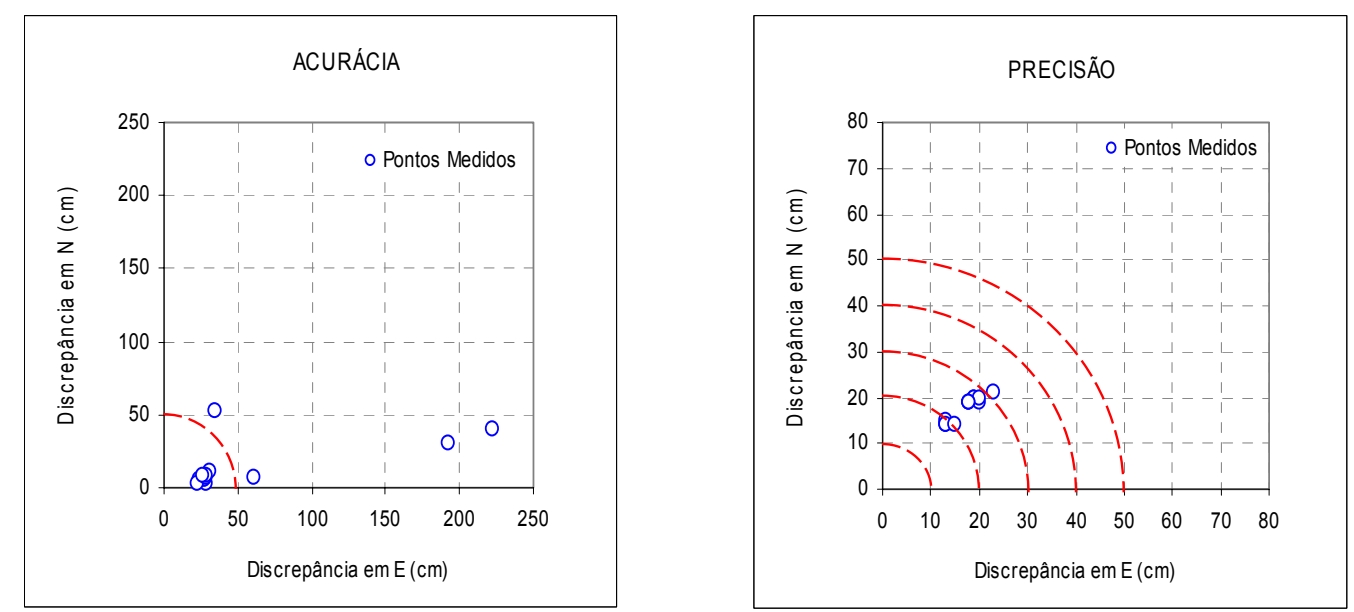

Figura 44 - Acurácia e precisão das coordenadas na seção 02 (localizada a 50 km da estação de referência), obtidas no $2^{\circ}$ dia de observação
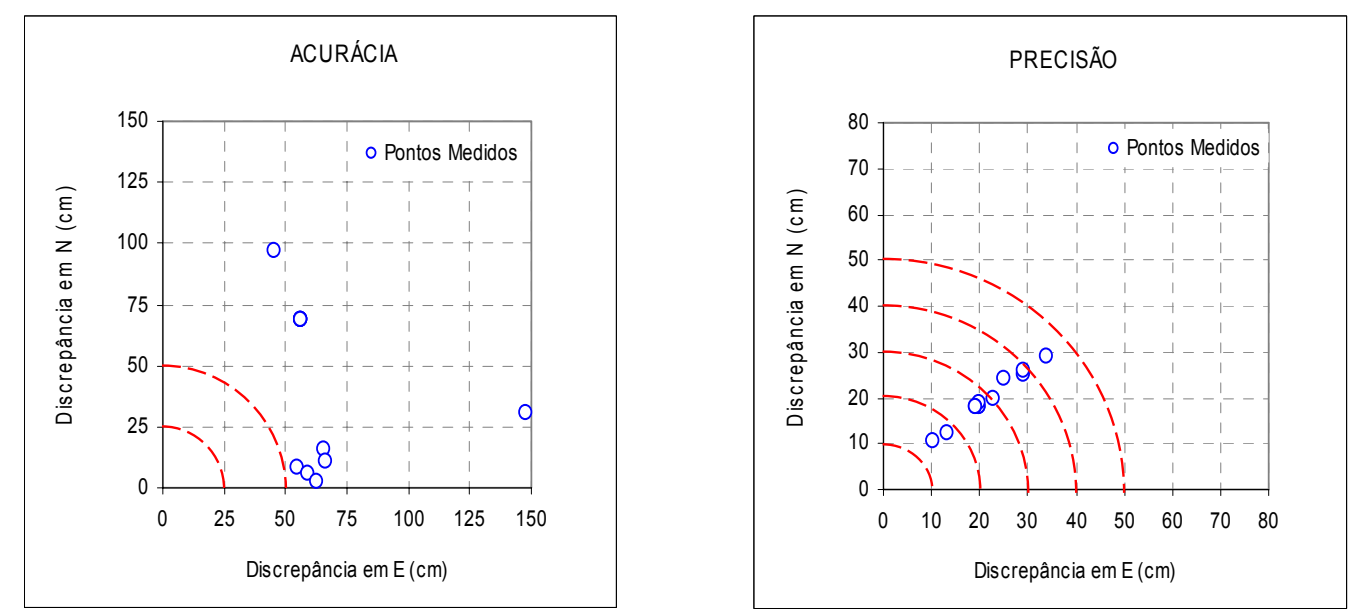

Figura 45 - Acurácia e precisão das coordenadas na seção 03 (localizada a 75 km da estação de referência), obtidas no $1^{\circ}$ dia de observação 

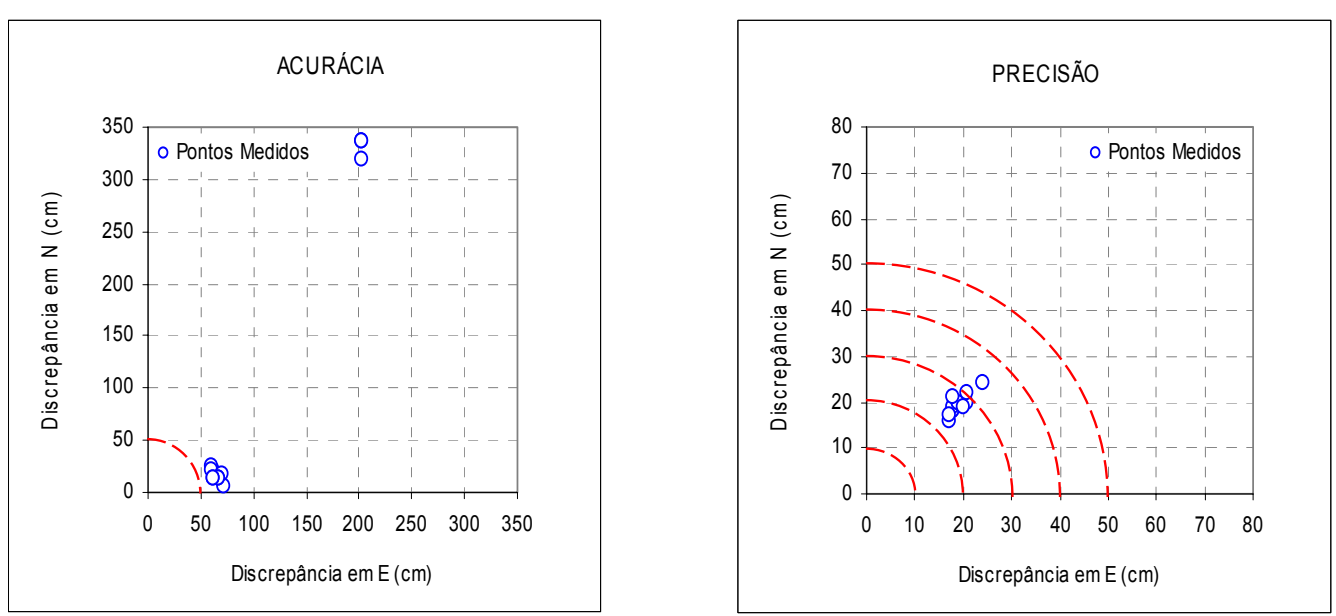

Figura 46 - Acurácia e precisão das coordenadas na seção 03 (localizada a 75 km da estação de referência), obtidas no $2^{\circ}$ dia de observação
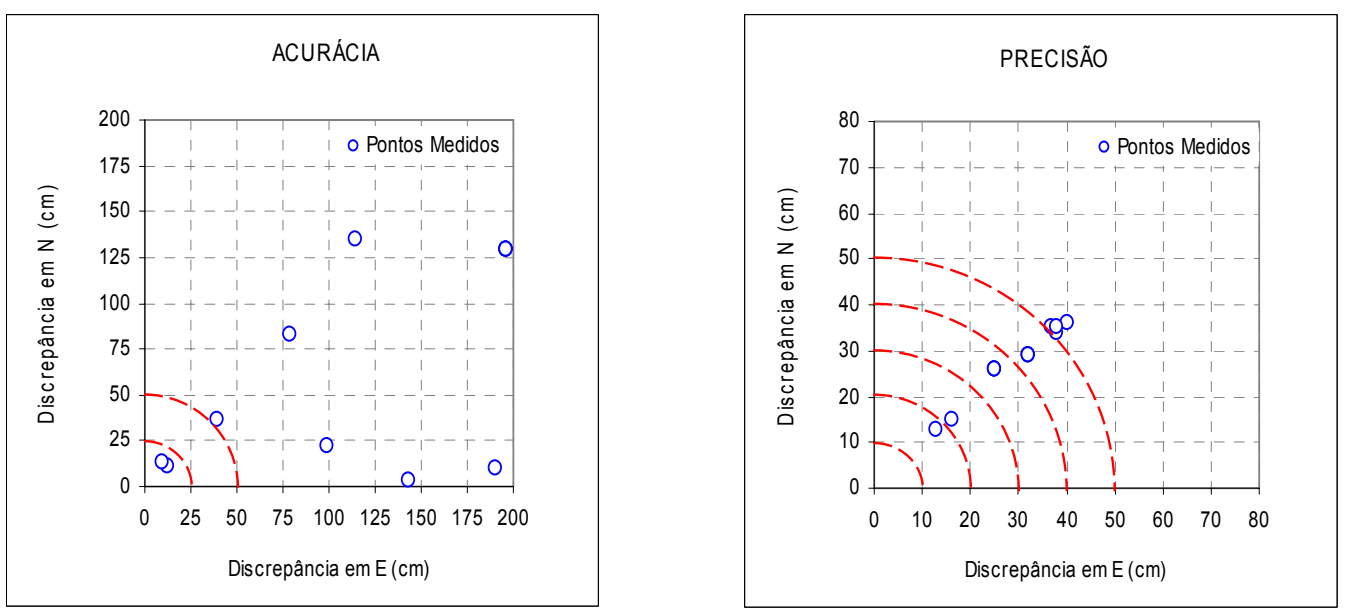

Figura 47 - Acurácia e precisão das coordenadas na seção 04 (localizada a 100 km da estação de referência), obtidas no $1^{\circ}$ dia de observação
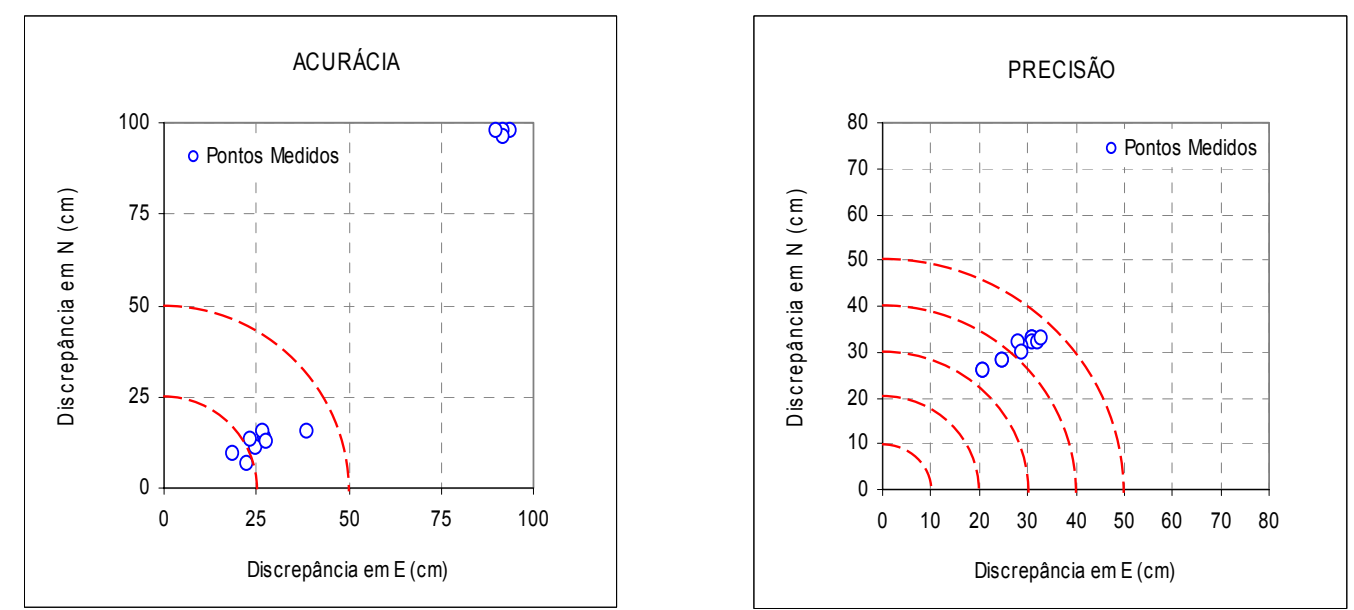

Figura 48 - Acurácia e precisão das coordenadas na seção 04 (localizada a 100 $\mathrm{km}$ da estação de referência), obtidas no $2^{\circ}$ dia de observação 

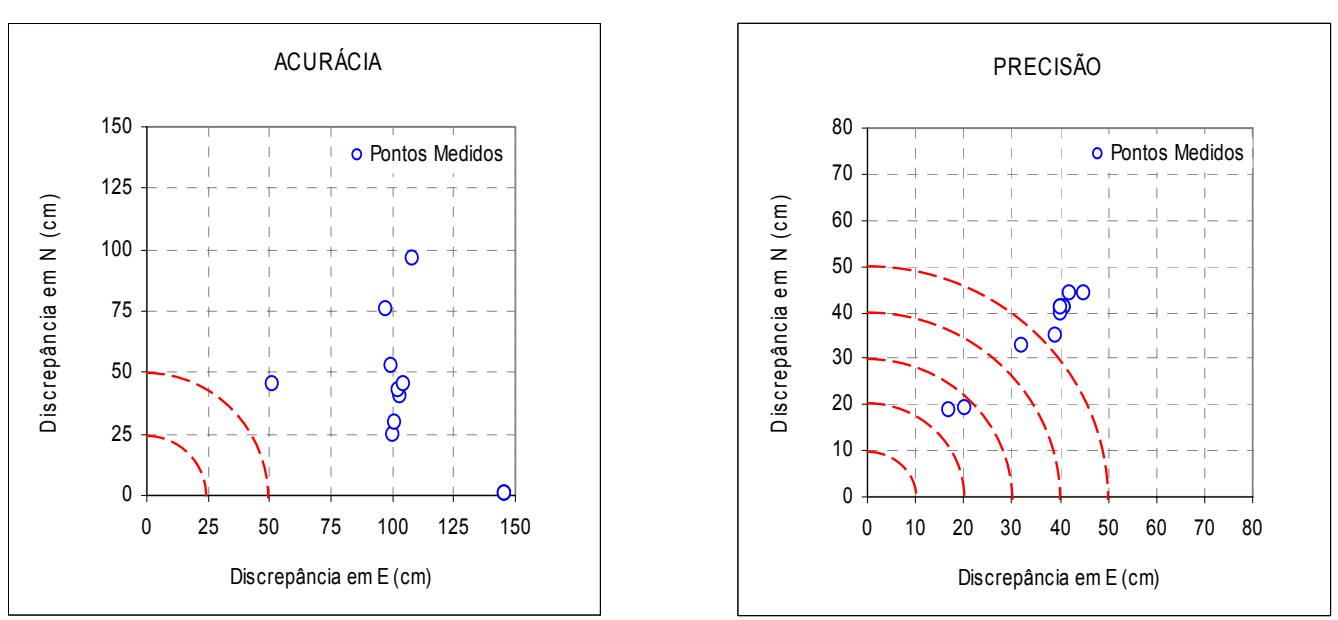

Figura 49 - Acurácia e precisão das coordenadas na seção 05 (localizada a 150 km da estação de referência), obtidas no $1^{\circ}$ dia de observação
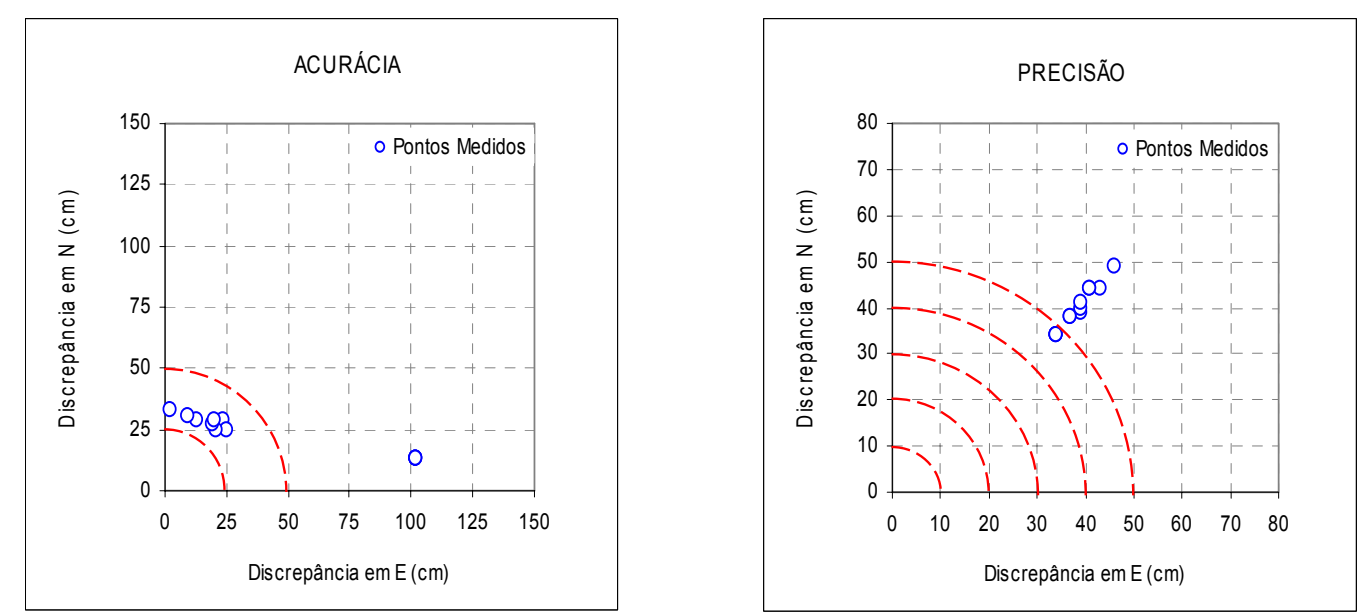

Figura 50 - Acurácia e precisão das coordenadas na seção 05 (localizada a 150 km da estação de referência), obtidas no $2^{\circ}$ dia de observação
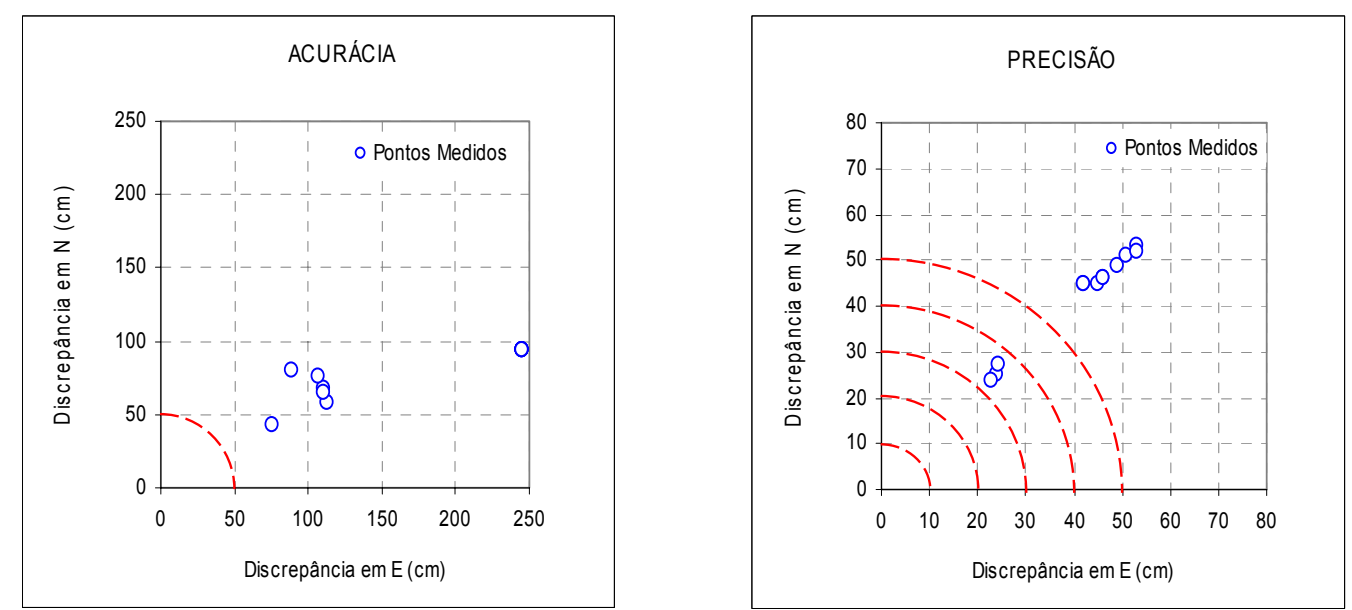

Figura 51 - Acurácia e precisão das coordenadas na seção 06 (localizada a 200 km da estação de referência), obtidas no $1^{\circ}$ dia de observação 

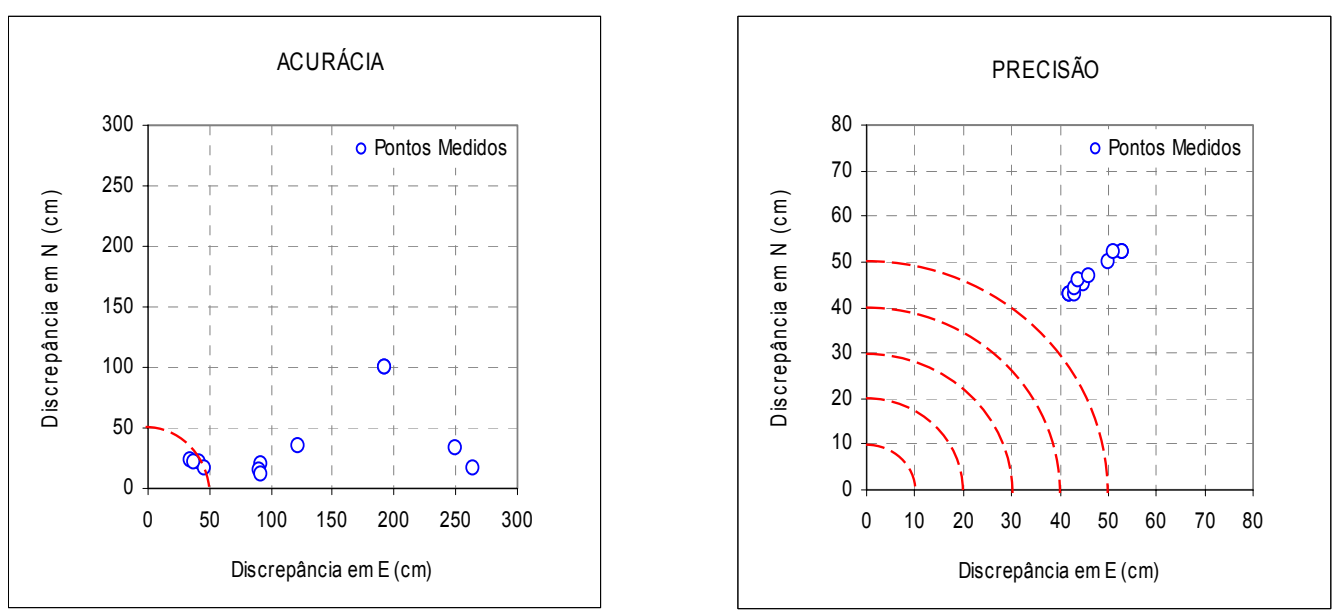

Figura 52 - Acurácia e precisão das coordenadas na seção 06 (localizada a 200 km da estação de referência), obtidas no $2^{\circ}$ dia de observação
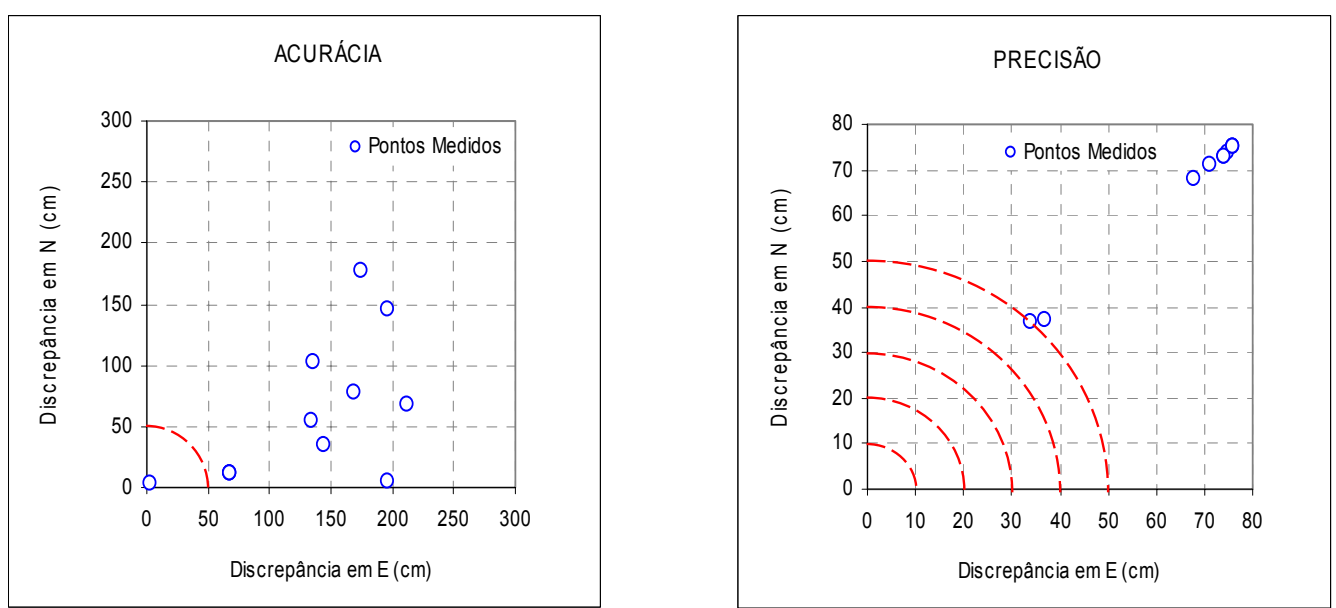

Figura 53 - Acurácia e precisão das coordenadas na seção 07 (localizada a 300 km da estação de referência), obtidas no $1^{\circ}$ dia de observação
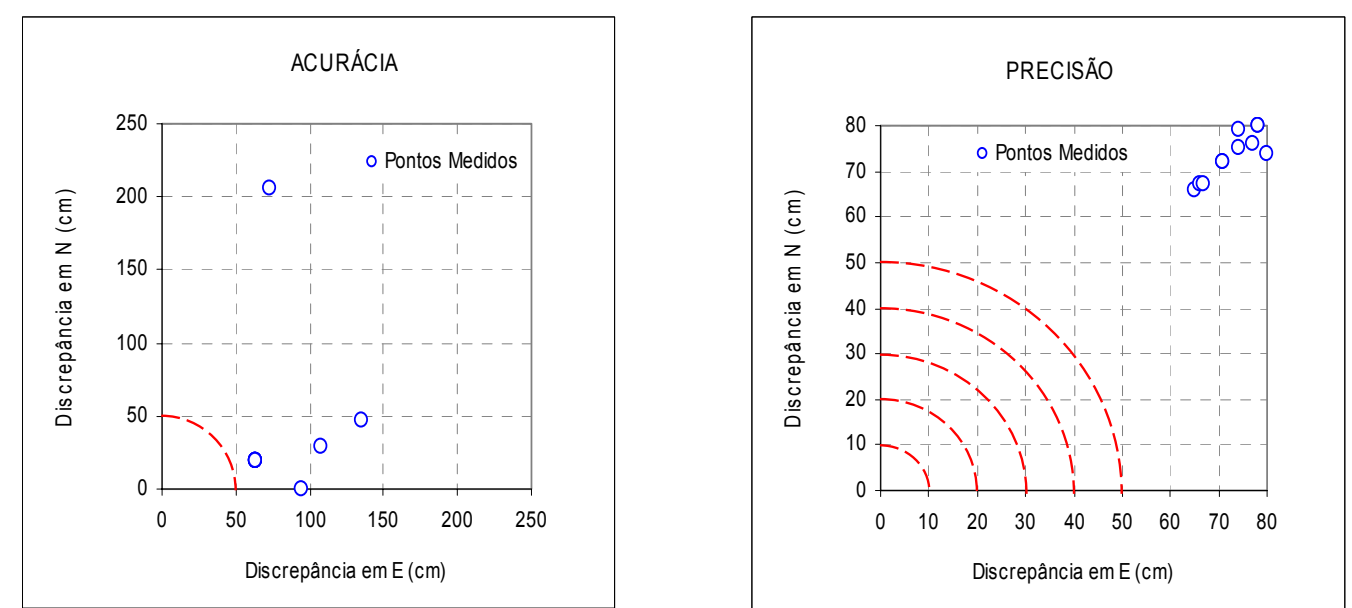

Figura 54 - Acurácia e precisão das coordenadas na seção 07 (localizada a 300 $\mathrm{km}$ da estação de referência), obtidas no $2^{\circ}$ dia de observação 


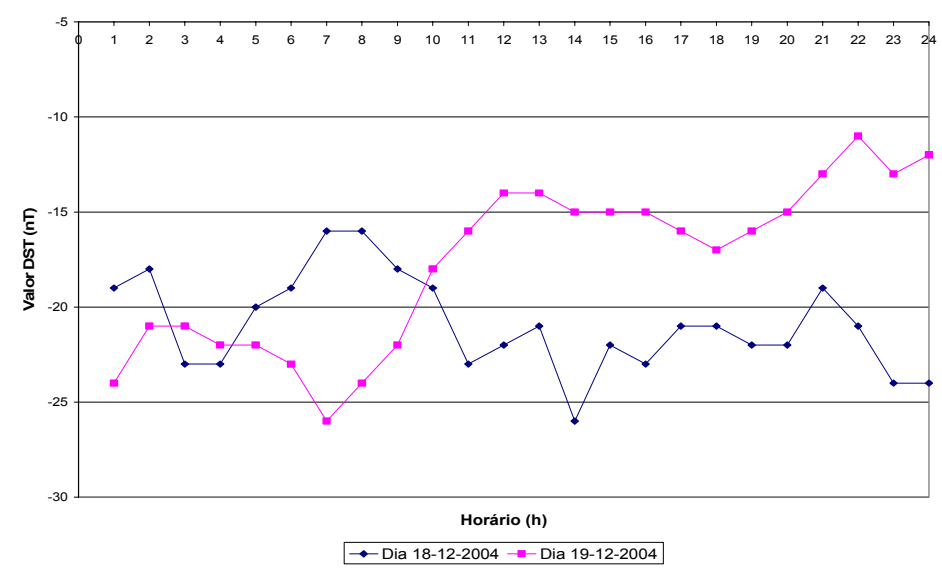

Figura 55 - Índice Dst para os dias 18 e 19-12-2004 - Fonte: Adaptado de http://swdcwww.kugi.kyoto-u.ac.jp/dstdir/dst1/prov.html, (22-01-2006)

\subsubsection{Receptor $\mathrm{C}$ - resultados obtidos}

As Figuras 56 a 83 ilustram graficamente a distribuição da acurácia e da precisão das coordenadas obtidas com o Receptor C, nas estações de controle previamente estabelecidas. Nessas figuras é apresentado o comportamento dos pontos sob a tolerância de $50 \mathrm{~cm}$, estipulada pela norma técnica para Georreferenciamento de imóveis rurais (INCRA, 2004).

A Figura 112 ilustra o Índice Dst para os dias 26 e 27-03-2005 e a Figura 113 apresenta o mesmo índice para os dias 02 e 03-04-2005. 

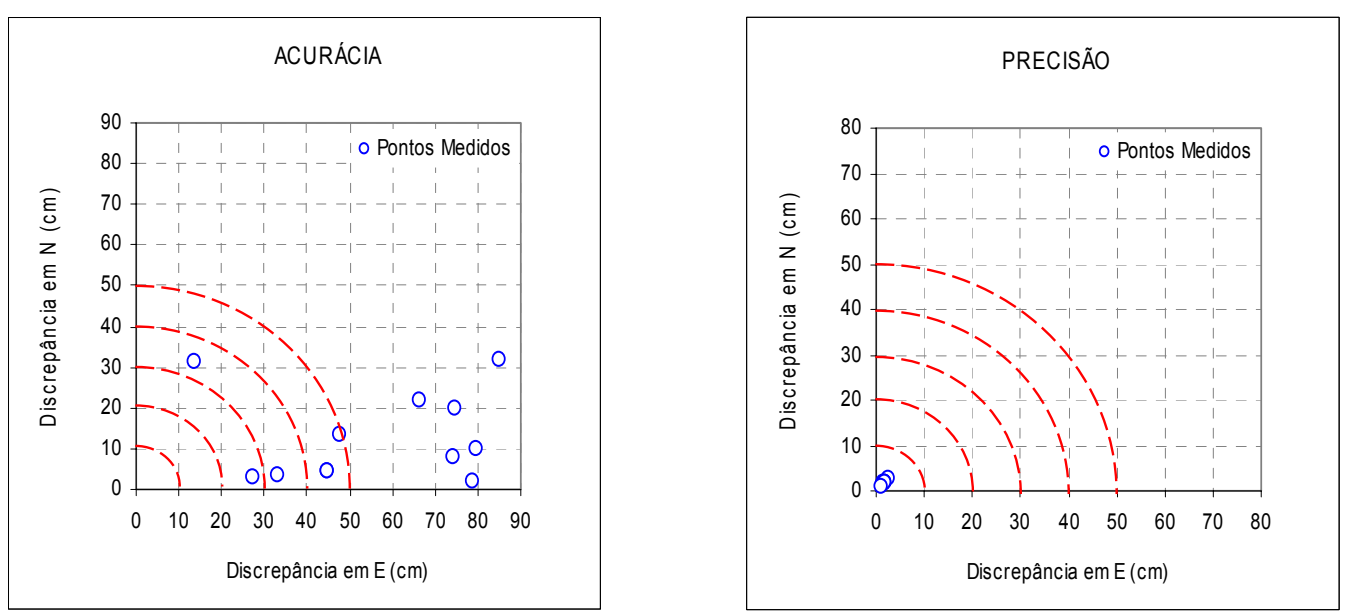

Figura 56 - Acurácia e precisão das coordenadas na seção 01 (localizada a 20 km da estação de referência), obtidas no $1^{\circ}$ dia de observação
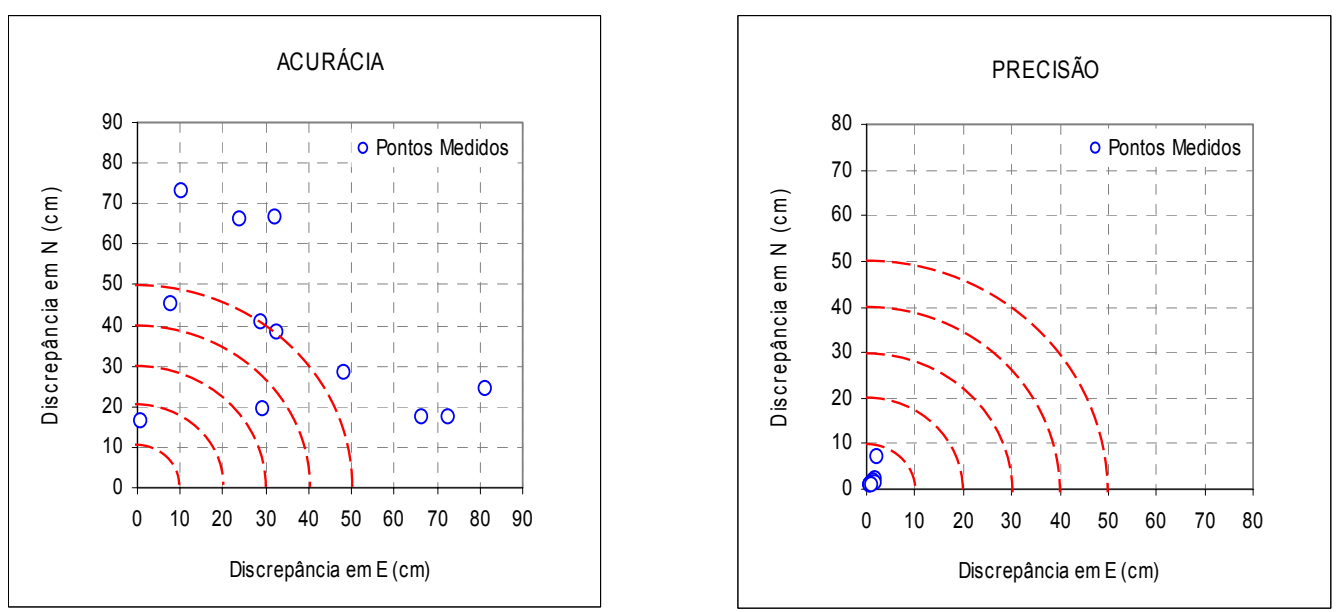

Figura 57 - Acurácia e precisão das coordenadas na seção 01 (localizada a 20 km da estação de referência), obtidas no $2^{\circ}$ dia de observação
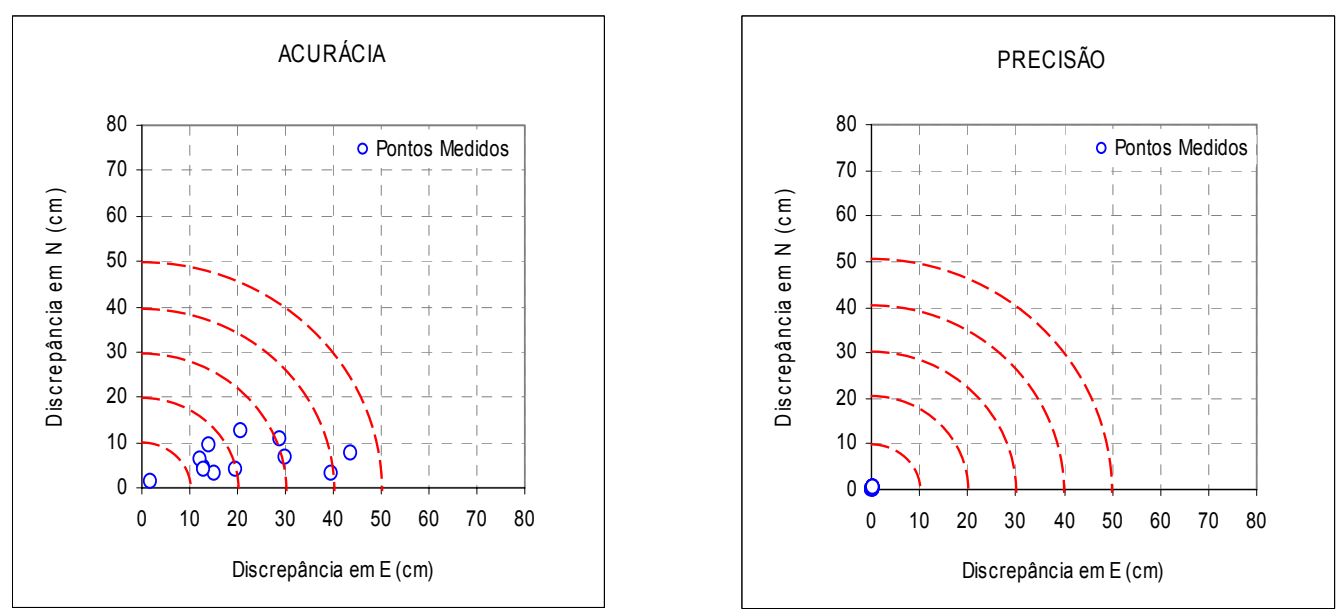

Figura 58 - Acurácia e precisão das coordenadas na seção 01 (localizada a 20 km da estação de referência), obtidas no $3^{\circ}$ dia de observação 

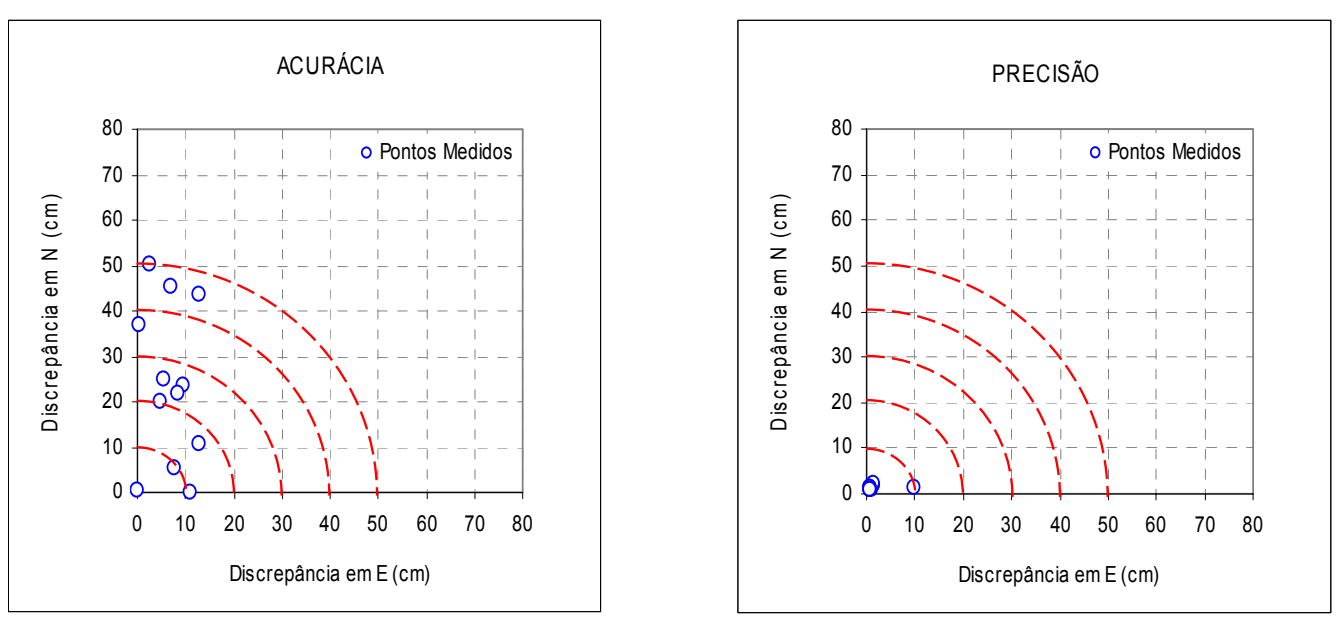

Figura 59 - Acurácia e precisão das coordenadas na seção 01 (localizada a 20 km da estação de referência), obtidas no $4^{\circ}$ dia de observação
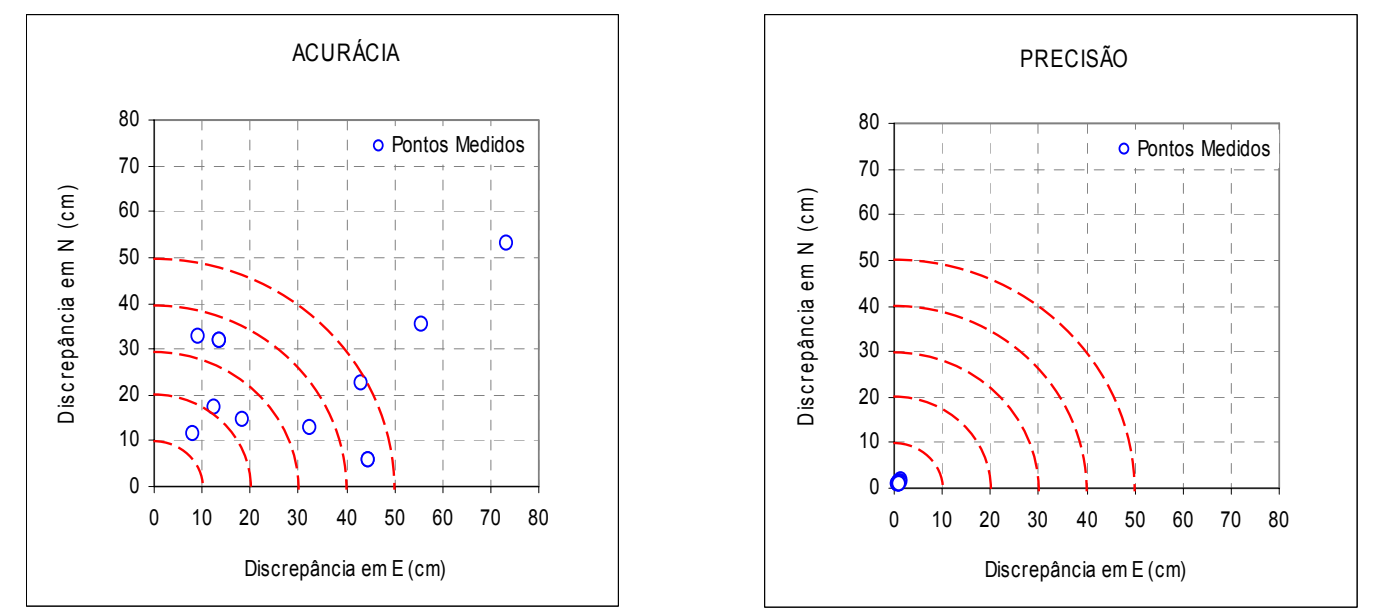

Figura 60 - Acurácia e precisão das coordenadas na seção 02 (localizada a 50 km da estação de referência), obtidas no $1^{\circ}$ dia de observação
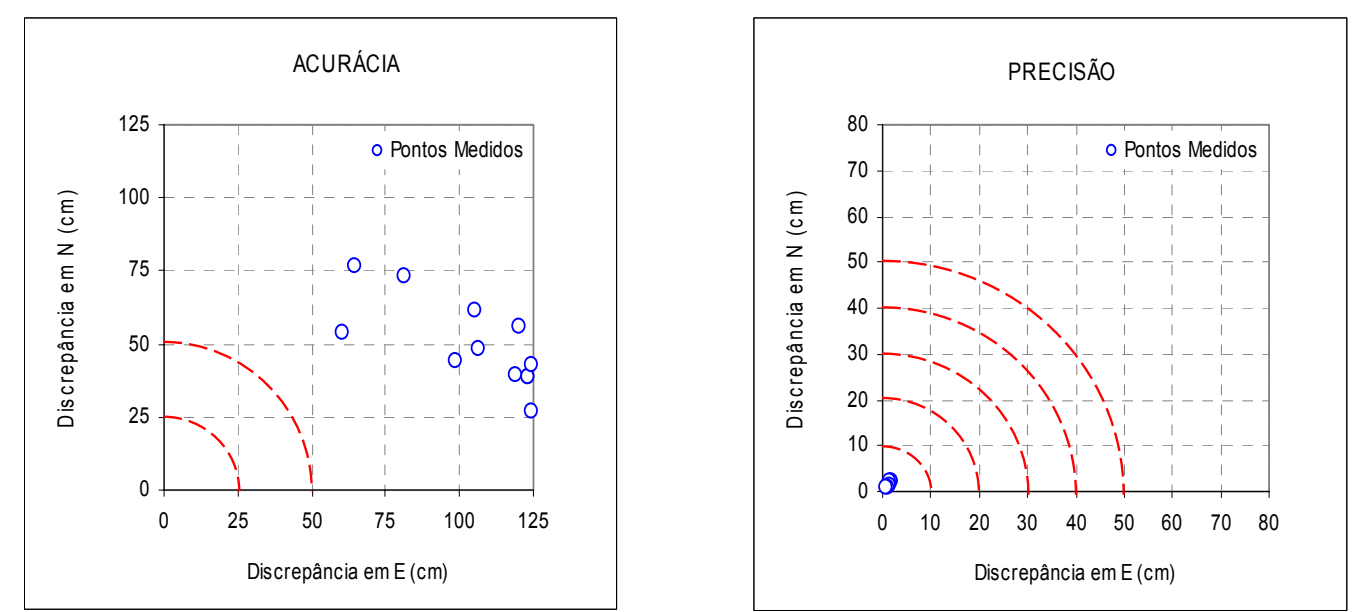

Figura 61 - Acurácia e precisão das coordenadas na seção 02 (localizada a 50 km da estação de referência), obtidas no $2^{\circ}$ dia de observação 

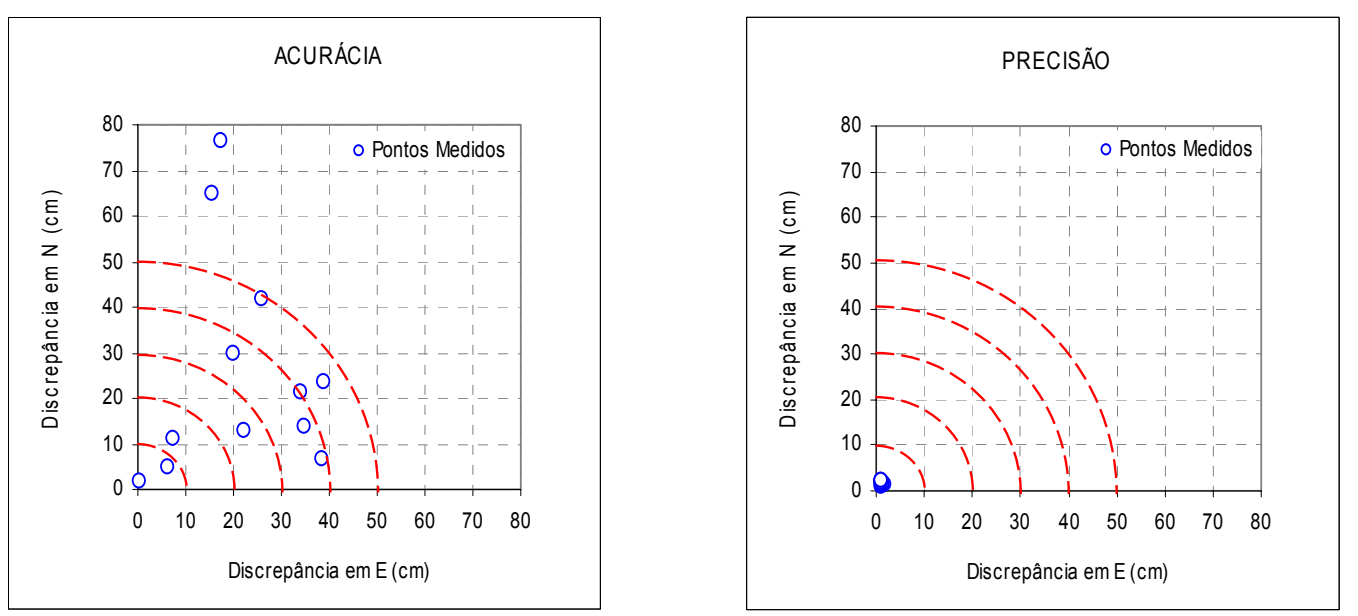

Figura 62 - Acurácia e precisão das coordenadas na seção 02 (localizada a 50 km da estação de referência), obtidas no $3^{\circ}$ dia de observação
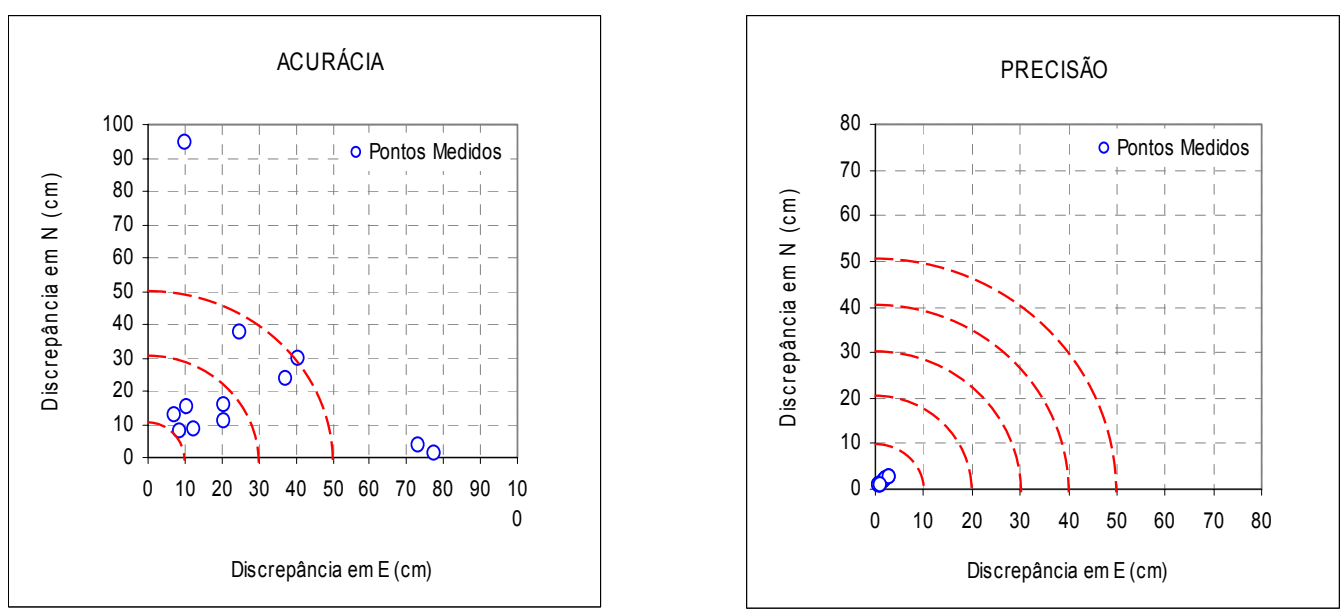

Figura 63 - Acurácia e precisão das coordenadas na seção 02 (localizada a 50 km da estação de referência), obtidas no $4^{\circ}$ dia de observação
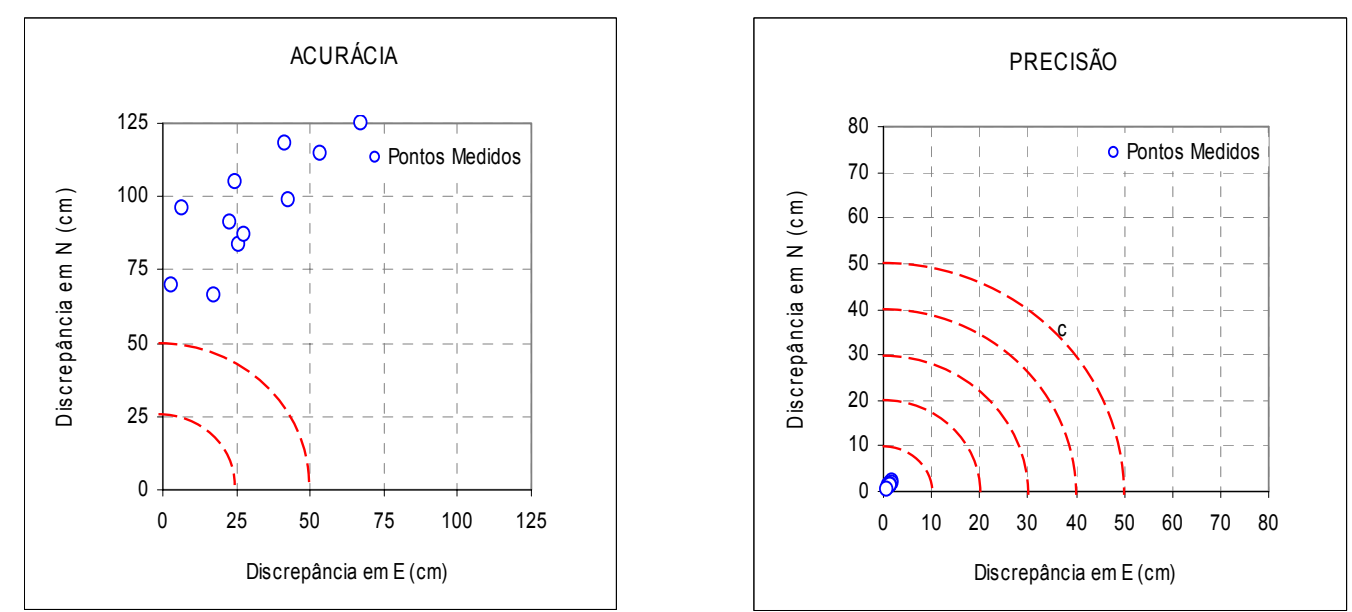

Figura 64 - Acurácia e precisão das coordenadas na seção 03 (localizada a 75 km da estação de referência), obtidas no $1^{\circ}$ dia de observação 

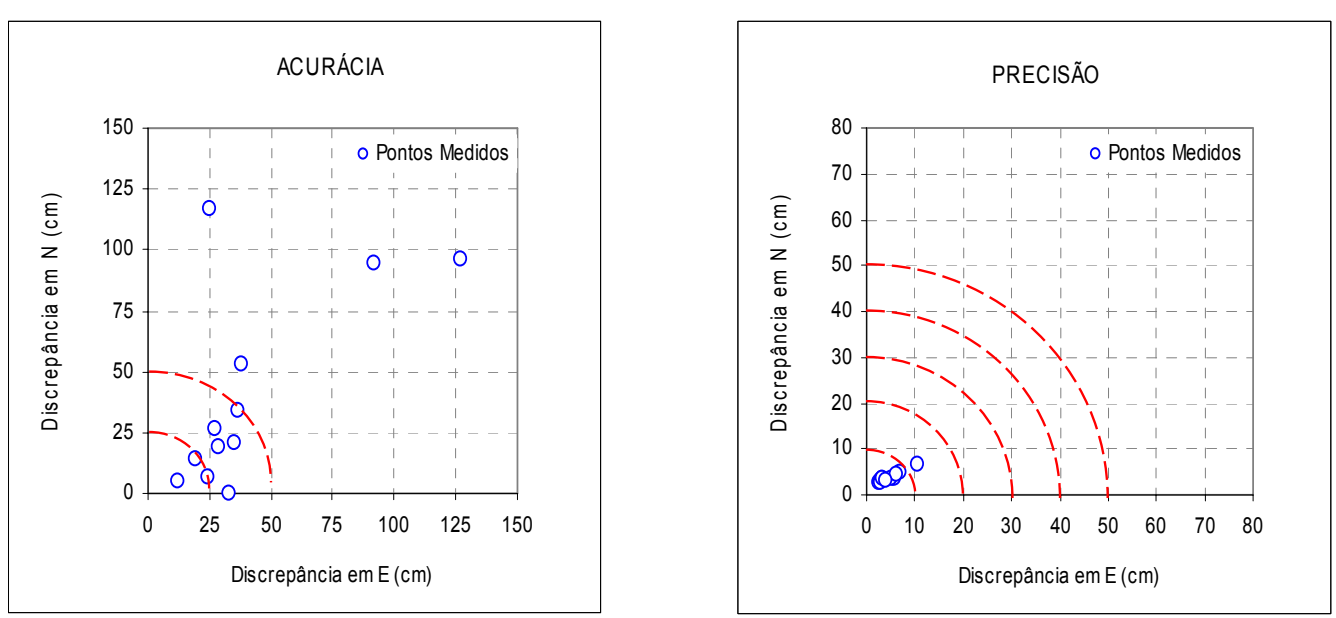

Figura 65 - Acurácia e precisão das coordenadas na seção 03 (localizada a 75 km da estação de referência), obtidas no $2^{\circ}$ dia de observação
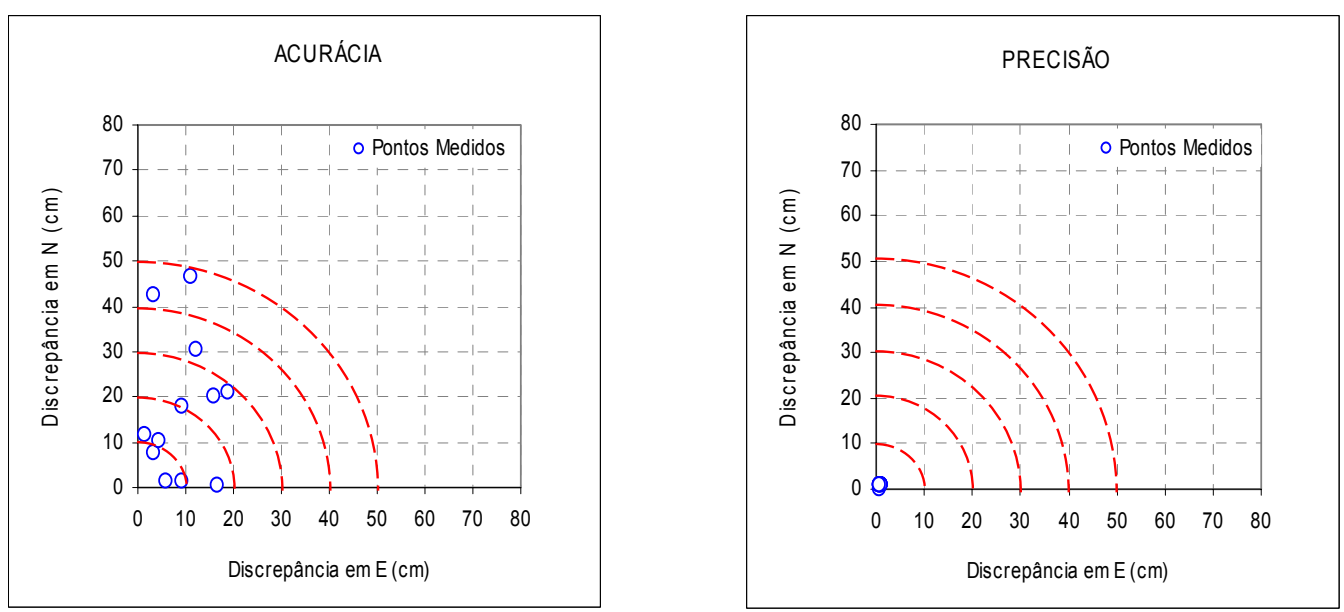

Figura 66 - Acurácia e precisão das coordenadas na seção 03 (localizada a 75 km da estação de referência), obtidas no $3^{\circ}$ dia de observação
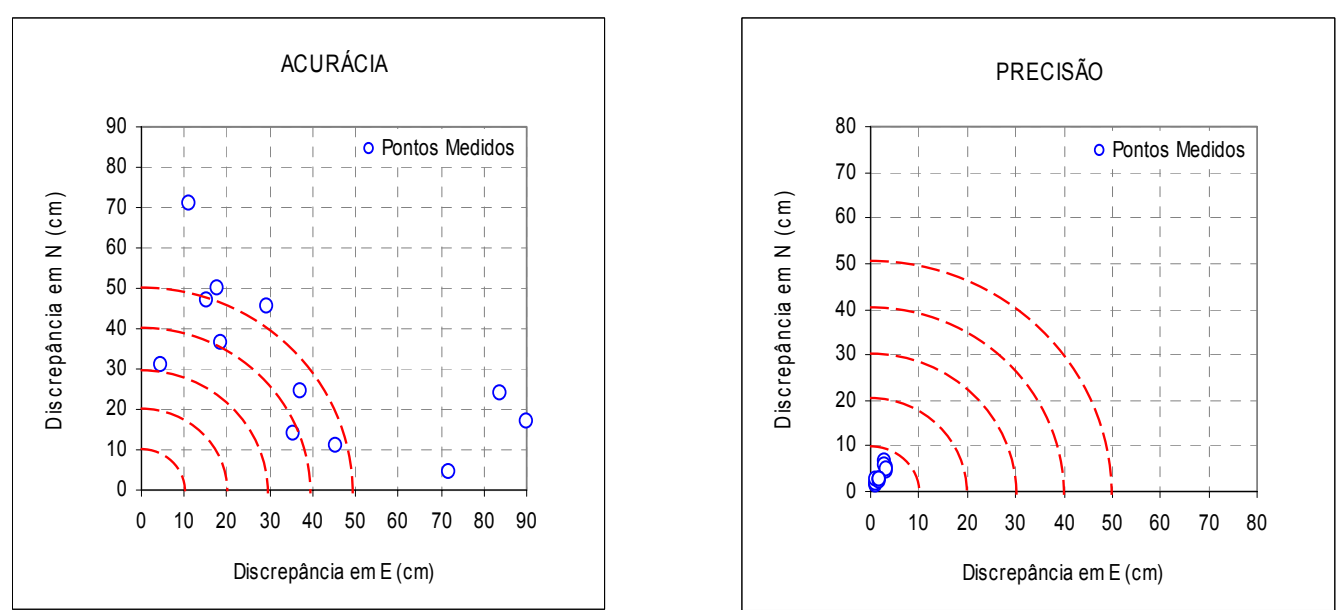

Figura 67 - Acurácia e precisão das coordenadas na seção 03 (localizada a 75 km da estação de referência), obtidas no $4^{\circ}$ dia de observação 

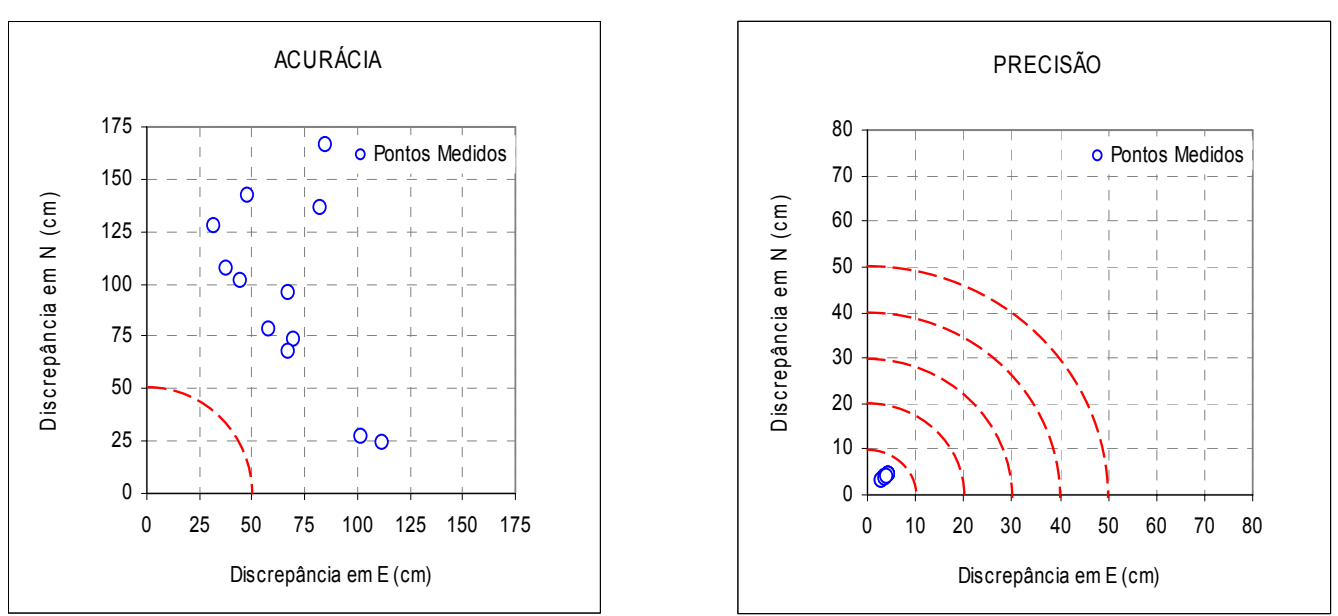

Figura 68 - Acurácia e precisão das coordenadas na seção 04 (localizada a 100 km da estação de referência), obtidas no $1^{\circ}$ dia de observação
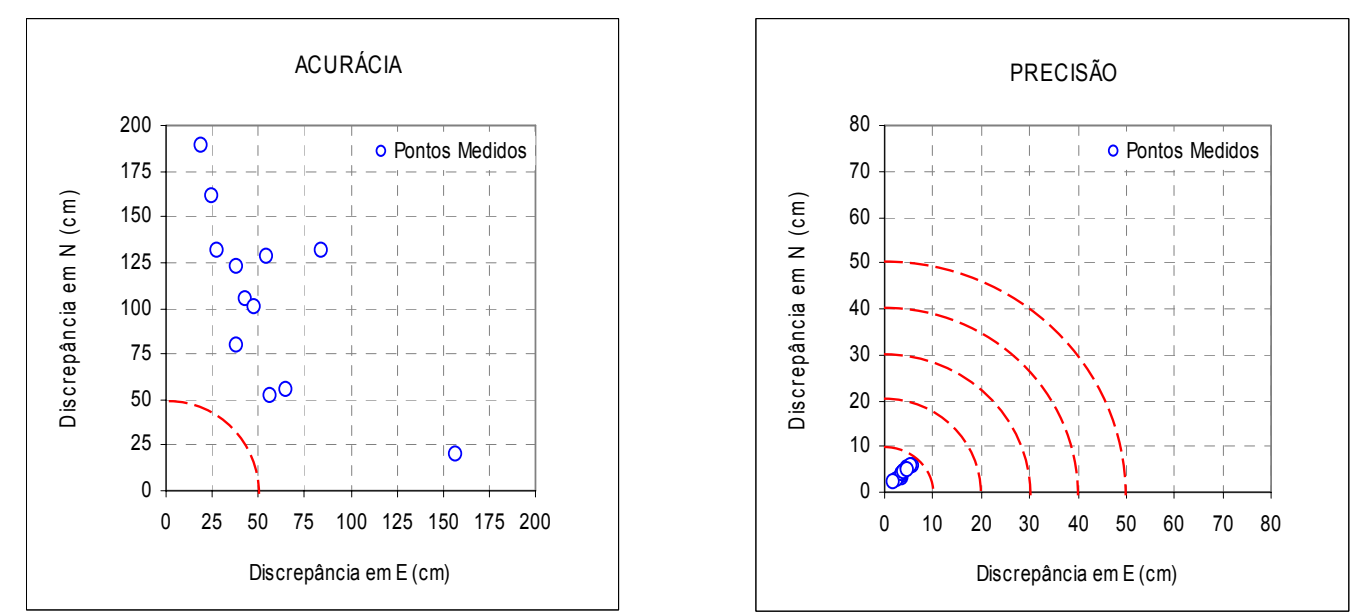

Figura 69 - Acurácia e precisão das coordenadas na seção 04 (localizada a 100 km da estação de referência), obtidas no $2^{\circ}$ dia de observação
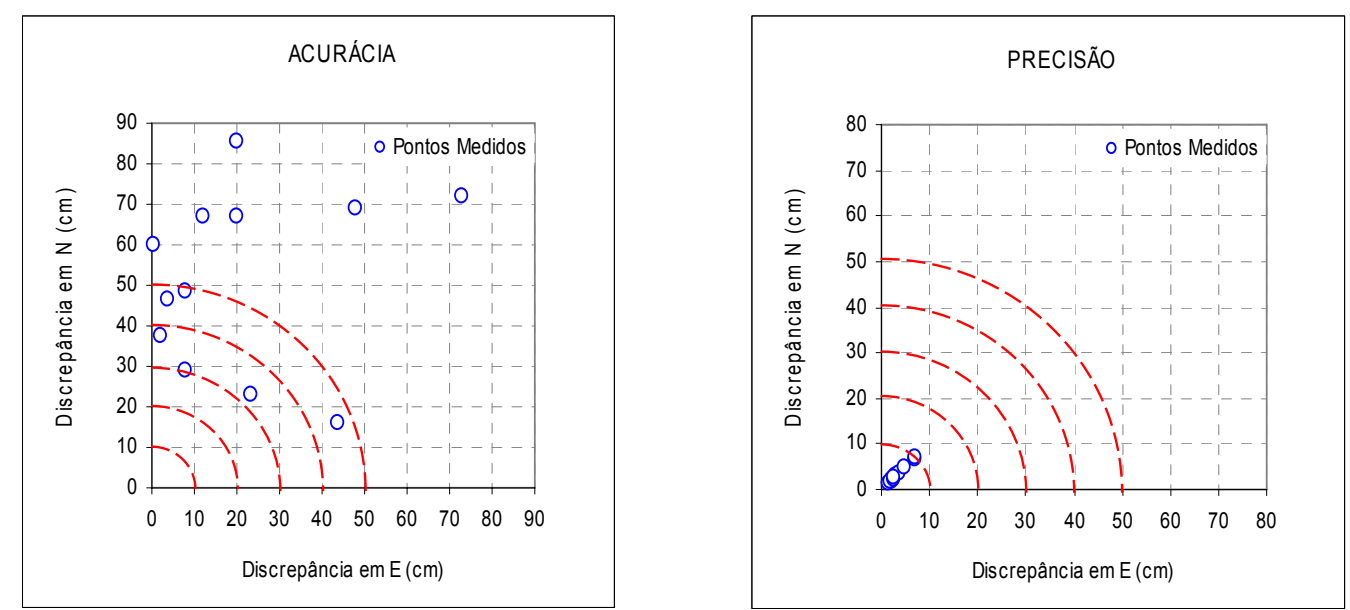

Figura 70 - Acurácia e precisão das coordenadas na seção 04 (localizada a 100 $\mathrm{km}$ da estação de referência), obtidas no $3^{\circ}$ dia de observação 

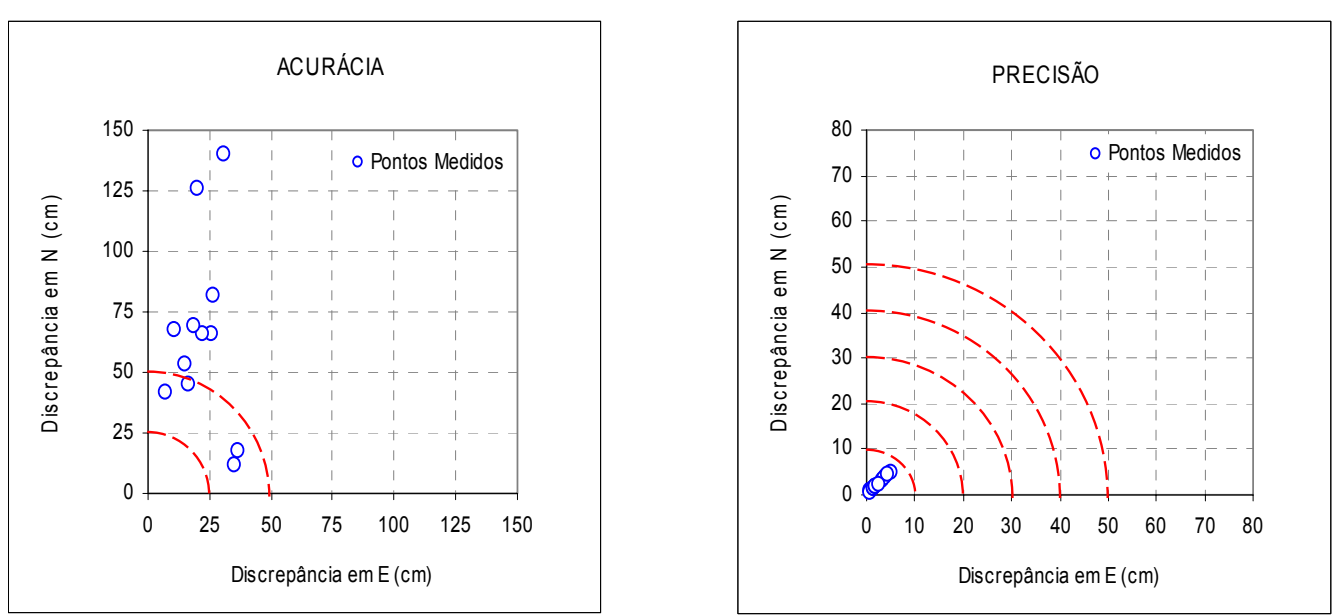

Figura 71 - Acurácia e precisão das coordenadas na seção 04 (localizada a 100 km da estação de referência), obtidas no $4^{\circ}$ dia de observação
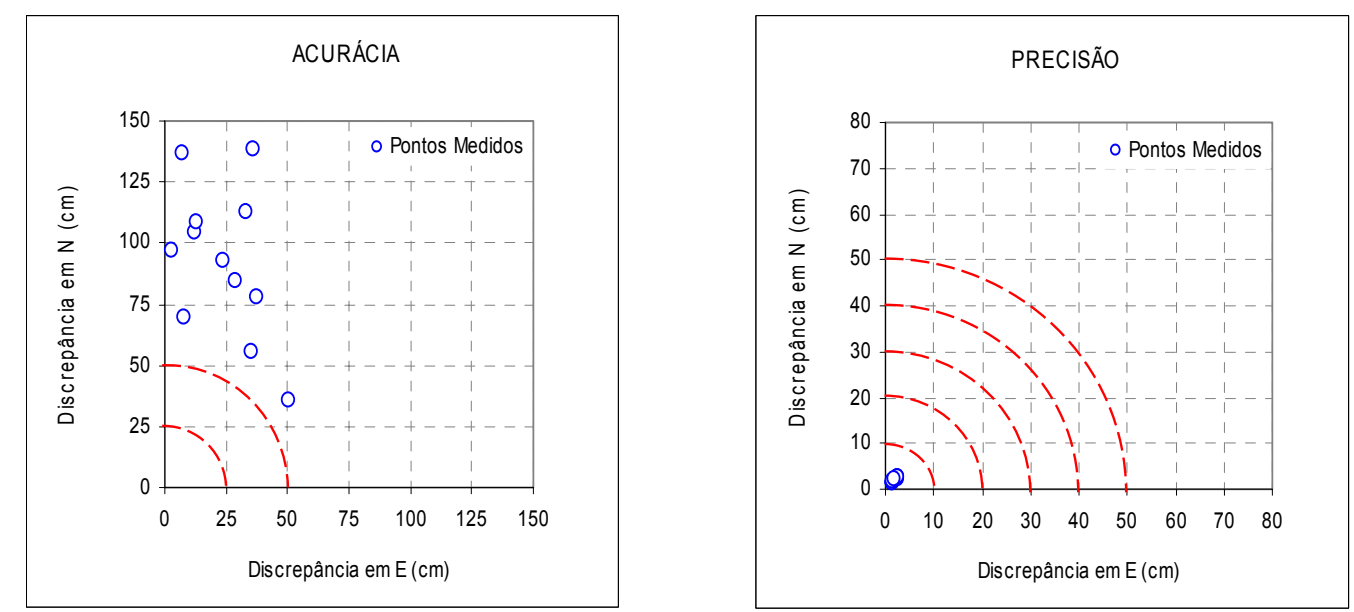

Figura 72 - Acurácia e precisão das coordenadas na seção 05 (localizada a 150 km da estação de referência), obtidas no $1^{\circ}$ dia de observação
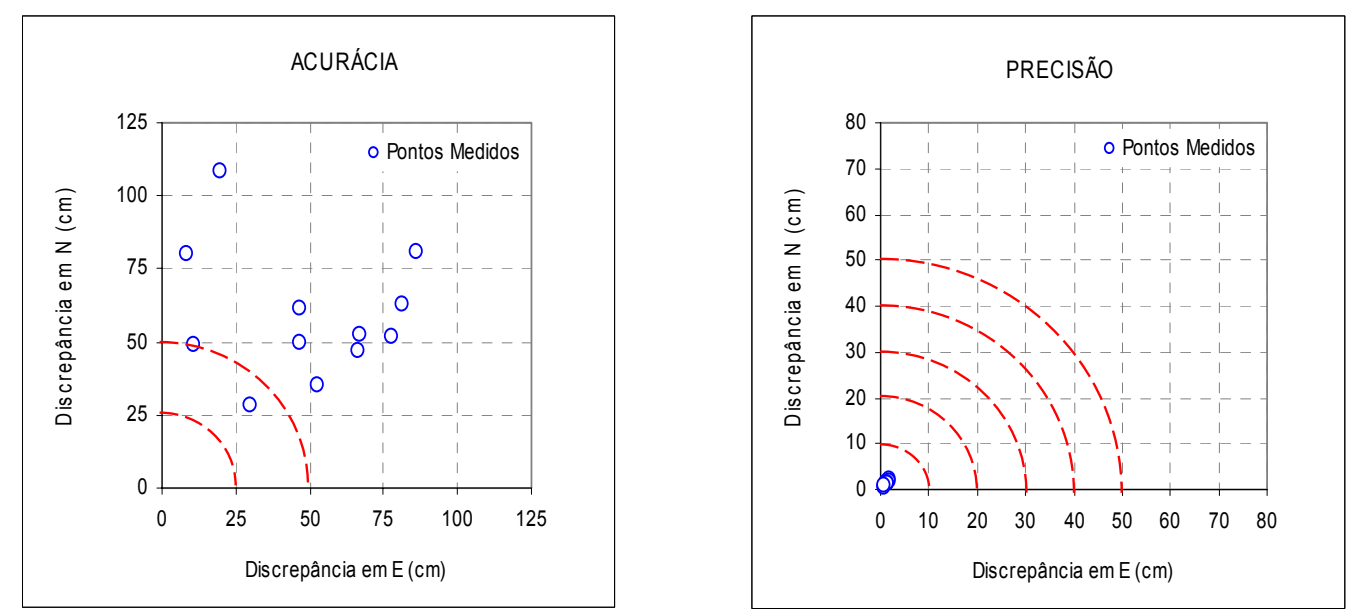

Figura 73 - Acurácia e precisão das coordenadas na seção 05 (localizada a 150 $\mathrm{km}$ da estação de referência), obtidas no $2^{\circ}$ dia de observação 

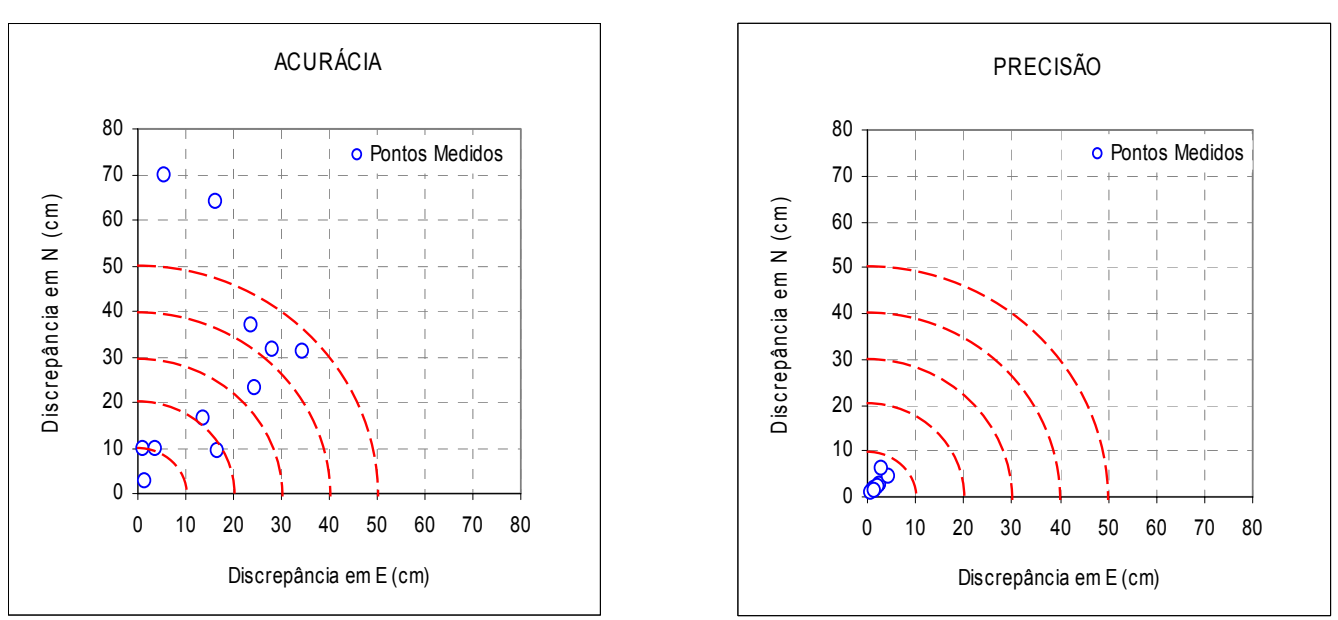

Figura 74 - Acurácia e precisão das coordenadas na seção 05 (localizada a 150 km da estação de referência), obtidas no $3^{\circ}$ dia de observação
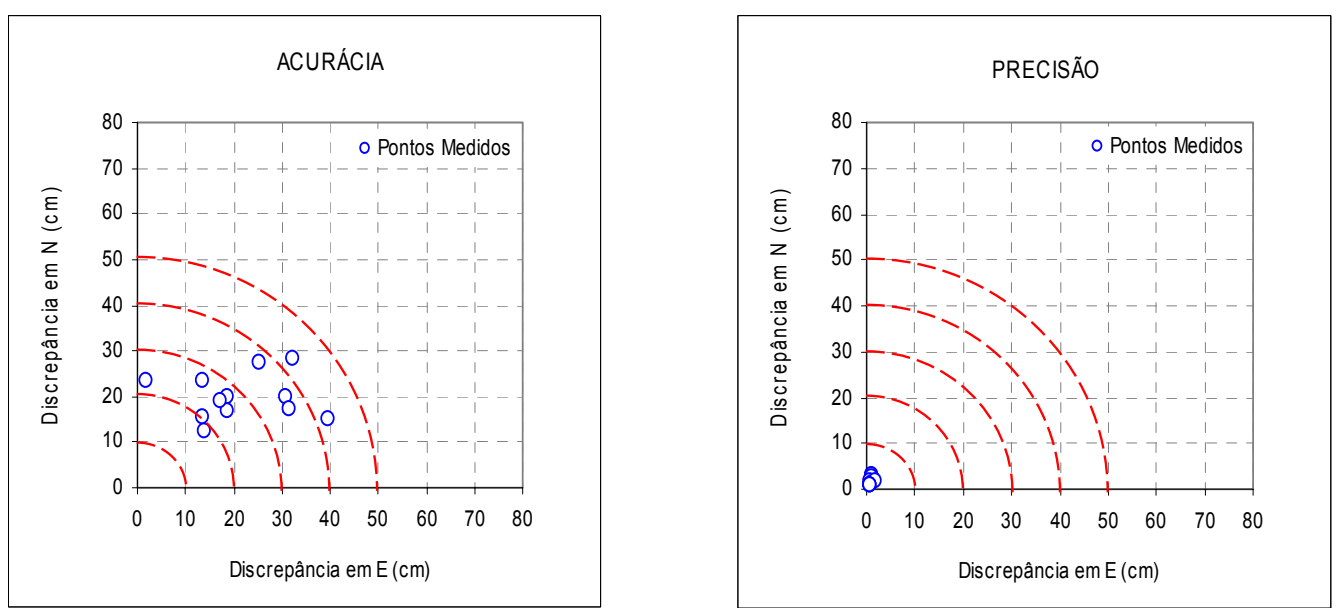

Figura 75 - Acurácia e precisão das coordenadas na seção 05 (localizada a 150 km da estação de referência), obtidas no $4^{\circ}$ dia de observação
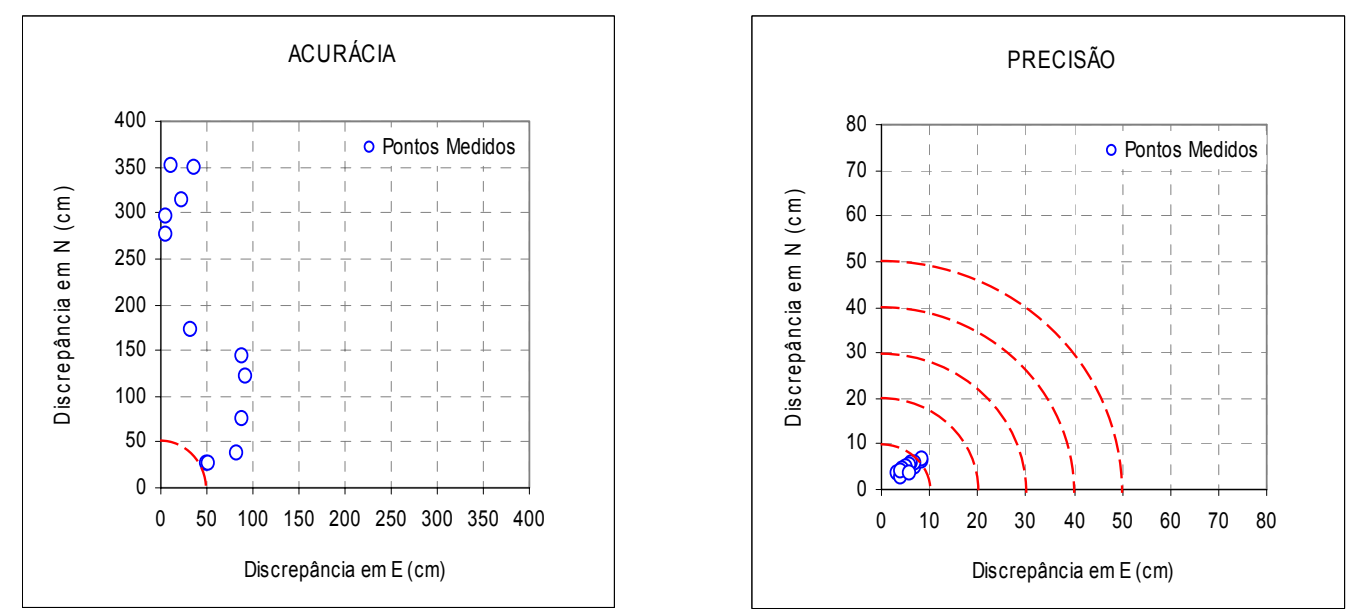

Figura 76 - Acurácia e precisão das coordenadas na seção 06 (localizada a 200 $\mathrm{km}$ da estação de referência), obtidas no $1^{\circ}$ dia de observação 

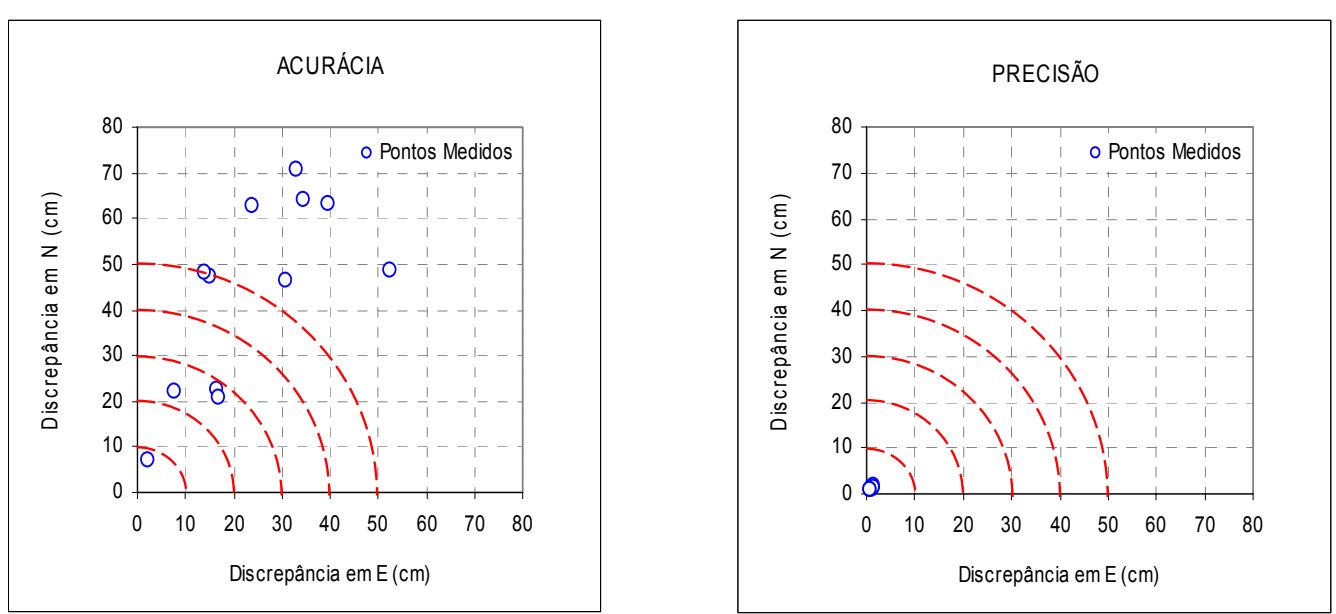

Figura 77 - Acurácia e precisão das coordenadas na seção 06 (localizada a 200 km da estação de referência), obtidas no $2^{\circ}$ dia de observação
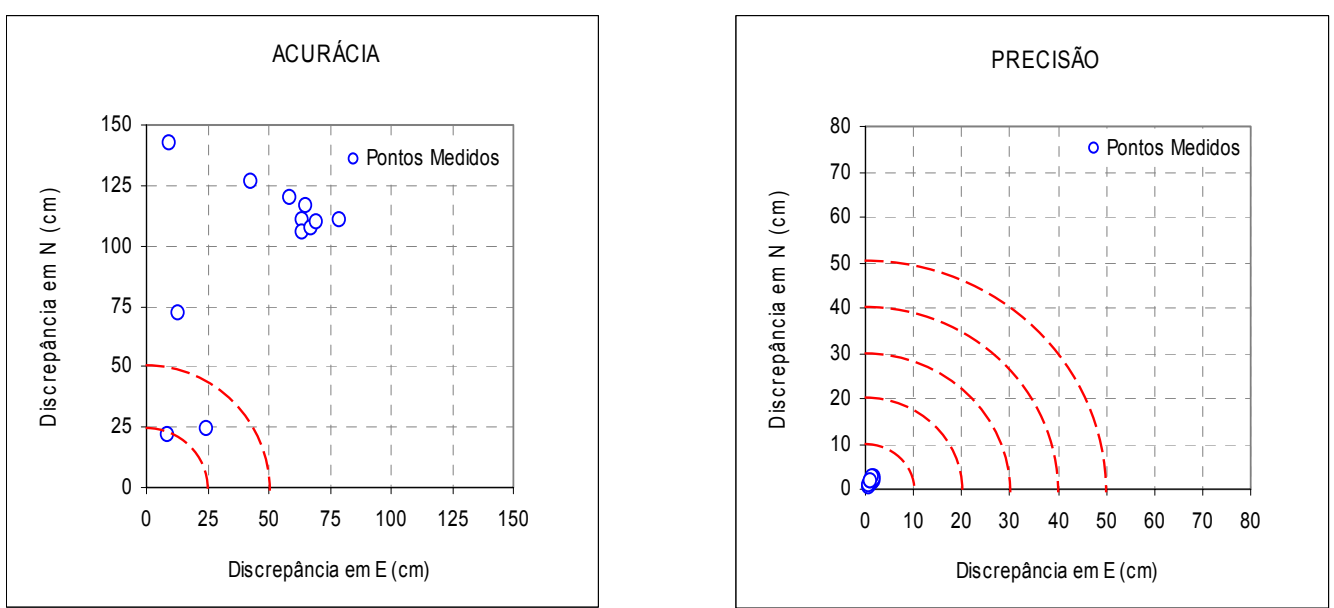

Figura 78 - Acurácia e precisão das coordenadas na seção 06 (localizada a 200 km da estação de referência), obtidas no $3^{\circ}$ dia de observação
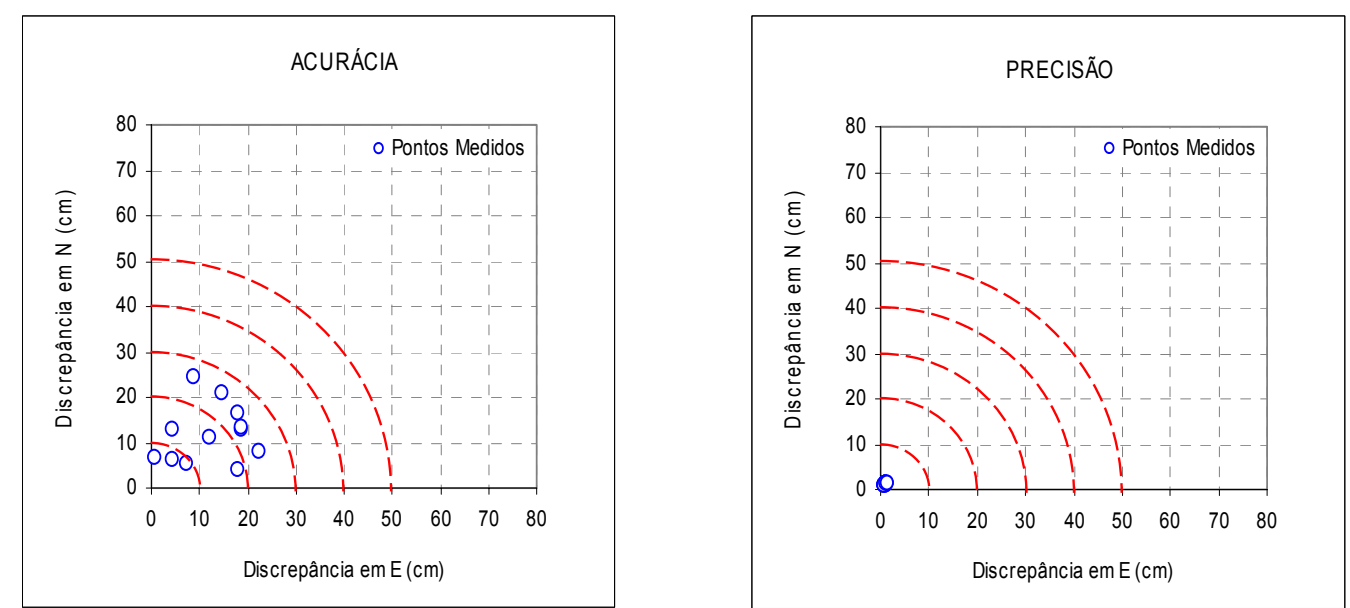

Figura 79 - Acurácia e precisão das coordenadas na seção 06 (localizada a 200 km da estação de referência), obtidas no $4^{\circ}$ dia de observação 

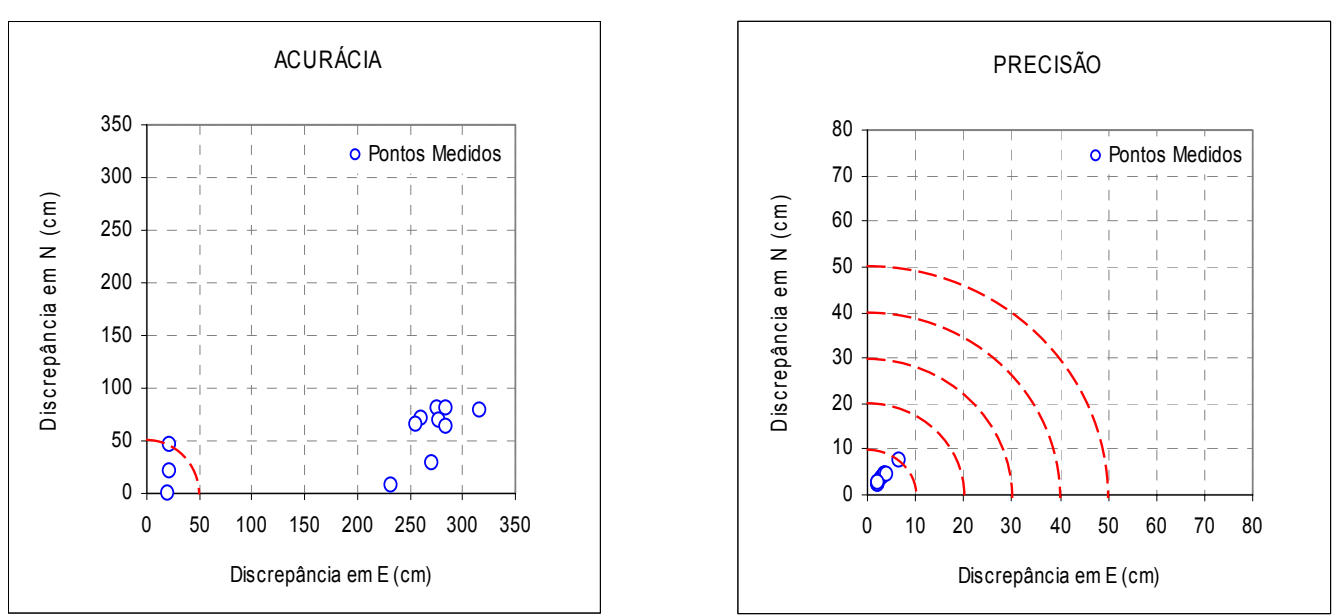

Figura 80 - Acurácia e precisão das coordenadas na seção 07 (localizada a 300 km da estação de referência), obtidas no $1^{\circ}$ dia de observação
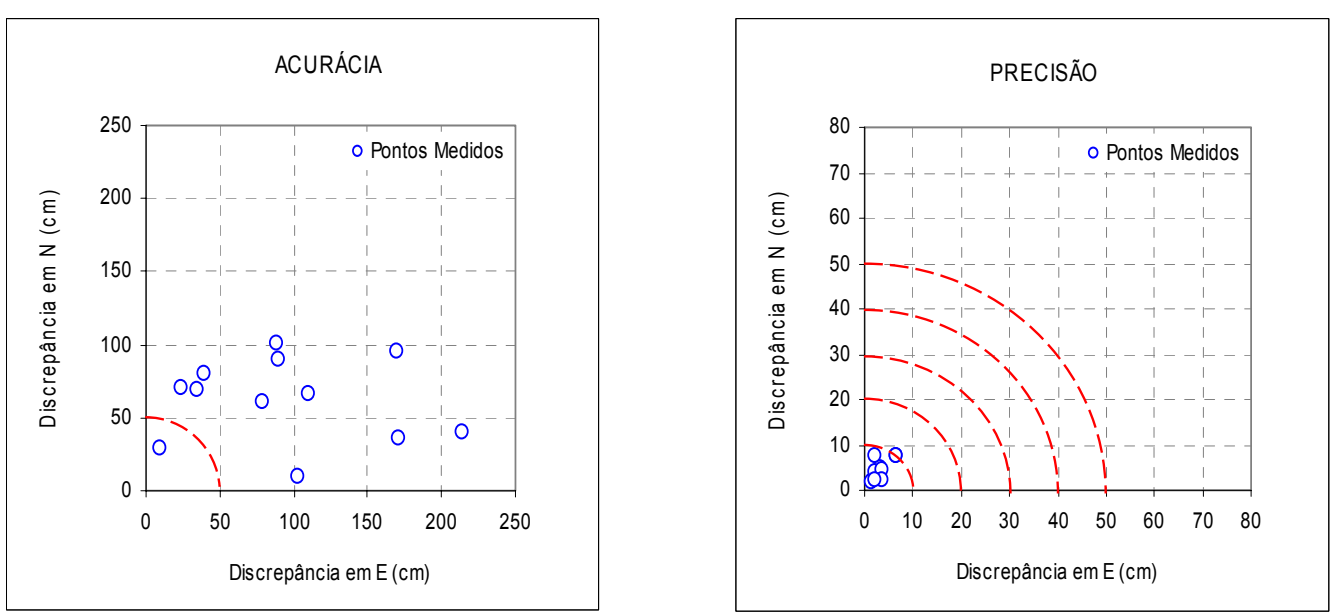

Figura 81 - Acurácia e precisão das coordenadas na seção 07 (localizada a 300 km da estação de referência), obtidas no $2^{\circ}$ dia de observação
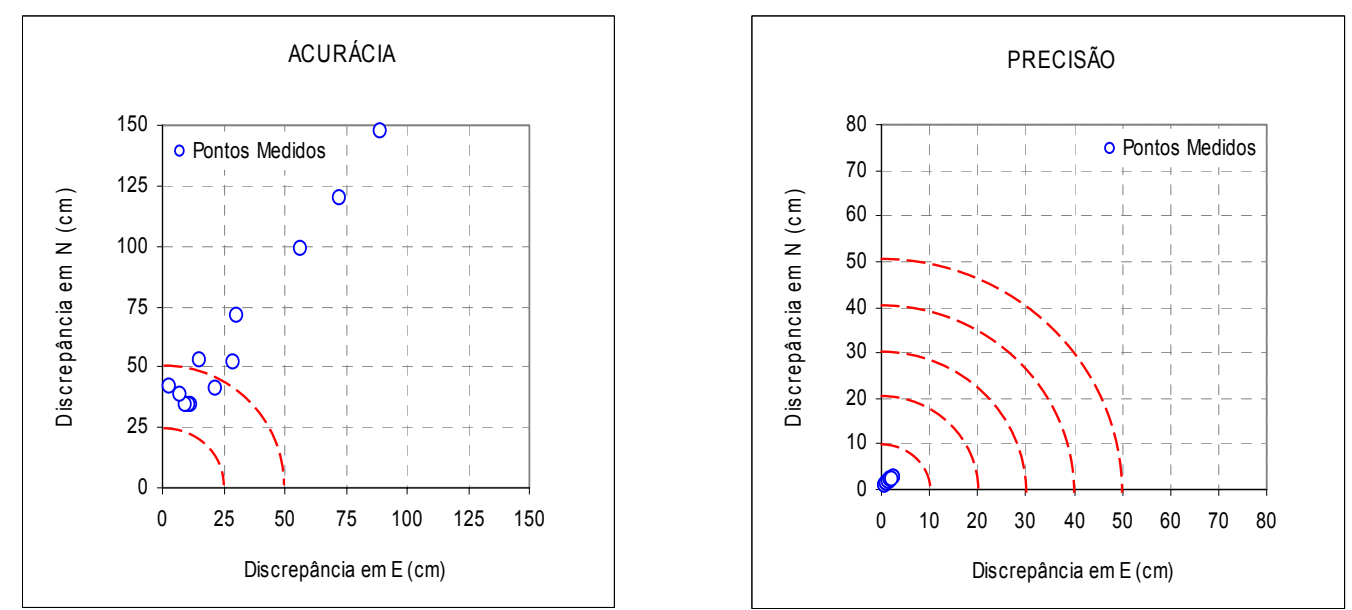

Figura 82 - Acurácia e precisão das coordenadas na seção 07 (localizada a 300 km da estação de referência), obtidas no $3^{\circ}$ dia de observação 

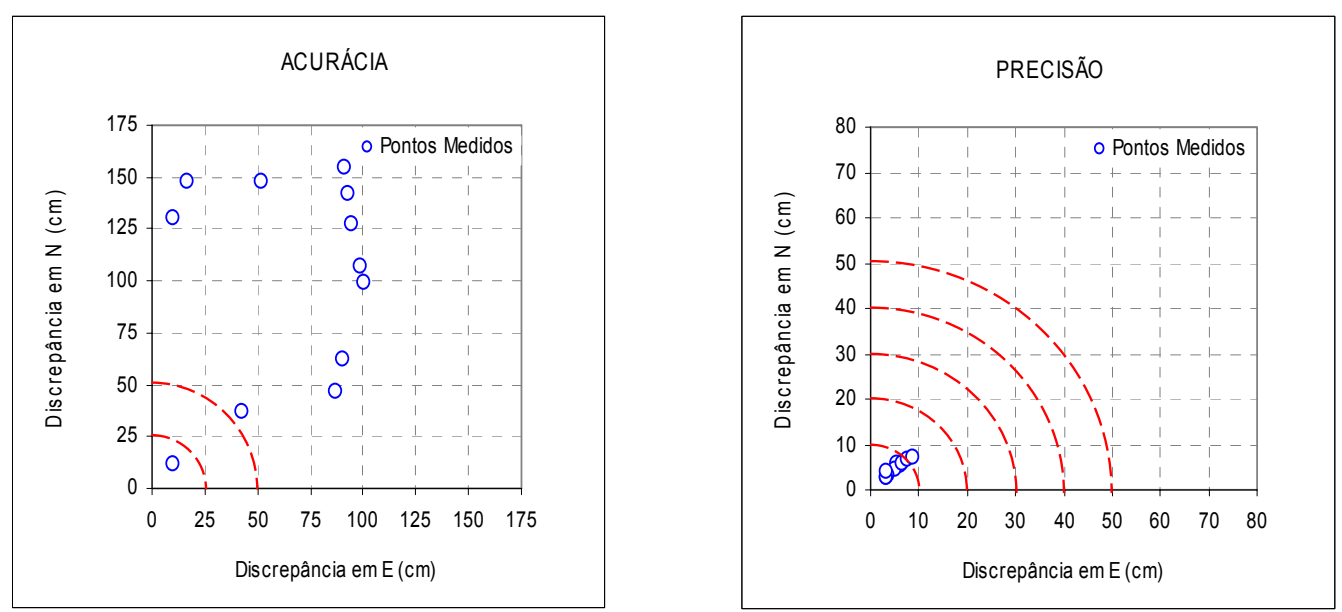

Figura 83 - Acurácia e precisão das coordenadas na seção 07 (localizada a 300 km da estação de referência), obtidas no $4^{\circ}$ dia de observação

\subsubsection{Receptor $D$ - resultados obtidos}

As Figuras 84 a 111 ilustram graficamente a distribuição da acurácia e da precisão das coordenadas obtidas com o Receptor D, nas estações de controle previamente estabelecidas. Nessas figuras é apresentado o comportamento dos pontos sob a tolerância de $50 \mathrm{~cm}$, estipulada pela norma técnica para Georreferenciamento de imóveis rurais (INCRA, 2004).

A Figura 112 ilustra o Índice Dst para os dias 26 e 27-03-2005 e a Figura 113 apresenta o índice para os dias 02 e 03-04-2005. 

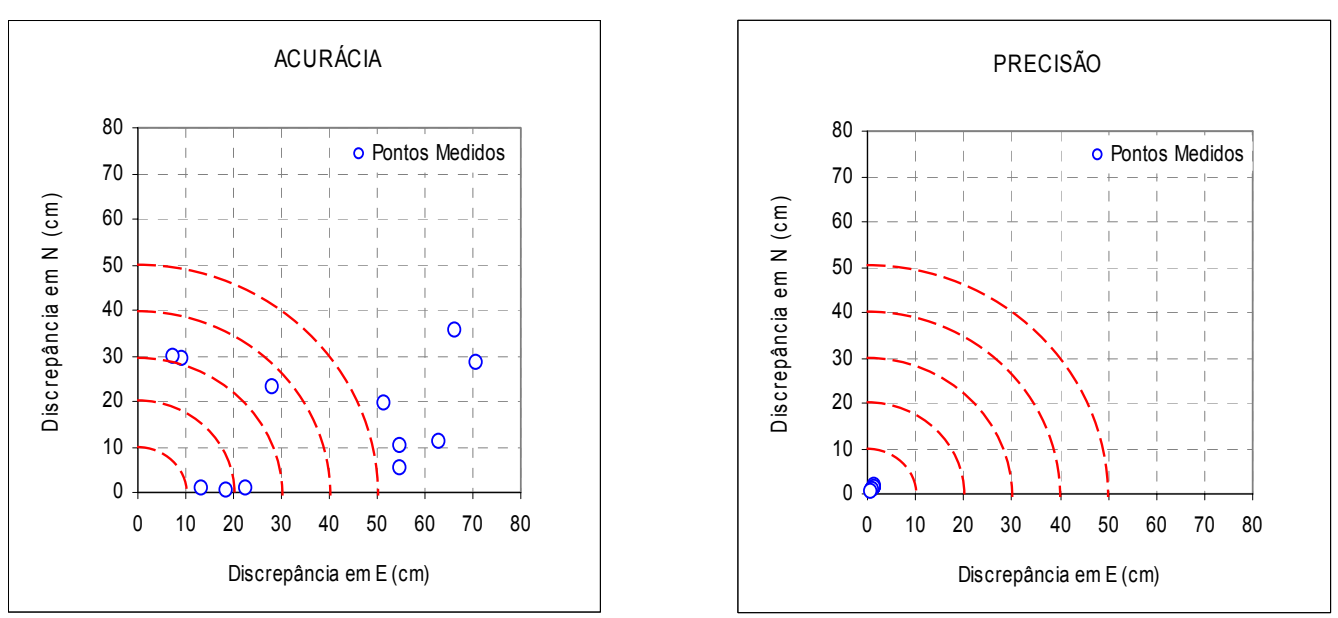

Figura 84 - Acurácia e precisão das coordenadas na seção 01 (localizada a 20 km da estação de referência), obtidas no $1^{\circ}$ dia de observação
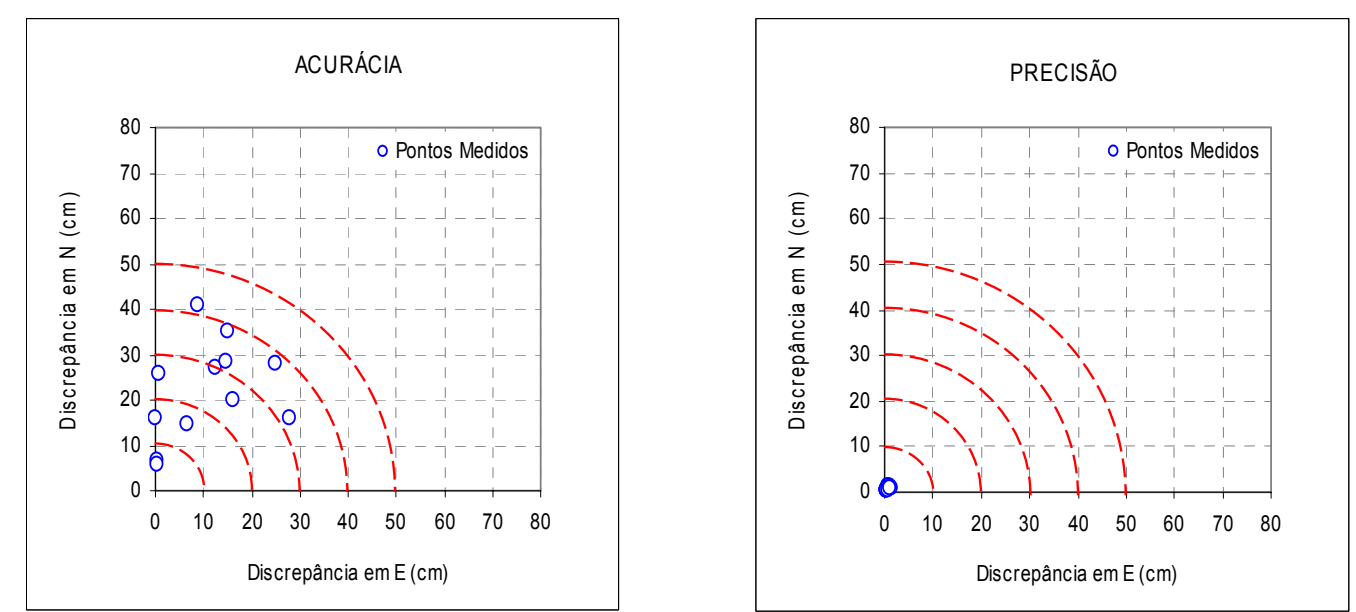

Figura 85 - Acurácia e precisão das coordenadas na seção 01 (localizada a 20 km da estação de referência), obtidas no $2^{\circ}$ dia de observação
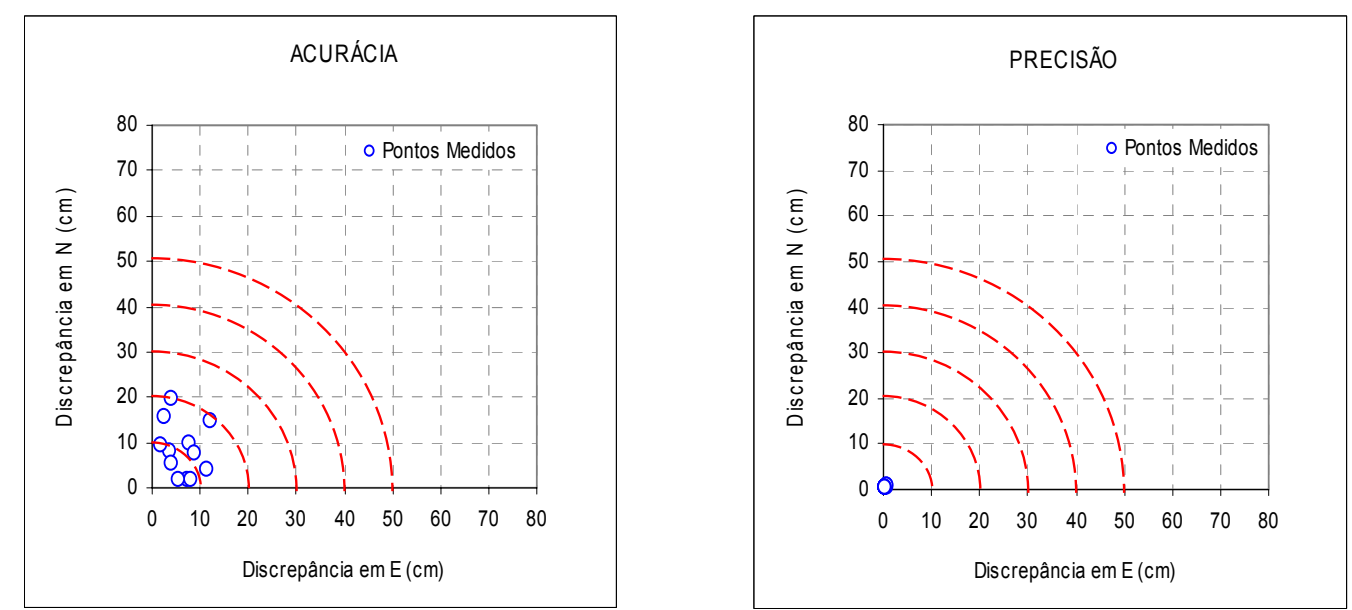

Figura 86 - Acurácia e precisão das coordenadas na seção 01 (localizada a 20 km da estação de referência), obtidas no $3^{\circ}$ dia de observação 

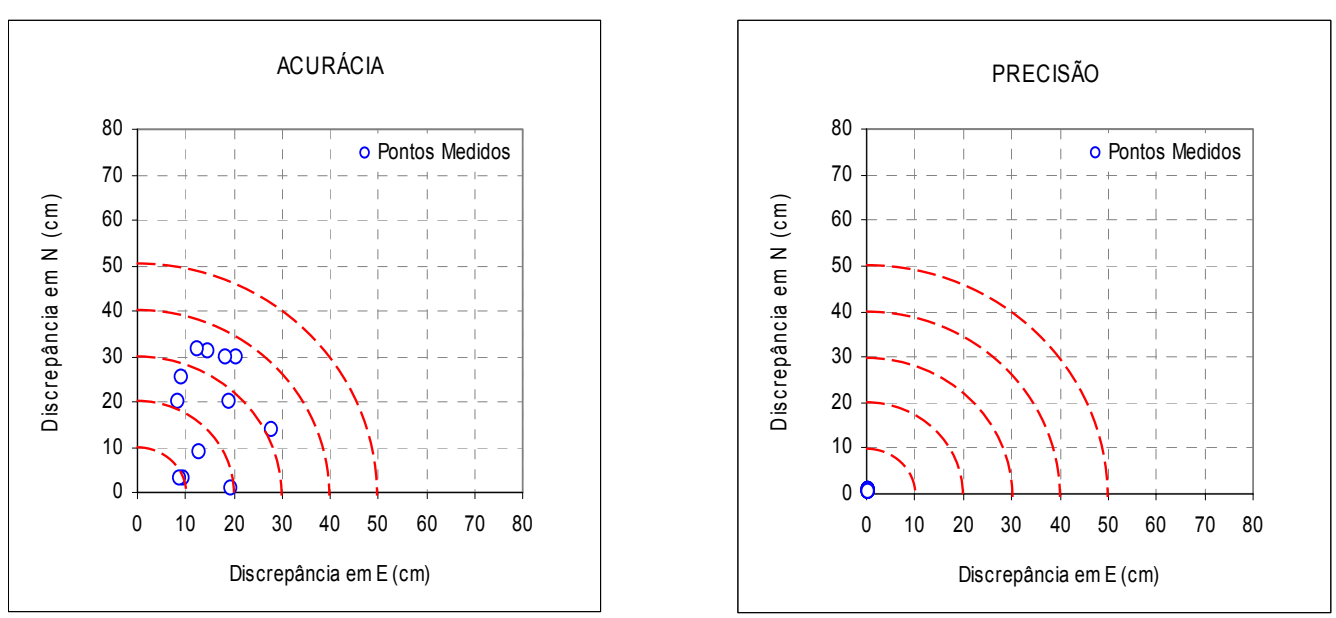

Figura 87 - Acurácia e precisão das coordenadas na seção 01 (localizada a 20 km da estação de referência), obtidas no $4^{\circ}$ dia de observação
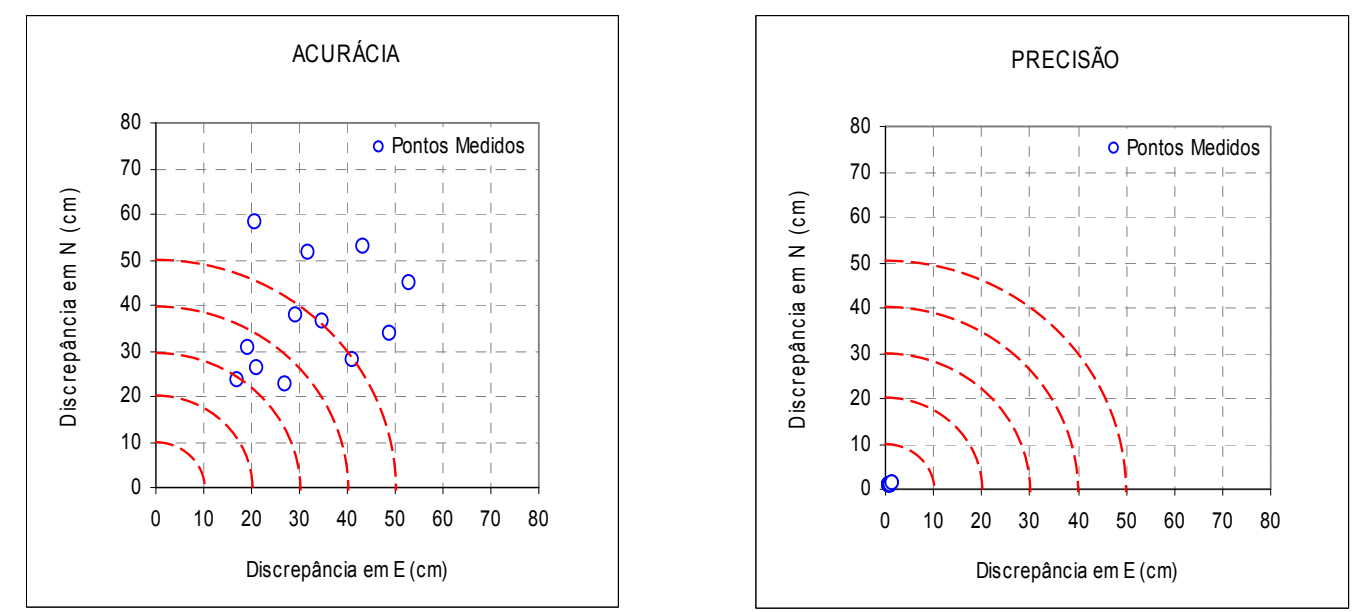

Figura 88 - Acurácia e precisão das coordenadas na seção 02 (localizada a 50 km da estação de referência), obtidas no $1^{\circ}$ dia de observação
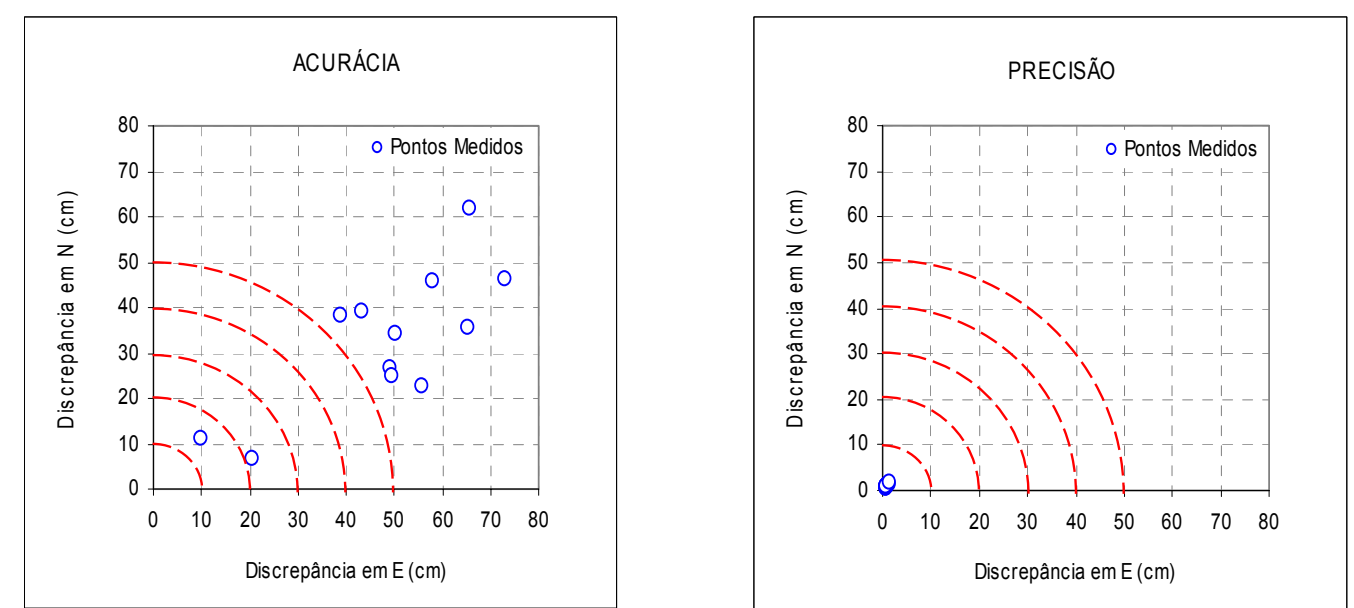

Figura 89 - Acurácia e precisão das coordenadas na seção 02 (localizada a 50 km da estação de referência), obtidas no $2^{\circ}$ dia de observação 

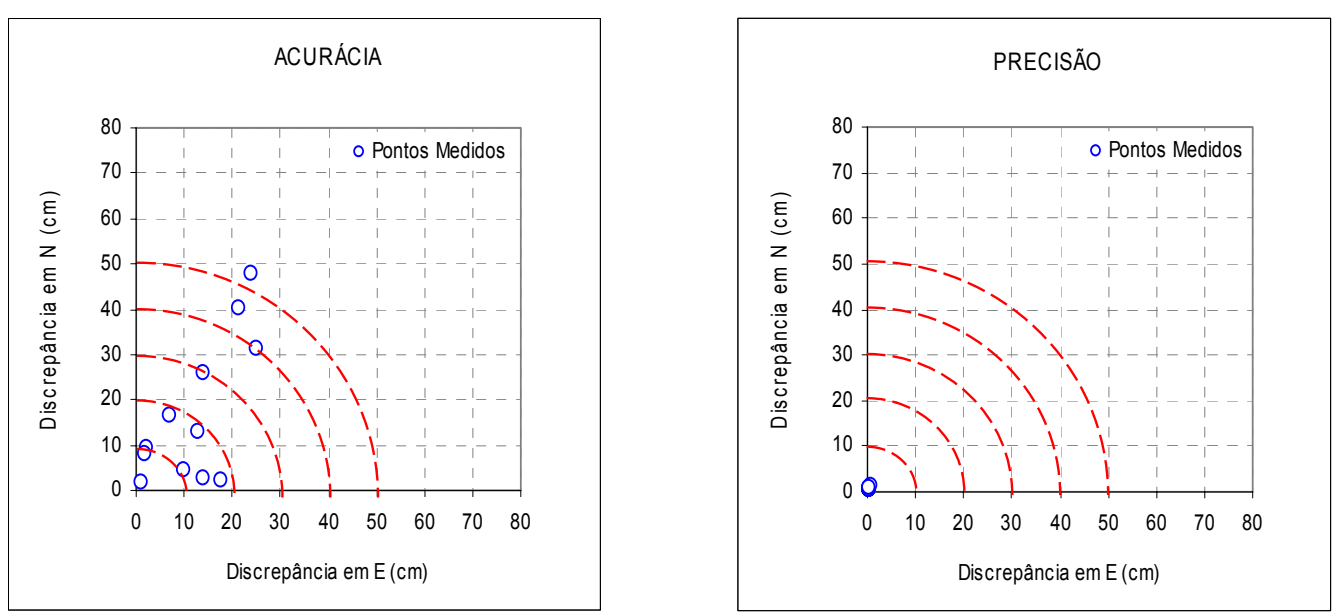

Figura 90 - Acurácia e precisão das coordenadas na seção 02 (localizada a 50 km da estação de referência), obtidas no $3^{\circ}$ dia de observação
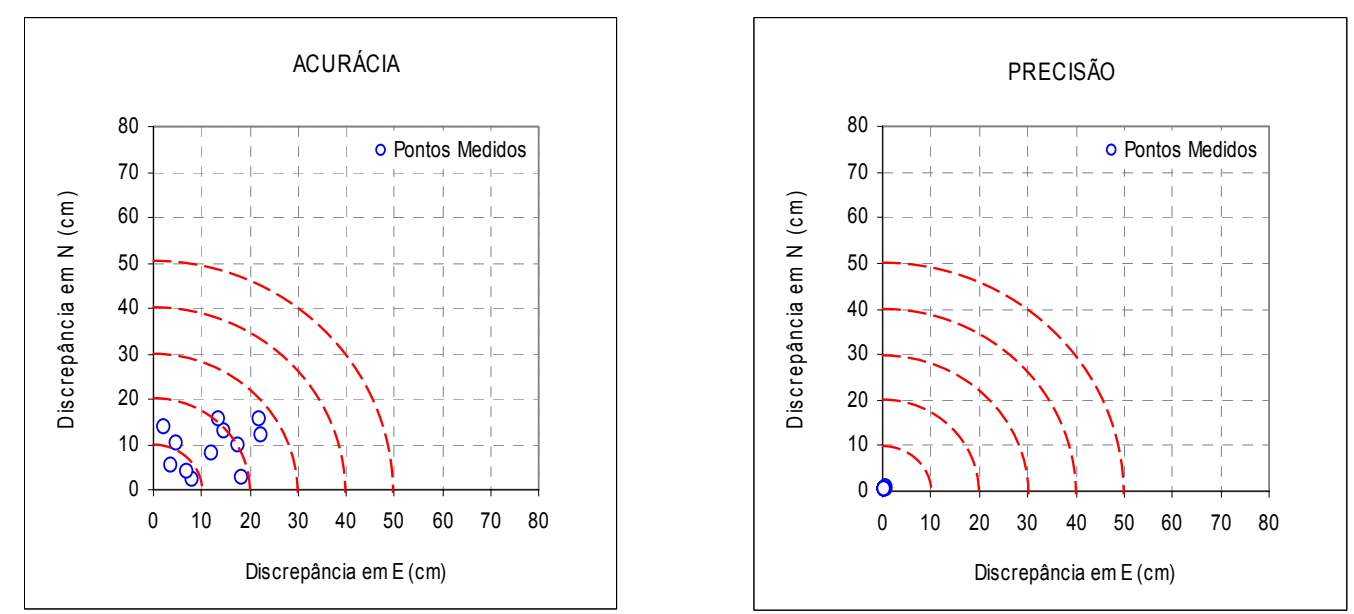

Figura 91 - Acurácia e precisão das coordenadas na seção 02 (localizada a 50 km da estação de referência), obtidas no $4^{\circ}$ dia de observação
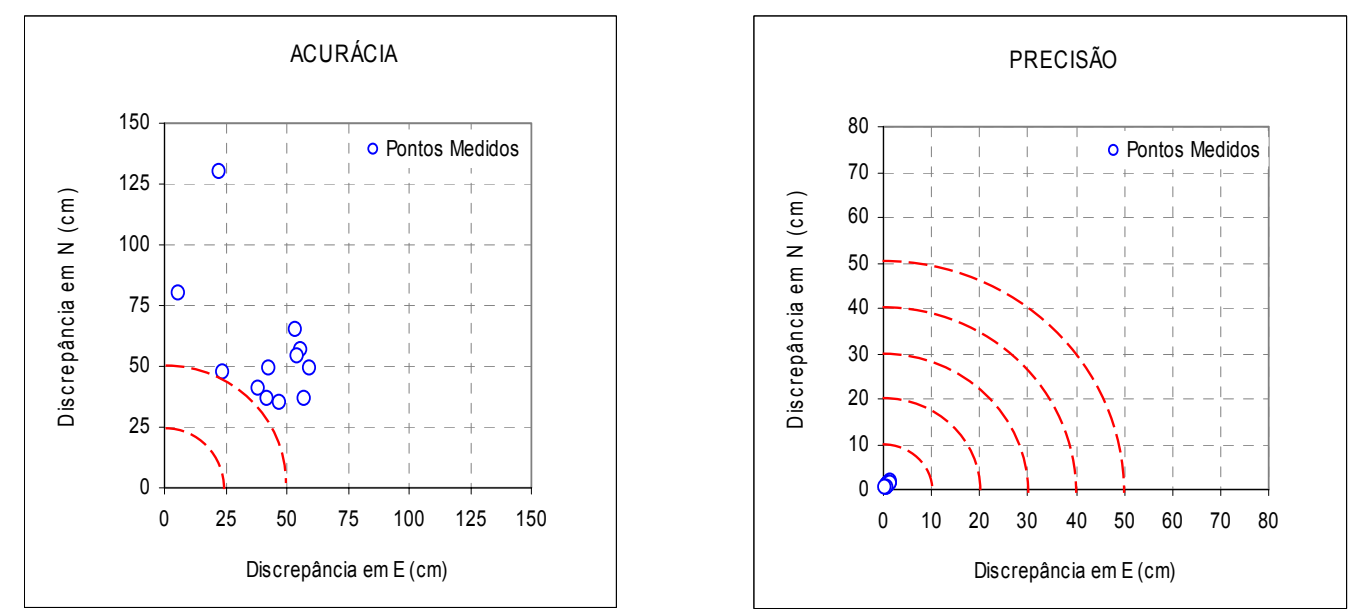

Figura 92 - Acurácia e precisão das coordenadas na seção 03 (localizada a 75 km da estação de referência), obtidas no $1^{\circ}$ dia de observação 

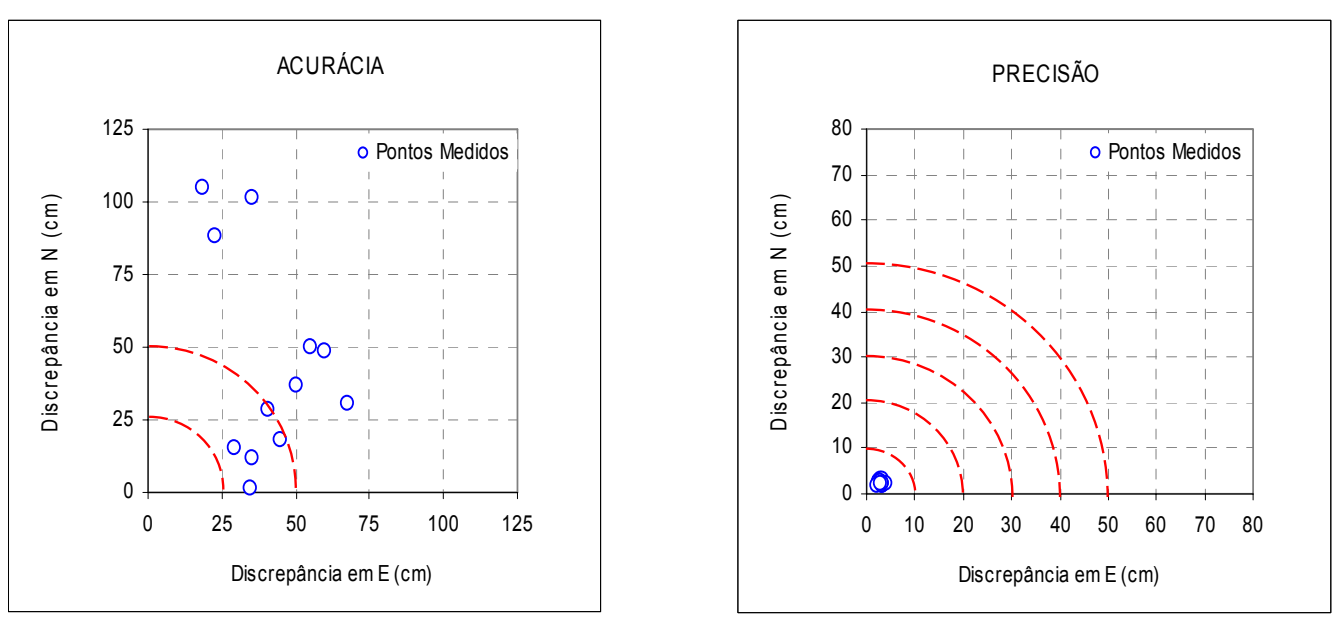

Figura 93 - Acurácia e precisão das coordenadas na seção 03 (localizada a 75 km da estação de referência), obtidas no $2^{\circ}$ dia de observação
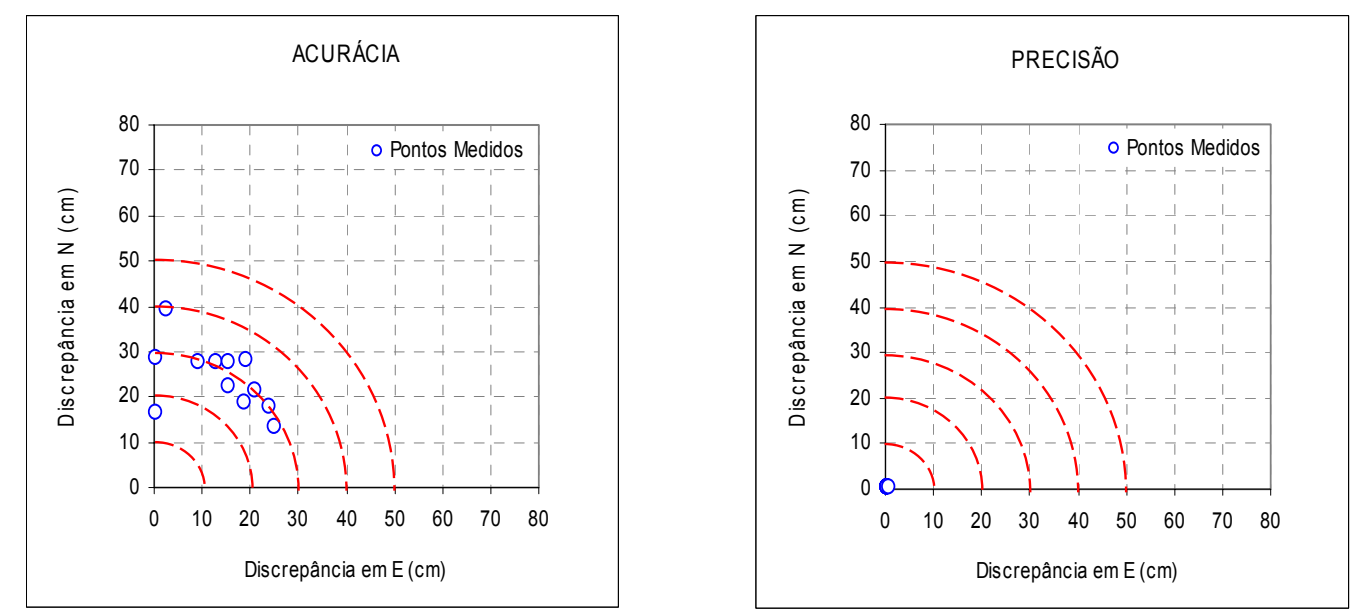

Figura 94 - Acurácia e precisão das coordenadas na seção 03 (localizada a 75 km da estação de referência), obtidas no $3^{\circ}$ dia de observação
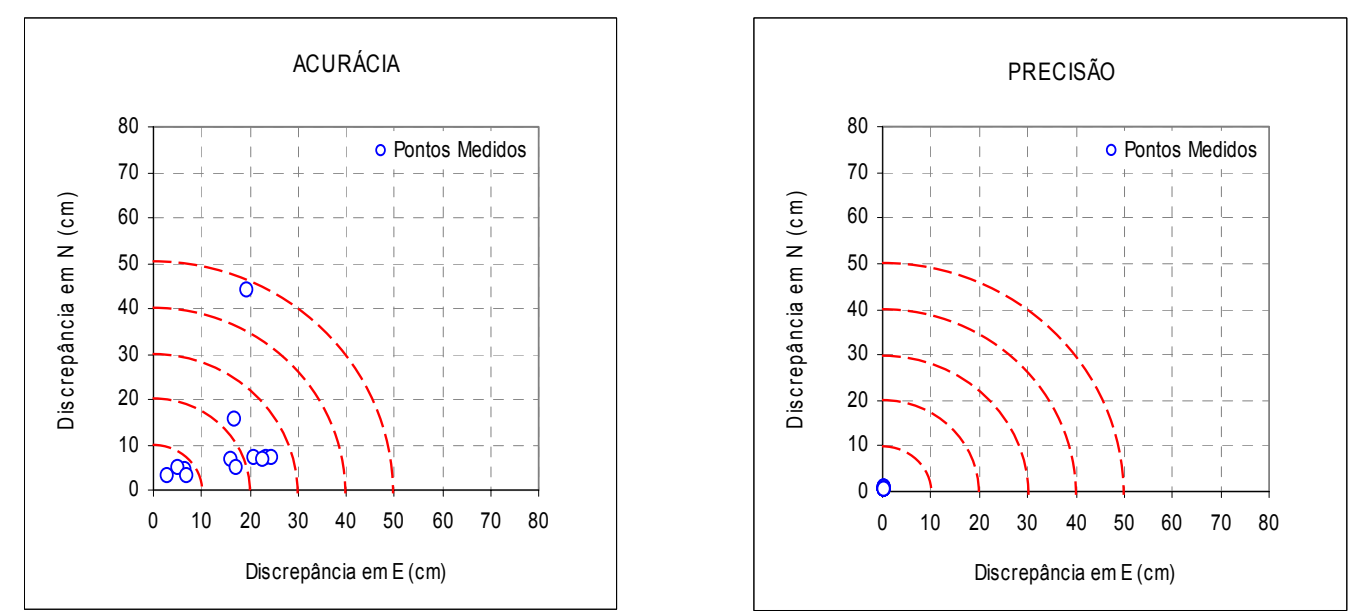

Figura 95 - Acurácia e precisão das coordenadas na seção 03 (localizada a 75 km da estação de referência), obtidas no $4^{\circ}$ dia de observação 

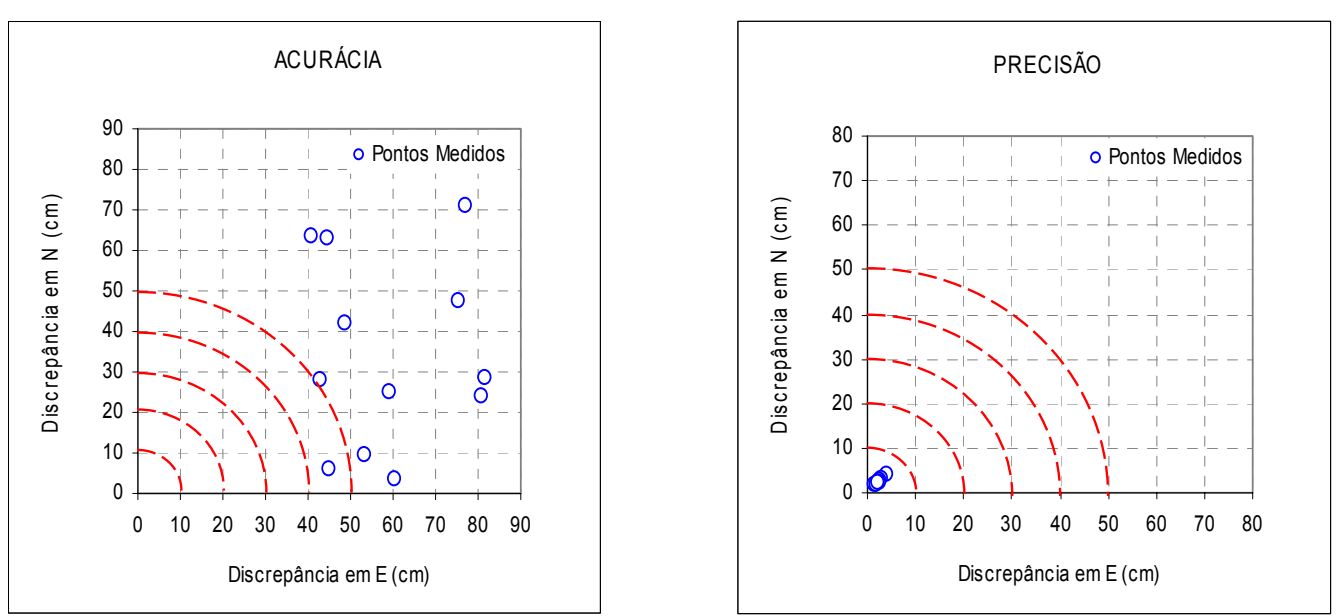

Figura 96 - Acurácia e precisão das coordenadas na seção 04 (localizada a 100 km da estação de referência), obtidas no $1^{\circ}$ dia de observação
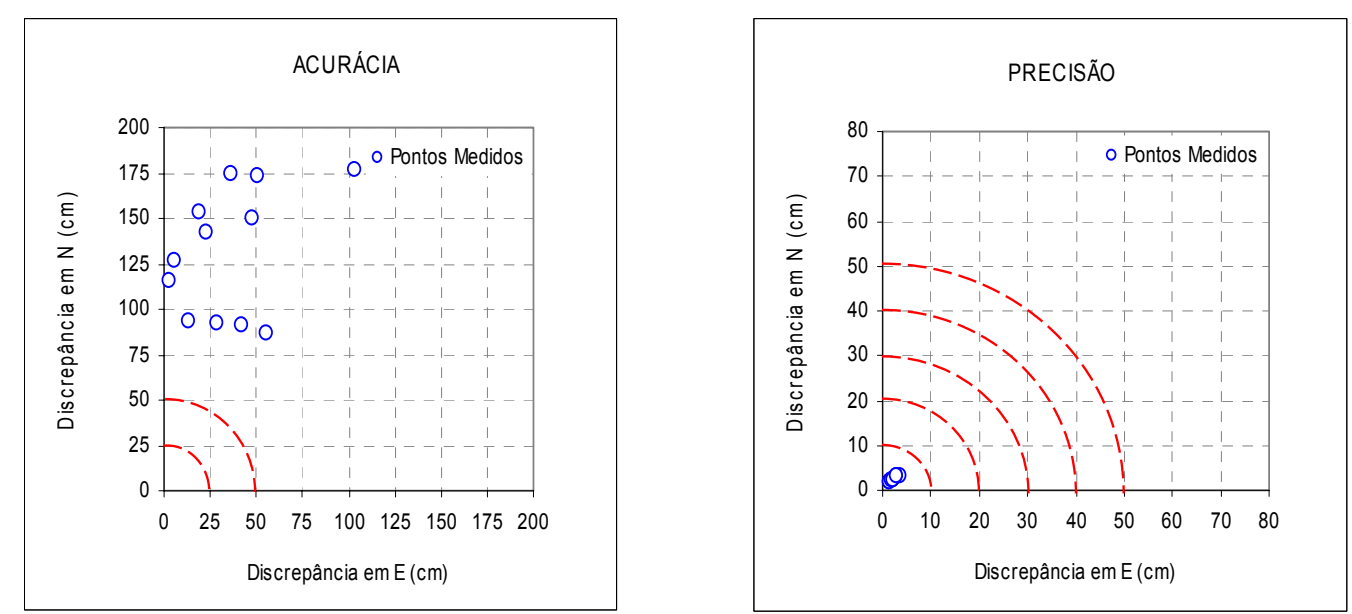

Figura 97 - Acurácia e precisão das coordenadas na seção 04 (localizada a 100 km da estação de referência), obtidas no $2^{\circ}$ dia de observação
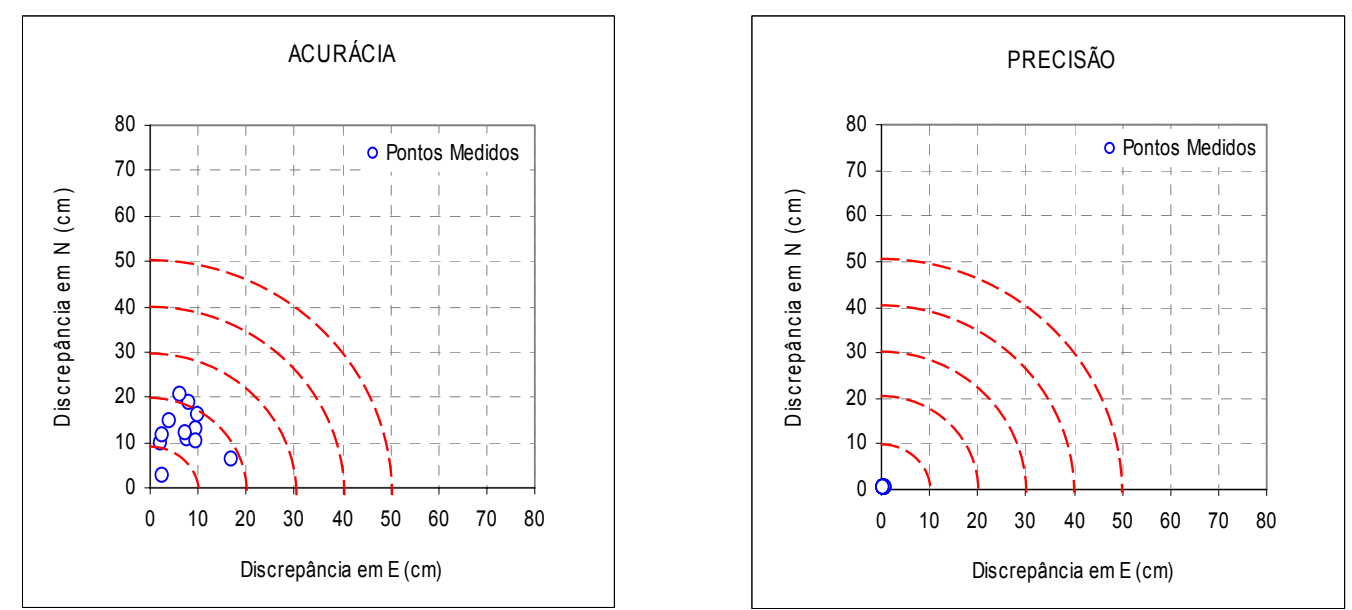

Figura 98 - Acurácia e precisão das coordenadas na seção 04 (localizada a 100 $\mathrm{km}$ da estação de referência), obtidas no $3^{\circ}$ dia de observação 

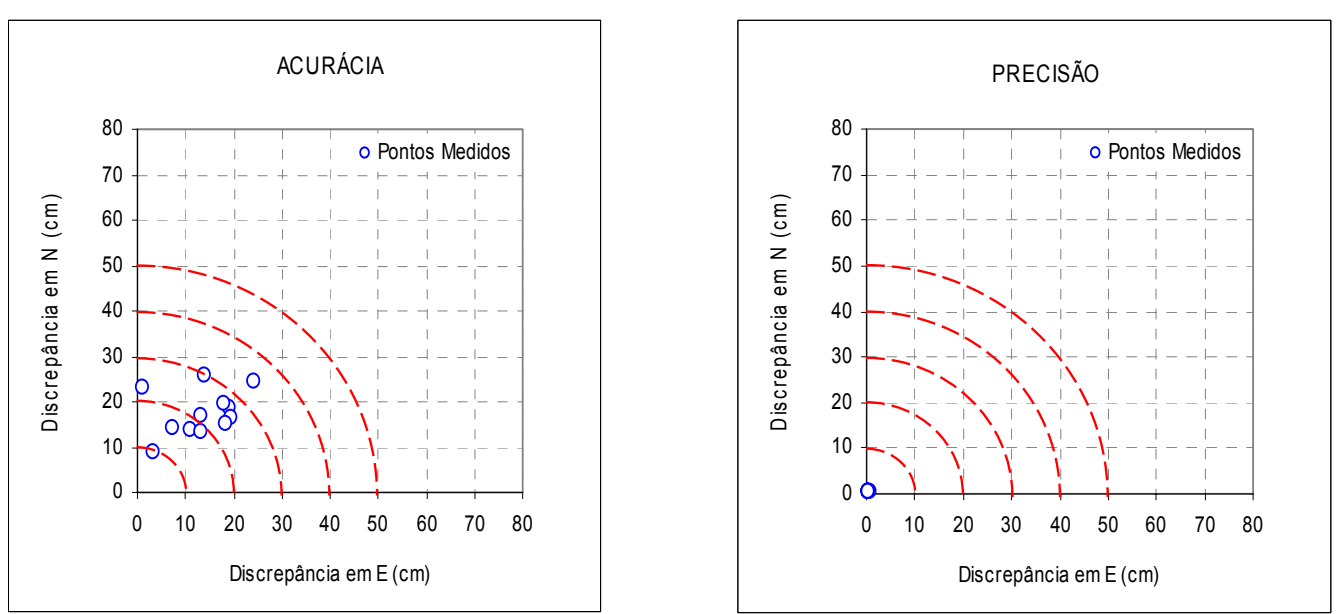

Figura 99 - Acurácia e precisão das coordenadas na seção 04 (localizada a 100 km da estação de referência), obtidas no $4^{\circ}$ dia de observação
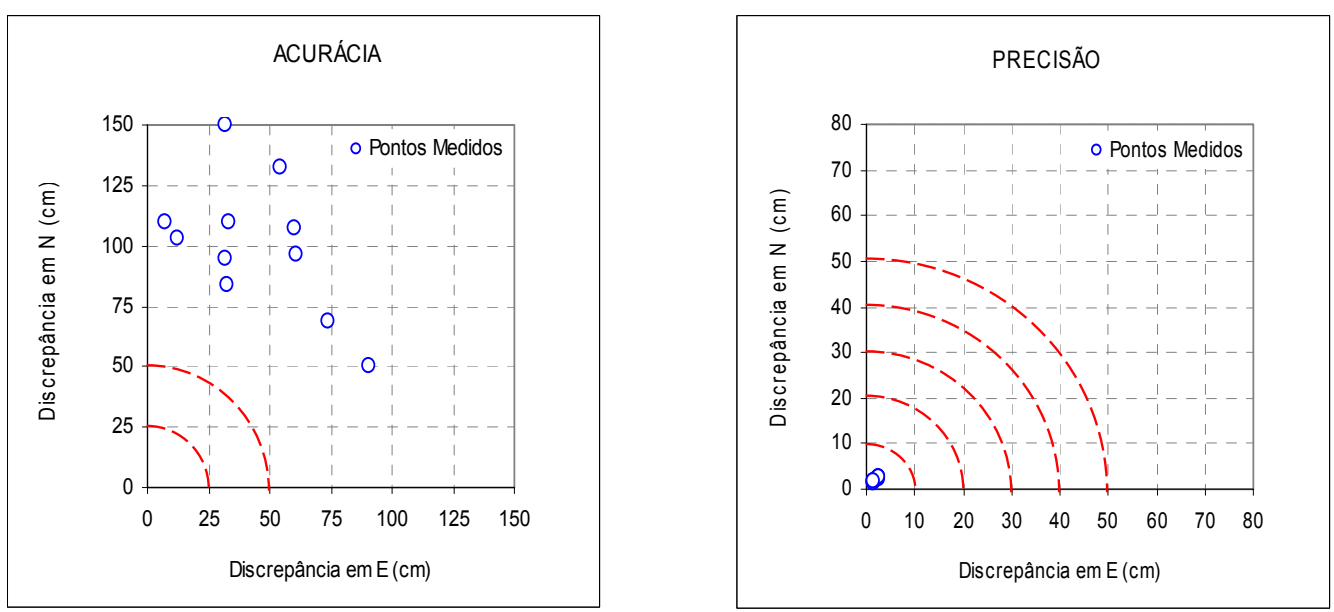

Figura 100 - Acurácia e precisão das coordenadas na seção 05 (localizada a 150 km da estação de referência), obtidas no $1^{\circ}$ dia de observação
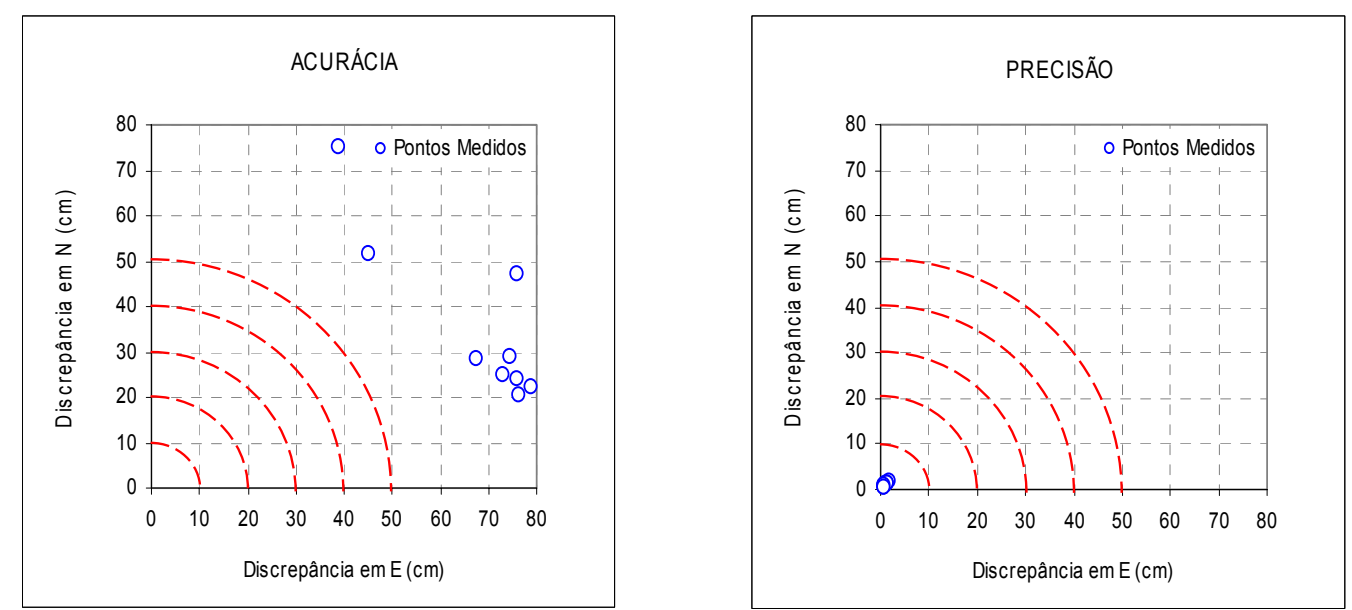

Figura 101 - Acurácia e precisão das coordenadas na seção 05 (localizada a 150 $\mathrm{km}$ da estação de referência), obtidas no $2^{\circ}$ dia de observação 

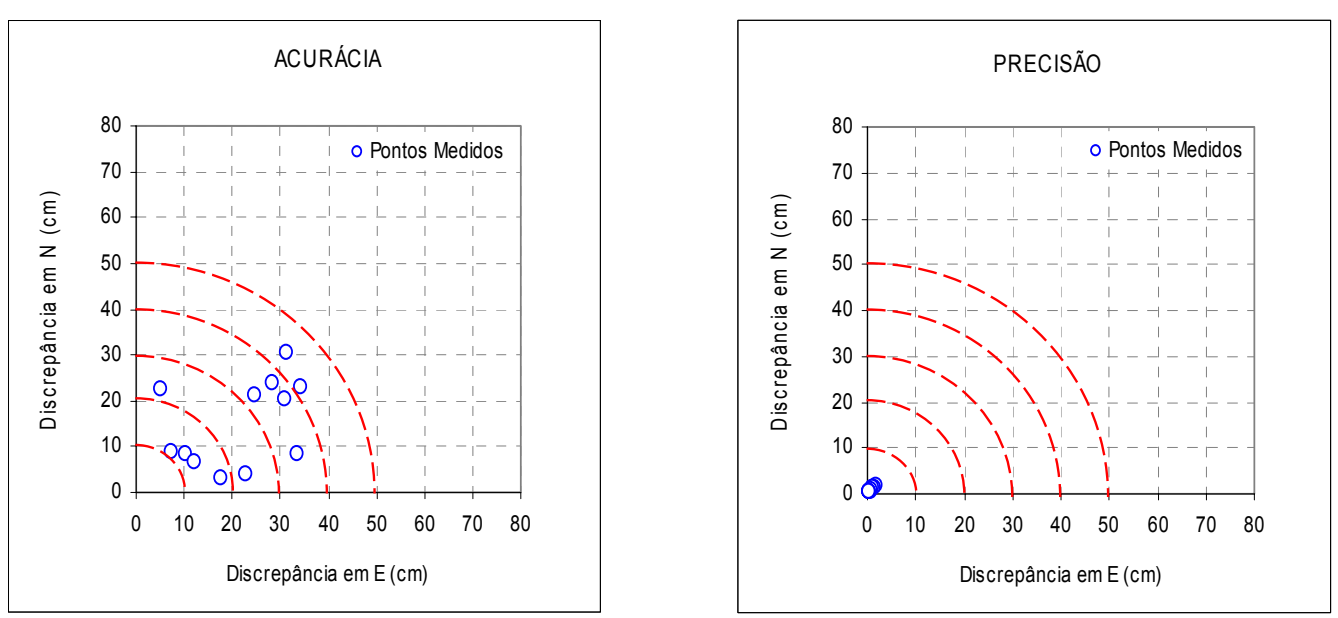

Figura 102 - Acurácia e precisão das coordenadas na seção 05 (localizada a 150 km da estação de referência), obtidas no $3^{\circ}$ dia de observação
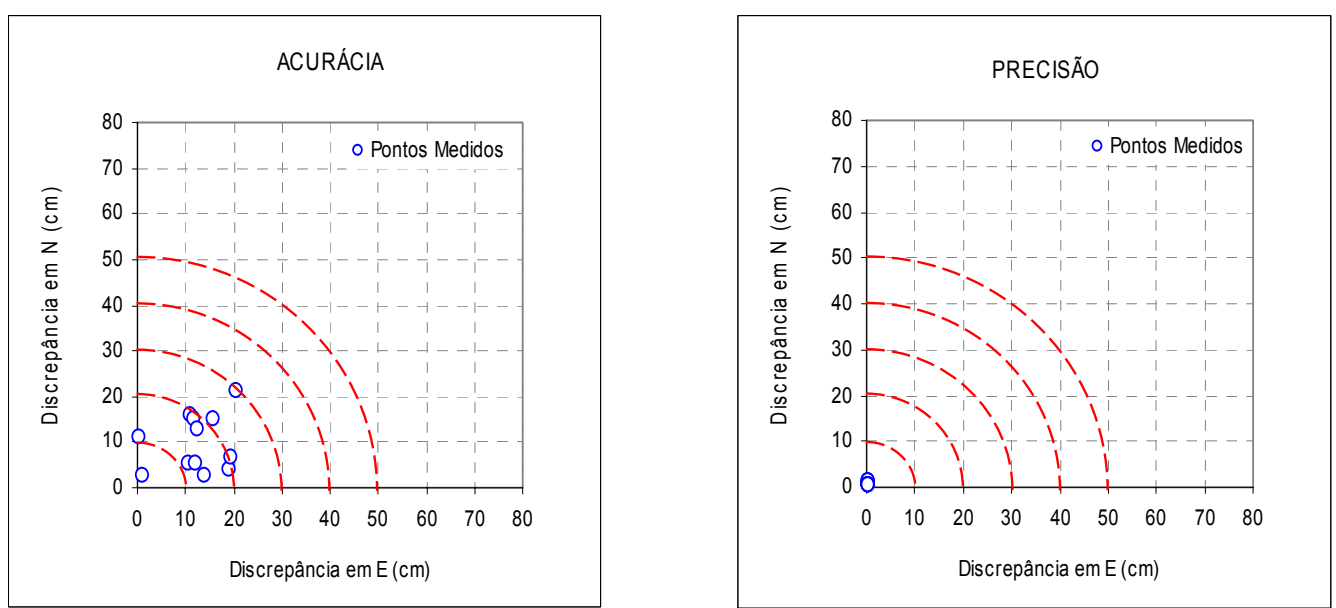

Figura 103 - Acurácia e precisão das coordenadas na seção 05 (localizada a 150 km da estação de referência), obtidas no $4^{\circ}$ dia de observação
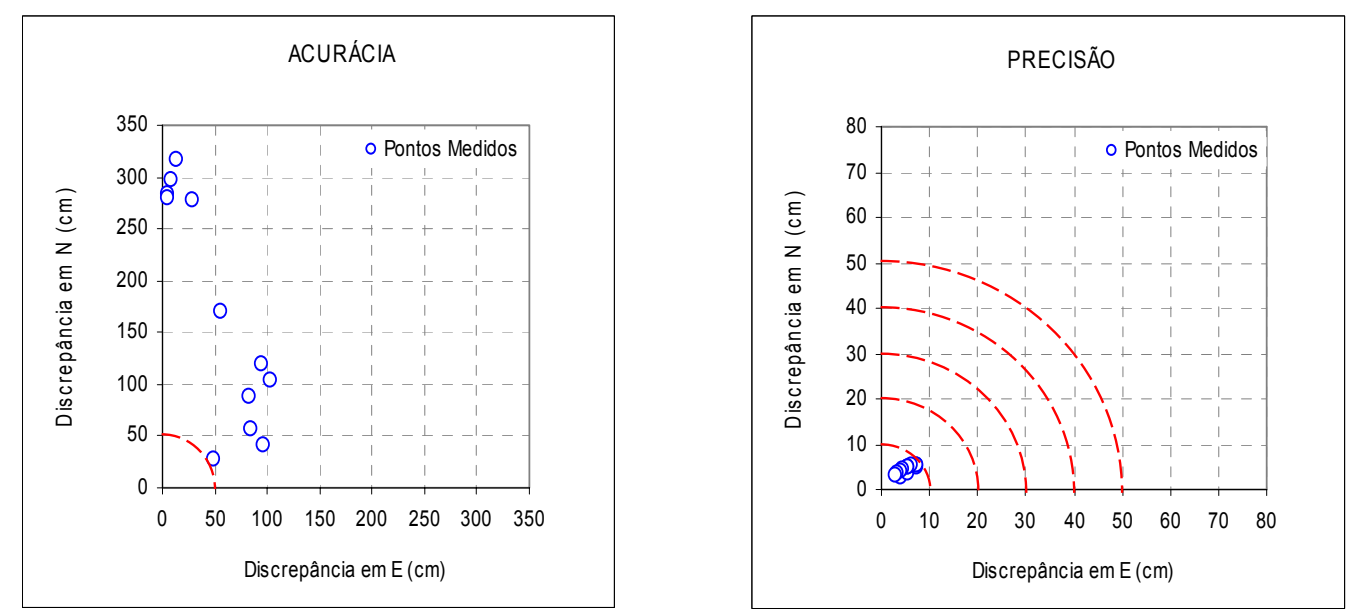

Figura 104 - Acurácia e precisão das coordenadas na seção 06 (localizada a 200 km da estação de referência), obtidas no $1^{\circ}$ dia de observação 

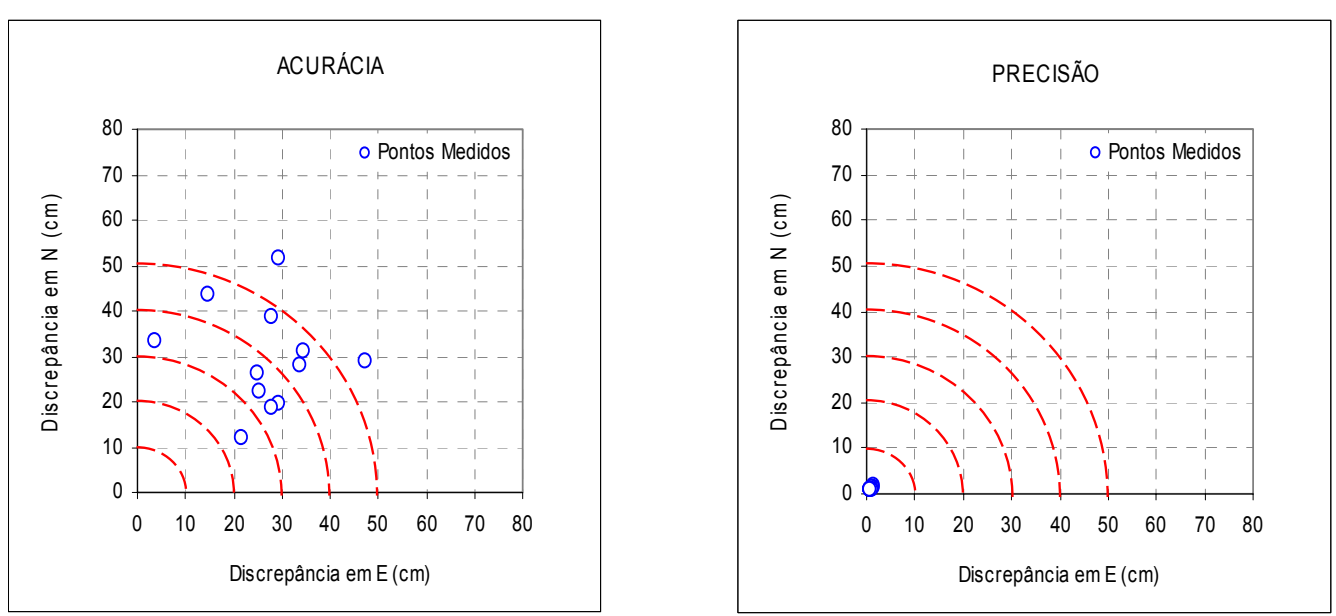

Figura 105 - Acurácia e precisão das coordenadas na seção 06 (localizada a 200 km da estação de referência), obtidas no $2^{\circ}$ dia de observação
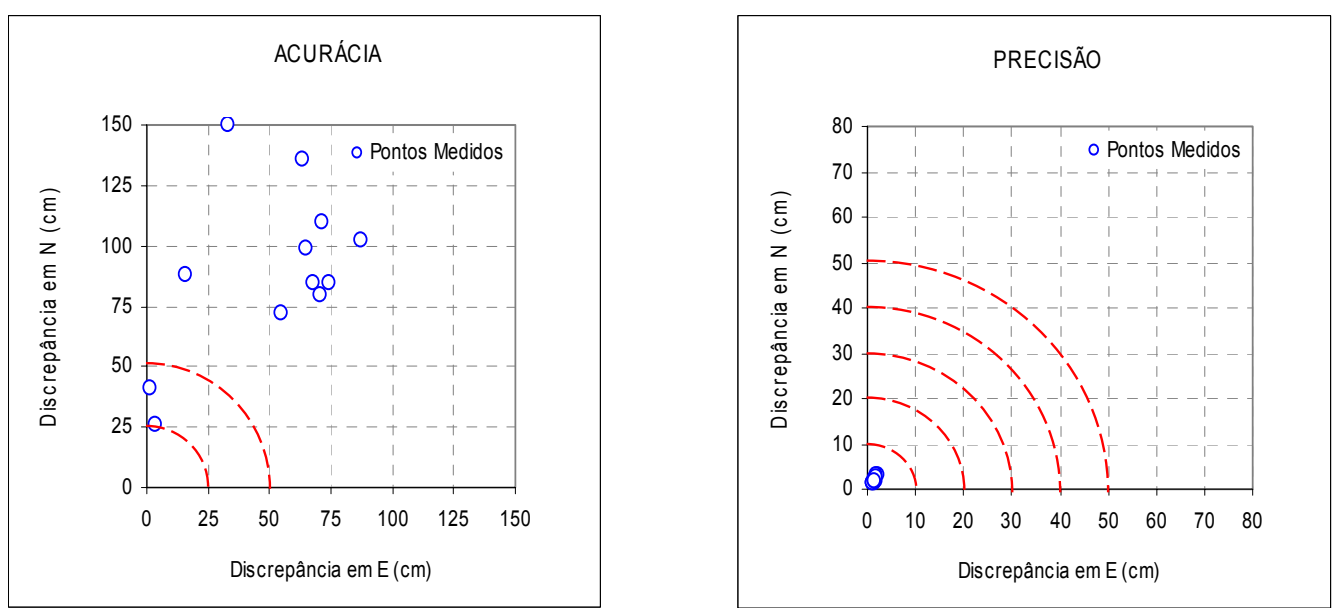

Figura 106 - Acurácia e precisão das coordenadas na seção 06 (localizada a 200 km da estação de referência), obtidas no $3^{\circ}$ dia de observação
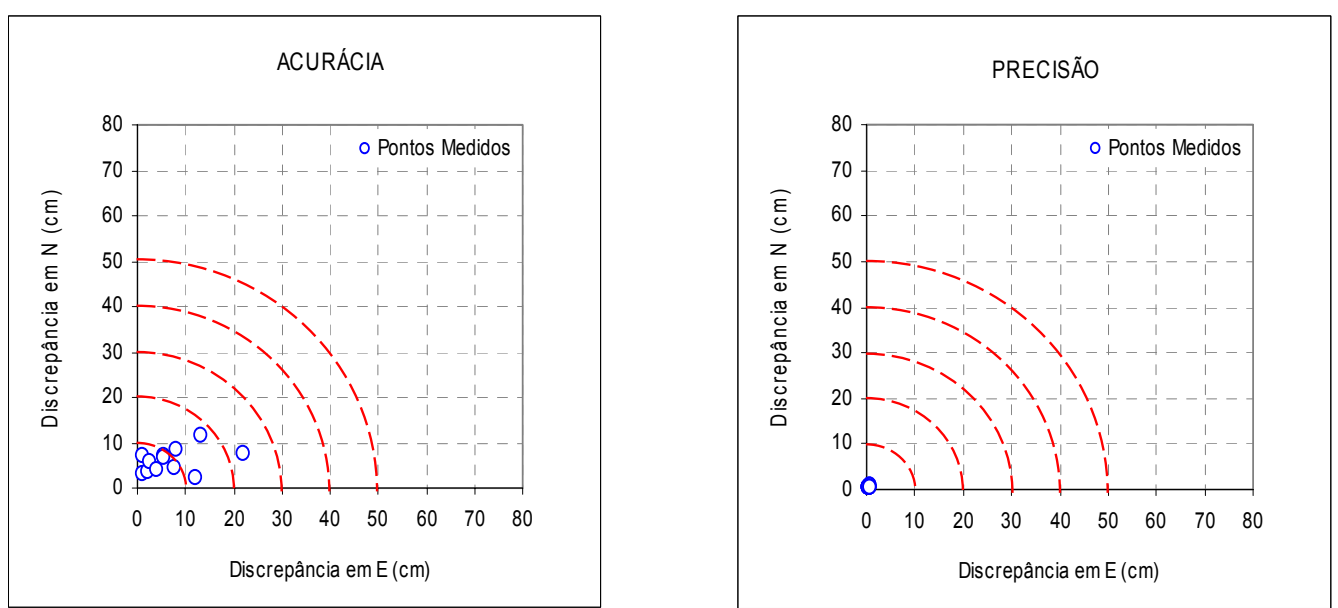

Figura 107 - Acurácia e precisão das coordenadas na seção 06 (localizada a 200 $\mathrm{km}$ da estação de referência), obtidas no $4^{\circ}$ dia de observação 

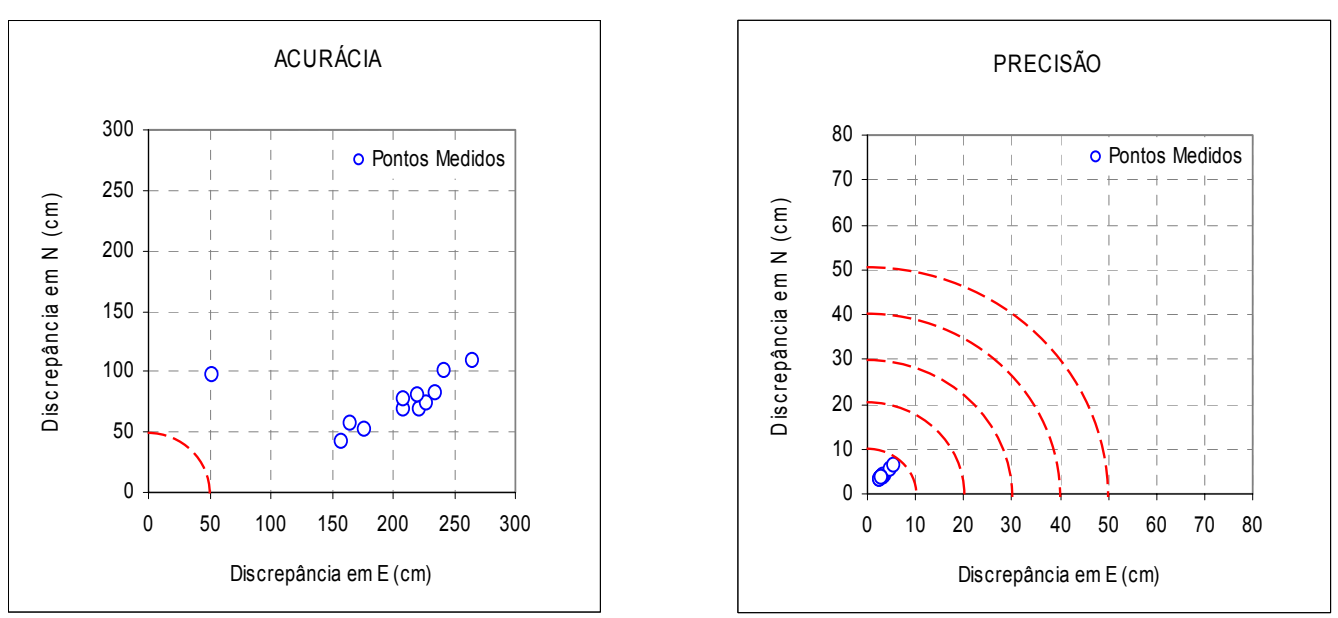

Figura 108 - Acurácia e precisão das coordenadas na seção 07 (localizada a 300 km da estação de referência), obtidas no $1^{\circ}$ dia de observação
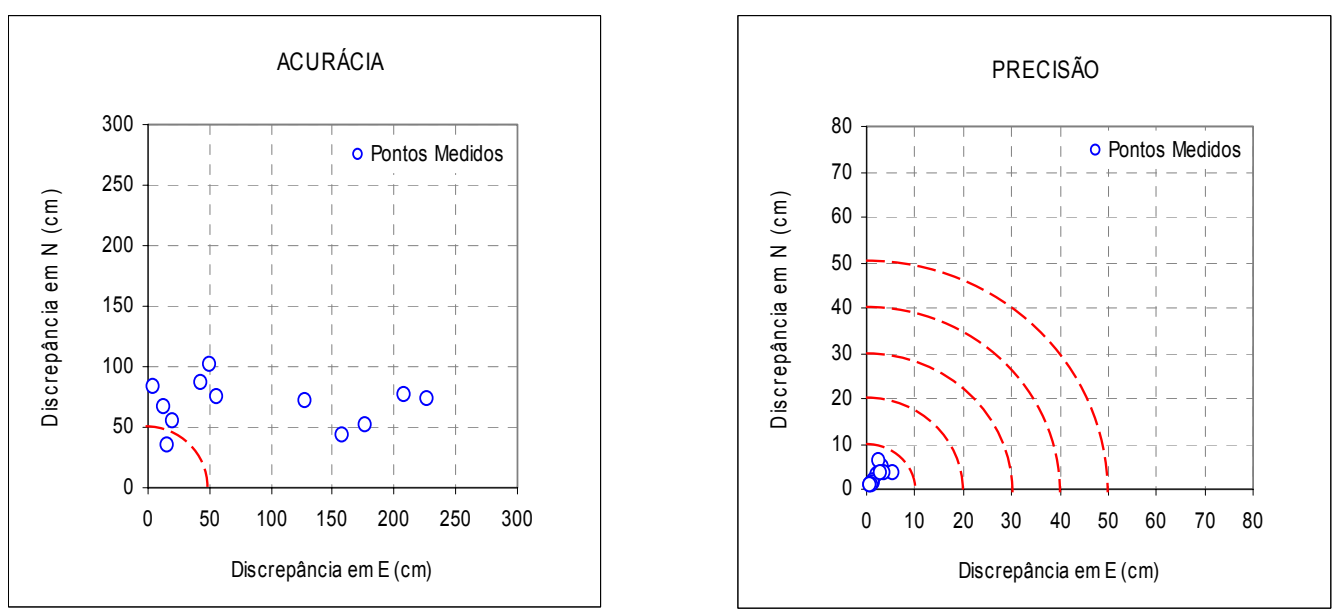

Figura 109 - Acurácia e precisão das coordenadas na seção 07 (localizada a 300 km da estação de referência), obtidas no $2^{\circ}$ dia de observação
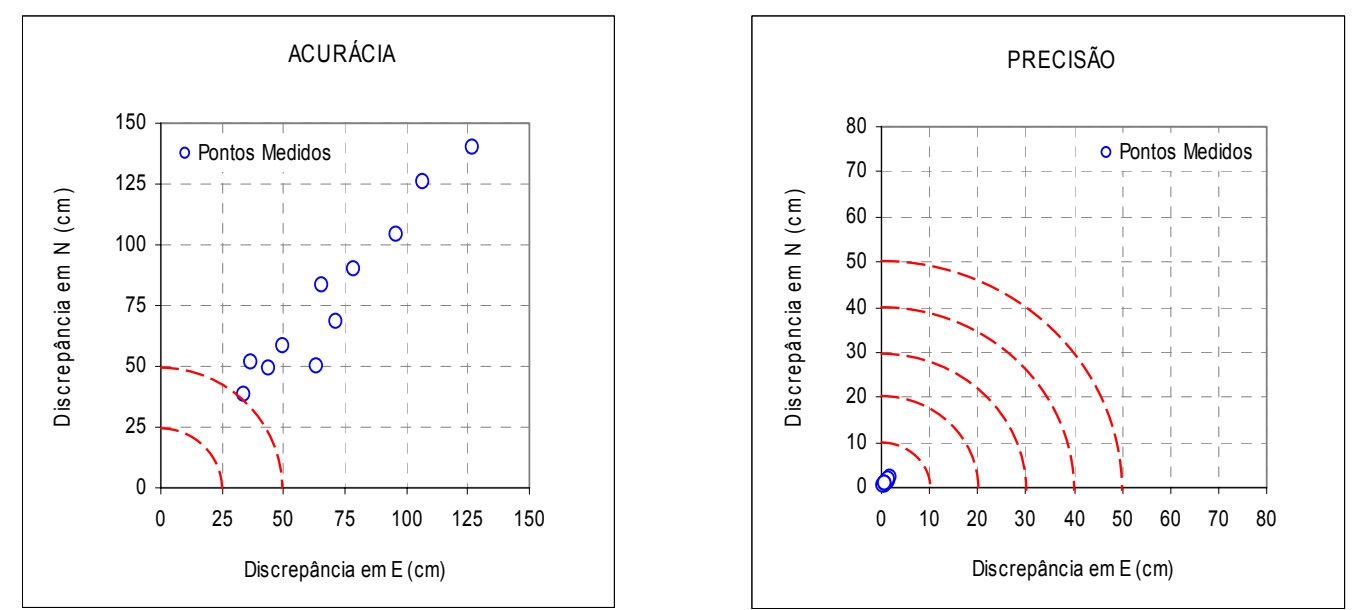

Figura 110 - Acurácia e precisão das coordenadas na seção 07 (localizada a 300 km da estação de referência), obtidas no $3^{\circ}$ dia de observação 

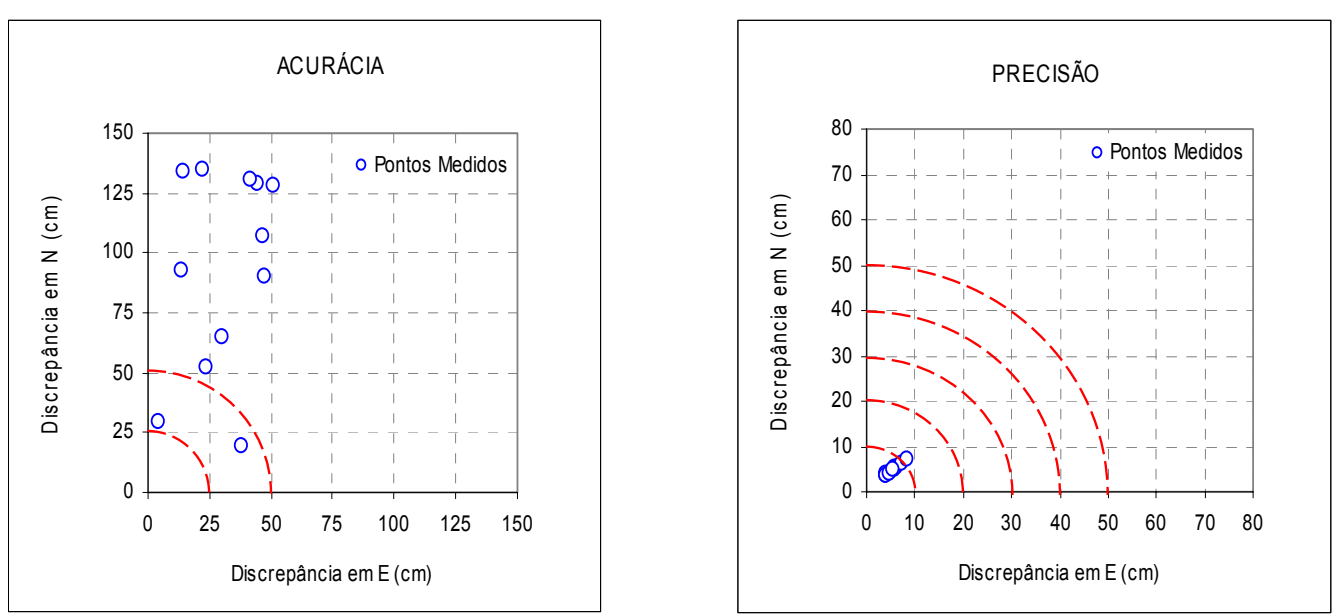

Figura 111 - Acurácia e precisão das coordenadas na seção 07 (localizada a 300 km da estação de referência), obtidas no $4^{\circ}$ dia de observação

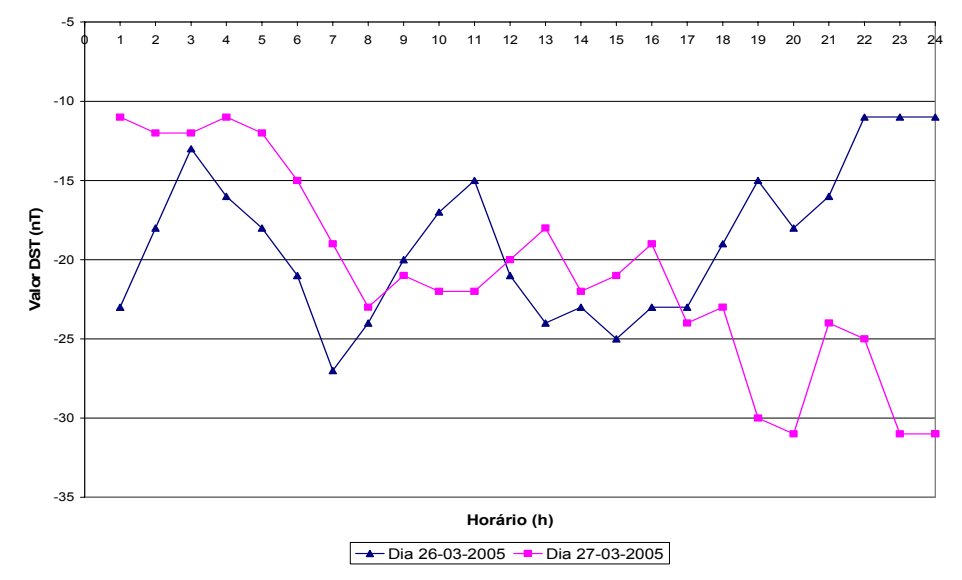

Figura 112 - Índice Dst para os dias 26 e 27-03-2005 - Fonte: Adaptado de http://swdcwww.kugi.kyoto-u.ac.jp/dstdir/dst1/prov.html

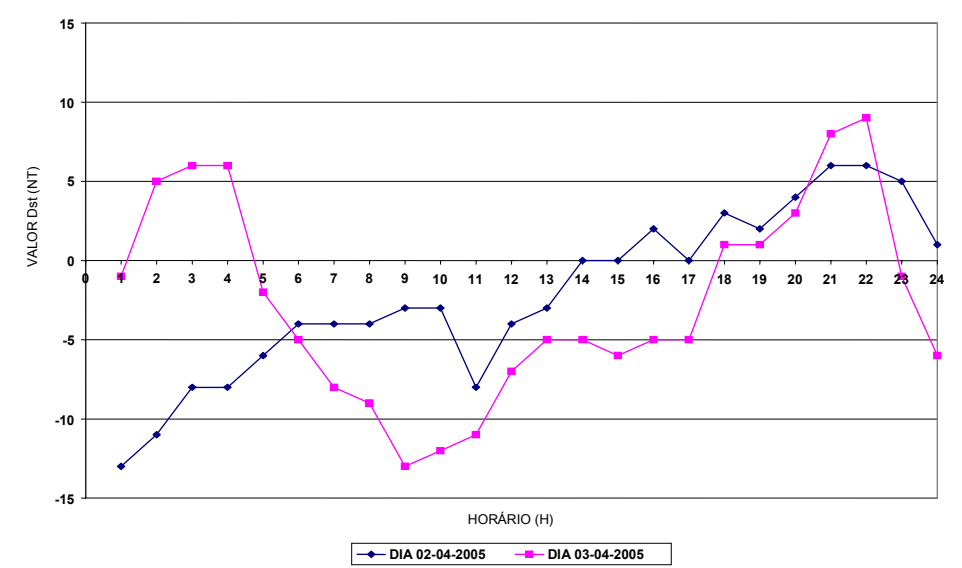

Figura 113 - Índice Dst para os dias 02 e 03-04-2005 - Fonte: Adaptado de http://swdcwww.kugi.kyoto-u.ac.jp/dstdir/dst1/prov.html 


\section{ANÁLISES}

Sintetizando o que fora discutido nos capítulos anteriores, este trabalho consistiu na avaliação do posicionamento relativo com GPS, com correções diferenciais dos dados da portadora $L 1$, fazendo uso da técnica de suavização do código pela portadora, no modo estático rápido, com sessões de 5 minutos tempo mínimo exigido no Georreferenciamento de Imóveis Rurais do INCRA. Nesse posicionamento, estão presentes várias fontes de erros sistemáticos, como a ocasionada pela ionosfera e pela geometria ruim dos satélites, que não podem ser contornadas por correções diferenciais, devido à curta duração da sessão.

Com relação à acurácia e à precisão proporcionada pelo Receptor $A$, apresentadas nas Figuras 36 a 42, verifica-se que somente as bases de $100 \mathrm{~km}$ e $300 \mathrm{~km}$ tiveram acurácia melhor do que $50 \mathrm{~cm}$, as demais apresentaram resultados piores. Entretanto, a precisão de todos os pontos de controle apresentou valores menores que $15 \mathrm{~cm}$, ou seja, a precisão foi sempre menor do que a acurácia, para esse receptor.

A acurácia e a precisão do Receptor B foram apresentadas nas Figuras 59 a 86. Com esse receptor, cujo sistema não faz uso da suavização do código, apenas as bases de $20 \mathrm{~km}\left(1^{\circ}\right.$ e $2^{\circ}$ dias $)$ e $150 \mathrm{~km}\left(2^{\circ}\right.$ dia $)$ apresentaram acurácia 
melhor que $50 \mathrm{~cm}$. Para as bases de $75 \mathrm{~km}\left(1^{\circ}\right.$ e $2^{\circ}$ dia $), 150\left(1^{\circ} \mathrm{dia}\right), 200 \mathrm{~km}\left(1^{\circ}\right.$ dia) e $300 \mathrm{~km}\left(1^{\circ}\right.$ e $2^{\circ}$ dias $)$ suas coordenadas apresentaram erros maiores que 50 $\mathrm{cm}$. Nas demais bases, os erros oscilaram entre maiores e menores que $50 \mathrm{~cm}$. As precisões das coordenadas mostraram valores altos, comparadas aos demais receptores, e apresentaram erros crescentes ao comprimento da base. Ainda, para a base de $100 \mathrm{~km}\left(2^{\circ} \mathrm{dia}\right)$ os valores da precisão foram, excepcionalmente, maiores que a acurácia.

Quanto a acurácia e a precisão do Receptor C foram apresentadas nas Figuras 59 a 86. Esse receptor foi utilizado nas duas últimas campanhas (terceira e quarta) de observação. A terceira campanha foi realizada em março de 2005; a quarta em abril de 2005. Na terceira, a acurácia de todas as estações oscilou entre valores maiores e menores que $50 \mathrm{~cm}$. Na quarta, a acurácia para a base de $20 \mathrm{~km}\left(1^{\circ}\right.$ e $2^{\circ}$ dias $), 50 \mathrm{~km}\left(1^{\circ} \mathrm{dia}\right), 75 \mathrm{~km}\left(1^{\circ} \mathrm{dia}\right), 150 \mathrm{~km}\left(1^{\circ}\right.$ e $2^{\circ}$ dias $)$ e $200 \mathrm{~km}$ ( $2^{\circ}$ dia) apresentaram valores melhores que $50 \mathrm{~cm}$. As bases de $300 \mathrm{~km}\left(2^{\circ} \mathrm{dia}\right) \mathrm{e}$ $200 \mathrm{~km}\left(1^{\circ}\right.$ dia) apresentaram acurácia piores que $50 \mathrm{~cm}$. A acurácia das coordenadas das demais estações oscilaram entre valores melhores e piores a 50 cm. Nas duas campanhas de observações, a precisão foi sempre melhor que 15 $\mathrm{cm}$. De um modo geral, os posicionamentos da quarta campanha apresentaram resultados mais otimistas, comparados aos da terceira.

Para a acurácia e precisão para o Receptor D, as quais foram apresentadas nas Figuras 87 a 114, utilizou-se o Receptor D na mesma época que o Receptor C, ou seja, nas duas últimas campanhas de observação. O Receptor D apresentou, na terceira campanha (março de 2005), para as bases de $20 \mathrm{~km}\left(2^{\circ}\right.$ dia) e $200 \mathrm{~km}$ 
( $2^{\circ}$ dia), acurácia melhor que $50 \mathrm{~cm}$. Para as bases de $50 \mathrm{~km}\left(2^{\circ} \mathrm{dia}\right), 75 \mathrm{~km}\left(1^{\circ}\right.$ dia), $100 \mathrm{~km}\left(1^{\circ}\right.$ e $2^{\circ}$ dias $), 150 \mathrm{~km}\left(1^{\circ}\right.$ e $2^{\circ}$ dias $), 200 \mathrm{~km}\left(1^{\circ} \mathrm{dia}\right)$ e $300 \mathrm{~km}\left(1^{\circ} \mathrm{e}\right.$ $2^{\circ}$ dias) apresentou acurácia melhor que $50 \mathrm{~cm}$. Nas demais bases, a acurácia oscilou entre valores melhores e piores que $50 \mathrm{~cm}$. Na quarta campanha, as bases de $20 \mathrm{~km}\left(1^{\circ}\right.$ e $2^{\circ}$ dias $), 50 \mathrm{~km}\left(1^{\circ}\right.$ e $2^{\circ}$ dias $), 75 \mathrm{~km}\left(1^{\circ}\right.$ e $2^{\circ}$ dias $), 100 \mathrm{~km}\left(1^{\circ}\right.$ e $2^{\circ}$ dias), $150 \mathrm{~km}\left(1^{\circ}\right.$ e $2^{\circ}$ dias $)$ e $200 \mathrm{~km}\left(2^{\circ}\right.$ dia $)$ apresentaram acurácia melhores que $50 \mathrm{~cm}$. As demais bases apresentaram acurácia pior que $50 \mathrm{~cm}$. A precisão para todas as estações analisadas foi menor que $10 \mathrm{~cm}$.

Diante dos resultados, pode-se perceber que a precisão das observações foi, na maioria, menor do que a acurácia. Isso indica que os erros fornecidos pelos programas de processamento são superestimados, ou seja, menores que os reais. Contudo, o Receptor B, apesar de apresentar coordenadas com bastante discrepância, proporcionou precisão quase sempre maior que a dos outros receptores e, para a base de $100 \mathrm{~km}$, a precisão foi excepcionalmente maior que a acurácia. Isso indica que o programa de processamento de dados utilizado apresentou erros mais realistas, comparados aos demais.

Na Figura 43 foi possível notar que o índice Dst para a primeira campanha (Receptor A) apresentou valores inferiores a $-60 \mathrm{nT}$, isso indica alta intensidade de tempestade eletromagnética, ou seja, grande perturbação ionosférica para esse período. Na segunda campanha (Receptor B), o nível de tempestade magnética não apresentou comportamento agressivo, variando entre baixa e média intensidade, entre -12 e -27 nT, conforme Figura 58. Na terceira Campanha (Receptores C e D), o índice Dst não ultrapassou -25 nT, que caracteriza uma 
transição de tempestade magnética, com intensidade variando entre média e baixa. Na quarta campanha (Receptores $C$ e D), o índice Dst variou entre 0 e -15 $\mathrm{nT}$, indicando uma baixa tempestade magnética, que caracteriza a melhor de todas as campanhas. Essa, possivelmente, é uma das razões que explica os bons resultados apresentados pelos receptores C e D nessa etapa.

Observa-se que, de modo geral, a acurácia das coordenadas apresentou relação direta com o índice Dst. $\mathrm{Na}$ primeira campanha, onde o índice Dst proporcionou valores que indicavam comportamento agressivo da ionosfera, a maioria das observações apresentou valores de acurácia piores que $50 \mathrm{~cm}$ para suas coordenadas. Na segunda campanha, a acurácia das observações oscilou em valores piores e melhores que $50 \mathrm{~cm}$. Na terceira campanha, a maioria das observações apresentou acurácia piores que $50 \mathrm{~cm}$. Já, na quarta campanha, na maioria das vezes, a acurácia apresentou valores bastante otimistas, com acurácia melhor que $50 \mathrm{~cm}$ na maioria dos casos.

Dessa forma, destaca-se a importância do planejamento de missões ${ }^{30}$, com o objetivo de realizar o posicionamento GPS nos melhores horários quando a atividade ionosférica não for tão intensa.

Como as sessões foram coletadas ao longo do dia e das estações do ano, esperava-se comportamentos diferentes das fontes de erros entre as sessões. Isso pode ser uma explicação do caráter aleatório da acurácia das observações, as quais não apresentaram comportamento específico em relação ao comprimento

\footnotetext{
${ }^{30}$ Análise da disponibilidade e posicionamento de satélites, nível de DOP, comportamento da ionosfera para determinada região.
} 
da base e ao tipo de receptor. Além disso, as campanhas de observações foram realizadas em localização, época e horários específicos; portanto, os resultados obtidos devem ser utilizados com ressalvas, ou seja, não devem ser utilizados de maneira generalizada para outras situações. 


\section{CONCLUSÕES E RECOMENDAÇÕES}

De acordo com os resultados e as análises obtidas nesta pesquisa, em função do emprego de diferentes receptores GPS de simples freqüência, fazendo uso da técnica de suavização do código pela portadora, pode-se concluir que:

A degradação observada nas coordenadas, nos diferentes comprimentos de linha base, apresentou comportamento aleatório, indicando que o comprimento da base não foi o único fator determinante da acurácia;

Na maioria dos casos, a acurácia das coordenadas se manteve maior que a precisão, com raríssimas exceções apresentadas pelo Receptor B (para base de 100 e 150 km). Portanto, pode-se afirmar que a acurácia não mostrou correlação com a precisão, não podendo ser utilizada como parâmetro de suposição ou estimativa uma em relação à outra. Além disso, pode-se afirmar que a precisão não pode ser usada como único parâmetro de avaliação da qualidade das coordenadas;

Dando sustentação à teoria apresentada na revisão bibliográfica, confirmouse que a agressividade ionosférica atingiu diretamente a qualidade das observações GPS. Percebeu-se tal fato na terceira campanha, cuja qualidade das 
observações foi baixa e o índice Dst apresentou maiores níveis de perturbações, e na quarta campanha, com excelentes níveis Dst e coordenadas mais acuradas. Outrossim, pode-se afirmar que um planejamento de missão, antes de realizar-se o levantamento GPS, seria uma saída para reduzir a influência da ionosfera e, consequentemente, obter-se coordenadas mais confiáveis;

A agressividade da ionosfera (mostrada pelo comportamento do índice Dst) na época das medições mostrou-se ser um indicador de degradação da acurácia das coordenadas; contudo, geralmente não apresentava influência nos valores de precisão;

Em várias situações, a acurácia não piorou com o aumento da linha base. Os dados do Receptor A são um bom exemplo disso, cujas coordenadas do vetor de $100 \mathrm{~km}$ apresentaram acurácia melhor que os vetores de 20, 50 e $75 \mathrm{~km}$ para o mesmo dia de observação. Em função disso, não se pode prever o comportamento das coordenadas em função do comprimento da base para este tipo de levantamento. Entretanto, para bases longas (superiores a $200 \mathrm{~km}$ ), as discrepâncias se mostraram acima de $50 \mathrm{~cm}$, exceto os resultados fornecidos pelo Receptor A;

Apesar de alguns fabricantes e/ou vendedores argumentarem que o sistema de seus receptores GPS, ao fazer uso da técnica de suavização, fornece coordenadas com acurácia melhor que $50 \mathrm{~cm}$, foi possível constatar tecnicamente que essa afirmação não condiz com a realidade, mesmo que tal afirmação esteja baseada em estudo específico de determinada região, com latitudes e comportamento característicos; 
Diante dos fatos, observou-se que a acurácia apresentou resultados, na maioria dos casos, submétrico, o que pode sugerir esse modo e técnica de pósprocessamento para o cadastro de área de preservação, agricultura (cadastro de talhões), cadastro rural, estimativa de áreas, Sistema de Informação Geográfico (que exijam as precisões apresentadas) e demais serviços que se enquadrem nesse padrão de acurácia;

Por fim, chega-se à conclusão de que a técnica de suavização do código por meio da fase da portadora melhora, significativamente, os resultados do posicionamento, quando comparado ao utilizado com o código C/A isolado, isto é, quando não se consegue trabalhar com a fase no modo convencional - a qual pode alcançar precisão em nível milimétrico e acurácia centimétrica. Todavia, os valores de acurácia, apresentados por meio dessa técnica, não garantem discrepâncias inferiores a $50 \mathrm{~cm}$ em 100\% das medidas. Outrossim, por apresentar grandes inconsistências na qualidade do posicionamento, recomendase que o usuário não deva proceder a um processo de medição para fins de georreferenciamento de imóveis rurais, Lei 10.267/01, sem antes estabelecer um processo confiável de verificação dos resultados. Complementando, afirma-se que a avaliação dos resultados com base na precisão das medidas, visto que são sempre otimistas e não são indicadoras da acurácia, pode levar a conclusões precipitadas.

Portanto, essa pesquisa contribuiu para mostrar que o georreferenciamento de imóveis rurais, fazendo uso do código C/A suavizado pela fase da portadora, em receptores de simples freqüência, não serve para fornecer, em todo e qualquer 
caso, coordenadas com acurácia melhor que $50 \mathrm{~cm}$, conforme especificado na Norma Técnica para georreferenciamento de imóveis rurais.

\section{Como sugestões para futuros estudos têm-se:}

Fazer a análise similar à desenvolvida nessa pesquisa em diferentes regiões do território nacional, que é todo pela vigência da Lei 10.267, como também, em diferentes períodos do ano, com diferentes comportamentos da ionosfera;

Utilizar a metodologia dessa pesquisa fazendo uso do código C/A e P com receptores de dupla freqüência, suavizado com a fase da portadora;

Verificar a precisão e acurácia das soluções de posição usando código suavizado pela fase portadora com uma malha de pontos num raio máximo de 20 km da estação de referência. 


\section{REFERÊNCIAS}

AMORIM, G, P., (2004). Confiabilidade de Rede GPS de Referência Cadastral Municipal, Estudo de Caso: Rede do Município de Vitória (ES). 149p. Escola de Engenharia de São Carlos - Universidade de São Paulo, São Carlos, São Paulo.

BRASIL (2001) Leis etc. INSTITUTO NACIONAL DE COLONIZAÇÃO E REFORMA AGRÁRIA. Lei $n^{\circ} 10267$, de 28 de agosto de 2001. Dispõe sobre a Criação do Sistema Público de Registro de Terras. Disponível em: <htt://www.incra.gov.br/_htm/serveinf/_htm/legislação/lei/sprt.htm>. Acesso em 26 de abril de 2002 .

CAMARGO, P. O., (1999). Modelo regional da ionosfera para uso em posicionamento com receptores GPS de uma freqüência. 191p. Tese de Doutorado - Departamento de Geociências, Universidade Federal do Paraná, Curitiba.

DAL POZ, W.R.; MATSUOKA, M.T., (2004). Impacto da ionosfera na propagação dos sinais GPS e estudo do comportamento do TEC na região brasileira utilizando a RBMC - Programa de Pós-Graduação em Ciências Cartográficas, Faculdade de Ciências e Tecnologia, Universidade Estadual Paulista, Presidente Prudente.

DAL POZ, W.R., (2005). Posicionamento relativo na região equatorial em diversas condições ionosféricas. 161p. Dissertação de Mestrado - Faculdade de Ciências e Tecnologia, Universidade Estadual Paulista, Presidente Prudente. 
EULER H, GOAD C., (1991) On optimal filtering of GPS dual frequency observations without using orbit information, Bulletin Géodésique 65: 130-143.

FONSECA JUNIOR, E.S., (2002). O sistema GPS como ferramenta para avaliação da refração ionosférica no Brasil. 176p. Tese de Doutorado - Departamento de Engenharia de Transportes, Escola Politécnica da Universidade de São Paulo, São Paulo.

HATCH, R. R., (1982). The synergism of GPS code and carrier measurements, Proceedings of the Third International Geodetic Symposium on Satellite Doppler Positioning, NM, February 8-12, 1982, Vol. 2, pp. 1213-1232.

HOFMANN-WELLENHOF, B., LICHTENEGGER, H. \& COLLINS, J., (2001). GPS: Theory and Practice, 5th ed. Wien New York. Springer Verlag.

INSTITUTO BRASILEIRO DE GEOGRAFIA E ESTATISTICA (1983). Resolução $\mathrm{PR}$ n. 22. Especificações e normas para levantamentos geodésicos. Boletim de serviço. n. 1602.

INSTITUTO NACIONAL DE COLONIZAÇÃO E REFORMA AGRÁRIA (2003). Norma Técnica para Georreferenciamento de Imóveis Rurais. 1. ed. Disponível em: ftp://200252805/Cartografia/download/Norma\%20T\%E9cnica.pdf. Acesso em 03 fev. 2004.

JIN, X.X., (1996). Theory of carrier adjusted DGPS positioning approach and some experimental results. Delft. PhD Thesis - Delft University of Technology.

LACHAPELLE G., CANNON M.E., LAN H., TANG C., WEE S., RYAN S., (1995). DGPS Positioning accuracy performance analysis with RTCM message types 1/9 and 18-21 using various receiver technologies. In: Proceedings of ION GPS - 95, The Institute of Navegation, Alexandria, VA, pp 899-906. 
LANGLEY, R. B., (1998). GPS Receivers and the Observables. In: P.J.G. Teunissen and A. Kleusberg (Eds.): GPS for Geodesy - 2nd Edition. SpringVerlag, Berlin.

LAROCCA, A. P. C., (2004). O uso do GPS como instrumento de controle de deslocamentos dinâmicos de obras civis. 203p. Tese (Doutorado), Escola de Engenharia de São Carlos da Universidade de São Paulo, São Carlos - SP.

LEANDRO, R. F., (2003). A influência da ionosfera no posicionamento GPS por ponto simples. 80p. Dissertação de Mestrado - Escola de Engenharia de São Carlos da Universidade de São Paulo, São Carlos - SP.

LEANDRO, R.F., (2004). A New Technique to TEC Regional Modeling using a Neural Network. proceedings of ION GNSS 2004, Long Beach, California, September, 2004.

LEICK, A., (2004). GPS Satellite Surveying. 3a Edição. New York. John Wiley \& Sons, Inc. 560p.

MARQUES, A. P., (2006). Proposta de um programa de gestão da qualidade para uma empresa genérica de posicionamentos com GPS. 208p. Tese de Doutorado Escola de Engenharia de São Carlos da Universidade de São Paulo, São Carlos SP.

MENZORI, M., (2005). Classificação da exatidão de coordenadas obtidas com a fase da portadora L1 do GPS. Tese de Doutorado - Escola de Engenharia de São Carlos da Universidade de São Paulo, São Carlos - SP.

MONICO, J.F.G. (2000) Posicionamento pelo NAVSTAR-GPS: descrição, fundamentos e aplicações. São Paulo. Editora UNESP. 
PARKINSON, B.W., (1997) Origins, Evolution, and Future of Satellite Navigation. Journal of Guidance, Control and Dynamics. Reston, v.20, n.1, p.11-25, jan.- feb.

PARKINSON, B.W., (1995) A History of Satellite Navigation. Navigation: Journal of the Institute of Navigation. Spring, v.42, n.1, p.109-164.

PARKINSON, B.W.; SPILKER JR, J.J., (1996) Global Positioning System: Theory and Aplications. v.I (163). Washington. Charles Stark Draper Laboratory, Inc.

RODRIGUES, D. D., (2002) Rede geodésica de precisão no estado de Minas Gerais: avaliação de diferentes estratégicas de processamento e ajustamento. 204p. Tese de Doutorado - Curso de pós-graduação em Engenharia de Transportes da EPUSP, São Paulo.

SANTOS, M.S.T., (2005). Potencialidades do GPS em levantamentos geofísicos terrestres. 140 p. Dissertação de Mestrado - Curso de pós-graduação em Geofísica do IAG-USP, São Paulo.

SEEBER, G., (2003). Satellite Geodesy: Foundations, Methods and Applications. Walter de Gruyter, Berlin.

SEGANTINE, P. C.L., (1995). Estabelecimento e ajuste de uma rede geodésica no Estado de São Paulo, com o sistema de posicionamento NAVSTAR/GPS. Tese de Doutorado - Curso de pós-graduação em Engenharia de Transportes da EPUSP, São Paulo

SEGANTINE, P. C.L., (2005). GPS: Sistema de Posicionamento Global. 381 p. São Carlos. Editora EDUSP.

SILVA, I., (2004). História dos pesos e medidas. 190p. São Carlos. Editora UFSCar. 
TEUNISSEN, P.J., (1991). The GPS phase-adjusted pseudorange. In: Proceedings of the Second International Workshop on High Precision Navigation, Stuttgart, Freudenstadt, Nov., 1991.

WERKEMA, M.C.C., (1996) Avaliação da qualidade de medidas - Belo Horizonte, MG: Fundação Christiano Ottoni, Escola de Engenharia da UFMG. 
APÊNDICE A - Registros de campo com GPS (L1/L2) 


\section{Reconhecimento e implantação}

Após a definição de cada seção, procedeu-se à implantação dos marco e, em seguida, foram feitos os registros de campo (descrição dos acessos, coordenadas aproximadas, mapa de obstruções, fotografias e anotações importantes). Os materiais e equipamentos utilizados nessa etapa foram conferidos e verificados um dia antes pela equipe. Entre eles:

- mapas, planilhas de registro e documentos de autorização;

- veículo;

- receptor GPS de navegação;

- computador portátil (Notebook) e máquina fotográfica;

- equipamentos de comunicação (celular e rádio comunicador);

- ferramentas gerais para limpeza e implantação dos marcos; e

- marcos de concreto.

Os registros de campo foram feitos em planilhas padronizadas que posteriormente foram digitadas no banco de dados do projeto (Figuras 113 a 126).

ESTAÇÃO DE CONTROLE

RELATÓRIO DE RECONHECIMENTO E IMPLANTACÃO

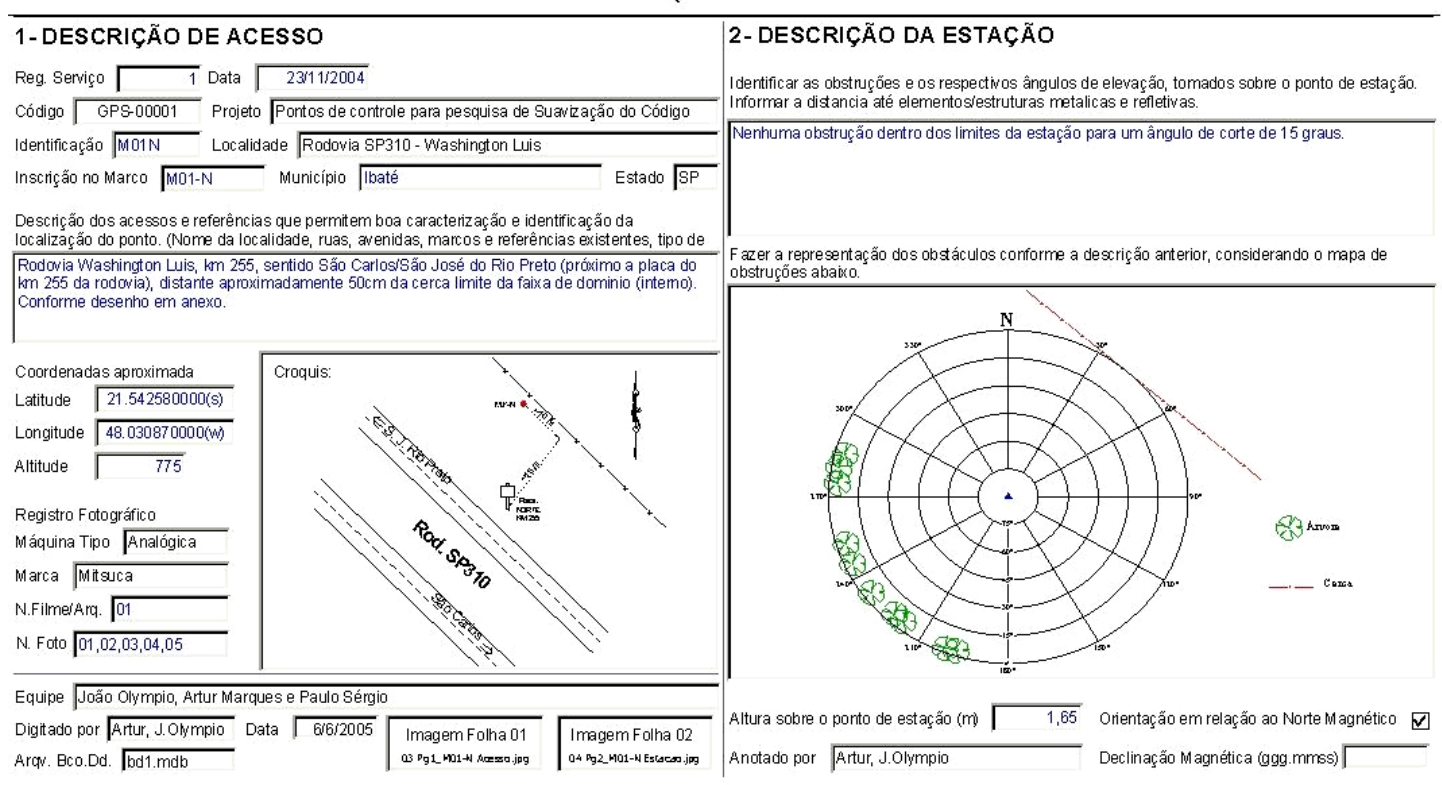

Figura 113 - Ponto M01- N 20km 


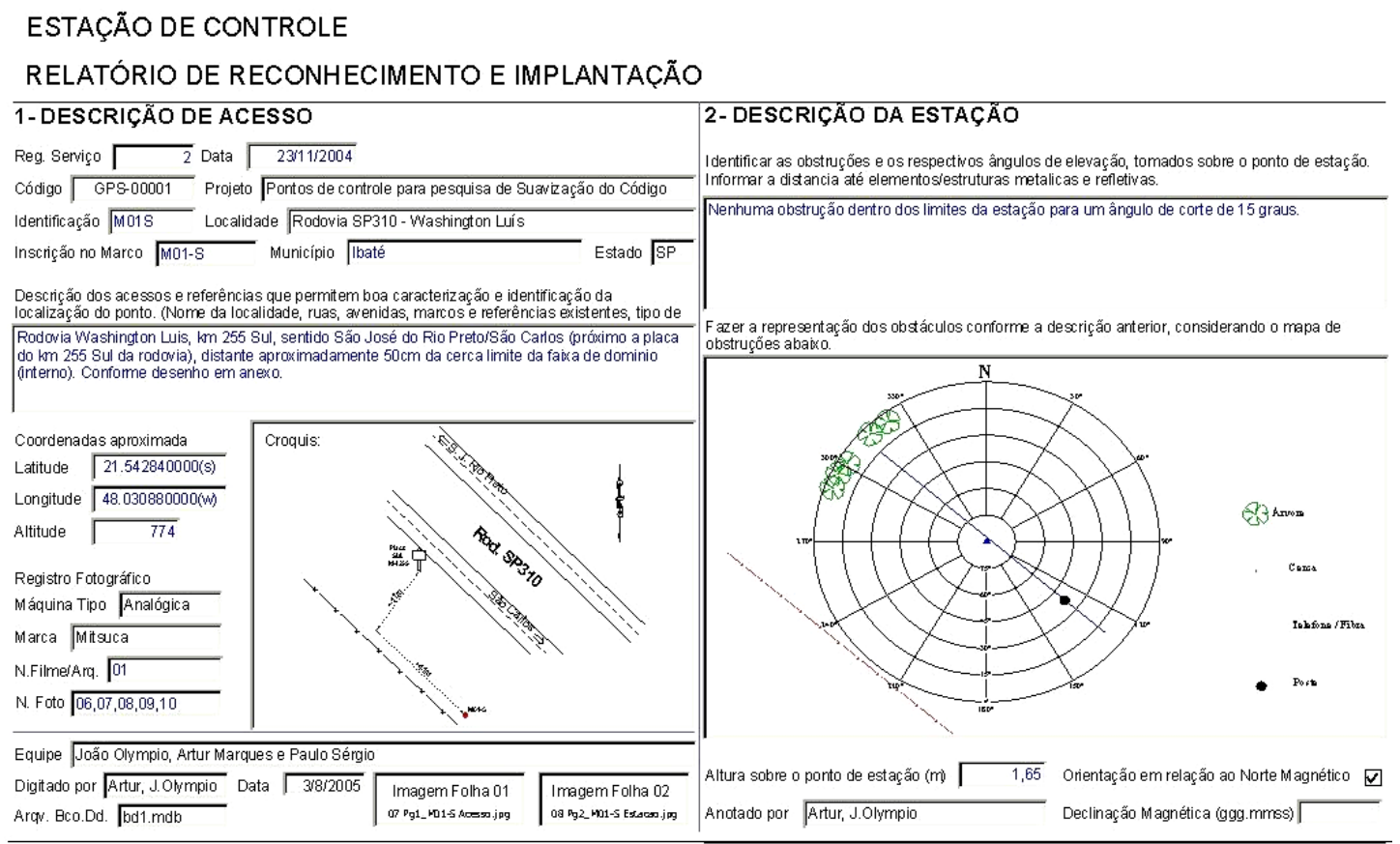

Figura 114 - Ponto M01-S 20km

\section{ESTAÇÃO DE CONTROLE}

RELATÓRIO DE RECONHECIMENTO E IMPLANTACÃO

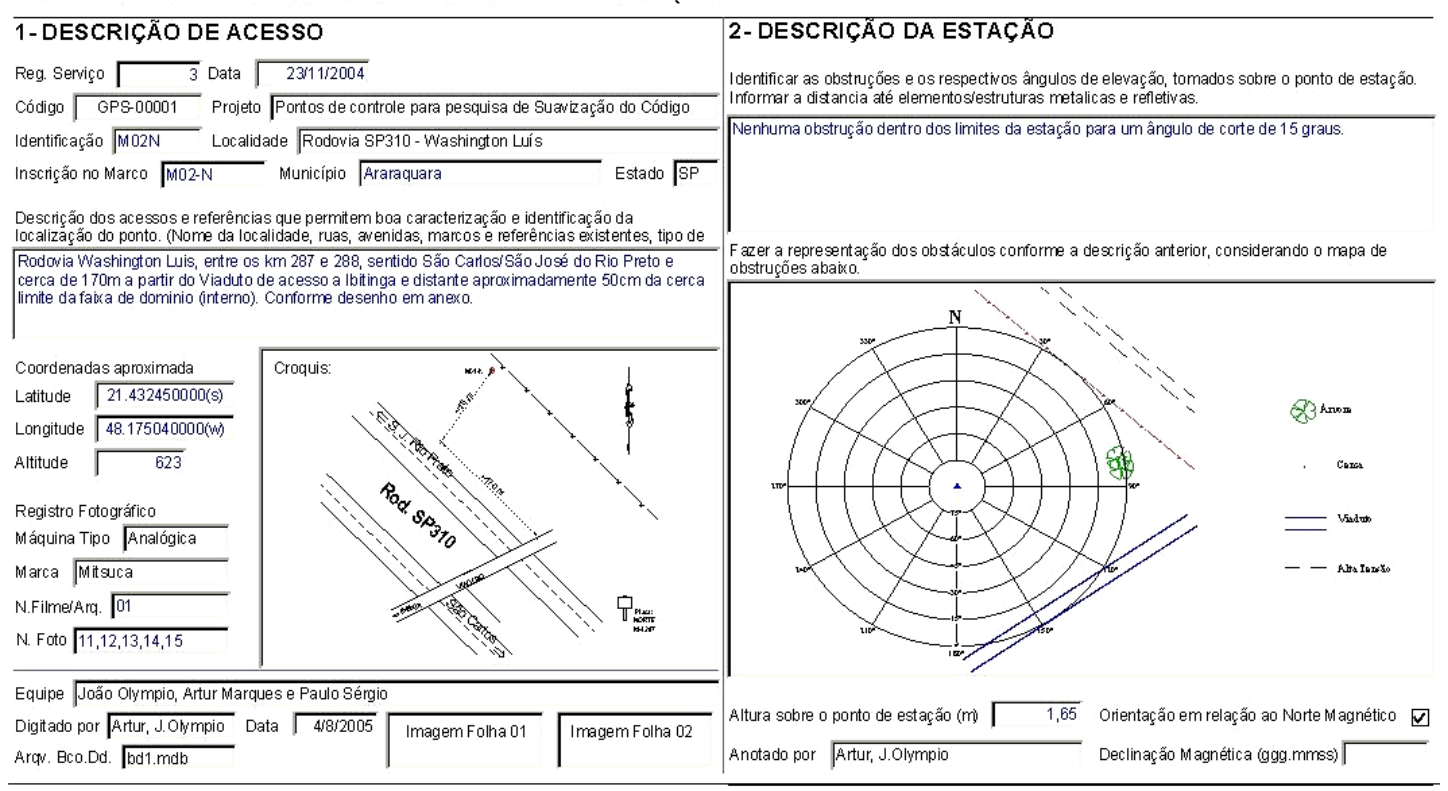

Figura 115 - Ponto M02-N 50km 


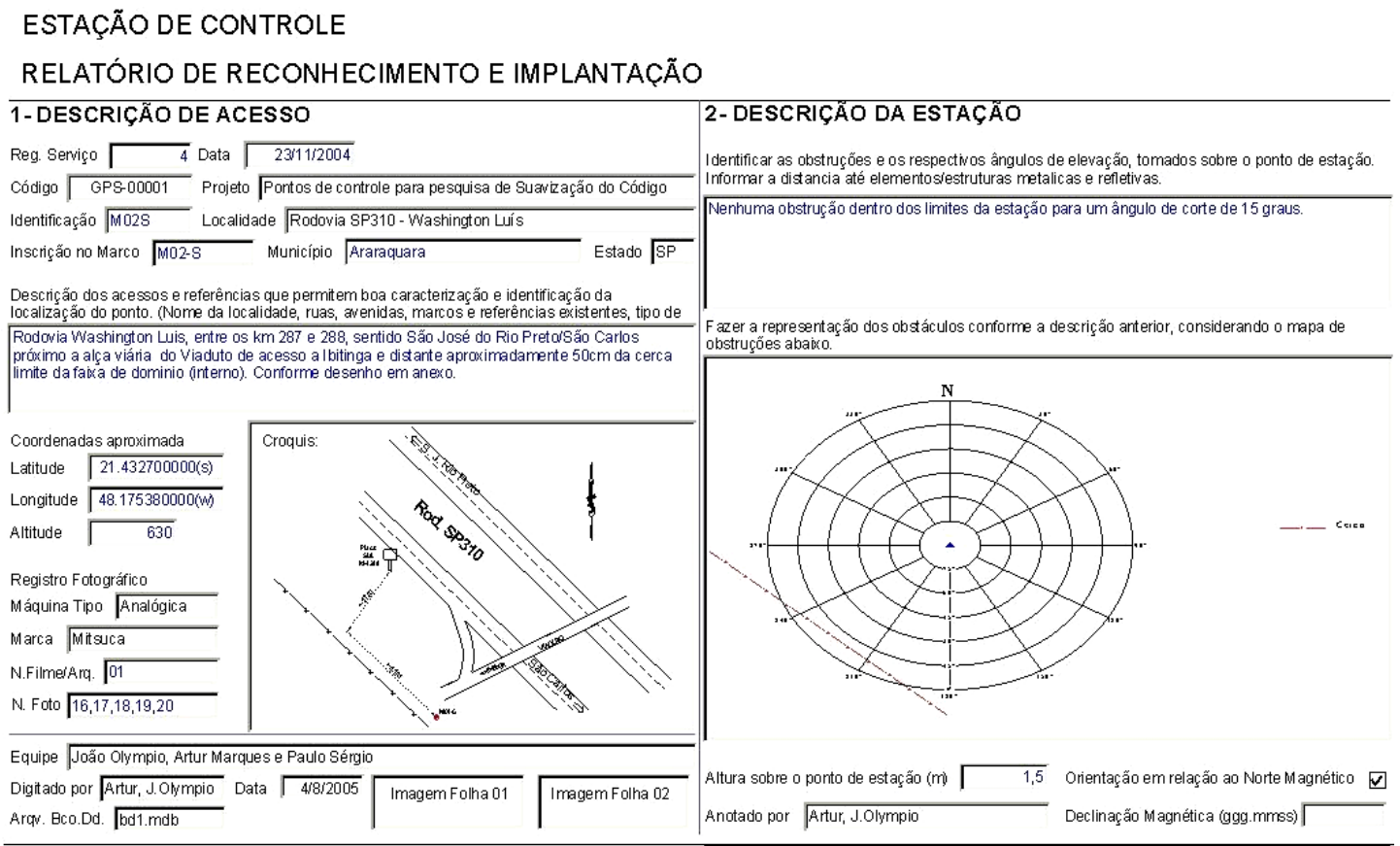

Figura 116 - Ponto M02-S 50km

\section{ESTAÇÃO DE CONTROLE}

RELATÓRIO DE RECONHECIMENTO E IMPLANTACCÃO

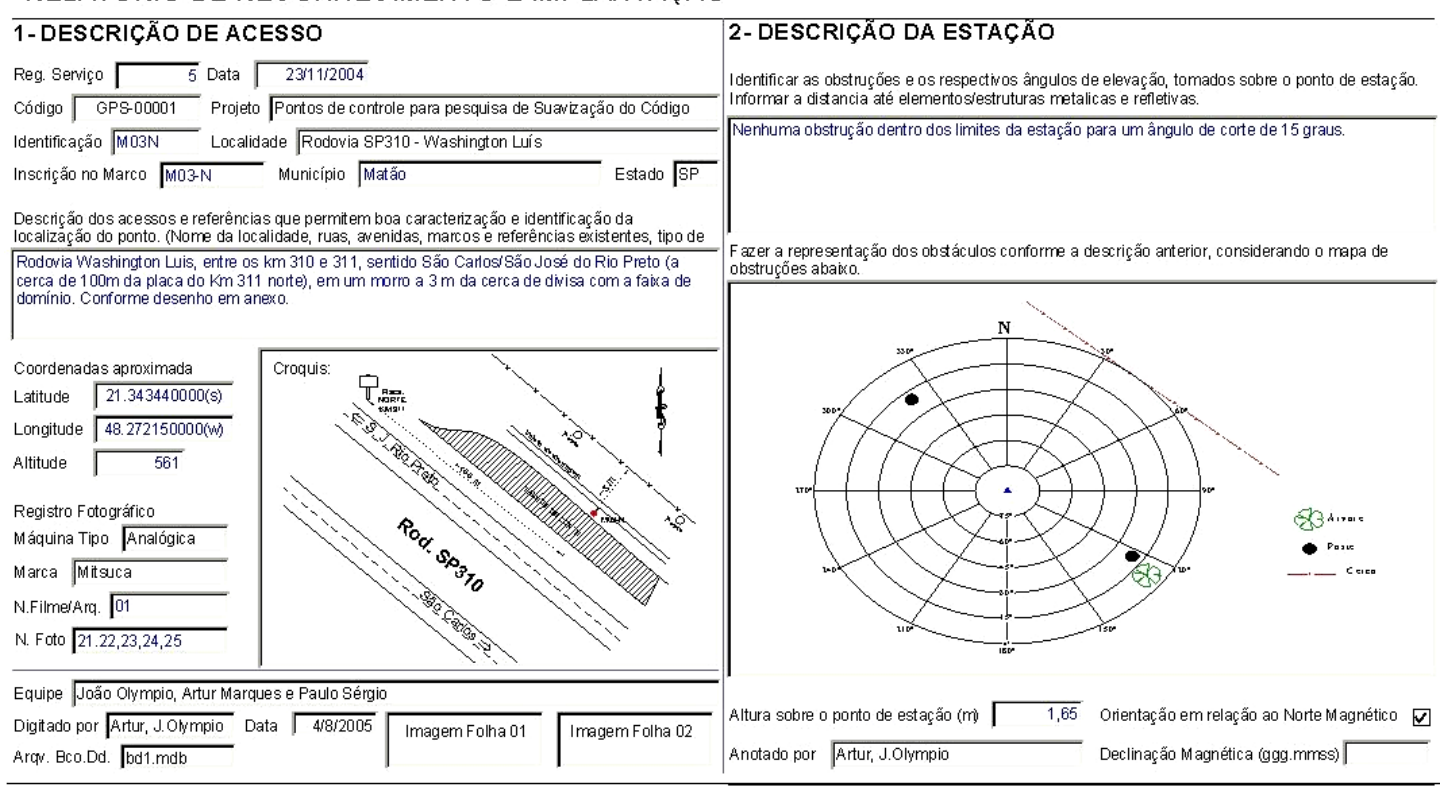

Figura 117 - Ponto M03-N 75km 


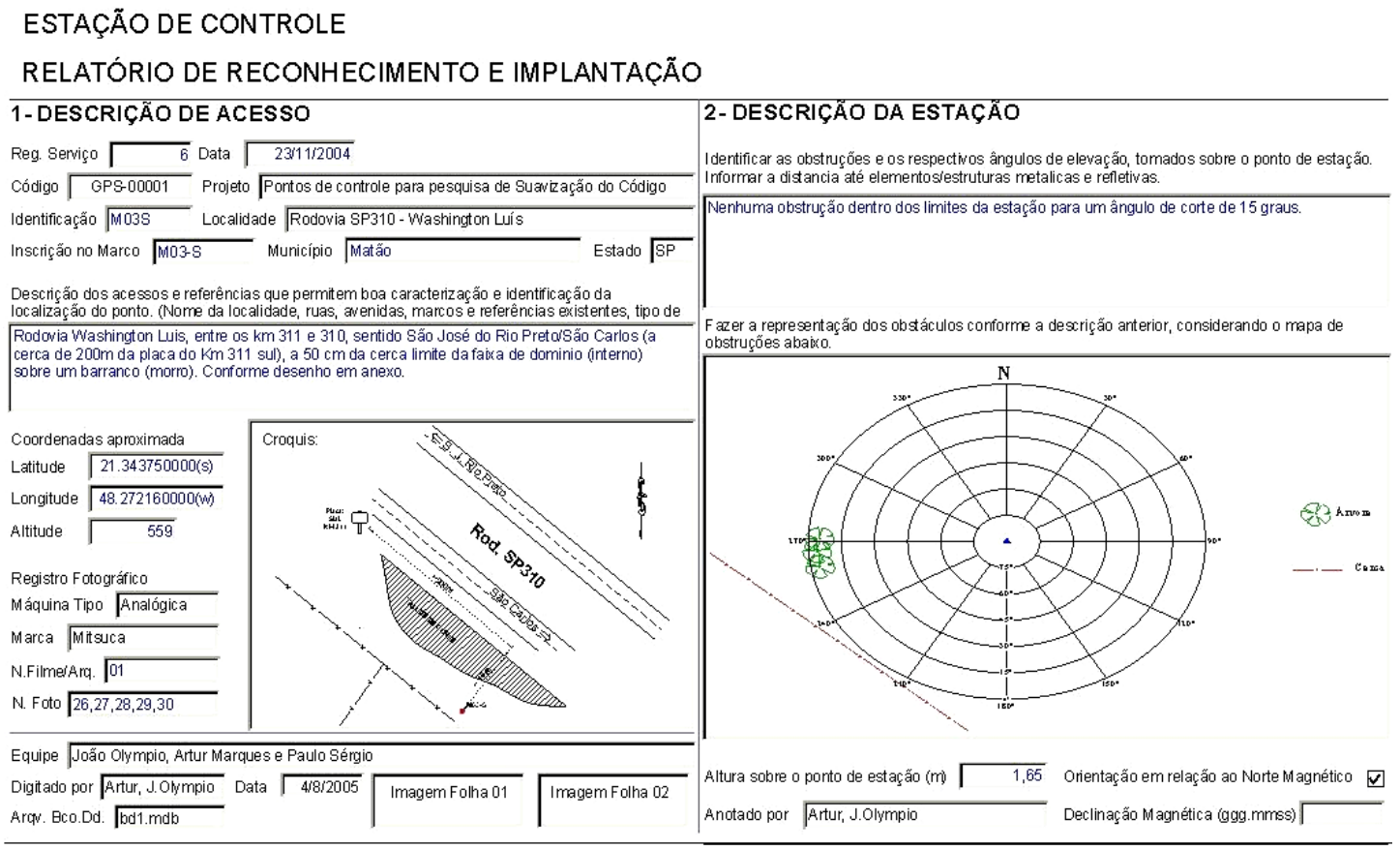

Figura 118 - Ponto M03-S 75km

\section{ESTAÇÃO DE CONTROLE}

RELATÓRIO DE RECONHECIMENTO E IMPLANTAÇÃO

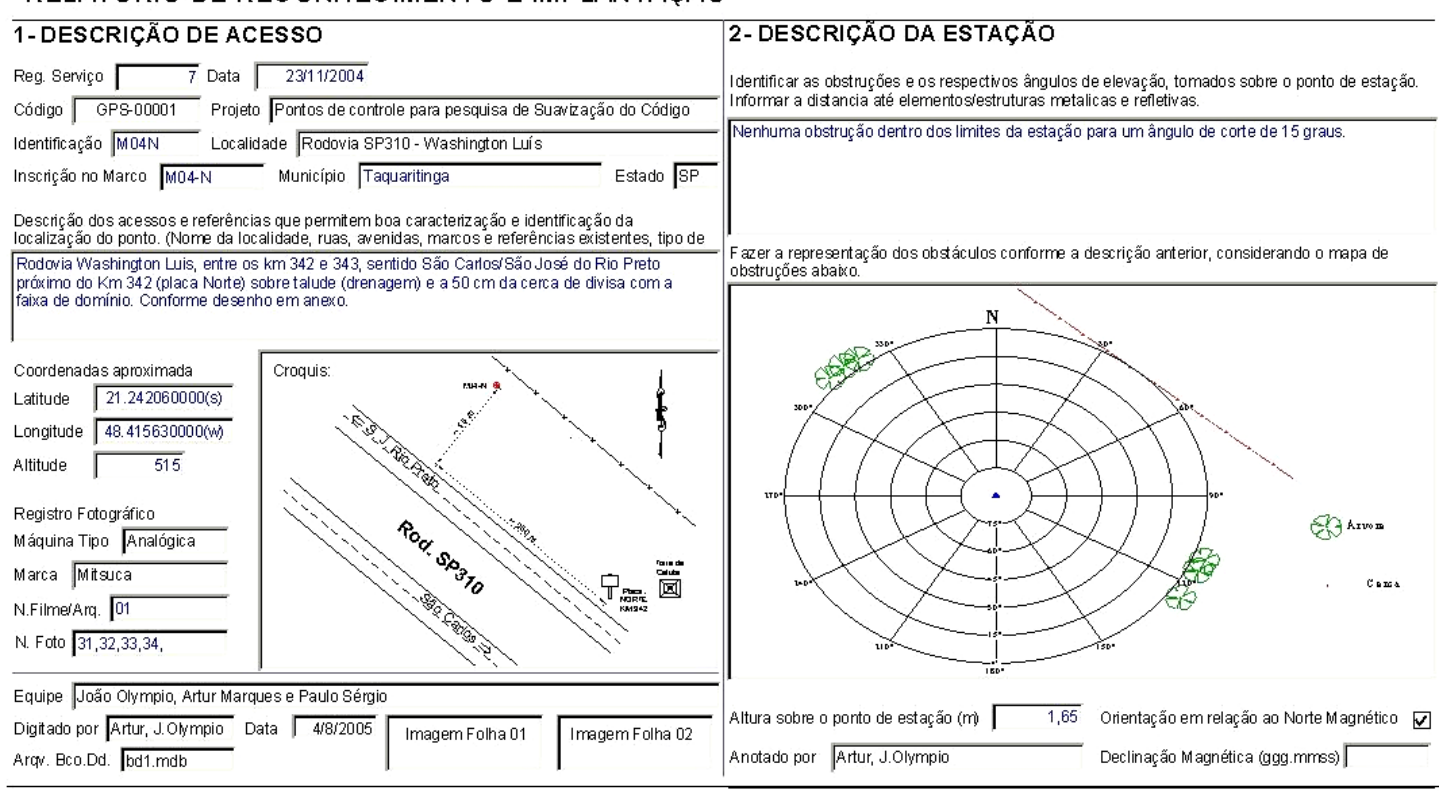

Figura 119 - Ponto M04-N 100km 


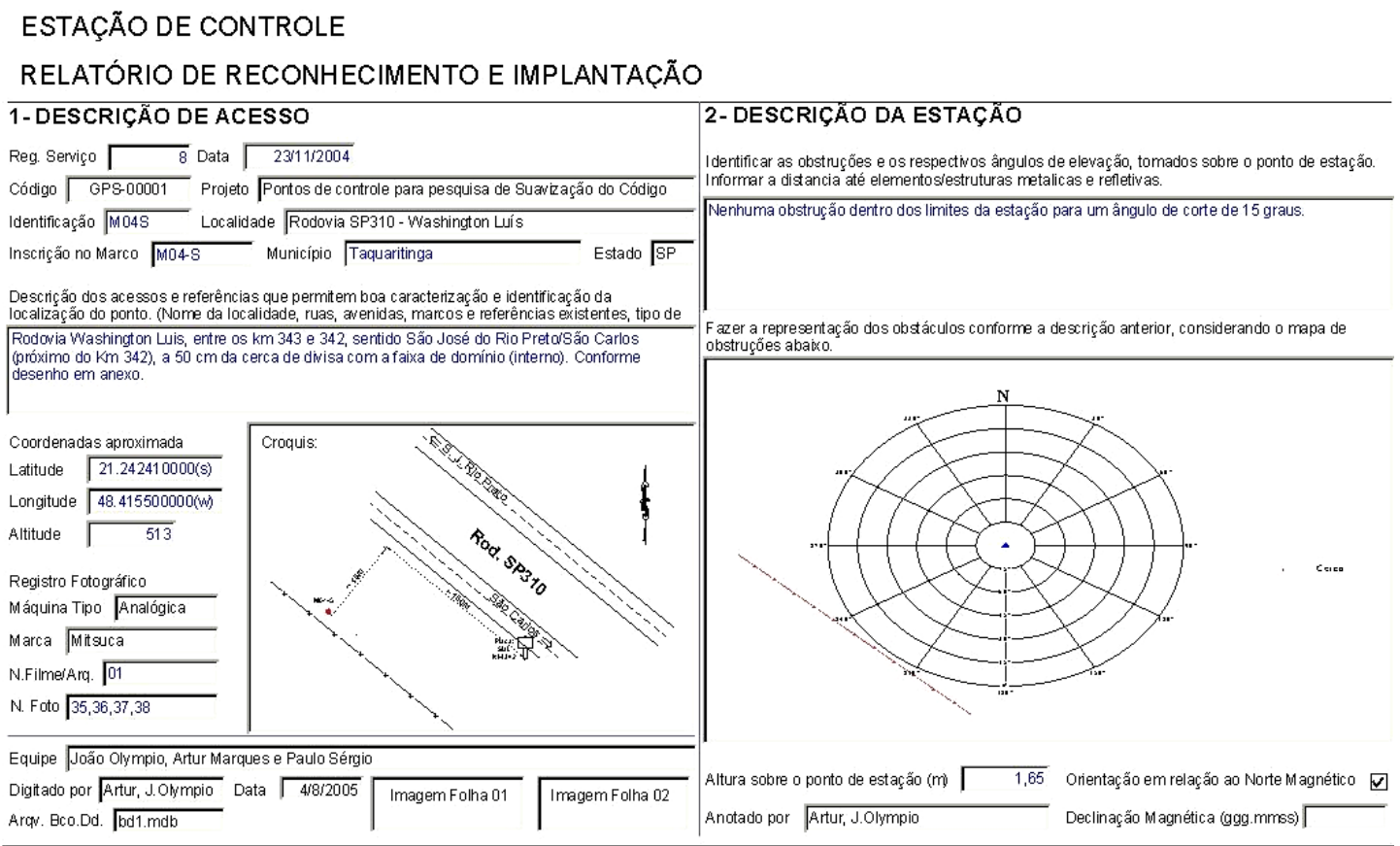

Figura 120 - Ponto M04-S 100km

\section{ESTAÇÃO DE CONTROLE}

RELATÓRIO DE RECONHECIMENTO E IMPLANTACÃO

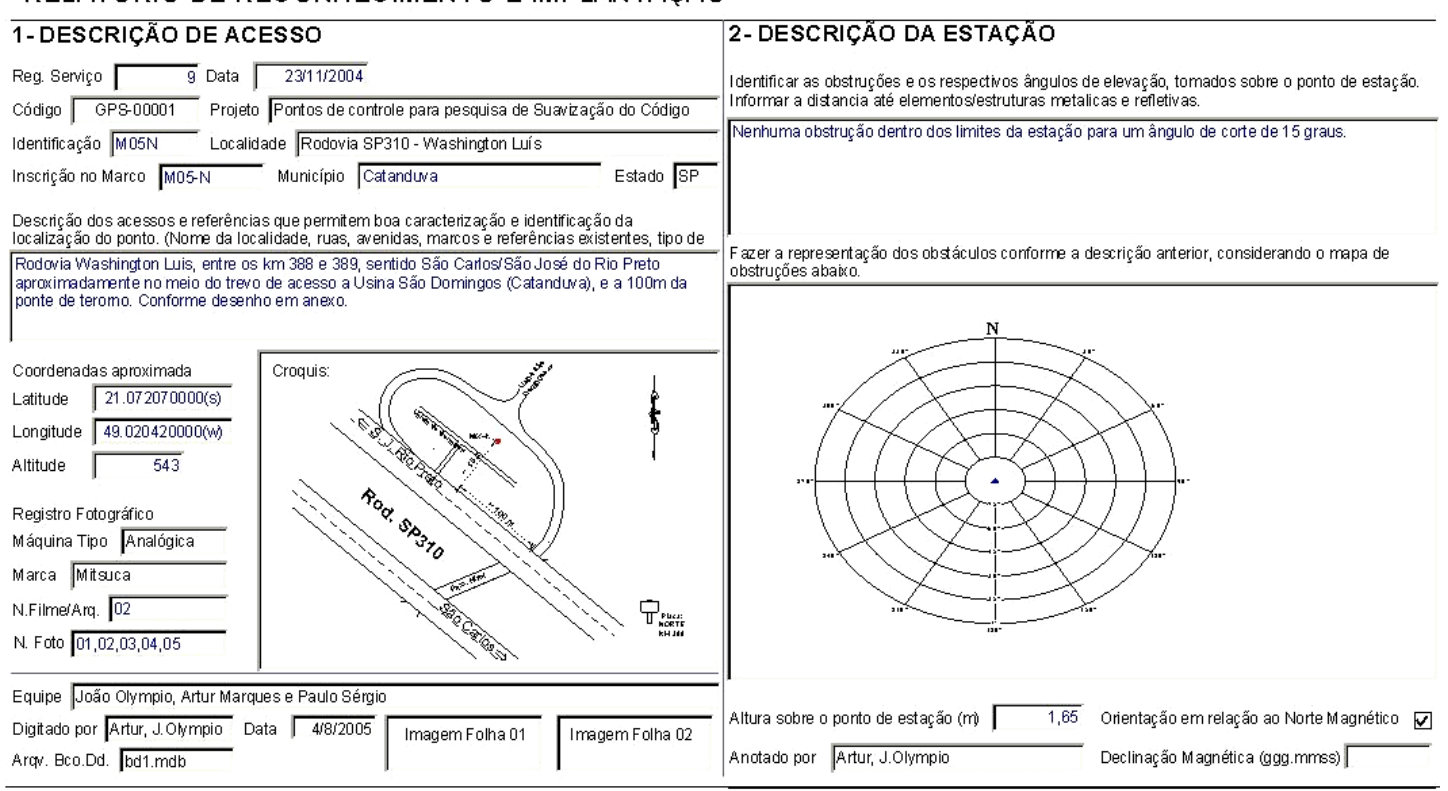

Figura 121 - Ponto M05-N 150km 


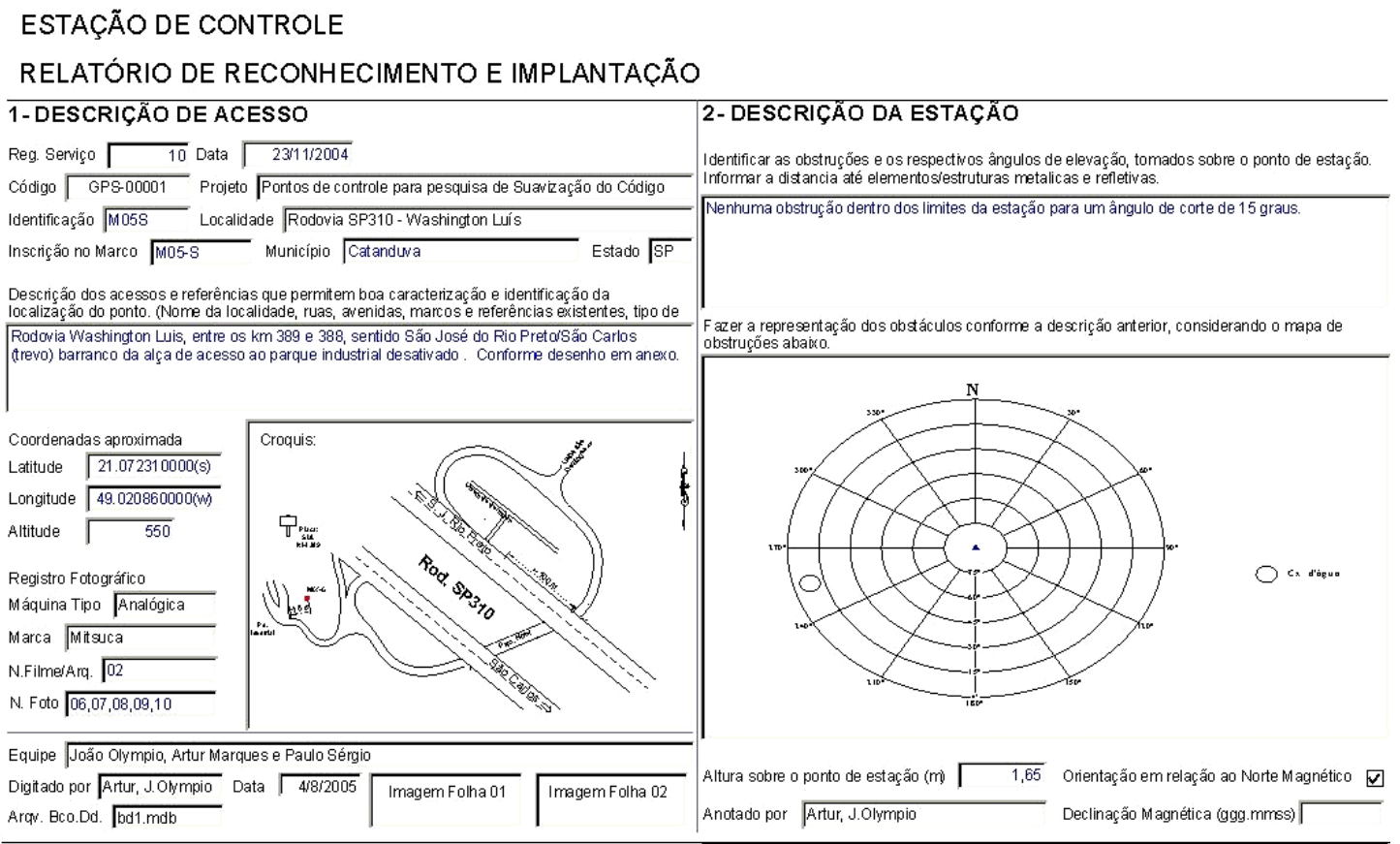

Figura 122 - Ponto M05-S 150km

\section{ESTAÇÃO DE CONTROLE}

RELATÓRIO DE RECONHECIMENTO E IMPLANTACÃO

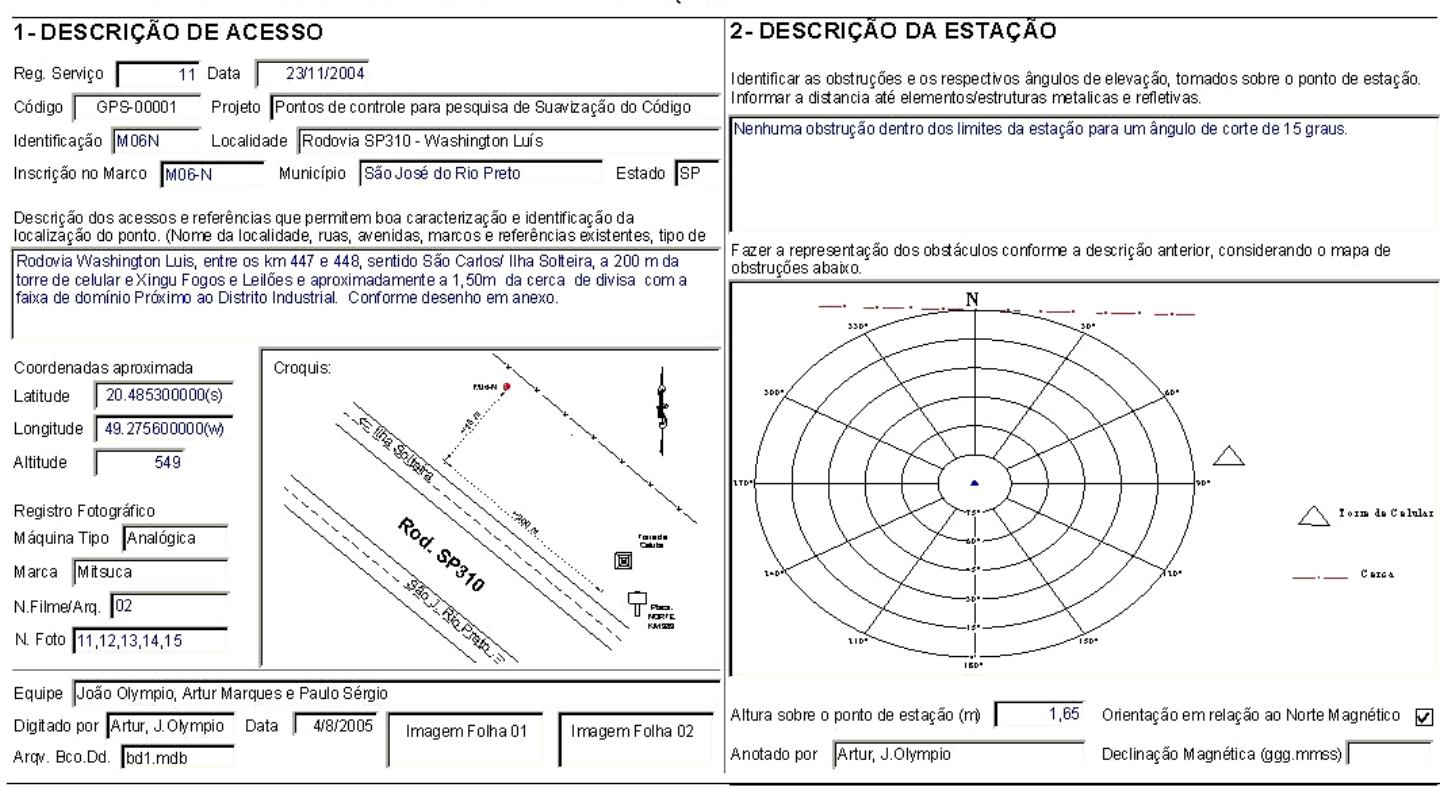

Figura 123 - Ponto M06-N 200km 


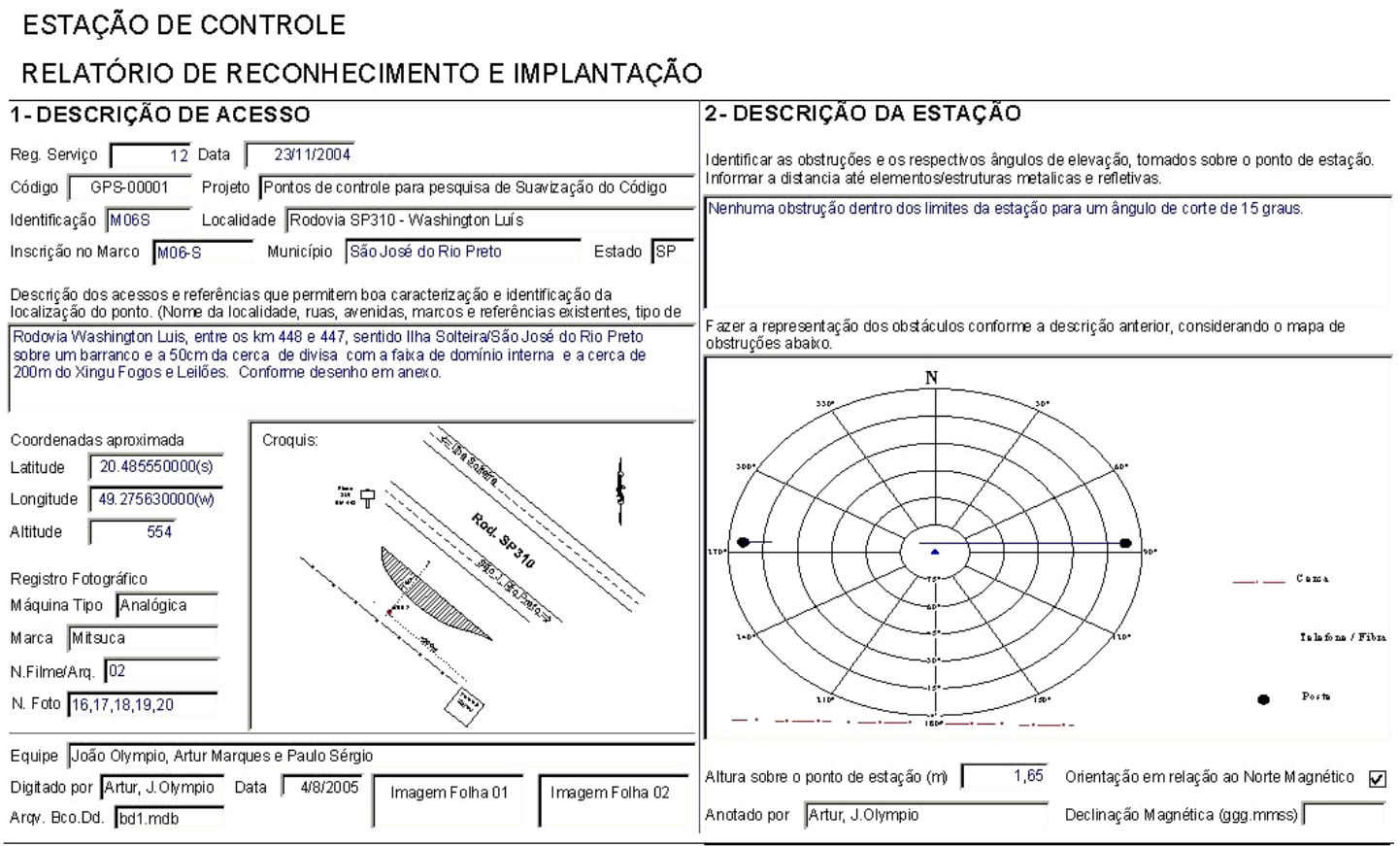

Figura 124 - Ponto M06-S 200km

\section{ESTAÇÃO DE CONTROLE}

\section{RELATÓRIO DE RECONHECIMENTO E IMPLANTAÇÃO}

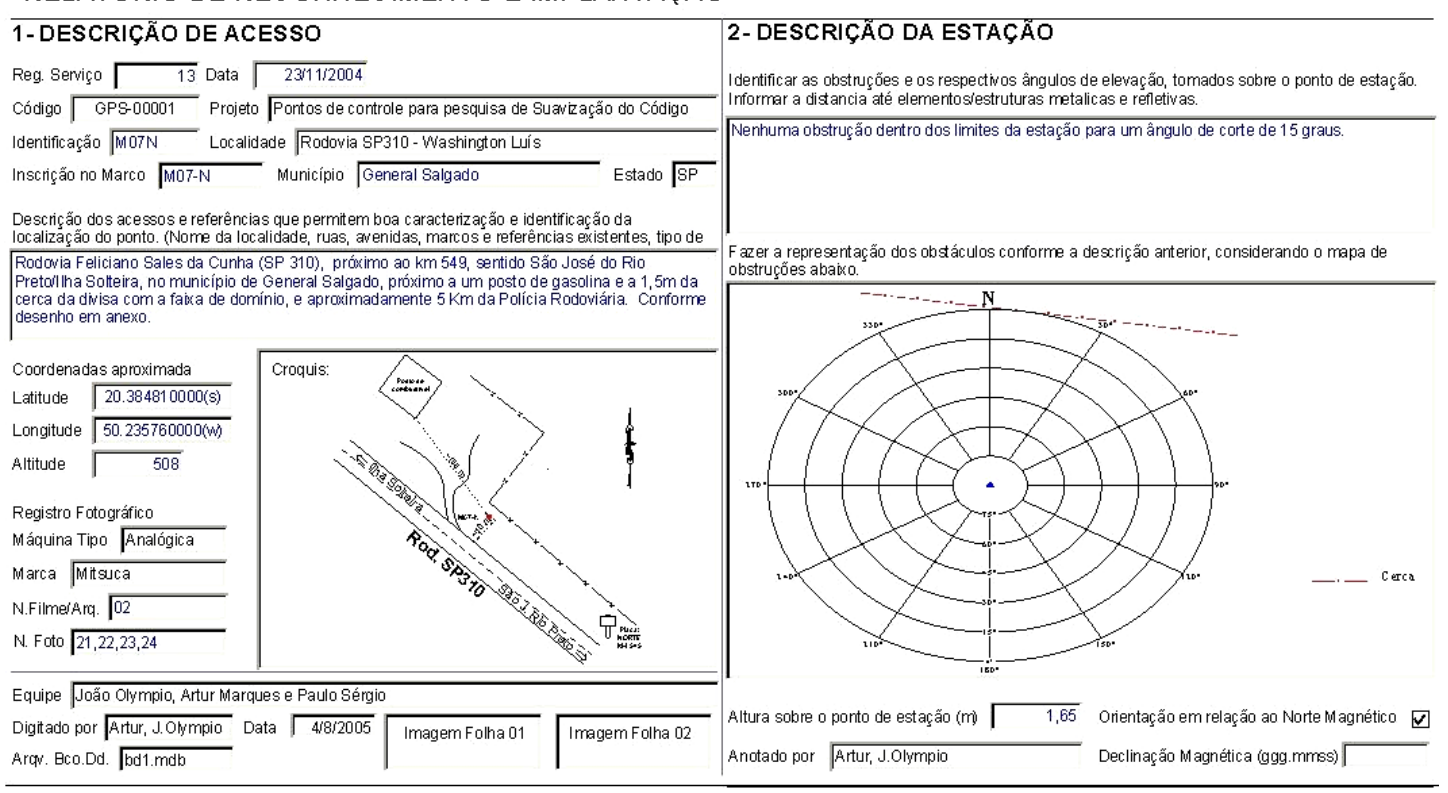

Figura 125 - Ponto M07-N 300km 
ESTAÇÃO DE CONTROLE

RELATÓRIO DE RECONHECIMENTO E IMPLANTACQÃO

1-DESCRIÇÃO DE ACESSO

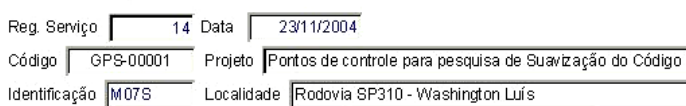

2- DESCRIÇÃO DA ESTAÇÃO

Identificar as obstruçốes e os respectivos ângulos de elevaçẫo, tomados sobre o ponto de estaçẫo. Nenhuma obstruu̧ẫo dentro dos limites da estaçẵo para um ângulo de corte de 15 graus.

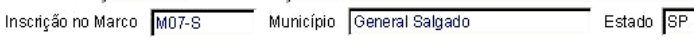

Descriçẫo dos acessos e referências que permitem boa caracterizaçẵo e identitic ą̧ẩo da

Fazer a representaçấo dos obstáculos conforme a descriçăa anterior, considerando o mapa de

Rodowla Felciano Sales da Cunha (SP 310 ), proximo ao $\mathrm{km} 549$, sentido lina Solteira São José do divisa com a faixa de domínio, e aproximadamente $5 \mathrm{~km}$ da Polícia Rodociária, e cerca de $10 \mathrm{~m} \mathrm{do}$ acostamento da rodovia. Confome desenho em anexo.

Coordenadas aproximada

Latitude $\longdiv { 2 0 . 3 8 4 9 7 0 0 0 0 ( \text { (s) } }$

Longitude $\longdiv { 5 0 . 2 3 5 8 4 0 0 0 0 ( \mathrm { m } ) }$

Altitude $\longdiv { 5 0 9 }$

Registro Fotográfico

Máquina Tipo Analógica

Marca Mitsuca

N.FilmeiArq. 02

N. Foto $25,26,27,28,29$

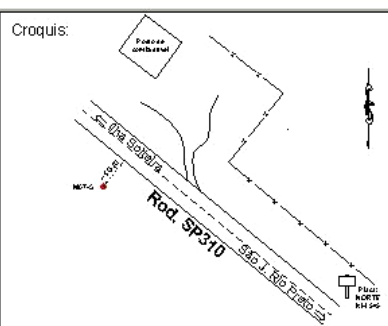

Equipe Joẫo Olympio, Artur Marques e Paulo Sérgio

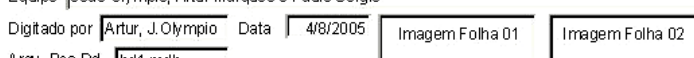

Arqv. Bco.Dd. bd1.mdb
Altura sobre o ponto de estaçăo (mi) Anotado por Artur, J.Olympio
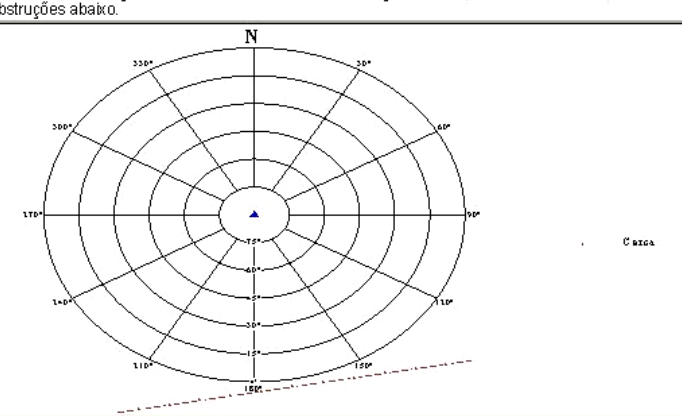

1.65 Orientaçå̃o em relaçẵo ao Norte Magnético Declinaçẫo Magnética (ggg.mmss)

Figura 126 - Ponto M07-S 300km 


\section{Levantamento de Campo}

Registraram-se todas as informações de campo, para cada local, em planilha (adaptada as do IBGE) que representa o registro das condições de campo, os relatórios de campo são apresentados da Figura 128 a 141 . A Figura 127 mostra as dificuldades encontradas no rastreio, as quais foram relatadas.

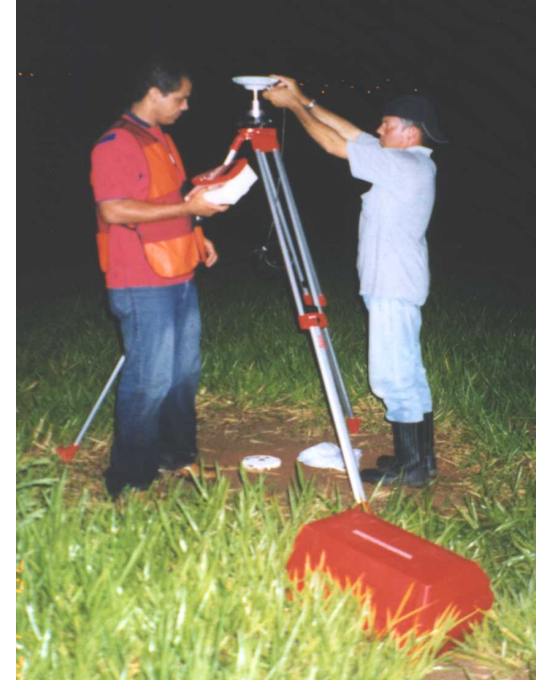

(a) Montagem do equipamento

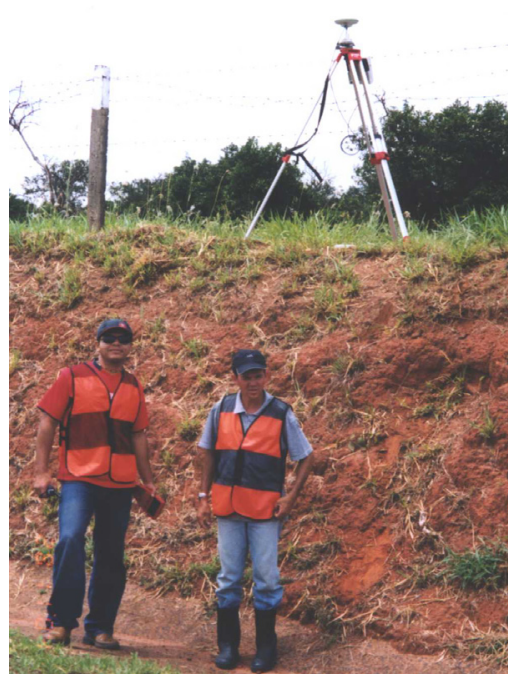

(b) Rastreio (monitoramento)

Figura 127 - Rastreio de dados em uma das estações de referência

ESTAÇÃO DE CONTROLE

RELATÓRIO DE OCUPAÇÃO

1- DESCRIÇÃO DO RASTREIO
Reg. Serviço

Figura 128 - Relatório de ocupação M01-N 


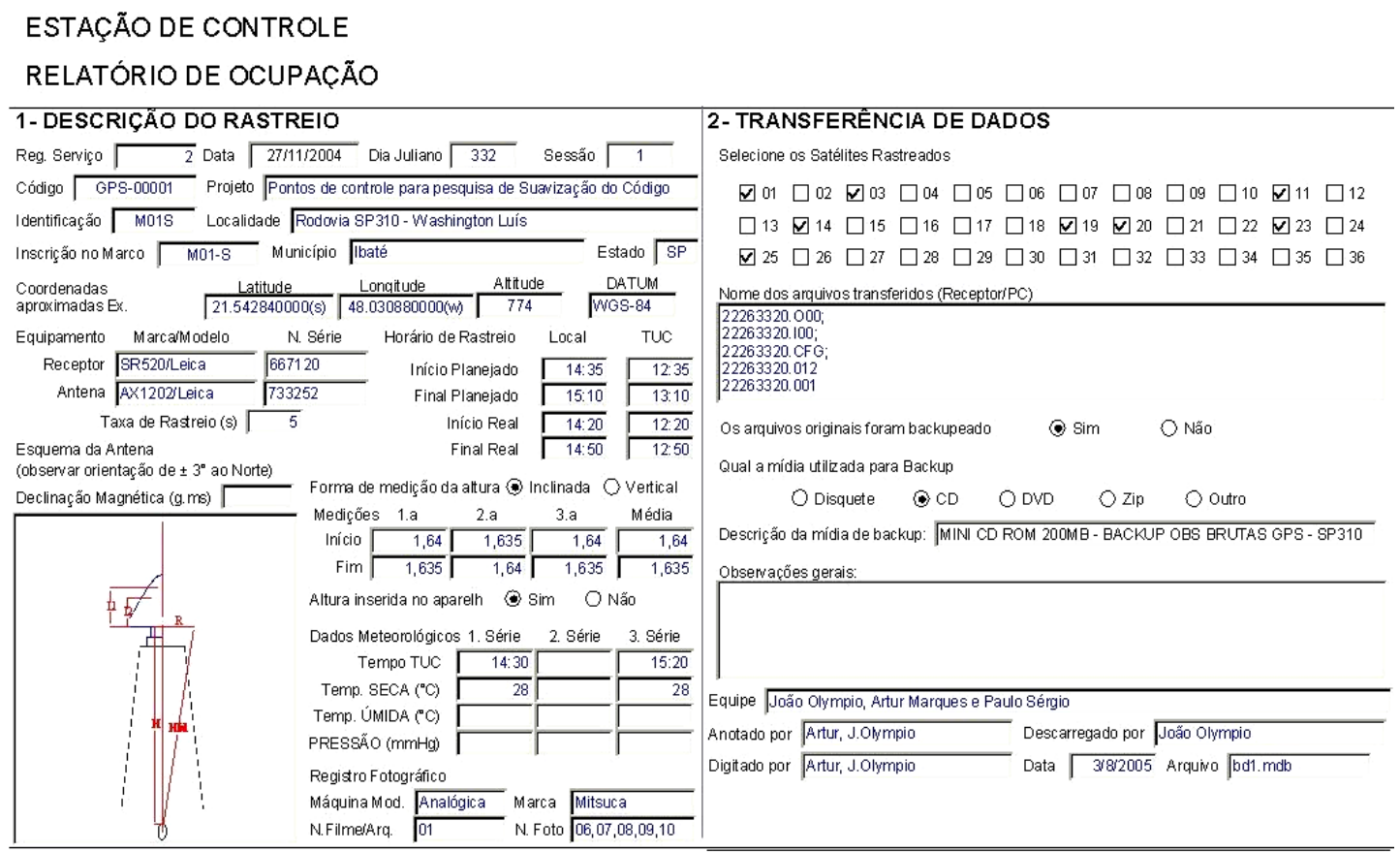

\section{Figura 129 - Relatório de ocupação M01-S}

\section{ESTAÇÃO DE CONTROLE}

RELATÓRIO DE OCUPAÇÃO

1- DESCRIÇÃO DO RASTREIO

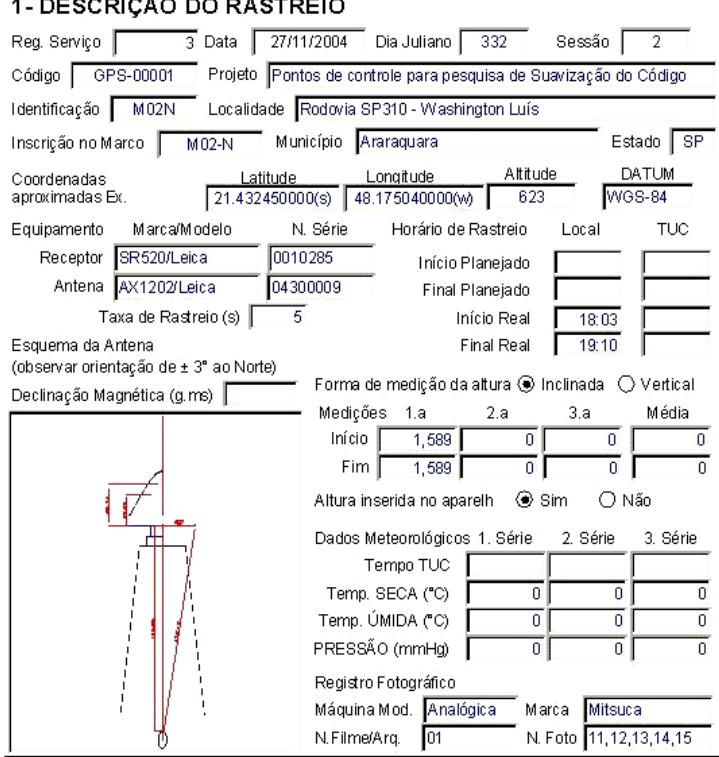

\section{2- TRANSFERÊNCIA DE DADOS}

Selecione os Satélites Rastreados

У $01 \square 02 \square 03 \quad \square 04 \quad \square 05 \square 06 \quad \square 07 \quad \square 08 \square 09 \square 10 \quad \square 11 \square 12$ $\square 13 \square 14 \square 15 \quad \square 16 \square 17 \square 18 \square 19 \square 20 \square 21 \square 22 \square 23 \square 24$ $\square 25 \square 26 \quad \square 27 \quad \square 28 \square 29 \square 30 \quad \square 31 \quad \square 32 \quad \square 33 \quad \square 34 \quad \square 35 \square 36$

Nome dos arquivos transferidos (Receptori $\mathrm{PC}$ )

$02853321 . C F G$
02853321.012

02853321.001

Os arquivos originais foram backupeado $\odot \operatorname{sim} \quad \bigcirc$ Não

Qual a mídia utilizada para Backup

$$
O \text { Disquete } \bigcirc \mathrm{CD} \quad \mathrm{ODV} \quad \bigcirc \mathrm{Zip} \quad \mathrm{O} \text { utro }
$$

Descriçẵo da mídia de backup: $\longdiv { \text { MINI CD ROM 200M - EACKUP OBS BRUAAS GPS - SP310 } }$

Observaçóes gerais:

Ocorrência de Chuva pesada evento mutto forte.

Equipe Joăo Olympio, Artur Marques e Paulo Sérgio

Anotado por Artur, J.Olympio Descarregado por Joăo Olympio

Digitado por $\sqrt{\text { Artur, J.Olympio }}$ Data ${ }_{4 / 82005}$ Arquivo bd1. mdb

\section{Figura 130 - Relatório de ocupação M02-N}




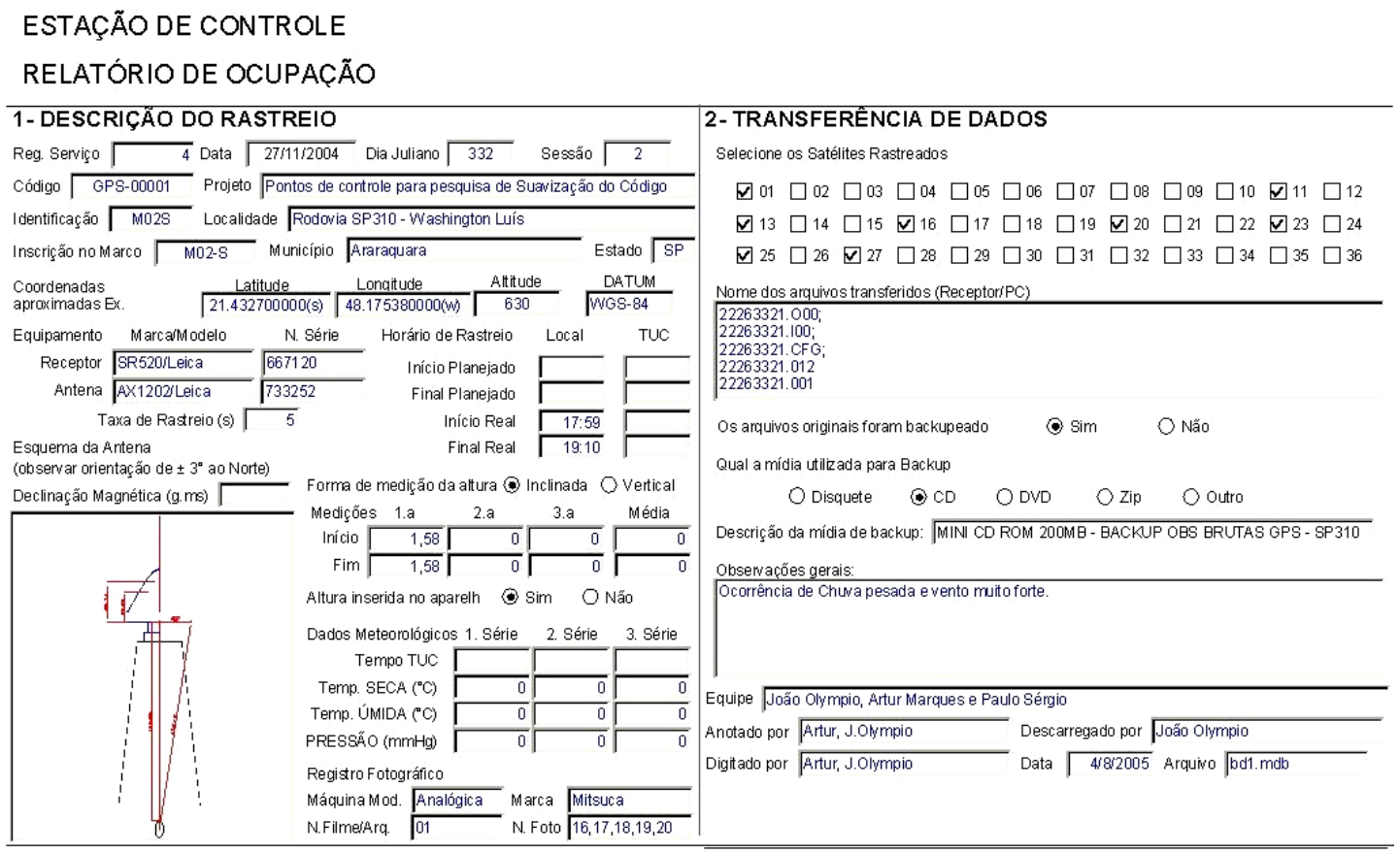

\section{Figura 131 - Relatório de ocupação M02-S}

\section{ESTAÇÃO DE CONTROLE}

RELATÓRIO DE OCUPAÇÃO

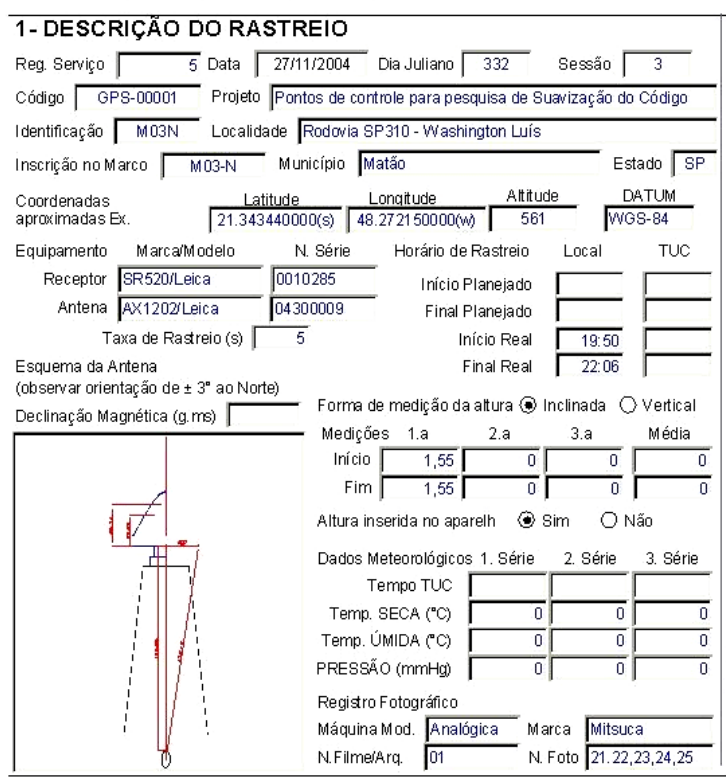

\section{2- TRANSFERÊNCIA DE DADOS}

Selecione os Satélites Rastreados

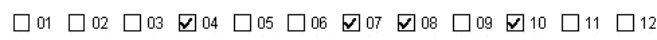

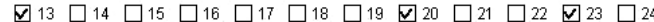
$\square 25 \square 26 \quad \square 27 \quad \square 28 \square 29 \square 30 \quad 31 \square 32 \square 33 \square 34 \square 35 \square 36$ Nome dos arquivos transferidos (ReceptoriPC)

\section{$02853322.000 ;$}

2853322.CFG

02853322.001

Os arquivos originais foram backupeado $\odot \operatorname{sim} \quad \bigcirc$ Nă̊

Qual a mídia utilizada para Backup

$$
\text { O Disquete } \bigcirc \mathrm{CD} \text { ODVD OZip O Outro }
$$

Descriçẫo da mídia de backup: $\longdiv { M I N I ~ C D ~ R O M ~ 2 0 0 M B ~ - ~ B A C K U P ~ O B S ~ B R U A S ~ G P S ~ - ~ S P 3 1 0 ~ }$

Observaçôes gerais:

Equipe Joåo Olympio, Artur Marques e Paulo Sérgio

Anotado por Artur, J.Olympio Descarregado por Joấo Olympio

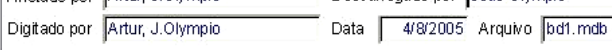

Figura 132 - Relatório de ocupação M03-N 


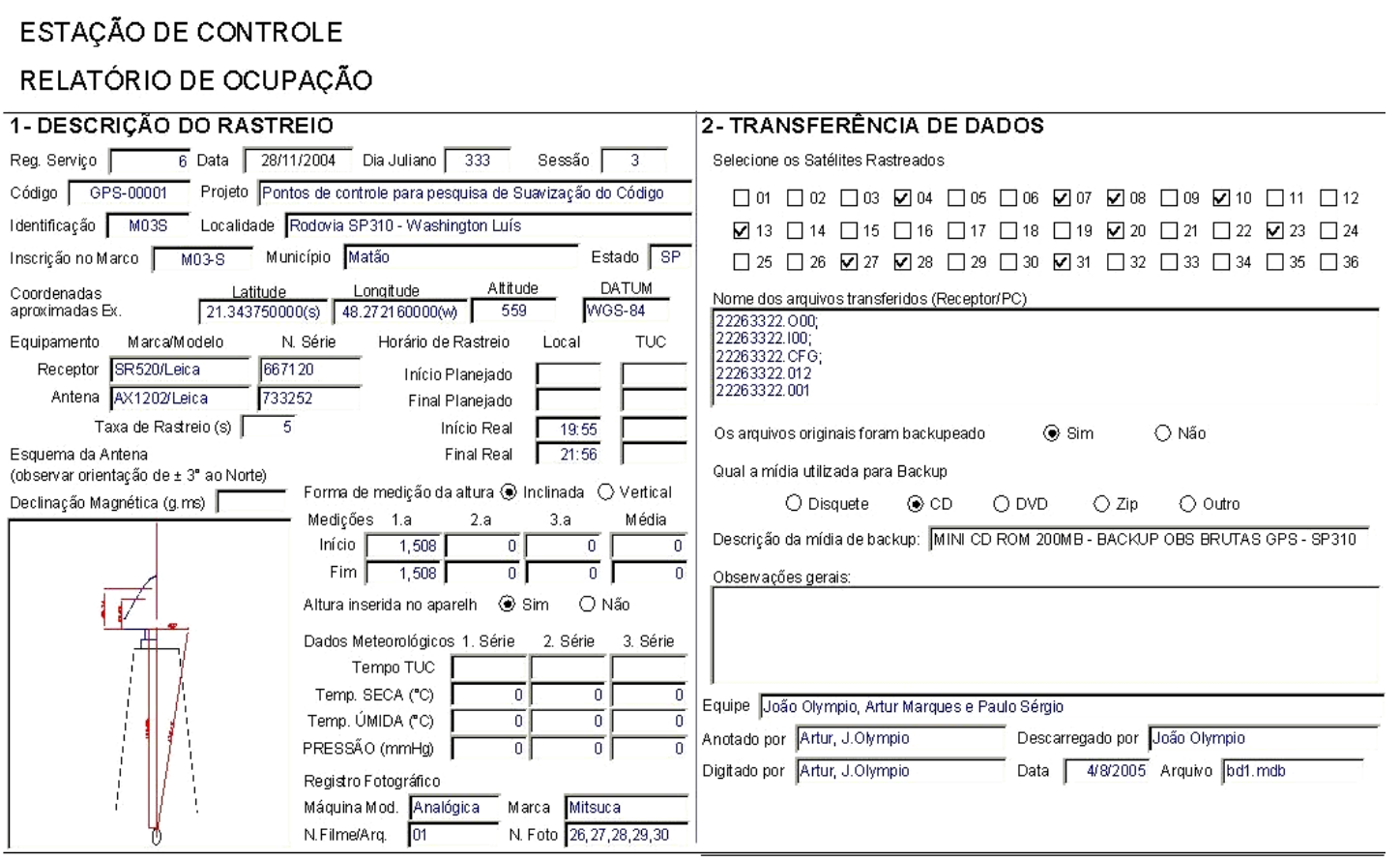

Figura 133 - Relatório de ocupação M03-S

\section{ESTAÇÃO DE CONTROLE}

RELATÓRIO DE OCUPAÇÃO

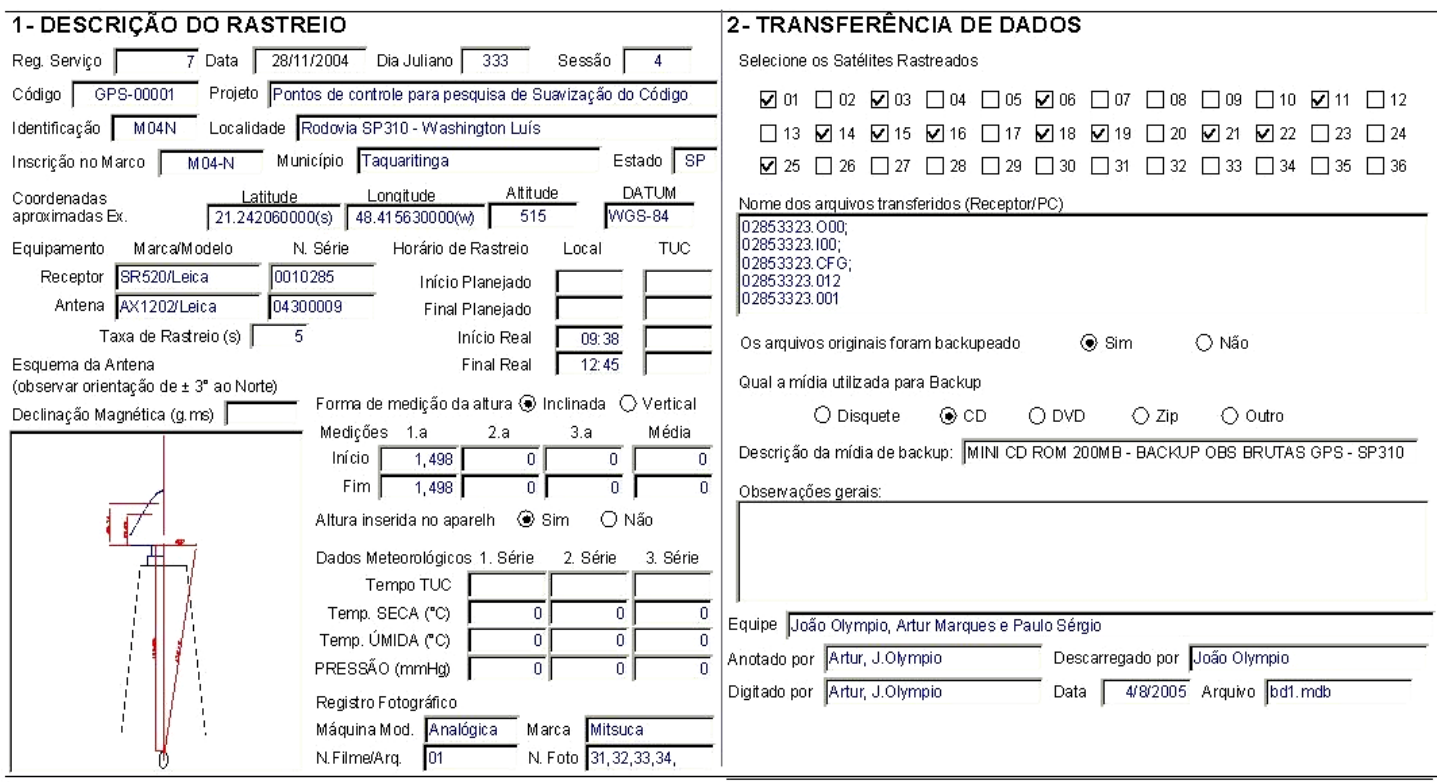

\section{Figura 134 - Relatório de ocupação M04-N}


ESTAÇÃO DE CONTROLE

RELATÓRIO DE OCUPAÇÃO

1- DESCRIÇÃO DO RASTREIO

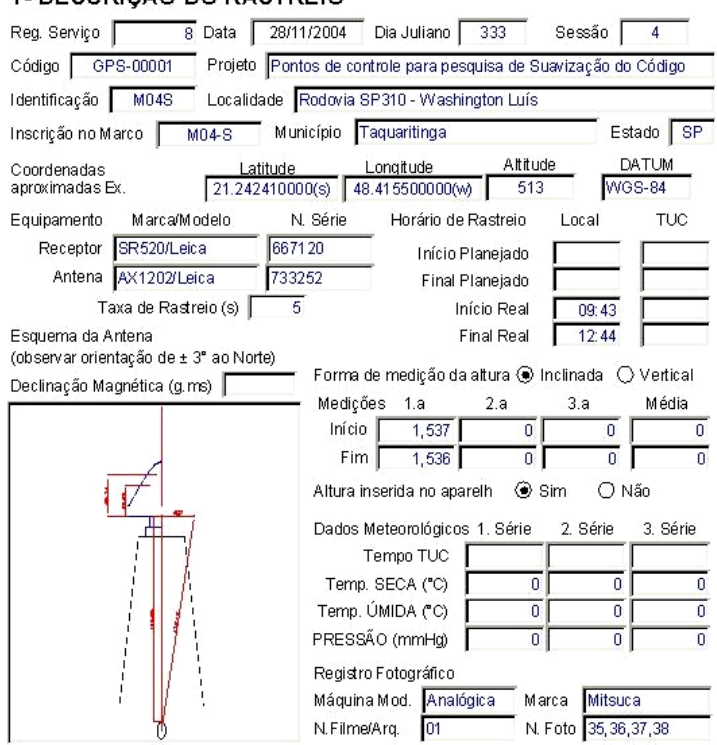

\section{2- TRANSFERÊNCIA DE DADOS}

Selecione os Satélites Rastreados

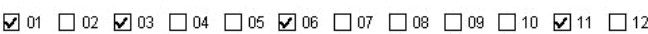
$\square 13 \square 14 \square 15 \square 16 \square 17 \nabla 18 \square 19 \square 20 \square 21 \nabla 22 \square 23 \square 24$ $\square 25 \square 26 \quad \square 27 \quad \square 28 \square 29 \square 30 \square 31 \quad \square 32 \quad \square 33 \square 34 \square 35 \square 36$

\section{Nome dos arquivos transferidos (Receptori $\mathrm{PC}$}

\subsection{0;}

22263323. CFO

22263323.012

Os arquivos originais foram backupeado $\odot \operatorname{sim} \quad$ Nấo

Qual a mídia utilizada para Backup

$$
O \text { Disquete } \odot \mathrm{CD} \text { ODVD Ozip O Outro }
$$

Descriçăo da mídia de backup: MINI CD ROM 200M - BACKUP OBS BRUAS GPS - SP310

observaçôes gerais

Equipe João Olympio, Artur Marques e Paulo Sérgio

Anotado por Artur, J.Olympio Descarregado por Joå̃o Olympio

Digitado por $\sqrt{\text { Artur, J.Olympio Data }} \stackrel{4 / 82005}{\text { Arquivo bd1. mdb }}$

\section{Figura 135 - Relatório de ocupação M04-S}

\section{ESTAÇÃO DE CONTROLE}

RELATÓRIO DE OCUPAÇÃO

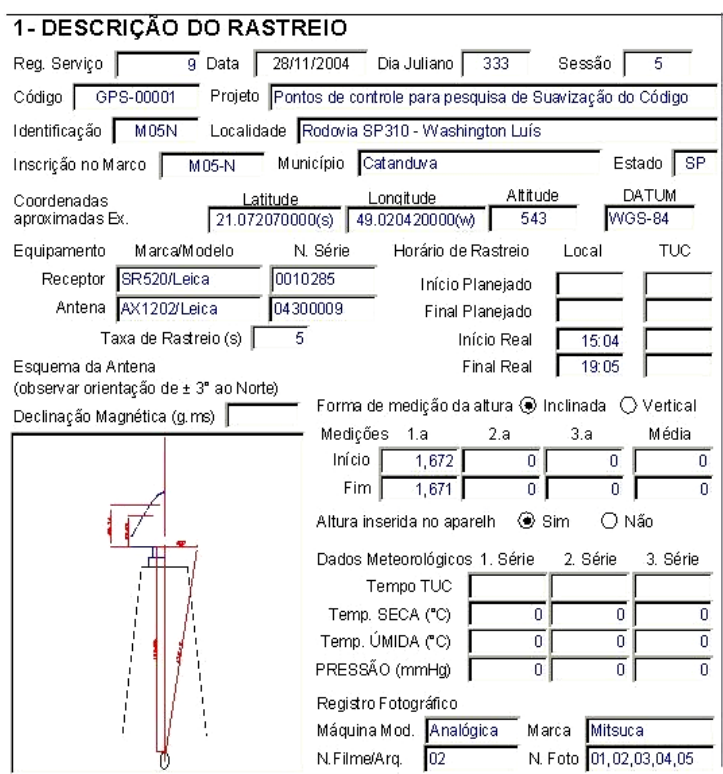

\section{- TRANSFERÊNCIA DE DADOS}

Selecione os Satélites Rastreados

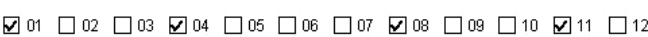
$\nabla 13 \square 14 \square 15 \nabla 16 \square 17 \square 18$ D $19 \nabla 20 \square 21 \square 22 \square 23 \square 24$ $\square 25 \square 26 \quad \square 27 \quad \square 28 \square 29 \square 30 \square 31 \quad \square 32 \quad \square 33 \square 34 \square 35 \square 36$ Nome dos arquivos transferidos (Receptori $\mathrm{PC}$ )

$02853324.000 ;$

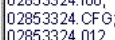

02853324.012

Os arquivos originais foram backupeado $\odot \operatorname{sim} \quad$ Não

Qual a mídia utilizada para Backup

$$
O \text { Disquete } \odot \mathrm{CD} \quad \mathrm{DVD} \quad \bigcirc \text { Zip } \bigcirc \text { Outro }
$$

Descriçẩo da mídia de backup: $\longdiv { \text { MINI CD ROM 200M - BACKUP OBS BRUAS GPS - SP310 } }$

observaçőes gerais:

Equipe Joåo Olympio, Artur Marques e Paulo Sérgio

Anotado por Artur, J.Olympio Descarregado por Joấo Olympio

Digitado por Artur, J.Olympio Data 4 4/\&2005 Arquivo bd1. mdb

\section{Figura 136 - Relatório de ocupação M05-N}




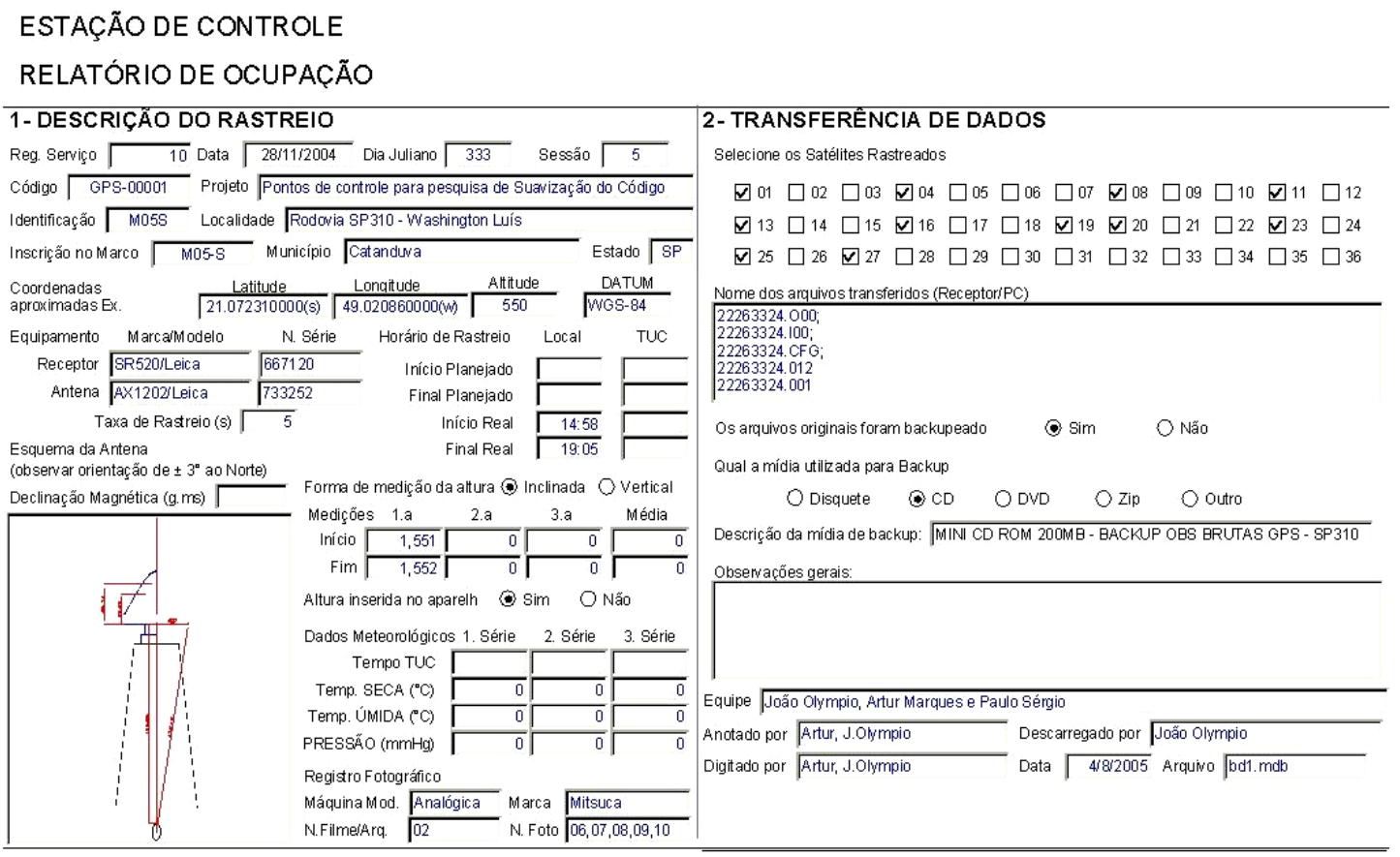

\section{Figura 137 - Relatório de ocupação M05-S}

\section{ESTAÇÃO DE CONTROLE}

RELATÓRIO DE OCUPAÇÃO

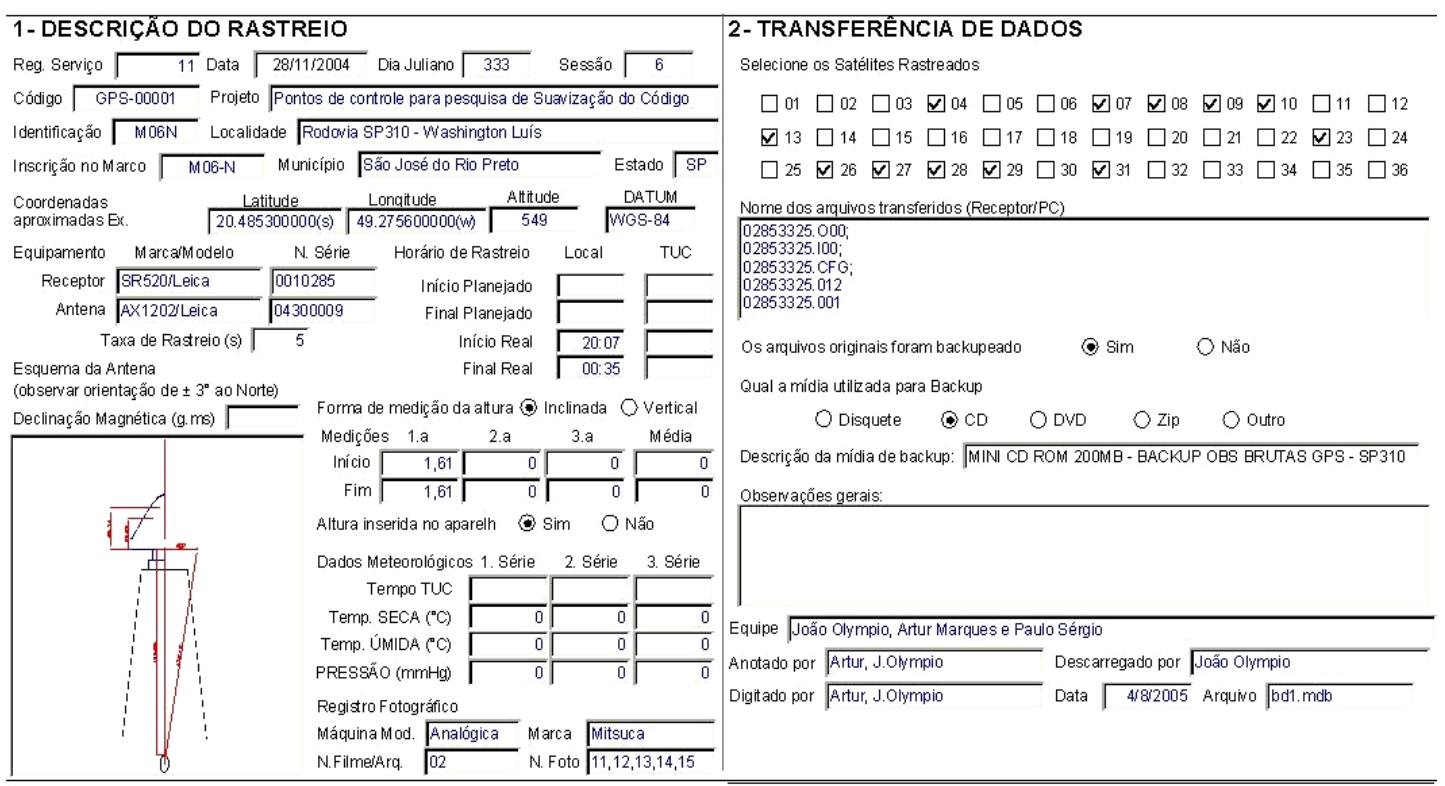

\section{Figura 138 - Relatório de ocupação M06-N}




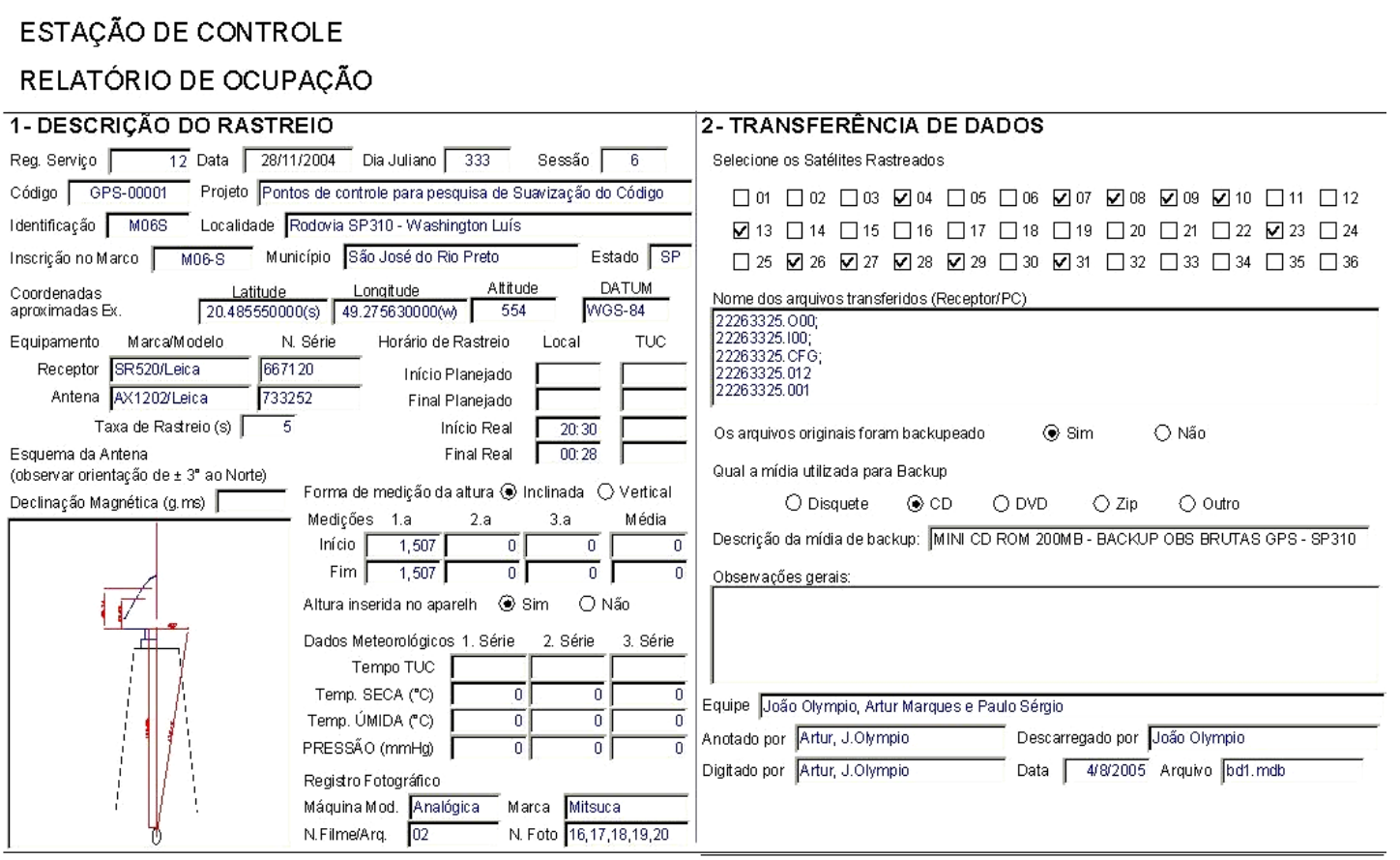

\section{Figura 139 - Relatório de ocupação M06-S}

\section{ESTAÇÃO DE CONTROLE}

RELATÓRIO DE OCUPAÇÃO

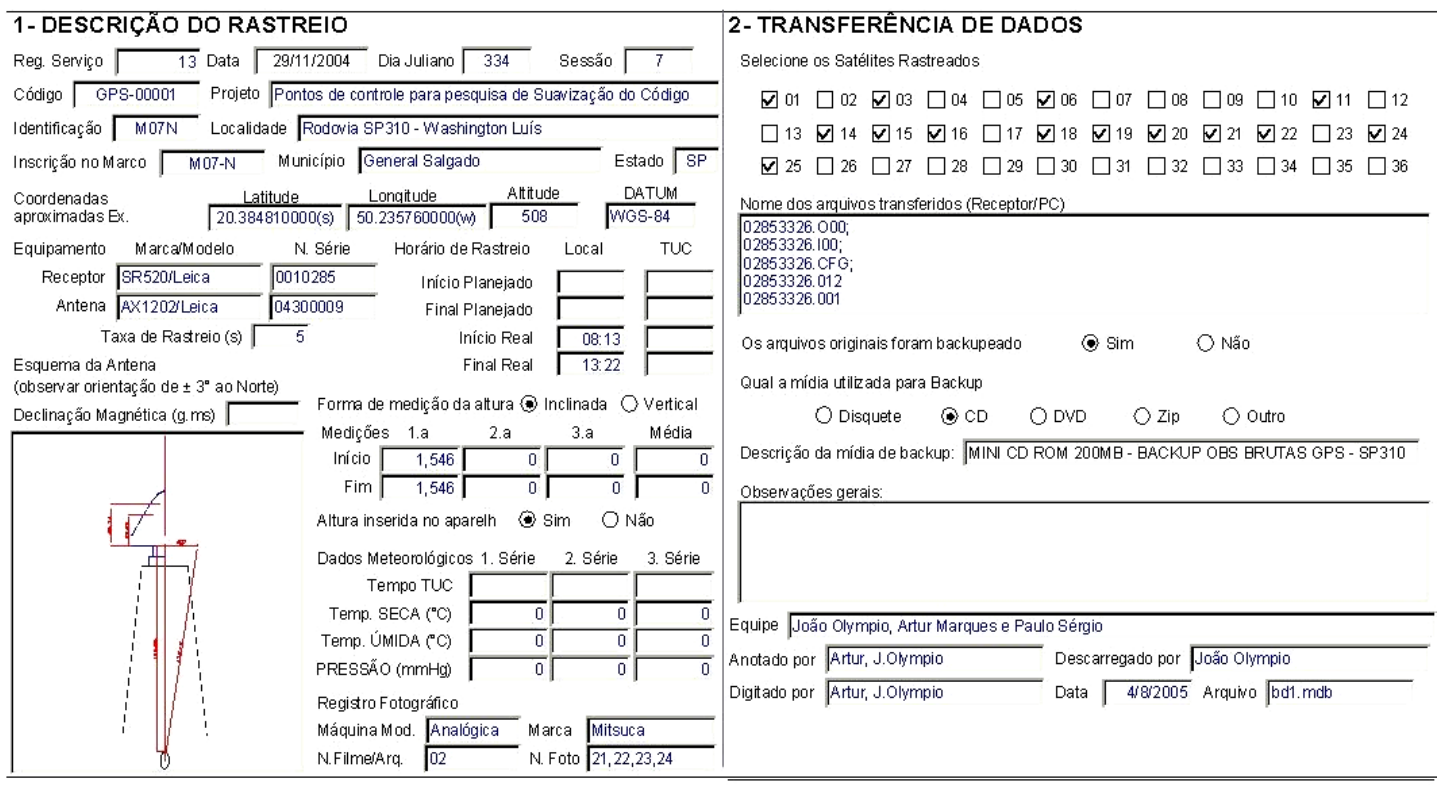

\section{Figura 140 - Relatório de ocupação M07-N}




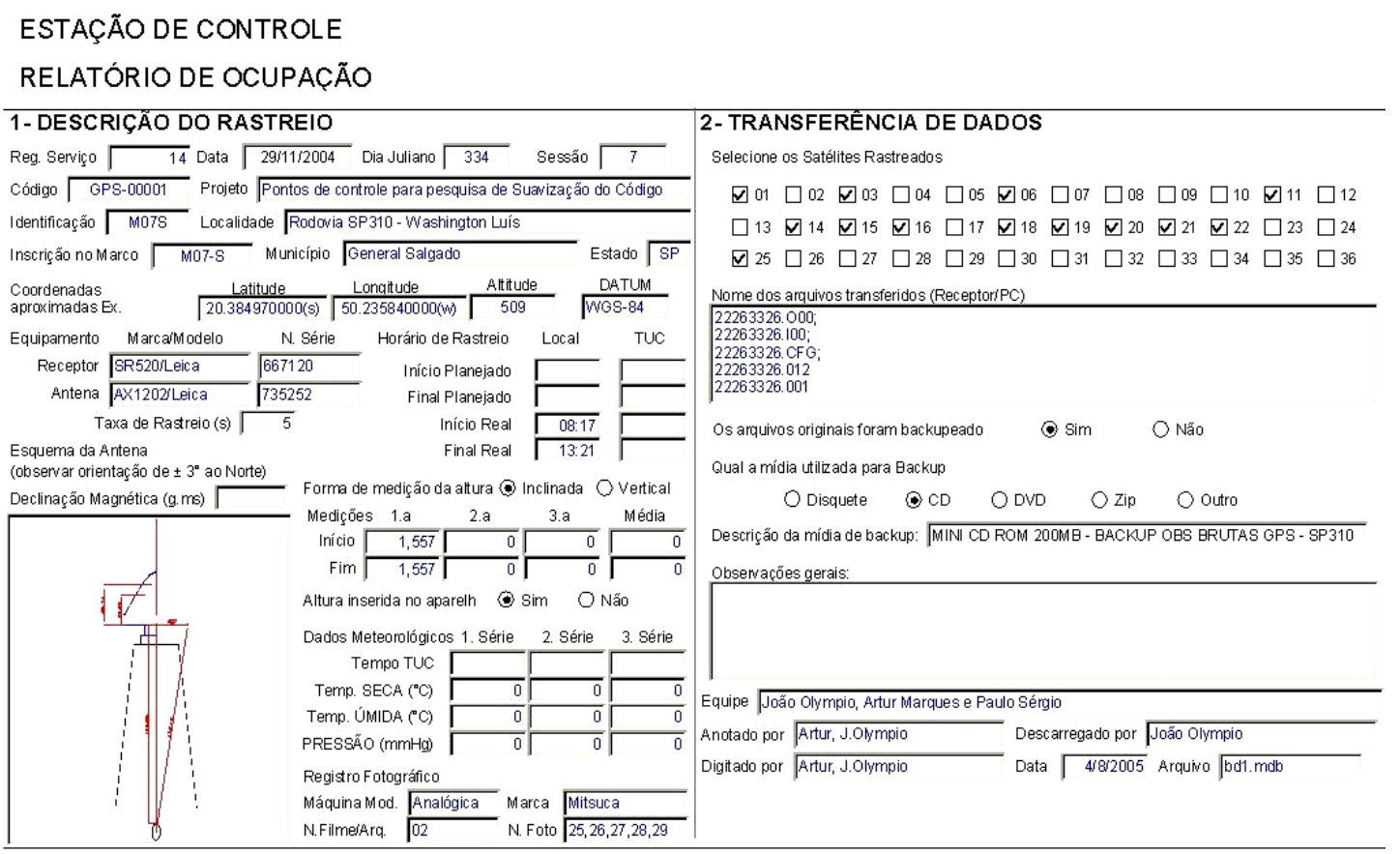

Figura 141 - Relatório de ocupação M07-S 
APÊNDICE B - Relatórios de processamento (L1/L2) 
Tabela 11 - STTU - M01-N

\begin{tabular}{|c|c|c|}
\hline \multicolumn{3}{|l|}{ INFORMAÇŌES DO PROJETO } \\
\hline NOME DO PROJETO & SUL 01 & \\
\hline DATA DE CRIAÇÄO: & 06/25/2005 19:18:46 & \\
\hline FUSO HORÁRIO: & $-3 \mathrm{H} 00^{\prime}$ & \\
\hline NOME DO SISTEMA DE COORDENADAS: & WGS-UTM 22 & \\
\hline APLICATIVO: & LEICA SKI-PRO 3.0 & \\
\hline PROCESSAMENTO KERNEL: & PSI-PRO 1.0 & \\
\hline PROCESSADO: & $1 / 6 / 200621: 27$ & \\
\hline \multicolumn{3}{|l|}{ INFORMAÇÕES DO PONTO } \\
\hline TIPO DE RECEPTOR / N/S: & SR9500 / 0 & SR520 / 22223 \\
\hline TIPO DE ANTENA / N/S: & AT202/302 GP / - & AX1202 TRENA / - \\
\hline ALTURA DA ANTENA: & $-0.0390 \mathrm{M}$ & $1.6060 \mathrm{M}$ \\
\hline \multicolumn{3}{|l|}{ COORDENADAS INICIAIS: } \\
\hline ESTE: & $820172.8429 \mathrm{M}$ & $804549.2283 \mathrm{M}$ \\
\hline NORTE: & $7563377.3263 \mathrm{M}$ & $7574525.8544 \mathrm{M}$ \\
\hline ALT. ELIP.: & $824.7000 \mathrm{M}$ & $778.2239 \mathrm{M}$ \\
\hline \multicolumn{3}{|l|}{ PARÂMETROS DE PROCESSAMENTO } \\
\hline PARÂMETROS & SELECIONADO & USADO \\
\hline ÂNGULO DE CORTE: & $15^{\circ}$ & $15^{\circ}$ \\
\hline TIPO DE EFEMÉRIDES: & TRANSMITIDA & TRANSMITIDA \\
\hline TIPO DE SOLUÇÃO: & AUTOMÁTICO & FASE \\
\hline FREQÜÊNCIA: & AUTOMÁTICO & AUTOMÁTICO \\
\hline FIXAR AMBIGÜIDADES ATÉ: & $80 \mathrm{KM}$ & $80 \mathrm{KM}$ \\
\hline DURAÇÃO MÍN. P/ A SOLUÇÃO FLOAT & 5' 00" & 5' $00^{\prime \prime}$ \\
\hline (ESTÁTICO): & & \\
\hline TAXA DE AMOSTRAGEM: & USAR TUDO & 5 \\
\hline MODELO TROPOSFÉRICO: & HOPFIELD & HOPFIELD \\
\hline MODELO IONOSFÉRICO: & KLOBUCHAR & KLOBUCHAR \\
\hline USAR MODELO ESTOCÁSTICO: & SIM & SIM \\
\hline DISTÂNCIA MÍN.: & $8 \mathrm{KM}$ & $8 \mathrm{KM}$ \\
\hline ATIVIDADE IONOSFÉRICA: & AUTOMÁTICO & AUTOMÁTICO \\
\hline \multicolumn{3}{|l|}{ SELECÃO DE SATÉLITES } \\
\hline \multicolumn{3}{|l|}{ SATÉLITES DESATIVADOS } \\
\hline \multicolumn{3}{|l|}{ MANUALMENTE: } \\
\hline \multicolumn{3}{|l|}{ ESTATÍSTICAS DA AMBIGÜIDADE } \\
\hline \multicolumn{3}{|l|}{ NÚMERO TOTAL DE AMBIGÜIDADES: } \\
\hline NÚMERO DE AMBIGÜIDADES FIXADAS: & 18 & \\
\hline NÚMERO DE AMBIGÜIDADES INDEPENDENTES: & \multicolumn{2}{|l|}{207} \\
\hline TEMPO MÉDIO ENTRE FIXADAS INDEPENDENTES: & \multicolumn{2}{|l|}{$10^{\prime \prime}$} \\
\hline PORCENTAGEM DE ÉPOCAS FIXADAS (L1): & \multicolumn{2}{|l|}{$100 \%$} \\
\hline PORCENTAGEM DE ÉPOCAS FIXADAS (L2): & \multicolumn{2}{|l|}{$100 \%$} \\
\hline PORCENTAGEM DE ÉPOCAS FIXADAS (TUDO): & \multicolumn{2}{|l|}{$100 \%$} \\
\hline ESTATISTIICAS GERAIS: & & \\
\hline $\begin{array}{ll}\text { STATUS } & \text { DE } \\
\end{array}$ & DURAÇÃO & \\
\hline FIXADA $\quad 11 / 27 / 200419: 15: 15$ & $36^{\prime} 20^{\prime \prime}$ & \\
\hline ESTATISTICAS DA PERDA DE CICLO & & \\
\hline NÚMERO TOTAL DE PERDAS DE CICLO: & 0 & \\
\hline COORDENADAS FINAIS & & \\
\hline & REFERÊNCIA: STTU & REMOTO: M01-N \\
\hline COORDENADAS: & & \\
\hline ESTE & $820172.8429 \mathrm{M}$ & $804549.4983 \mathrm{M}$ \\
\hline NORTE & $7563377.3263 \mathrm{M}$ & $7574525.9259 \mathrm{M}$ \\
\hline ALT. ELIP & $824.7000 \mathrm{M}$ & $772.1894 \mathrm{M}$ \\
\hline TIPO DE SOLUÇÃO: & FASE & \\
\hline FREQÜÊNCIA: & IONOLIVRE (L3) & \\
\hline AMBIGÜIDADE: & SIM & \\
\hline QUALIDADE: & DP. E: $0.0005 \mathrm{M}$ & DP. N: $0.0005 \mathrm{M}$ \\
\hline & QLD. POS.: $0.0008 \mathrm{M}$ & DP. ALT.: $0.0018 \mathrm{M}$ \\
\hline VETOR DA LINHA DE BASE & DLAT: $0^{\circ} 05^{\prime} 52.07251^{\prime \prime}$ & DLON: $-0^{\circ} 09^{\prime} 11.62800^{\prime \prime}$ \\
\hline & DECLIVIDADE: $19180.2436 \mathrm{M}$ & \\
\hline DOPS (MÍN-MÁX): & GDOP: $2.0-5.8$ & PDOP: $1.8-4.8$ \\
\hline
\end{tabular}


Tabela 12 - STTU - M01-S

\begin{tabular}{|c|c|c|}
\hline INFORMAÇÕES DO PROJETO & & \\
\hline NOME DO PROJETO & SUL 01 & \\
\hline DATA DE CRIAÇÃO: & 06/25/2005 19:18:46 & \\
\hline FUSO HORÁRIO: & $-3 \mathrm{H} \mathrm{00}$ & \\
\hline NOME DO SISTEMA DE COORDENADAS: & WGS-UTM 22 & \\
\hline APLICATIVO: & LEICA SKI-PRO 3.0 & \\
\hline PROCESSAMENTO KERNEL: & PSI-PRO 1.0 & \\
\hline PROCESSADO: & $1 / 6 / 200621: 27$ & \\
\hline INFORMAÇÕES DO PONTO & & \\
\hline TIPO DE RECEPTOR / N/S: & SR9500 / 0 & SR520 / 22226 \\
\hline TIPO DE ANTENA / N/S: & AT202/302 GP / - & AX1202 TRENA / - \\
\hline ALTURA DA ANTENA: & $-0.0390 \mathrm{M}$ & $1.6380 \mathrm{M}$ \\
\hline COORDENADAS INICIAIS: & & \\
\hline ESTE: & $820172.8429 \mathrm{M}$ & $804542.3894 \mathrm{M}$ \\
\hline NORTE: & $7563377.3263 \mathrm{M}$ & $7574441.7525 \mathrm{M}$ \\
\hline ALT. ELIP.: & $824.7000 \mathrm{M}$ & $776.6666 \mathrm{M}$ \\
\hline PARÂMETROS DE PROCESSAMENTO & & \\
\hline PARÂMETROS & SELECIONADO & USADO \\
\hline ÂNGULO DE CORTE: & $15^{\circ}$ & $15^{\circ}$ \\
\hline TIPO DE EFEMÉRIDES: & TRANSMITIDA & TRANSMITIDA \\
\hline TIPO DE SOLUÇÃO: & AUTOMÁTICO & FASE \\
\hline FREQÜÊNCIA: & AUTOMÁTICO & AUTOMÁTICO \\
\hline FIXAR AMBIGÜIDADES ATÉ: & $80 \mathrm{KM}$ & $80 \mathrm{KM}$ \\
\hline DURAÇÃO MÍN. P/ A SOLUÇÃO & 5' 00" & 5' 00" \\
\hline FLOAT (ESTÁTICO): & & \\
\hline TAXA DE AMOSTRAGEM: & USAR TUDO & 5 \\
\hline MODELO TROPOSFÉRICO: & HOPFIELD & HOPFIELD \\
\hline MODELO IONOSFÉRICO: & KLOBUCHAR & KLOBUCHAR \\
\hline USAR MODELO ESTOCÁSTICO: & SIM & SIM \\
\hline DISTÂNCIA MÍN.: & $8 \mathrm{KM}$ & $8 \mathrm{KM}$ \\
\hline ATIVIDADE IONOSFÉRICA: & AUTOMÁTICO & AUTOMÁTICO \\
\hline SELEÇÃO DE SATÉLITES & & \\
\hline SATÉLITES DESATIVADOS & & \\
\hline MANUALMENTE: & NENHUM & \\
\hline ESTATÍSTICAS DA AMBIGÜIDADE & & \\
\hline NÚMERO TOTAL DE & 16 & \\
\hline NÚMERO DE AMBIGÜIDADES FIXADAS: & 16 & \\
\hline NÚMERO DE AMBIGÜIDADES INDEPENDENTES: & 173 & \\
\hline TEMPO MÉDIO ENTRE FIXADAS INDEPENDENTES: & $10 "$ & \\
\hline PORCENTAGEM DE ÉPOCAS FIXADAS (L1): & $100 \%$ & \\
\hline PORCENTAGEM DE ÉPOCAS FIXADAS (L2): & $100 \%$ & \\
\hline PORCENTAGEM DE ÉPOCAS FIXADAS (TUDO): & $100 \%$ & \\
\hline ESTATÍSTICAS GERAIS: & & \\
\hline $\begin{array}{ll}\text { STATUS } & \text { DE } \\
\end{array}$ & DURAÇÃO & \\
\hline $\begin{array}{ll}\text { FIXADA } & 11 / 27 / 2004 \text { 19:20:05 } \\
\end{array}$ & $30^{\prime} 00^{\prime \prime}$ & \\
\hline ESTATÍSTICAS DA PERDA DE CICLO & & \\
\hline NÚMERO TOTAL DE PERDAS DE CICLO: & 0 & \\
\hline COORDENADAS FINAIS & & \\
\hline COORDENADAS: & REFERÊNCIA: STTU & REMOTO: M01-S \\
\hline ESTE & $820172.8429 \mathrm{M}$ & $804542.2572 \mathrm{M}$ \\
\hline NORTE & $7563377.3263 \mathrm{M}$ & $7574442.1559 \mathrm{M}$ \\
\hline ALT. ELIP & $824.7000 \mathrm{M}$ & $772.5050 \mathrm{M}$ \\
\hline TIPO DE SOLUÇÃO: & FASE & \\
\hline FREQÜÊNCIA: & IONOLIVRE (L3) & \\
\hline AMBIGÜIDADE: & SIM & \\
\hline QUALIDADE: & DP. E: $0.0006 \mathrm{M}$ & DP. N: $0.0006 \mathrm{M}$ \\
\hline & QLD. POS.: $0.0008 \mathrm{M}$ & DP. ALT.: $0.0020 \mathrm{M}$ \\
\hline VETOR DA LINHA DE BASE & DLAT: $0^{\circ} 05^{\prime} 49.34701^{\prime \prime}$ & DLON: - \\
\hline & DECLIVIDADE: $19137.6453 \mathrm{M}$ & \\
\hline DOPS (MÍN-MÁX): & GDOP: $2.1-5.8$ & PDOP: $1.9-4.8$ \\
\hline
\end{tabular}


Tabela 13 - M01-N - M01-S

\begin{tabular}{|c|c|c|}
\hline INFORMAÇÕES DO PROJETO & & \\
\hline NOME DO PROJETO & SUL 01 & \\
\hline DATA DE CRIAÇÃO: & 06/25/2005 19:18:46 & \\
\hline FUSO HORÁRIO: & $-3 \mathrm{H} 00^{\prime}$ & \\
\hline NOME DO SISTEMA DE COORDENADAS: & WGS-UTM 22 & \\
\hline APLICATIVO: & LEICA SKI-PRO 3.0 & \\
\hline PROCESSAMENTO KERNEL: & PSI-PRO 1.0 & \\
\hline PROCESSADO: & $1 / 6 / 200621: 27$ & \\
\hline INFORMAÇÕES DO PONTO & & \\
\hline TIPO DE RECEPTOR / N/S: & SR20 / 0 & PROXR \\
\hline TIPO DE ANTENA / N/S: & AT 501 & \\
\hline ALTURA DA ANTENA: & $1.598 \mathrm{M}$ & $1.679 \mathrm{M}$ \\
\hline COORDENADAS INICIAIS: & & \\
\hline ESTE: & $804549.5678 \mathrm{M}$ & $804542.4897 \mathrm{M}$ \\
\hline NORTE: & $7574526.0259 \mathrm{M}$ & $7574442.1894 \mathrm{M}$ \\
\hline ALT. ELIP.: & $772.1572 \mathrm{M}$ & $773.005 \mathrm{M}$ \\
\hline PARÂMETROS DE PROCESSAMENTO & & \\
\hline PARÂMETROS & SELECIONADO & USADO \\
\hline ÂNGULO DE CORTE: & $15^{\circ}$ & $15^{\circ}$ \\
\hline TIPO DE EFEMÉRIDES: & TRANSMITIDA & TRANSMITIDA \\
\hline TIPO DE SOLUÇÃO: & AUTOMÁTICO & FASE \\
\hline FREQÜÊNCIA: & L1 & L1 \\
\hline FIXAR AMBIGÜIDADES ATÉ: & $80 \mathrm{KM}$ & $80 \mathrm{KM}$ \\
\hline $\begin{array}{l}\text { DURAÇÃO MÍN. P/ A SOLUÇÃO } \\
\text { FLOAT (ESTÁTICO): }\end{array}$ & 5'00" & 5'00" \\
\hline TAXA DE AMOSTRAGEM: & USAR TUDO & 5 \\
\hline MODELO TROPOSFÉRICO: & HOPFIELD & HOPFIELD \\
\hline MODELO IONOSFÉRICO: & KLOBUCHAR & KLOBUCHAR \\
\hline USAR MODELO ESTOCÁSTICO: & SIM & SIM \\
\hline DISTÂNCIA MÍN.: & $8 \mathrm{KM}$ & $8 \mathrm{KM}$ \\
\hline ATIVIDADE IONOSFÉRICA: & AUTOMÁTICO & AUTOMÁTICO \\
\hline SELEÇÃO DE SATÉLITES & & \\
\hline $\begin{array}{l}\text { SATÉLITES DESATIVADOS } \\
\text { MANUALMENTE: }\end{array}$ & NENHUM & \\
\hline ESTATÍSTICAS DA AMBIGÜIDADE & & \\
\hline NÚMERO TOTAL DE AMBIGÜIDADES: & 8 & \\
\hline NÚMERO DE AMBIGÜIDADES FIXADAS: & 8 & \\
\hline NÚMERO DE AMBIGÜIDADES INDEPENDENTES: & 178 & \\
\hline TEMPO MÉDIO ENTRE FIXADAS INDEPENDENTES: & $10^{\prime \prime}$ & \\
\hline PORCENTAGEM DE ÉPOCAS FIXADAS (L1): & $100 \%$ & \\
\hline PORCENTAGEM DE ÉPOCAS FIXADAS (TUDO): & $100 \%$ & \\
\hline ESTATÍSTICAS GERAIS: & & \\
\hline $\begin{array}{ll}\text { STATUS } & \text { DE } \\
\end{array}$ & DURAÇÃO & \\
\hline FIXADA $\quad 3 / 4 / 200517: 02$ & $1 \mathrm{H}$ & \\
\hline ESTATÍSTICAS DA PERDA DE CICLO & & \\
\hline NÚMERO TOTAL DE PERDAS DE CICLO: & 0 & \\
\hline COORDENADAS FINAIS & & \\
\hline & REFERÊNCIA: STTU & REMOTO: M01-S \\
\hline COORDENADAS: & & \\
\hline ESTE & $804549.4983 \mathrm{M}$ & $804542.2591 \mathrm{M}$ \\
\hline NORTE & $7574525.9259 \mathrm{M}$ & $7574442.1631 \mathrm{M}$ \\
\hline ALT. ELIP & $772.1894 \mathrm{M}$ & $772.5019 \mathrm{M}$ \\
\hline TIPO DE SOLUÇÃO: & FASE & \\
\hline FREQÜÊNCIA: & SÓ L1 & \\
\hline AMBIGÜIDADE: & SIM & \\
\hline QUALIDADE: & DP. E: $0.0001 \mathrm{M}$ & DP. N: $0.0001 \mathrm{M}$ \\
\hline & QLD. POS.: $0.0002 \mathrm{M}$ & DP. ALT.: $0.0004 \mathrm{M}$ \\
\hline VETOR DA LINHA DE BASE & DLAT: $-0^{\circ} 00^{\prime} 02.72527^{\prime \prime}$ & DLON: $-0^{\circ} 00^{\prime} 00.19597^{\prime \prime}$ \\
\hline & DECLIVIDADE: $84.0232 \mathrm{M}$ & \\
\hline DOPS (MÍN-MÁX): & GDOP: $2.8-3.9$ & PDOP: $2.4-3.5$ \\
\hline
\end{tabular}


Tabela 14 - STTU - M02-N

\begin{tabular}{|c|c|c|}
\hline \multicolumn{3}{|l|}{ INFORMAÇÕES DO PROJETO } \\
\hline NOME DO PROJETO & SUL 02 - ANTES TEMPORAL & \\
\hline DATA DE CRIAÇÃO: & 06/13/2005 21:29:53 & \\
\hline FUSO HORÁRIO: & $-3 \mathrm{H} 00^{\prime}$ & \\
\hline NOME DO SISTEMA DE COORDENADAS: & WGS-UTM 22 & \\
\hline APLICATIVO: & LEICA SKI-PRO 3.0 & \\
\hline PROCESSAMENTO KERNEL: & PSI-PRO 1.0 & \\
\hline PROCESSADO: & 1/7/2006 10:18 & \\
\hline \multicolumn{3}{|l|}{ INFORMAÇÕES DO PONTO } \\
\hline TIPO DE RECEPTOR / N/S: & $\mathrm{SR} 9500 / 0$ & SR520 / 22223 \\
\hline TIPO DE ANTENA / N/S: & AT202/302 GP / - & AX1202 TRENA / - \\
\hline ALTURA DA ANTENA: & $-0.0390 \mathrm{M}$ & $1.587 \mathrm{M}$ \\
\hline \multicolumn{3}{|l|}{ COORDENADAS INICIAIS: } \\
\hline ESTE: & $820172.8427 \mathrm{M}$ & $779588.5449 \mathrm{M}$ \\
\hline NORTE: & $7563377.3263 \mathrm{M}$ & $7595336.7393 \mathrm{M}$ \\
\hline ALT. ELIP.: & $824.7000 \mathrm{M}$ & $619.9948 \mathrm{M}$ \\
\hline \multicolumn{3}{|l|}{ PARÂMETROS DE PROCESSAMENTO } \\
\hline PARÂMETROS & SELECIONADO & USADO \\
\hline ÂNGULO DE CORTE: & $15^{\circ}$ & $15^{\circ}$ \\
\hline TIPO DE EFEMÉRIDES: & TRANSMITIDA & TRANSMITIDA \\
\hline TIPO DE SOLUÇÃO: & AUTOMÁTICO & FASE \\
\hline FREQÜÊNCIA: & AUTOMÁTICO & AUTOMÁTICO \\
\hline FIXAR AMBIGÜIDADES ATÉ: & $80 \mathrm{KM}$ & $80 \mathrm{KM}$ \\
\hline $\begin{array}{l}\text { DURAÇÃO MÍN. P/ A SOLUÇÃO FLOAT } \\
\text { (ESTÁTICO): }\end{array}$ & 5' $00^{\prime \prime}$ & 5'00" \\
\hline TAXA DE AMOSTRAGEM: & USAR TUDO & 5 \\
\hline MODELO TROPOSFÉRICO: & HOPFIELD & HOPFIELD \\
\hline MODELO IONOSFÉRICO: & KLOBUCHAR & KLOBUCHAR \\
\hline USAR MODELO ESTOCÁSTICO: & SIM & SIM \\
\hline DISTÂNCIA MÍN.: & $8 \mathrm{KM}$ & $8 \mathrm{KM}$ \\
\hline ATIVIDADE IONOSFÉRICA: & AUTOMÁTICO & AUTOMÁTICO \\
\hline \multicolumn{3}{|l|}{ SELEÇÃO DE SATÉLITES } \\
\hline \multicolumn{3}{|l|}{$\begin{array}{l}\text { SATÉLITES DESATIVADOS } \\
\text { MANUALMENTE: }\end{array}$} \\
\hline \multicolumn{3}{|l|}{ ESTATÍSTICAS DA AMBIGÜIDADE } \\
\hline NÚMERO TOTAL DE AMBIGÜIDADES: & \multicolumn{2}{|l|}{14} \\
\hline NÚMERO DE AMBIGÜIDADES FIXADAS: & \multicolumn{2}{|l|}{14} \\
\hline NÚMERO DE AMBIGÜIDADES INDEPENDENTES: & \multicolumn{2}{|l|}{71} \\
\hline TEMPO MÉDIO ENTRE FIXADAS INDEPENDENTES: & \multicolumn{2}{|l|}{$10 "$} \\
\hline PORCENTAGEM DE ÉPOCAS FIXADAS (L1): & \multicolumn{2}{|l|}{$100 \%$} \\
\hline PORCENTAGEM DE ÉPOCAS FIXADAS (L2): & \multicolumn{2}{|l|}{$100 \%$} \\
\hline PORCENTAGEM DE ÉPOCAS FIXADAS (TUDO): & \multicolumn{2}{|l|}{$100 \%$} \\
\hline \multicolumn{3}{|l|}{$\begin{array}{ll}\text { ESTATISTICAS GERAIS: } & \\
\text { STATUS } & \text { DE }\end{array}$} \\
\hline $\begin{array}{ll}\text { STATUS } & \text { DE } \\
\end{array}$ & DURAÇÃO & \\
\hline FIXADA $\quad 11 / 27 / 2004$ 19:43:20 & $36^{\prime} 10^{\prime \prime}$ & \\
\hline \multicolumn{3}{|l|}{ ESTATÍSTICAS DA PERDA DE CICLO } \\
\hline NÚMERO TOTAL DE PERDAS DE CICLO: & 0 & \\
\hline COORDENADAS FINAIS & & \\
\hline ESTE & $820172.8429 \mathrm{M}$ & $779587.3900 \mathrm{M}$ \\
\hline NORTE & $7563377.3263 \mathrm{M}$ & $7595338.7492 \mathrm{M}$ \\
\hline ALT. ELIP & $824.7000 \mathrm{M}$ & $615.0300 \mathrm{M}$ \\
\hline TIPO DE SOLUÇÃO: & FASE & \\
\hline FREQÜÊNCIA: & IONOLIVRE (L3) & \\
\hline AMBIGÜIDADE: & SIM & \\
\hline & DP. E: $0.0006 \mathrm{M}$ & DP. N: $0.0006 \mathrm{M}$ \\
\hline & QLD. POS.: $0.0009 \mathrm{M}$ & DP. ALT.: $0.0016 \mathrm{M}$ \\
\hline VETOR DA LINHA DE BASE & DLAT: $0^{\circ} 16^{\prime} 53.31423 "$ & DLON: $-0^{\circ} 23^{\prime} 53.31911^{\prime \prime}$ \\
\hline & DECLIVIDADE: $51628.8857 \mathrm{M}$ & \\
\hline & DALT: -209.6700 M & \\
\hline DOPS (MÍN-MÁX): & GDOP: $2.6-2.8$ & PDOP: $2.3-2.4$ \\
\hline
\end{tabular}


Tabela 15 - STTU - M02-S

\begin{tabular}{|c|c|c|}
\hline \multicolumn{3}{|l|}{ INFORMAÇÕES DO PROJETO } \\
\hline NOME DO PROJETO & \multicolumn{2}{|l|}{ SUL 02 - ANTES TEMPORAL } \\
\hline DATA DE CRIAÇÃO: & \multicolumn{2}{|l|}{ 06/25/2005 21:29:53 } \\
\hline FUSO HORÁRIO: & \multicolumn{2}{|l|}{$-3 \mathrm{H} 00^{\prime}$} \\
\hline NOME DO SISTEMA DE COORDENADAS: & \multicolumn{2}{|l|}{ WGS-UTM 22} \\
\hline APLICATIVO: & \multicolumn{2}{|l|}{ LEICA SKI-PRO 3.0} \\
\hline PROCESSAMENTO KERNEL: & \multicolumn{2}{|l|}{ PSI-PRO 1.0} \\
\hline PROCESSADO: & \multicolumn{2}{|l|}{ 1/7/2006 10:18 } \\
\hline \multicolumn{3}{|l|}{ INFORMAÇÕES DO PONTO } \\
\hline TIPO DE RECEPTOR / N/S: & SR9500 / 0 & SR520 / 22226 \\
\hline TIPO DE ANTENA / N/S: & AT202/302 GP / - & AX1202 TRENA / - \\
\hline ALTURA DA ANTENA: & $-0.0390 \mathrm{M}$ & 1,580 \\
\hline COORDENADAS INICIAIS: & & \\
\hline ESTE: & $820172.8429 \mathrm{M}$ & $779489.0128 \mathrm{M}$ \\
\hline NORTE: & $7563377.3263 \mathrm{M}$ & $7595258.3676 \mathrm{M}$ \\
\hline ALT. ELIP.: & $824.7000 \mathrm{M}$ & $629.7538 \mathrm{M}$ \\
\hline PARÂMETROS DE PROCESSAMENTO & & \\
\hline PARÂMETROS & SELECIONADO & USADO \\
\hline ÂNGULO DE CORTE: & $15^{\circ}$ & $15^{\circ}$ \\
\hline TIPO DE EFEMÉRIDES: & TRANSMITIDA & TRANSMITIDA \\
\hline TIPO DE SOLUÇÃO: & AUTOMÁTICO & FASE \\
\hline FREQÜÊNCIA: & AUTOMÁTICO & AUTOMÁTICO \\
\hline FIXAR AMBIGÜIDADES ATÉ: & $80 \mathrm{KM}$ & $80 \mathrm{KM}$ \\
\hline $\begin{array}{l}\text { DURAÇÃO MÍN. P/ A SOLUÇÃO FLOAT } \\
\text { (ESTÁTICO): }\end{array}$ & $55^{\prime} 00 "$ & $55^{\prime} 00^{\prime \prime}$ \\
\hline TAXA DE AMOSTRAGEM: & USAR TUDO & 5 \\
\hline MODELO TROPOSFÉRICO: & HOPFIELD & HOPFIELD \\
\hline MODELO IONOSFÉRICO: & KLOBUCHAR & KLOBUCHAR \\
\hline USAR MODELO ESTOCÁSTICO: & SIM & SIM \\
\hline DISTÂNCIA MÍN.: & $8 \mathrm{KM}$ & $8 \mathrm{KM}$ \\
\hline ATIVIDADE IONOSFÉRICA: & AUTOMÁTICO & AUTOMÁTICO \\
\hline SELEÇÃO DE SATÉLITES & & \\
\hline $\begin{array}{l}\text { SATÉLITES DESATIVADOS } \\
\text { MANUALMENTE: }\end{array}$ & NENHUM & \\
\hline ESTATÍSTICAS DA AMBIGÜIDADE & & \\
\hline NÚMERO TOTAL DE AMBIGÜIDADES: & 14 & \\
\hline NÚMERO DE AMBIGÜIDADES FIXADAS: & 14 & \\
\hline NÚMERO DE AMBIGÜIDADES INDEPENDENTES: & 53 & \\
\hline TEMPO MÉDIO ENTRE FIXADAS INDEPENDENTES: & $20 "$ & \\
\hline PORCENTAGEM DE ÉPOCAS FIXADAS (L1): & $100 \%$ & \\
\hline PORCENTAGEM DE ÉPOCAS FIXADAS (L2): & $100 \%$ & \\
\hline PORCENTAGEM DE ÉPOCAS FIXADAS (TUDO): & $100 \%$ & \\
\hline ESTATÍSTICAS GERAIS: & & \\
\hline STATUS $\quad$ DE & DURAÇÃO & \\
\hline FIXADA $\quad 11 / 27 / 200419: 38: 20$ & $366^{\prime} 55^{\prime \prime}$ & \\
\hline ESTATÍSTICAS DA PERDA DE CICLO & & \\
\hline NÚMERO TOTAL DE PERDAS DE CICLO: & 0 & \\
\hline COORDENADAS FINAIS & & \\
\hline ESTE & $820172.8429 \mathrm{M}$ & $779487.9822 \mathrm{M}$ \\
\hline NORTE & $7563377.3263 \mathrm{M}$ & $7595259.9382 \mathrm{M}$ \\
\hline ALT. ELIP & $824.7000 \mathrm{M}$ & $624.9178 \mathrm{M}$ \\
\hline TIPO DE SOLUÇÃO: & FASE & \\
\hline FREQÜÊNCIA: & IONOLIVRE (L3) & \\
\hline AMBIGÜIDADE: & SIM & \\
\hline QUALIDADE: & DP. E: $0.0006 \mathrm{M}$ & DP. N: $0.0006 \mathrm{M}$ \\
\hline & QLD. POS.: $0.0008 \mathrm{M}$ & DP. ALT.: $0.0015 \mathrm{M}$ \\
\hline VETOR DA LINHA DE BASE & DLAT: $0^{\circ} 16^{\prime} 50.69730^{\prime \prime}$ & DLON: $-0^{\circ} 23^{\prime} 56.72773^{\prime \prime}$ \\
\hline & DECLIVIDADE: $51658.3726 \mathrm{M}$ & \\
\hline & DALT: $-199.7822 \mathrm{M}$ & \\
\hline DOPS (MÍN-MÁX): & GDOP: $2.5-3.6$ & PDOP: $2.3-3.2$ \\
\hline
\end{tabular}


Tabela 16 - M02-N - M02-S

\begin{tabular}{|c|c|c|}
\hline INFORMAÇÕES DO PROJETO & & \\
\hline NOME DO PROJETO & SUL 02 - ANTES TEMPORAL & \\
\hline DATA DE CRIAÇÃO: & 06/13/2005 21:29:53 & \\
\hline FUSO HORÁRIO: & $-3 \mathrm{H} 00^{\prime}$ & \\
\hline NOME DO SISTEMA DE COORDENADAS: & WGS-UTM 22 & \\
\hline APLICATIVO: & LEICA SKI-PRO 3.0 & \\
\hline PROCESSAMENTO KERNEL: & PSI-PRO 1.0 & \\
\hline PROCESSADO: & $1 / 6 / 200621: 27$ & \\
\hline INFORMAÇÕES DO PONTO & & \\
\hline TIPO DE RECEPTOR / N/S: & $\mathrm{SR} 20 / 0$ & PROXR \\
\hline TIPO DE ANTENA / N/S: & AT 501 & \\
\hline ALTURA DA ANTENA: & $1.635 \mathrm{M}$ & $1.641 \mathrm{M}$ \\
\hline COORDENADAS INICIAIS: & & \\
\hline ESTE: & $779587.042 \mathrm{M}$ & $779487.8221 \mathrm{M}$ \\
\hline NORTE: & $7595339.0542 \mathrm{M}$ & $7595259.881 \mathrm{M}$ \\
\hline ALT. ELIP.: & $614.9000 \mathrm{M}$ & $624.9478 \mathrm{M}$ \\
\hline PARÂMETROS DE PROCESSAMENTO & & \\
\hline PARÂMETROS & SELECIONADO & USADO \\
\hline ÂNGULO DE CORTE: & $15^{\circ}$ & $15^{\circ}$ \\
\hline TIPO DE EFEMÉRIDES: & TRANSMITIDA & TRANSMITIDA \\
\hline TIPO DE SOLUÇÃO: & AUTOMÁTICO & FASE \\
\hline FREQÜÊNCIA: & SÓ L1 & SÓ L1 \\
\hline FIXAR AMBIGÜIDADES ATÉ: & $80 \mathrm{KM}$ & $80 \mathrm{KM}$ \\
\hline $\begin{array}{l}\text { DURAÇÃO MÍN. P/ A SOLUÇÃO FLOAT } \\
\text { (ESTÁTICO): }\end{array}$ & $5^{\prime} 00^{\prime \prime}$ & 5 5" $00 "$ \\
\hline TAXA DE AMOSTRAGEM: & USAR TUDO & 5 \\
\hline MODELO TROPOSFÉRICO: & HOPFIELD & HOPFIELD \\
\hline MODELO IONOSFÉRICO: & KLOBUCHAR & KLOBUCHAR \\
\hline USAR MODELO ESTOCÁSTICO: & SIM & SIM \\
\hline DISTÂNCIA MÍN.: & $8 \mathrm{KM}$ & $8 \mathrm{KM}$ \\
\hline ATIVIDADE IONOSFÉRICA: & AUTOMÁTICO & AUTOMÁTICO \\
\hline SELEÇÃO DE SATÉLITES & & \\
\hline $\begin{array}{l}\text { SATÉLITES DESATIVADOS } \\
\text { MANUALMENTE: }\end{array}$ & NENHUM & \\
\hline ESTATÍSTICAS DA AMBIGÜIDADE & & \\
\hline NÚMERO TOTAL DE AMBIGÜIDADES: & 7 & \\
\hline NÚMERO DE AMBIGÜIDADES FIXADAS: & 7 & \\
\hline NÚMERO DE AMBIGÜIDADES INDEPENDENTES: & 190 & \\
\hline TEMPO MÉDIO ENTRE FIXADAS INDEPENDENTES: & $10 "$ & \\
\hline PORCENTAGEM DE ÉPOCAS FIXADAS (L1): & $100 \%$ & \\
\hline PORCENTAGEM DE ÉPOCAS FIXADAS (TUDO): & $99 \%$ & \\
\hline ESTATÍSTICAS GERAIS: & & \\
\hline STATUS & DURAÇÃO & \\
\hline $\begin{array}{ll}\text { FIXADA } & 3 / 4 / 200515: 36 \\
\end{array}$ & $50^{\prime} 10^{\prime \prime}$ & \\
\hline ESTATÍSTICAS DA PERDA DE CICLO & & \\
\hline NÚMERO TOTAL DE PERDAS DE CICLO: & 0 & \\
\hline COORDENADAS FINAIS & & \\
\hline ESTE & $779587.3900 \mathrm{M}$ & $779487.9822 \mathrm{M}$ \\
\hline NORTE & $7595338.7492 \mathrm{M}$ & $7595259.9383 \mathrm{M}$ \\
\hline ALT. ELIP & $615.0300 \mathrm{M}$ & $624.9317 \mathrm{M}$ \\
\hline TIPO DE SOLUÇÃO: & FASE & \\
\hline FREQÜÊNCIA: & SÓ L2 & \\
\hline AMBIGÜIDADE: & SIM & \\
\hline QUALIDADE: & DP. E: $0.0001 \mathrm{M}$ & DP. E: $0.0001 \mathrm{M}$ \\
\hline & QLD. POS.: $0.0002 \mathrm{M}$ & QLD. POS.: $0.0002 \mathrm{M}$ \\
\hline & DP. ALT.: $0.0003 \mathrm{M}$ & DP. ALT.: $0.0003 \mathrm{M}$ \\
\hline VETOR DA LINHA DE BASE & DLAT: $-0^{\circ} 00^{\prime} 02.61692 "$ & DLON: $-0^{\circ} 00^{\prime} 03.40861^{\prime \prime}$ \\
\hline & DECLIVIDADE: $127.1850 \mathrm{M}$ & \\
\hline & DALT: $9.9017 \mathrm{M}$ & \\
\hline DOPS (MÍN-MÁX): & GDOP: $2.0-4.0$ & PDOP: $1.8-3.5$ \\
\hline
\end{tabular}


Tabela 17 - STTU - M03-S

\begin{tabular}{|c|c|c|}
\hline \multicolumn{3}{|l|}{ INFORMAÇÕES DO PROJETO } \\
\hline NOME DO PROJETO & SUL 03 & \\
\hline DATA DE CRIAÇÃO: & 06/13/2005 21:30:00 & \\
\hline FUSO HORÁRIO: & $-3 \mathrm{H} \mathrm{O0}^{\prime}$ & \\
\hline NOME DO SISTEMA DE COORDENADAS: & WGS-UTM 22 & \\
\hline APLICATIVO: & LEICA SKI-PRO 3.0 & \\
\hline PROCESSAMENTO KERNEL: & PSI-PRO 1.0 & \\
\hline PROCESSADO: & $1 / 7 / 200617: 45$ & \\
\hline \multicolumn{3}{|l|}{ INFORMAÇÖES DO PONTO } \\
\hline & REFERÊNCIA: STTU & REMOTO: M03-S \\
\hline TIPO DE RECEPTOR / N/S: & SR9500/ 0 & SR520 / 22226 \\
\hline TIPO DE ANTENA / N/S: & AT202/302 GP / - & AX1202 TRENA / - \\
\hline ALTURA DA ANTENA: & $-0.0390 \mathrm{M}$ & 1,560 \\
\hline \multicolumn{3}{|l|}{ COORDENADAS INICIAIS: } \\
\hline ESTE: & $820172.8427 \mathrm{M}$ & $763429.6580 \mathrm{M}$ \\
\hline NORTE: & $7563377.3263 \mathrm{M}$ & $7611824.2051 \mathrm{M}$ \\
\hline ALT. ELIP.: & $824.7000 \mathrm{M}$ & $551.9573 \mathrm{M}$ \\
\hline \multicolumn{3}{|l|}{ PARÂMETROS DE PROCESSAMENTO } \\
\hline PARÂMETROS & SELECIONADO & USADO \\
\hline ÂNGULO DE CORTE: & $15^{\circ}$ & $15^{\circ}$ \\
\hline TIPO DE EFEMÉRIDES: & TRANSMITIDA & TRANSMITIDA \\
\hline TIPO DE SOLUÇÃO: & AUTOMÁTICO & FASE \\
\hline FREQÜÊNCIA: & AUTOMÁTICO & AUTOMÁTICO \\
\hline FIXAR AMBIGÜIDADES ATÉ: & $80 \mathrm{KM}$ & $80 \mathrm{KM}$ \\
\hline DURAÇÃO MÍN. PI A SOLUÇẢO FLOAT & $5.00 "$ & $5.00 "$ \\
\hline \multicolumn{3}{|l|}{ TICO): } \\
\hline TAXA DE AMOSTRAGEM: & USAR TUDO & 5 \\
\hline MODELO TROPOSFÉRICO: & HOPFIELD & HOPFIELD \\
\hline MODELO IONOSFÉRICO: & AUTOMÁTICO & CALCULADO \\
\hline USAR MODELO ESTOCÁSTICO: & SIM & SIM \\
\hline DISTÂNCIA MÍN.: & $8 \mathrm{KM}$ & $8 \mathrm{KM}$ \\
\hline ATIVIDADE IONOSFÉRICA: & AUTOMÁTICO & AUTOMÁTICO \\
\hline \multicolumn{3}{|l|}{ ESTATÍSTICAS GERAIS: } \\
\hline STATUS & PARA & DURAÇÃO \\
\hline 11/27/2004 23:51:00 & 11/28/2004 01:08:25 & $1 \mathrm{H}^{\prime 17} 25^{\prime \prime}$ \\
\hline $11 / 28 / 200401: 08: 25$ & $11 / 28 / 200401: 51: 15$ & $42,50 "$ \\
\hline \multicolumn{3}{|l|}{ SELEÇÃO DE SATÉLITES } \\
\hline & JANELA DE SATÉLITES & DURAÇÃO \\
\hline \multirow{2}{*}{ SATÉLITES DESATIVADOS MANUALMENTE: } & SV 04 & 9' $52 "$ \\
\hline & SV 07 & 4' 15" \\
\hline \multicolumn{3}{|l|}{ ESTATÍSTICAS DA AMBIGÜIDADE } \\
\hline NÚMERO TOTAL DE AMBIGÜIDADES: & 351 & \\
\hline NÚMERO DE AMBIGÜIDADES FIXADAS: & 8 & \\
\hline NÚMERO DE AMBIGÜIDADES INDEPENDENTES: & 67 & \\
\hline TEMPO MÉDIO ENTRE FIXADAS INDEPENDENTES: & $10 "$ & \\
\hline PORCENTAGEM DE ÉPOCAS FIXADAS (L1): & $69 \%$ & \\
\hline PORCENTAGEM DE ÉPOCAS FIXADAS (L2): & $71 \%$ & \\
\hline PORCENTAGEM DE ÉPOCAS FIXADAS (TUDO): & $64 \%$ & \\
\hline \multicolumn{3}{|l|}{ ESTATISTICAS DA PERDA DE CICLO } \\
\hline NÚMERO TOTAL DE PERDAS DE CICLO: & 195 & \\
\hline \multicolumn{3}{|l|}{ COORDENADAS FINAIS } \\
\hline COORDENADAS: & REFERÊNCIA: STTU & REMOTO: M03-S \\
\hline ESTE & $820172.8427 \mathrm{M}$ & $763429.6686 \mathrm{M}$ \\
\hline NORTE & $7563377.3263 \mathrm{M}$ & $7611824.2102 \mathrm{M}$ \\
\hline ALT. ELIP & $824.7000 \mathrm{M}$ & $551.9684 \mathrm{M}$ \\
\hline TIPO DE SOLUÇÃO: & FASE & \\
\hline FREQÜÊNCIA: & IONOLIVRE (L3) & \\
\hline AMBIGÜIDADE: & SIM & \\
\hline \multirow[t]{3}{*}{ QUALIDADE: } & DP. E: $0.0005 \mathrm{M}$ & DP. N: $0.0005 \mathrm{M}$ \\
\hline & QLD. POS.: $0.0007 \mathrm{M}$ & DP. DECLIVID: $0.0004 \mathrm{M}$ \\
\hline & DP. ALT.: $0.0019 \mathrm{M}$ & \\
\hline \multirow[t]{3}{*}{ VETOR DA LINHA DE BASE } & DLAT: $0^{\circ} 25^{\prime} 40.07765^{\prime \prime}$ & DLON: $-0^{\circ} 33^{\prime} 24.57268 "$ \\
\hline & DECLIVIDADE: $74570.8372 \mathrm{M}$ & \\
\hline & DALT: -272.7316 M & \\
\hline DOPS (MÍN-MÁX): & GDOP: $3.2-16.1$ & PDOP: $2.8-13.6$ \\
\hline
\end{tabular}


Tabela 18 - STTU - M03-N

\begin{tabular}{|c|c|c|c|}
\hline \multicolumn{4}{|l|}{ INFORMAÇŌES DO PROJETO } \\
\hline NOME DO PROJETO & SUL 03 & & \\
\hline DATA DE CRIAÇÃO: & 06/13/2005 21:30:00 & & \\
\hline FUSO HORÁRIO: & $-3 \mathrm{H} 00^{\prime}$ & & \\
\hline NOME DO SISTEMA DE COORDENADAS: & WGS-UTM 22 & & \\
\hline APLICATIVO: & LEICA SKI-PRO 3.0 & & \\
\hline PROCESSAMENTO KERNEL: & PSI-PRO 1.0 & & \\
\hline PROCESSADO: & $1 / 7 / 200617: 45$ & & \\
\hline \multicolumn{4}{|l|}{ INFORMAÇÕES DO PONTO } \\
\hline & REFERÊNCIA: STTU & & REMOTO: M01-N \\
\hline TIPO DE RECEPTOR / N/S: & SR9500/0 & & SR520 / 22223 \\
\hline TIPO DE ANTENA / N/S: & AT202/302 GP / - & & AX1202 TRENA / - \\
\hline ALTURA DA ANTENA: & $-0.0390 \mathrm{M}$ & & $1.548 \mathrm{M}$ \\
\hline \multicolumn{4}{|l|}{ COORDENADAS INICIAIS: } \\
\hline ESTE: & $820172.8427 \mathrm{M}$ & & $763433.3859 \mathrm{M}$ \\
\hline NORTE: & $7563377.3263 \mathrm{M}$ & & $7611921.5073 \mathrm{M}$ \\
\hline ALT. ELIP.: & $824.7000 \mathrm{M}$ & & $553.4507 \mathrm{M}$ \\
\hline \multicolumn{4}{|l|}{ PARÂMETROS DE PROCESSAMENTO } \\
\hline PARÂMETROS & SELECIONADO & & USADO \\
\hline ÂNGULO DE CORTE: & $15^{\circ}$ & & $15^{\circ}$ \\
\hline TIPO DE EFEMÉRIDES: & TRANSMITIDA & & TRANSMITIDA \\
\hline TIPO DE SOLUÇÃO: & AUTOMÁTICO & & FASE \\
\hline FREQÜÊNCIA: & AUTOMÁTICO & & AUTOMÁTICO \\
\hline FIXAR AMBIGÜIDADES ATÉ: & $80 \mathrm{KM}$ & & $80 \mathrm{KM}$ \\
\hline DURAÇÃO MÍN. P/ A SOLUÇÃO & 5 50" & & 5 50" \\
\hline FLOAT (ESTÁTICO): & & & \\
\hline TAXA DE AMOSTRAGEM: & USAR TUDO & & 5 \\
\hline MODELO TROPOSFÉRICO: & HOPFIELD & & HOPFIELD \\
\hline MODELO IONOSFÉRICO: & KLOBUCHAR & & KLOBUCHAR \\
\hline USAR MODELO ESTOCÁSTICO: & SIM & & SIM \\
\hline DISTÂNCIA MÍN.: & $8 \mathrm{KM}$ & & $8 \mathrm{KM}$ \\
\hline ATIVIDADE IONOSFÉRICA: & AUTOMÁTICO & & AUTOMÁTICO \\
\hline \multicolumn{4}{|l|}{ ESTATISTICAS GERAIS: } \\
\hline STATUS $\quad$ DE & PARA & & DURAÇÃO \\
\hline NÃO $\quad 11 / 27 / 200423: 45: 25$ & 11/27/2004 23:46:55 & & 1'30" \\
\hline FIXADA $\quad 11 / 27 / 200423: 46: 55$ & 11/28/2004 01:08:30 & & $1 \mathrm{H} 21^{\prime} 35^{\prime \prime}$ \\
\hline NÃO $\quad 11 / 28 / 2004$ 01:08:30 & 11/28/2004 01:58:05 & & $49^{\prime} 35^{\prime \prime}$ \\
\hline \multicolumn{4}{|l|}{ SELEÇÃO DE SATÉLITES } \\
\hline & JANELA DE SATÉLITES & & DURAÇẪO \\
\hline \multirow{2}{*}{$\begin{array}{l}\text { SATÉLITES DESATIVADOS } \\
\text { MANUALMENTE: }\end{array}$} & SV 07 & & 9'52" \\
\hline & SV 20 & & $22^{\prime} 50^{\prime \prime}$ \\
\hline \multicolumn{4}{|l|}{ ESTATÍSTICAS DA AMBIGÜIDADE } \\
\hline \multicolumn{2}{|l|}{ NÚMERO TOTAL DE AMBIGÜIDADES: } & 438 & \\
\hline \multicolumn{2}{|l|}{ NÚMERO DE AMBIGÜIDADES FIXADAS: } & 8 & \\
\hline \multicolumn{2}{|l|}{ NÚMERO DE AMBIGÜIDADES INDEPENDENTES: } & 43 & \\
\hline \multicolumn{2}{|l|}{ TEMPO MÉDIO ENTRE FIXADAS INDEPENDENTES: } & $20 "$ & \\
\hline \multicolumn{2}{|l|}{ PORCENTAGEM DE ÉPOCAS FIXADAS (L1): } & $64 \%$ & \\
\hline \multicolumn{2}{|l|}{ PORCENTAGEM DE ÉPOCAS FIXADAS (L2): } & $67 \%$ & \\
\hline PORCENTAGEM DE ÉPOCAS FIXADAS (TUDO): & & $61 \%$ & \\
\hline ESTATÍSTICAS DA PERDA DE CICLO & & & \\
\hline NÚMERO TOTAL DE PERDAS DE CICLO: & 245 & & \\
\hline COORDENADAS FINAIS & & & \\
\hline COORDENADAS: & REFERÊNCIA: STTU & & REMOTO: M03-N \\
\hline ESTE & $820172.8429 \mathrm{M}$ & & $763433.3972 \mathrm{M}$ \\
\hline NORTE & $7563377.3263 \mathrm{M}$ & & $7611921.5124 \mathrm{M}$ \\
\hline ALT. ELIP & $824.7000 \mathrm{M}$ & & $553.4636 \mathrm{M}$ \\
\hline TIPO DE SOLUÇÃO: & FASE & & \\
\hline FREQÜÊNCIA: & IONOLIVRE (L3) & & \\
\hline AMBIGÜIDADE: & SIM & & \\
\hline QUALIDADE: & DP. E: $0.0004 \mathrm{M}$ & & DP. N: $0.0005 \mathrm{M}$ \\
\hline & QLD. POS.: $0.0007 \mathrm{M}$ & & DP. DECLIVID: $0.0004 \mathrm{M}$ \\
\hline & DP. ALT.: $0.0019 \mathrm{M}$ & & \\
\hline VETOR DA LINHA DE BASE & DLAT: $0^{\circ} 25^{\prime} 43.24136^{\prime \prime}$ & & DLON: $-0^{\circ} 33^{\prime} 24.49838^{\prime \prime}$ \\
\hline & DECLIVIDADE: $74631.1889 \mathrm{M}$ & & \\
\hline & DALT: $-271.2364 \mathrm{M}$ & & \\
\hline DOPS (MÍN-MÁX): & GDOP: $3.1-20.0$ & & PDOP: $2.7-16.9$ \\
\hline
\end{tabular}


Tabela 19 - M03-N - M03-S

\begin{tabular}{|c|c|c|}
\hline INFORMAÇÕES DO PROJETO & & \\
\hline NOME DO PROJETO & SUL 03 & \\
\hline DATA DE CRIAÇÃO: & 06/13/2005 21:30:00 & \\
\hline FUSO HORÁRIO: & $-3 \mathrm{H} 00^{\prime}$ & \\
\hline NOME DO SISTEMA DE COORDENADAS: & WGS-UTM 22 & \\
\hline APLICATIVO: & LEICA SKI-PRO 3.0 & \\
\hline PROCESSAMENTO KERNEL: & PSI-PRO 1.0 & \\
\hline PROCESSADO: & $1 / 7 / 200618: 35$ & \\
\hline INFORMAÇÕES DO PONTO & & \\
\hline & REFERÊNCIA: M02-N & REMOTO: M02-S \\
\hline TIPO DE RECEPTOR / N/S: & SR20 / 0 & PROXR \\
\hline TIPO DE ANTENA / N/S: & AT 501 & \\
\hline ALTURA DA ANTENA: & $1.599 \mathrm{M}$ & $1.601 \mathrm{M}$ \\
\hline COORDENADAS INICIAIS: & & \\
\hline ESTE: & $763433.4972 \mathrm{M}$ & $763429.6781 \mathrm{M}$ \\
\hline NORTE: & $7611921.4984 \mathrm{M}$ & $7611824.3412 \mathrm{M}$ \\
\hline ALT. ELIP.: & $553.4873 \mathrm{M}$ & $551.899 \mathrm{M}$ \\
\hline PARÂMETROS DE PROCESSAMENTO & & \\
\hline PARÂMETROS & SELECIONADO & USADO \\
\hline ÂNGULO DE CORTE: & $15^{\circ}$ & $15^{\circ}$ \\
\hline TIPO DE EFEMÉRIDES: & TRANSMITIDA & TRANSMITIDA \\
\hline TIPO DE SOLUÇÃO: & AUTOMÁTICO & FASE \\
\hline FREQÜÊNCIA: & $\mathrm{L} 1$ & $\mathrm{~L} 1$ \\
\hline FIXAR AMBIGÜIDADES ATÉ: & $80 \mathrm{KM}$ & $80 \mathrm{KM}$ \\
\hline $\begin{array}{l}\text { DURAÇÃO MÍN. PI A SOLUÇÃO } \\
\text { FLOAT (ESTÁTICO): }\end{array}$ & $55^{\prime} 00 "$ & 5'00" \\
\hline TAXA DE AMOSTRAGEM: & USAR TUDO & 5 \\
\hline MODELO TROPOSFÉRICO: & HOPFIELD & HOPFIELD \\
\hline MODELO IONOSFÉRICO: & AUTOMÁTICO & CALCULADO \\
\hline USAR MODELO ESTOCÁSTICO: & SIM & SIM \\
\hline DISTÂNCIA MÍN.: & $8 \mathrm{KM}$ & $8 \mathrm{KM}$ \\
\hline ATIVIDADE IONOSFÉRICA: & AUTOMÁTICO & AUTOMÁTICO \\
\hline ESTATÍSTICAS GERAIS: & & \\
\hline STATUS DE & PARA & DURAÇÃO \\
\hline FIXADA $\quad 3 / 4 / 200513: 44$ & $3 / 4 / 200514: 48$ & $1 \mathrm{H}^{\circ} 04^{\prime} 10^{\prime \prime}$ \\
\hline SELEÇÃO DE SATÉLITES & & \\
\hline $\begin{array}{l}\text { SATÉLITES DESATIVADOS } \\
\text { MANUALMENTE: }\end{array}$ & & \\
\hline ESTATÍSTICAS DA AMBIGÜIDADE & & \\
\hline NÚMERO TOTAL DE AMBIGÜIDADES: & 7 & \\
\hline NÚMERO DE AMBIGÜIDADES FIXADAS: & 7 & \\
\hline NÚMERO DE AMBIGÜIDADES INDEPENDENTES: & 190 & \\
\hline TEMPO MÉDIO ENTRE FIXADAS INDEPENDENTES: & $10^{\prime \prime}$ & \\
\hline PORCENTAGEM DE ÉPOCAS FIXADAS (L1): & $100 \%$ & \\
\hline PORCENTAGEM DE ÉPOCAS FIXADAS (TUDO): & $99 \%$ & \\
\hline ESTATÍSTICAS DA PERDA DE CICLO & & \\
\hline NÚMERO TOTAL DE PERDAS DE CICLO: & 10 & \\
\hline COORDENADAS FINAIS & & \\
\hline COORDENADAS: & REFERÊNCIA: M03-N & REMOTO: M03-S \\
\hline ESTE & $763433.3972 \mathrm{M}$ & $763429.6700 \mathrm{M}$ \\
\hline NORTE & $7611921.5124 \mathrm{M}$ & $7611824.2104 \mathrm{M}$ \\
\hline ALT. ELIP & $553.4636 \mathrm{M}$ & $551.9702 \mathrm{M}$ \\
\hline TIPO DE SOLUÇÃO: & FASE & \\
\hline FREQÜÊNCIA: & $\mathrm{L} 2$ & \\
\hline AMBIGÜIDADE: & SIM & \\
\hline QUALIDADE: & DP. E: $0.0001 \mathrm{M}$ & DP. N: $0.0001 \mathrm{M}$ \\
\hline & QLD. POS.: $0.0001 \mathrm{M}$ & DP. DECLIVID: $0.0001 \mathrm{M}$ \\
\hline & DP. ALT.: $0.0002 \mathrm{M}$ & \\
\hline VETOR DA LINHA DE BASE & DLAT: $-0^{\circ} 00^{\prime} 03.16370^{\prime \prime}$ & DLON: $-0^{\circ} 00^{\prime} 00.07425^{\prime \prime}$ \\
\hline & DECLIVIDADE: $97.3488 \mathrm{M}$ & \\
\hline & DALT: $-1.4934 \mathrm{M}$ & \\
\hline DOPS (MÍN-MÁX): & GDOP: $2.6-3.1$ & PDOP: $2.3-3.9$ \\
\hline
\end{tabular}


Tabela 20 - STTU - M04-N

\begin{tabular}{|c|c|c|}
\hline INFORMAÇÕES DO PROJETO & & \\
\hline NOME DO PROJETO & SUL 04 & \\
\hline DATA DE CRIAÇÃO: & 06/13/2005 21:30:10 & \\
\hline FUSO HORÁRIO: & $-3 \mathrm{H} 00^{\prime}$ & \\
\hline NOME DO SISTEMA DE COORDENADAS: & WGS-UTM 22 & \\
\hline APLICATIVO: & LEICA SKI-PRO 3.0 & \\
\hline PROCESSAMENTO KERNEL: & PSI-PRO 1.0 & \\
\hline PROCESSADO: & 06/26/2005 18:25:49 & \\
\hline \multicolumn{3}{|l|}{ INFORMAÇÕES DO PONTO } \\
\hline & REFERÊNCIA: STTU & REMOTO: M04-N \\
\hline TIPO DE RECEPTOR / N/S: & SR9500/ 0 & SR520 / 22223 \\
\hline TIPO DE ANTENA / N/S: & AT202/302 GP / - & AX1202 TRENA / - \\
\hline ALTURA DA ANTENA: & $-0.0390 \mathrm{M}$ & $1.4960 \mathrm{M}$ \\
\hline \multicolumn{3}{|l|}{ COORDENADAS INICIAIS: } \\
\hline ESTE: & $820172.8427 \mathrm{M}$ & $738539.5516 \mathrm{M}$ \\
\hline NORTE: & $7563377.3263 \mathrm{M}$ & $7631201.3995 \mathrm{M}$ \\
\hline ALT. ELIP.: & $824.7000 \mathrm{M}$ & $505.3974 \mathrm{M}$ \\
\hline \multicolumn{3}{|l|}{ PARÂMETROS DE PROCESSAMENTO } \\
\hline PARÂMETROS & SELECIONADO & USADO \\
\hline ÂNGULO DE CORTE: & $15^{\circ}$ & $15^{\circ}$ \\
\hline TIPO DE EFEMÉRIDES: & TRANSMITIDA & TRANSMITIDA \\
\hline TIPO DE SOLUÇÃO: & AUTOMÁTICO & FASE \\
\hline FREQÜÊNCIA: & AUTOMÁTICO & AUTOMÁTICO \\
\hline FIXAR AMBIGÜIDADES ATÉ: & $80 \mathrm{KM}$ & $80 \mathrm{KM}$ \\
\hline $\begin{array}{l}\text { DURAÇÃO MÍN. PI A SOLUÇÃO } \\
\text { FLOAT (ESTÁTICO): }\end{array}$ & $55^{\prime} 00 "$ & 5' 00" \\
\hline TAXA DE AMOSTRAGEM: & USAR TUDO & 5 \\
\hline MODELO TROPOSFÉRICO: & HOPFIELD & HOPFIELD \\
\hline MODELO IONOSFÉRICO: & AUTOMÁTICO & CALCULADO \\
\hline USAR MODELO ESTOCÁSTICO: & SIM & SIM \\
\hline DISTÂNCIA MÍN.: & $8 \mathrm{KM}$ & $8 \mathrm{KM}$ \\
\hline ATIVIDADE IONOSFÉRICA: & AUTOMÁTICO & AUTOMÁTICO \\
\hline \multicolumn{3}{|l|}{ ESTATÍSTICAS GERAIS: } \\
\hline STATUS $\quad$ DE & PARA & DURAÇÃO \\
\hline $\begin{array}{ll}\text { FIXADA } & 11 / 28 / 200413: 33: 10 \\
\end{array}$ & 11/28/2004 16:40:55 & $3 \mathrm{H} 07^{\prime} 45^{\prime \prime}$ \\
\hline \multicolumn{3}{|l|}{ SELEÇÃO DE SATÉLITES } \\
\hline \multicolumn{3}{|l|}{$\begin{array}{l}\text { SATÉLITES DESATIVADOS } \\
\text { NUALMENTE: }\end{array}$} \\
\hline \multicolumn{3}{|l|}{ ESTATÍSTICAS DA AMBIGÜIDADE } \\
\hline NÚMERO TOTAL DE AMBIGÜIDADES: & \multicolumn{2}{|l|}{29} \\
\hline NÚMERO DE AMBIGÜIDADES FIXADAS: & \multicolumn{2}{|l|}{26} \\
\hline NÚMERO DE AMBIGÜIDADES INDEPENDENTES: & \multicolumn{2}{|l|}{729} \\
\hline TEMPO MÉDIO ENTRE FIXADAS INDEPENDENTES: & \multicolumn{2}{|l|}{$10^{\prime \prime}$} \\
\hline PORCENTAGEM DE ÉPOCAS FIXADAS (L1): & \multicolumn{2}{|l|}{$100 \%$} \\
\hline PORCENTAGEM DE ÉPOCAS FIXADAS (L2): & \multicolumn{2}{|l|}{$100 \%$} \\
\hline PORCENTAGEM DE ÉPOCAS FIXADAS (TUDO): & \multicolumn{2}{|l|}{$100 \%$} \\
\hline \multicolumn{3}{|l|}{ ESTATÍSTICAS DA PERDA DE CICLO } \\
\hline NÚMERO TOTAL DE PERDAS DE CICLO: & 1 & \\
\hline \multicolumn{3}{|l|}{ COORDENADAS FINAIS } \\
\hline COORDENADAS: & REFERÊNCIA: STTU & REMOTO: M04-N \\
\hline ESTE & $820172.8427 \mathrm{M}$ & $738540.6728 \mathrm{M}$ \\
\hline NORTE & $7563377.3263 \mathrm{M}$ & $7631201.8640 \mathrm{M}$ \\
\hline ALT. ELIP & $824.7000 \mathrm{M}$ & $505.3842 \mathrm{M}$ \\
\hline TIPO DE SOLUÇÃO: & FASE & \\
\hline FREQÜÊNCIA: & IONOLIVRE (L3) & \\
\hline AMBIGÜIDADE: & SIM & \\
\hline \multirow[t]{2}{*}{ QUALIDADE: } & DP. E: $0.0002 \mathrm{M}$ & DP. N: $0.0002 \mathrm{M}$ \\
\hline & QLD. POS.: $0.0003 \mathrm{M}$ & DP. ALT.: $0.0006 \mathrm{M}$ \\
\hline \multirow[t]{3}{*}{ VETOR DA LINHA DE BASE } & DLAT: $0^{\circ} 35^{\prime} 57.26019^{\prime \prime}$ & DLON: $-0^{\circ} 47^{\prime} 59.22039 "$ \\
\hline & DECLIVIDADE: $106081.6335 \mathrm{M}$ & \\
\hline & DALT: $-319.3158 \mathrm{M}$ & \\
\hline DOPS (MÍN-MÁX): & GDOP: $2.0-5.9$ & PDOP: $1.7-4.7$ \\
\hline
\end{tabular}


Tabela 21 - STTU - M04-S

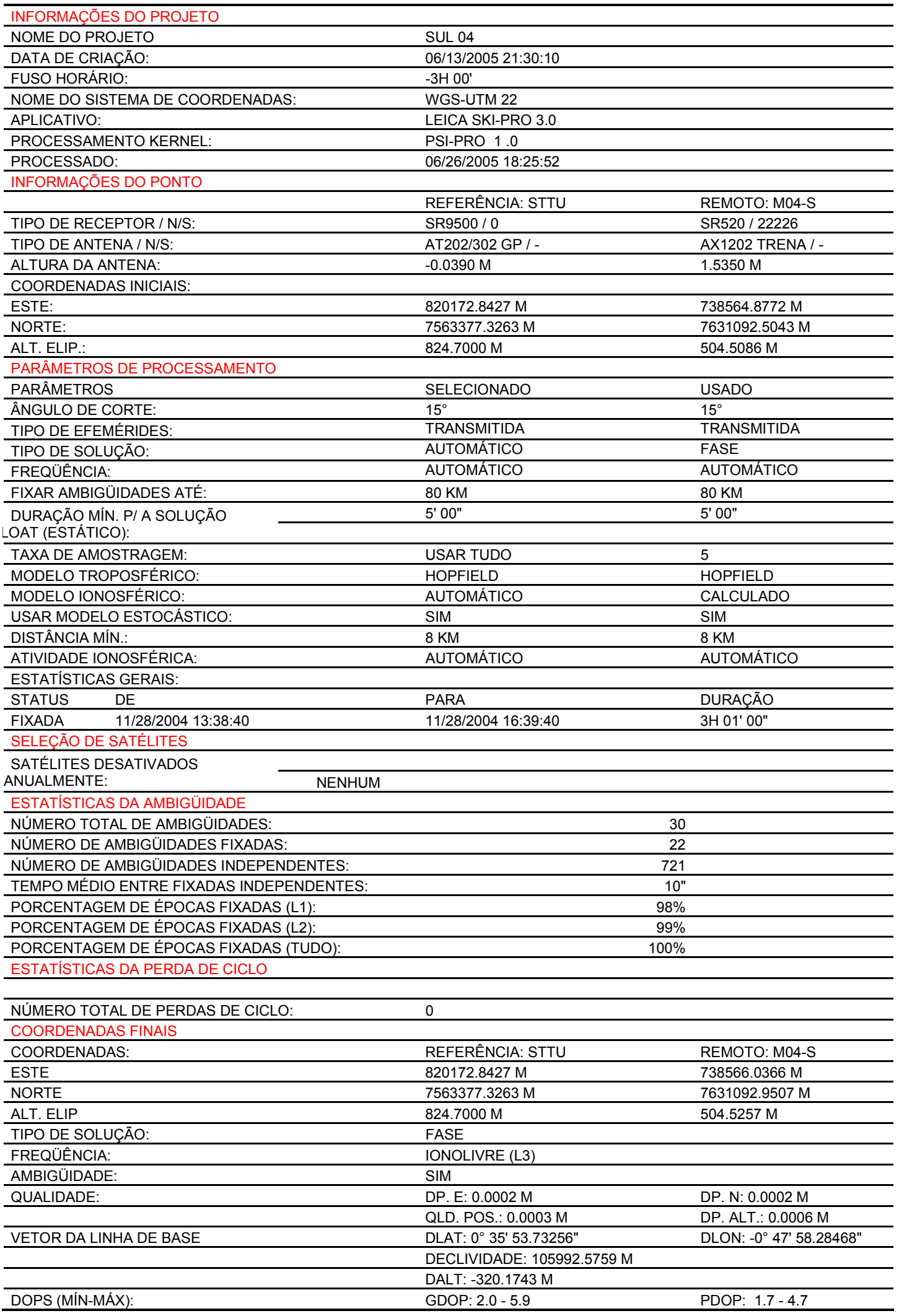


Tabela 22 - M04-N - M04-S

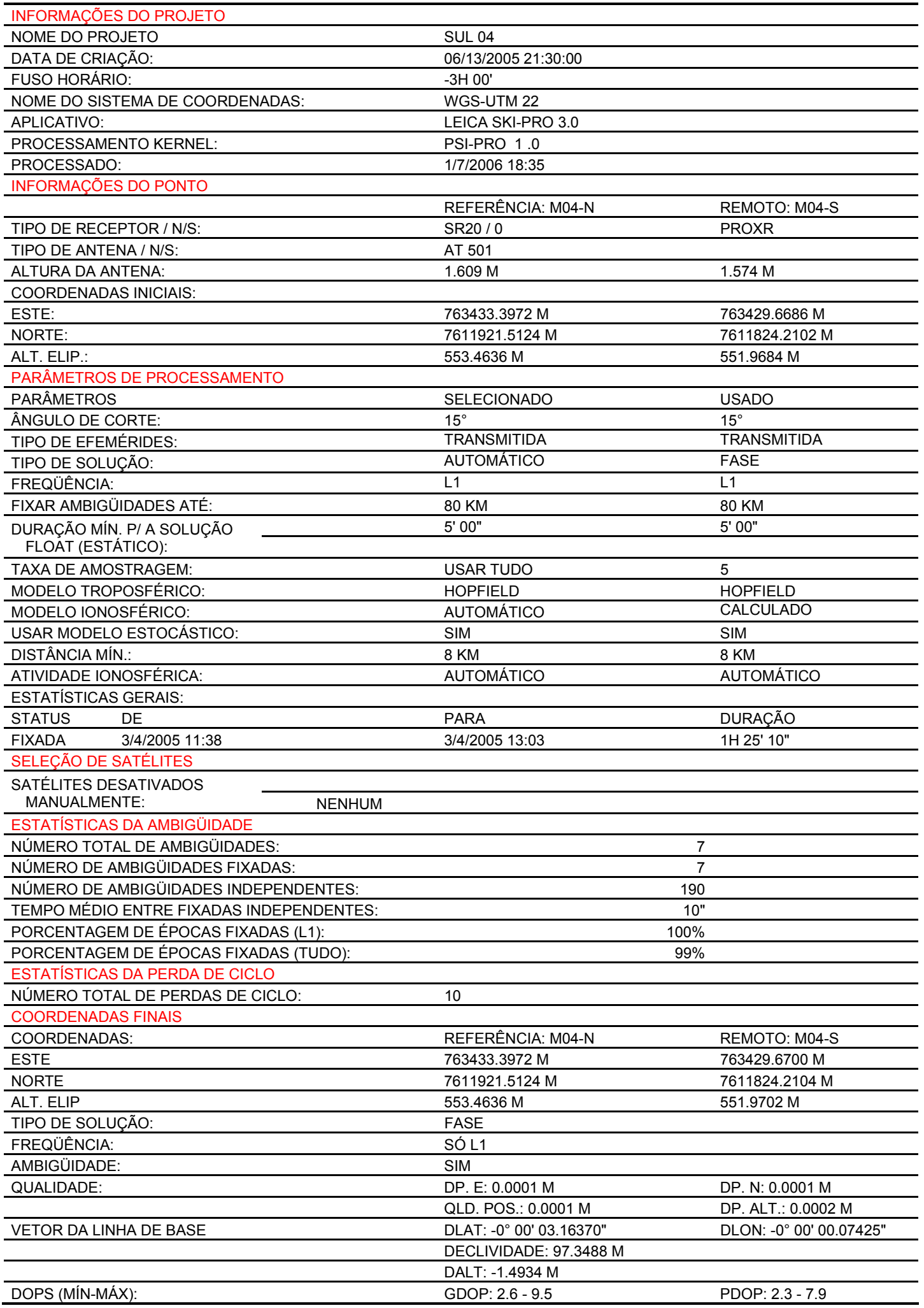


Tabela 23 - STTU - M05-N

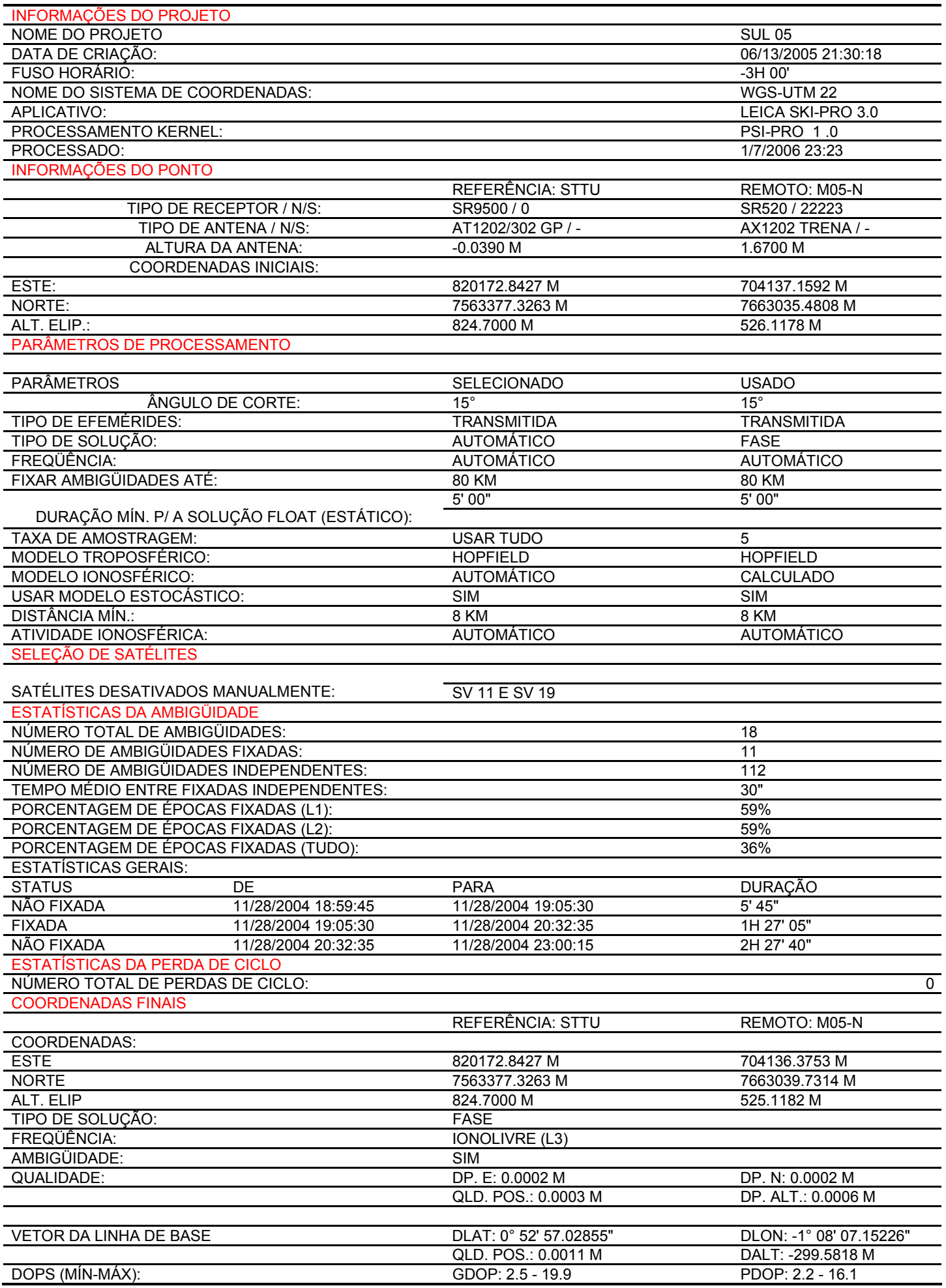


Tabela 24 - STTU - M05-S

\begin{tabular}{|c|c|c|c|}
\hline \multicolumn{4}{|l|}{ INFORMAÇŐES DO PROJETO } \\
\hline NOME DO PROJETO & & SUL 05 & \\
\hline DATA DE CRIAÇÃO: & & 06/13/2005 21:30:18 & \\
\hline FUSO HORÁRIO: & & $-3 \mathrm{H} 00^{\prime}$ & \\
\hline NOME DO SISTEMA DE COORDENADAS: & & WGS-UTM 22 & \\
\hline APLICATIVO: & & LEICA SKI-PRO 3.0 & \\
\hline PROCESSAMENTO KERNEL: & & PSI-PRO 1.0 & \\
\hline PROCESSADO: & & 1/7/2006 23:23 & \\
\hline \multicolumn{4}{|l|}{ INFORMAÇŐES DO PONTO } \\
\hline & REFERÊNCIA: STTU & REMOTO: M05-S & \\
\hline TIPO DE RECEPTOR / N/S: & SR9500/ 0 & SR520 / 22226 & \\
\hline TIPO DE ANTENA / N/S: & AT202/302 GP / - & AX1202 TRENA / - & \\
\hline ALTURA DA ANTENA: & $-0.0390 \mathrm{M}$ & $1.5490 \mathrm{M}$ & \\
\hline \multicolumn{4}{|l|}{ COORDENADAS INICIAIS: } \\
\hline ESTE: & $820172.8427 \mathrm{M}$ & $704011.3761 \mathrm{M}$ & \\
\hline NORTE: & $7563377.3263 \mathrm{M}$ & $7662964.2064 \mathrm{M}$ & \\
\hline ALT. ELIP.: & $824.7000 \mathrm{M}$ & $529.5868 \mathrm{M}$ & \\
\hline \multicolumn{4}{|l|}{ PARÂMETROS DE PROCESSAMENTO } \\
\hline PARÂMETROS & SELECIONADO & USADO & \\
\hline ÂNGULO DE CORTE: & $15^{\circ}$ & $15^{\circ}$ & \\
\hline TIPO DE EFEMÉRIDES: & TRANSMITIDA & TRANSMITIDA & \\
\hline TIPO DE SOLUÇÃO: & AUTOMÁTICO & FASE & \\
\hline FREQÜÊNCIA: & AUTOMÁTICO & AUTOMÁTICO & \\
\hline FIXAR AMBIGÜIDADES ATÉ: & $80 \mathrm{KM}$ & $80 \mathrm{KM}$ & \\
\hline & 5' 00" & 5'00" & \\
\hline \multicolumn{4}{|l|}{ DURAÇÃO MÍN. P/ A SOLUÇÃO FLOAT (ESTÁTICO): } \\
\hline TAXA DE AMOSTRAGEM: & USAR TUDO & 5 & \\
\hline MODELO TROPOSFÉRICO: & HOPFIELD & HOPFIELD & \\
\hline MODELO IONOSFÉRICO: & AUTOMÁTICO & CALCULADO & \\
\hline USAR MODELO ESTOCÁSTICO: & SIM & SIM & \\
\hline DISTÂNCIA MÍN.: & $8 \mathrm{KM}$ & $8 \mathrm{KM}$ & \\
\hline ATIVIDADE IONOSFÉRICA: & AUTOMÁTICO & AUTOMÁTICO & \\
\hline \multicolumn{4}{|l|}{ SELEÇÃO DE SATÉLITES } \\
\hline \multirow{2}{*}{$\begin{array}{l}\text { SATÉLITES DESATIVADOS MANUALMENTE: } \\
\text { ESTATÍSTICAS DA AMBIGÜIDADE }\end{array}$} & SV 11 E SV 19 & & \\
\hline & \multicolumn{3}{|c|}{ ESTATÍSTICAS DA AMBIGÜIDADE } \\
\hline \multicolumn{2}{|l|}{ NÚMERO TOTAL DE AMBIGÜIDADES: } & 16 & \\
\hline \multicolumn{2}{|l|}{ NÚMERO DE AMBIGÜIDADES FIXADAS: } & 11 & \\
\hline \multicolumn{2}{|l|}{ NÚMERO DE AMBIGÜIDADES INDEPENDENTES: } & 171 & \\
\hline \multicolumn{2}{|l|}{ TEMPO MÉDIO ENTRE FIXADAS INDEPENDENTES: } & $20 "$ & \\
\hline \multicolumn{2}{|l|}{ PORCENTAGEM DE ÉPOCAS FIXADAS (L1): } & $59 \%$ & \\
\hline \multicolumn{2}{|l|}{ PORCENTAGEM DE ÉPOCAS FIXADAS (L2): } & $60 \%$ & \\
\hline \multicolumn{2}{|l|}{ PORCENTAGEM DE ÉPOCAS FIXADAS (TUDO): } & $35 \%$ & \\
\hline \multicolumn{4}{|l|}{ ESTATÍSTICAS GERAIS: } \\
\hline & PARA & DURAÇÃO & \\
\hline NÃO FIXADA 11/28/2004 18:53:15 & $11 / 28 / 200419: 05: 30$ & $12^{\prime} 15^{\prime \prime}$ & \\
\hline $\begin{array}{ll}\text { FIXADA } & 11 / 28 / 200419: 05: 30 \\
\end{array}$ & $11 / 28 / 200420: 32: 35$ & $1 \mathrm{H}_{2} 27^{\prime} 05^{\prime \prime}$ & \\
\hline NÃO FIXADA $11 / 28 / 200420: 32: 35$ & 11/28/2004 23:01:10 & $2 \mathrm{H} 28^{\prime} 35^{\prime \prime}$ & \\
\hline ESTATÍSTICAS DA PERDA DE CICLO & & & \\
\hline NÚMERO TOTAL DE PERDAS DE CICLO: & & & 0 \\
\hline COORDENADAS FINAIS & & & \\
\hline COORDENADAS: & REFERÊNCIA: STTU & REMOTO: M05-S & \\
\hline ESTE & $820172.8427 \mathrm{M}$ & $704010.5965 \mathrm{M}$ & \\
\hline NORTE & $7563377.3263 \mathrm{M}$ & $7662968.4268 \mathrm{M}$ & \\
\hline ALT. ELIP & $824.7000 \mathrm{M}$ & $528.7662 \mathrm{M}$ & \\
\hline TIPO DE SOLUÇÃO: & FASE & & \\
\hline FREQÜÊNCIA: & IONOLIVRE (L3) & & \\
\hline AMBIGÜIDADE: & SIM & & \\
\hline QUALIDADE: & DP. E: $0.0009 \mathrm{M}$ & DP. N: $0.0006 \mathrm{M}$ & \\
\hline & QLD. POS.: $0.0011 \mathrm{M}$ & DP. ALT.: $0.0009 \mathrm{M}$ & \\
\hline VETOR DA LINHA DE BASE & DLAT: $0^{\circ} 52^{\prime} 54.65999^{\prime \prime}$ & DLON: $-1^{\circ} 08^{\prime} 11.47957^{\prime \prime}$ & \\
\hline & DECLIVIDADE: $152952.0736 \mathrm{M}$ & & \\
\hline DOPS (MÍN-MÁX): & GDOP: $2.5-19.7$ & PDOP: $2.2-16.0$ & \\
\hline
\end{tabular}


Tabela 25 - M05-N - M05-S

\begin{tabular}{|c|c|c|}
\hline INFORMAÇÕES DO PROJETO & & \\
\hline NOME DO PROJETO & & SUL 05 \\
\hline DATA DE CRIAÇÃO: & & 06/13/2005 21:30:18 \\
\hline FUSO HORÁRIO: & & $-3 \mathrm{H} 00^{\prime}$ \\
\hline NOME DO SISTEMA DE COORDENADAS: & & WGS-UTM 22 \\
\hline APLICATIVO: & & LEICA SKI-PRO 3.0 \\
\hline PROCESSAMENTO KERNEL: & & PSI-PRO 1.0 \\
\hline PROCESSADO: & & 1/7/2006 23:24 \\
\hline INFORMAÇÕES DO PONTO & & \\
\hline & REFERÊNCIA: M05-S & REMOTO: M05-N \\
\hline TIPO DE RECEPTOR / N/S: & SR20 / 0 & PROXR \\
\hline TIPO DE ANTENA / N/S: & AT 501 & \\
\hline ALTURA DA ANTENA: & $1.568 \mathrm{M}$ & $1.506 \mathrm{M}$ \\
\hline COORDENADAS INICIAIS: & & \\
\hline ESTE: & $704010.5782 \mathrm{M}$ & $704136.578 \mathrm{M}$ \\
\hline NORTE: & $7662968.4514 \mathrm{M}$ & $7663039.8455 \mathrm{M}$ \\
\hline ALT. ELIP.: & $528.4862 \mathrm{M}$ & $525.2282 \mathrm{M}$ \\
\hline PARÂMETROS DE PROCESSAMENTO & & \\
\hline PARÂMETROS & SELECIONADO & USADO \\
\hline ÂNGULO DE CORTE: & $15^{\circ}$ & $15^{\circ}$ \\
\hline TIPO DE EFEMÉRIDES: & TRANSMITIDA & TRANSMITIDA \\
\hline TIPO DE SOLUÇÃO: & AUTOMÁTICO & FASE \\
\hline FREQÜÊNCIA: & L1 & L1 \\
\hline FIXAR AMBIGÜIDADES ATÉ: & $80 \mathrm{KM}$ & $80 \mathrm{KM}$ \\
\hline & 5'00" & 5'00" \\
\hline DURAÇÃO MÍN. P/ A SOLUÇÃO FLOAT (ESTÁTICO): & & \\
\hline TAXA DE AMOSTRAGEM: & USAR TUDO & 5 \\
\hline MODELO TROPOSFÉRICO: & HOPFIELD & HOPFIELD \\
\hline MODELO IONOSFÉRICO: & AUTOMÁTICO & CALCULADO \\
\hline USAR MODELO ESTOCÁSTICO: & SIM & SIM \\
\hline DISTÂNCIA MÍN.: & $8 \mathrm{KM}$ & $8 \mathrm{KM}$ \\
\hline ATIVIDADE IONOSFÉRICA: & AUTOMÁTICO & AUTOMÁTICO \\
\hline SELEÇÃO DE SATÉLITES & & \\
\hline SATÉLITES DESATIVADOS MANUALMENTE: & NENHUM & \\
\hline ESTATÍSTICAS DA AMBIGÜIDADE & & \\
\hline NÚMERO TOTAL DE AMBIGÜIDADES: & & 10 \\
\hline NÚMERO DE AMBIGÜIDADES FIXADAS: & & 9 \\
\hline NÚMERO DE AMBIGÜIDADES INDEPENDENTES: & & 1436 \\
\hline TEMPO MÉDIO ENTRE FIXADAS INDEPENDENTES: & & $10 "$ \\
\hline PORCENTAGEM DE ÉPOCAS FIXADAS (L1): & & $100 \%$ \\
\hline PORCENTAGEM DE ÉPOCAS FIXADAS (TUDO): & & $98 \%$ \\
\hline ESTATÍSTICAS GERAIS: & & \\
\hline STATUS & PARA & DURAÇÃO \\
\hline $\begin{array}{ll}\text { FIXADA } & 3 / 4 / 200509: 27 \\
\end{array}$ & $3 / 4 / 200510: 40$ & $1 \mathrm{H} 13^{\prime}$ \\
\hline ESTATÍSTICAS DA PERDA DE CICLO & & \\
\hline NÚMERO TOTAL DE PERDAS DE CICLO: & & \\
\hline COORDENADAS FINAIS & & \\
\hline COORDENADAS: & REFERÊNCIA: M05-N & REMOTO: M05-S \\
\hline ESTE & $704010.5965 \mathrm{M}$ & $704136.3758 \mathrm{M}$ \\
\hline NORTE & $7662968.4268 \mathrm{M}$ & $7663039.7334 \mathrm{M}$ \\
\hline ALT. ELIP & $528.7662 \mathrm{M}$ & $525.1251 \mathrm{M}$ \\
\hline TIPO DE SOLUÇÃO: & FASE & \\
\hline FREQÜÊNCIA: & L1 & \\
\hline AMBIGÜIDADE: & SIM & \\
\hline QUALIDADE: & DP. E: $0.0001 \mathrm{M}$ & DP. N: $0.0000 \mathrm{M}$ \\
\hline & QLD. POS.: $0.0001 \mathrm{M}$ & DP. ALT.: $0.0001 \mathrm{M}$ \\
\hline VETOR DA LINHA DE BASE & DLAT: $0^{\circ} 00^{\prime} 02.36863 "$ & DLON: $0^{\circ} 00^{\prime} 04.32733^{\prime \prime}$ \\
\hline & DECLIVIDADE: $144.6270 \mathrm{M}$ & \\
\hline DOPS (MÍN-MÁX): & GDOP: $2.5-19.9$ & PDOP: $2.2-16.1$ \\
\hline
\end{tabular}


Tabela 26 - STTU - M06-N

\begin{tabular}{|c|c|}
\hline \multicolumn{2}{|l|}{ INFORMAÇÕES DO PROJETO } \\
\hline NOME DO PROJETO & SUL 06 \\
\hline DATA DE CRIAÇÃO: & 06/13/2005 21:30:25 \\
\hline FUSO HORÁRIO: & $-3 \mathrm{H} \mathrm{00}$ \\
\hline NOME DO SISTEMA DE COORDENADAS: & WGS-UTM 22 \\
\hline APLICATIVO: & LEICA SKI-PRO 3.0 \\
\hline PROCESSAMENTO KERNEL: & PSI-PRO 1.0 \\
\hline PROCESSADO: & 1/8/2006 13:20 \\
\hline \multicolumn{2}{|l|}{ INFORMAÇÕES DO PONTO } \\
\hline REFERÊNCIA: STTU & REMOTO: M06-N \\
\hline TIPO DE & SR520 / 22223 \\
\hline TIPO DE ANTENA / N/S: $\quad$ AT1202/302 GP / - & AX1202 TRENA / - \\
\hline ALTURA DA ANTENA: $\quad-\mathbf{0 . 0 3 9 0 ~ M ~}$ & $1.608 \mathrm{M}$ \\
\hline \multicolumn{2}{|l|}{ COORDENADAS } \\
\hline $820172.8427 \mathrm{M}$ & 659686.6457 M \\
\hline $7563377.3263 \mathrm{M}$ & $7697592.5727 \mathrm{M}$ \\
\hline ALT. ELIP.: & $520.2956 \mathrm{M}$ \\
\hline \multicolumn{2}{|l|}{ PARÂMETROS DE PROCESSAMENTO } \\
\hline PARÂMETROS & USADO \\
\hline ÂNGULO DE CORTE: $15^{\circ}$ & $15^{\circ}$ \\
\hline TIPO DE EFEMÉRIDES: TRANSMITIDA & TRANSMITIDA \\
\hline TIPO DE SOLUÇÃO: $\quad$ AUTOMÁTICO & FASE \\
\hline FREQÜÊNCIA: $\quad$ AUTOMÁTICO & AUTOMÁTICO \\
\hline FIXAR AMBIGÜIDADES $80 \mathrm{KM}$ & $80 \mathrm{KM}$ \\
\hline \begin{tabular}{ll} 
DURAÇÃO MÍN. PI A & $5^{\prime} 00^{\prime \prime}$ \\
\cline { 2 - 2 } SOLUÇOO FLOAT &
\end{tabular} & 5'00" \\
\hline USAR TUDO & 5 \\
\hline HOPFIELD & HOPFIELD \\
\hline AUTOMÁTICO & NENHUM \\
\hline USAR MODELO & SIM \\
\hline DISTÂNCIA MÍN.: & $8 \mathrm{KM}$ \\
\hline ATIVIDADE $\quad$ AUTOMÁTICO & AUTOMÁTICO \\
\hline \multirow{2}{*}{\multicolumn{2}{|c|}{$\begin{array}{l}\text { SELEÇÃO DE SATÉLITES } \\
\text { SATÉLITES }\end{array}$}} \\
\hline & \\
\hline \multicolumn{2}{|l|}{ ESTATÍSTICAS DA AMBIGÜIDADE } \\
\hline NÚMERO TOTAL DE AMBIGÜIDADES: & 61 \\
\hline NÚMERO DE AMBIGÜIDADES FIXADAS: & 60 \\
\hline NÚMERO DE AMBIGÜIDADES INDEPENDENTES: & 100 \\
\hline TEMPO MÉDIO ENTRE FIXADAS INDEPENDENTES: & 11" \\
\hline PORCENTAGEM DE ÉPOCAS FIXADAS (L1): & $69 \%$ \\
\hline PORCENTAGEM DE ÉPOCAS FIXADAS (L2): & $70 \%$ \\
\hline PORCENTAGEM DE ÉPOCAS FIXADAS (TUDO): & $40 \%$ \\
\hline ESTATÍSTICAS & \\
\hline $\begin{array}{lll}\text { STATUS } & \text { DE } & \text { PARA } \\
\end{array}$ & DURAÇÃO \\
\hline NÃO $\quad 11 / 29 / 2004 \quad 11 / 29 / 2004$ 04:33:10 & $4 \mathrm{H}^{\prime} 30^{\prime} 45^{\prime \prime}$ \\
\hline ESTATÍSTICAS DA PERDA DE CICLO & \\
\hline NÚMERO TOTAL DE PERDAS DE CICLO: & 493 \\
\hline COORDENADAS FINAIS & \\
\hline REFERÊNCIA: STTU & REMOTO: M06-N \\
\hline $820172.8427 \mathrm{M}$ & $659684.1123 \mathrm{M}$ \\
\hline $7563377.3263 \mathrm{M}$ & $7697597.4324 \mathrm{M}$ \\
\hline $824.7000 \mathrm{M}$ & $515.9629 \mathrm{M}$ \\
\hline TIPO DE SOLUÇÃO: & \\
\hline FREQÜÊNCIA: & \\
\hline AMBIGÜIDADE: & \\
\hline DP. E: $0.0001 \mathrm{M}$ & DP. N: $0.0003 \mathrm{M}$ \\
\hline QLD. POS.: 0.0004 M & DP. DECLIVIDADE: $0.0003 \mathrm{M}$ \\
\hline DLAT: $1^{\circ} 11^{\prime} 24.80241^{\prime \prime}$ & DLON: $-1^{\circ} 33^{\prime} 58.97689^{\prime \prime}$ \\
\hline DECLIVIDADE: 209158.9784 & \\
\hline GDOP: $2.4-9.1$ & PDOP: 2.1 - 7.6 \\
\hline
\end{tabular}


Tabela 27 - STTU - M06-S

\begin{tabular}{|c|c|c|}
\hline \multicolumn{3}{|l|}{ INFORMAÇÕES DO PROJETO } \\
\hline NOME DO PROJETO & & SUL 06 \\
\hline DATA DE CRIAÇÃO: & & 06/13/2005 21:30:25 \\
\hline FUSO HORÁRIO: & & $-3 \mathrm{H} \mathrm{00}$ \\
\hline NOME DO SISTEMA DE COORDENADAS: & & WGS-UTM 22 \\
\hline APLICATIVO: & & LEICA SKI-PRO 3.0 \\
\hline PROCESSAMENTO KERNEL: & & PSI-PRO 1.0 \\
\hline PROCESSADO: & & 1/8/2006 13:20 \\
\hline \multicolumn{3}{|l|}{ INFORMAÇÕES DO PONTO } \\
\hline & REFERÊNCIA: STTU & REMOTO: M06-S \\
\hline TIPO DE RECEPTOR / N/S: & SR9500/ 0 & SR520 / 22226 \\
\hline TIPO DE ANTENA / N/S: & AT202/302 GP / - & AX1202 TRENA / - \\
\hline ALTURA DA ANTENA: & $-0.0390 \mathrm{M}$ & $1.5049 \mathrm{M}$ \\
\hline \multicolumn{3}{|l|}{ COORDENADAS INICIAIS: } \\
\hline ESTE: & $820172.8427 \mathrm{M}$ & $659677.0137 \mathrm{M}$ \\
\hline NORTE: & $7563377.3263 \mathrm{M}$ & $7697515.9890 \mathrm{M}$ \\
\hline ALT. ELIP.: & $824.7000 \mathrm{M}$ & $524.8680 \mathrm{M}$ \\
\hline \multicolumn{3}{|l|}{ PARÂMETROS DE PROCESSAMENTO } \\
\hline PARÂMETROS & SELECIONADO & USADO \\
\hline ÂNGULO DE CORTE: & $15^{\circ}$ & $15^{\circ}$ \\
\hline TIPO DE EFEMÉRIDES: & TRANSMITIDA & TRANSMITIDA \\
\hline TIPO DE SOLUÇÃO: & AUTOMÁTICO & FASE \\
\hline FREQÜÊNCIA: & AUTOMÁTICO & AUTOMÁTICO \\
\hline FIXAR AMBIGÜIDADES ATÉ: & $80 \mathrm{KM}$ & $80 \mathrm{KM}$ \\
\hline \multirow{2}{*}{\multicolumn{3}{|c|}{ DURAÇÃO MÍN. P/ A SOLUÇÃO FLOAT (ESTÁTICO): }} \\
\hline & & \\
\hline TAXA DE AMOSTRAGEM: & USAR TUDO & 5 \\
\hline MODELO TROPOSFÉRICO: & HOPFIELD & HOPFIELD \\
\hline MODELO IONOSFÉRICO: & AUTOMÁTICO & NENHUM \\
\hline USAR MODELO ESTOCÁSTICO: & SIM & SIM \\
\hline DISTÂNCIA MÍN.: & $8 \mathrm{KM}$ & $8 \mathrm{KM}$ \\
\hline ATIVIDADE IONOSFÉRICA: & AUTOMÁTICO & AUTOMÁTICO \\
\hline \multicolumn{3}{|l|}{ SELEÇÃO DE SATÉLITES } \\
\hline SATÉLITES DESATIVADOS MANUALMENTE: & SV 04 & \\
\hline \multicolumn{3}{|l|}{ ESTATÍSTICAS DA AMBIGÜIDADE } \\
\hline NÚMERO TOTAL DE AMBIGÜIDADES: & & 46 \\
\hline NÚMERO DE AMBIGÜIDADES FIXADAS: & & 47 \\
\hline NÚMERO DE AMBIGÜIDADES INDEPENDENTES: & & 99 \\
\hline TEMPO MÉDIO ENTRE FIXADAS INDEPENDENTES: & & $10^{\prime \prime}$ \\
\hline PORCENTAGEM DE ÉPOCAS FIXADAS (L1): & & $69 \%$ \\
\hline PORCENTAGEM DE ÉPOCAS FIXADAS (L2): & & $70 \%$ \\
\hline PORCENTAGEM DE ÉPOCAS FIXADAS (TUDO): & & $40 \%$ \\
\hline \multicolumn{3}{|l|}{ ESTATISTICAS GERAIS: } \\
\hline STATUS & PARA & DURAÇÃO \\
\hline NÃO FIXADA $\quad 11 / 29 / 2004$ 00:21:00 & 11/29/2004 04:26:30 & $4 \mathrm{H} 05^{\prime} 30 "$ \\
\hline \multicolumn{3}{|l|}{ ESTATÍSTICAS DA PERDA DE CICLO } \\
\hline NÚMERO TOTAL DE PERDAS DE CICLO: & & 470 \\
\hline \multicolumn{3}{|l|}{ COORDENADAS FINAIS } \\
\hline COORDENADAS: & REFERÊNCIA: STTU & REMOTO: M06-S \\
\hline ESTE & $820172.8427 \mathrm{M}$ & $659674.3334 \mathrm{M}$ \\
\hline NORTE & $7563377.3263 \mathrm{M}$ & $7697521.0271 \mathrm{M}$ \\
\hline ALT. ELIP & $824.7000 \mathrm{M}$ & $520.3645 \mathrm{M}$ \\
\hline TIPO DE SOLUÇÃO: & FLOAT & \\
\hline FREQÜÊNCIA: & IONOLIVRE (L3) & \\
\hline AMBIGÜIDADE: & NÃO & \\
\hline \multirow[t]{3}{*}{ QUALIDADE: } & DP. E: $0.0001 \mathrm{M}$ & DP. N: $0.0005 \mathrm{M}$ \\
\hline & QLD. POS.: $0.0005 \mathrm{M}$ & DALT: $-304.3355 \mathrm{M}$ \\
\hline & DP. ALT.: $0.0004 \mathrm{M}$ & \\
\hline \multirow[t]{2}{*}{ VETOR DA LINHA DE BASE } & DLAT: $1^{\circ} 11^{\prime} 22.31489^{\prime \prime}$ & DLON: $-1^{\circ} 33^{\prime} 59.28993^{\prime \prime}$ \\
\hline & DECLIVIDADE: $209117.5596 \mathrm{M}$ & \\
\hline DOPS (MÍN-MÁX): & GDOP: $2.4-6.5$ & PDOP: $2.1-5.4$ \\
\hline
\end{tabular}


Tabela 28 - M06-N - M06-S

\begin{tabular}{|c|c|c|}
\hline \multicolumn{3}{|l|}{ INFORMAÇÕES DO PROJETO } \\
\hline NOME DO PROJETO & & SUL 06 \\
\hline DATA DE CRIAÇÃO: & & 06/13/2005 21:30:25 \\
\hline FUSO HORÁRIO: & & $-3 \mathrm{H} \mathrm{00}$ \\
\hline NOME DO SISTEMA DE COORDENADAS: & & WGS-UTM 22 \\
\hline APLICATIVO: & & LEICA SKI-PRO 3.0 \\
\hline PROCESSAMENTO KERNEL: & & PSI-PRO 1.0 \\
\hline PROCESSADO: & & 1/8/2006 11:56 \\
\hline \multicolumn{3}{|l|}{ INFORMAÇÕES DO PONTO } \\
\hline & REFERÊNCIA: M06-S & REMOTO: M06-N \\
\hline TIPO DE RECEPTOR / N/S: & SR20 / 0 & PROXR \\
\hline TIPO DE ANTENA / N/S: & AT 501 & \\
\hline ALTURA DA ANTENA: & $1.611 \mathrm{M}$ & $1.540 \mathrm{M}$ \\
\hline \multicolumn{3}{|l|}{ COORDENADAS INICIAIS: } \\
\hline ESTE: & $659684.1454 \mathrm{M}$ & $659674.4586 \mathrm{M}$ \\
\hline NORTE: & $7697597.4417 \mathrm{M}$ & $7697521.1281 \mathrm{M}$ \\
\hline ALT. ELIP.: & $515.7892 \mathrm{M}$ & $520.875 \mathrm{M}$ \\
\hline \multicolumn{3}{|l|}{ PARÂMETROS DE PROCESSAMENTO } \\
\hline PARÂMETROS & SELECIONADO & USADO \\
\hline ÂNGULO DE CORTE: & $15^{\circ}$ & $15^{\circ}$ \\
\hline TIPO DE EFEMÉRIDES: & TRANSMITIDA & TRANSMITIDA \\
\hline TIPO DE SOLUÇÃO: & AUTOMÁTICO & FASE \\
\hline FREQÜÊNCIA: & L1 & $\mathrm{L} 1$ \\
\hline FIXAR AMBIGÜIDADES ATÉ: & $80 \mathrm{KM}$ & $80 \mathrm{KM}$ \\
\hline & 5'00" & $5^{\prime} 00^{\prime \prime}$ \\
\hline \multicolumn{3}{|l|}{ DURAÇÃO MÍN. P/ A SOLUÇÃO FLOAT (ESTÁTICO): } \\
\hline TAXA DE AMOSTRAGEM: & USAR TUDO & 5 \\
\hline MODELO TROPOSFÉRICO: & HOPFIELD & HOPFIELD \\
\hline MODELO IONOSFÉRICO: & KLOBUCHAR & KLOBUCHAR \\
\hline USAR MODELO ESTOCÁSTICO: & SIM & SIM \\
\hline DISTÂNCIA MÍN.: & $8 \mathrm{KM}$ & $8 \mathrm{KM}$ \\
\hline ATIVIDADE IONOSFÉRICA: & AUTOMÁTICO & AUTOMÁTICO \\
\hline \multicolumn{3}{|l|}{ SELEÇÃO DE SATÉLITES } \\
\hline SATÉLITES DESATIVADOS MANUALMENTE: & NENHUM & \\
\hline \multicolumn{3}{|l|}{ ESTATÍSTICAS DA AMBIGÜIDADE } \\
\hline NÚMERO TOTAL DE AMBIGÜIDADES: & & 29 \\
\hline NÚMERO DE AMBIGÜIDADES FIXADAS: & & 14 \\
\hline NÚMERO DE AMBIGÜIDADES INDEPENDENTES: & & 454 \\
\hline TEMPO MÉDIO ENTRE FIXADAS INDEPENDENTES: & & $10^{\prime \prime}$ \\
\hline PORCENTAGEM DE ÉPOCAS FIXADAS (L1): & & $100 \%$ \\
\hline PORCENTAGEM DE ÉPOCAS FIXADAS (TUDO): & & $100 \%$ \\
\hline \multicolumn{3}{|l|}{ ESTATÍSTICAS GERAIS: } \\
\hline STATUS & PARA & DURAÇÃO \\
\hline FIXADA $\quad 3 / 4 / 200507: 33$ & 3/4/2005 08:37 & $1 \mathrm{H} 04^{\prime}$ \\
\hline \multicolumn{3}{|l|}{ ESTATÍSTICAS DA PERDA DE CICLO } \\
\hline NÚMERO TOTAL DE PERDAS DE CICLO: & & 2 \\
\hline \multicolumn{3}{|l|}{ COORDENADAS FINAIS } \\
\hline COORDENADAS: & REFERÊNCIA: M06-N & REMOTO: M06-S \\
\hline ESTE & $659684.1564 \mathrm{M}$ & $659674.3382 \mathrm{M}$ \\
\hline NORTE & $7697597.4417 \mathrm{M}$ & $7697521.0473 \mathrm{M}$ \\
\hline ALT. ELIP & $515.8872 \mathrm{M}$ & $520.3054 \mathrm{M}$ \\
\hline TIPO DE SOLUÇÃO: & FASE & \\
\hline FREQÜÊNCIA: & SÓ L1 & \\
\hline AMBIGÜIDADE: & SIM & \\
\hline \multirow[t]{3}{*}{ QUALIDADE: } & DP. E: $0.0001 \mathrm{M}$ & DP. N: $0.0001 \mathrm{M}$ \\
\hline & QLD. POS.: $0.0001 \mathrm{M}$ & DP. ALT.: $0.0002 \mathrm{M}$ \\
\hline & DALT: $4.4183 \mathrm{M}$ & \\
\hline \multirow[t]{2}{*}{ VETOR DA LINHA DE BASE } & DLAT: $-0^{\circ} 00^{\prime} 02.48718 "$ & DLON: $-0^{\circ} 00^{\prime} 00.31441^{\prime \prime}$ \\
\hline & DECLIVIDADE: $77.1622 \mathrm{M}$ & \\
\hline DOPS (MÍN-MÁX): & GDOP: $2.1-3.3$ & PDOP: $1.8-2.8$ \\
\hline
\end{tabular}


Tabela 29 - STTU - M07-N

\begin{tabular}{|c|c|c|}
\hline \multicolumn{3}{|l|}{ INFORMAÇÕES DO PROJETO } \\
\hline \multicolumn{2}{|l|}{ NOME DO PROJETO } & SUL 07 \\
\hline \multicolumn{2}{|l|}{ DATA DE CRIAÇÃO: } & 06/13/2005 21:30:33 \\
\hline \multicolumn{2}{|l|}{ FUSO HORÁRIO: } & $-3 \mathrm{H} 00^{\prime}$ \\
\hline \multicolumn{2}{|l|}{ NOME DO SISTEMA DE COORDENADAS: } & WGS-UTM 22 \\
\hline \multicolumn{2}{|l|}{ APLICATIVO: } & LEICA SKI-PRO 3.0 \\
\hline \multicolumn{2}{|l|}{ PROCESSAMENTO KERNEL: } & PSI-PRO 1.0 \\
\hline \multicolumn{2}{|l|}{ PROCESSADO: } & 1/8/2006 22:09 \\
\hline \multicolumn{3}{|l|}{ INFORMAÇÕES DO PONTO } \\
\hline & REFERÊNCIA: STTU & REMOTO: M07-N \\
\hline TIPO DE RECEPTOR / N/S: & SR9500 / 0 & SR520 / 22223 \\
\hline TIPO DE ANTENA / N/S: & AT1202/302 GP / - & AX1202 TRENA / - \\
\hline ALTURA DA ANTENA: & $-0.0390 \mathrm{M}$ & $1.544 \mathrm{M}$ \\
\hline \multicolumn{3}{|l|}{ COORDENADAS INICIAIS: } \\
\hline ESTE: & $820172.8427 \mathrm{M}$ & $562574.0881 \mathrm{M}$ \\
\hline NORTE: & $7563377.3263 \mathrm{M}$ & $7716836.6213 \mathrm{M}$ \\
\hline ALT. ELIP.: & $824.7000 \mathrm{M}$ & $459.2265 \mathrm{M}$ \\
\hline \multicolumn{3}{|l|}{ PARÂMETROS DE PROCESSAMENTO } \\
\hline PARÂMETROS & SELECIONADO & USADO \\
\hline ÂNGULO DE CORTE: & $15^{\circ}$ & $15^{\circ}$ \\
\hline TIPO DE EFEMÉRIDES: & TRANSMITIDA & TRANSMITIDA \\
\hline TIPO DE SOLUÇÃO: & AUTOMÁTICO & FASE \\
\hline FREQÜÊNCIA: & AUTOMÁTICO & AUTOMÁTICO \\
\hline FIXAR AMBIGÜIDADES ATÉ: & $80 \mathrm{KM}$ & $80 \mathrm{KM}$ \\
\hline $\begin{array}{l}\text { DURAÇÃO MÍN. P/ A SOLUÇÃO FLOAT } \\
\text { (ESTÁTICO): }\end{array}$ & 5'00" & 5' 00" \\
\hline $\begin{array}{l}\text { TAXA DE AMOSTRAGEM: } \\
\text { MODELO TROPOSFÉRICO: }\end{array}$ & USAR TUDO & 5 \\
\hline MODELO TROPOSFÉRICO: & HOPFIELD & HOPFIELD \\
\hline MODELO IONOSFÉRICO: & KLOBUCHAR & KLOBUCHAR \\
\hline \multirow{2}{*}{$\begin{array}{l}\text { USAR MODELO ESTOCÁSTICO: } \\
\text { SELEÇÃO DE SATÉLITES }\end{array}$} & NÃO & NÃO \\
\hline & & \\
\hline SATÉLITES DESATIVADOS MANUALMENTE & SV 11, SV 19 E SV 30 & \\
\hline \multicolumn{3}{|l|}{ ESTATÍSTICAS DA AMBIGÜIDADE } \\
\hline \multicolumn{2}{|l|}{ NÚMERO TOTAL DE AMBIGÜIDADES: } & 101 \\
\hline \multicolumn{2}{|l|}{ NÚMERO DE AMBIGÜIDADES FIXADAS: } & 104 \\
\hline NÚMERO DE AMBIGÜIDADES INDEPENDEN & & 99 \\
\hline TEMPO MÉDIO ENTRE FIXADAS INDEPEND & ITES: & $10 "$ \\
\hline PORCENTAGEM DE ÉPOCAS FIXADAS (L1) & & $79 \%$ \\
\hline PORCENTAGEM DE ÉPOCAS FIXADAS (L2) & & $80 \%$ \\
\hline PORCENTAGEM DE ÉPOCAS FIXADAS (TUI & & $98 \%$ \\
\hline ESTATÍSTICAS GERAIS: & & \\
\hline $\begin{array}{ll}\text { STATUS } & \text { DE } \\
\end{array}$ & PARA & DURAÇÃO \\
\hline 11/29/2004 12:08:40 & 11/29/2004 17:17:45 & $5 \mathrm{H}^{\circ} 09^{\prime} 05 "$ \\
\hline ESTATÍSTICAS DA PERDA DE CICLO & & \\
\hline NÚMERO TOTAL DE PERDAS DE CICLO: & & 0 \\
\hline COORDENADAS FINAIS & & \\
\hline COORDENADAS: & REFERÊNCIA: STTU & REMOTO: M07-N \\
\hline ESTE & $820172.8427 \mathrm{M}$ & $562574.0434 \mathrm{M}$ \\
\hline NORTE & $7563377.3263 \mathrm{M}$ & $7716836.6049 \mathrm{M}$ \\
\hline ALT. ELIP & $824.7000 \mathrm{M}$ & $459.2784 \mathrm{M}$ \\
\hline TIPO DE SOLUÇÃO: & FLOAT & \\
\hline FREQÜÊNCIA: & IONOLIVRE (L3) & \\
\hline AMBIGÜIDADE: & $\mathrm{NÃO}$ & \\
\hline QUALIDADE: & DP. E: $0.0001 \mathrm{M}$ & DP. N: $0.0003 \mathrm{M}$ \\
\hline & QLD. POS.: $0.0003 \mathrm{M}$ & DP. DECLIVIDADE: $0.0003 \mathrm{M}$ \\
\hline VETOR DA LINHA DE BASE & DLAT: $1^{\circ} 21^{\prime} 29.68183^{\prime \prime}$ & DLON: $-2^{\circ} 30^{\prime} 00.57358^{\prime \prime}$ \\
\hline & DECLIVIDADE: $299811.3265 \mathrm{M}$ & \\
\hline DOPS (MÍN-MÁX): & GDOP: $2.1-6.3$ & PDOP: $1.9-5.2$ \\
\hline
\end{tabular}


Tabela 30 - STTU - M07-S

\begin{tabular}{|c|c|c|c|}
\hline INFORMAÇÕES DO PROJETO & & & \\
\hline NOME DO PROJETO & & SUL 07 & \\
\hline DATA DE CRIAÇÃO: & & 06/13/2005 21:30:33 & \\
\hline FUSO HORÁRIO: & & $-3 \mathrm{H} \mathrm{OO}^{\prime}$ & \\
\hline NOME DO SISTEMA DE COORDENADAS: & & WGS-UTM 22 & \\
\hline APLICATIVO: & & LEICA SKI-PRO 3.0 & \\
\hline PROCESSAMENTO KERNEL: & & PSI-PRO 1.0 & \\
\hline PROCESSADO: & & 1/8/2006 22:09 & \\
\hline \multicolumn{4}{|l|}{ INFORMAÇÕES DO PONTO } \\
\hline & REFERÊNCIA: STTU & REMOTO: M07-S & \\
\hline TIPO DE RECEPTOR / N/S: & SR9500 / 0 & SR520 / 22226 & \\
\hline TIPO DE ANTENA / N/S: & AT202/302 GP / - & AX1202 TRENA / - & \\
\hline ALTURA DA ANTENA: & $-0.0390 \mathrm{M}$ & $1.555 \mathrm{M}$ & \\
\hline \multicolumn{4}{|l|}{ COORDENADAS INICIAIS: } \\
\hline ESTE: & $820172.8427 \mathrm{M}$ & $562549.2799 \mathrm{M}$ & \\
\hline NORTE: & $7563377.3263 \mathrm{M}$ & $7716786.7242 \mathrm{M}$ & \\
\hline ALT. ELIP.: & $824.7000 \mathrm{M}$ & $459.6960 \mathrm{M}$ & \\
\hline \multicolumn{4}{|l|}{ PARÂMETROS DE PROCESSAMENTO } \\
\hline PARÂMETROS & SELECIONADO & USADO & \\
\hline ÂNGULO DE CORTE: & $15^{\circ}$ & $15^{\circ}$ & \\
\hline TIPO DE EFEMÉRIDES: & TRANSMITIDA & TRANSMITIDA & \\
\hline TIPO DE SOLUÇÃO: & AUTOMÁTICO & FASE & \\
\hline FREQÜÊNCIA: & AUTOMÁTICO & AUTOMÁTICO & \\
\hline FIXAR AMBIGÜIDADES ATÉ: & $80 \mathrm{KM}$ & $80 \mathrm{KM}$ & \\
\hline & $55^{\prime} 00^{\prime \prime}$ & 5'00" & \\
\hline \multicolumn{4}{|l|}{ DURAÇÃO MÍN. P/ A SOLUÇÃO FLOAT (ESTÁTICO): } \\
\hline TAXA DE AMOSTRAGEM: & USAR TUDO & 5 & \\
\hline MODELO TROPOSFÉRICO: & HOPFIELD & HOPFIELD & \\
\hline MODELO IONOSFÉRICO: & KLOBUCHAR & KLOBUCHAR & \\
\hline USAR MODELO ESTOCÁSTICO: & NÃO & NÃO & \\
\hline \multicolumn{4}{|l|}{ SELEÇÃO DE SATÉLITES } \\
\hline SATÉLITES DESATIVADOS MANUALMENTE: & SV 11, SV $19 \mathrm{E}$ SV 30 & & \\
\hline \multicolumn{4}{|l|}{ ESTATÍSTICAS DA AMBIGÜIDADE } \\
\hline NÚMERO TOTAL DE AMBIGÜIDADES: & & 98 & \\
\hline NÚMERO DE AMBIGÜIDADES FIXADAS: & & 97 & \\
\hline NÚMERO DE AMBIGÜIDADES INDEPENDENTES: & & 101 & \\
\hline TEMPO MÉDIO ENTRE FIXADAS INDEPENDENTES: & & $10 "$ & \\
\hline PORCENTAGEM DE ÉPOCAS FIXADAS (L1): & & $79 \%$ & \\
\hline PORCENTAGEM DE ÉPOCAS FIXADAS (L2): & & $80 \%$ & \\
\hline PORCENTAGEM DE ÉPOCAS FIXADAS (TUDO): & & $98 \%$ & \\
\hline \multicolumn{4}{|l|}{ ESTATÍSTICAS GERAIS: } \\
\hline STATUS & PARA & DURAÇÃO & \\
\hline NÃO FIXADA $\quad 11 / 29 / 2004$ 12:12:05 & 11/29/2004 17:16:40 & $5{\mathrm{H} 04 ' 35^{\prime \prime}}^{2}$ & \\
\hline \multicolumn{4}{|l|}{ ESTATÍSTICAS DA PERDA DE CICLO } \\
\hline NÚMERO TOTAL DE PERDAS DE CICLO: & & & 0 \\
\hline \multicolumn{4}{|l|}{ COORDENADAS FINAIS } \\
\hline COORDENADAS: & REFERÊNCIA: STTU & REMOTO: M07-S & \\
\hline ESTE & $820172.8427 \mathrm{M}$ & $562549.2433 \mathrm{M}$ & \\
\hline NORTE & $7563377.3263 \mathrm{M}$ & $7716786.7100 \mathrm{M}$ & \\
\hline ALT. ELIP & $824.7000 \mathrm{M}$ & $459.7474 \mathrm{M}$ & \\
\hline TIPO DE SOLUÇÃO: & FLOAT & & \\
\hline FREQÜÊNCIA: & IONOLIVRE (L3) & & \\
\hline AMBIGÜIDADE: & $\mathrm{NÃO}$ & & \\
\hline \multirow[t]{2}{*}{ QUALIDADE: } & DP. E: $0.0001 \mathrm{M}$ & DP. N: $0.0003 \mathrm{M}$ & \\
\hline & QLD. POS.: $0.0003 \mathrm{M}$ & DP. ALT.: $0.0002 \mathrm{M}$ & \\
\hline \multirow[t]{2}{*}{ VETOR DA LINHA DE BASE } & DLAT: $1^{\circ} 21^{\prime} 28.05587^{\prime \prime}$ & DLON: $-2^{\circ} 30^{\prime} 01.42422^{\prime \prime}$ & \\
\hline & DECLIVIDADE: $299807.1270 \mathrm{M}$ & DALT: $-364.9527 \mathrm{M}$ & \\
\hline DOPS (MÍN-MÁX): & GDOP: $2.1-6.3$ & PDOP: $1.9-5.2$ & \\
\hline
\end{tabular}


Tabela 31 - M07-N - M07-S

\begin{tabular}{|c|c|c|}
\hline INFORMAÇÕES DO PROJETO & & \\
\hline NOME DO PROJETO & & SUL 07 \\
\hline DATA DE CRIAÇÃO: & & 06/13/2005 21:30:33 \\
\hline FUSO HORÁRIO: & & $-3 \mathrm{H} 00^{\prime}$ \\
\hline NOME DO SISTEMA DE COORDENADAS: & & WGS-UTM 22 \\
\hline APLICATIVO: & & LEICA SKI-PRO 3.0 \\
\hline PROCESSAMENTO KERNEL: & & PSI-PRO 1.0 \\
\hline PROCESSADO: & & $1 / 8 / 200622: 12$ \\
\hline INFORMAÇÕES DO PONTO & & \\
\hline & REFERÊNCIA: M07-N & REMOTO: M07-S \\
\hline TIPO DE RECEPTOR / N/S: & PROXR & SR20/0 \\
\hline TIPO DE ANTENA / N/S: & & AT 501 \\
\hline ALTURA DA ANTENA: & $1.590 \mathrm{M}$ & $1.575 \mathrm{M}$ \\
\hline COORDENADAS INICIAIS: & & \\
\hline ESTE: & $562574.1981 \mathrm{M}$ & $562549.7845 \mathrm{M}$ \\
\hline NORTE: & $7716836.7113 \mathrm{M}$ & $7716787.0242 \mathrm{M}$ \\
\hline ALT. ELIP.: & $459.2895 \mathrm{M}$ & $459.7165 \mathrm{M}$ \\
\hline PARÂMETROS DE PROCESSAMENTO & & \\
\hline PARÂMETROS & SELECIONADO & USADO \\
\hline ÂNGULO DE CORTE: & $15^{\circ}$ & $15^{\circ}$ \\
\hline TIPO DE EFEMÉRIDES: & TRANSMITIDA & TRANSMITIDA \\
\hline TIPO DE SOLUÇÃO: & AUTOMÁTICO & FASE \\
\hline FREQÜÊNCIA: & L1 & $\mathrm{L} 1$ \\
\hline FIXAR AMBIGÜIDADES ATÉ: & $80 \mathrm{KM}$ & $80 \mathrm{KM}$ \\
\hline & 5' 00" & 5'00" \\
\hline DURAÇÃO MÍN. PI A SOLUÇÃO FLOAT (ESTÁTICO): & & \\
\hline TAXA DE AMOSTRAGEM: & USAR TUDO & 5 \\
\hline MODELO TROPOSFÉRICO: & HOPFIELD & HOPFIELD \\
\hline MODELO IONOSFÉRICO: & KLOBUCHAR & KLOBUCHAR \\
\hline USAR MODELO ESTOCÁSTICO: & NÃO & NÃO \\
\hline SELEÇÃO DE SATÉLITES & & \\
\hline SATÉLITES DESATIVADOS MANUALMENTE: & NENHUM & \\
\hline ESTATÍSTICAS DA AMBIGÜIDADE & & \\
\hline NÚMERO TOTAL DE AMBIGÜIDADES: & & 9 \\
\hline NÚMERO DE AMBIGÜIDADES FIXADAS: & & 9 \\
\hline NÚMERO DE AMBIGÜIDADES INDEPENDENTES: & & 457 \\
\hline TEMPO MÉDIO ENTRE FIXADAS INDEPENDENTES: & & $10^{\prime \prime}$ \\
\hline PORCENTAGEM DE ÉPOCAS FIXADAS (L1): & & $100 \%$ \\
\hline PORCENTAGEM DE ÉPOCAS FIXADAS (TUDO): & & $100 \%$ \\
\hline ESTATÍSTICAS GERAIS: & & \\
\hline STATUS & PARA & DURAÇÃO \\
\hline FIXADA $\quad 2 / 4 / 200519: 27$ & $2 / 4 / 200520: 36$ & $1 \mathrm{H} 09^{\prime}$ \\
\hline ESTATÍSTICAS DA PERDA DE CICLO & & \\
\hline NÚMERO TOTAL DE PERDAS DE CICLO: & & 0 \\
\hline COORDENADAS FINAIS & & \\
\hline COORDENADAS: & REFERÊNCIA: M07-N & REMOTO: M07-S \\
\hline ESTE & $562574.0881 \mathrm{M}$ & $562549.2797 \mathrm{M}$ \\
\hline NORTE & $7716836.6213 \mathrm{M}$ & $7716786.7249 \mathrm{M}$ \\
\hline ALT. ELIP & $459.2265 \mathrm{M}$ & $459.6974 \mathrm{M}$ \\
\hline TIPO DE SOLUÇÃO: & FASE & \\
\hline FREQÜÊNCIA: & $\mathrm{L} 1$ & \\
\hline AMBIGÜIDADE: & SIM & \\
\hline QUALIDADE: & DP. E: $0.0001 \mathrm{M}$ & DP. N: $0.0001 \mathrm{M}$ \\
\hline & QLD. POS.: $0.0001 \mathrm{M}$ & DP. DECLIVIDADE: $0.0001 \mathrm{M}$ \\
\hline & DP. ALT.: $0.0002 \mathrm{M}$ & DALT: $0.4709 \mathrm{M}$ \\
\hline VETOR DA LINHA DE BASE & DLAT: $-0^{\circ} 00^{\prime} 01.62601 "$ & DLON: $-0^{\circ} 00^{\prime} 00.85092^{\prime \prime}$ \\
\hline & DECLIVIDADE: $55.7491 \mathrm{M}$ & \\
\hline DOPS (MÍN-MÁX): & GDOP: $2.3-3.7$ & PDOP: $2.0-3.1$ \\
\hline
\end{tabular}


APÊNDICE C - Tabelas das discrepâncias das coordenadas obtidas com os receptores L1 e suas respectivas precisões. 


\section{Resultados do Receptor $A$ (Primeira campanha)}

Tabela 32 - Resultados do Receptor A para o marco M01 20 km

\begin{tabular}{lcccccc}
\hline & \multicolumn{3}{c}{ ACURÁCIA $(\mathrm{m})$} & \multicolumn{3}{c}{ PRECISÃO $(\mathrm{m})$} \\
\hline ID & $\mathrm{DE}$ & $\mathrm{DN}$ & $\mathrm{ERRO}$ & $\mathrm{DE}$ & $\mathrm{DN}$ & ERRO \\
\hline M1\#1 & 0,99 & 0,10 & 0,99 & 0,06 & 0,06 & 0,08 \\
\hline M1\#2 & 1,19 & 0,00 & 1,19 & 0,07 & 0,08 & 0,11 \\
\hline M1\#3 & 1,36 & 0,17 & 1,37 & 0,07 & 0,08 & 0,11 \\
\hline M1\#4 & 1,26 & 0,22 & 1,28 & 0,06 & 0,07 & 0,09 \\
\hline M1\#5 & 1,14 & 0,09 & 1,14 & 0,06 & 0,06 & 0,08 \\
\hline M1\#6 & 1,06 & 0,07 & 1,06 & 0,06 & 0,05 & 0,08 \\
\hline M1\#7 & 1,01 & 0,14 & 1,02 & 0,05 & 0,04 & 0,06 \\
\hline M1\#8 & 1,19 & 0,12 & 1,19 & 0,08 & 0,08 & 0,11 \\
\hline M1\#9 & 1,12 & 0,01 & 1,12 & 0,06 & 0,06 & 0,08 \\
\hline M1\#10 & 1,08 & 0,03 & 1,08 & 0,06 & 0,05 & 0,08 \\
\hline M1\#11 & 1,01 & 0,02 & 1,01 & 0,05 & 0,04 & 0,06 \\
\hline M1\#12 & 1,13 & 0,04 & 1,13 & 0,06 & 0,06 & 0,09 \\
\hline MÉDIA & 1,13 & 0,08 & 1,13 & 0,06 & 0,06 & 0,09 \\
\hline DESVPAD & 0,11 & 0,07 & 0,11 & 0,01 & 0,01 & 0,02 \\
\hline MAX & 1,36 & 0,22 & 1,37 & 0,08 & 0,08 & 0,11 \\
\hline MIN & 0,99 & 0,00 & 0,99 & 0,05 & 0,04 & 0,06 \\
\hline
\end{tabular}

Tabela 33 - Resultados do Receptor A para o marco M02 50 km

\begin{tabular}{lcccccc}
\hline & \multicolumn{3}{c}{ ACURÁCIA $(\mathrm{m})$} & & PRECISÃO $(\mathrm{m})$ \\
\hline ID & DE & DN & ERRO & DE & DN & ERRO \\
\hline M2\#1 & 1,08 & 0,01 & 1,08 & 0,05 & 0,04 & 0,06 \\
\hline M2\#2 & 1,06 & 0,19 & 1,08 & 0,06 & 0,05 & 0,08 \\
\hline M2\#3 & 0,95 & 0,04 & 0,96 & 0,05 & 0,05 & 0,07 \\
\hline M2\#4 & 1,02 & 0,06 & 1,02 & 0,06 & 0,06 & 0,08 \\
\hline M2\#5 & 0,94 & 0,01 & 0,94 & 0,06 & 0,06 & 0,09 \\
\hline M2\#6 & 0,72 & 0,15 & 0,74 & 0,05 & 0,05 & 0,08 \\
\hline M2\#7 & 0,68 & 0,05 & 0,68 & 0,06 & 0,06 & 0,08 \\
\hline M2\#8 & 0,73 & 0,08 & 0,73 & 0,06 & 0,06 & 0,08 \\
\hline M2\#9 & 0,59 & 0,25 & 0,64 & 0,05 & 0,06 & 0,08 \\
\hline M2\#10 & 0,39 & 0,40 & 0,56 & 0,04 & 0,05 & 0,06 \\
\hline M2\#11 & 0,35 & 0,63 & 0,72 & 0,05 & 0,05 & 0,07 \\
\hline M2\#12 & 0,34 & 0,67 & 0,75 & 0,05 & 0,05 & 0,07 \\
\hline MÉDIA & 0,74 & 0,21 & 0,83 & 0,05 & 0,05 & 0,07 \\
\hline DESVPAD & 0,28 & 0,23 & 0,18 & 0,01 & 0,01 & 0,01 \\
\hline MAX & 1,08 & 0,67 & 1,08 & 0,06 & 0,06 & 0,09 \\
\hline MIN & 0,34 & 0,01 & 0,56 & 0,04 & 0,04 & 0,06 \\
\hline
\end{tabular}

Tabela 34 - Resultados do Receptor A para o marco M03 $\sim 75 \mathrm{~km}$

\begin{tabular}{lcccccc}
\hline & \multicolumn{3}{c}{ ACURÁCIA $(\mathrm{m})$} & \multicolumn{3}{c}{ PRECISÃO (m) } \\
\hline ID & DE & DN & ERRO & DE & DN & ERRO \\
\hline M3\#1 & 0,69 & 2,00 & 2,11 & 0,01 & 0,01 & 0,02 \\
\hline M3\#2 & 0,91 & 1,69 & 1,92 & 0,01 & 0,01 & 0,02 \\
\hline M3\#3 & 0,79 & 1,62 & 1,80 & 0,00 & 0,00 & 0,00 \\
\hline M3\#4 & 0,66 & 1,54 & 1,67 & 0,01 & 0,01 & 0,01 \\
\hline M3\#5 & 0,57 & 1,69 & 1,79 & 0,01 & 0,01 & 0,01 \\
\hline M3\#6 & 0,69 & 1,33 & 1,50 & 0,01 & 0,02 & 0,02 \\
\hline M3\#7 & 0,45 & 1,05 & 1,14 & 0,01 & 0,02 & 0,02 \\
\hline M3\#8 & 0,28 & 1,05 & 1,09 & 0,01 & 0,01 & 0,01 \\
\hline M3\#9 & 0,40 & 0,90 & 0,98 & 0,02 & 0,02 & 0,03 \\
\hline M3\#10 & 0,47 & 0,68 & 0,83 & 0,03 & 0,03 & 0,04 \\
\hline M3\#11 & 0,40 & 0,53 & 0,67 & 0,04 & 0,03 & 0,05 \\
\hline M3\#12 & 0,30 & 0,72 & 0,78 & 0,02 & 0,02 & 0,03 \\
\hline DÉEIA & 0,55 & 1,23 & 1,36 & 0,01 & 0,01 & 0,02 \\
\hline MAX & 0,20 & 0,48 & 0,50 & 0,01 & 0,01 & 0,01 \\
\hline MIN & 0,91 & 2,00 & 2,11 & 0,04 & 0,03 & 0,05 \\
\hline
\end{tabular}


Tabela 35 - Resultados do Receptor A para o marco M04 100 km

\begin{tabular}{|c|c|c|c|c|c|c|}
\hline & \multicolumn{3}{|c|}{ ACURÁCIA (m) } & \multicolumn{3}{|c|}{ PRECISÃO (m) } \\
\hline ID & $\overline{\mathrm{DE}}$ & DN & ERRO & $\mathrm{DE}$ & DN & ERRO \\
\hline M4\#1 & 0,04 & 0,21 & 0,21 & 0,05 & 0,06 & 0,07 \\
\hline M4\#2 & 0,13 & 0,22 & 0,26 & 0,05 & 0,05 & 0,07 \\
\hline M4\#3 & 0,09 & 0,15 & 0,17 & 0,05 & 0,06 & 0,08 \\
\hline M4\#4 & 0,03 & 0,13 & 0,14 & 0,05 & 0,06 & 0,08 \\
\hline M4\#5 & 0,04 & 0,15 & 0,16 & 0,05 & 0,06 & 0,08 \\
\hline M4\#6 & 0,06 & 0,26 & 0,26 & 0,04 & 0,05 & 0,06 \\
\hline M4\#7 & 0,14 & 0,29 & 0,33 & 0,04 & 0,05 & 0,06 \\
\hline M4\#8 & 0,25 & 0,40 & 0,47 & 0,03 & 0,04 & 0,05 \\
\hline M4\#9 & 0,07 & 0,33 & 0,34 & 0,04 & 0,05 & 0,06 \\
\hline M4\#10 & 0,13 & 0,30 & 0,33 & 0,04 & 0,05 & 0,07 \\
\hline M4\#11 & 0,08 & 0,24 & 0,25 & 0,04 & 0,05 & 0,06 \\
\hline M4\#12 & 0,00 & 0,33 & 0,33 & 0,04 & 0,05 & 0,06 \\
\hline MÉDIA & 0,09 & 0,25 & 0,27 & 0,04 & 0,05 & 0,07 \\
\hline DESVPAD & 0,07 & 0,08 & 0,09 & 0,01 & 0,01 & 0,01 \\
\hline MAX & 0,25 & 0,40 & 0,47 & 0,05 & 0,06 & 0,08 \\
\hline $\mathrm{MIN}$ & 0,00 & 0,13 & 0,14 & 0,03 & 0,04 & 0,05 \\
\hline
\end{tabular}

Tabela 36 - Resultados do Receptor A para o marco M05 $150 \mathrm{~km}$

\begin{tabular}{lcccccc}
\hline & \multicolumn{3}{c}{ ACURÁCIA $(\mathrm{m})$} & & PRECISÃO $(\mathrm{m})$ \\
\hline ID & $\mathrm{DE}$ & $\mathrm{DN}$ & $\mathrm{ERRO}$ & $\mathrm{DE}$ & $\mathrm{DN}$ & ERRO \\
\hline M5\#1 & 1,33 & 0,07 & 1,33 & 0,04 & 0,03 & 0,04 \\
\hline M5\#2 & 1,26 & 0,14 & 1,27 & 0,03 & 0,02 & 0,03 \\
\hline M5\#3 & 1,24 & 0,04 & 1,24 & 0,02 & 0,02 & 0,03 \\
\hline M5\#4 & 1,27 & 0,06 & 1,27 & 0,05 & 0,03 & 0,05 \\
\hline M5\#5 & 1,31 & 0,01 & 1,31 & 0,05 & 0,03 & 0,06 \\
\hline M5\#6 & 1,32 & 0,12 & 1,32 & 0,04 & 0,03 & 0,05 \\
\hline M5\#7 & 1,42 & 0,19 & 1,43 & 0,04 & 0,03 & 0,05 \\
\hline M5\#8 & 1,45 & 0,03 & 1,45 & 0,02 & 0,02 & 0,03 \\
\hline M5\#9 & 1,41 & 0,09 & 1,41 & 0,03 & 0,03 & 0,04 \\
\hline M5\#10 & 1,17 & 0,22 & 1,19 & 0,04 & 0,03 & 0,05 \\
\hline M5\#11 & 1,34 & 0,28 & 1,36 & 0,04 & 0,04 & 0,06 \\
\hline M5\#12 & 1,22 & 0,22 & 1,24 & 0,05 & 0,05 & 0,07 \\
\hline MÉDIA & 1,31 & 0,12 & 1,32 & 0,04 & 0,03 & 0,05 \\
\hline DESVPAD & 0,09 & 0,09 & 0,08 & 0,01 & 0,01 & 0,01 \\
\hline MAX & 1,45 & 0,28 & 1,45 & 0,05 & 0,05 & 0,07 \\
\hline MIN & 1,17 & 0,01 & 1,19 & 0,02 & 0,02 & 0,03 \\
\hline
\end{tabular}

Tabela 37 - Resultados do Receptor A para o marco M06 200 km

\begin{tabular}{lcccccc}
\hline & \multicolumn{3}{c}{ ACURÁCIA $(\mathrm{m})$} & & $\mathrm{PRECISA} O(\mathrm{~m})$ \\
\hline ID & $\mathrm{DE}$ & $\mathrm{DN}$ & $\mathrm{ERRO}$ & $\mathrm{DE}$ & $\mathrm{DN}$ & ERRO \\
\hline M6\#1 & 0,97 & 3,20 & 3,34 & 0,04 & 0,03 & 0,05 \\
\hline M6\#2 & 1,17 & 2,80 & 3,03 & 0,04 & 0,04 & 0,06 \\
\hline M6\#3 & 1,34 & 2,70 & 3,01 & 0,03 & 0,03 & 0,04 \\
\hline M6\#4 & 1,64 & 2,34 & 2,85 & 0,03 & 0,03 & 0,04 \\
\hline M6\#5 & 1,62 & 2,02 & 2,59 & 0,03 & 0,04 & 0,05 \\
\hline M6\#6 & 1,53 & 1,88 & 2,43 & 0,03 & 0,03 & 0,04 \\
\hline M6\#7 & 1,88 & 2,30 & 2,97 & 0,08 & 0,09 & 0,12 \\
\hline M6\#8 & 2,18 & 2,51 & 3,32 & 0,01 & 0,01 & 0,02 \\
\hline M6\#9 & 2,21 & 1,42 & 2,63 & 0,05 & 0,06 & 0,08 \\
\hline M6\#10 & 2,39 & 0,55 & 2,45 & 0,09 & 0,01 & 0,09 \\
\hline M6\#11 & 1,96 & 0,05 & 1,96 & 0,08 & 0,06 & 0,10 \\
\hline M6\#12 & 1,87 & 0,12 & 1,88 & 0,07 & 0,07 & 0,10 \\
\hline MÉDIA & 1,73 & 1,82 & 2,71 & 0,05 & 0,04 & 0,07 \\
\hline DESVPAD & 0,43 & 1,06 & 0,47 & 0,02 & 0,02 & 0,03 \\
\hline MAX & 2,39 & 3,20 & 3,34 & 0,09 & 0,09 & 0,12 \\
\hline MIN & 0,97 & 0,05 & 1,88 & 0,01 & 0,01 & 0,02 \\
\hline
\end{tabular}

Tabela 38 - Resultados do Receptor A para o marco M07 300 km 


\begin{tabular}{lcccccc}
\hline & \multicolumn{3}{c}{ ACURÁCIA $(\mathrm{m})$} & \multicolumn{3}{c}{ PRECISÃO $(\mathrm{m})$} \\
\hline $\mathrm{ID}$ & $\mathrm{DE}$ & $\mathrm{DN}$ & $\mathrm{ERRO}$ & $\mathrm{DE}$ & $\mathrm{DN}$ & ERRO \\
\hline $\mathrm{M7 \# 1}$ & 0,06 & 0,11 & 0,13 & 0,04 & 0,05 & 0,06 \\
\hline $\mathrm{M7 \# 2}$ & 0,02 & 0,07 & 0,07 & 0,04 & 0,05 & 0,06 \\
\hline $\mathrm{M7 \# 3}$ & 0,12 & 0,05 & 0,13 & 0,04 & 0,05 & 0,06 \\
\hline $\mathrm{M7 \# 4}$ & 0,11 & 0,13 & 0,17 & 0,04 & 0,05 & 0,07 \\
\hline $\mathrm{M7 \# 5}$ & 0,14 & 0,02 & 0,15 & 0,04 & 0,05 & 0,06 \\
\hline $\mathrm{M7 \# 6}$ & 0,26 & 0,01 & 0,26 & 0,03 & 0,04 & 0,05 \\
\hline M7\#7 & 0,36 & 0,13 & 0,39 & 0,03 & 0,04 & 0,05 \\
\hline M7\#8 & 0,49 & 0,00 & 0,49 & 0,03 & 0,04 & 0,05 \\
\hline M7\#9 & 0,22 & 0,17 & 0,28 & 0,03 & 0,04 & 0,05 \\
\hline M7\#10 & 0,11 & 0,14 & 0,18 & 0,03 & 0,04 & 0,05 \\
\hline M7\#11 & 0,24 & 0,27 & 0,36 & 0,03 & 0,04 & 0,04 \\
\hline M7\#12 & 0,19 & 0,07 & 0,21 & 0,03 & 0,04 & 0,06 \\
\hline MÉDIA & 0,19 & 0,10 & 0,23 & 0,03 & 0,04 & 0,06 \\
\hline DESVPAD & 0,13 & 0,08 & 0,12 & 0,01 & 0,01 & 0,01 \\
\hline MAX & 0,49 & 0,27 & 0,49 & 0,04 & 0,05 & 0,07 \\
\hline MIN & 0,02 & 0,00 & 0,07 & 0,03 & 0,04 & 0,04 \\
\hline
\end{tabular}

\section{Resultados do Receptor B (Segunda Campanha)}

Tabela 39 - Resultados do Receptor B, $1^{\circ}$ dia, para o marco M01 20 km

\begin{tabular}{lcccccc}
\hline & \multicolumn{3}{c}{ ACURÁCIA $(\mathrm{m})$} & \multicolumn{3}{c}{ PRECISÃO $(\mathrm{m})$} \\
\hline $\mathrm{ID}$ & $\mathrm{DE}$ & $\mathrm{DN}$ & $\mathrm{ERRO}$ & $\mathrm{DE}$ & $\mathrm{DN}$ & $\mathrm{ERRO}$ \\
\hline $\mathrm{M} 1 \# 1$ & 0,02 & 0,15 & 0,15 & 0,04 & 0,04 & 0,06 \\
\hline M1\#2 & 0,15 & 0,10 & 0,18 & 0,06 & 0,06 & 0,08 \\
\hline M1\#3 & 1,99 & 0,83 & 2,16 & 0,05 & 0,05 & 0,07 \\
\hline M1\#4 & 0,00 & 0,82 & 0,82 & 0,15 & 0,14 & 0,21 \\
\hline M1\#5 & 0,21 & 0,72 & 0,75 & 0,09 & 0,08 & 0,12 \\
\hline M1\#6 & 0,00 & 0,31 & 0,31 & 0,09 & 0,09 & 0,13 \\
\hline M1\#7 & 0,25 & 0,43 & 0,50 & 0,09 & 0,09 & 0,13 \\
\hline M1\#8 & 0,15 & 0,28 & 0,31 & 0,15 & 0,14 & 0,21 \\
\hline M1\#9 & 0,08 & 0,16 & 0,18 & 0,12 & 0,12 & 0,17 \\
\hline M1\#10 & 0,10 & 0,17 & 0,19 & 0,06 & 0,06 & 0,08 \\
\hline M1\#11 & 0,07 & 0,15 & 0,16 & 0,06 & 0,06 & 0,08 \\
\hline M1\#12 & 0,04 & 0,14 & 0,15 & 0,04 & 0,04 & 0,06 \\
\hline MÉDIA & 0,60 & 0,45 & 0,82 & 0,09 & 0,08 & 0,12 \\
\hline DESVPAD & 0,87 & 0,32 & 0,86 & 0,04 & 0,03 & 0,05 \\
\hline MAX & 1,99 & 0,83 & 2,16 & 0,15 & 0,14 & 0,21 \\
\hline MIN & 0,00 & 0,10 & 0,15 & 0,04 & 0,04 & 0,06 \\
\hline
\end{tabular}

Tabela 40 - Resultados do Receptor B, $2^{\circ}$ dia, para o marco M01 $\sim 20$ km

\begin{tabular}{lcccccc}
\hline & \multicolumn{3}{c}{ ACURÁlA $(\mathrm{m})$} & \multicolumn{3}{c}{ PRECISÃO $(\mathrm{m})$} \\
\hline ID & $\mathrm{DE}$ & $\mathrm{DN}$ & $\mathrm{ERRO}$ & $\mathrm{DE}$ & $\mathrm{DN}$ & $\mathrm{ERRO}$ \\
\hline M1\#1 & 0,30 & 0,16 & 0,34 & 0,05 & 0,06 & 0,08 \\
\hline M1\#2 & 0,27 & 0,31 & 0,41 & 0,05 & 0,05 & 0,07 \\
\hline M1\#3 & 0,30 & 0,14 & 0,33 & 0,05 & 0,06 & 0,08 \\
\hline M1\#4 & 0,28 & 0,14 & 0,32 & 0,06 & 0,06 & 0,08 \\
\hline M1\#5 & 0,28 & 0,12 & 0,30 & 0,06 & 0,08 & 0,10 \\
\hline M1\#6 & 0,24 & 0,11 & 0,27 & 0,07 & 0,08 & 0,11 \\
\hline M1\#7 & 0,27 & 0,31 & 0,41 & 0,09 & 0,09 & 0,13 \\
\hline M1\#8 & 0,25 & 0,15 & 0,29 & 0,05 & 0,04 & 0,06 \\
\hline M1\#9 & 0,27 & 0,31 & 0,41 & 0,07 & 0,08 & 0,11 \\
\hline M1\#10 & 0,27 & 0,31 & 0,41 & 0,05 & 0,06 & 0,08 \\
\hline M1\#11 & 0,23 & 0,18 & 0,29 & 0,05 & 0,06 & 0,08 \\
\hline M1\#12 & 0,24 & 0,21 & 0,32 & 0,05 & 0,05 & 0,07 \\
\hline MÉDIA & 0,26 & 0,20 & 0,34 & 0,06 & 0,07 & 0,09 \\
\hline DESVPAD & 0,02 & 0,08 & 0,05 & 0,01 & 0,02 & 0,02 \\
\hline MAX & 0,30 & 0,31 & 0,41 & 0,09 & 0,09 & 0,13 \\
\hline MIN & 0,23 & 0,11 & 0,27 & 0,05 & 0,04 & 0,06 \\
\hline
\end{tabular}


Tabela 41 - Resultados do Receptor B, $1^{\circ}$ dia, para o marco M02 50 km

\begin{tabular}{lcccccc}
\hline & & ACURÁCIA $(m)$ & & & PRECISÃO $(m)$ & DERO \\
\hline ID & DE & DN & ERRO & 0,04 & 0,04 & 0,06 \\
\hline M2\#1 & 0,12 & 0,17 & 0,21 & 0,10 & 0,09 & 0,14 \\
\hline M2\#2 & 0,06 & 0,46 & 0,46 & 0,16 & 0,15 & 0,22 \\
\hline M2\#3 & 1,62 & 0,19 & 1,63 & 0,22 & 0,21 & 0,30 \\
\hline M2\#4 & 0,19 & 0,30 & 0,36 & 0,22 & 0,21 & 0,30 \\
\hline M2\#5 & 0,12 & 0,35 & 0,37 & 0,15 & 0,16 & 0,22 \\
\hline M2\#6 & 0,48 & 0,04 & 0,48 & 0,19 & 0,19 & 0,27 \\
\hline M2\#7 & 0,08 & 0,32 & 0,33 & 0,16 & 0,15 & 0,22 \\
\hline M2\#8 & 1,62 & 0,19 & 1,63 & 0,20 & 0,19 & 0,28 \\
\hline M2\#9 & 0,73 & 0,31 & 0,79 & 0,20 & 0,20 & 0,28 \\
\hline M2\#10 & 1,62 & 0,19 & 1,63 & 0,14 & 0,14 & 0,20 \\
\hline M2\#11 & 0,70 & 0,31 & 0,76 & 0,14 & 0,14 & 0,20 \\
\hline M2\#12 & 1,62 & 0,19 & 1,63 & 0,16 & 0,16 & 0,22 \\
\hline MÉDIA & 0,75 & 0,25 & 0,86 & 0,05 & 0,05 & 0,07 \\
\hline DESVPAD & 0,69 & 0,11 & 0,60 & 0,22 & 0,21 & 0,30 \\
\hline MAX & 1,62 & 0,46 & 1,63 & 0,04 & 0,04 & 0,06 \\
\hline MIN & 0,06 & 0,04 & 0,21 & & & \\
\hline
\end{tabular}

Tabela 42 - Resultados do Receptor B, $2^{\circ}$ dia, para o marco M02 50 km

\begin{tabular}{lcccccc}
\hline & \multicolumn{3}{c}{ ACURÁCIA $(\mathrm{m})$} & & \multicolumn{3}{c}{ PRECISÃO $(\mathrm{m})$} \\
\hline $\mathrm{ID}$ & $\mathrm{DE}$ & $\mathrm{DN}$ & $\mathrm{ERRO}$ & $\mathrm{DE}$ & $\mathrm{DN}$ & ERRO \\
\hline $\mathrm{M} 2 \# 1$ & 0,29 & 0,02 & 0,29 & 0,18 & 0,19 & 0,26 \\
\hline $\mathrm{M} 2 \# 2$ & 0,27 & 0,06 & 0,28 & 0,19 & 0,20 & 0,28 \\
\hline $\mathrm{M} 2 \# 3$ & 1,93 & 0,30 & 1,95 & 0,13 & 0,14 & 0,19 \\
\hline $\mathrm{M} 2 \# 4$ & 0,24 & 0,06 & 0,25 & 0,19 & 0,20 & 0,28 \\
\hline $\mathrm{M} 2 \# 5$ & 2,23 & 0,41 & 2,27 & 0,13 & 0,15 & 0,20 \\
\hline $\mathrm{M} 2 \# 6$ & 0,23 & 0,03 & 0,23 & 0,13 & 0,14 & 0,19 \\
\hline $\mathrm{M} 2 \# 7$ & 0,29 & 0,07 & 0,30 & 0,15 & 0,14 & 0,21 \\
\hline $\mathrm{M} 2 \# 8$ & 0,31 & 0,11 & 0,33 & 0,23 & 0,21 & 0,31 \\
\hline $\mathrm{M} 2 \# 9$ & 0,29 & 0,09 & 0,30 & 0,20 & 0,19 & 0,28 \\
\hline $\mathrm{M} 2 \# 10$ & 0,35 & 0,53 & 0,63 & 0,20 & 0,20 & 0,28 \\
\hline $\mathrm{M} 2 \# 11$ & 0,26 & 0,09 & 0,28 & 0,18 & 0,19 & 0,26 \\
\hline $\mathrm{M} 2 \# 12$ & 0,61 & 0,06 & 0,65 & 0,18 & 0,19 & 0,26 \\
\hline MÉDIA & 0,61 & 0,15 & 0,65 & 0,17 & 0,18 & 0,25 \\
\hline $\mathrm{DESVPAD}$ & 0,70 & 0,17 & 0,70 & 0,03 & 0,03 & 0,04 \\
\hline MAX & 2,23 & 0,53 & 2,27 & 0,23 & 0,21 & 0,31 \\
\hline MIN & 0,23 & 0,02 & 0,23 & 0,13 & 0,14 & 0,19 \\
\hline
\end{tabular}

Tabela 43 - Resultados do Receptor B, $1^{\circ}$ dia, para o marco M03 75 km

\begin{tabular}{lcccccc}
\hline & \multicolumn{3}{c}{ ACURÁCIA $(\mathrm{m})$} & & \multicolumn{3}{c}{ PRECISÃO $(\mathrm{m})$} \\
\hline $\mathrm{ID}$ & $\mathrm{DE}$ & $\mathrm{DN}$ & $\mathrm{ERRO}$ & $\mathrm{DE}$ & $\mathrm{DN}$ & $\mathrm{ERRO}$ \\
\hline $\mathrm{M} 3 \# 1$ & 1,48 & 0,31 & 1,51 & 0,13 & 0,12 & 0,18 \\
\hline $\mathrm{M} 3 \# 2$ & 0,56 & 0,69 & 0,89 & 0,10 & 0,11 & 0,15 \\
\hline $\mathrm{M} 3 \# 3$ & 0,56 & 0,69 & 0,89 & 0,20 & 0,18 & 0,27 \\
\hline $\mathrm{M} 3 \# 4$ & 0,46 & 0,97 & 1,07 & 0,20 & 0,18 & 0,27 \\
\hline $\mathrm{M} 3 \# 5$ & 0,66 & 0,16 & 0,68 & 0,20 & 0,19 & 0,28 \\
\hline $\mathrm{M} 3 \#$ & 0,67 & 0,11 & 0,67 & 0,29 & 0,25 & 0,38 \\
\hline $\mathrm{M} 3 \# 7$ & 0,55 & 0,08 & 0,55 & 0,29 & 0,26 & 0,39 \\
\hline $\mathrm{M} 3 \# 8$ & 0,56 & 0,69 & 0,89 & 0,34 & 0,29 & 0,45 \\
\hline $\mathrm{M} 3 \# 9$ & 0,59 & 0,05 & 0,60 & 0,23 & 0,20 & 0,30 \\
\hline $\mathrm{M} 3 \# 10$ & 0,56 & 0,69 & 0,89 & 0,19 & 0,18 & 0,26 \\
\hline M3\#11 & 0,63 & 0,02 & 0,63 & 0,19 & 0,18 & 0,26 \\
\hline M3\#12 & 0,56 & 0,69 & 0,89 & 0,25 & 0,24 & 0,35 \\
\hline MÉDIA & 0,72 & 0,42 & 0,90 & 0,22 & 0,20 & 0,29 \\
\hline DESVPAD & 0,35 & 0,32 & 0,32 & 0,06 & 0,05 & 0,08 \\
\hline MAX & 1,52 & 0,97 & 1,56 & 0,34 & 0,29 & 0,45 \\
\hline MIN & 0,46 & 0,02 & 0,55 & 0,10 & 0,11 & 0,15 \\
\hline
\end{tabular}


Tabela 44 - Resultados do Receptor B, $2^{\circ}$ dia, para o marco M03 $\sim 75$ km

\begin{tabular}{|c|c|c|c|c|c|c|}
\hline & \multicolumn{3}{|c|}{ ACURÁCIA (m) } & \multicolumn{3}{|c|}{ PRECISÃO (m) } \\
\hline ID & $\mathrm{DE}$ & $\mathrm{DN}$ & ERRO & $\mathrm{DE}$ & $\mathrm{DN}$ & ERRO \\
\hline M3\#1 & 0,62 & 0,22 & 0,66 & 0,24 & 0,24 & 0,34 \\
\hline M3\#2 & 0,60 & 0,25 & 0,65 & 0,18 & 0,18 & 0,25 \\
\hline M3\#3 & 0,59 & 0,22 & 0,63 & 0,18 & 0,18 & 0,25 \\
\hline M3\#4 & 2,03 & 3,36 & 3,93 & 0,18 & 0,19 & 0,26 \\
\hline M3\#5 & 0,72 & 0,05 & 0,72 & 0,21 & 0,20 & 0,29 \\
\hline M3\#6 & 2,03 & 3,36 & 3,93 & 0,19 & 0,20 & 0,28 \\
\hline M3\#7 & 0,70 & 0,17 & 0,72 & 0,17 & 0,16 & 0,23 \\
\hline M3\#8 & 2,03 & 3,36 & 3,93 & 0,17 & 0,17 & 0,24 \\
\hline M3\#9 & 0,68 & 0,14 & 0,69 & 0,19 & 0,20 & 0,28 \\
\hline M3\#10 & 0,67 & 0,14 & 0,68 & 0,18 & 0,21 & 0,28 \\
\hline M3\#11 & 0,62 & 0,14 & 0,63 & 0,21 & 0,22 & 0,30 \\
\hline M3\#12 & 0,61 & 0,14 & 0,63 & 0,20 & 0,19 & 0,28 \\
\hline MÉDIA & 0,99 & 0,96 & 1,48 & 0,19 & 0,20 & 0,27 \\
\hline DESVPAD & 0,63 & 1,45 & 1,47 & 0,02 & 0,02 & 0,03 \\
\hline MAX & 2,03 & 3,36 & 3,93 & 0,24 & 0,24 & 0,34 \\
\hline MIN & 0,59 & 0,05 & 0,63 & 0,17 & 0,16 & 0,23 \\
\hline
\end{tabular}

Tabela 45 - Resultados do Receptor $B, 1^{\circ}$ dia, para o marco M04 $100 \mathrm{~km}$

\begin{tabular}{lcccccc}
\hline & \multicolumn{3}{c}{ ACURÁCIA $(\mathrm{m})$} & \multicolumn{3}{c}{ PRECISÃO (m) } \\
\hline ID & DE & DN & ERRO & DE & DN & ERRO \\
\hline M4\#1 & 1,43 & 0,03 & 1,43 & 0,16 & 0,15 & 0,22 \\
\hline M4\#2 & 1,96 & 1,30 & 2,35 & 0,13 & 0,13 & 0,18 \\
\hline M4\#3 & 0,79 & 0,83 & 1,15 & 0,40 & 0,36 & 0,54 \\
\hline M4\#4 & 1,96 & 1,30 & 2,35 & 0,37 & 0,35 & 0,51 \\
\hline M4\#5 & 1,14 & 1,35 & 1,77 & 0,32 & 0,29 & 0,43 \\
\hline M4\#6 & 1,91 & 0,10 & 1,91 & 0,38 & 0,34 & 0,51 \\
\hline M4\#7 & 0,40 & 0,37 & 0,54 & 0,32 & 0,29 & 0,43 \\
\hline M4\#8 & 0,99 & 0,22 & 1,01 & 0,38 & 0,35 & 0,52 \\
\hline M4\#9 & 1,96 & 1,30 & 2,35 & 0,32 & 0,29 & 0,43 \\
\hline M4\#10 & 0,13 & 0,10 & 0,17 & 0,25 & 0,26 & 0,36 \\
\hline M4\#11 & 1,96 & 1,30 & 2,35 & 0,25 & 0,26 & 0,36 \\
\hline M4\#12 & 0,10 & 0,14 & 0,17 & 0,25 & 0,26 & 0,36 \\
\hline MÉDIA & 1,28 & 0,74 & 1,53 & 0,29 & 0,28 & 0,40 \\
\hline DESVPAD & 0,74 & 0,58 & 0,85 & 0,08 & 0,07 & 0,11 \\
\hline MAX & 1,96 & 1,35 & 2,35 & 0,40 & 0,36 & 0,54 \\
\hline MIN & 0,10 & 0,03 & 0,17 & 0,13 & 0,13 & 0,18 \\
\hline
\end{tabular}

Tabela 46 - Resultados do Receptor B, $2^{\circ}$ dia, para o marco M04 100 km

\begin{tabular}{lcccccc}
\hline & & ACURÁCIA $(\mathrm{m})$ & \multicolumn{3}{c}{ PRECISÃO (m) } \\
\hline ID & DE & DN & ERRO & DE & DN & ERRO \\
\hline M4\#1 & 0,25 & 0,11 & 0,27 & 0,31 & 0,33 & 0,45 \\
\hline M4\#2 & 0,92 & 0,98 & 1,34 & 0,31 & 0,33 & 0,45 \\
\hline M4\#3 & 0,23 & 0,13 & 0,27 & 0,31 & 0,32 & 0,45 \\
\hline M4\#4 & 0,92 & 0,98 & 1,34 & 0,29 & 0,31 & 0,42 \\
\hline M4\#5 & 0,27 & 0,14 & 0,30 & 0,32 & 0,32 & 0,45 \\
\hline M4\#6 & 0,92 & 0,98 & 1,34 & 0,25 & 0,28 & 0,38 \\
\hline M4\#7 & 0,27 & 0,15 & 0,31 & 0,33 & 0,33 & 0,47 \\
\hline M4\#8 & 0,19 & 0,09 & 0,21 & 0,28 & 0,32 & 0,43 \\
\hline M4\#9 & 0,23 & 0,07 & 0,23 & 0,29 & 0,30 & 0,42 \\
\hline M4\#10 & 0,28 & 0,13 & 0,30 & 0,25 & 0,28 & 0,38 \\
\hline M4\#11 & 0,92 & 0,98 & 1,34 & 0,21 & 0,26 & 0,33 \\
\hline M4\#12 & 0,39 & 0,15 & 0,41 & 0,21 & 0,26 & 0,33 \\
\hline MÉDIA & 0,48 & 0,41 & 0,64 & 0,28 & 0,30 & 0,41 \\
\hline DESVPAD & 0,33 & 0,42 & 0,52 & 0,04 & 0,03 & 0,05 \\
\hline MAX & 0,92 & 0,98 & 1,34 & 0,33 & 0,33 & 0,47 \\
\hline MIN & 0,19 & 0,07 & 0,21 & 0,21 & 0,26 & 0,33 \\
\hline
\end{tabular}


Tabela 47 - Resultados do Receptor B, $1^{\circ}$ dia, para o marco M05 150 km

\begin{tabular}{lcccccc}
\hline & & ACURÁCIA $(m)$ & & & PRECISÃO $(m)$ & DE \\
\hline ID & DE & DN & ERRO & 0,20 & 0,19 & 0,28 \\
\hline M5\#1 & 0,51 & 0,46 & 0,68 & 0,17 & 0,19 & 0,25 \\
\hline M5\#2 & 1,00 & 0,24 & 1,03 & 0,32 & 0,33 & 0,46 \\
\hline M5\#3 & 1,46 & 0,01 & 1,46 & 0,45 & 0,44 & 0,63 \\
\hline M5\#4 & 1,01 & 0,29 & 1,05 & 0,39 & 0,35 & 0,52 \\
\hline M5\#5 & 1,46 & 0,01 & 1,46 & 0,41 & 0,41 & 0,58 \\
\hline M5\#6 & 1,03 & 0,40 & 1,11 & 0,40 & 0,41 & 0,57 \\
\hline M5\#7 & 1,46 & 0,01 & 1,46 & 0,40 & 0,41 & 0,57 \\
\hline M5\#8 & 1,03 & 0,43 & 1,11 & 0,42 & 0,44 & 0,61 \\
\hline M5\#9 & 1,05 & 0,46 & 1,14 & 0,41 & 0,41 & 0,58 \\
\hline M5\#10 & 0,99 & 0,53 & 1,12 & 0,40 & 0,40 & 0,57 \\
\hline M5\#11 & 0,98 & 0,75 & 1,23 & 0,40 & 0,41 & 0,57 \\
\hline M5\#12 & 1,08 & 0,97 & 1,45 & 0,36 & 0,37 & 0,52 \\
\hline MÉDIA & 1,09 & 0,38 & 1,19 & 0,09 & 0,09 & 0,12 \\
\hline DESVPAD & 0,27 & 0,30 & 0,24 & 0,45 & 0,44 & 0,63 \\
\hline MAX & 1,46 & 0,97 & 1,46 & 0,17 & 0,19 & 0,25 \\
\hline MIN & 0,51 & 0,01 & 0,68 & & & \\
\hline
\end{tabular}

Tabela 48 - Resultados do Receptor B, $2^{\circ}$ dia, para o marco M05 $150 \mathrm{~km}$

\begin{tabular}{|c|c|c|c|c|c|c|}
\hline & \multicolumn{3}{|c|}{ ACURÁCIA (m) } & \multicolumn{3}{|c|}{ PRECISÃO (m) } \\
\hline ID & $\mathrm{DE}$ & $\mathrm{DN}$ & ERRO & $\mathrm{DE}$ & DN & ERRO \\
\hline M5\#1 & 0,24 & 0,29 & 0,37 & 0,34 & 0,34 & 0,48 \\
\hline M5\#2 & 1,02 & 0,13 & 1,03 & 0,34 & 0,34 & 0,48 \\
\hline M5\#3 & 0,25 & 0,25 & 0,35 & 0,34 & 0,34 & 0,48 \\
\hline M5\#4 & 0,21 & 0,24 & 0,32 & 0,39 & 0,39 & 0,55 \\
\hline M5\#5 & 0,19 & 0,27 & 0,33 & 0,43 & 0,44 & 0,62 \\
\hline M5\#6 & 0,20 & 0,29 & 0,35 & 0,46 & 0,49 & 0,67 \\
\hline M5\#7 & 1,02 & 0,13 & 1,03 & 0,41 & 0,44 & 0,60 \\
\hline M5\#8 & 0,13 & 0,29 & 0,31 & 0,41 & 0,44 & 0,60 \\
\hline M5\#9 & 1,02 & 0,13 & 1,03 & 0,37 & 0,38 & 0,53 \\
\hline M5\#10 & 0,09 & 0,30 & 0,32 & 0,39 & 0,40 & 0,56 \\
\hline M5\#11 & 1,02 & 0,13 & 1,03 & 0,39 & 0,41 & 0,57 \\
\hline M5\#12 & 0,02 & 0,33 & 0,33 & 0,37 & 0,38 & 0,53 \\
\hline MÉDIA & 0,45 & 0,23 & 0,57 & 0,39 & 0,40 & 0,56 \\
\hline DESVPAD & 0,42 & 0,08 & 0,34 & 0,04 & 0,05 & 0,06 \\
\hline MAX & 1,02 & 0,33 & 1,03 & 0,46 & 0,49 & 0,67 \\
\hline $\mathrm{MIN}$ & 0,02 & 0,13 & 0,31 & 0,34 & 0,34 & 0,48 \\
\hline
\end{tabular}

Tabela 49 - Resultados do Receptor B, $1^{\circ}$ dia, para o marco M06 $\sim 200$ km

\begin{tabular}{lcccccc}
\hline & \multicolumn{3}{c}{ ACURÁCIA $(\mathrm{m})$} & \multicolumn{3}{c}{ PRECISÃO $(\mathrm{m})$} \\
\hline $\mathrm{ID}$ & $\mathrm{DE}$ & $\mathrm{DN}$ & $\mathrm{ERRO}$ & $\mathrm{DE}$ & $\mathrm{DN}$ & $\mathrm{ERRO}$ \\
\hline $\mathrm{M}$ 61 & 1,12 & 0,57 & 1,26 & 0,24 & 0,25 & 0,35 \\
\hline M6\#2 & 2,45 & 0,94 & 2,63 & 0,23 & 0,24 & 0,33 \\
\hline M6\#3 & 1,11 & 0,68 & 1,30 & 0,24 & 0,27 & 0,37 \\
\hline M6\#4 & 2,45 & 0,94 & 2,63 & 0,42 & 0,45 & 0,62 \\
\hline M6\#5 & 1,10 & 0,65 & 1,28 & 0,42 & 0,45 & 0,62 \\
\hline M6\#6 & 2,45 & 0,94 & 2,63 & 0,49 & 0,49 & 0,69 \\
\hline M6\#7 & 1,07 & 0,76 & 1,31 & 0,53 & 0,53 & 0,75 \\
\hline M6\#8 & 2,45 & 0,94 & 2,63 & 0,46 & 0,46 & 0,65 \\
\hline M6\#9 & 0,89 & 0,80 & 1,19 & 0,45 & 0,45 & 0,64 \\
\hline M6\#10 & 2,45 & 0,94 & 2,63 & 0,51 & 0,51 & 0,72 \\
\hline M6\#11 & 0,76 & 0,43 & 0,88 & 0,46 & 0,46 & 0,65 \\
\hline M6\#12 & 2,45 & 0,94 & 2,63 & 0,53 & 0,52 & 0,74 \\
\hline MÉDIA & 1,79 & 0,81 & 1,97 & 0,42 & 0,43 & 0,60 \\
\hline DESVPAD & 0,76 & 0,18 & 0,75 & 0,11 & 0,10 & 0,15 \\
\hline MAX & 2,45 & 0,94 & 2,63 & 0,53 & 0,53 & 0,75 \\
\hline MIN & 0,76 & 0,43 & 0,88 & 0,23 & 0,24 & 0,33 \\
\hline
\end{tabular}


Tabela 50 - Resultados do Receptor B, $2^{\circ}$ dia, para o marco M06 $\sim 200$ km

\begin{tabular}{|c|c|c|c|c|c|c|}
\hline & \multicolumn{3}{|c|}{ ACURÁCIA (m) } & \multicolumn{3}{|c|}{ PRECISÃO (m) } \\
\hline ID & $\mathrm{DE}$ & DN & ERRO & $\mathrm{DE}$ & $\mathrm{DN}$ & ERRO \\
\hline M6\#1 & 0,35 & 0,24 & 0,42 & 0,53 & 0,52 & 0,74 \\
\hline M6\#2 & 1,92 & 1,00 & 2,17 & 0,45 & 0,45 & 0,64 \\
\hline M6\#3 & 0,42 & 0,21 & 0,47 & 0,53 & 0,52 & 0,74 \\
\hline M6\#4 & 2,50 & 0,34 & 2,52 & 0,50 & 0,50 & 0,71 \\
\hline M6\#5 & 0,47 & 0,17 & 0,50 & 0,42 & 0,43 & 0,60 \\
\hline M6\#6 & 1,92 & 1,00 & 2,17 & 0,42 & 0,43 & 0,60 \\
\hline M6\#7 & 0,37 & 0,22 & 0,43 & 0,42 & 0,43 & 0,60 \\
\hline M6\#8 & 0,93 & 0,20 & 0,95 & 0,43 & 0,43 & 0,61 \\
\hline M6\#9 & 0,91 & 0,16 & 0,92 & 0,43 & 0,44 & 0,62 \\
\hline M6\#10 & 2,64 & 0,17 & 2,65 & 0,51 & 0,52 & 0,73 \\
\hline M6\#11 & 0,92 & 0,11 & 0,93 & 0,44 & 0,46 & 0,64 \\
\hline M6\#12 & 1,21 & 0,35 & 1,28 & 0,46 & 0,47 & 0,66 \\
\hline MÉDIA & 1,21 & 0,35 & 1,28 & 0,46 & 0,47 & 0,66 \\
\hline DESVPAD & 0,87 & 0,33 & 0,90 & 0,05 & 0,04 & 0,06 \\
\hline MAX & 2,64 & 1,00 & 2,65 & 0,53 & 0,52 & 0,74 \\
\hline $\mathrm{MIN}$ & 0,35 & 0,11 & 0,42 & 0,42 & 0,43 & 0,60 \\
\hline
\end{tabular}

Tabela 51 - Resultados do Receptor B, $1^{\circ}$ dia, para o marco M07 300 km

\begin{tabular}{|c|c|c|c|c|c|c|}
\hline & \multicolumn{3}{|c|}{ ACURÁCIA (m) } & \multicolumn{3}{|c|}{ PRECISÃO (m) } \\
\hline ID & $\mathrm{DE}$ & $\mathrm{DN}$ & ERRO & $\mathrm{DE}$ & DN & ERRO \\
\hline M7\#1 & 1,34 & 0,54 & 1,44 & 0,34 & 0,37 & 0,50 \\
\hline M7\#2 & 0,68 & 0,12 & 0,69 & 0,37 & 0,37 & 0,52 \\
\hline M7\#3 & 1,44 & 0,34 & 1,48 & 0,68 & 0,68 & 0,96 \\
\hline M7\#4 & 2,12 & 0,68 & 2,23 & 0,75 & 0,81 & 1,10 \\
\hline M7\#5 & 1,69 & 0,78 & 1,86 & 0,74 & 0,73 & 1,04 \\
\hline M7\#6 & 1,96 & 0,04 & 1,96 & 0,76 & 0,75 & 1,07 \\
\hline M7\#7 & 0,68 & 0,12 & 0,69 & 0,75 & 0,74 & 1,05 \\
\hline M7\#8 & 1,35 & 1,03 & 1,70 & 0,76 & 0,75 & 1,07 \\
\hline M7\#9 & 0,68 & 0,12 & 0,69 & 0,74 & 0,73 & 1,04 \\
\hline M7\#10 & 1,75 & 1,77 & 2,49 & 0,75 & 0,83 & 1,12 \\
\hline M7\#11 & 0,02 & 0,03 & 0,04 & 0,71 & 0,71 & 1,00 \\
\hline M7\#12 & 1,97 & 1,46 & 2,45 & 0,76 & 0,75 & 1,07 \\
\hline MÉDIA & 1,31 & 0,59 & 1,48 & 0,68 & 0,68 & 0,96 \\
\hline DESVPAD & 0,65 & 0,58 & 0,79 & 0,15 & 0,15 & 0,21 \\
\hline MAX & 2,12 & 1,77 & 2,49 & 0,76 & 0,83 & 1,12 \\
\hline $\mathrm{MIN}$ & 0,02 & 0,03 & 0,04 & 0,34 & 0,37 & 0,50 \\
\hline
\end{tabular}

Tabela 52 - Resultados do Receptor B, $2^{\circ}$ dia, para o marco M07 $\sim 300$ km

\begin{tabular}{|c|c|c|c|c|c|c|}
\hline & \multicolumn{3}{|c|}{ ACURÁCIA (m) } & \multicolumn{3}{|c|}{ PRECISÃO (m) } \\
\hline ID & $\mathrm{DE}$ & DN & ERRO & $\mathrm{DE}$ & DN & ERRO \\
\hline M7\#1 & 1,07 & 0,28 & 1,11 & 0,65 & 0,66 & 0,93 \\
\hline M7\#2 & 0,94 & 0,00 & 0,94 & 0,78 & 0,80 & 1,12 \\
\hline M7\#3 & 1,36 & 0,47 & 1,44 & 0,71 & 0,72 & 1,01 \\
\hline M7\#4 & 0,63 & 0,19 & 0,66 & 0,78 & 0,80 & 1,12 \\
\hline M7\#5 & 0,73 & 2,06 & 2,19 & 0,71 & 0,72 & 1,01 \\
\hline M7\#6 & 0,63 & 0,19 & 0,66 & 0,87 & 0,84 & 1,21 \\
\hline M7\#7 & 0,63 & 0,19 & 0,66 & 0,66 & 0,67 & 0,94 \\
\hline M7\#8 & 0,63 & 0,19 & 0,66 & 0,67 & 0,67 & 0,95 \\
\hline M7\#9 & 0,63 & 0,19 & 0,66 & 0,74 & 0,75 & 1,05 \\
\hline M7\#10 & 0,63 & 0,19 & 0,66 & 0,74 & 0,79 & 1,08 \\
\hline M7\#11 & 0,63 & 0,19 & 0,66 & 0,77 & 0,76 & 1,08 \\
\hline M7\#12 & 0,63 & 0,19 & 0,66 & 0,80 & 0,74 & 1,09 \\
\hline MÉDIA & 0,76 & 0,36 & 0,91 & 0,74 & 0,74 & 1,05 \\
\hline DESVPAD & 0,24 & 0,55 & 0,47 & 0,06 & 0,06 & 0,08 \\
\hline MAX & 1,36 & 2,06 & 2,19 & 0,87 & 0,84 & 1,21 \\
\hline MIN & 0,63 & 0,00 & 0,66 & 0,65 & 0,66 & 0,93 \\
\hline
\end{tabular}




\section{Resultados do Receptor $C$ (Terceira e Quarta Campanha)}

Tabela 53 - Resultados do Receptor C, $1^{\circ}$ dia, para o marco M01 20 km ( $3^{a}$ Campanha)

\begin{tabular}{lcccccc}
\hline & \multicolumn{3}{c}{ ACURÁCIA $(\mathrm{m})$} & \multicolumn{3}{c}{ PRECISÃO (m) } \\
\hline ID & $\mathrm{DE}$ & $\mathrm{DN}$ & $\mathrm{ERRO}$ & $\mathrm{DE}$ & $\mathrm{DN}$ & $\mathrm{ERRO}$ \\
\hline $\mathrm{M} 1 \# 1$ & 0,85 & 0,32 & 0,91 & 0,02 & 0,02 & 0,02 \\
\hline $\mathrm{M} 1 \# 2$ & 0,66 & 0,22 & 0,70 & 0,02 & 0,02 & 0,02 \\
\hline M1\#3 & 0,75 & 0,20 & 0,77 & 0,02 & 0,02 & 0,02 \\
\hline M1\#4 & 0,74 & 0,08 & 0,75 & 0,02 & 0,02 & 0,02 \\
\hline M1\#5 & 0,79 & 0,02 & 0,79 & 0,02 & 0,02 & 0,03 \\
\hline M1\#6 & 0,80 & 0,10 & 0,80 & 0,03 & 0,03 & 0,04 \\
\hline M1\#7 & 0,33 & 0,03 & 0,34 & 0,01 & 0,01 & 0,02 \\
\hline M1\#8 & 0,14 & 0,32 & 0,34 & 0,01 & 0,01 & 0,02 \\
\hline M1\#9 & 0,45 & 0,05 & 0,45 & 0,02 & 0,02 & 0,02 \\
\hline M1\#10 & 0,27 & 0,03 & 0,27 & 0,02 & 0,02 & 0,02 \\
\hline M1\#11 & 0,45 & 0,05 & 0,45 & 0,02 & 0,02 & 0,02 \\
\hline M1\#12 & 0,48 & 0,14 & 0,50 & 0,01 & 0,01 & 0,01 \\
\hline MÉDIA & 0,56 & 0,13 & 0,59 & 0,02 & 0,02 & 0,02 \\
\hline DESVPAD & 0,24 & 0,11 & 0,22 & 0,00 & 0,00 & 0,01 \\
\hline MAXIMO & 0,85 & 0,32 & 0,91 & 0,03 & 0,03 & 0,04 \\
\hline MINIMO & 0,14 & 0,02 & 0,27 & 0,01 & 0,01 & 0,01 \\
\hline
\end{tabular}

Tabela 54 - Resultados do Receptor C, $2^{\circ}$ dia, para o marco M01 20 km (3 ${ }^{a}$ Campanha)

\begin{tabular}{|c|c|c|c|c|c|c|}
\hline & \multicolumn{3}{|c|}{ ACURÁCIA (m) } & \multicolumn{3}{|c|}{ PRECISÃO (m) } \\
\hline ID & $\mathrm{DE}$ & $\mathrm{DN}$ & ERRO & $\mathrm{DE}$ & $\mathrm{DN}$ & ERRO \\
\hline M1\#1 & 0,24 & 0,66 & 0,71 & 0,01 & 0,01 & 0,02 \\
\hline M1\#2 & 0,32 & 0,67 & 0,74 & 0,02 & 0,02 & 0,02 \\
\hline M1\#3 & 0,29 & 0,41 & 0,50 & 0,01 & 0,01 & 0,02 \\
\hline M1\#4 & 0,33 & 0,38 & 0,50 & 0,02 & 0,07 & 0,07 \\
\hline M1\#5 & 0,01 & 0,16 & 0,16 & 0,02 & 0,02 & 0,03 \\
\hline M1\#6 & 0,29 & 0,19 & 0,35 & 0,01 & 0,02 & 0,02 \\
\hline M1\#7 & 0,48 & 0,29 & 0,56 & 0,01 & 0,01 & 0,02 \\
\hline M1\#8 & 0,73 & 0,17 & 0,75 & 0,01 & 0,01 & 0,01 \\
\hline M1\#9 & 0,82 & 0,25 & 0,85 & 0,01 & 0,01 & 0,01 \\
\hline M1\#10 & 0,67 & 0,17 & 0,69 & 0,01 & 0,01 & 0,01 \\
\hline M1\#11 & 0,08 & 0,45 & 0,46 & 0,02 & 0,02 & 0,02 \\
\hline M1\#12 & 0,10 & 0,73 & 0,74 & 0,01 & 0,01 & 0,01 \\
\hline MÉDIA & 0,36 & 0,38 & 0,58 & 0,01 & 0,02 & 0,02 \\
\hline DESVPAD & 0,26 & 0,21 & 0,20 & 0,01 & 0,02 & 0,02 \\
\hline MAXIMO & 0,82 & 0,73 & 0,85 & 0,02 & 0,07 & 0,07 \\
\hline MINIMO & 0,01 & 0,16 & 0,16 & 0,01 & 0,01 & 0,01 \\
\hline
\end{tabular}

Tabela 55 - Resultados do Receptor C, $1^{\circ}$ dia, para o marco M01 $\sim 20$ km (4 Campanha)

\begin{tabular}{|c|c|c|c|c|c|c|}
\hline & \multicolumn{3}{|c|}{ ACURÁCIA (m) } & \multicolumn{3}{|c|}{ PRECISÃO (m) } \\
\hline ID & $\mathrm{DE}$ & $\mathrm{DN}$ & ERRO & $\mathrm{DE}$ & DN & ERRO \\
\hline M1\#1 & 0,29 & 0,11 & 0,31 & 0,01 & 0,00 & 0,01 \\
\hline M1\#2 & 0,02 & 0,02 & 0,02 & 0,00 & 0,00 & 0,00 \\
\hline M1\#3 & 0,13 & 0,04 & 0,14 & 0,00 & 0,00 & 0,00 \\
\hline M1\#4 & 0,21 & 0,13 & 0,24 & 0,01 & 0,00 & 0,01 \\
\hline M1\#5 & 0,15 & 0,03 & 0,16 & 0,00 & 0,00 & 0,01 \\
\hline M1\#6 & 0,39 & 0,03 & 0,40 & 0,00 & 0,00 & 0,01 \\
\hline M1\#7 & 0,14 & 0,09 & 0,17 & 0,01 & 0,00 & 0,01 \\
\hline M1\#8 & 0,12 & 0,06 & 0,14 & 0,00 & 0,00 & 0,00 \\
\hline M1\#9 & 0,13 & 0,04 & 0,14 & 0,00 & 0,00 & 0,00 \\
\hline M1\#10 & 0,44 & 0,08 & 0,44 & 0,01 & 0,00 & 0,01 \\
\hline $\mathrm{M} 1 \# 11$ & 0,30 & 0,07 & 0,31 & 0,00 & 0,00 & 0,01 \\
\hline M1\#12 & 0,20 & 0,04 & 0,20 & 0,00 & 0,00 & 0,01 \\
\hline MÉDIA & 0,21 & 0,06 & 0,22 & 0,00 & 0,00 & 0,00 \\
\hline DESVPAD & 0,12 & 0,03 & 0,12 & 0,00 & 0,00 & 0,00 \\
\hline MAX & 0,44 & 0,13 & 0,44 & 0,01 & 0,00 & 0,01 \\
\hline MIN & 0,02 & 0,02 & 0,02 & 0,00 & 0,00 & 0,00 \\
\hline
\end{tabular}


Tabela 56 - Resultados do Receptor C, $2^{\circ}$ dia, para o marco M01 20 km

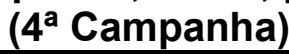

\begin{tabular}{lcccccc}
\hline & \multicolumn{3}{c}{ ACURÁCIA $(\mathrm{m})$} & \multicolumn{3}{c}{ PRECISÃO (m) } \\
\hline ID & $\mathrm{DE}$ & $\mathrm{DN}$ & $\mathrm{ERRO}$ & $\mathrm{DE}$ & $\mathrm{DN}$ & ERRO \\
\hline M1\#1 & 0,10 & 0,24 & 0,26 & 0,01 & 0,01 & 0,01 \\
\hline M1\#2 & 0,13 & 0,11 & 0,17 & 0,01 & 0,02 & 0,02 \\
\hline M1\#3 & 0,00 & 0,00 & 0,00 & 0,01 & 0,01 & 0,01 \\
\hline M1\#4 & 0,05 & 0,20 & 0,21 & 0,10 & 0,01 & 0,10 \\
\hline M1\#5 & 0,08 & 0,05 & 0,09 & 0,01 & 0,02 & 0,02 \\
\hline M1\#6 & 0,11 & 0,00 & 0,11 & 0,01 & 0,02 & 0,03 \\
\hline M1\#7 & 0,05 & 0,25 & 0,25 & 0,01 & 0,01 & 0,02 \\
\hline M1\#8 & 0,08 & 0,22 & 0,23 & 0,01 & 0,01 & 0,01 \\
\hline M1\#9 & 0,07 & 0,45 & 0,46 & 0,01 & 0,01 & 0,01 \\
\hline M1\#10 & 0,00 & 0,37 & 0,37 & 0,01 & 0,01 & 0,01 \\
\hline M1\#11 & 0,13 & 0,44 & 0,46 & 0,01 & 0,01 & 0,01 \\
\hline M1\#12 & 0,03 & 0,50 & 0,50 & 0,01 & 0,01 & 0,01 \\
\hline MÉDIA & 0,07 & 0,24 & 0,26 & 0,02 & 0,01 & 0,02 \\
\hline DESVPAD & 0,04 & 0,17 & 0,16 & 0,03 & 0,00 & 0,02 \\
\hline MAX & 0,13 & 0,50 & 0,50 & 0,10 & 0,02 & 0,10 \\
\hline MIN & 0,00 & 0,00 & 0,00 & 0,01 & 0,01 & 0,01 \\
\hline
\end{tabular}

Tabela 57 - Resultados do Receptor C, $1^{\circ}$ dia, para o marco M02 50 km ( $3^{\mathrm{a}}$ Campanha)

\begin{tabular}{lcccccc}
\hline & \multicolumn{3}{c}{ ACURÁCIA $(\mathrm{m})$} & & PRECISÃO $(\mathrm{m})$ \\
\hline ID & $\mathrm{DE}$ & $\mathrm{DN}$ & $\mathrm{ERRO}$ & $\mathrm{DE}$ & $\mathrm{DN}$ & ERRO \\
\hline M2\#1 & 0,18 & 0,14 & 0,23 & 0,01 & 0,01 & 0,01 \\
\hline M2\#2 & 0,12 & 0,17 & 0,21 & 0,01 & 0,01 & 0,01 \\
\hline M2\#3 & 0,08 & 0,12 & 0,14 & 0,01 & 0,01 & 0,02 \\
\hline M2\#4 & 0,33 & 0,13 & 0,35 & 0,01 & 0,01 & 0,02 \\
\hline M2\#5 & 0,44 & 0,06 & 0,45 & 0,01 & 0,01 & 0,01 \\
\hline M2\#6 & 0,43 & 0,23 & 0,49 & 0,02 & 0,02 & 0,02 \\
\hline M2\#7 & 0,56 & 0,35 & 0,66 & 0,01 & 0,01 & 0,02 \\
\hline M2\#8 & 0,73 & 0,53 & 0,91 & 0,01 & 0,01 & 0,02 \\
\hline M2\#9 & 0,14 & 0,32 & 0,35 & 0,01 & 0,01 & 0,01 \\
\hline M2\#10 & 0,09 & 0,33 & 0,34 & 0,01 & 0,01 & 0,02 \\
\hline M2\#11 & 0,44 & 0,06 & 0,45 & 0,01 & 0,01 & 0,01 \\
\hline M2\#12 & 0,14 & 0,32 & 0,35 & 0,01 & 0,01 & 0,01 \\
\hline MÉDIA & 0,31 & 0,23 & 0,41 & 0,01 & 0,01 & 0,02 \\
\hline DESVPAD & 0,21 & 0,14 & 0,21 & 0,00 & 0,00 & 0,00 \\
\hline MAXIMO & 0,73 & 0,53 & 0,91 & 0,02 & 0,02 & 0,02 \\
\hline MINIMO & 0,08 & 0,06 & 0,14 & 0,01 & 0,01 & 0,01 \\
\hline
\end{tabular}

Tabela 58 - Resultados do Receptor C, $2^{\circ}$ dia, para o marco M02 $~ 50$ km (3a Campanha)

\begin{tabular}{lcccccc}
\hline & \multicolumn{3}{c}{ ACURÁCIA $(\mathrm{m})$} & & PRECISÃO $(\mathrm{m})$ \\
\hline ID & $\mathrm{DE}$ & $\mathrm{DN}$ & $\mathrm{ERRO}$ & $\mathrm{DE}$ & $\mathrm{DN}$ & ERRO \\
\hline M2\#1 & 1,24 & 0,27 & 1,27 & 0,01 & 0,02 & 0,02 \\
\hline M2\#2 & 1,23 & 0,39 & 1,29 & 0,01 & 0,02 & 0,02 \\
\hline M2\#3 & 1,19 & 0,40 & 1,26 & 0,01 & 0,02 & 0,02 \\
\hline M2\#4 & 1,23 & 0,39 & 1,29 & 0,01 & 0,02 & 0,02 \\
\hline M2\#5 & 0,99 & 0,44 & 1,08 & 0,02 & 0,02 & 0,03 \\
\hline M2\#6 & 1,24 & 0,43 & 1,31 & 0,02 & 0,02 & 0,03 \\
\hline M2\#7 & 1,20 & 0,56 & 1,33 & 0,02 & 0,02 & 0,02 \\
\hline M2\#8 & 1,06 & 0,49 & 1,17 & 0,01 & 0,02 & 0,02 \\
\hline M2\#9 & 1,05 & 0,62 & 1,22 & 0,02 & 0,02 & 0,03 \\
\hline M2\#10 & 0,82 & 0,73 & 1,10 & 0,02 & 0,02 & 0,02 \\
\hline M2\#11 & 0,64 & 0,77 & 1,00 & 0,01 & 0,01 & 0,01 \\
\hline M2\#12 & 0,60 & 0,54 & 0,81 & 0,01 & 0,01 & 0,01 \\
\hline MÉDIA & 1,04 & 0,50 & 1,18 & 0,01 & 0,02 & 0,02 \\
\hline DESVPAD & 0,23 & 0,15 & 0,16 & 0,00 & 0,00 & 0,00 \\
\hline MAXIMO & 1,24 & 0,77 & 1,33 & 0,02 & 0,02 & 0,03 \\
\hline MINIMO & 0,60 & 0,27 & 0,81 & 0,01 & 0,01 & 0,01 \\
\hline
\end{tabular}


Tabela 59 - Resultados do Receptor C, $1^{\circ}$ dia, para o marco M02 50 km (4ª Campanha)

\begin{tabular}{lcccccc}
\hline & \multicolumn{3}{c}{ ACURÁCIA $(\mathrm{m})$} & & & PRECISÃO $(\mathrm{m})$ \\
\hline ID & $\mathrm{DE}$ & $\mathrm{DN}$ & ERRO & DE & DN & ERRO \\
\hline M2\#1 & 0,06 & 0,05 & 0,08 & 0,01 & 0,01 & 0,02 \\
\hline M2\#2 & 0,01 & 0,02 & 0,02 & 0,02 & 0,01 & 0,02 \\
\hline M2\#3 & 0,07 & 0,11 & 0,13 & 0,01 & 0,01 & 0,02 \\
\hline M2\#4 & 0,34 & 0,21 & 0,40 & 0,01 & 0,01 & 0,02 \\
\hline M2\#5 & 0,35 & 0,14 & 0,38 & 0,01 & 0,02 & 0,02 \\
\hline M2\#6 & 0,39 & 0,07 & 0,39 & 0,01 & 0,01 & 0,02 \\
\hline M2\#7 & 0,39 & 0,24 & 0,45 & 0,01 & 0,01 & 0,02 \\
\hline M2\#8 & 0,22 & 0,13 & 0,26 & 0,01 & 0,02 & 0,02 \\
\hline M2\#9 & 0,20 & 0,30 & 0,36 & 0,01 & 0,02 & 0,02 \\
\hline M2\#10 & 0,26 & 0,42 & 0,49 & 0,01 & 0,02 & 0,02 \\
\hline M2\#11 & 0,18 & 0,77 & 0,79 & 0,01 & 0,02 & 0,02 \\
\hline M2\#12 & 0,16 & 0,65 & 0,67 & 0,01 & 0,02 & 0,02 \\
\hline MÉDIA & 0,22 & 0,26 & 0,37 & 0,01 & 0,02 & 0,02 \\
\hline DESVPAD & 0,13 & 0,24 & 0,23 & 0,00 & 0,00 & 0,00 \\
\hline MAX & 0,39 & 0,77 & 0,79 & 0,02 & 0,02 & 0,02 \\
\hline MIN & 0,01 & 0,02 & 0,02 & 0,01 & 0,01 & 0,02 \\
\hline
\end{tabular}

Tabela 60 - Resultados do Receptor C, $2^{\circ}$ dia, para o marco M02 $\sim 50$ km (4 Campanha)

\begin{tabular}{lcccccc}
\hline & \multicolumn{3}{c}{ ACURÁCIA $(\mathrm{m})$} & & PRECISÃO $(\mathrm{m})$ \\
\hline ID & DE & DN & ERRO & DE & DN & ERRO \\
\hline M2\#1 & 0,21 & 0,16 & 0,26 & 0,01 & 0,01 & 0,01 \\
\hline M2\#2 & 0,10 & 0,15 & 0,19 & 0,01 & 0,01 & 0,01 \\
\hline M2\#3 & 0,21 & 0,11 & 0,23 & 0,01 & 0,01 & 0,01 \\
\hline M2\#4 & 0,37 & 0,24 & 0,44 & 0,02 & 0,02 & 0,03 \\
\hline M2\#5 & 0,25 & 0,37 & 0,45 & 0,02 & 0,02 & 0,03 \\
\hline M2\#6 & 0,73 & 0,04 & 0,73 & 0,02 & 0,02 & 0,03 \\
\hline M2\#7 & 0,12 & 0,09 & 0,15 & 0,01 & 0,01 & 0,02 \\
\hline M2\#8 & 0,10 & 0,95 & 0,95 & 0,03 & 0,03 & 0,04 \\
\hline M2\#9 & 0,07 & 0,13 & 0,15 & 0,01 & 0,01 & 0,01 \\
\hline M2\#10 & 0,78 & 0,01 & 0,78 & 0,02 & 0,02 & 0,03 \\
\hline M2\#11 & 0,41 & 0,30 & 0,50 & 0,03 & 0,03 & 0,04 \\
\hline M2\#12 & 0,09 & 0,08 & 0,12 & 0,01 & 0,01 & 0,01 \\
\hline MÉDIA & 0,29 & 0,22 & 0,41 & 0,02 & 0,02 & 0,02 \\
\hline DESVPAD & 0,24 & 0,25 & 0,28 & 0,01 & 0,01 & 0,01 \\
\hline MAX & 0,78 & 0,95 & 0,95 & 0,03 & 0,03 & 0,04 \\
\hline MIN & 0,07 & 0,01 & 0,12 & 0,01 & 0,01 & 0,01 \\
\hline
\end{tabular}

Tabela 61 - Resultados do Receptor C, $1^{\circ}$ dia, para o marco M03 75 km ( $3^{\mathrm{a}}$ Campanha)

\begin{tabular}{|c|c|c|c|c|c|c|}
\hline & \multicolumn{3}{|c|}{ ACURÁCIA (m) } & \multicolumn{3}{|c|}{ PRECISÃO $(\mathrm{m})$} \\
\hline ID & $\mathrm{DE}$ & $\mathrm{DN}$ & ERRO & $\mathrm{DE}$ & $\mathrm{DN}$ & ERRO \\
\hline M3\#1 & 0,18 & 0,66 & 0,69 & 0,02 & 0,02 & 0,02 \\
\hline M3\#2 & 0,03 & 0,70 & 0,70 & 0,01 & 0,01 & 0,02 \\
\hline M3\#3 & 0,07 & 0,96 & 0,96 & 0,01 & 0,01 & 0,02 \\
\hline M3\#4 & 0,25 & 1,05 & 1,08 & 0,02 & 0,02 & 0,03 \\
\hline M3\#5 & 0,26 & 0,83 & 0,87 & 0,02 & 0,02 & 0,03 \\
\hline M3\#6 & 0,23 & 0,91 & 0,94 & 0,01 & 0,01 & 0,01 \\
\hline M3\#7 & 0,28 & 0,87 & 0,91 & 0,02 & 0,01 & 0,02 \\
\hline M3\#8 & 0,53 & 1,15 & 1,26 & 0,02 & 0,01 & 0,02 \\
\hline M3\#9 & 0,67 & 1,25 & 1,42 & 0,01 & 0,01 & 0,02 \\
\hline M3\#10 & 0,41 & 1,18 & 1,25 & 0,01 & 0,01 & 0,02 \\
\hline M3\#11 & 0,43 & 0,99 & 1,08 & 0,02 & 0,02 & 0,02 \\
\hline M3\#12 & 0,31 & 1,42 & 1,46 & 0,01 & 0,01 & 0,01 \\
\hline MÉDIA & 0,30 & 1,00 & 1,05 & 0,01 & 0,01 & 0,02 \\
\hline DESVPAD & 0,18 & 0,22 & 0,25 & 0,00 & 0,00 & 0,00 \\
\hline MAXIMO & 0,67 & 1,42 & 1,46 & 0,02 & 0,02 & 0,03 \\
\hline MINIMO & 0,03 & 0,66 & 0,69 & 0,01 & 0,01 & 0,01 \\
\hline
\end{tabular}


Tabela 62 - Resultados do Receptor C, $2^{\circ}$ dia, para o marco M03 75 km (3 $3^{\mathrm{a}}$ Campanha)

\begin{tabular}{lcccccc}
\hline & & ACURÁCIA $(\mathrm{m})$ & & \multicolumn{3}{c}{ PRFCISÃO (m) } \\
\hline ID & DE & DN & ERRO & DE & DN & ERRO \\
\hline M3\#1 & 0,20 & 0,14 & 0,24 & 0,03 & 0,03 & 0,04 \\
\hline M3\#2 & 0,33 & 0,00 & 0,33 & 0,03 & 0,04 & 0,05 \\
\hline M3\#3 & 0,25 & 0,07 & 0,26 & 0,03 & 0,03 & 0,04 \\
\hline M3\#4 & 1,27 & 0,96 & 1,59 & 0,07 & 0,05 & 0,09 \\
\hline M3\#5 & 0,36 & 0,34 & 0,50 & 0,03 & 0,03 & 0,04 \\
\hline M3\#6 & 0,27 & 0,26 & 0,38 & 0,03 & 0,03 & 0,05 \\
\hline M3\#7 & 0,25 & 1,17 & 1,19 & 0,06 & 0,03 & 0,06 \\
\hline M3\#8 & 0,92 & 0,94 & 1,32 & 0,11 & 0,07 & 0,13 \\
\hline M3\#9 & 0,35 & 0,21 & 0,41 & 0,06 & 0,04 & 0,07 \\
\hline M3\#10 & 0,29 & 0,19 & 0,34 & 0,05 & 0,03 & 0,06 \\
\hline M3\#11 & 0,38 & 0,53 & 0,65 & 0,06 & 0,04 & 0,07 \\
\hline M3\#12 & 0,12 & 0,05 & 0,13 & 0,04 & 0,03 & 0,05 \\
\hline MÉDIA & 0,42 & 0,40 & 0,61 & 0,05 & 0,04 & 0,06 \\
\hline DESVPAD & 0,33 & 0,40 & 0,48 & 0,02 & 0,01 & 0,02 \\
\hline MAXIMO & 1,27 & 1,17 & 1,59 & 0,11 & 0,07 & 0,13 \\
\hline MINIMO & 0,12 & 0,00 & 0,13 & 0,03 & 0,03 & 0,04 \\
\hline
\end{tabular}

Tabela 63 - Resultados do Receptor C, $1^{\circ}$ dia, para o marco M03 75 km (4 Campanha)

\begin{tabular}{lcccccc}
\hline & \multicolumn{3}{c}{ ACURÁCIA $(\mathrm{m})$} & & & PRECISÃO (m) \\
\hline ID & DE & DN & ERRO & DE & DN & ERRO \\
\hline M3\#1 & 0,09 & 0,18 & 0,20 & 0,01 & 0,01 & 0,01 \\
\hline M3\#2 & 0,16 & 0,20 & 0,26 & 0,01 & 0,01 & 0,01 \\
\hline M3\#3 & 0,09 & 0,02 & 0,09 & 0,01 & 0,01 & 0,01 \\
\hline M3\#4 & 0,17 & 0,00 & 0,17 & 0,01 & 0,00 & 0,01 \\
\hline M3\#5 & 0,06 & 0,01 & 0,06 & 0,01 & 0,01 & 0,01 \\
\hline M3\#6 & 0,03 & 0,08 & 0,09 & 0,01 & 0,01 & 0,01 \\
\hline M3\#7 & 0,02 & 0,12 & 0,12 & 0,01 & 0,01 & 0,01 \\
\hline M3\#8 & 0,04 & 0,10 & 0,11 & 0,01 & 0,01 & 0,01 \\
\hline M3\#9 & 0,19 & 0,21 & 0,28 & 0,01 & 0,01 & 0,01 \\
\hline M3\#10 & 0,12 & 0,30 & 0,33 & 0,01 & 0,01 & 0,01 \\
\hline M3\#11 & 0,03 & 0,42 & 0,42 & 0,01 & 0,01 & 0,01 \\
\hline M3\#12 & 0,11 & 0,46 & 0,48 & 0,01 & 0,01 & 0,01 \\
\hline MÉDIA & 0,09 & 0,18 & 0,22 & 0,01 & 0,01 & 0,01 \\
\hline DESVPAD & 0,06 & 0,15 & 0,14 & 0,00 & 0,00 & 0,00 \\
\hline MAX & 0,19 & 0,46 & 0,48 & 0,01 & 0,01 & 0,01 \\
\hline MIN & 0,02 & 0,00 & 0,06 & 0,01 & 0,00 & 0,01 \\
\hline
\end{tabular}

Tabela 64 - Resultados do Receptor C, $2^{\circ}$ dia, para o marco M03 75 km (4a Campanha)

\begin{tabular}{|c|c|c|c|c|c|c|}
\hline & \multicolumn{3}{|c|}{ ACURÁCIA (m) } & \multicolumn{3}{|c|}{ PRECISÃO (m) } \\
\hline ID & $\mathrm{DE}$ & $\mathrm{DN}$ & ERRO & $\mathrm{DE}$ & $\mathrm{DN}$ & ERRO \\
\hline M3\#1 & 0,90 & 0,17 & 0,92 & 0,03 & 0,04 & 0,06 \\
\hline M3\#2 & 0,46 & 0,11 & 0,47 & 0,01 & 0,01 & 0,02 \\
\hline M3\#3 & 0,35 & 0,14 & 0,38 & 0,01 & 0,02 & 0,02 \\
\hline M3\#4 & 0,84 & 0,24 & 0,87 & 0,03 & 0,05 & 0,06 \\
\hline M3\#5 & 0,11 & 0,71 & 0,72 & 0,01 & 0,03 & 0,03 \\
\hline M3\#6 & 0,15 & 0,47 & 0,49 & 0,03 & 0,07 & 0,07 \\
\hline M3\#7 & 0,72 & 0,05 & 0,72 & 0,03 & 0,06 & 0,06 \\
\hline M3\#8 & 0,18 & 0,50 & 0,53 & 0,03 & 0,05 & 0,06 \\
\hline M3\#9 & 0,04 & 0,31 & 0,31 & 0,02 & 0,03 & 0,03 \\
\hline M3\#10 & 0,18 & 0,37 & 0,41 & 0,02 & 0,02 & 0,03 \\
\hline M3\#11 & 0,29 & 0,46 & 0,54 & 0,02 & 0,03 & 0,03 \\
\hline M3\#12 & 0,37 & 0,25 & 0,44 & 0,02 & 0,03 & 0,03 \\
\hline MÉDIA & 0,38 & 0,31 & 0,57 & 0,02 & 0,04 & 0,04 \\
\hline DESVPAD & 0,29 & 0,19 & 0,19 & 0,01 & 0,02 & 0,02 \\
\hline MAX & 0,90 & 0,71 & 0,92 & 0,03 & 0,07 & 0,07 \\
\hline MIN & 0,04 & 0,05 & 0,31 & 0,01 & 0,01 & 0,02 \\
\hline
\end{tabular}


Tabela 65 - Resultados do Receptor C, $1^{\circ}$ dia, para o marco M04 100 km (3 $3^{\mathrm{a}}$ Campanha)

\begin{tabular}{lcccccc}
\hline & & ACURÁCIA $(m)$ & & PRFCISÃO $(m)$ & DE & DN \\
\hline ID & DE & DN & ERRO & 0,04 & 0,04 & 0,05 \\
\hline M4\#1 & 0,82 & 1,36 & 1,59 & 0,04 & 0,05 & 0,06 \\
\hline M4\#2 & 0,85 & 1,66 & 1,87 & 0,03 & 0,03 & 0,05 \\
\hline M4\#3 & 0,48 & 1,42 & 1,50 & 0,03 & 0,03 & 0,04 \\
\hline M4\#4 & 0,32 & 1,28 & 1,32 & 0,03 & 0,03 & 0,04 \\
\hline M4\#5 & 0,38 & 1,07 & 1,14 & 0,04 & 0,04 & 0,06 \\
\hline M4\#6 & 0,45 & 1,01 & 1,11 & 0,04 & 0,05 & 0,06 \\
\hline M4\#7 & 0,58 & 0,78 & 0,98 & 0,04 & 0,05 & 0,06 \\
\hline M4\#8 & 0,70 & 0,73 & 1,01 & 0,05 & 0,05 & 0,06 \\
\hline M4\#9 & 0,67 & 0,67 & 0,95 & 0,04 & 0,04 & 0,06 \\
\hline M4\#10 & 1,02 & 0,27 & 1,05 & 0,04 & 0,04 & 0,05 \\
\hline M4\#11 & 1,12 & 0,24 & 1,15 & 0,04 & 0,04 & 0,06 \\
\hline M4\#12 & 0,67 & 0,95 & 1,17 & 0,04 & 0,04 & 0,06 \\
\hline MÉDIA & 0,67 & 0,95 & 1,24 & 0,01 & 0,01 & 0,01 \\
\hline DESVPAD & 0,25 & 0,44 & 0,28 & 0,05 & 0,05 & 0,06 \\
\hline MAXIMO & 1,12 & 1,66 & 1,87 & 0,03 & 0,03 & 0,04 \\
\hline MINIMO & 0,32 & 0,24 & 0,95 & & & \\
\hline
\end{tabular}

Tabela 66 - Resultados do Receptor C, $2^{\circ}$ dia, para o marco M04 100 km (3 $3^{\mathrm{a}}$ Campanha)

\begin{tabular}{lcccccc}
\hline & & ACURÁCIA $(m)$ & & \multicolumn{2}{c}{ PRECISÃO $(m)$} \\
\hline ID & DE & DN & ERRO & DE & DN & ERRO \\
\hline M4\#1 & 0,38 & 1,23 & 1,29 & 0,06 & 0,06 & 0,08 \\
\hline M4\#2 & 0,54 & 1,28 & 1,39 & 0,04 & 0,03 & 0,05 \\
\hline M4\#3 & 0,84 & 1,31 & 1,56 & 0,04 & 0,03 & 0,05 \\
\hline M4\#4 & 0,43 & 1,05 & 1,13 & 0,04 & 0,04 & 0,06 \\
\hline M4\#5 & 0,19 & 1,89 & 1,90 & 0,04 & 0,04 & 0,05 \\
\hline M4\#6 & 0,25 & 1,62 & 1,64 & 0,03 & 0,03 & 0,04 \\
\hline M4\#7 & 0,56 & 0,52 & 0,77 & 0,04 & 0,04 & 0,05 \\
\hline M4\#8 & 0,65 & 0,55 & 0,85 & 0,04 & 0,04 & 0,06 \\
\hline M4\#9 & 1,57 & 0,20 & 1,59 & 0,05 & 0,05 & 0,07 \\
\hline M4\#10 & 0,27 & 1,31 & 1,34 & 0,02 & 0,02 & 0,03 \\
\hline M4\#11 & 0,47 & 1,00 & 1,11 & 0,05 & 0,06 & 0,08 \\
\hline M4\#12 & 0,38 & 0,80 & 0,88 & 0,05 & 0,05 & 0,07 \\
\hline MÉDIA & 0,55 & 1,06 & 1,29 & 0,04 & 0,04 & 0,06 \\
\hline DESVPAD & 0,37 & 0,48 & 0,35 & 0,01 & 0,01 & 0,02 \\
\hline MAXIMO & 1,57 & 1,89 & 1,90 & 0,06 & 0,06 & 0,08 \\
\hline MINIMO & 0,19 & 0,20 & 0,77 & 0,02 & 0,02 & 0,03 \\
\hline
\end{tabular}

Tabela 67 - Resultados do Receptor C, $1^{\circ}$ dia, para o marco M04 100 km (4 Campanha)

\begin{tabular}{lcccccc}
\hline & \multicolumn{3}{c}{ ACURÁCIA $(\mathrm{m})$} & & \multicolumn{3}{c}{$\mathrm{PRECISÃO}(\mathrm{m})$} \\
\hline ID & $\mathrm{DE}$ & $\mathrm{DN}$ & $\mathrm{ERRO}$ & $\mathrm{DE}$ & $\mathrm{DN}$ & $\mathrm{ERRO}$ \\
\hline M4\#1 & 0,12 & 0,67 & 0,68 & 0,01 & 0,01 & 0,02 \\
\hline M4\#2 & 0,02 & 0,38 & 0,38 & 0,02 & 0,02 & 0,03 \\
\hline M4\#3 & 0,08 & 0,29 & 0,30 & 0,02 & 0,02 & 0,03 \\
\hline M4\#4 & 0,23 & 0,23 & 0,33 & 0,03 & 0,03 & 0,04 \\
\hline M4\#5 & 0,48 & 0,69 & 0,84 & 0,07 & 0,07 & 0,10 \\
\hline M4\#6 & 0,08 & 0,48 & 0,49 & 0,02 & 0,02 & 0,03 \\
\hline M4\#7 & 0,04 & 0,47 & 0,47 & 0,02 & 0,02 & 0,03 \\
\hline M4\#8 & 0,44 & 0,16 & 0,47 & 0,04 & 0,04 & 0,05 \\
\hline M4\#9 & 0,00 & 0,60 & 0,60 & 0,02 & 0,02 & 0,03 \\
\hline M4\#10 & 0,20 & 0,85 & 0,88 & 0,05 & 0,05 & 0,07 \\
\hline M4\#11 & 0,73 & 0,72 & 1,03 & 0,07 & 0,07 & 0,10 \\
\hline M4\#12 & 0,20 & 0,67 & 0,70 & 0,03 & 0,03 & 0,04 \\
\hline MÉDIA & 0,22 & 0,52 & 0,60 & 0,03 & 0,03 & 0,05 \\
\hline DESVPAD & 0,22 & 0,22 & 0,23 & 0,02 & 0,02 & 0,03 \\
\hline MAX & 0,73 & 0,85 & 1,03 & 0,07 & 0,07 & 0,10 \\
\hline MIN & 0,00 & 0,16 & 0,30 & 0,01 & 0,01 & 0,02 \\
\hline
\end{tabular}


Tabela 68 - Resultados do Receptor C, $2^{\circ}$ dia, para o marco M04 100 km (4 Campanha)

\begin{tabular}{lcccccc}
\hline & & ACURÁCIA $(m)$ & & PRFCISÃO $(m)$ & DE & DRO \\
\hline ID & DE & DN & ERRO & 0,01 & 0,01 & 0,01 \\
\hline M4\#1 & 0,26 & 0,66 & 0,71 & 0,01 & 0,01 & 0,01 \\
\hline M4\#2 & 0,22 & 0,66 & 0,70 & 0,03 & 0,03 & 0,05 \\
\hline M4\#3 & 0,20 & 1,26 & 1,27 & 0,01 & 0,01 & 0,02 \\
\hline M4\#4 & 0,19 & 0,69 & 0,72 & 0,01 & 0,01 & 0,02 \\
\hline M4\#5 & 0,11 & 0,67 & 0,68 & 0,02 & 0,02 & 0,02 \\
\hline M4\#6 & 0,15 & 0,54 & 0,56 & 0,02 & 0,02 & 0,02 \\
\hline M4\#7 & 0,16 & 0,45 & 0,48 & 0,04 & 0,04 & 0,05 \\
\hline M4\#8 & 0,31 & 1,40 & 1,44 & 0,04 & 0,04 & 0,05 \\
\hline M4\#9 & 0,35 & 0,12 & 0,37 & 0,05 & 0,05 & 0,07 \\
\hline M4\#10 & 0,26 & 0,81 & 0,86 & 0,04 & 0,04 & 0,06 \\
\hline M4\#11 & 0,36 & 0,18 & 0,40 & 0,02 & 0,02 & 0,03 \\
\hline MÉDIA & 0,07 & 0,42 & 0,42 & 0,03 & 0,02 & 0,04 \\
\hline DESVPAD & 0,22 & 0,65 & 0,72 & 0,02 & 0,01 & 0,02 \\
\hline MAX & 0,09 & 0,38 & 0,33 & 0,05 & 0,05 & 0,07 \\
\hline MIN & 0,36 & 1,40 & 1,44 & 0,01 & 0,01 & 0,01 \\
\hline
\end{tabular}

Tabela 69 - Resultados do Receptor C, $1^{\circ}$ dia, para o marco M05 150 km ( $3^{a}$ Campanha)

\begin{tabular}{lcccccc}
\hline & & ACURÁCIA $(m)$ & & \multicolumn{2}{c}{ PRECISÃO $(m)$} \\
\hline ID & DE & DN & ERRO & DE & ERRO \\
\hline M5\#1 & 0,50 & 0,36 & 0,62 & 0,03 & 0,03 & 0,04 \\
\hline M5\#2 & 0,36 & 0,56 & 0,66 & 0,01 & 0,01 & 0,02 \\
\hline M5\#3 & 0,38 & 0,78 & 0,86 & 0,01 & 0,01 & 0,02 \\
\hline M5\#4 & 0,33 & 1,13 & 1,18 & 0,01 & 0,01 & 0,02 \\
\hline M5\#5 & 0,36 & 1,38 & 1,43 & 0,02 & 0,02 & 0,03 \\
\hline M5\#6 & 0,08 & 1,37 & 1,37 & 0,02 & 0,02 & 0,03 \\
\hline M5\#7 & 0,03 & 0,97 & 0,97 & 0,02 & 0,02 & 0,03 \\
\hline M5\#8 & 0,12 & 1,04 & 1,05 & 0,03 & 0,03 & 0,04 \\
\hline M5\#9 & 0,13 & 1,09 & 1,10 & 0,02 & 0,02 & 0,03 \\
\hline M5\#10 & 0,29 & 0,85 & 0,89 & 0,03 & 0,03 & 0,04 \\
\hline M5\#11 & 0,08 & 0,70 & 0,70 & 0,02 & 0,02 & 0,02 \\
\hline M5\#12 & 0,24 & 0,93 & 0,96 & 0,02 & 0,02 & 0,03 \\
\hline MÉDIA & 0,24 & 0,93 & 0,98 & 0,02 & 0,02 & 0,03 \\
\hline DESVPAD & 0,15 & 0,31 & 0,26 & 0,00 & 0,01 & 0,01 \\
\hline MAXIMO & 0,50 & 1,38 & 1,43 & 0,03 & 0,03 & 0,04 \\
\hline MINIMO & 0,03 & 0,36 & 0,62 & 0,01 & 0,01 & 0,02 \\
\hline
\end{tabular}

Tabela 70 - Resultados do Receptor C, $2^{\circ}$ dia, para o marco M05 150 km (3 $3^{a}$ Campanha)

\begin{tabular}{lcccccc}
\hline & \multicolumn{3}{c}{ ACURÁCIA (m) } & \multicolumn{3}{c}{ PRECISÃO (m) } \\
\hline ID & DE & DN & ERRO & DE & DN & ERRO \\
\hline M5\#1 & 0,20 & 1,08 & 1,10 & 0,01 & 0,01 & 0,01 \\
\hline M5\#2 & 0,08 & 0,80 & 0,80 & 0,01 & 0,01 & 0,02 \\
\hline M5\#3 & 0,11 & 0,49 & 0,50 & 0,02 & 0,02 & 0,02 \\
\hline M5\#4 & 0,30 & 0,28 & 0,41 & 0,02 & 0,02 & 0,02 \\
\hline M5\#5 & 0,46 & 0,62 & 0,77 & 0,02 & 0,02 & 0,03 \\
\hline M5\#6 & 0,47 & 0,50 & 0,68 & 0,02 & 0,02 & 0,03 \\
\hline M5\#7 & 0,53 & 0,35 & 0,64 & 0,01 & 0,01 & 0,02 \\
\hline M5\#8 & 0,67 & 0,47 & 0,82 & 0,01 & 0,01 & 0,02 \\
\hline M5\#9 & 0,67 & 0,52 & 0,85 & 0,01 & 0,01 & 0,02 \\
\hline M5\#10 & 0,78 & 0,52 & 0,93 & 0,02 & 0,02 & 0,02 \\
\hline M5\#11 & 0,81 & 0,63 & 1,03 & 0,01 & 0,01 & 0,02 \\
\hline M5\#12 & 0,86 & 0,81 & 1,18 & 0,01 & 0,01 & 0,01 \\
\hline MĖDIA & 0,49 & 0,59 & 0,81 & 0,01 & 0,01 & 0,02 \\
\hline DESVPAD & 0,27 & 0,22 & 0,23 & 0,00 & 0,00 & 0,01 \\
\hline MAXIMO & 0,86 & 1,08 & 1,18 & 0,02 & 0,02 & 0,03 \\
\hline MINIMO & 0,08 & 0,28 & 0,41 & 0,01 & 0,01 & 0,01 \\
\hline
\end{tabular}


Tabela 71 - Resultados do Receptor C, $1^{\circ}$ dia, para o marco M05 150 km (4 Campanha)

\begin{tabular}{|c|c|c|c|c|c|c|}
\hline \multirow[b]{2}{*}{ ID } & \multicolumn{3}{|c|}{ ACURÁCIA (m) } & \multicolumn{3}{|c|}{ PRFCISÃO (m) } \\
\hline & $\mathrm{DE}$ & $\mathrm{DN}$ & ERRO & $\mathrm{DE}$ & DN & ERRO \\
\hline M5\#1 & 0,28 & 0,31 & 0,42 & 0,01 & 0,01 & 0,02 \\
\hline M5\#2 & 0,24 & 0,37 & 0,44 & 0,01 & 0,01 & 0,02 \\
\hline M5\#3 & 0,14 & 0,16 & 0,21 & 0,02 & 0,02 & 0,02 \\
\hline M5\#4 & 0,01 & 0,10 & 0,10 & 0,02 & 0,02 & 0,03 \\
\hline M5\#5 & 0,02 & 0,03 & 0,03 & 0,02 & 0,02 & 0,03 \\
\hline M5\#6 & 0,24 & 0,23 & 0,33 & 0,03 & 0,03 & 0,04 \\
\hline M5\#7 & 0,34 & 0,31 & 0,46 & 0,03 & 0,03 & 0,04 \\
\hline M5\#8 & 0,17 & 0,10 & 0,19 & 0,01 & 0,01 & 0,01 \\
\hline M5\#9 & 0,16 & 0,64 & 0,66 & 0,02 & 0,02 & 0,03 \\
\hline M5\#10 & 0,55 & 1,16 & 1,28 & 0,04 & 0,04 & 0,06 \\
\hline M5\#11 & 0,04 & 0,10 & 0,10 & 0,03 & 0,06 & 0,07 \\
\hline M5\#12 & 0,06 & 0,70 & 0,70 & 0,01 & 0,01 & 0,02 \\
\hline MÉDIA & 0,19 & 0,35 & 0,41 & 0,02 & 0,02 & 0,03 \\
\hline DESVPAD & 0,16 & 0,33 & 0,35 & 0,01 & 0,01 & 0,02 \\
\hline MAX & 0,55 & 1,16 & 1,28 & 0,04 & 0,06 & 0,07 \\
\hline $\mathrm{MIN}$ & 0,01 & 0,03 & 0,03 & 0,01 & 0,01 & 0,01 \\
\hline
\end{tabular}

Tabela 72 - Resultados do Receptor C, $2^{\circ}$ dia, para o marco M05 150 km (4 $4^{\mathrm{a}}$ Campanha)

\begin{tabular}{lcccccc}
\hline & & ACURÁCIA $(m)$ & & \multicolumn{2}{c}{ PRFCISÃO (m) } \\
\hline ID & DE & DN & ERRO & DE & ERRO \\
\hline M5\#1 & 0,25 & 0,27 & 0,37 & 0,01 & 0,02 & 0,02 \\
\hline M5\#2 & 0,19 & 0,20 & 0,27 & 0,01 & 0,02 & 0,02 \\
\hline M5\#3 & 0,31 & 0,20 & 0,36 & 0,01 & 0,03 & 0,03 \\
\hline M5\#4 & 0,39 & 0,15 & 0,42 & 0,01 & 0,03 & 0,03 \\
\hline M5\#5 & 0,32 & 0,28 & 0,43 & 0,01 & 0,03 & 0,03 \\
\hline M5\#6 & 0,32 & 0,17 & 0,36 & 0,01 & 0,02 & 0,02 \\
\hline M5\#7 & 0,19 & 0,17 & 0,25 & 0,01 & 0,01 & 0,02 \\
\hline M5\#8 & 0,17 & 0,19 & 0,26 & 0,01 & 0,01 & 0,01 \\
\hline M5\#9 & 0,02 & 0,24 & 0,24 & 0,02 & 0,02 & 0,03 \\
\hline M5\#10 & 0,13 & 0,24 & 0,27 & 0,01 & 0,01 & 0,01 \\
\hline M5\#11 & 0,13 & 0,15 & 0,20 & 0,01 & 0,01 & 0,01 \\
\hline M5\#12 & 0,14 & 0,12 & 0,19 & 0,01 & 0,01 & 0,01 \\
\hline MÉDIA & 0,21 & 0,20 & 0,30 & 0,01 & 0,02 & 0,02 \\
\hline DESVPAD & 0,11 & 0,05 & 0,08 & 0,00 & 0,01 & 0,01 \\
\hline MAX & 0,39 & 0,28 & 0,43 & 0,02 & 0,03 & 0,03 \\
\hline MIN & 0,02 & 0,12 & 0,19 & 0,01 & 0,01 & 0,01 \\
\hline
\end{tabular}

Tabela 73 - Resultados do Receptor C, $1^{\circ}$ dia, para o marco M06 $\sim 200$ km (3a Campanha)

\begin{tabular}{lcccccc}
\hline & \multicolumn{3}{c}{ ACURÁCIA (m) } & \multicolumn{3}{c}{ PRECISÃO (m) } \\
\hline ID & DE & DN & ERRO & DE & DN & ERRO \\
\hline M6\#1 & 0,50 & 0,26 & 0,56 & 0,03 & 0,04 & 0,05 \\
\hline M6\#2 & 0,12 & 3,51 & 3,51 & 0,04 & 0,03 & 0,05 \\
\hline M6\#3 & 0,06 & 2,76 & 2,76 & 0,07 & 0,05 & 0,09 \\
\hline M6\#4 & 0,37 & 3,48 & 3,50 & 0,09 & 0,06 & 0,11 \\
\hline M6\#5 & 0,24 & 3,14 & 3,15 & 0,09 & 0,07 & 0,11 \\
\hline M6\#6 & 0,33 & 1,73 & 1,76 & 0,07 & 0,06 & 0,09 \\
\hline M6\#7 & 0,88 & 1,44 & 1,68 & 0,06 & 0,06 & 0,08 \\
\hline M6\#8 & 0,92 & 1,22 & 1,53 & 0,06 & 0,06 & 0,08 \\
\hline M6\#9 & 0,88 & 0,75 & 1,16 & 0,05 & 0,05 & 0,07 \\
\hline M6\#10 & 0,83 & 0,38 & 0,91 & 0,04 & 0,05 & 0,06 \\
\hline M6\#11 & 0,51 & 0,26 & 0,57 & 0,04 & 0,04 & 0,06 \\
\hline M6\#12 & 0,06 & 2,95 & 2,95 & 0,06 & 0,04 & 0,07 \\
\hline MĖDIA & 0,47 & 1,82 & 2,00 & 0,06 & 0,05 & 0,08 \\
\hline DESVPAD & 0,33 & 1,28 & 1,12 & 0,02 & 0,01 & 0,02 \\
\hline MAXIMO & 0,92 & 3,51 & 3,51 & 0,09 & 0,07 & 0,11 \\
\hline MINIMO & 0,06 & 0,26 & 0,56 & 0,03 & 0,03 & 0,05 \\
\hline
\end{tabular}


Tabela 74 - Resultados do Receptor C, $2^{\circ}$ dia, para o marco M06 200 km (3 $3^{\mathrm{a}}$ Campanha)

\begin{tabular}{lcccccc}
\hline & & ACURÁCIA $(m)$ & & PRFCISÃO $(m)$ & DN & ERRO \\
\hline ID & DE & DN & ERRO & 0,01 & 0,01 & 0,02 \\
\hline M6\#1 & 0,52 & 0,49 & 0,71 & 0,01 & 0,01 & 0,01 \\
\hline M6\#2 & 0,33 & 0,71 & 0,78 & 0,01 & 0,01 & 0,02 \\
\hline M6\#3 & 0,35 & 0,64 & 0,73 & 0,01 & 0,01 & 0,02 \\
\hline M6\#4 & 0,24 & 0,63 & 0,67 & 0,02 & 0,02 & 0,02 \\
\hline M6\#5 & 0,40 & 0,63 & 0,74 & 0,01 & 0,01 & 0,02 \\
\hline M6\#6 & 0,31 & 0,46 & 0,56 & 0,01 & 0,01 & 0,02 \\
\hline M6\#7 & 0,15 & 0,47 & 0,50 & 0,01 & 0,01 & 0,02 \\
\hline M6\#8 & 0,08 & 0,22 & 0,24 & 0,01 & 0,01 & 0,02 \\
\hline M6\#9 & 0,02 & 0,07 & 0,08 & 0,01 & 0,01 & 0,02 \\
\hline M6\#10 & 0,17 & 0,22 & 0,28 & 0,01 & 0,01 & 0,01 \\
\hline M6\#11 & 0,17 & 0,21 & 0,27 & 0,01 & 0,01 & 0,01 \\
\hline MÉDIA & 0,14 & 0,48 & 0,50 & 0,01 & 0,01 & 0,02 \\
\hline DESVPAD & 0,24 & 0,44 & 0,50 & 0,00 & 0,00 & 0,00 \\
\hline MAXIMO & 0,15 & 0,21 & 0,24 & 0,02 & 0,02 & 0,02 \\
\hline MINIMO & 0,02 & 0,71 & 0,78 & 0,01 & 0,01 & 0,01 \\
\hline
\end{tabular}

Tabela 75 - Resultados do Receptor C, $1^{\circ}$ dia, para o marco M06 200 km (4 ${ }^{\mathrm{a}}$ Campanha)

\begin{tabular}{lcccccc}
\hline & & ACURÁCIA $(m)$ & & \multicolumn{2}{c}{ PRFCISÃO (m) } \\
\hline ID & DE & DN & ERRO & DE & DN & ERRO \\
\hline M6\#1 & 0,79 & 1,11 & 1,36 & 0,02 & 0,02 & 0,03 \\
\hline M6\#2 & 0,64 & 1,11 & 1,28 & 0,02 & 0,02 & 0,02 \\
\hline M6\#3 & 0,64 & 1,06 & 1,24 & 0,01 & 0,02 & 0,02 \\
\hline M6\#4 & 0,68 & 1,07 & 1,27 & 0,01 & 0,01 & 0,02 \\
\hline M6\#5 & 0,65 & 1,16 & 1,34 & 0,01 & 0,01 & 0,01 \\
\hline M6\#6 & 0,59 & 1,20 & 1,33 & 0,01 & 0,01 & 0,01 \\
\hline M6\#7 & 0,69 & 1,10 & 1,30 & 0,01 & 0,01 & 0,01 \\
\hline M6\#8 & 0,43 & 1,27 & 1,34 & 0,02 & 0,03 & 0,03 \\
\hline M6\#9 & 0,10 & 1,42 & 1,43 & 0,01 & 0,02 & 0,02 \\
\hline M6\#10 & 0,13 & 0,72 & 0,73 & 0,02 & 0,02 & 0,03 \\
\hline M6\#11 & 0,09 & 0,22 & 0,23 & 0,02 & 0,03 & 0,03 \\
\hline M6\#12 & 0,25 & 0,24 & 0,35 & 0,01 & 0,02 & 0,02 \\
\hline MÉDIA & 0,47 & 0,97 & 1,10 & 0,01 & 0,02 & 0,02 \\
\hline DESVPAD & 0,26 & 0,38 & 0,42 & 0,00 & 0,01 & 0,01 \\
\hline MAX & 0,79 & 1,42 & 1,43 & 0,02 & 0,03 & 0,03 \\
\hline MIN & 0,09 & 0,22 & 0,23 & 0,01 & 0,01 & 0,01 \\
\hline
\end{tabular}

Tabela 76 - Resultados do Receptor C, $2^{\circ}$ dia, para o marco M06 $\sim 200$ km (4 Campanha)

\begin{tabular}{lcccccc}
\hline & \multicolumn{3}{c}{ ACURÁCIA (m) } & \multicolumn{3}{c}{ PRECISÃO (m) } \\
\hline ID & DE & DN & ERRO & DE & DN & ERRO \\
\hline M6\#1 & 0,18 & 0,04 & 0,18 & 0,01 & 0,01 & 0,02 \\
\hline M6\#2 & 0,19 & 0,13 & 0,23 & 0,01 & 0,01 & 0,01 \\
\hline M6\#3 & 0,19 & 0,13 & 0,23 & 0,01 & 0,01 & 0,01 \\
\hline M6\#4 & 0,18 & 0,16 & 0,24 & 0,01 & 0,01 & 0,01 \\
\hline M6\#5 & 0,22 & 0,08 & 0,24 & 0,01 & 0,01 & 0,01 \\
\hline M6\#6 & 0,07 & 0,05 & 0,09 & 0,01 & 0,01 & 0,02 \\
\hline M6\#7 & 0,01 & 0,07 & 0,07 & 0,01 & 0,01 & 0,02 \\
\hline M6\#8 & 0,04 & 0,13 & 0,14 & 0,01 & 0,01 & 0,02 \\
\hline M6\#9 & 0,12 & 0,11 & 0,16 & 0,01 & 0,01 & 0,01 \\
\hline M6\#10 & 0,04 & 0,06 & 0,08 & 0,01 & 0,01 & 0,02 \\
\hline M6\#11 & 0,15 & 0,21 & 0,26 & 0,01 & 0,01 & 0,02 \\
\hline M6\#12 & 0,09 & 0,24 & 0,26 & 0,01 & 0,01 & 0,02 \\
\hline MÉDIA & 0,12 & 0,12 & 0,18 & 0,01 & 0,01 & 0,02 \\
\hline DESVPAD & 0,07 & 0,06 & 0,07 & 0,00 & 0,00 & 0,00 \\
\hline MAX & 0,22 & 0,24 & 0,26 & 0,01 & 0,01 & 0,02 \\
\hline MIN & 0,01 & 0,04 & 0,07 & 0,01 & 0,01 & 0,01 \\
\hline
\end{tabular}


Tabela 77 - Resultados do Receptor C, $1^{\circ}$ dia, para o marco M07 300 km (3 $3^{\mathrm{a}}$ Campanha)

\begin{tabular}{lcccccc}
\hline & & ACURÁCIA $(m)$ & & & PRFCISÃO $(m)$ \\
\hline ID & DE & DN & ERRO & DE & DN & ERRO \\
\hline M7\#1 & 2,32 & 0,08 & 2,32 & 0,02 & 0,03 & 0,04 \\
\hline M7\#2 & 2,71 & 0,29 & 2,73 & 0,03 & 0,03 & 0,04 \\
\hline M7\#3 & 2,75 & 0,80 & 2,87 & 0,04 & 0,05 & 0,06 \\
\hline M7\#4 & 2,85 & 0,81 & 2,96 & 0,07 & 0,08 & 0,10 \\
\hline M7\#5 & 3,16 & 0,79 & 3,25 & 0,04 & 0,04 & 0,06 \\
\hline M7\#6 & 2,78 & 0,69 & 2,86 & 0,04 & 0,04 & 0,05 \\
\hline M7\#7 & 2,84 & 0,64 & 2,91 & 0,04 & 0,04 & 0,06 \\
\hline M7\#8 & 2,61 & 0,71 & 2,70 & 0,04 & 0,04 & 0,06 \\
\hline M7\#9 & 2,56 & 0,66 & 2,65 & 0,04 & 0,05 & 0,06 \\
\hline M7\#10 & 0,21 & 0,45 & 0,50 & 0,02 & 0,02 & 0,03 \\
\hline M7\#11 & 0,22 & 0,21 & 0,31 & 0,02 & 0,02 & 0,03 \\
\hline M7\#12 & 0,20 & 0,00 & 0,20 & 0,02 & 0,03 & 0,04 \\
\hline MÉDIA & 2,10 & 0,51 & 2,19 & 0,03 & 0,04 & 0,05 \\
\hline DESVPAD & 1,157 & 0,293 & 1,141 & 0,012 & 0,014 & 0,02 \\
\hline MAXIMO & 3,16 & 0,81 & 3,25 & 0,07 & 0,08 & 0,10 \\
\hline MINIMO & 0,198 & 0,003 & 0,198 & 0,021 & 0,023 & 0,031 \\
\hline
\end{tabular}

Tabela 78 - Resultados do Receptor C, $2^{\circ}$ dia, para o marco M07 300 km (3 ${ }^{\mathrm{a}}$ Campanha)

\begin{tabular}{lcccccc}
\hline & & ACIIRÁCIA $(m)$ & & \multicolumn{2}{c}{ PRECISÃO $(m)$} \\
\hline ID & DE & DN & ERRO & DE & ERRO \\
\hline M7\#1 & 0,10 & 0,29 & 0,31 & 0,02 & 0,02 & 0,03 \\
\hline M7\#2 & 0,79 & 0,61 & 1,00 & 0,01 & 0,02 & 0,02 \\
\hline M7\#3 & 1,09 & 0,66 & 1,28 & 0,02 & 0,04 & 0,04 \\
\hline M7\#4 & 2,14 & 0,40 & 2,18 & 0,03 & 0,04 & 0,05 \\
\hline M7\#5 & 1,71 & 0,35 & 1,74 & 0,03 & 0,05 & 0,06 \\
\hline M7\#6 & 0,24 & 0,70 & 0,74 & 0,02 & 0,08 & 0,08 \\
\hline M7\#7 & 0,35 & 0,69 & 0,77 & 0,02 & 0,04 & 0,05 \\
\hline M7\#8 & 0,40 & 0,80 & 0,89 & 0,04 & 0,05 & 0,06 \\
\hline M7\#9 & 0,90 & 0,90 & 1,27 & 0,07 & 0,08 & 0,10 \\
\hline M7\#10 & 0,89 & 1,01 & 1,35 & 0,07 & 0,08 & 0,10 \\
\hline M7\#11 & 1,70 & 0,95 & 1,95 & 0,04 & 0,02 & 0,04 \\
\hline M7\#12 & 1,03 & 0,09 & 1,03 & 0,02 & 0,02 & 0,03 \\
\hline MÉDIA & 0,95 & 0,62 & 1,21 & 0,03 & 0,04 & 0,05 \\
\hline DESVPAD & 0,64 & 0,28 & 0,54 & 0,02 & 0,02 & 0,03 \\
\hline MAXIMO & 2,14 & 1,01 & 2,18 & 0,07 & 0,08 & 0,10 \\
\hline MINIMO & 0,10 & 0,09 & 0,31 & 0,01 & 0,02 & 0,02 \\
\hline
\end{tabular}

Tabela 79 - Resultados do Receptor C, $1^{\circ}$ dia, para o marco M07 300 km (4 ${ }^{\mathrm{a}}$ Campanha)

\begin{tabular}{lcccccc}
\hline & \multicolumn{3}{c}{ ACURÁCIA (m) } & \multicolumn{3}{c}{ PRECISÃO (m) } \\
\hline ID & DE & DN & ERRO & DE & DN & ERRO \\
\hline M7\#1 & 0,03 & 0,42 & 0,42 & 0,03 & 0,03 & 0,04 \\
\hline M7\#2 & 0,22 & 0,41 & 0,46 & 0,03 & 0,02 & 0,04 \\
\hline M7\#3 & 0,12 & 0,34 & 0,36 & 0,02 & 0,02 & 0,02 \\
\hline M7\#4 & 0,11 & 0,35 & 0,36 & 0,01 & 0,01 & 0,02 \\
\hline M7\#5 & 0,09 & 0,34 & 0,36 & 0,01 & 0,01 & 0,01 \\
\hline M7\#6 & 0,07 & 0,39 & 0,40 & 0,01 & 0,01 & 0,01 \\
\hline M7\#7 & 0,16 & 0,53 & 0,55 & 0,01 & 0,01 & 0,02 \\
\hline M7\#8 & 0,29 & 0,52 & 0,59 & 0,01 & 0,01 & 0,02 \\
\hline M7\#9 & 0,30 & 0,71 & 0,78 & 0,02 & 0,02 & 0,02 \\
\hline M7\#10 & 0,56 & 0,99 & 1,14 & 0,02 & 0,02 & 0,03 \\
\hline M7\#11 & 0,73 & 1,19 & 1,40 & 0,02 & 0,02 & 0,03 \\
\hline M7\#12 & 0,89 & 1,47 & 1,72 & 0,02 & 0,02 & 0,03 \\
\hline MÉDIA & 0,30 & 0,64 & 0,71 & 0,02 & 0,02 & 0,02 \\
\hline DESVPAD & 0,28 & 0,38 & 0,46 & 0,01 & 0,01 & 0,01 \\
\hline MAX & 0,89 & 1,47 & 1,72 & 0,03 & 0,03 & 0,04 \\
\hline MIN & 0,03 & 0,34 & 0,36 & 0,01 & 0,01 & 0,01 \\
\hline
\end{tabular}


Tabela 80 - Resultados do Receptor C, $2^{\circ}$ dia, para o marco M07 300 km (4 ${ }^{\mathrm{a}}$ Campanha)

\begin{tabular}{|c|c|c|c|c|c|c|}
\hline & \multicolumn{3}{|c|}{ ACURÁCIA (m) } & \multicolumn{3}{|c|}{ PRFCISÃO (m) } \\
\hline ID & $\mathrm{DE}$ & DN & ERRO & $\mathrm{DE}$ & DN & ERRO \\
\hline M7\#1 & 0,10 & 0,12 & 0,15 & 0,06 & 0,06 & 0,09 \\
\hline M7\#2 & 0,43 & 0,37 & 0,57 & 0,07 & 0,06 & 0,09 \\
\hline M7\#3 & 0,87 & 0,47 & 0,99 & 0,06 & 0,05 & 0,08 \\
\hline M7\#4 & 0,90 & 0,62 & 1,10 & 0,05 & 0,06 & 0,08 \\
\hline M7\#5 & 1,00 & 0,99 & 1,41 & 0,05 & 0,04 & 0,07 \\
\hline M7\#6 & 0,99 & 1,07 & 1,45 & 0,04 & 0,03 & 0,05 \\
\hline M7\#7 & 0,94 & 1,27 & 1,58 & 0,03 & 0,03 & 0,04 \\
\hline M7\#8 & 0,93 & 1,42 & 1,70 & 0,03 & 0,03 & 0,04 \\
\hline M7\#9 & 0,92 & 1,54 & 1,79 & 0,03 & 0,04 & 0,05 \\
\hline M7\#10 & 0,52 & 1,48 & 1,57 & 0,07 & 0,06 & 0,09 \\
\hline M7\#11 & 0,17 & 1,48 & 1,49 & 0,08 & 0,07 & 0,10 \\
\hline M7\#12 & 0,10 & 1,31 & 1,31 & 0,09 & 0,07 & 0,11 \\
\hline MÉDIA & 0,66 & 1,01 & 1,26 & 0,05 & 0,05 & 0,07 \\
\hline DESVPAD & 0,37 & 0,50 & 0,49 & 0,02 & 0,02 & 0,02 \\
\hline MAX & 1,00 & 1,54 & 1,79 & 0,09 & 0,07 & 0,11 \\
\hline $\mathrm{MIN}$ & 0,10 & 0,12 & 0,15 & 0,03 & 0,03 & 0,04 \\
\hline
\end{tabular}

7. Resultados do Receptor D(Terceira e Quarta Campanha)

Tabela 81 - Resultados do Receptor D, $1^{\circ}$ dia, para o marco M01 20 km (3a Campanha)

\begin{tabular}{lcccccc}
\hline & \multicolumn{3}{c}{ ACURÁCIA $(\mathrm{m})$} & & PRECISÃO $(\mathrm{m})$ \\
\hline ID & $\mathrm{DE}$ & $\mathrm{DN}$ & $\mathrm{ERRO}$ & $\mathrm{DE}$ & $\mathrm{DN}$ & ERRO \\
\hline $\mathrm{M} 1 \# 1$ & 0,66 & 0,36 & 0,75 & 0,01 & 0,01 & 0,01 \\
\hline $\mathrm{M} 1 \# 2$ & 0,51 & 0,20 & 0,55 & 0,01 & 0,01 & 0,01 \\
\hline M1\#3 & 0,71 & 0,29 & 0,76 & 0,01 & 0,01 & 0,02 \\
\hline M1\#4 & 0,55 & 0,10 & 0,56 & 0,02 & 0,02 & 0,02 \\
\hline M1\#5 & 0,63 & 0,11 & 0,64 & 0,01 & 0,02 & 0,02 \\
\hline M1\#6 & 0,55 & 0,06 & 0,55 & 0,02 & 0,02 & 0,02 \\
\hline M1\#7 & 0,19 & 0,00 & 0,19 & 0,01 & 0,01 & 0,02 \\
\hline M1\#8 & 0,09 & 0,30 & 0,31 & 0,01 & 0,01 & 0,01 \\
\hline M1\#9 & 0,07 & 0,30 & 0,31 & 0,01 & 0,01 & 0,01 \\
\hline M1\#10 & 0,13 & 0,01 & 0,13 & 0,01 & 0,01 & 0,02 \\
\hline M1\#11 & 0,22 & 0,01 & 0,22 & 0,01 & 0,01 & 0,01 \\
\hline M1\#12 & 0,28 & 0,23 & 0,36 & 0,01 & 0,01 & 0,01 \\
\hline MÉDIA & 0,38 & 0,16 & 0,44 & 0,01 & 0,01 & 0,02 \\
\hline DESVPAD & 0,24 & 0,13 & 0,22 & 0,00 & 0,00 & 0,00 \\
\hline MAXIMO & 0,71 & 0,36 & 0,76 & 0,02 & 0,02 & 0,02 \\
\hline MINIMO & 0,07 & 0,00 & 0,13 & 0,01 & 0,01 & 0,01 \\
\hline
\end{tabular}

Tabela 82 - Resultados do Receptor D, $2^{\circ}$ dia, para o marco M01 20 km (3 ${ }^{\mathrm{a}}$ Campanha)

\begin{tabular}{lcccccc}
\hline & & ACURÁCIA $(\mathrm{m})$ & & \multicolumn{2}{c}{ PRECISÃO (m) } \\
\hline ID & DE & DN & ERRO & DE & DN & ERRO \\
\hline M1\#1 & 0,00 & 0,07 & 0,07 & 0,02 & 0,01 & 0,02 \\
\hline M1\#2 & 0,28 & 0,16 & 0,32 & 0,01 & 0,02 & 0,02 \\
\hline M1\#3 & 0,25 & 0,28 & 0,38 & 0,01 & 0,01 & 0,02 \\
\hline M1\#4 & 0,16 & 0,20 & 0,26 & 0,01 & 0,01 & 0,02 \\
\hline M1\#5 & 0,13 & 0,27 & 0,30 & 0,01 & 0,01 & 0,01 \\
\hline M1\#6 & 0,09 & 0,41 & 0,42 & 0,00 & 0,00 & 0,01 \\
\hline M1\#7 & 0,15 & 0,28 & 0,32 & 0,00 & 0,00 & 0,00 \\
\hline M1\#8 & 0,01 & 0,26 & 0,26 & 0,00 & 0,00 & 0,01 \\
\hline M1\#9 & 0,00 & 0,06 & 0,06 & 0,00 & 0,01 & 0,01 \\
\hline M1\#10 & 0,00 & 0,16 & 0,16 & 0,01 & 0,01 & 0,01 \\
\hline M1\#11 & 0,07 & 0,15 & 0,16 & 0,01 & 0,01 & 0,01 \\
\hline M1\#12 & 0,15 & 0,35 & 0,38 & 0,01 & 0,01 & 0,02 \\
\hline MÉDIA & 0,11 & 0,22 & 0,26 & 0,01 & 0,01 & 0,01 \\
\hline DESVPAD & 0,10 & 0,11 & 0,12 & 0,00 & 0,00 & 0,01 \\
\hline MAXIMO & 0,28 & 0,41 & 0,42 & 0,02 & 0,02 & 0,02 \\
\hline MINIMO & 0,00 & 0,06 & 0,06 & 0,00 & 0,00 & 0,00 \\
\hline
\end{tabular}


Tabela 83 - Resultados do Receptor D, $1^{\circ}$ dia, para o marco M01 20 km (4 ${ }^{\text {a }}$ Campanha)

\begin{tabular}{|c|c|c|c|c|c|c|}
\hline & \multicolumn{3}{|c|}{ ACIURACIA (m) } & \multicolumn{3}{|c|}{ PRECISAO (m) } \\
\hline ID & $\mathrm{DE}$ & DN & ERRO & $\mathrm{DE}$ & DN & ERRO \\
\hline M1\#1 & 0,07 & 0,02 & 0,08 & 0,00 & 0,00 & 0,01 \\
\hline M1\#2 & 0,08 & 0,02 & 0,08 & 0,00 & 0,00 & 0,01 \\
\hline M1\#3 & 0,04 & 0,08 & 0,09 & 0,01 & 0,01 & 0,01 \\
\hline M1\#4 & 0,08 & 0,10 & 0,12 & 0,01 & 0,01 & 0,01 \\
\hline M1\#5 & 0,12 & 0,15 & 0,19 & 0,01 & 0,01 & 0,01 \\
\hline M1\#6 & 0,06 & 0,02 & 0,06 & 0,01 & 0,01 & 0,01 \\
\hline M1\#7 & 0,02 & 0,09 & 0,09 & 0,00 & 0,01 & 0,01 \\
\hline M1\#8 & 0,04 & 0,20 & 0,20 & 0,01 & 0,01 & 0,01 \\
\hline M1\#9 & 0,09 & 0,07 & 0,12 & 0,01 & 0,01 & 0,01 \\
\hline M1\#10 & 0,04 & 0,06 & 0,07 & 0,00 & 0,00 & 0,00 \\
\hline M1\#11 & 0,11 & 0,04 & 0,12 & 0,00 & 0,00 & 0,01 \\
\hline M1\#12 & 0,03 & 0,16 & 0,16 & 0,00 & 0,00 & 0,01 \\
\hline MÉDIA & 0,06 & 0,08 & 0,12 & 0,00 & 0,01 & 0,01 \\
\hline DESVPAD & 0,03 & 0,06 & 0,05 & 0,00 & 0,00 & 0,00 \\
\hline MAX & 0,12 & 0,20 & 0,20 & 0,01 & 0,01 & 0,01 \\
\hline $\mathrm{MIN}$ & 0,02 & 0,02 & 0,06 & 0,00 & 0,00 & 0,00 \\
\hline
\end{tabular}

Tabela 84 - Resultados do Receptor D, $2^{\circ}$ dia, para o marco M01 20 km (4 Campanha)

\begin{tabular}{lcccccc}
\hline & & ACURACIA $(m)$ & & & PRECISAO & DE \\
\hline ID & DE & DN & ERRO & DN & ERRO \\
\hline M1\#1 & 0,09 & 0,03 & 0,10 & 0,00 & 0,00 & 0,00 \\
\hline M1\#2 & 0,28 & 0,14 & 0,31 & 0,00 & 0,00 & 0,01 \\
\hline M1\#3 & 0,13 & 0,09 & 0,16 & 0,00 & 0,01 & 0,01 \\
\hline M1\#4 & 0,09 & 0,03 & 0,09 & 0,00 & 0,00 & 0,00 \\
\hline M1\#5 & 0,19 & 0,01 & 0,19 & 0,00 & 0,00 & 0,00 \\
\hline M1\#6 & 0,19 & 0,20 & 0,28 & 0,00 & 0,01 & 0,01 \\
\hline M1\#7 & 0,15 & 0,31 & 0,35 & 0,00 & 0,01 & 0,01 \\
\hline M1\#8 & 0,09 & 0,26 & 0,27 & 0,00 & 0,01 & 0,01 \\
\hline M1\#9 & 0,13 & 0,32 & 0,34 & 0,00 & 0,01 & 0,01 \\
\hline M1\#10 & 0,20 & 0,30 & 0,36 & 0,01 & 0,01 & 0,01 \\
\hline M1\#11 & 0,19 & 0,30 & 0,35 & 0,00 & 0,01 & 0,01 \\
\hline M1\#12 & 0,08 & 0,20 & 0,22 & 0,00 & 0,01 & 0,01 \\
\hline MÉDIA & 0,15 & 0,18 & 0,25 & 0,00 & 0,01 & 0,01 \\
\hline DESVPAD & 0,06 & 0,12 & 0,10 & 0,00 & 0,00 & 0,00 \\
\hline MAX & 0,28 & 0,32 & 0,36 & 0,01 & 0,01 & 0,01 \\
\hline MIN & 0,08 & 0,01 & 0,09 & 0,00 & 0,00 & 0,00 \\
\hline
\end{tabular}

Tabela 85 - Resultados do Receptor D, $1^{\circ}$ dia, para o marco M02 50 km (3a Campanha)

\begin{tabular}{lcccccc}
\hline & & ACURÁCIA $(\mathrm{m})$ & & & PRECISÃO (m) & DE \\
\hline ID & DE & DN & ERRO & DRRO \\
\hline M2\#1 & 0,53 & 0,45 & 0,69 & 0,01 & 0,01 & 0,01 \\
\hline M2\#2 & 0,43 & 0,53 & 0,68 & 0,01 & 0,01 & 0,01 \\
\hline M2\#3 & 0,29 & 0,38 & 0,48 & 0,01 & 0,01 & 0,01 \\
\hline M2\#4 & 0,17 & 0,23 & 0,29 & 0,01 & 0,01 & 0,02 \\
\hline M2\#5 & 0,49 & 0,34 & 0,59 & 0,01 & 0,01 & 0,01 \\
\hline M2\#6 & 0,27 & 0,23 & 0,35 & 0,01 & 0,01 & 0,01 \\
\hline M2\#7 & 0,41 & 0,28 & 0,50 & 0,01 & 0,01 & 0,01 \\
\hline M2\#8 & 0,35 & 0,36 & 0,50 & 0,01 & 0,01 & 0,01 \\
\hline M2\#9 & 0,21 & 0,26 & 0,34 & 0,01 & 0,01 & 0,01 \\
\hline M2\#10 & 0,19 & 0,31 & 0,36 & 0,01 & 0,01 & 0,02 \\
\hline M2\#11 & 0,21 & 0,58 & 0,62 & 0,01 & 0,01 & 0,02 \\
\hline M2\#12 & 0,32 & 0,52 & 0,61 & 0,01 & 0,01 & 0,02 \\
\hline MÉDIA & 0,32 & 0,37 & 0,50 & 0,01 & 0,01 & 0,01 \\
\hline DESVPAD & 0,12 & 0,12 & 0,14 & 0,00 & 0,00 & 0,00 \\
\hline MAXIMO & 0,53 & 0,58 & 0,69 & 0,01 & 0,01 & 0,02 \\
\hline MINIMO & 0,17 & 0,23 & 0,29 & 0,01 & 0,01 & 0,01 \\
\hline
\end{tabular}


Tabela 86 - Resultados do Receptor D, $2^{\circ}$ dia, para o marco M02 50 km ( $3^{a}$ Campanha)

\begin{tabular}{|c|c|c|c|c|c|c|}
\hline & \multicolumn{3}{|c|}{ ACURÁCIA (m) } & \multicolumn{3}{|c|}{ PRFCISÃO (m) } \\
\hline ID & $\mathrm{DE}$ & $\mathrm{DN}$ & ERRO & $\mathrm{DE}$ & DN & ERRO \\
\hline M2\#1 & 0,20 & 0,07 & 0,22 & 0,01 & 0,01 & 0,01 \\
\hline M2\#2 & 0,10 & 0,11 & 0,15 & 0,01 & 0,01 & 0,01 \\
\hline M2\#3 & 0,39 & 0,38 & 0,55 & 0,01 & 0,01 & 0,02 \\
\hline $\mathrm{M} 2 \# 4$ & 0,43 & 0,39 & 0,58 & 0,01 & 0,01 & 0,02 \\
\hline M2\#5 & 0,49 & 0,27 & 0,56 & 0,01 & 0,01 & 0,02 \\
\hline M2\#6 & 0,65 & 0,36 & 0,74 & 0,01 & 0,01 & 0,02 \\
\hline M2\#7 & 0,50 & 0,25 & 0,55 & 0,01 & 0,01 & 0,01 \\
\hline M2\#8 & 0,50 & 0,34 & 0,61 & 0,01 & 0,01 & 0,01 \\
\hline M2\#9 & 0,56 & 0,23 & 0,60 & 0,01 & 0,01 & 0,01 \\
\hline M2\#10 & 0,73 & 0,46 & 0,87 & 0,01 & 0,01 & 0,01 \\
\hline M2\#11 & 0,66 & 0,62 & 0,90 & 0,01 & 0,01 & 0,01 \\
\hline M2\#12 & 0,58 & 0,46 & 0,74 & 0,01 & 0,02 & 0,02 \\
\hline MÉDIA & 0,48 & 0,33 & 0,59 & 0,01 & 0,01 & 0,01 \\
\hline DESVPAD & 0,18 & 0,15 & 0,23 & 0,00 & 0,00 & 0,00 \\
\hline MAXIMO & 0,73 & 0,62 & 0,90 & 0,01 & 0,02 & 0,02 \\
\hline MINIMO & 0,10 & 0,07 & 0,15 & 0,01 & 0,01 & 0,01 \\
\hline
\end{tabular}

Tabela 87 - Resultados do Receptor D, $1^{\circ}$ dia, para o marco M02 $~ 50$ km (4 Campanha)

\begin{tabular}{lcccccc}
\hline & & ACIRACIA $(\mathrm{m})$ & & \multicolumn{2}{c}{ PRECISAO $(\mathrm{m})$} \\
\hline ID & $\mathrm{DE}$ & $\mathrm{DN}$ & $\mathrm{ERRO}$ & \multicolumn{2}{c}{ DN } & ERRO \\
\hline M2\#1 & 0,10 & 0,04 & 0,11 & 0,01 & 0,00 & 0,01 \\
\hline M2\#2 & 0,18 & 0,02 & 0,18 & 0,00 & 0,00 & 0,01 \\
\hline M2\#3 & 0,14 & 0,03 & 0,14 & 0,00 & 0,00 & 0,01 \\
\hline M2\#4 & 0,02 & 0,10 & 0,10 & 0,00 & 0,01 & 0,01 \\
\hline M2\#5 & 0,02 & 0,08 & 0,08 & 0,00 & 0,00 & 0,01 \\
\hline M2\#6 & 0,01 & 0,02 & 0,02 & 0,00 & 0,00 & 0,00 \\
\hline M2\#7 & 0,07 & 0,17 & 0,18 & 0,00 & 0,00 & 0,01 \\
\hline M2\#8 & 0,13 & 0,13 & 0,18 & 0,00 & 0,00 & 0,00 \\
\hline M2\#9 & 0,14 & 0,26 & 0,30 & 0,00 & 0,00 & 0,01 \\
\hline M2\#10 & 0,25 & 0,31 & 0,40 & 0,00 & 0,01 & 0,01 \\
\hline M2\#11 & 0,24 & 0,48 & 0,54 & 0,01 & 0,01 & 0,01 \\
\hline M2\#12 & 0,21 & 0,40 & 0,45 & 0,00 & 0,01 & 0,01 \\
\hline MÉDIA & 0,13 & 0,17 & 0,22 & 0,00 & 0,01 & 0,01 \\
\hline DESVPAD & 0,08 & 0,16 & 0,16 & 0,00 & 0,00 & 0,00 \\
\hline MAX & 0,25 & 0,48 & 0,54 & 0,01 & 0,01 & 0,01 \\
\hline MIN & 0,01 & 0,02 & 0,02 & 0,00 & 0,00 & 0,00 \\
\hline
\end{tabular}

Tabela 88 - Resultados do Receptor D, $2^{\circ}$ dia, para o marco M02 50 km (4ªmpanha)

\begin{tabular}{lcccccc}
\hline & \multicolumn{3}{c}{ ACURACIA $(\mathrm{m})$} & & \multicolumn{3}{c}{ PRECISAO $(\mathrm{m})$} \\
\hline ID & $\mathrm{DE}$ & $\mathrm{DN}$ & $\mathrm{ERRO}$ & $\mathrm{DE}$ & $\mathrm{D}$ \\
\hline M2\#1 & 0,15 & 0,13 & 0,19 & 0,01 & 0,01 & ERRO \\
\hline M2\#2 & 0,22 & 0,16 & 0,27 & 0,00 & 0,00 & 0,01 \\
\hline M2\#3 & 0,23 & 0,12 & 0,25 & 0,01 & 0,01 & 0,01 \\
\hline M2\#4 & 0,02 & 0,14 & 0,14 & 0,00 & 0,00 & 0,01 \\
\hline M2\#5 & 0,13 & 0,16 & 0,21 & 0,00 & 0,00 & 0,01 \\
\hline M2\#6 & 0,18 & 0,03 & 0,19 & 0,00 & 0,00 & 0,01 \\
\hline M2\#7 & 0,08 & 0,02 & 0,08 & 0,00 & 0,00 & 0,01 \\
\hline M2\#8 & 0,18 & 0,10 & 0,20 & 0,00 & 0,00 & 0,01 \\
\hline M2\#9 & 0,04 & 0,06 & 0,07 & 0,01 & 0,01 & 0,01 \\
\hline M2\#10 & 0,07 & 0,04 & 0,08 & 0,00 & 0,00 & 0,01 \\
\hline M2\#11 & 0,05 & 0,10 & 0,11 & 0,00 & 0,00 & 0,01 \\
\hline M2\#12 & 0,12 & 0,08 & 0,15 & 0,00 & 0,00 & 0,01 \\
\hline MÉDIA & 0,12 & 0,09 & 0,16 & 0,00 & 0,00 & 0,01 \\
\hline DESVPAD & 0,07 & 0,05 & 0,07 & 0,00 & 0,00 & 0,00 \\
\hline MAX & 0,23 & 0,16 & 0,27 & 0,01 & 0,01 & 0,01 \\
\hline MIN & 0,02 & 0,02 & 0,07 & 0,00 & 0,00 & 0,01 \\
\hline
\end{tabular}


Tabela 89 - Resultados do Receptor D, $1^{\circ}$ dia, para o marco M03 75 km (3 ${ }^{\text {a }}$ Campanha)

\begin{tabular}{lcccccc}
\hline & & ACURÁCIA $(\mathrm{m})$ & & \multicolumn{3}{c}{ PRFCISÃO $(\mathrm{m})$} \\
\hline ID & $\mathrm{DE}$ & $\mathrm{DN}$ & $\mathrm{ERRO}$ & $\mathrm{DE}$ & $\mathrm{DN}$ \\
\hline M3\#1 & 0,22 & 1,30 & 1,32 & 0,01 & 0,00 & 0,01 \\
\hline M3\#2 & 0,06 & 0,80 & 0,80 & 0,01 & 0,01 & 0,01 \\
\hline M3\#3 & 0,24 & 0,47 & 0,53 & 0,01 & 0,01 & 0,02 \\
\hline M3\#4 & 0,47 & 0,35 & 0,59 & 0,01 & 0,01 & 0,01 \\
\hline M3\#5 & 0,56 & 0,56 & 0,79 & 0,01 & 0,01 & 0,02 \\
\hline M3\#6 & 0,54 & 0,65 & 0,84 & 0,02 & 0,02 & 0,02 \\
\hline M3\#7 & 0,42 & 0,37 & 0,56 & 0,01 & 0,01 & 0,02 \\
\hline M3\#8 & 0,38 & 0,41 & 0,56 & 0,01 & 0,01 & 0,01 \\
\hline M3\#9 & 0,43 & 0,49 & 0,65 & 0,01 & 0,01 & 0,02 \\
\hline M3\#10 & 0,55 & 0,54 & 0,77 & 0,01 & 0,02 & 0,02 \\
\hline M3\#11 & 0,59 & 0,50 & 0,77 & 0,01 & 0,01 & 0,01 \\
\hline M3\#12 & 0,57 & 0,37 & 0,68 & 0,00 & 0,00 & 0,01 \\
\hline MÉDIA & 0,42 & 0,57 & 0,74 & 0,01 & 0,01 & 0,01 \\
\hline DESVPAD & 0,17 & 0,26 & 0,21 & 0,00 & 0,00 & 0,01 \\
\hline MAXIMO & 0,59 & 1,30 & 1,32 & 0,02 & 0,02 & 0,02 \\
\hline MINIMO & 0,06 & 0,35 & 0,53 & 0,00 & 0,00 & 0,01 \\
\hline
\end{tabular}

Tabela 90 - Resultados do Receptor D, $2^{\circ}$ dia, para o marco M03 75 km (3 ${ }^{\mathrm{a}}$ Campanha)

\begin{tabular}{lcccccc}
\hline & & ACURÁCIA $(m)$ & & \multicolumn{2}{c}{ PRFCISÃO $(m)$} \\
\hline ID & DE & DN & ERRO & DE & ERRO \\
\hline M3\#1 & 0,45 & 0,18 & 0,48 & 0,03 & 0,03 & 0,04 \\
\hline M3\#2 & 0,67 & 0,30 & 0,74 & 0,03 & 0,03 & 0,04 \\
\hline M3\#3 & 0,60 & 0,49 & 0,77 & 0,03 & 0,03 & 0,04 \\
\hline M3\#4 & 0,50 & 0,37 & 0,62 & 0,03 & 0,03 & 0,04 \\
\hline M3\#5 & 0,41 & 0,29 & 0,50 & 0,03 & 0,03 & 0,04 \\
\hline M3\#6 & 0,55 & 0,50 & 0,74 & 0,02 & 0,02 & 0,03 \\
\hline M3\#7 & 0,35 & 1,01 & 1,07 & 0,03 & 0,02 & 0,04 \\
\hline M3\#8 & 0,18 & 1,05 & 1,06 & 0,03 & 0,02 & 0,04 \\
\hline M3\#9 & 0,23 & 0,88 & 0,91 & 0,04 & 0,02 & 0,05 \\
\hline M3\#10 & 0,29 & 0,15 & 0,33 & 0,03 & 0,02 & 0,04 \\
\hline M3\#11 & 0,35 & 0,12 & 0,37 & 0,03 & 0,02 & 0,04 \\
\hline M3\#12 & 0,35 & 0,01 & 0,35 & 0,03 & 0,02 & 0,04 \\
\hline MÉDIA & 0,41 & 0,45 & 0,66 & 0,03 & 0,02 & 0,04 \\
\hline DESVPAD & 0,15 & 0,35 & 0,26 & 0,00 & 0,00 & 0,00 \\
\hline MAXIMO & 0,67 & 1,05 & 1,07 & 0,04 & 0,03 & 0,05 \\
\hline MINIMO & 0,18 & 0,01 & 0,33 & 0,02 & 0,02 & 0,03 \\
\hline
\end{tabular}

Tabela 91 - Resultados do Receptor D, $1^{\circ}$ dia, para o marco M03 75 km (4 ${ }^{\mathrm{a}}$ Campanha)

\begin{tabular}{lcccccc}
\hline & \multicolumn{3}{c}{ ACURACIA $(\mathrm{m})$} & \multicolumn{3}{c}{ PRECISAO (m) } \\
\hline ID & DE & DN & ERRO & DE & DN & ERRO \\
\hline M3\#1 & 0,25 & 0,13 & 0,28 & 0,00 & 0,00 & 0,01 \\
\hline M3\#2 & 0,19 & 0,19 & 0,27 & 0,00 & 0,00 & 0,00 \\
\hline M3\#3 & 0,24 & 0,18 & 0,30 & 0,00 & 0,00 & 0,00 \\
\hline M3\#4 & 0,21 & 0,21 & 0,30 & 0,00 & 0,00 & 0,01 \\
\hline M3\#5 & 0,15 & 0,22 & 0,27 & 0,00 & 0,00 & 0,01 \\
\hline M3\#6 & 0,13 & 0,28 & 0,31 & 0,00 & 0,00 & 0,00 \\
\hline M3\#7 & 0,16 & 0,28 & 0,32 & 0,00 & 0,00 & 0,01 \\
\hline M3\#8 & 0,19 & 0,28 & 0,34 & 0,00 & 0,00 & 0,00 \\
\hline M3\#9 & 0,09 & 0,28 & 0,29 & 0,00 & 0,00 & 0,00 \\
\hline M3\#10 & 0,03 & 0,39 & 0,39 & 0,00 & 0,01 & 0,01 \\
\hline M3\#11 & 0,00 & 0,29 & 0,29 & 0,01 & 0,01 & 0,01 \\
\hline M3\#12 & 0,01 & 0,17 & 0,17 & 0,01 & 0,01 & 0,01 \\
\hline MÉDIA & 0,14 & 0,24 & 0,29 & 0,00 & 0,00 & 0,01 \\
\hline DESVPAD & 0,09 & 0,07 & 0,05 & 0,00 & 0,00 & 0,00 \\
\hline MAX & 0,25 & 0,39 & 0,39 & 0,01 & 0,01 & 0,01 \\
\hline MIN & 0,00 & 0,13 & 0,17 & 0,00 & 0,00 & 0,00 \\
\hline
\end{tabular}


Tabela 92 - Resultados do Receptor D, $2^{\circ}$ dia, para o marco M03 75 km (4 Campanha)

\begin{tabular}{|c|c|c|c|c|c|c|}
\hline & \multicolumn{3}{|c|}{ ACURACIA (m) } & \multicolumn{3}{|c|}{ PRFCISAO (m) } \\
\hline ID & $\mathrm{DE}$ & $\mathrm{DN}$ & ERRO & $\mathrm{DE}$ & DN & ERRO \\
\hline M3\#1 & 0,21 & 0,07 & 0,22 & 0,00 & 0,00 & 0,01 \\
\hline M3\#2 & 0,16 & 0,07 & 0,17 & 0,00 & 0,00 & 0,00 \\
\hline M3\#3 & 0,07 & 0,05 & 0,08 & 0,00 & 0,00 & 0,00 \\
\hline M3\#4 & 0,03 & 0,03 & 0,04 & 0,00 & 0,00 & 0,01 \\
\hline M3\#5 & 0,17 & 0,15 & 0,23 & 0,00 & 0,01 & 0,01 \\
\hline M3\#6 & 0,19 & 0,44 & 0,48 & 0,00 & 0,01 & 0,01 \\
\hline M3\#7 & 0,23 & 0,07 & 0,24 & 0,00 & 0,01 & 0,01 \\
\hline M3\#8 & 0,25 & 0,07 & 0,26 & 0,01 & 0,01 & 0,01 \\
\hline M3\#9 & 0,05 & 0,05 & 0,07 & 0,00 & 0,01 & 0,01 \\
\hline M3\#10 & 0,07 & 0,03 & 0,08 & 0,00 & 0,01 & 0,01 \\
\hline M3\#11 & 0,17 & 0,05 & 0,18 & 0,00 & 0,01 & 0,01 \\
\hline M3\#12 & 0,23 & 0,06 & 0,24 & 0,00 & 0,01 & 0,01 \\
\hline MÉDIA & 0,15 & 0,10 & 0,19 & 0,00 & 0,01 & 0,01 \\
\hline DESVPAD & 0,08 & 0,11 & 0,12 & 0,00 & 0,00 & 0,00 \\
\hline MAX & 0,25 & 0,44 & 0,48 & 0,01 & 0,01 & 0,01 \\
\hline $\mathrm{MIN}$ & 0,03 & 0,03 & 0,04 & 0,00 & 0,00 & 0,00 \\
\hline
\end{tabular}

Tabela 93 - Resultados do Receptor D, $1^{\circ}$ dia, para o marco M04 $100 \mathrm{~km}$ (3 $3^{\mathrm{a}}$ Campanha)

\begin{tabular}{lcccccc}
\hline & & ACURÁCIA $(m)$ & & \multicolumn{2}{c}{ PRECISÃO $(m)$} \\
\hline ID & DE & DN & ERRO & DE & ERRO \\
\hline M4\#1 & 0,77 & 0,71 & 1,05 & 0,04 & 0,04 & 0,06 \\
\hline M4\#2 & 0,75 & 0,47 & 0,89 & 0,03 & 0,03 & 0,04 \\
\hline M4\#3 & 0,45 & 0,63 & 0,77 & 0,02 & 0,02 & 0,03 \\
\hline M4\#4 & 0,41 & 0,63 & 0,76 & 0,02 & 0,02 & 0,03 \\
\hline M4\#5 & 0,49 & 0,42 & 0,65 & 0,02 & 0,02 & 0,02 \\
\hline M4\#6 & 0,43 & 0,28 & 0,51 & 0,02 & 0,02 & 0,03 \\
\hline M4\#7 & 0,45 & 0,06 & 0,45 & 0,03 & 0,03 & 0,04 \\
\hline M4\#8 & 0,53 & 0,09 & 0,54 & 0,02 & 0,03 & 0,03 \\
\hline M4\#9 & 0,60 & 0,03 & 0,61 & 0,02 & 0,02 & 0,03 \\
\hline M4\#10 & 0,82 & 0,28 & 0,86 & 0,02 & 0,02 & 0,03 \\
\hline M4\#11 & 0,81 & 0,24 & 0,85 & 0,02 & 0,02 & 0,03 \\
\hline M4\#12 & 0,59 & 0,25 & 0,64 & 0,02 & 0,02 & 0,03 \\
\hline MÉDIA & 0,59 & 0,34 & 0,71 & 0,02 & 0,02 & 0,03 \\
\hline DESVPAD & 0,16 & 0,23 & 0,18 & 0,01 & 0,01 & 0,01 \\
\hline MAXIMO & 0,82 & 0,71 & 1,05 & 0,04 & 0,04 & 0,06 \\
\hline MINIMO & 0,41 & 0,03 & 0,45 & 0,02 & 0,02 & 0,02 \\
\hline
\end{tabular}

Tabela 94 - Resultados do Receptor D, 2 dia, para o marco M04 $100 \mathrm{~km}$ (3a Campanha)

\begin{tabular}{lcccccc}
\hline & & ACIIRÁCIA $(m)$ & & \multicolumn{2}{c}{ PRFCISÃO $(m)$} \\
\hline ID & DE & DN & ERRO & DN & ERRO \\
\hline M4\#1 & 1,03 & 1,76 & 2,04 & 0,04 & 0,03 & 0,05 \\
\hline M4\#2 & 0,51 & 1,74 & 1,81 & 0,03 & 0,03 & 0,04 \\
\hline M4\#3 & 0,37 & 1,74 & 1,78 & 0,03 & 0,03 & 0,04 \\
\hline M4\#4 & 0,19 & 1,54 & 1,55 & 0,03 & 0,03 & 0,04 \\
\hline M4\#5 & 0,48 & 1,50 & 1,57 & 0,02 & 0,02 & 0,02 \\
\hline M4\#6 & 0,23 & 1,42 & 1,44 & 0,02 & 0,02 & 0,02 \\
\hline M4\#7 & 0,06 & 1,26 & 1,26 & 0,02 & 0,02 & 0,03 \\
\hline M4\#8 & 0,03 & 1,16 & 1,16 & 0,02 & 0,02 & 0,03 \\
\hline M4\#9 & 0,13 & 0,93 & 0,94 & 0,02 & 0,02 & 0,03 \\
\hline M4\#10 & 0,29 & 0,92 & 0,96 & 0,02 & 0,02 & 0,03 \\
\hline M4\#11 & 0,43 & 0,91 & 1,00 & 0,02 & 0,02 & 0,03 \\
\hline M4\#12 & 0,55 & 0,87 & 1,03 & 0,03 & 0,03 & 0,04 \\
\hline MÉDIA & 0,36 & 1,31 & 1,38 & 0,02 & 0,02 & 0,03 \\
\hline DESVPAD & 0,27 & 0,35 & 0,38 & 0,01 & 0,01 & 0,01 \\
\hline MAXIMO & 1,03 & 1,76 & 2,04 & 0,04 & 0,03 & 0,05 \\
\hline MINIMO & 0,03 & 0,87 & 0,94 & 0,02 & 0,02 & 0,02 \\
\hline
\end{tabular}


Tabela 95 - Resultados do Receptor D, $1^{\circ}$ dia, para o marco M04 100 km (4 Campanha)

\begin{tabular}{lcccccc}
\hline & \multicolumn{3}{c}{ ACURACIA $(\mathrm{m})$} & \multicolumn{3}{c}{ PRFCISAO $(\mathrm{m})$} \\
\hline ID & $\mathrm{DE}$ & $\mathrm{DN}$ & $\mathrm{ERRO}$ & $\mathrm{DE}$ & $\mathrm{DN}$ & ERRO \\
\hline M4\#1 & 0,10 & 0,13 & 0,16 & 0,01 & 0,01 & 0,01 \\
\hline M4\#2 & 0,08 & 0,19 & 0,20 & 0,01 & 0,01 & 0,01 \\
\hline M4\#3 & 0,03 & 0,03 & 0,04 & 0,00 & 0,00 & 0,01 \\
\hline M4\#4 & 0,02 & 0,10 & 0,10 & 0,01 & 0,01 & 0,01 \\
\hline M4\#5 & 0,06 & 0,21 & 0,22 & 0,00 & 0,00 & 0,01 \\
\hline M4\#6 & 0,10 & 0,16 & 0,19 & 0,00 & 0,00 & 0,01 \\
\hline M4\#7 & 0,08 & 0,11 & 0,13 & 0,00 & 0,00 & 0,00 \\
\hline M4\#8 & 0,17 & 0,06 & 0,18 & 0,01 & 0,01 & 0,01 \\
\hline M4\#9 & 0,10 & 0,10 & 0,14 & 0,01 & 0,01 & 0,01 \\
\hline M4\#10 & 0,03 & 0,12 & 0,12 & 0,01 & 0,01 & 0,01 \\
\hline M4\#11 & 0,04 & 0,15 & 0,15 & 0,01 & 0,01 & 0,01 \\
\hline M4\#12 & 0,07 & 0,12 & 0,14 & 0,01 & 0,01 & 0,01 \\
\hline MÉDIA & 0,07 & 0,12 & 0,15 & 0,01 & 0,01 & 0,01 \\
\hline DESVPAD & 0,04 & 0,05 & 0,05 & 0,00 & 0,00 & 0,00 \\
\hline MAX & 0,17 & 0,21 & 0,22 & 0,01 & 0,01 & 0,01 \\
\hline MIN & 0,02 & 0,03 & 0,04 & 0,00 & 0,00 & 0,00 \\
\hline
\end{tabular}

Tabela 96 - Resultados do Receptor D, $2^{\circ}$ dia, para o marco M04 100 km (4 ${ }^{\mathrm{a}}$ Campanha)

\begin{tabular}{lcccccc}
\hline & \multicolumn{3}{c}{ ACURACIA $(\mathrm{m})$} & & \multicolumn{3}{c}{ PRFCISAO (m) } \\
\hline ID & $\mathrm{DE}$ & $\mathrm{DN}$ & $\mathrm{ERRO}$ & $\mathrm{DE}$ & $\mathrm{DN}$ & $\mathrm{ERRO}$ \\
\hline M4\#1 & 0,13 & 0,17 & 0,22 & 0,00 & 0,00 & 0,01 \\
\hline M4\#2 & 0,14 & 0,26 & 0,29 & 0,00 & 0,00 & 0,01 \\
\hline M4\#3 & 0,19 & 0,19 & 0,27 & 0,01 & 0,01 & 0,01 \\
\hline M4\#4 & 0,19 & 0,16 & 0,25 & 0,00 & 0,00 & 0,01 \\
\hline M4\#5 & 0,18 & 0,20 & 0,26 & 0,00 & 0,00 & 0,00 \\
\hline M4\#6 & 0,24 & 0,24 & 0,34 & 0,00 & 0,00 & 0,00 \\
\hline M4\#7 & 0,18 & 0,15 & 0,24 & 0,01 & 0,01 & 0,01 \\
\hline M4\#8 & 0,11 & 0,14 & 0,18 & 0,01 & 0,01 & 0,01 \\
\hline M4\#9 & 0,01 & 0,23 & 0,23 & 0,01 & 0,00 & 0,01 \\
\hline M4\#10 & 0,03 & 0,09 & 0,09 & 0,00 & 0,00 & 0,00 \\
\hline M4\#11 & 0,07 & 0,14 & 0,16 & 0,00 & 0,00 & 0,00 \\
\hline M4\#12 & 0,13 & 0,13 & 0,19 & 0,00 & 0,00 & 0,01 \\
\hline MÉDIA & 0,13 & 0,17 & 0,23 & 0,00 & 0,00 & 0,01 \\
\hline DESVPAD & 0,07 & 0,05 & 0,07 & 0,00 & 0,00 & 0,00 \\
\hline MAX & 0,24 & 0,26 & 0,34 & 0,01 & 0,01 & 0,01 \\
\hline MIN & 0,01 & 0,09 & 0,09 & 0,00 & 0,00 & 0,00 \\
\hline
\end{tabular}

Tabela 97 - Resultados do Receptor D, $1^{\circ}$ dia, para o marco M05 150 km (3a Campanha)

\begin{tabular}{lcccccc}
\hline & \multicolumn{3}{c}{ ACURÁCIA (m) } & \multicolumn{3}{c}{ PRECISÃO (m) } \\
\hline ID & DE & DN & ERRO & DE & DN & ERRO \\
\hline M5\#1 & 0,91 & 0,50 & 1,04 & 0,02 & 0,02 & 0,02 \\
\hline M5\#2 & 0,74 & 0,69 & 1,01 & 0,02 & 0,02 & 0,03 \\
\hline M5\#3 & 0,61 & 0,97 & 1,14 & 0,02 & 0,02 & 0,02 \\
\hline M5\#4 & 0,60 & 1,07 & 1,23 & 0,01 & 0,01 & 0,02 \\
\hline M5\#5 & 0,55 & 1,33 & 1,43 & 0,02 & 0,02 & 0,03 \\
\hline M5\#6 & 0,41 & 1,64 & 1,69 & 0,02 & 0,02 & 0,03 \\
\hline M5\#7 & 0,32 & 1,50 & 1,53 & 0,03 & 0,03 & 0,04 \\
\hline M5\#8 & 0,07 & 1,10 & 1,10 & 0,03 & 0,03 & 0,04 \\
\hline M5\#9 & 0,12 & 1,03 & 1,04 & 0,02 & 0,02 & 0,03 \\
\hline M5\#10 & 0,33 & 1,10 & 1,15 & 0,02 & 0,02 & 0,03 \\
\hline M5\#11 & 0,32 & 0,95 & 1,00 & 0,02 & 0,03 & 0,04 \\
\hline M5\#12 & 0,32 & 0,83 & 0,90 & 0,02 & 0,02 & 0,02 \\
\hline MÉDIA & 0,44 & 1,06 & 1,19 & 0,02 & 0,02 & 0,03 \\
\hline DESVPAD & 0,25 & 0,32 & 0,24 & 0,00 & 0,00 & 0,01 \\
\hline MAXIMO & 0,91 & 1,64 & 1,69 & 0,03 & 0,03 & 0,04 \\
\hline MINIMO & 0,07 & 0,50 & 0,90 & 0,01 & 0,01 & 0,02 \\
\hline
\end{tabular}


Tabela 98 - Resultados do Receptor D, $2^{\circ}$ dia, para o marco M05 150 km (3 $3^{\mathrm{a}}$ Campanha)

\begin{tabular}{lcccccc}
\hline & & ACURÁCIA $(m)$ & & PRFCISÃO $(m)$ & DN & ERRO \\
\hline ID & DE & DN & ERRO & 0,01 & 0,01 & 0,01 \\
\hline M5\#1 & 0,22 & 1,08 & 1,10 & 0,01 & 0,01 & 0,02 \\
\hline M5\#2 & 0,39 & 0,75 & 0,85 & 0,01 & 0,01 & 0,02 \\
\hline M5\#3 & 0,45 & 0,51 & 0,68 & 0,01 & 0,01 & 0,02 \\
\hline M5\#4 & 0,67 & 0,29 & 0,73 & 0,02 & 0,02 & 0,02 \\
\hline M5\#5 & 0,91 & 0,58 & 1,08 & 0,01 & 0,01 & 0,02 \\
\hline M5\#6 & 0,76 & 0,47 & 0,89 & 0,01 & 0,01 & 0,01 \\
\hline M5\#7 & 0,76 & 0,21 & 0,79 & 0,01 & 0,01 & 0,02 \\
\hline M5\#8 & 0,76 & 0,24 & 0,80 & 0,01 & 0,01 & 0,02 \\
\hline M5\#9 & 0,73 & 0,25 & 0,77 & 0,01 & 0,01 & 0,02 \\
\hline M5\#10 & 0,85 & 0,28 & 0,90 & 0,01 & 0,01 & 0,01 \\
\hline M5\#11 & 0,79 & 0,22 & 0,82 & 0,01 & 0,01 & 0,01 \\
\hline M5\#12 & 0,74 & 0,29 & 0,80 & 0,01 & 0,01 & 0,02 \\
\hline MÉDIA & 0,67 & 0,43 & 0,85 & 0,00 & 0,00 & 0,01 \\
\hline DESVPAD & 0,21 & 0,27 & 0,13 & 0,02 & 0,02 & 0,02 \\
\hline MAXIMO & 0,91 & 1,08 & 1,10 & 0,01 & 0,01 & 0,01 \\
\hline MINIMO & 0,22 & 0,21 & 0,68 & & & \\
\hline
\end{tabular}

Tabela 99 - Resultados do Receptor D, $1^{\circ}$ dia, para o marco M05 150 km (4 Campanha)

\begin{tabular}{lcccccc}
\hline & & ACINACIA $(m)$ & & PRERISAO (m) \\
\hline ID & DE & DN & ERRO & DE & DN & ERRO \\
\hline M5\#1 & 0,18 & 0,03 & 0,18 & 0,01 & 0,01 & 0,01 \\
\hline M5\#2 & 0,23 & 0,04 & 0,23 & 0,00 & 0,00 & 0,01 \\
\hline M5\#3 & 0,34 & 0,08 & 0,35 & 0,01 & 0,01 & 0,02 \\
\hline M5\#4 & 0,34 & 0,23 & 0,41 & 0,02 & 0,02 & 0,02 \\
\hline M5\#5 & 0,31 & 0,30 & 0,44 & 0,01 & 0,01 & 0,02 \\
\hline M5\#6 & 0,31 & 0,20 & 0,37 & 0,01 & 0,01 & 0,02 \\
\hline M5\#7 & 0,28 & 0,24 & 0,37 & 0,01 & 0,01 & 0,01 \\
\hline M5\#8 & 0,10 & 0,09 & 0,13 & 0,00 & 0,00 & 0,01 \\
\hline M5\#9 & 0,08 & 0,09 & 0,12 & 0,00 & 0,00 & 0,01 \\
\hline M5\#10 & 0,12 & 0,07 & 0,14 & 0,00 & 0,00 & 0,01 \\
\hline M5\#11 & 0,25 & 0,21 & 0,33 & 0,00 & 0,00 & 0,01 \\
\hline M5\#12 & 0,05 & 0,23 & 0,23 & 0,00 & 0,00 & 0,01 \\
\hline MÉDIA & 0,22 & 0,15 & 0,27 & 0,01 & 0,01 & 0,01 \\
\hline DESVPAD & 0,11 & 0,09 & 0,12 & 0,00 & 0,00 & 0,01 \\
\hline MAX & 0,34 & 0,30 & 0,44 & 0,02 & 0,02 & 0,02 \\
\hline MIN & 0,05 & 0,03 & 0,12 & 0,00 & 0,00 & 0,01 \\
\hline
\end{tabular}

Tabela 100 - Resultados do Receptor D, $2^{\circ}$ dia, para o marco M05 150 km (4 ${ }^{\mathrm{a}}$ Campanha)

\begin{tabular}{lcccccc}
\hline & \multicolumn{3}{c}{ ACURACIA $(\mathrm{m})$} & & PRECISAO $(\mathrm{m})$ \\
\hline ID & DE & DN & ERRO & DE & DN & ERRO \\
\hline M5\#1 & 0,11 & 0,05 & 0,12 & 0,00 & 0,01 & 0,01 \\
\hline M5\#2 & 0,14 & 0,03 & 0,14 & 0,00 & 0,01 & 0,01 \\
\hline M5\#3 & 0,11 & 0,16 & 0,19 & 0,00 & 0,01 & 0,02 \\
\hline M5\#4 & 0,00 & 0,11 & 0,11 & 0,00 & 0,01 & 0,01 \\
\hline M5\#5 & 0,01 & 0,02 & 0,03 & 0,00 & 0,01 & 0,01 \\
\hline M5\#6 & 0,12 & 0,05 & 0,13 & 0,01 & 0,01 & 0,01 \\
\hline M5\#7 & 0,19 & 0,04 & 0,19 & 0,00 & 0,00 & 0,00 \\
\hline M5\#8 & 0,12 & 0,15 & 0,19 & 0,00 & 0,00 & 0,00 \\
\hline M5\#9 & 0,19 & 0,07 & 0,21 & 0,00 & 0,00 & 0,01 \\
\hline M5\#10 & 0,21 & 0,21 & 0,30 & 0,00 & 0,00 & 0,00 \\
\hline M5\#11 & 0,16 & 0,15 & 0,22 & 0,00 & 0,00 & 0,00 \\
\hline M5\#12 & 0,12 & 0,13 & 0,18 & 0,00 & 0,00 & 0,01 \\
\hline MÉDIA & 0,12 & 0,10 & 0,17 & 0,00 & 0,01 & 0,01 \\
\hline DESVPAD & 0,06 & 0,06 & 0,07 & 0,00 & 0,00 & 0,00 \\
\hline MAX & 0,21 & 0,21 & 0,30 & 0,01 & 0,01 & 0,02 \\
\hline MIN & 0,00 & 0,02 & 0,03 & 0,00 & 0,00 & 0,00 \\
\hline
\end{tabular}


Tabela 101 - Resultados do Receptor D, $1^{\circ}$ dia, para o marco M06 200 km (3 $3^{\mathrm{a}}$ Campanha)

\begin{tabular}{lcccccc}
\hline & & ACURÁCIA $(m)$ & & PRFCISÃO $(m)$ & DE & DN \\
\hline ID & DE & DN & ERRO & 0,04 & 0,03 & 0,05 \\
\hline M6\#1 & 0,14 & 3,16 & 3,16 & 0,06 & 0,04 & 0,07 \\
\hline M6\#2 & 0,05 & 2,84 & 2,84 & 0,07 & 0,05 & 0,09 \\
\hline M6\#3 & 0,06 & 2,79 & 2,79 & 0,08 & 0,05 & 0,09 \\
\hline M6\#4 & 0,09 & 2,98 & 2,98 & 0,07 & 0,05 & 0,09 \\
\hline M6\#5 & 0,28 & 2,77 & 2,78 & 0,06 & 0,05 & 0,08 \\
\hline M6\#6 & 0,57 & 1,71 & 1,80 & 0,06 & 0,05 & 0,07 \\
\hline M6\#7 & 0,94 & 1,20 & 1,53 & 0,05 & 0,05 & 0,07 \\
\hline M6\#8 & 1,04 & 1,03 & 1,46 & 0,05 & 0,05 & 0,06 \\
\hline M6\#9 & 0,83 & 0,88 & 1,21 & 0,04 & 0,04 & 0,06 \\
\hline M6\#10 & 0,97 & 0,41 & 1,05 & 0,03 & 0,03 & 0,05 \\
\hline M6\#11 & 0,84 & 0,56 & 1,01 & 0,03 & 0,03 & 0,04 \\
\hline M6\#12 & 0,50 & 0,28 & 0,57 & 0,05 & 0,04 & 0,07 \\
\hline MÉDIA & 0,53 & 1,72 & 1,93 & 0,02 & 0,01 & 0,02 \\
\hline DESVPAD & 0,39 & 1,12 & 0,92 & 0,08 & 0,05 & 0,09 \\
\hline MAXIMO & 1,04 & 3,16 & 3,16 & 0,03 & 0,03 & 0,04 \\
\hline MINIMO & 0,05 & 0,28 & 0,57 & & & \\
\hline
\end{tabular}

Tabela 102 - Resultados do Receptor D, $2^{\circ}$ dia, para o marco M06 200 km ( $3^{\mathrm{a}}$ Campanha)

\begin{tabular}{lcccccc}
\hline & \multicolumn{3}{c}{ ACURÁCIA $(\mathrm{m})$} & & \multicolumn{3}{c}{ PRFCISÃO (m) } \\
\hline ID & DE & DN & ERRO & DE & ERRO \\
\hline M6\#1 & 0,47 & 0,29 & 0,55 & 0,01 & 0,01 & 0,01 \\
\hline M6\#2 & 0,29 & 0,52 & 0,59 & 0,01 & 0,01 & 0,01 \\
\hline M6\#3 & 0,15 & 0,43 & 0,46 & 0,01 & 0,01 & 0,01 \\
\hline M6\#4 & 0,04 & 0,33 & 0,33 & 0,02 & 0,02 & 0,02 \\
\hline M6\#5 & 0,25 & 0,26 & 0,36 & 0,01 & 0,01 & 0,02 \\
\hline M6\#6 & 0,29 & 0,20 & 0,35 & 0,01 & 0,01 & 0,02 \\
\hline M6\#7 & 0,34 & 0,31 & 0,46 & 0,01 & 0,01 & 0,01 \\
\hline M6\#8 & 0,34 & 0,28 & 0,44 & 0,01 & 0,01 & 0,01 \\
\hline M6\#9 & 0,28 & 0,19 & 0,34 & 0,01 & 0,01 & 0,01 \\
\hline M6\#10 & 0,25 & 0,22 & 0,34 & 0,01 & 0,01 & 0,01 \\
\hline M6\#11 & 0,22 & 0,12 & 0,25 & 0,01 & 0,01 & 0,01 \\
\hline M6\#12 & 0,28 & 0,39 & 0,48 & 0,01 & 0,01 & 0,01 \\
\hline MÉDIA & 0,27 & 0,30 & 0,41 & 0,01 & 0,01 & 0,01 \\
\hline DESVPAD & 0,11 & 0,11 & 0,10 & 0,00 & 0,00 & 0,00 \\
\hline MAXIMO & 0,47 & 0,52 & 0,59 & 0,02 & 0,02 & 0,02 \\
\hline MINIMO & 0,04 & 0,12 & 0,25 & 0,01 & 0,01 & 0,01 \\
\hline
\end{tabular}

Tabela 103 - Resultados do Receptor D, $1^{\circ}$ dia, para o marco M06 200 km (4 Campanha)

\begin{tabular}{lcccccc}
\hline & \multicolumn{3}{c}{ ACINRACIA $(\mathrm{m})$} & \multicolumn{3}{c}{ PRFCISAO $(\mathrm{m})$} \\
\hline ID & $\mathrm{DE}$ & $\mathrm{DN}$ & $\mathrm{ERRO}$ & $\mathrm{DE}$ & $\mathrm{D}$ \\
\hline M6\#1 & 0,70 & 0,80 & 1,06 & 0,02 & 0,02 & ERRO \\
\hline M6\#2 & 0,55 & 0,72 & 0,90 & 0,01 & 0,01 & 0,02 \\
\hline M6\#3 & 0,74 & 0,85 & 1,13 & 0,01 & 0,01 & 0,02 \\
\hline M6\#4 & 0,68 & 0,84 & 1,08 & 0,01 & 0,01 & 0,02 \\
\hline M6\#5 & 0,65 & 0,99 & 1,19 & 0,01 & 0,01 & 0,02 \\
\hline M6\#6 & 0,71 & 1,10 & 1,31 & 0,01 & 0,01 & 0,02 \\
\hline M6\#7 & 0,88 & 1,02 & 1,34 & 0,01 & 0,02 & 0,02 \\
\hline M6\#8 & 0,64 & 1,36 & 1,50 & 0,02 & 0,03 & 0,04 \\
\hline M6\#9 & 0,33 & 1,50 & 1,53 & 0,01 & 0,02 & 0,03 \\
\hline M6\#10 & 0,16 & 0,88 & 0,89 & 0,02 & 0,03 & 0,04 \\
\hline M6\#11 & 0,01 & 0,41 & 0,41 & 0,02 & 0,03 & 0,03 \\
\hline M6\#12 & 0,03 & 0,26 & 0,26 & 0,01 & 0,02 & 0,02 \\
\hline MÉDIA & 0,51 & 0,89 & 1,05 & 0,01 & 0,02 & 0,02 \\
\hline DESVPAD & 0,30 & 0,35 & 0,39 & 0,00 & 0,01 & 0,01 \\
\hline MAX & 0,88 & 1,50 & 1,53 & 0,02 & 0,03 & 0,04 \\
\hline MIN & 0,01 & 0,26 & 0,26 & 0,01 & 0,01 & 0,02 \\
\hline
\end{tabular}


Tabela 104 - Resultados do Receptor D, $2^{\circ}$ dia, para o marco M06 200 km (4 Campanha)

\begin{tabular}{lcccccc}
\hline & \multicolumn{3}{c}{ ACURACIA $(\mathrm{m})$} & & & PRECISAO (m) \\
\hline ID & DE & DN & ERRO & DE & DN & ERRO \\
\hline M6\#1 & 0,08 & 0,04 & 0,09 & 0,01 & 0,01 & 0,01 \\
\hline M6\#2 & 0,08 & 0,09 & 0,12 & 0,00 & 0,00 & 0,01 \\
\hline M6\#3 & 0,22 & 0,08 & 0,23 & 0,00 & 0,00 & 0,01 \\
\hline M6\#4 & 0,12 & 0,02 & 0,12 & 0,01 & 0,01 & 0,01 \\
\hline M6\#5 & 0,06 & 0,07 & 0,09 & 0,01 & 0,01 & 0,01 \\
\hline M6\#6 & 0,01 & 0,03 & 0,03 & 0,01 & 0,01 & 0,01 \\
\hline M6\#7 & 0,01 & 0,07 & 0,07 & 0,01 & 0,01 & 0,01 \\
\hline M6\#8 & 0,02 & 0,04 & 0,04 & 0,01 & 0,01 & 0,01 \\
\hline M6\#9 & 0,02 & 0,06 & 0,06 & 0,01 & 0,01 & 0,01 \\
\hline M6\#10 & 0,04 & 0,04 & 0,06 & 0,00 & 0,00 & 0,01 \\
\hline M6\#11 & 0,13 & 0,11 & 0,18 & 0,01 & 0,01 & 0,01 \\
\hline M6\#12 & 0,05 & 0,07 & 0,09 & 0,01 & 0,01 & 0,01 \\
\hline MÉDIA & 0,07 & 0,06 & 0,10 & 0,01 & 0,01 & 0,01 \\
\hline DESVPAD & 0,06 & 0,03 & 0,06 & 0,00 & 0,00 & 0,00 \\
\hline MAX & 0,22 & 0,11 & 0,23 & 0,01 & 0,01 & 0,01 \\
\hline MIN & 0,01 & 0,02 & 0,03 & 0,00 & 0,00 & 0,01 \\
\hline
\end{tabular}

Tabela 105 - Resultados do Receptor D, $1^{\circ}$ dia, para o marco M07 300 km (3 ${ }^{a}$ Campanha)

\begin{tabular}{lcccccc}
\hline & & ACURÁCIA $(\mathrm{m})$ & & & PRECISÃO & DE \\
\hline ID & DE & DN & ERRO & DN & ERRO \\
\hline M7\#1 & 2,09 & 0,69 & 2,20 & 0,04 & 0,04 & 0,05 \\
\hline M7\#2 & 2,22 & 0,69 & 2,32 & 0,03 & 0,04 & 0,05 \\
\hline M7\#3 & 2,27 & 0,74 & 2,39 & 0,03 & 0,03 & 0,04 \\
\hline M7\#4 & 2,35 & 0,81 & 2,48 & 0,03 & 0,04 & 0,05 \\
\hline M7\#5 & 2,65 & 1,10 & 2,87 & 0,03 & 0,04 & 0,05 \\
\hline M7\#6 & 2,42 & 1,01 & 2,62 & 0,05 & 0,05 & 0,07 \\
\hline M7\#7 & 2,20 & 0,81 & 2,34 & 0,05 & 0,06 & 0,08 \\
\hline M7\#8 & 2,08 & 0,77 & 2,22 & 0,03 & 0,04 & 0,05 \\
\hline M7\#9 & 1,76 & 0,52 & 1,84 & 0,03 & 0,04 & 0,05 \\
\hline M7\#10 & 1,66 & 0,57 & 1,75 & 0,03 & 0,03 & 0,04 \\
\hline M7\#11 & 1,58 & 0,43 & 1,64 & 0,03 & 0,03 & 0,04 \\
\hline M7\#12 & 0,52 & 0,97 & 1,10 & 0,03 & 0,04 & 0,05 \\
\hline MÉDIA & 1,98 & 0,76 & 2,15 & 0,03 & 0,04 & 0,05 \\
\hline DESVPAD & 0,56 & 0,20 & 0,49 & 0,01 & 0,01 & 0,01 \\
\hline MAXIMO & 2,65 & 1,10 & 2,87 & 0,05 & 0,06 & 0,08 \\
\hline MINIMO & 0,52 & 0,43 & 1,10 & 0,03 & 0,03 & 0,04 \\
\hline
\end{tabular}

Tabela 106 - Resultados do Receptor D, $2^{\circ}$ dia, para o marco M07 300 km (3a Campanha)

\begin{tabular}{|c|c|c|c|c|c|c|}
\hline & \multicolumn{3}{|c|}{ ACURÁCIA (m) } & \multicolumn{3}{|c|}{ PRECISÃO (m) } \\
\hline ID & $\mathrm{DE}$ & $\mathrm{DN}$ & ERRO & DE & $\mathrm{DN}$ & ERRO \\
\hline M7\#1 & 0,51 & 1,01 & 1,13 & 0,02 & 0,03 & 0,04 \\
\hline M7\#2 & 0,43 & 0,87 & 0,96 & 0,01 & 0,02 & 0,02 \\
\hline M7\#3 & 0,05 & 0,84 & 0,84 & 0,01 & 0,01 & 0,01 \\
\hline M7\#4 & 0,12 & 0,66 & 0,67 & 0,01 & 0,02 & 0,02 \\
\hline M7\#5 & 0,21 & 0,56 & 0,59 & 0,01 & 0,01 & 0,01 \\
\hline M7\#6 & 0,16 & 0,36 & 0,39 & 0,01 & 0,01 & 0,01 \\
\hline M7\#7 & 1,28 & 0,72 & 1,47 & 0,03 & 0,04 & 0,05 \\
\hline M7\#8 & 0,56 & 0,76 & 0,94 & 0,03 & 0,05 & 0,06 \\
\hline M7\#9 & 2,08 & 0,77 & 2,22 & 0,05 & 0,04 & 0,06 \\
\hline M7\#10 & 1,76 & 0,52 & 1,84 & 0,03 & 0,06 & 0,07 \\
\hline M7\#11 & 1,58 & 0,43 & 1,64 & 0,04 & 0,04 & 0,05 \\
\hline M7\#12 & 2,27 & 0,74 & 2,39 & 0,03 & 0,04 & 0,05 \\
\hline MÉDIA & 0,92 & 0,68 & 1,26 & 0,02 & 0,03 & 0,04 \\
\hline DESVPAD & 0,82 & 0,19 & 0,65 & 0,01 & 0,02 & 0,02 \\
\hline MAXIMO & 2,27 & 1,01 & 2,39 & 0,05 & 0,06 & 0,07 \\
\hline MINIMO & 0,05 & 0,36 & 0,39 & 0,01 & 0,01 & 0,01 \\
\hline
\end{tabular}


Tabela 107 - Resultados do Receptor D, $1^{\circ}$ dia, para o marco M07 300 km (4 Campanha)

\begin{tabular}{|c|c|c|c|c|c|c|}
\hline \multicolumn{4}{|c|}{ ACURACIA (m) } & \multicolumn{3}{|c|}{ PRECISAO (m) } \\
\hline ID & $\mathrm{DE}$ & DN & ERRO & $\mathrm{DE}$ & DN & ERRO \\
\hline M7\#1 & 0,63 & 0,50 & 0,81 & 0,01 & 0,01 & 0,01 \\
\hline M7\#2 & 0,34 & 0,39 & 0,51 & 0,02 & 0,02 & 0,02 \\
\hline M7\#3 & 0,44 & 0,49 & 0,66 & 0,01 & 0,01 & 0,02 \\
\hline M7\#4 & 0,36 & 0,52 & 0,64 & 0,01 & 0,01 & 0,01 \\
\hline M7\#5 & 0,50 & 0,58 & 0,76 & 0,00 & 0,00 & 0,01 \\
\hline M7\#6 & 0,71 & 0,68 & 0,99 & 0,01 & 0,01 & 0,02 \\
\hline M7\#7 & 0,66 & 0,83 & 1,06 & 0,01 & 0,02 & 0,02 \\
\hline M7\#8 & 0,79 & 0,90 & 1,19 & 0,02 & 0,02 & 0,03 \\
\hline M7\#9 & 0,96 & 1,04 & 1,42 & 0,01 & 0,02 & 0,02 \\
\hline M7\#10 & 1,07 & 1,26 & 1,65 & 0,01 & 0,01 & 0,01 \\
\hline M7\#11 & 1,27 & 1,40 & 1,89 & 0,01 & 0,01 & 0,01 \\
\hline M7\#12 & 1,45 & 1,61 & 2,17 & 0,01 & 0,01 & 0,01 \\
\hline MÉDIA & 0,76 & 0,85 & 1,15 & 0,01 & 0,01 & 0,02 \\
\hline DESVPAD & 0,36 & 0,40 & 0,53 & 0,00 & 0,00 & 0,01 \\
\hline MAX & 1,45 & 1,61 & 2,17 & 0,02 & 0,02 & 0,03 \\
\hline $\mathrm{MIN}$ & 0,34 & 0,39 & 0,51 & 0,00 & 0,00 & 0,01 \\
\hline
\end{tabular}

Tabela 108 - Resultados do Receptor D, $2^{\circ}$ dia, para o marco M07 300 km (4 Campanha)

\begin{tabular}{lcccccc}
\hline & & ACURACIA $(m)$ & & \multicolumn{2}{c}{ PRFCISAO (m) } \\
\hline ID & DE & DN & ERRO & DE & DN & ERRO \\
\hline M7\#1 & 0,38 & 0,19 & 0,43 & 0,06 & 0,05 & 0,08 \\
\hline M7\#2 & 0,04 & 0,29 & 0,30 & 0,06 & 0,05 & 0,08 \\
\hline M7\#3 & 0,24 & 0,52 & 0,57 & 0,06 & 0,05 & 0,08 \\
\hline M7\#4 & 0,30 & 0,65 & 0,72 & 0,05 & 0,05 & 0,07 \\
\hline M7\#5 & 0,47 & 0,90 & 1,02 & 0,05 & 0,04 & 0,06 \\
\hline M7\#6 & 0,47 & 1,07 & 1,17 & 0,04 & 0,03 & 0,05 \\
\hline M7\#7 & 0,44 & 1,29 & 1,36 & 0,04 & 0,04 & 0,05 \\
\hline M7\#8 & 0,42 & 1,30 & 1,37 & 0,04 & 0,03 & 0,05 \\
\hline M7\#9 & 0,22 & 1,35 & 1,36 & 0,05 & 0,04 & 0,06 \\
\hline M7\#10 & 0,14 & 1,34 & 1,35 & 0,07 & 0,06 & 0,10 \\
\hline M7\#11 & 0,51 & 1,28 & 1,38 & 0,08 & 0,07 & 0,11 \\
\hline M7\#12 & 0,14 & 0,93 & 0,94 & 0,05 & 0,05 & 0,07 \\
\hline MÉDIA & 0,31 & 0,93 & 1,00 & 0,05 & 0,05 & 0,07 \\
\hline DESVPAD & 0,16 & 0,42 & 0,40 & 0,01 & 0,01 & 0,02 \\
\hline MAX & 0,51 & 1,35 & 1,38 & 0,08 & 0,1 & 0,11 \\
\hline MIN & 0,04 & 0,19 & 0,30 & 0,04 & 0,03 & 0,05 \\
\hline
\end{tabular}

